\author{
UNIVERSIDADE DE BRASIILIA - UnB \\ INSTITUTO DE CIÊNCIAS HUMANAS - IH \\ DEPARTAMENTO DE GEOGRAFIA - GEA \\ PROGRAMA DE PÓS-GRADUAÇÃO EM GEOGRAFIA - PPGGEA
}

\title{
REESTRUTURAÇÃO PRODUTIVA, PRODUÇÃO DE SUBCENTROS E DESIGUALDADES SOCIOESPACIAIS NA RIDE-DF
}




\author{
UNIVERSIDADE DE BRASÍLIA - UnB \\ INSTITUTO DE CIÊNCIAS HUMANAS - IH \\ DEPARTAMENTO DE GEOGRAFIA - GEA \\ PROGRAMA DE PÓS-GRADUAÇÃO EM GEOGRAFIA - PPGGEA
}

\title{
REESTRUTURAÇÃO PRODUTIVA, PRODUÇÃO DE SUBCENTROS E DESIGUALDADES SOCIOESPACIAIS NA RIDE-DF
}

Sergio Magno Carvalho de Souza

Orientadora: Lúcia Cony Faria Cidade

Tese de Doutorado

Brasília: dezembro/ 2016 
UNIVERSIDADE DE BRASÍLIA - UnB

INSTITUTO DE CIÊNCIAS HUMANAS - IH

DEPARTAMENTO DE GEOGRAFIA - GEA

PROGRAMA DE PÓS-GRADUAÇÃO EM GEOGRAFIA - PPGGEA

\title{
REESTRUTURAÇÃO PRODUTIVA, PRODUÇÃO DE SUBCENTROS E DESIGUALDADES SOCIOESPACIAIS NA RIDE-DF
}

\author{
Sergio Magno Carvalho de Souza
}

Tese de Doutorado submetida ao Departamento de Geografia da Universidade de Brasília, como parte dos requisitos necessários para a obtenção do Grau de Doutor em Geografia, área de concentração Gestão Ambiental e Territorial.

Aprovado por:

Lúcia Cony Faria Cidade - GEA/IH/UnB

(Orientadora)

Marília Luiza Peluso - GEA/IH/UnB

(Examinadora interna)

Fernando Luiz Araújo Sobrinho - GEA/IH/UnB

(Examinador interno)

João Mendes da Rocha Neto - PPGA/UnB e MPDG

(Examinador externo)

Alexandre Barbosa Brandão da Costa - Codeplan/GDF

(Examinador externo)

Nelba Azevedo Penna - GEA/IH/UnB

(Examinadora suplente)

Brasília, dezembro de 2016 


\section{FICHA CATALOGRÁFICA}

Carvalho de Souza, Sergio Magno

Reestruturação produtiva, produção de subcentros e desigualdades socioespaciais na Ride-DF - Sergio Magno Carvalho de Souza; orientadora: Lúcia Cony Faria Cidade. Brasília, 2016.

$321 \mathrm{f}$.

Tese (Doutorado - Doutorado em Geografia) - Universidade de Brasília, 2016

1. Ride-DF. 2. Reestruturação produtiva. 3. Centros e subcentros. 4. Desigualdades socioespaciais.

I. UnB-GEA. II. Título III. Cidade, Lúcia Cony Faria, orient.

\section{REFERÊNCIA BIBLIOGRÁFICA}

CARVALHO DE SOUZA, S. M. Reestruturação produtiva, produção de subcentros e desigualdades socioespaciais na Ride-DF. 321f. Tese (Doutorado em Geografia). Universidade de Brasília, Brasília, 2016.

\section{CESSÃO DE DIREITOS}

É concedida à Universidade de Brasília permissão para reproduzir cópias desta tese e emprestar ou vender tais cópias somente para propósitos acadêmicos e científicos. O autor reserva outros direitos de publicação e nenhuma parte desta tese de doutorado pode ser reproduzida sem a autorização por escrito do autor.

Sergio Magno Carvalho de Souza 


\section{AGRADECIMENTOS}

A Deus, fundamento último e pulsão amorosa primordial de todas as coisas.

A Juliana Brandão, que teve tantas horas roubadas para que eu pudesse me dedicar a este trabalho, mas que jamais me negou seu amor, sua compreensão e companheirismo. E ao Gabriel, que já mudou tanta coisa em mim e cujo rosto e jeito tantas vezes imaginei, ansioso, enquanto me dediquei a este trabalho.

A meus pais, Antônio Magno e Sônia Maria, cujo amor, carinho e apoio foram fundamentais para que eu chegasse aqui. Ainda nestes tempos tão complicados, tem se mostrado fortes e tenazes e me serviram de exemplo nos momentos mais difíceis da vida acadêmica.

A meus irmãos, Vinícius e Rachel, companheiros de uma vida toda, a quem cada vez mais fortemente amo e admiro. A meus cunhados, Aline e Thiago, e ao Luiz Gustavo, que enche nossas vidas de alegria com seu sorriso do tamanho do mundo.

À professora Lúcia Cony Faria Cidade, que tem me orientado desde o primeiro PIBIC, passando pela monografia de Graduação e pela Dissertação de Mestrado (desde quando eu era um menino, certa vez me disse). Ao longo de tantos anos, aprendi a admirar sua atuação profissional e dedicada aos alunos, seu vasto conhecimento e sua preocupação com o trabalho desenvolvido pelos orientandos, seja na graduação ou na pós-graduação.

Aos professores Fernando Sobrinho e Marília Peluso, por participarem avaliando este trabalho e pelas valiosas críticas realizadas na Banca de Qualificação do Projeto de Tese. Ao João Mendes, com quem tive o prazer de conviver, partilhar ideias e trabalhar em algumas ações no Ministério da Integração Nacional e que gentilmente aceitou avaliar este trabalho. Agradeço ainda ao interesse e disponibilidade do Alexandre Brandão e da professora Nelba Penna em avaliar este trabalho.

Aos colegas da pós-graduação, especialmente o Wallace Pantoja, com quem sempre tenho fecundas discussões.

Aos colegas da Superintendência do Desenvolvimento do Centro-Oeste, pelo companheirismo diário e pelo trabalho em torno do desenvolvimento deste "pedaço" do Brasil. Agradeço ainda aos superiores imediatos, sempre solícitos e compreensivos quando precisei me ausentar para atender às necessidades da pós-graduação. 
Aos amigos e amigas que tornam os dias e a caminhada mais suave e feliz, por partilharem de suas vidas comigo. Em especial ao Rodrigo e Kátia, cuja valiosa e genuína amizade está sempre em minha memória e coração.

Por fim, à Universidade de Brasília, onde me graduei, me tornei mestre e agora doutor em Geografia. Mais que apenas uma instituição, a universidade sempre foi para mim um local de amadurecimento, não apenas intelectual, mas pessoal e mesmo profissional, algo de que serei eternamente grato. 


\section{RESUMO}

Nas últimas décadas, a reestruturação produtiva capitalista tem sido responsável pela reorganização dos espaços regionais, por meio da flexibilização na produção industrial e agropecuária, da emergência de novos centros de serviços e da integração econômica e financeira dos centros de gestão e controle do capital. Estas dinâmicas têm levado a modificações nos espaços regionais brasileiros, com o reforço aos centros tradicionais, a emergência de novas centralidades e o surgimento de novos espaços produtivos. Ao mesmo tempo, este processo tem suscitado tendências a uma fragmentação da malha ocupada e contribuído para o acirramento das desigualdades socioeconômicas internas às regiões. $\mathrm{Na}$ Região Integrada de Desenvolvimento do Distrito Federal e Entorno- Ride-DF, cuja gênese esteve ligada à transferência da Capital para o Centro-Oeste brasileiro, parecem ocorrer processos semelhantes. Assim, o objetivo desta pesquisa é compreender as modificações recentes na organização espacial da Ride-DF, sob o pano de fundo da reestruturação produtiva. Argumenta-se que essa dinâmica se manifesta historicamente a partir de três processos estruturantes: a expansão metropolitana de Brasília, a expansão da agropecuária moderna e a integração do eixo Brasília-Anápolis-Goiânia. Inicialmente o Estado promoveu a construção de Brasília com foco em seu papel de Nova Capital, sem grande atenção à área circunvizinha. Formou-se, assim, um espaço regional polarizado por um centro principal em construção e composto por municípios tradicionalmente voltados à agropecuária de subsistência. Numa segunda fase, de formação metropolitana e de implantação da agropecuária moderna, o Estado passa a ter uma política definida para a região de Brasília, cujo propósito era preservar o centro principal da pressão demográfica então existente. Como desdobramentos, o espaço regional estruturou-se em torno da metrópole brasiliense e da agropecuária moderna que se estabelecia a leste do Distrito Federal. Tal quadro levou a um processo que combinou a consolidação de Brasília como centro regional com a formação inicial de subcentros em municípios ligados à agropecuária tecnificada. Finalmente, no período mais recente, o Estado passou a atuar por meio de subsídios e inventivos a atividades privadas, relativizando a preocupação anterior em ordenar os processos no território da Capital. Esta nova postura estimulou a atuação tanto do capital imobiliário, na escala urbana e metropolitana, como do agronegócio, na escala regional. Como desdobramento, acentuou-se o papel de Brasília como centro metropolitano e regional, a emergência de subcentros e o acirramento das desigualdades socioespaciais.

Palavras-chave: Ride-DF; Reestruturação Produtiva; Centros e subcentros; desigualdades socioespaciais. 


\begin{abstract}
Over recent decades, the capitalist productive restructuration has been responsible for the reorganization of regional spaces, by the flexibilization of the industrial and agricultural production, the emergence of new services centres and the economic and financial integration of the capital management and control centres. These dynamics have led to modifications in the Brazilian regional spaces, by the reinforcement of traditional centres, the emergence of new centralities and the appearance of new productive spaces. At the same time, this process has led to tendencies such as fragmentation in urban settlements and intensification of internal socioeconomic inequalities. The same process seems to be in progress in the Integrated Region of Development of Brasília (Ride-DF) whose genesis was linked to the Brazilian Capital transfer to the Brazilian Center-West Region. Thus, this research aims to comprehend the recent modifications in the spatial organization of the Ride-DF, under the occurrence of productive restructuration. The central argument is that this dynamic occurs historically by the existence of three structuring process: the metropolitan expansion of Brasilia, the expansion of modern agriculture and the integration of the Brasília-Anápolis-Goiânia axis. Initially the state promoted the construction of Brasilia with focus in its role as New Capital, without great attention to the surrounding areas. A regional space was made polarized by a main centre under construction and composed of municipalities traditionally linked to subsistence agriculture. In a second phase of metropolitan formation and implantation of modern agriculture, the State began to execute a defined policy for the Brasilia's region, which purpose was to preserve the main centre of the demographic pressure. As a consequence, the regional space was structured around the metropolis of Brasília and the modern agriculture which was establishing itself at the East of the Federal District. This regional frame led to a process which combined the consolidation of Brasilia as a regional centre and the initial formation of subcentres linked to the modern agriculture. Recently, the State began to act through subsidies and incentives to private activities, relativizing the former preoccupation with planning spatial process in the Brasilia's territory. This new position stimulated the action of real-state capital in urban and metropolitan scale, and of agribusiness capital in regional scale. Thus the role of Brasilia as a metropolitan and regional centre was reinforced, subcentres emerged and sociospatial inequalities were accentuated.
\end{abstract}

Keywords: Ride-DF; Productive restructuration; Centres and subcentres; sociospatial inequalities. 


\section{SUMÁRIO}

1. INTRODUÇÃ̃O

1.1 Reestruturação produtiva capitalista e os espaços regionais: dinâmicas e efeitos em escala

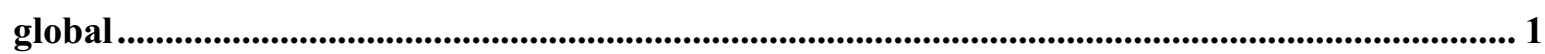

1.2 Reestruturação produtiva e os espaços regionais nacionais.................................................... 4

1.3 Reestruturação produtiva e o espaço da Ride-DF .............................................................. 7

1.4 Questões pesquisa, objetivos e hipóteses ........................................................................ 12

1.5 Aspectos metodológicos .......................................................................................................................... 14

2. A REGIÃo E SUA DISCUSSÃO: DA CLASSIFICAÇÃO DE ÁREAS À PERSPECTIVA DAS REGIÕES FRAGMENTADAS ..............................................17

2.1 A perspectiva da Geografia teorética-quantitativa ............................................................ 17

2.2 As perspectivas marxistas: da dominação e reprodução capitalista aos arranjos de poder

2.3 Os neomarxistas: globalização, arquipélagos fraturados, relações sociais e região como artefato .25

2.4 Síntese e discussão. 29

3. REESTRUTURAÇÃO PRODUTIVA E ESPAÇOS REGIONAIS: EXPANSÃo METROPOLITANA, AGROPECUÁRIA MODERNA E INFRAESTRUTURA...........31

3.1 Reestruturação produtiva, metropolização e expansão metropolitana .................................. 31

3.2 Reestruturação produtiva e expansão da agropecuária moderna.......................................... 38

3.3 Reestruturação produtiva e estruturação de redes e eixos.................................................. 42

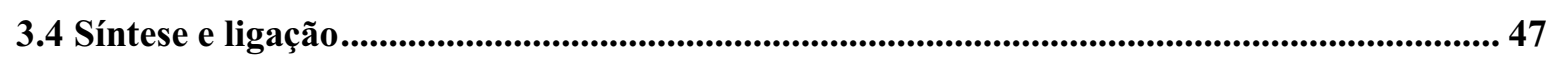

4. CENTROS E SUBCENTROS REGIONAIS E AS DESIGUALDADES REGIONAIS .49

4.1 A questão do centro e da centralidade urbana, metropolitana e regional.

4.1.1 Visões teóricas em torno do centro, centralidade e subcentros nas escalas urbana,

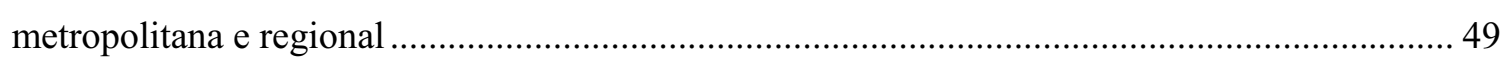

4.1.2 A identificação de centros e subcentros em escala urbana e regional ................................. 58

4.2 Desenvolvimento regional e desigualdades socioespaciais.................................................6 61

4.2.1 As teorias do desenvolvimento regional e as desigualdades socioespaciais ........................ 61

4.2.2 As formas de mensuração das desigualdades regionais ....................................................... 67

4.3 Síntese e ligação.......................................................................................................................................... 69 


\section{REESTRUTURAÇÃO PRODUTIVA E OS ESPAÇOS METROPOLITANO E}

REGIONAIS BRASILEIROS: PRODUÇÃO DE SUBCENTROS E DESIGUALDADES

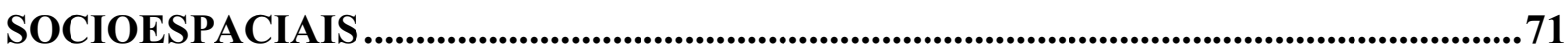

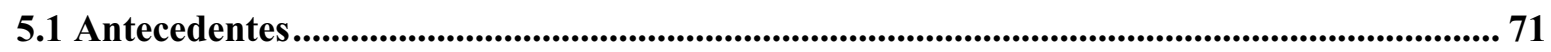

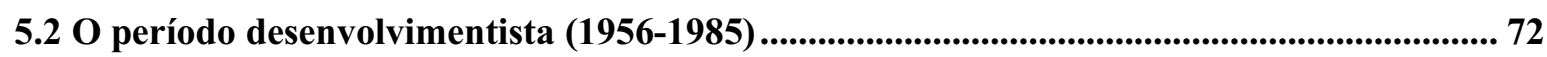

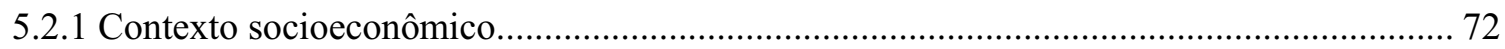

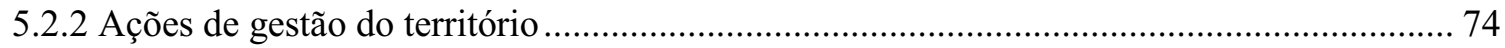

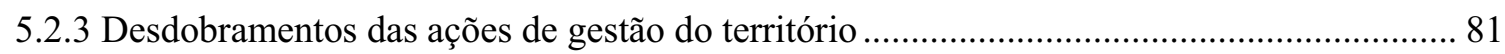

5.3 O período do neoliberalismo (1986-2016) ......................................................................................... 86

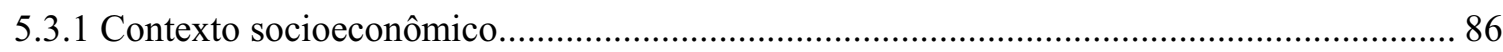

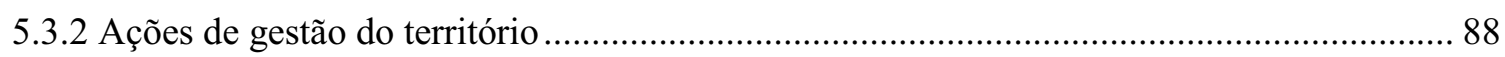

5.3.3 Desdobramentos das ações de gestão do território .............................................................. 95

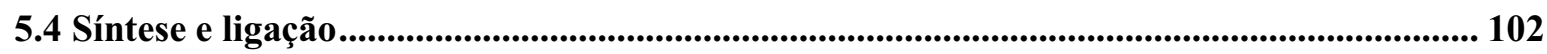

6. A GÊNESE: O PERÍODO DA IMPLANTAÇÃO DAS BASES TERRITORIAIS DA REGIÃO DE BRASÍLIA (1956-1969) .....................................................................104

6.1 Antecedentes da implantação de Brasília e das bases territoriais da Ride-DF .................. 104

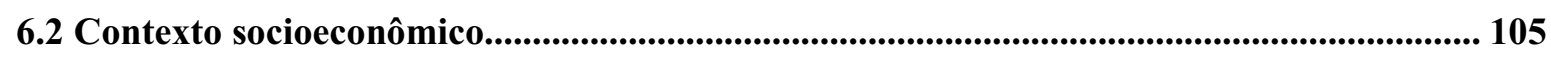

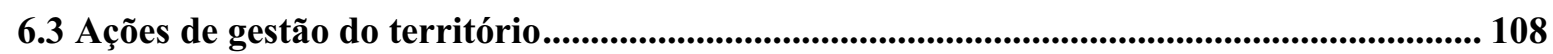

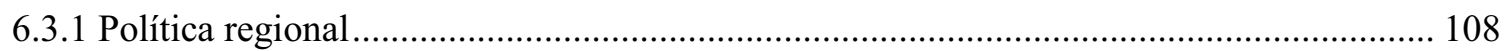

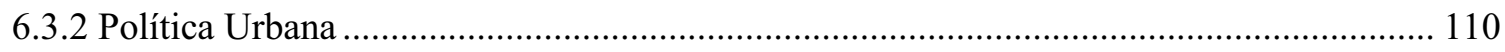

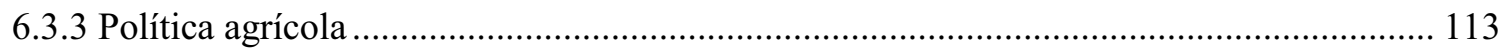

6.3.4 Política de transportes - eixos rodoviários ........................................................................ 113

6.4 Desdobramentos das ações de gestão do território …....................................................... 115

6.4.1 Desdobramentos e processos espaciais: urbanização, modificações no espaço agrário e implantação das bases do eixo Brasília-Anápolis-Goiânia

6.4.2 Desdobramentos e processos espaciais: subcentros e desigualdades regionais na região de Brasília...

7. O PERÍODO DA FORMAÇÃO METROPOLITANA E IMPLANTAÇÃO DA AGROPECUÁRIA MODERNA (1970-1985), NA REGIÃO DE INFLUÊNCIA DE

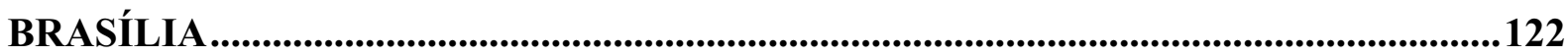

7.1 Contexto socioeconômico.......................................................................................................... 122

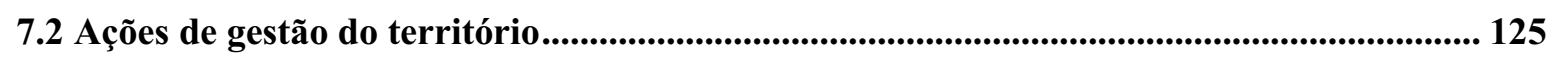

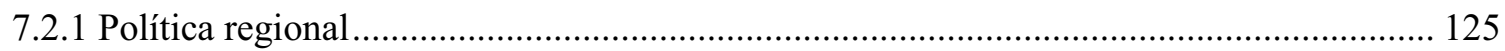

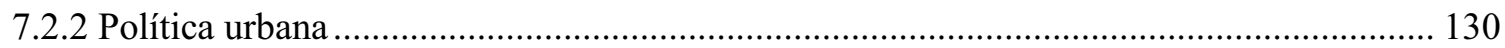


7.2.3 Política agrícola. 132

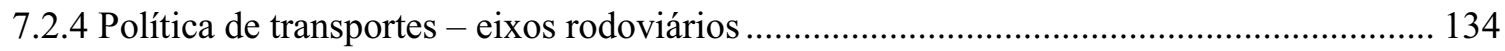

7.3 Desdobramentos das ações de gestão do território …………………............................................. 136

7.3.1 Desdobramentos e processos espaciais: a formação da metrópole brasiliense................... 136

7.3.2 Desdobramentos e processos espaciais: a implantação da agropecuária moderna na Região de Brasília

7.3.3 Desdobramentos e processos espaciais: a implantação do corredor rodoviário entre Brasília e Goiânia

7.3.4 Subcentros e desigualdades regionais na Região de Brasília 141

7.4 Síntese, discussão e ligação 148

8. REESTRUTURAÇÃo PROdUtiVA NA RIDE-DF: PERÍOdO DA EXPANSÃo METROPOLITANA, EXPANSÃO DA AGROPECUÁRIA MODERNA E INTEGRAÇÃO DO EIXO BRASÍLIA-ANÁPOLIS-GOIÂNIA (1985-2016)..................150

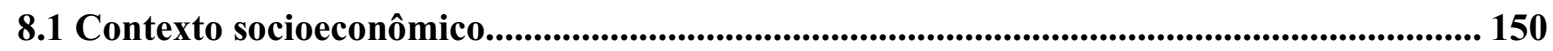

8.2 Ações de gestão do território ............................................................................................................. 155

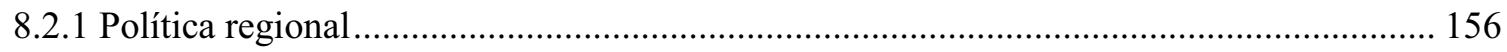

8.2.3 Política urbana (e o esboço de uma política metropolitana) ............................................... 165

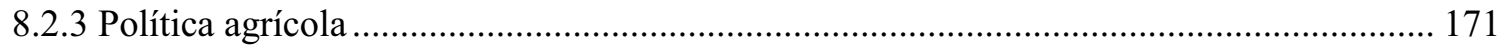

8.2.4 Política de transportes - eixos rodoviários ....................................................................... 174

8.3 Desdobramentos das ações de gestão do território ............................................................ 177

8.3.1 Desdobramentos e processos espaciais: expansão metropolitana de Brasília .................... 177

8.3.2 Desdobramentos e processos espaciais: a expansão da agropecuária moderna na Ride-DF

8.3.3 Desdobramentos e processos espaciais: a integração do Eixo Brasília-Anápolis-Goiânia 183

8.4 Síntese, fecho e ligação................................................................................................................................. 186

\section{A PRODUÇÃO DE SUBCENTROS E AS DESIGUALDADES SOCIOESPACIAIS NA}

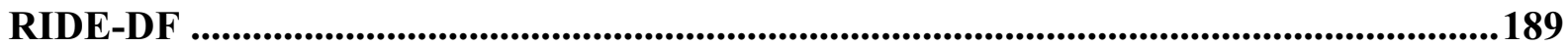

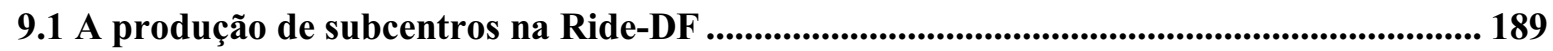

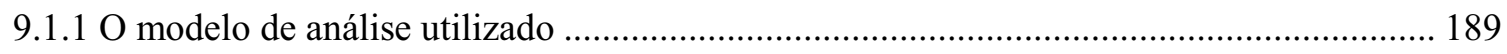

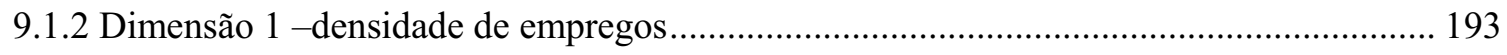

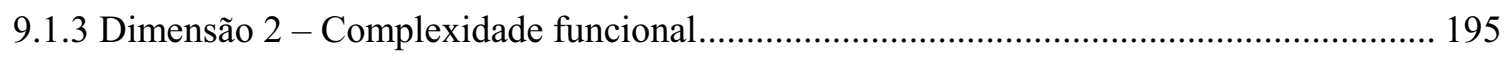

9.1.4 Dimensão 3 - polarização....................................................................................... 218

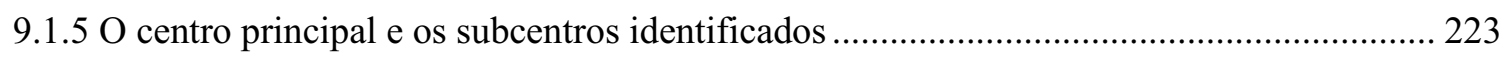

9.2 Os efeitos sobre as desigualdades socioespaciais na Ride-DF ................................................. 229

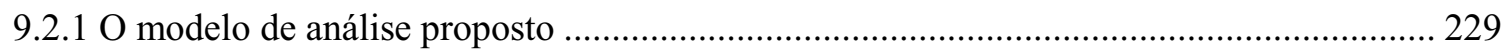

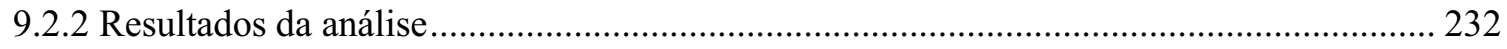




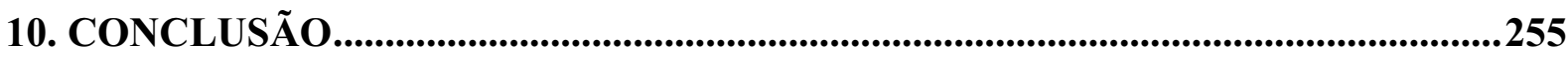

10.1 Análise e discussão dos resultados obtidos ............................................................................. 255

10.2 Limitações e perspectivas de pesquisa ………………........................................................................ 261

REFERÊNCIAS BIBLIOGRÁFICAS .....................................................................263

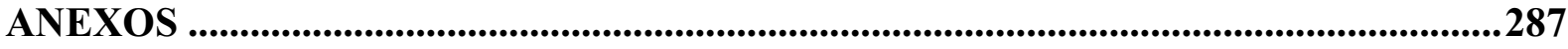

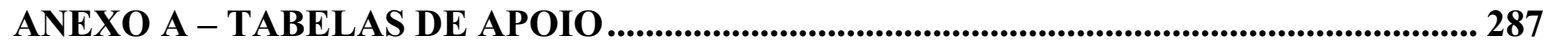

ANEXO B - LEGISLAÇÃO REFERENTE À RIDE-DF .................................................. 299 


\section{LISTA DE FIGURAS}

Figura 7.1 - Escalas de abrangência do Pergeb. ............................................................. 128

Figura 7.2 - Região de influência de Goiânia, segundo o estudo da REGIC de 1987........ 147

Figura 8.1 - Municípios pertencentes à Região Integrada de Desenvolvimento do

Distrito Federal e Entorno........................................................................................... 160

Figura 8.2 - Municípios da Ride-DF e da AMB...................................................... 168

Figura 8.3 - Eixos Nacionais de Integração e Desenvolvimento.................................... 175

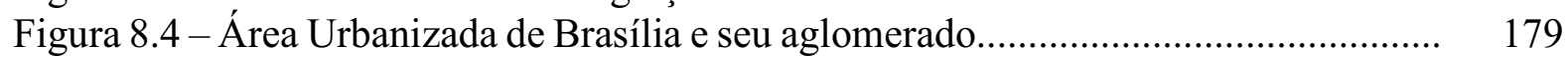

Figura 8.5 - Ride-DF, Anápolis, Região Metropolitana de Goiânia e a BR 060.............. 185

Figura 8.6 - Processos estruturantes do espaço da Ride-DF........................................ 187

Figura 9.1 - Subcentros identificados na Ride-DF................................................... 226

Figura 9.2 - Subcentros identificados, área urbanizada e processos estruturantes na Ride-DF.

Figura 9.3 - Classificação dos municípios da Ride-DF a partir da tipologia proposta para renda e crescimento da economia.............................................................................. 236

Figura 9.4 - Regionalização sugerida para os municípios da Ride-DF............................ 244

\section{LISTA DE FOTOS}

Foto 9.1 - Rua da Câmara de Vereadores e centro de Novo Gama-GO.......................... 245

Foto 9.2 - Loja do McDonald's em Valparaíso de Goiás-GO......................................... 246

Foto 9.3 - Luziânia Shopping, no centro da cidade de Luziânia-GO............................... 247

Foto 9.4 - Lavoura nos arredores da cidade de Luziânia-GO (margens da GO 010)........ 247

Foto 9.5 - Lavoura em Unaí-MG............................................................................. 248

Foto 9.6 - Edifício residencial em Buritis-MG............................................................. 249

Foto 9.7 - Concessionária da John Deere em Cristalina-GO......................................... 249

Foto 9.8 - Silos de armazenagem em Padre Bernardo - GO........................................... 250

Foto 9.9 - Pastagem em Mimoso de Goiás-GO............................................................. 251

Foto 9.10 - Outlet Premium em Alexânia-GO.................................................................. 252

Foto 9.11 - Silo de armazenagem, na franja urbana de Alexânia-GO............................. 252

Foto 9.12 - Igreja Matriz de Pirenópolis-GO................................................................ 253 


\section{LISTA DE TABELAS, QUADROS E GRÁFICOS}

Tabela 6.1 - População residente nos municípios que formam a atual Ride-DF, 1970..... Tabela 7.1 - Investimentos realizados no ano - agropecuária - variação entre os anos pesquisados $(1975,1980$ e 1985).

Tabela 7.2 - Área colhida - lavoura temporária - variação, em percentual.

Tabela 7.3 - Valor adicionado bruto ao PIB municipal, em percentual, dos municípios do Entorno, por setor (agregado), 1985.

Tabela 7.4 - Valor Total dos Rendimentos recebidos - variação, em percentual, entre os anos registrados $(1970,1980$ e 1991).

Tabela 8.1 - População total (2000 e 2010), variação percentual e percentual da população da Ride-DF por município em 2010.

Tabela 8.2 - Esperança de vida da população dos municípios da Ride-DF, em 1991, 2000 e 2010.

Tabela 8.3 - Taxa de fecundidade da população dos municípios da Ride-DF, nos anos de 1991,2000 e 2010.

Tabela 8.4 - Financiamentos à agricultura e pecuária - valor total e per capita - 2000 - municípios goianos da Ride-DF.

Tabela 8.5 - Financiamentos à agricultura e pecuária - valor total e per capita - 2010 municípios goianos da Ride-DF.

Tabela 8.6 - Área dos estabelecimentos por método utilizado para irrigação dos municípios da Ride-DF em 2006, em percentual.

Tabela 8.7 - Variação, em percentual, da área plantada nos municípios da Ride-DF........ Tabela 9.1 - Número total de empregos no município, população e densidade de empregos nos municípios da Ride-DF.

Tabela 9.2 - Total de unidades do setor comercial, unidade do setor comercial per capita e densidade de empresas do setor comercial, para os municípios da Ride-DF 2006.

Tabela 9.3 - Grandes equipamentos de consumo na Ride-DF - 2016.

Tabela 9.4 - Número de agências bancárias, população, agências bancárias per capita e resultado do cálculo de densidade das agências bancárias para a Ride-DF.....

Tabela 9.5 - Densidade de matrículas, número de matrículas de nível superior, população e matrículas per capita, nos municípios da Ride-DF.

Tabela 9.6 - Agências da Previdência Social, Receita Federal e Regionais do Trabalho, e resultado quanto à função de prestação de serviços públicos do Executivo Federal 2016.

Tabela 9.7 - Varas da Justiça Federal, da Justiça do Trabalho e do Poder Judiciário Estadual na Ride-DF - 2016.

Tabela 9.8 - Total de leitos, população, leitos per capita e resultado do cálculo de densidade das leitos para a Ride-DF - 2016.

Tabela 9.9 - Especialização e existência de hospitais nos municípios da Ride-DF 2016.

Tabela 9.10 - Densidade de procedimentos cirúrgicos, procedimentos cirúrgicos, por local de internação, população, procedimentos cirúrgicos per capita nos municípios da Ride-DF.

Tabela 9.11 - Número de empresas, população, empresas per capita e densidade de empresas do setor "agricultura, pecuária e serviços relacionados" - 2006. 
Tabela 9.12 - Pessoal ocupado, população, pessoal ocupado per capita e densidade do pessoal ocupado nas empresas do setor "agricultura, pecuária e serviços relacionados" $-2006$.

Tabela 9.13 - Pessoas que frequentavam escola ou creche e resultado da caracterização da polarização - 2010 .

Tabela 9.14 - Pessoas de 10 anos ou mais de idade, ocupadas, por local de ocupação, e resultado quanto à polarização.

Tabela 9.15 - Renda per capita, faixa de percentual da renda per capita da região e tipologia de renda, por município da Ride-DF, 2010.

Tabela 9.16 - PIB nos anos de 2000 e 2010 (em mil reais), variação percentual do PIB e classificação das economias, por municípios da Ride-DF

Tabela 9.17 - População total nos anos de 2000 e 2010, variação percentual e classificação do crescimento demográfico, por municípios da Ride-DF.

Tabela 9.18 - Índice de Gini (2000 e 2010), variação percentual, tipologia renda e crescimento e divisão por processo estruturante, na Ride-DF

Gráfico 8.1 -Área total plantada na Ride-DF (hectares).

Quadro 9.1 - Comparativo dos resultados para a função comercial para os municípios da Ride-DF

Quadro 9.2 - Comparativo dos resultados para a função prestação de serviços de saúde para os municípios da Ride-DF

Quadro 9.3 - Comparativo dos resultados para a função prestação de serviços e comércio direcionado para a agropecuária para os municípios da Ride-DF

Quadro 9.4 - Resultado final da análise da complexidade funcional.

Quadro 9.5 - Resultados da polarização dos municípios da Ride-DF, em relação ao centro principal ou outros subcentros.

Quadro 9.6 - Resultado final das dimensões de análise dos subcentros

Quadro 9.7 - Tipologias de renda e dinamismo da economia, por municípios da RideDF. 


\section{LISTA DE ABREVIATURAS E SIGLAS}

AIH - Autorizações de Internação Hospitalar

AMB - Área Metropolitana de Brasília

ANTT - Agência Nacional de Transportes Terrestres

AUB - Aglomerado Urbano de Brasília

Basa - Banco da Amazônia S. A.

BNB - Banco do Nordeste

BNH - Banco Nacional da Habitação

CAI - Complexo Agroindustrial

CBD - Central Business District

CEF - Caixa Econômica Federal

CNAE - Classificação Nacional de Atividades Econômicas

CNDU - Conselho Nacional de Desenvolvimento Urbano

CNPU - Comissão Nacional das Regiões Metropolitanas e Política Urbana

Coaride - Conselho Administrativo da Região Integrada de Desenvolvimento do Distrito Federal e Entorno

Conviver - Programa de Desenvolvimento Integrado e Sustentável do Semiárido

Condel/ Sudeco - Conselho Deliberativo do Desenvolvimento do Centro-Oeste

Corsap DF/GO - Consórcio Público de Manejo dos Resíduos Sólidos e de Águas Pluviais

Região Integrada do Distrito Federal e Goiás

Embrapa - Empresa Brasileira de Pesquisa Agropecuária

ENIDs - Eixos Nacionais de Integração e Desenvolvimento

EPIA - Estrada Parque Indústria e Abastecimento

FCO - Fundo Constitucional de Financiamento do Centro-Oeste

FDCO - Fundo de Desenvolvimento do Centro-Oeste

FNE - Fundo Constitucional de Financiamento do Nordeste

FNO - Fundo Constitucional do Norte

Fundefe - Fundo de Desenvolvimento do Distrito Federal

GER - Grupo Executivo de Remoções

IBGE - Instituto Brasileiro de Geografia e Estatística

MDA - Ministério do Desenvolvimento Agrário

Minter - Ministério do Interior 
MTE - Ministério do Trabalho e Emprego

PAC - Programa de Aceleração do Crescimento

PDOT - Plano Diretor de Ordenamento Territorial

PEDCO - Plano Estratégico de Desenvolvimento do Centro-Oeste

Peot - Plano Estrutural de Organização Territorial do Distrito Federal

Pergeb - Programa Especial da Região Geoeconômica de Brasília

Pladesco - Plano de Desenvolvimento Econômico e Social do Centro-Oeste

Planidro - Plano Diretor de Água, Esgoto e Controle da Poluição do Distrito Federal

PMAD - Pesquisa Metropolitana por Amostra de Domicílios

PMCMV - Programa Minha Casa Minha Vida

PND - Plano Nacional de Desenvolvimento

PNDU - Política Nacional de Desenvolvimento Urbano

PNDR - Política Nacional de Desenvolvimento Regional

Poloamazônia - Programa de Polos Agropecuários e Agrominerais da Amazônia

Polocentro - Programa de Desenvolvimento dos Cerrados

POT - Plano de Ocupação Territorial do Distrito Federal

PPA - Plano Plurianual

PRDCO - Plano Regional de Desenvolvimento do Centro-Oeste

Prodoeste - Programa de Desenvolvimento do Centro-Oeste

Prodecer - Programa de Cooperação Nipo-Brasileira para o Desenvolvimento dos Cerrados

Promeso - Promoção da Sustentabilidade de Espaços Sub-regionais

Proride - Programa Especial para o Desenvolvimento do Entorno do Distrito Federal

RA - Região Administrativa

Rais - Relação Anual de Informações Sociais

Regic - Estudo das Regiões de Influência das Cidades Brasileiras

Ride-DF - Região Integrada de Desenvolvimento do Distrito Federal e Entorno

SCO/ MI - Secretaria de Desenvolvimento do Centro-Oeste

Serfhau - Serviço Federal de Habitação e Urbanismo

Sepre - Secretaria Especial de Políticas Regionais

SFH - Sistema de Financeiro da Habitação

SHIS - Sociedade de Habitações de Interesse Social

SNCR - Sistema Nacional de Crédito Rural

Sudesul - Superintendência do Desenvolvimento da Região Sul

Sudam - Superintendência de Desenvolvimento da Amazônia 
Sudeco - Superintendência do Desenvolvimento do Centro-Oeste

Sudene - Superintendência do Desenvolvimento do Nordeste

Suframa - Superintendência para o Desenvolvimento da Zona Franca de Manaus 


\section{INTRODUÇÃO}

A reestruturação da produção capitalista das últimas décadas, com o aumento da flexibilidade na fabricação industrial, emergência dos serviços e grande expansão das finanças, tem impactado na produção dos espaços urbanos e regionais em todo mundo. A dinâmica produtiva contribui para acentuar tendências de reforço ao centro principal, ao lado de uma dispersão dos espaços de assentamento e do surgimento de centralidades em áreas periféricas, além do acirramento das desigualdades socioespaciais. No Brasil, tal tendência tem se manifestado a partir da descentralização de investimentos e do surgimento de novos espaços associados à agropecuária moderna e à indústria. Apresentando processos análogos, a Região Integrada de Desenvolvimento do Distrito Federal e Entorno (Ride-DF), tendo como núcleo dominante Brasília - o Distrito Federal - é composta também por municípios de Goiás e Minas Gerais. Dessa forma, o objetivo desta pesquisa é compreender as modificações recentes na organização espacial da Ride-DF, no quadro da reestruturação produtiva. O argumento central da tese é que essa dinâmica foi estabelecida na região a partir da construção de Brasília e instalada por meio de três processos estruturantes: a expansão metropolitana, a expansão da agropecuária moderna e a integração do eixo Brasília-Anápolis-Goiânia. O amplo processo, apoiado na ação governamental e em iniciativas de agentes privados, expressou-se particularmente na emergência de subcentros regionais e na acentuação das desigualdades socioespaciais internas. Marcados pela inauguração da capital brasileira em 1960, os processos em curso na Ride-DF remontam a uma evolução histórico-geográfica ampla.

\subsection{Reestruturação produtiva capitalista e os espaços regionais: dinâmicas e efeitos em escala global}

O modelo de desenvolvimento do capitalismo mundial do pós-guerra até meados da década de 1970, caracterizou-se por sua forte associação ao capital estatal. Tal associação deu-se pelo estabelecimento da garantia do consumo e da reprodução da classe trabalhadora por parte do Estado, e pela produção do capital privado, porém nas bases rígidas do fordismo. Em 
termos espaciais, Swyngedouw ${ }^{1}$ (apud HARVEY, 1992, p. 167-169) aponta como características: a especialização funcional e a dicotomia centralização/ descentralização; a busca pela homogeneização do espaço e por uma divisão espacial do trabalho; uma distribuição mundial de contratantes e subcontratantes. Nesse quadro, Lipietz (1988) considera uma hierarquia de regiões que inclui aquelas que reúnem atividades de direção e valorização; as de produção qualificada; e as de montagem não qualificada. No cerne desse agrupamento estaria uma metrópole internacional ou nacional, concentrando a valorização financeira e os avanços tecnológicos do processo de trabalho, que poderia ser complementada por níveis metropolitanos menos elevados.

Após a crise do fordismo, a reestruturação da economia levou a um regime de produção menos regulado, com menor participação do Estado no planejamento e direção da economia, propiciando maior protagonismo ao capital e sua circulação mais livre, ou flexível, segundo Harvey (1992). A produção passa a se organizar em cadeias mais heterogêneas, compostas de empresas diversas, com a subcontratação de empresas nos processos mais elementares e menos técnicos de produção, resultando em piora nas condições trabalhistas (DUPAS, 2001). O peso relativo da indústria na economia diminui, enquanto há uma emergência dos serviços e uma desregulamentação na economia, favorecendo um enorme crescimento do ramo financeiro.

Nesse contexto, a dinâmica regional reflete as movimentações do capital no território em busca de valorização, a articulação de espaços produtivos do primário e do secundário e o crescente papel dos serviços avançados nos circuitos produtivos. A continuada dependência dos processos econômicos territorializados a uma infraestrutura adequada e a fluxos contínuos de pessoas, mercadorias e informações contribuiu para a intensificação das relações entre metrópoles e regiões. Em termos espaciais, Swyngedouw aponta para as seguintes características para o regime de acumulação que seguiu o fordismo: "agregação e aglomeração espaciais; integração espacial; diversificação do mercado de trabalho; e proximidade espacial de firmas verticalmente quase integradas" (apud HARVEY, 1992, p. 168).

Este quadro tem levado à alteração de diversos processos fundamentais ao entendimento dos espaços regionais, podendo ser destacados ao menos três: a expansão

\footnotetext{
${ }^{1} \mathrm{O}$ texto de Erik Swyngedouw referido por Harvey é de 1986 e se intitula "The socio-spatial implications of innovation in industrial organizations, " Working Paper, $N^{\circ}$ 20, Johns Hopkins European Center for Regional Planning and Research. Lille.
} 
metropolitana, os novos espaços apropriados pela agropecuária moderna e a integração dos espaços em eixos e redes. Sobre o primeiro processo espacial, Salgueiro (1994) identifica o surgimento destas novas formas urbanas, em movimentos que adquirem nomes diversos na literatura especializada: desurbanização, exurbanização, edge cities entre outros. Em uma compreensão com maior interface com os efeitos regionais, Veltz (1996) aponta para uma nova realidade do processo de metropolização, cada vez mais marcado pela fragmentação dos espaços metropolitanos e de suas regiões próximas (daí ele falar na ideia figurada de um arquipélago, para definir tais metrópoles e suas regiões).

Quanto ao segundo processo mencionado, a expansão da agropecuária moderna, Elias (2003) aponta para um processo constante de internacionalização das atividades agrícolas, alinhada à lógica mais recente da globalização. Assim, na atualidade "a agricultura se realiza de forma globalizada, se não na sua produção propriamente, na sua circulação, distribuição ou seu consumo, mostrando-se uma das atividades mais contagiadas pela revolução tecnológica" (ELIAS, 2003, p. 59). A autora aponta que, no momento mais recente, há um predomínio do capital e da tecnologia como fatores de produção. Daí que, especialmente pelas novas bases tecnológicas, há a necessidade de incorporação de novos espaços, os quais tem sua dinâmica produtiva fortemente alterada. Muitas cidades passam a prestar serviços diretamente a estes espaços de produção moderna, sendo incorporados em redes articuladas em nível global.

Já sobre a estruturação de eixos e redes, Castells (1999) argumenta no sentido de uma sociedade da informação, cuja estrutura básica é a constituição de redes. As principais cidades tornam-se nós deste processo de articulação global, demandando, para poder exercer os papeis necessários de gestão do capital global, redes de infraestrutura dedicadas às trocas de informações, bens e pessoas em escala global. Por outro lado, Randolph (2002) afirma que o processo não é apenas uma mera expansão dos espaços metropolitanos tradicionais, mas um novo padrão de metrópole, organizado não mais na lógica centro-periferia, mas numa lógica regional e de redes. Regionalmente, a estruturação destas redes permite visualizar os pontos "luminosos" (mais integrados, inclusos) e os pontos "opacos" (menos integrados, excluídos) de tal processo de integração, já que ele ocorre de forma altamente seletiva (SANTOS; SILVEIRA, 2001).

Tendo em mente as modificações nos processos acima mencionados, estes (juntamente com outros) levarão a que, nas regiões, verifiquem-se duas alterações significativas, dentre outras: a produção de subcentros, em escala regional; o acirramento das desigualdades socioespaciais internas. Sobre a produção de subcentros, diversos estudos, para o caso europeu, têm apontando para o surgimento de subcentros em nível regional a partir de 
diversos fatores, tais como segundas residências de turismo e tendo como principal agente o capital imobiliário (ARTIGUES; RULLAN, 2007). Para o caso latino-americano, Heinrichs et al (2009) identificam também forte atuação do mercado imobiliário no fenômeno, responsável por um primeiro momento de expansão do tecido urbano e consequente surgimento de subcentros. Os trabalhos de Borsdorf (2003) e Janoschka (2002), apontam para o mesmo processo. Os estudos têm se centrado no tema dos subcentros em um contexto metropolitano e na sua interface regional. Além disto, ao lado da grande criação de riquezas envolvida no processo, há efeitos sobre o aumento das desigualdades.

A discussão sugere também que, a partir da reestruturação econômica em diferentes setores e de mudanças no papel do Estado e das políticas públicas, com amplas repercussões sociais, há uma série de processos atuantes no crescimento urbano e metropolitano. Essa complexa dinâmica tem contribuído para manter e expandir uma articulação regional e, ainda, promover um crescimento desconcentrado, mas também disperso, das malhas metropolitanas. Nesse contexto, enquanto as centralidades principais renovam seu poder de atração, novas nucleações operam como áreas de aglomeração de atividades de comércio e serviços. Nos Estados Unidos, as novas centralidades parecem estar diretamente ligadas a atividades de serviços e de consumo de luxo. No Brasil, parece haver algumas diferenças.

\subsection{Reestruturação produtiva e os espaços regionais nacionais}

No território brasileiro, as tendências atuais para os espaços regionais em escala global combinam a atuação de processos em rede com a articulação a centros urbanos, produzindo novas centralidades regionais e acirrando desigualdades socioespaciais. Há uma associação a tendências mais gerais, embora com particularidades. É possível analisar a forma pela qual as regiões brasileiras inserem-se neste contexto e assumem formas próprias, a partir de um olhar histórico sobre o processo.

Assim, em um primeiro período da análise, chamado de desenvolvimentista ${ }^{2}$ (19561985), o contexto geral socioeconômico no Brasil é o da instalação de um modelo periférico do fordismo (CIDADE, 1999a; CIDADE; VARGAS; JATOBÁ, 2008). Neste período viveu-se o auge e o declínio das políticas chamadas desenvolvimentistas, que pressupunham maior participação do Estado no processo de desenvolvimento econômico, sendo agente e financiador

\footnotetext{
${ }^{2}$ Nos capítulos de análise do tema na escala nacional serão melhor descritos os critérios adotados para a periodização.
} 
de diversas iniciativas. Em termos políticos o período é marcado pelo autoritarismo, que se manifestará em políticas públicas com forte perfil tecnocrático e pouca negociação com a base da sociedade.

Em termos de ações, ocorreu um momento de fortalecimento da ação estatal, com forte viés planejador e tecnocrático. No quadro regional, a atuação se deu pela tentativa de desconcentrar o parque industrial nacional e desenvolver as regiões ainda não atingidas pela modernização, realizado, de forma operacional, por órgãos do governo federal. Entretanto, para a questão específica do urbano e do metropolitano, tal visão planejadora careceu de unificação normativa e metodológica, prevalecendo nessa fase iniciativas locais de planejamento e gestão. Por outro lado, os agentes econômicos buscaram localizações próximas das áreas de maior investimento do Estado, ao passo que a população originária do campo se desloca para as grandes aglomerações urbanas, principalmente para a periferia destas.

Como desdobramentos de tais ações, os espaços regionais brasileiros demonstraram, inicialmente, uma concentração de renda e dos investimentos estatais e privados nas regiões Sudeste e Sul, no plano macrorregional. Em termos microrregionais tais desigualdades também se reproduzem, sendo mais brutais em regiões de reduzido desenvolvimento. A partir dos estímulos estatais, muitas atividades passam por desconcentração, como as indústrias, e há uma reorientação do avanço da agropecuária nacional. Alguns estudos analisam a desconcentração de atividades no âmbito das regiões metropolitanas, como sintomas deste processo, que ocorria em escala maior (LENCIONI, 2011; DAVIDOVICH, 2010). Além das atividades urbanas, novos espaços já dedicados à agropecuária moderna surgem, especialmente no Centro-Oeste brasileiro, alvo de vultuosos investimentos públicos e privados.

O segundo período, chamado de neoliberal (1986-2016), apresenta, no caso brasileiro, dois momentos - um em que houve a adoção da clara ortodoxia liberal e um outro, mais recente, em que houve relativização da ortodoxia, mas não de forma generalizada (algo chamado de novo desenvolvimentismo por Bresser-Pereira, 2006). Ocorre a redução do papel do Estado no planejamento e direcionamento do desenvolvimento econômico, o que leva a um momento de entrada de diversos agentes econômicos estrangeiros no país. Este assume um papel maior de coordenação das iniciativas e de fomento ao setor privado, algo bastante acentuado no período do "novo desenvolvimentismo". As políticas públicas ganham um viés de formulação e gestão mais democráticas, ainda que com restrições.

Além do papel de coordenador do desenvolvimento nacional, como ação, o Estado assume o papel de regulador dos agentes econômicos, que busca criar estímulos para que o 
capital privado assuma diversos serviços públicos. Acentua-se a redução do tamanho do Estado, ao passo que, por outro lado, o planejamento de longo prazo, em bases estratégicas (ao menos do ponto de vista formal), passa a ganhar força. Os agentes privados mantêm a tendência de tomar a primazia das ações, o que parece se reforçar mais recentemente como desdobramento da crise política e econômica.

Como desdobramentos, no quadro regional, houve um reforço à tendência já anteriormente verificada ao término do período anterior, de desconcentração da produção (especialmente a industrial), porém com circunscrição ainda restrita ao Sul e Sudeste brasileiros (é verdade que surgiram polos industriais em outras regiões, mas ainda de forma esparsa). Manteve-se o avanço da produção agrícola moderna, com a incorporação quase total do CentroOeste e o avanço desta fronteira para o Norte. Num outro movimento, as redes de articulação e troca entre os espaços urbanos tem sido densificadas, apesar das deficiências na infraestrutura.

Especificamente sobre o tema dos subcentros na escala das regiões metropolitanas brasileiras, a ampliação dos processos de reorientação da localização dos espaços produtivos em escala macrorregional, bem como a emergência de novos processos, como a implantação e expansão da agropecuária moderna têm levado à produção destes pontos em suas estruturas regionais. A expansão metropolitana tem resultado em espaços mais dispersos e com a formação de subcentros no espaço metropolizado e nas suas regiões imediatas, criando, nos casos mais extremos como de São Paulo, uma ampla região urbanizada pontuada de centros de diversas atividades (LENCIONI, 2011). A recente coleção do Observatório das Metrópoles, "Transformações na ordem urbana", tem observado fenômenos próximos, em menores proporções, em muitos dos espaços das Regiões Metropolitanas, a partir do deslocamento e surgimento de novas atividades nas franjas metropolitanas. Por outro lado, novos espaços tem sido ressignificados e refuncionalizados a partir do avanço da agropecuária moderna, naquilo que Elias e Pequeno (2007) chamam de "cidades do agronegócio". Vale lembrar que muitos destes processos que levam ao surgimento de subcentros e à concentração de recursos em municípios/ espaços específicos das regiões metropolitanas têm levado a um "parceiro dialético", o acirramento das desigualdades socioespaciais, caso dos novos espaços urbanizados de apoio ao agronegócio.

Comum a distintas dinâmicas parece ser um quadro regional dominado por redes e uma relação metrópole-região de tipo cada vez mais fragmentado, impulsionado por cadeias produtivas diversas e sobrepostas no território metropolitano e regional. Como desdobramento do processo de reestruturação produtiva no território nacional, em escala metropolitana e em sua região imediata, observa-se o surgimento de subcentros de diferentes tipos, bem como um 
aumento nas desigualdades socioespaciais. Com particularidades, quadro semelhante parece estar ocorrendo na Ride-DF.

\subsection{Reestruturação produtiva e o espaço da Ride-DF}

A Região Integrada de Desenvolvimento do Distrito Federal e Entorno (Ride-DF), por um lado, apresenta características que podem ser consideradas regionais e, por outro, compartilha da dinâmica recente das metrópoles brasileiras. Instituída enquanto um complexo geoeconômico e social voltado para a articulação de ações para o desenvolvimento e a redução das desigualdades regionais, a Ride-DF inclui municípios dos estados de Goiás e Minas Gerais e, ainda, o Distrito Federal. Brasília, centro polarizador da região, é classificada pelo estudo das Regiões de Influência das Cidades (Regic) - do Instituto Brasileiro de Geografia e Estatística (IBGE, 2008), como Metrópole Nacional.

Englobando uma vasta área, a Ride-DF inclui a capital administrativa e política do país, Brasília, que se caracteriza de forma predominante, por atividades terciárias. Abrange também parte de um corredor dinâmico de base agrícola e industrial - o eixo Brasília-AnápolisGoiânia - e, ainda, áreas de produção primária e agroindustrial com distintos níveis e formas de integração às funcionalidades metropolitanas. Com uma institucionalização formal, sem contrapartidas financeiras, políticas e técnicas suficientes dos órgãos que nela atuam para promover o desenvolvimento regional preconizado, a Ride-DF tem sido frequentemente tomada como com um espaço metropolitano. Na realidade, seria mais apropriado considerar que há uma metrópole dentro desta região, que, por sua vez, abarca um espaço maior e apresenta outras dinâmicas.

Embora mudanças na forma da metrópole contemporânea globalizada, incluindo o crescimento disperso, tenham sido atribuídas, em larga medida, à flexibilização de processos industriais, em Brasília, cidade governamental e terciária, esse não poderia ser o caso. Em um contexto de elevada valorização da terra e dos imóveis na área central e de grande disparidade na distribuição de renda, estabeleceu-se, a partir da construção da cidade, uma organização espacial polinucleada. Na fase atual, em que diferenças ocupacionais e de renda acentuam as desigualdades e a segregação socioespacial, intensifica-se uma expansão urbana dispersa. Acrescenta-se, ainda, uma crescente articulação de atividades metropolitanas com frentes de expansão agrícola, enquanto os limites da área urbanizada começam a se confundir com nucleações rurais próximas. No agregado regional da Ride-DF, os possíveis efeitos da 
reestruturação produtiva sobre a organização do espaço, embora notados, ainda não estão plenamente reconhecidos.

Para iniciar a compreensão do tema, é necessária uma breve reconstituição histórica. Em um primeiro período, chamado de implementação das bases territoriais ${ }^{3}$ (19561969), há, na escala dos municípios goianos e mineiros do espaço que viria a ser a Ride-DF, um contexto de municípios pequenos e de população rarefeita, numa região cuja ocupação inicial esteve ligada ao longínquo ciclo econômico da mineração e que então estava afastada da expansão econômica do Estado de Goiás, centrado na construção de Goiânia. Conforme Miragaya (2010), a economia desta região estava pautada na produção agropecuária de subsistência. Considerando ainda o contexto nacional, de ações que visavam a integração das economias nacionais, houve na região específica, como principais ações, o esforço empreendido para a construção a Nova Capital, demandando organização das prefeituras aí existentes em comitês específicos. Como desdobramentos, tais municípios cederam parte de seus territórios à Nova Capital, passaram por mudanças internas (como a construção de novos bairros, ou o surgimento de núcleos urbanos fora do centro principal, em geral ao redor das principais rodovias de ligação) e passaram, na prática, a orbitar ao redor do novo centro que se construía. Como demonstra Magalhães (2010), havia uma expectativa de que a Nova Capital trouxesse o almejado desenvolvimento a uma região quase "esquecida" do Estado de Goiás e parte do Estado de Minas Gerais; na prática, tal expectativa foi aos poucos sendo revertida.

Na escala do Distrito Federal, o contexto geral aponta para a rápida implantação da Nova Capital, em bases autoritárias, dada a urgência da construção de Brasília. Esta tendência se manteve por todo o período, internamente ao quadrilátero, tanto durante a construção da cidade quanto nos primeiros anos após isto. As ações foram, assim, pautadas num planejamento urbano moderno e rigoroso, que se tentou manter a todo custo, ainda que com a segregação das populações mais pobres. Como desdobramentos, produziu-se uma cidade polinucleada, marcada por um centro principal dedicado a atividades da administração pública e nucleações de caráter "dormitório" afastadas.

Assim, no quadro regional, ia se formando uma região nova, a partir do fato novo da construção da Capital Federal num ponto do território em que as redes técnicas ainda parcamente chegavam. Brasília transformou a realidade deste "canto" do Estado de Goiás e parte de Minas Gerais, modificando profundamente o cotidiano e a produção do espaço de uma

\footnotetext{
${ }^{3}$ A periodização adotada visou dividir o estudo a partir, principalmente, da atuação dos principais processos de organização e estruturação da região em análise. Nos capítulos específicos de análise da temática maiores explanações sobre isso serão feitas.
} 
região pouco habitada e com economia voltada à sua subsistência. É importante ressaltar que o otimismo dos primeiros anos logo deu lugar à desconfiança em relação à Nova Capital por parte da população dos municípios afetados, já que o sonhado desenvolvimento não chegou. A construção de rodovias e a implantação da Capital tiveram como desdobramentos o início dos processos espaciais que dão origem ao que hoje se chama de Entorno de Brasília, além de criar a base para um eixo entre a então jovem capital federal e a então também jovem capital goiana. Neste primeiro momento, a implantação de Brasília não levou a uma ampla revolução na base técnica da produção agrícola, mas com a infraestrutura necessária para sua construção iam se criando as bases para a expansão da agricultura moderna em fases seguintes.

Numa segunda fase, chamada aqui de formação metropolitana e implantação da agropecuária moderna (1970-1985), na escala dos municípios goianos e mineiros da Região de Brasília havia um contexto socioeconômico de mudanças provocadas pelas alterações promovidas pela implantação na Nova Capital. Neste cenário, inicia-se o processo de evolução técnica da agropecuária, abandonando seu caráter anterior de subsistência. Em tal quadro, as ações apontam para uma preocupação maior com o planejamento regional em torno de Brasília, cujo principal marco foi o Programa Especial para a Região Geoeconômica de Brasília (Pergeb). Apesar da tentativa de um efetivo planejamento regional, muitas das ações deste programa não se concretizaram. Por outro lado, o estímulo dado pelo Estado brasileiro à agropecuária moderna atingirá a região de Brasília, neste primeiro momento a partir, principalmente, de Unaí e Formosa, por meio das ações do Programa de Desenvolvimento de Cerrados (Polocentro). Daí tem-se como desdobramentos a implantação de bases mais modernas na agropecuária local, restrita ainda à porção leste da região. Em uma outra frente, verificam-se mudanças no âmbito do espaço urbano dos municípios vizinhos a Brasília, com atuação do mercado imobiliário no sentido de ofertar terras à população imigrante (em alguns casos, em conjunto com as prefeituras). Por outro lado, os municípios vizinhos ao Distrito Federal são atingidos pela expansão urbana e formação da metrópole brasiliense, passando a ter espaços integrados ao processo de metropolização. Nos outros municípios, não se verificava a integração a estes processos.

No Distrito Federal o contexto aponta para sua consolidação como Capital Federal, implicando na transferência definitiva de órgãos da administração pública. O setor terciário se consolida e se expande, em torno das atividades governamentais. Como principais ações, passou a haver um planejamento mais claro para toda a extensão do território do Distrito Federal, a partir do Plano Estrutural de Organização Territorial do Distrito Federal (Peot), de 1978. O governo buscou controlar o mercado de terras e sua oferta, o que aumentou a 
especulação e a busca por novos espaços. Como desdobramentos, a cidade irá se expandir, novas cidades-satélites são construídas e o processo atingirá os municípios vizinhos. Ao término deste período, a cidade ia ganhando claros contornos de centro de uma metrópole em formação e de uma região de influência que ia se ampliando, à medida que mais claramente ia se pondo como Capital Federal.

Desta forma, o quadro regional resultante aponta para um maior dinamismo de dois processos: a expansão urbana, que mais ao término do período se converte em expansão metropolitana; e a evolução técnica da agropecuária, que culminará na implantação de espaços da agropecuária moderna. Tal processo não atingia a toda a região que seria, já nessa época, enunciada como Entorno de Brasília (sua delimitação mais próxima já era dada pelo Pergeb). Algumas porções mantinham a tendência de uma produção de subsistência e de espaços urbanos pequenos. Ainda como desdobramento, vê-se o surgimento dos primeiros indícios de subcentros regionais, em Unaí e Formosa, decorrente da evolução da agropecuária. No quadro das desigualdades socioespaciais internas, a consolidação da metropolização e da expansão da agropecuária moderna levaram ao acirramento das desigualdades. Tornou-se mais evidente o contraste entre a urbanização acelerada de Brasília, a modernização do campo e a realidade dos municípios não participantes destas dinâmicas (mesmo naqueles participantes, especialmente como periferias metropolizada, o contraste com o centro, Brasília, ganhava contornos e realidade mais clara).

Finalmente, no período mais recente, chamado aqui de expansão metropolitana, expansão da agropecuária moderna e integração do eixo Brasília-Anápolis-Goiânia (19862016), na escala dos municípios goianos e mineiros da Ride-DF há um contexto socioeconômico de diversificação produtiva, impulsionado, principalmente, pela agropecuária moderna. Persiste uma clara dependência de Brasília, porém já se encontram municípios com novos perfis econômicos. Dentre as ações, vê-se que a política para o tema regional de Brasília acabará por formalizada e identificada pela Lei Complementar nº 94/1998, que cria a Ride-DF, para, segundo o texto legal, "efeitos de articulação da ação administrativa da União, dos Estados de Goiás e Minas Gerais e do Distrito Federal”. Apesar da "criação" de uma região oficial para coordenar as ações dos Governos Federal, Estaduais e Distrital, as políticas públicas têm se mostrado desarticuladas e com impactos reduzidos. Por outro lado, o apoio à produção na agropecuária tem crescido, a partir do uso de mecanismos de fomento à produção. É ainda importante mencionar os investimentos realizados na estruturação do eixo que liga Brasília com Goiânia, destacando-se a duplicação das BRs 060 e 153. Como desdobramentos, há a consolidação da agropecuária moderna na porção leste da região e seu avanço ao sul. A oeste, 
principalmente nos municípios de Alexânia e Abadiânia, passa a atuar mais claramente a integração do eixo Brasília-Anápolis-Goiânia, com o recebimento de novos investimentos (dos quais o Outlet Premium e investimentos no setor de transformação, como fábricas cervejeiras, sejam os que mais se destacam atualmente). Há ainda a continuidade da expansão metropolitana, que passa a afetar municípios a oeste e a norte do Distrito Federal.

No Distrito Federal o contexto aponta para a manutenção do peso do terciário e para a atração de investimentos neste setor. Brasília passa a oferecer bens e serviços mais diversificados e anteriormente vistos apenas nas cabeças da hierarquia urbana nacional ${ }^{4}$. Como principais ações, o planejamento territorial mantem sua tendência de institucionalização, apesar do descolamento com as efetivas práticas. A atuação do mercado imobiliário e suas pressões junto ao poder público libera novos espaços e permite a densificação em outros, ocorrendo de forma legal ou não. Como desdobramentos, ocorre a expansão urbana e a consolidação de Brasília como metrópole nacional, possuindo influência em todo o território nacional (IBGE, 2008). Diversos “vazios” urbanos são ocupados, além da verticalização de outros já ocupados anteriormente (sendo o principal caso, no momento, o Setor Noroeste).

Desta forma, o quadro regional resultante aponta para a atuação dos três principais processos responsáveis pela produção atual do espaço da Ride-DF: a expansão metropolitana de Brasília, a expansão dos espaços da agropecuária moderna e a integração do eixo BrasíliaAnápolis-Goiânia. Neste quadro de fragmentação regional, a perspectiva de uma área com característica geral de elevada dependência de Brasília, como se tinha antes, começa a alterarse, em consonância com a globalização produtiva e financeira e com processos controlados por centros de gestão que podem ser internacionais ou nacionais e se encontram, alguns deles, a muitos quilômetros da região. Surgem, ainda, na esteira destes processos, subcentros regionais ligados às três dinâmicas, ainda por desvendar, além de um aparente aprofundamento das desigualdades socioespaciais da região.

Assim, há a necessidade de estudo destas dinâmicas na região de Brasília, aqui tomada como sendo aquela assim instituída, a Ride-DF ${ }^{5}$. O novo quadro que se apresenta demanda um esforço de compreensão para a relação entre os três processos enunciados como os principais de sua estruturação, bem como a partir dos efeitos que tem causado na organização

\footnotetext{
${ }^{4}$ Algo que pode servir como termômetro desta diversificação diz respeito ao fato de Aeroporto Internacional Juscelino Kubitschek estar se consolidando como grande hub da aviação doméstica, além dos planos recentes de expansão deste equipamento.

${ }^{5}$ Como se verá, ao longo da argumentação do trabalho, a Ride-DF não corresponde totalmente à região sob influência de Brasília, mas sim a institucionalização de uma parte dela como espaço de ação e planejamento diferenciado do Governo Federal.
} 
espacial da região. Por este primeiro esforço já se percebe a clara fragmentação ocorrida na região de estudo, o que a aproxima, de certa forma do que vem ocorrendo em outros espaços regionais nacionais e internacionais.

Dada tal necessidade, alguns estudos têm se dedicado a elucidar alguns dos pontos/ dinâmicas aqui mencionados. Sobre o tema dos subcentros, há importantes pesquisas que tem verificado a formação de novos espaços desempenhando tal função na estrutura urbana de Brasília, especialmente em algumas cidades-satélites (como o Gama e Taguatinga), podendo mencionar os casos de Carvalho de Souza (2010) e Frazão (2009). Entretanto, há uma lacuna na pesquisa sobre o tema em nível regional. Neste, especificamente sobre a Ride-DF, destacase o trabalho de Queiroz (2007), cujas conclusões já apontavam para o quadro de região fragmentada descrito acima. O tema do eixo Brasília-Anápolis-Goiânia tem sido alvo de uma crescente produção acadêmica, podendo ser destacados trabalhos sobre municípios específicos, como o França (2009) analisando o caso de Alexânia. Miragaya (2003) analisa também o eixo, com foco nos efeitos da integração sobre a questão da migração de populações. Araújo Sobrinho (2008) analisa o tema do turismo no eixo Brasília-Goiânia, argumentando ser esta atividade uma das responsáveis pela produção do espaço desta região, tendo na estrutura de circulação um elemento fundamental.

Além do já mencionado trabalho de Queiroz, poucos outros tem se debruçado especificamente sobre a Ride-DF. Há uma grande quantidade de trabalhos dedicados à análise da questão metropolitana de Brasília, que acaba permeando a produção do espaço dos municípios vizinhos, mas estes tem feito uso de outros recortes espaciais na definição de seus objetos de estudo, como a Área Metropolitana de Brasília (AMB) ou o Aglomerado Urbano de Brasília (AUB).

Um trabalho que analise, de forma integrada, os três processos identificados como fundamentais na produção do espaço da Ride-DF, a expansão metropolitana de Brasília, a expansão dos espaços da agropecuária moderna e a integração do eixo Brasília-AnápolisGoiânia, é ainda uma ausência, apontando a necessidade de se redescobrir e analisar a região de Brasília. Esse é o objeto de estudo aqui proposto.

\subsection{Questões pesquisa, objetivos e hipóteses}

As considerações apresentadas no caminho da construção do problema sugerem que os processos em curso na Ride-DF e em seu núcleo polarizador principal, Brasília, representam 
formas territoriais em constante movimento. As relações entre o trajeto do capitalismo avançado e a dinâmica socioespacial da região em estudo, embora objetos de expressiva contribuição acadêmica, ainda guardam lacunas de compreensão. A discussão acima conduz às seguintes questões de pesquisa, que, de forma progressiva no tempo e nos recortes escalares, orientam as reflexões deste trabalho:

1. Sob que aspectos é possível discernir a influência da reestruturação produtiva capitalista em espaços de articulação metropolitana e regional brasileiros?

2. Como se constituiu historicamente a produção das bases territoriais de ocupação da região de Brasília?

3. Qual o papel dos processos de expansão metropolitana de Brasília, expansão da agropecuária moderna e integração do Eixo Brasília-Anápolis-Goiânia no sentido de estruturar e organizar o espaço da Ride-DF?

4. Como se relacionam os processos de consolidação de Brasília como centro principal e de produção de subcentros regionais, associados à dinâmica de desigualdades socioespaciais na Ride-DF?

Enquanto as duas primeiras questões abordam uma temática relativamente ampla e tem uma finalidade de contextualização, a terceira é menos geral e a quarta, mais específica. Assim, a aproximação inicia-se com uma visão referencial dos condicionantes históricos e espaciais dos processos em estudo e segue mais detalhada ao aproximar-se do foco.

Neste sentido, o objetivo geral deste trabalho é compreender as modificações recentes na organização espacial da Ride-DF, sob o pano de fundo da reestruturação produtiva. A partir daí, são os seguintes os objetivos específicos:

- Compreender a forma pela qual a reestruturação produtiva do capitalismo tem afetado a produção dos espaços regionais brasileiros, a partir, principalmente, da emergência de novos centros e do aumento das desigualdades regionais;

- Resgatar e reconstituir o processo de organização e estruturação do espaço regional de Brasília, especificamente seu espaço econômico-produtivo, a partir da 
identificação e análise das interações dos principais processos espaciais responsáveis;

- Compreender de que forma os processos de expansão metropolitana de Brasília, expansão da agropecuária moderna e integração do Eixo Brasília-Anápolis-Goiânia tem atuado na estruturação do espaço da Ride-DF;

- Identificar os subcentros regionais atualmente existentes na Ride-DF;

- Analisar a evolução recente das desigualdades socioespaciais internas a esta região;

Enuncia-se, a partir das discussões anteriores, a seguinte hipótese de trabalho: o processo de reestruturação produtiva manifesta-se na Ride-DF a partir de três processos, principais responsáveis pela estruturação deste espaço regional: a expansão metropolitana de Brasília, a expansão da agropecuária moderna e, mais recentemente a integração do Eixo Brasília-Anápolis-Goiânia.

\subsection{Aspectos metodológicos}

A pesquisa foi realizada, a partir de etapas que buscaram, a partir de uma contextualização inicial, constituir o problema de pesquisa e especificar a discussão em direção ao foco. Em seguida, a partir das principais dimensões envolvidas nas questões de pesquisa e hipóteses, buscaram-se bases de compreensão do processo em curso, analisando-o teoricamente. Passou-se, finalmente, a uma análise da temática por meio de uma aproximação histórica e escalar ao problema e ao foco. De forma mais prática, os procedimentos foram divididos em cinco etapas não estanques.

A primeira etapa consistiu em uma análise do estágio atual das pesquisas referentes ao tema da produção dos espaços metropolitano e regional contemporâneos e os impactos causados pelo processo de reestruturação produtiva e pelo atual funcionamento do modo de produção capitalista. Foi operacionalizada a partir de uma revisão bibliográfica de trabalhos publicados em periódicos nacionais e internacionais, referentes aos temas da reestruturação produtiva, da expansão dos espaços metropolitanos e da questão dos centros e subcentros. De forma mais concreta, esta etapa subsidiou o refinamento da construção do objeto e, em realimentações progressivas, das questões de pesquisa, dos objetivos e hipóteses.

Na segunda etapa foi feita uma revisão e discussão dos pressupostos teóricos, aprofundando o entendimento acerca das questões tratadas na pesquisa (constituem o segundo, 
terceiro e quarto capítulos deste trabalho). São tratados os seguintes temas: as diversas definições e enfoques da região; alguns processos fundamentais para compreensão do quadro regional em estudo e sua interface com a reestruturação produtiva - expansão metropolitana, evolução da agropecuária moderna e a implantação de infraestrutura como suporte aos fluxos e redes; a questão do centro e subcentros em escala regional e o tema das desigualdades regionais e socioespaciais.

Em seguida, na terceira etapa, a temática da reestruturação produtiva e seus efeitos regionais foi analisada em escala nacional. Foram analisadas as condições gerais de produção dos espaços regionais brasileiros, a partir de seu contexto socioeconômico. Em seguida, foi analisado o quadro de ações, tanto públicas quanto privadas, que possuem rebatimentos territoriais. Finalmente, buscou-se delinear possíveis desdobramentos ou efeitos dos processos analisados, principalmente, a partir da produção de novos centros e pelo aumento das desigualdades socioespaciais. Tal análise deu-se na escala macrorregional e nas Regiões Metropolitanas nas quais o IBGE (2008) reconhece dinâmica metropolitana. De forma prática, a terceira etapa foi realizada a partir de uma ampla revisão bibliográfica. Constitui o material do quinto capítulo.

Já a quarta etapa tratou da análise sobre o histórico da constituição do espaço de Brasília e de sua região. Foi mantida a lógica de análise do contexto socioeconômico, das ações de gestão do território e dos desdobramentos. Foi operacionalizada a partir de revisão bibliográfica e da análise de dados estatísticos disponíveis para a região, especialmente a composição do PIB dos municípios, e dados referentes às desigualdades socioespaciais internas. Esta análise deu-se de forma preliminar e em menor escala que na etapa seguinte, por conta da inexistência da mesma vastidão atual das bases de dados secundárias consultadas. Constitui o sexto e sétimo capítulos.

Na sequência, a quinta etapa constituiu-se do estudo do período mais recente da produção do espaço da Ride-DF. Assim como na etapa anterior, a análise do contexto socioeconômico e das ações de gestão de território foi realizada a partir de revisão bibliográfica. Já a análise dos desdobramentos das ações foi realizada a partir dos estudos referentes à identificação dos subcentros regionais na Ride-DF e da evolução mais recente da desigualdade socioespacial desta região. A partir deles, foi possível a elaboração de material cartográfico que permitiu a visualização e análise do desenrolar recente dos processos espaciais em estudo. Por fim, foi proposto um mapeamento da ocorrência destes processos bem como de uma tipologia interna para os municípios da Ride-DF. Constitui o oitavo e nono capítulos. 
Ao término, foram apresentadas as reflexões finais e as conclusões, indicando os achados, os avanços possíveis com esta pesquisa, suas limitações e outros temas/ questões/ dinâmicas que demandam maior aprofundamento, em trabalhos futuros. O próximo capítulo inicia a discussão teórica que servirá de subsídio para formar as bases de compreensão das análises. 


\section{A REGIÃo E SUA DISCUSSÃO: DA CLASSIFICAÇÃo DE ÁREAS À PERSPECTIVA DAS REGIÕES FRAGMENTADAS}

Este capítulo apresenta a primeira parte do debate teórico do trabalho. O quadro geral de referência é o da dinâmica histórica da acumulação de capital, buscando compreender possíveis mudanças e seus rebatimentos sobre a cambiante compreensão da região. A dinâmica de múltiplas atividades que se interligam reflete-se nos conceitos de região e em seus delineamentos. O debate ora proposto visa situar a forma de construção das regiões e o entendimento das diversas dinâmicas que aí se inserem. A contribuição desta fase do trabalho está na busca por se entender a problemática contemporânea da Ride-DF como região "oficial" (e mesmo a validade de sua existência) e a possibilidade de compreensão teórica dos processos variados que nela se situam.

A discussão proposta busca apresentar uma evolução cronológica não rígida para o tema, buscando compreender como a ideia e o conceito de região foi inserido e discutido, especialmente nos estudos da Geografia. No contexto da evolução histórica desta disciplina, e considerando a Ride-DF como uma região de planejamento do Estado, o interesse se inicia a partir da corrente teorética-quantitativa.

\subsection{A perspectiva da Geografia teorética-quantitativa}

O que aqui chamamos de perspectiva teorético-quantitativa, é chamada por Haesbaert (2014) de perspectiva neopositivista. Essa linha, que buscava promover a geografia como ciência usando a quantificação, foi dominante no pensamento norte-americano da disciplina a partir da década de 1950 e influenciou bastante a área no Brasil. Como características gerais, este autor aponta a importância da classificação de áreas, superando o paradigma da Geografia clássica de apenas diferenciar áreas. Eram buscadas, essencialmente, as características que pudessem dar unidade às regiões, com interesse de, para elas, elaborar amplas tipologias (buscavam-se similaridades entre diversos objetos).

Neste contexto, a região foi um conceito privilegiado nesta corrente, tendo obtido expressivas contribuições de Brian Berry (1968). Ele retoma, inicialmente, os procedimentos padrão de regionalização até então existentes (vindos das correntes clássicas em Geografia, especialmente a francesa), baseados na perspectiva da classificação: o primeiro seria a busca pela homogeneidade; o segundo, a busca pela regionalização e pela ideia de nodalidade das 
regiões; a terceira atenderia a perspectiva da região criada a partir da orientação para as políticas, para os programas de atuação (de empresas, do Estado). Berry propõe um entendimento da região a partir dos dois últimos paradigmas, o que daria origem a uma teoria de campos (field theory). A região seria abstraída, assim, de um sistema espacial composto por lugares, por atributos destes lugares e pelas interações entre eles (p. 419). A delimitação da região e sua "criação" ocorreriam, então, a partir de dois procedimentos básicos: a criação de uma matriz de estrutura dos atributos dos lugares e uma matriz de interação (matriz de comportamento). Desta forma, regiões com similaridade na primeira matriz apontam para regiões uniformes, ao passo que as similaridades na segunda matriz dão origem às regiões funcionais.

O modelo proposto por Berry foi largamente utilizado nos processos de planejamento regional que viveram seu auge em meados do século passado. Avança, em relação as correntes clássicas no que tange à ideia da região natural, dada especialmente pela homogeneidade, algo que rejeita, buscando maior base empírica para sua delimitação. Por outro lado, o modelo é excessivamente funcional e mesmo rígido; a perspectiva de uma função já dada a ser "descoberta" pelos procedimentos matemáticos torna possível mesmo a crítica de que a visão naturalista da Geografia clássica permanece. Há um claro avanço em termos metodológicos, e mesmo na utilização prática das conclusões, mas as regiões permanecem sob uma visão pouco flexível. Obviamente, à época, não havia ainda a visão humanista e os estudos sobre espaço e identidades ainda não se encontravam no nível de desenvolvimento posteriormente obtido.

Uma visão complementar a esta de Berry é proposta por Grigg (1974). Esta busca definir a região a partir de um resgate das contribuições anteriores, partindo da crítica a ideia da Terra como um mosaico de regiões isoladas, algo comum nas perspectivas clássicas. Neste sentido, ele não chega a formular um conceito explícito sobre o que é a região, porém, por sua crítica, pode-se depreender a busca por um recorte mais dinâmico do que o até então procurado, além da refutação da tese clássica da totalidade do mundo construída a partir de mosaicos de diferenciação regional. Como forma de identificação e delimitação dos espaços regionais, Grigg, recorre à tendência geral da classificação regional, partindo da ideia de que as regiões são delimitadas a partir de suas similaridades.

Tal visão, ainda que complementar, acaba por corroborar a crítica acima feita aos trabalhos de Berry, além de relativizar ainda mais o interesse dessa corrente em repensar profundamente a perspectiva da região tida nas correntes clássicas em Geografia. Se ali ela fora definida como naturalmente dada por suas similaridades, o trabalho de Grigg caminha de forma 
parecida e a análise funcional de Berry apenas refina metodologicamente o que antes era realizado pela observação e enumeração dos elementos da paisagem.

Na perspectiva proposta de região, surge o debate em torno de quais processos seriam responsáveis pela organização e estruturação de seus espaços. Berry aponta no sentido de que a relação dos processos que geram a totalidade ocorre a partir da aglutinação e da separação dos atributos e processos que ocorrem nos lugares. Desta forma, pode-se argumentar no sentido de que a estruturação e organização dos espaços regionais ${ }^{6}$ decorre de processos espaciais/ dinâmicas que fazem parte de uma totalidade, que compõem por justaposição.

Tal visão reforça uma perspectiva mecanicista em torno da forma como a região é constituída, na medida em que os processos que aí ocorrem são, na realidade, frações de uma totalidade maior. Tal perspectiva guarda forte relação com a teoria geral dos sistemas, muito cara a esta corrente. Por outro lado, a experiência mais recente tem demonstrado que os processos espaciais responsáveis pela produção dos espaços regionais não necessariamente correspondem a uma parte de um todo maior, sendo difícil precisá-los de forma tão rígida. Obviamente, à época, tal perspectiva era pouco considerada, a partir do modelo rígido proposto para a região.

Neste sentido, sobre as contribuições desta corrente de análise, é fundamental para a análise dos antigos planos de desenvolvimento e no seu desdobramento regional, até a década de 1970. A região é tida, diversas vezes, como um ente identificado e fechado, de características gerais pouco dada a variações internas. Como se verá a seguir, o planejamento regional brasileiro foi fortemente influenciado por tal perspectiva. Em termos dos avanços propostos, é necessário reconhecer o aspecto metodológico, que apresenta claro maior rigor. Por outro lado, esta corrente não dava conta de explicar certos fenômenos e negligenciava o papel da história e a das relações de poder na reprodução das crescentes desigualdades sociais e territoriais. A preocupação maior estava na busca de identificar os processos correntes e em criar modelos explicativos para a organização das regiões, não propriamente para a produção destes espaços. Estas preocupações serão vistas a frente, quando aprofundadas a partir de parte da linha marxista.

\footnotetext{
${ }^{6}$ A perspectiva de espaços "produzidos" é algo mais caro às correntes marxistas em Geografia, notadamente a partir dos trabalhos de Lefebvre. O uso de tal terminologia aqui é próprio do olhar do autor, não dos trabalhos analisados.
} 


\subsection{As perspectivas marxistas: da dominação e reprodução capitalista aos arranjos de poder}

Especificamente dentro da ciência geográfica, o pensamento regional emerge a partir da crítica radical realizada a partir da década de 1970, que propõe uma renovação da disciplina à luz do materialismo histórico. Neste sentido, Haesbaert (2014) aponta para um movimento duplo: alguns dos teóricos abordam a região como resultado da articulação espacial do capital; outros falam da "morte" da região, pela homogeneização do espaço pelo capital. Nesta parte do trabalho, são usadas as contribuições de três autores: Alain Lipietz (1988), David Harvey (2013) e Francisco de Oliveira (1981).

Lipietz (1988) propõe uma análise da região a partir da articulação dos modos de produção no espaço. Há um modo dominante e um modo dominado, próximo daquilo que estabelecia o pacto colonial: há a tendência de que um grupo social estabeleça uma relação de dominância com espaços regionais inteiros. Tal relação teria ligação com o estágio técnico de evolução das sociedades. A articulação entre estes modos de produção dá origem a uma estrutura regional, sendo para Lipietz, "uma região de articulação de relações sociais que não dispõe de um aparelho de Estado completo, mas onde se regulam, todavia, as contradições secundárias entre as classes dominantes sociais" (p. 39). O processo ocorre em estágios: inicialmente, o capital rompe a autossuficiência do modo com o qual está se articulando (entra aqui o papel da colonização); daí pratica trocas com os setores da divisão do trabalho onde não domina; finalmente, os produtos advindos do modo capitalista pela importação tornam-se mais baratos que os do modo dominado, completando o ciclo (e criando, obviamente, dependência). Desta forma, para Lipietz, as regiões são definidas a partir destas relações de dominação impostas entre elas. Ele articula a existência da região com a divisão do trabalho imposta pelo capitalismo, na medida em que, após a dominação inicial, passa a vigorar uma divisão espacial do trabalho que origina as diferenciações regionais.

A visão de Lipietz confronta, claramente, a perspectiva da Geografia teoréticaquantitativa, ao abordar a perspectiva de que as regiões são produzidas a partir de relações desiguais e não apenas organizadas a partir das funções assumidas pelas regiões. Neste sentido, esta parte da crítica marxista busca deslocar a visão do espaço, de simples organização para uma produção desigual. Esta primeira aproximação aponta para um modelo regional pautado quase na perspectiva de dominação de uma região sobre a outra, não especificamente de sociedades umas sobre as outras. Além disto, as relações de dominação são fundamentais para a compreensão da forma como os espaços regionais são produzidos, mas acabam por resvalar 
num modelo de região fechado, dominado por outra região, sendo incapaz de enxergar, por exemplo, como fatores internos levam à situação de pobreza ou às desigualdades internas.

Neste mesmo quadro, há o trabalho de David Harvey (2004; 2013). Seu intento inicial é a espacialização dos conceitos marxistas, considerando a lacuna existente na obra de Marx, por conta de um certo "mutismo" sobre o espaço. Sua argumentação, assim, caminha no sentido de demonstrar que o espaço é uma categoria fundamental à existência e reprodução do capitalismo, tanto quanto o tempo. Ele identifica a seguinte contradição: dado que, no capital, há uma tendência de aniquilação do espaço pelo tempo, por meio, por exemplo, da construção de infraestruturas, o capital precisa organizar o espaço, afim de superar as limitações que este impõe à sua reprodução. A partir dos ajustamentos no espaço, é possível reduzir o tempo necessário de circulação do capital, um dos objetivos fundamentais da implantação de infraestruturas. Surge, deste intuito e segundo Harvey, uma coerência estruturada, que precisa organizar no espaço os processos de produção e consumo.

Esta coerência estrutural acaba por ser minada e contradita por algumas tendências próprias do capital, das quais Harvey destaca as pressões sofridas por uma determinada região, que pode levar a fluxos não desejados pelo capital (como a entrada de imigrantes), ou ainda a maior liberdade locacional que os empreendimentos gozam a partir dos avanços tecnológicos (permite que escolham outras regiões). Harvey aborda ainda a questão da necessidade da construção de estruturas fixas no espaço que permitam o desenvolvimento do capital, retomando a importância do espaço e mesmo das regiões. Desta necessidade de estruturas fixas, Harvey busca aproximar o pensamento histórico de Marx do geográfico de Lênin, apontando para a necessidade da criação de uma aliança de classes regional para que o desenvolvimento capitalista ocorra. Harvey aponta que o capital se incumbe da tarefa de criar as duas características regionais. Entra aqui a importância do Estado, elemento capaz de forjar tanto as estruturas quanto a aliança entre as classes. O tema das estruturas espaciais fixas será retomado a frente, na parte do capítulo três que discute o tema das infraestruturas na criação (ou suporte) de redes e fluxos.

Harvey apresenta, desta forma, uma visão em que a produção das regiões é algo ligado a alianças de classes formadas, e, a partir delas, das estruturas criadas para permitir e acelerar a circulação do capital. Neste sentido, por este acordo formado entre as classes, podese enxergar certa convergência em relação a visão de Lipietz, em que pese uma certa relativização da perspectiva do "imperialismo" exercido entre uma região e outra. Harvey avança também ao incluir o tema das estruturas criadas como essenciais na perspectiva do 
entendimento da região, uma vez que elas se tornam o elemento palpável da produção das regiões.

Outro autor fundamental à corrente em discussão é Francisco de Oliveira (1981), especialmente por sua obra em torno da região Nordeste. Antes de falar especificamente sobre o desenvolvimento nordestino, aborda alguns temas importantes em sua exposição, como a questão do planejamento regional, buscando analisá-lo a partir dos desequilíbrios regionais brasileiros e da atuação do Estado brasileiro, que se deu apoiada na perspectiva estruturalista, esteio das políticas nacional-desenvolvimentistas do séc. XX. Desta forma, refletindo especificamente sobre o que seria uma região, Oliveira aponta para a tendência ao sumiço destas a partir de uma homogeneização do capital (como o que ocorria, então, nos EUA) - no Brasil haveria ainda um longo caminho para chegar a tal estágio. Neste sentido, para aquele país, ele afirma: "não há mais regiões no país norte-americano; há zonas de localização diferenciada de atividades econômicas" (p. 26 - grifo do autor). Daí ele conceitua que "as regiões seriam definidas pelo caráter diverso das leis de sua própria reprodução e pelo caráter de suas relações com as demais" (p. 26). Ele aponta, assim, para um conceito de região que privilegia as formas de reprodução do capital no espaço, apontando para a tendência de homogeneização anteriormente posta - ainda que, não plenamente realizada no Brasil, já que haveria aqui ainda regiões desiguais e diferenciadas.

Em Oliveira encontra-se uma relativização da própria ideia de região, o que torna sua preocupação em delimitá-las reduzida. Apesar disto, o Nordeste retratado em sua obra não tem suas fronteiras contestadas ou mesmo opostas, sendo aceito como região ali já posta (ou produzida) pela marcha do capital no espaço brasileiro. É bem verdade que ele reconhece a existência de "vários Nordestes" ao longo da história brasileira, mas não se questiona especificamente sobre o Nordeste em si. É como se desde a implantação do capitalismo no país, ainda na colônia, o capital houvesse definido alguns papeis para a região, sem antes mesmo têla criado. Da perspectiva dos papeis desempenhados pela região pode-se resgatar um tema essencial no entendimento da perspectiva de Oliveira, que é a questão da divisão regional do trabalho. As regiões, como entes econômicos e políticos, desempenham papeis a elas atribuídas pela organização espacial do capitalismo, que articula as partes ao todo, ou a uma lógica única. Como se viu, na perspectiva de Oliveira à medida que as "barreiras" espaciais são reduzidas ou relativizadas, o capital tenderia a homogeneizar o espaço, eliminando as regiões.

Assim, a visão proposta por Oliveira se contrapõe, relativamente, à perspectiva de Harvey e Lipietz no sentido de enxergar as regiões como criações "provisórias" do capital, à medida que este precisa suplantar as diferenças regionais. Por outro lado, ao apontar que o 
capital tem este objetivo, Oliveira converge com as ideias de Harvey, que analisa a composição das regiões justamente a partir da implantação da infraestrutura necessária à sua reprodução. Por ter uma visão de dissolução das regiões, ainda que partindo da premissa da divisão regional do trabalho (que parece comum à Harvey e Lipietz, especialmente quando estes tratam das alianças de classe ou da dominação de uma região por outra), Oliveira acaba por convergir com a visão de Albuquerque Jr. (1999) da corrente pós-moderna, brevemente comentadas a seguir: propõe, de certa forma, não haver base espacial específica que crie (ou seja parte do processo de criação das regiões) as regiões, sendo estas pura produção social.

Considerando a questão dos processos espaciais que atuam na produção dos espaços regionais, Lipietz e Harvey apontam que estes devem ser estudados a partir do arranjo de poder que se forma na produção das regiões, responsável, desta forma, pela produção da estrutura necessária. Lipietz enxerga que tal processo ocorre "de fora" da região, a partir da relação de dominação de uma região por outra, ao passo que Harvey considera haver uma aliança de classes que pode ser interna à região. Oliveira analisa também uma produção a partir de fatores externos, notadamente a divisão regional do trabalho, organizada pelos centros do capitalismo global e que acaba por disciplinar o processo produtivo e a organização regional global.

Analisando as contribuições acima, pode-se apontar que a visão clássica do marxismo sobre as regiões indica, no que tange à ideia de região, para um conceito atrelado ao processo geral de reprodução o capital no espaço, o que, é uma diferenciação importante em relação ao modelo de região produzido pela Geografia teorética-quantitativa. Esta se notabilizou pela identificação da região a partir de uma metodologia própria, porém mantendo a perspectiva das regiões como dadas, analisando sua organização. Ao propor um modelo de análise em que a região é fruto dos arranjos de classes diferenciados, internos ou externos a região, a perspectiva de uma região natural começa a ser relativizada. Entretanto, os marxistas não avançaram, com exceção de Oliveira, na ideia de que as regiões podem ser puros constructos humanos, logo passíveis de relativização; Harvey e Lipietz parecem mais preocupados com os desdobramentos das associações classistas no entendimento da dinâmica regional do que na gênese delas. Oliveira não chega a questionar a região, mas advoga a possibilidade de sua extinção.

Antes de passar ao debate das perspectivas neomarxistas, deve-se considerar, brevemente, outras perspectivas que falam na "morte" da região, conforme posta por Haesbaert (2014). Neste sentido, há os trabalhos de Giddens (1989) e Albuquerque Jr. (1999). Giddens analisa a região a partir da teoria da estruturação e da perspectiva de um tempo-geografia, no qual o caráter rotinizado da vida é algo fundamental na determinação dos espaços regionais. A 
partir das restrições existentes na vida cotidiana, surge a região: "o movimento de trajetórias de vida através de cenários de interação que tem várias formas de demarcação espacial” (p. 136). A delimitação das regiões ocorre a partir das limitações da vida cotidiana, específicas do que Giddens chama de domínios.

Já Albuquerque Jr. (1999), em seu trabalho acerca da "construção" do Nordeste, parte da premissa de que a espacialidade advém das percepções espaciais presentes na linguagem e tem relação com o campo de forças que constitui tais percepções. Desta forma, Albuquerque Jr parte da ideia de que as regiões são construídas a partir dos discursos produzidos sobre elas. Não há, desta forma, uma região dada, uma vez que os discursos e as identidades são produzidos por diversas forças. No caso concreto do estudo de Albuquerque Jr, ele aponta como a delimitação do Nordeste iniciou-se a partir da visão da população do Sul e Sudeste brasileiro sobre um Norte distante, dividido entre a Amazônia e as secas da porção Nordeste desta entidade regional primitiva.

A visão destes dois últimos autores, que pode bem ser associada a algo como um pós-modernismo, parte de uma crítica à formulação regional fechada e dada da visão da Geografia teorética-quantitativa e do marxismo clássico. Tal crítica é centrada na questão das regiões como "naturalmente" postas, apontando, na realidade, para o valor de elementos simbólicos e das relações sociais na determinação dos espaços regionais. Mais do que simplesmente "matar" a região, os dois autores buscam apontar que as regiões são constructos sociais mutáveis. Desta forma, podem ser postos em alguma afinidade com Oliveira, mas diferentemente dele não argumentam pela "morte" da região a partir de uma total homogeneização do espaço (algo amplamente refutado, especialmente por Giddens). Esta crítica, levará, entre outros fatores, à inserção nas análises marxistas da perspectiva de regiões fragmentadas.

Assim, embora se adote uma perspectiva histórica da região (algo não tido na perspectiva teorético-quantitativa, e posteriormente adotado pelas correntes pós-modernas), no marxismo clássico as regiões ainda são vistas de forma relativamente rígida, como entes fechados a partir dos processos de produção capitalista que as organizam. A introdução de uma perspectiva diferenciada, em que as regiões podem ser algo fragmentado e não um todo comum estarão mais presentes nos trabalhos dos neomarxistas, a seguir. 


\subsection{Os neomarxistas: globalização, arquipélagos fraturados, relações sociais e região como artefato}

Os chamados neomarxistas retomam o tema da região a partir de um viés crítico, em um contexto histórico posterior ao dos anos 1980, em que, por conta do avanço do neoliberalismo (entre outros fatores), houve teóricos (marxistas, inclusive) que proclamavam a "morte" da região. Trata-se da ideia de que as diferenciações do espaço tornar-se-iam irrelevantes, em função de um capital global que torna tudo homogêneo. Há, nos neomarxistas, um resgate do tema da região, porém com avanços que incorporam efeitos de dinâmicas territoriais contemporâneas, especialmente o valor da região na globalização: a maior parte das formulações recentes parte da perspectiva de uma região fragmentada. Os principais expoentes deste grupo são Michael Storper (1997), Allan Scott, John Agnew, Edward Soja e Storper (2001), Pierre Veltz (1996) e John Allen, Doreen Massey e Allan Cochrane (1998).

Storper (1997) possui uma perspectiva sobre a definição de região baseada fortemente na economia, apontando ele para uma retomada e revalorização do ente regional nas últimas décadas. Assim, a região se caracteriza a partir das relações que estabelece. A economia regional seria, desta maneira, regida por uma trindade santa, composta pela tecnologia, pelas organizações e pelos territórios. Além das relações, as regiões são ainda definidas a partir das convenções estabelecidas entre os atores, estas não sendo necessariamente convenções formais, mas um quadro de ações em comum esperadas quando ocorrem as interações. O papel das relações e das convenções é reforçado pelo entendimento da atual fase do capitalismo por Storper, que considera como sua principal característica a questão da reflexividade. Tal termo é por ele definido como "the possibility for groups of actors in the various institutional spheres of modern capitalism - firms, markets, governments, households, and other collectivities - to shape the course of economic evolution" (p. 29). As regiões são delimitadas a partir da associação entre as tecnologias e as organizações junto ao território, que produzem espaços regionais diferenciados (já que o modo de associação é próprio de cada região). Vão se formando, assim, coerências regionais próprias nos diversos espaços. A região, desta forma, em sua perspectiva, é organizada e estruturada a partir das relações existentes nos diferentes espaços globais. Ocorre um processo local de associação entre organizações e suas tecnologias (que se personificam, obviamente, em instituições que produzem tais tecnologias) e destas com o território que ocupam, que resulta na produção de regiões econômicas disponíveis ao desenvolvimento do capitalismo reflexivo. 
A perspectiva de Storper aponta para a grande influência da globalização nos processos de formação das regiões. Já apresentando uma perspectiva mais flexível sobre o tema, ele vê na associação da tecnologia com o território o elemento essencial na diferenciação dos espaços que leva ao processo de regionalização. A ligação com o tema da tecnologia permite associar justamente os processos à globalização, apesar de ele não apontar para a tendência de homogeneização dos espaços regionais. A região é vista como unidade essencial de associação e organização dos diversos atores no sentido de torná-la competitiva em nível global.

Scott et al (2001) buscam uma aproximação da temática urbana com a regional. $\mathrm{Na}$ realidade, a perspectiva apresentada não busca especificamente uma delimitação sobre a natureza da região, limitando-se a afirmar a importância das chamadas cidades-regiões globais como motores do desenvolvimento econômico do capitalismo atual. Pode-se depreender, destes autores, a ideia de que a região (e por extensão o território) é fundamental ao desenvolvimento do capitalismo globalizado, especialmente a partir das relações econômicas internas às regiões. Estas não ocorrem de forma homogeneizada, a partir do interesse da cidade (não é ratificada a ideia da cidade que controla totalmente sua região), mas estabelecem-se no sentido de promover toda a região como mola do capital. A região é, desta forma, organizada e estruturada, a partir das relações econômicas nela existentes. Os autores consideram ainda o papel elementar das identidades internas existentes e da tendência ao aumento das desigualdades internas nestas regiões (já que a teia de relações aí existentes é afetada pelo processo de concorrência capitalista).

A perspectiva apresentada por este grupo de autores tem forte ligação com a analisada anteriormente, na medida em que as regiões são produzidas a partir da sua dinâmica econômica interna. Em comum com Scott há a perspectiva de que a região é um elemento fundamental do processo de globalização, na perspectiva de se distanciar das perspectivas do "fim da região" - como no caso de Oliveira. Na realidade, a perspectiva destes autores avança ao apontar a associação da cidade com sua região como escala fundamental do desenvolvimento do capitalismo no momento atual. Entretanto, essa realidade parece ainda muito circunscrita a algumas metrópoles que se expandem por vastas porções do território, em geral nos principais nós da gestão do capital. Além disto, essa “associação" territorial proposta nem sempre é homogênea e, como se verá, é carregada de fissuras e desigualdades internas, com espaços mais e menos incluídos.

Em uma contribuição que busca também analisar o novo papel das cidades nas regiões - e que acaba por trabalhar este conceito - há a contribuição de Pierre Veltz (1996). Ele parte de um contexto em que considera uma economia de arquipélagos: em oposição ao 
modelo clássico de compreensão da economia de forma extensiva, ele propõe entender a espacialização da economia a partir de uma geografia muito mais complexa, em que se combinam diferentes tipologias: as pontuais (polos), as matriciais (redes) e a zonal. Veltz fala nas micro desigualdades e em territórios cada vez mais fraturados, impondo uma noção de região na qual prevalecem mais suas heterogeneidades que suas homogeneidades. Tal ideia fica ainda mais clara em sua defesa sobre a questão da pertinência da relação espacial em centroperiferia, advogando por sua pertinência: “le résultat est qu'au lieu de s'opposer globalement, par grands blocs, les centres et les périphéries tendent aujourd'hui à s'interpénétrer, à s'imbriquer les uns dans les autres" (p. 65). Tais descontinuidades e imbricações ocorrem porque há uma nova relação entre horizontalidades e verticalidades, que permite falar em um território-rede e em um território-zona (os dois não são excludentes, especialmente a partir da relação da cidade com a região). Desta forma, a definição ou identificação de um espaço regional torna-se algo cada vez mais complexo, uma vez que a perspectiva de continuidade e de regiões mais rígidas se torna algo com menor base na realidade. Estas são um espaço de relações complexas, onde dinâmicas locais e exteriores atuam. Daí a apropriação da metáfora dos arquipélagos: há uma realidade de processos espaciais em formatos puntiformes, zonais ou em eixos e redes que se superpõem.

A análise proposta por Veltz, desta forma, se opõe à perspectiva dos autores anteriormente expostos nesta seção. Isto porque neles permanecia a tendência de consideração da região como algo fechado, delimitado seja pela relação da tecnologia com o território, seja da cidade que se espraia por uma região. $\mathrm{O}$ conceito aqui torna-se aberto a consideração de lógicas contínuas ou não nos espaços regionais, fazendo com que mesmo a concepção de uma única região seja difícil de se manter. Abre-se, desta forma, a possibilidade de crítica das regiões estáticas, muitas delas comuns ao planejamento regional, ao passo que se torna possível analisar estas a partir de lógicas múltiplas que aí atuam.

Em uma visão muito próxima da de Veltz está o trabalho de Allen et al (1998), no estudo da região londrina (especificamente do sudeste inglês). Parte-se da premissa de que o espaço social somente pode ser compreendido a partir das relações sociais que são estabelecidas em torno de sua produção. Neste sentido, a ideia de região advém justamente disto: uma região é definida, essencialmente, pelas relações sociais que ela mantem, seja interna ou externamente. As diversas relações possíveis criam, desta forma, diversos formatos para a superfície, relativizando a ideia de uma região única, uma zona homogênea de características únicas ou diferenciadas. Daí surge também a explicação das desigualdades próprias das regiões: elas baseiam-se nas desigualdades próprias das relações sociais. As regiões são, assim, delimitadas 
justamente pelas relações sociais que as produzem, a extensão que elas se dão no território. Por outro lado, os autores consideram a questão identitária envolvida na produção das regiões. Como a política é também uma relação, torna-se possível validar e justificar a existência das regiões de planejamento típicas do Estado. As regiões são passíveis de mudanças, dado que as relações sociais também mudam com o tempo.

Esse modelo de conceituação das regiões leva a algumas importantes consequências: primeiro, a definição dos espaços regionais torna-se praticamente ilimitada, sendo que os padrões de "criação" de uma região ficam mais ligados à interconexão das relações sociais do que as diferenças em relação aos espaços vizinhos; tal conceito permite ainda pensar em regiões não contínuas, ou mesmo na ideia de regiões com "buracos", dado que existem diversas relações em andamento em um determinado recorte regional; independentemente do critério adotado para a regionalização, haverá sempre uma tendência à desigualdade e descontinuidade internas.

Assim, os chamados neomarxistas convergem na perspectiva da importância da região e de seu resgate num momento em que muito se falava (especialmente na década de 1990) do fim da região. Sua discussão é expressiva em revalorizar a temática regional, havendo aqui continuidade com as análises dos marxistas clássicos: o espaço é fundamental à reprodução do capital, não apenas sua base física (em que pese o pensamento de Oliveira opor-se a isto). Dentro dos autores analisados, os primeiros posicionam-se em torno de regiões mais "rígidas", contínuas, organizadas por processos estruturantes claros; já as últimas advogam a ideia de regiões mais flexíveis, não necessariamente contínuas e produzidas por lógicas diversas.

Este grupo de autores, desta forma, avança para além da pura perspectiva da divisão regional do trabalho ou da dominação de uma região por outra. Eles conseguem abarcar processos mais diversos na formação das regiões, dialogando melhor com o fenômeno da reestruturação produtiva. Além disto, propõem uma análise em torno da região para além da questão da identidade e do cotidiano - que são considerados, diga-se de passagem, por Allen et al - e que busca compreender outras características e, principalmente, outros processos espaciais.

Uma última visão, importante para o tratamento do tema regional, especialmente para o tema de regiões "oficialmente" criadas, é posto por Haesbaert (2014). Este autor propõe uma outra forma de lidar com a questão regional, considerando-a como um artefato. O próprio nome contem a síntese da ideia: por um lado, a região é vista como um artifício, como uma criação da sociedade seja pelos fatores próprios da identidade, ou mesmo por outros interesses 
como as políticas públicas; por outro lado, há a consideração dos fatos espaciais, das realidades naturais e sociais já postas e que precisam ser consideradas no momento da regionalização.

Assim, o processo de regionalização visa comportar tanto a perspectiva do zonal com o reticular, do imaginado com o real. A proposta tem alto caráter de síntese, e, até certo ponto, de conciliação entre uma visão anteriormente muito baseada nos caracteres do espaço e as mais atuais que enfatizam mais claramente as relações (econômicas ou sociais) aí estabelecidas. A regionalização proposta por Haesbaert considera ainda fundamental a questão das descontinuidades espaciais (como já posto por Veltz e Allen et al) e também das múltiplas escalas nas quais se dão os fenômenos espaciais.

Desta forma, a questão em torno da região com o todo encontra ligação a partir das diversas escalas nas quais os fenômenos espaciais se dão, não, havendo, na realidade, uma composição da região com o todo, mas de diversas escalas (infra e supra regionais). Vê-se, a partir disto, que a proposta converge em muito do que já fora exposto pelos autores neomarxistas; a grande diferença talvez esteja na busca de uma base material para a regionalização, algo somente visto de forma mais contundente no trabalho de Allen et al (1998).

\subsection{Síntese e discussão}

As contribuições teóricas analisadas apontam para a evolução da ideia de região: de entes espaciais homogêneos e fechados a visões que a aceitam como heterogênea e fragmentada. A perspectiva de Veltz e Allen et al sobre as descontinuidades regionais parecem estar bem próximas do que de fato ocorre na maior parte das regiões, especialmente naqueles limitadas a partir de um propósito político-administrativo, como no caso da Ride-DF. Conforme já anteriormente discutido (e contando com a contribuição de Queiroz, 2007), há uma forte heterogeneidade na região proposta, fruto, provavelmente, dos diversos processos espaciais que aí operam (no caso concreto, a expansão metropolitana de Brasília, a expansão da agropecuária moderna e a integração do Eixo Brasília-Anápolis-Goiânia). A lógica das descontinuidades internas às regiões torna-se ainda mais evidente se considerarmos o atual período do capitalismo, em que as suas dinâmicas passam a agir em uma variedade de escalas e em diversos tempos, fraturando a ideia de uma região una e ligada exclusivamente à cidade (ou metrópole) mais próxima. Apesar de apresentarem visões abertas da região, os autores pós-modernos, especialmente Albuquerque Jr., não apresentam elementos de análise concreta dos processos que organizam e estruturam no espaço as regiões atendo-se à sua construção identitária. Sua 
contribuição será fundamental na análise histórica da constituição da região em estudo, com a perspectiva de entender quando e com quais intuitos ela foi socialmente "criada".

Como complemento, é importante ainda mencionar as contribuições de Haesbaert (2014) para a validade de se pensar e discutir a Ride-DF. Ao considerar a região como um "artefato", ou seja, algo que provem do artifício humano, mas que demanda base na realidade fatual, ele abre uma perspectiva para considerar regiões institucionalizadas para fins políticoadministrativos como objetos de estudo em Geografia. Alguns trabalhos recentes têm privilegiado o tratamento de escalas inferiores, de sub-regiões dentro deste recorte, mas há, conforme mencionado, pouca produção sobre tal recorte regional. A ideia da região como artefato, daí, inicialmente artifício, torna válido o estudo de regiões criadas, em diversos casos (especialmente no Brasil) como recorte de gestão pública com viés político. A Ride-DF pode não corresponder, em seu tamanho atual, a toda a extensão do fenômeno da influência regional ou metropolitana de Brasília, mas como "região oficial" utilizada na formulação de políticas públicas (ainda que pouco coordenadas e eficientes), torna-se viável seu estudo como artefato político-administrativo, que pode tornar-se materialidade. Não apenas com este recorte, mas é visível certa resistência da academia em analisar regiões criadas de forma não técnica, em muitos casos por interesses políticos (relações sociais também legitimas no processo de regionalização). Tal ponto de vista é fundamental pois permite reafirmar a validade do estudo de uma região considerada "pouco eficaz" no provimento do desenvolvimento de parte do espaço regional de Brasília (ainda que não seja função das regiões instituídas fazê-lo - e sim da constelação de instituições responsáveis por sua gestão - mas é uma crítica costumeiramente ouvida).

A partir da discussão aqui proposta, permite-se iniciar a operacionalização de dimensões de análise que se tornarão amadurecidas com o evoluir do debate teórico. Exemplo disto é que, ao se assumir a região como um espaço descontínuo, abre-se a perspectiva da análise dos muitos processos que aí atuam, bem como da desigualdade existente. A compreensão da região de forma descontínua dá margem, ainda, para se trabalhar as dimensões espaciais dos processos, como a estruturação das redes. Justamente a questão de alguns processos espaciais, essenciais no estudo em curso é o tema do próximo capítulo. 


\section{REESTRUTURAÇÃO PRODUTIVA E ESPAÇOS REGIONAIS: EXPANSÃo METROPOLITANA, AGROPECUÁRIA MODERNA E INFRAESTRUTURA}

Considerando as discussões acima realizadas, viu-se que os espaços regionais passam a ter diversos processos espaciais responsáveis por sua produção. As visões que mais se aproximam do interesse do presente trabalho preconizam a questão da atuação de diversos processos espaciais nas regiões, ou mesmo a possibilidade de pensar múltiplas regiões em um espaço tido ou delimitado. Estas múltiplas regiões na prática são delimitadas a partir de diversos processos que atuam em conjunto nos espaços regionais. Considerando as tendências mais flexíveis do capitalismo no momento atual, além de sua tendência concentradora, há a centralização do terciário nas principais metrópoles, que passam a controlar não apenas espaços regionais imediatos, como distantes. Atendendo a tal lógica, surge a atividade da agropecuária moderna, processo que localmente tende a impor demandas globais. Dada a necessidade de estruturação de redes técnicas para o controle destes espaços longínquos, bem como a integração com outras metrópoles de comando do capital, surgem redes que se materializam a partir de, entre outros, eixos econômicos.

No caso da Ride-DF, espaço formalmente definido, trata-se, da ocorrência de três processos fundamentais responsáveis pela produção deste espaço regional, associados à lógica exposta anteriormente: a expansão metropolitana de Brasília, a expansão da agropecuária moderna e a integração do Eixo Brasília-Anápolis-Goiânia. Em uma perspectiva teórica destes três processos espaciais concretos e sua correlação com a reestruturação produtiva, tem-se a análise do seguinte: o processo de metropolização e expansão metropolitana; a reestruturação produtiva e a expansão da agropecuária moderna; a estruturação de eixos e redes no espaço geográfico.

\subsection{Reestruturação produtiva, metropolização e expansão metropolitana}

No contexto do crescente papel de atividades com base regional na acumulação, as facilidades provenientes da metrópole e o apoio de áreas urbanas tornam-se cada vez mais relevantes para alimentar o circuito produtivo territorializado. Assim, o interesse aqui recai sobre o processo de metropolização e de expansão metropolitana. A discussão, analisa as contribuições em torno da definição destes processos, bem como algumas perspectivas mais recentes que tem analisado o tema da metrópole em conjunção com o da região. 
Desta forma, em uma primeira aproximação, George e Verger (1970, p. 272) definem o processo de metropolização da seguinte forma:

"Dynamique spatiale fondée sur le développement des villes-métropoles et des grandes villes associées dans des réseaux urbains de plus en plus étendus. La métropolisation est favorisée par le développement de communications et des échanges. Elle s'inscrit dans le processus de mondialisation et d'interconnexions des économies"

O conceito proposto por George e Verger aponta no sentido de compreender a metropolização a partir do desenvolvimento de uma (ou das) cidade(s) metropolitana(s). Assim, atrela-se a perspectiva de metropolização à de desenvolvimento, que, pela complementação do conceito proposto tem ligação com os fluxos econômicos ou com a associação com redes de cidades. Curiosamente, não se anuncia a metropolização a partir da expansão de uma cidade, mas principalmente do crescente papel de importância que tal objeto espacial, a metrópole, adquire nas redes e na economia como um todo. Essa ausência, de certa forma, enuncia uma tensão comum em torno da perspectiva da metropolização e da expansão metropolitana: a metropolização acaba encarada a partir das funções assumidas pela cidade que vai se transmutando em metrópole; a expansão metropolitana como consequência disso (ou como a causa da assunção de novas funções, a depender da visão).

Dada esta "dualidade" anunciada, dentro da Geografia Teorética-Quantitativa, autores como Brian Berry e Frank Horton (1970) se associam a uma perspectiva da metropolização a partir das funções assumidas pelos aglomerados urbanos. Assim, ao analisarem o critério dos EUA para identificação das metrópoles, apontam para a existência de um espaço urbano cuja principal característica reside na função (ou nas diversas funções) que executam. Há uma primazia do papel econômico da cidade para que seja assim reconhecida como metrópole, além de outros fatores como a mobilidade e as comunicações internas. Desta forma, a metropolização é claramente o processo de ascensão nas hierarquias urbanas, a partir da assunção de novas funções. Ainda nesta perspectiva de valorização da função exercida pelas metrópoles, e já percebendo suas tendências de interdependência em nível global, Peter Hall (1966) disserta sobre as cidades mundiais. Estas apresentam características como: centros do poder político; centros de comércio; existência de importantes equipamentos que operam em lógica global, como os grandes aeroportos; presença de mão de obra altamente qualificada. Há aí também a concentração de riqueza, com a moradia do extrato mais rico do planeta. Tudo isto 
faz com que tais cidades tenham influência não apenas regional ou nacional, mas sejam elementos-chave na política, economia e espaço globais.

A conceituação proposta por estes autores reside claramente na associação metrópole com a função exercida, relativizando o peso do tamanho da metrópole, de sua extensão e da integração e partilha de serviços (sem falar da questão dos movimentos pendulares). Neste sentido, joga peso excessivo na questão da rede urbana e nas funções aí exercidas, e menos nos processos e fatos espaciais concretos que formam os espaços metropolitanos. Obviamente que, à medida que os espaços urbanos assumem tais funções de controle, há a tendência de crescimento, mas este talvez demande melhor consideração.

Nesse grupo de autores, a principal contribuição que irá enfatizar o tema da extensão do processo metropolitano será a de Jean Gottman (1959), ao abordar a ideia de “megalópole". Tal conceito refere-se a uma ampla região urbanizada, caracterizada por sua excepcionalidade quanto ao tamanho e quanto aquilo que ele chama de pioneirismo. Esta última característica estaria ligada à perspectiva de que outros espaços urbanos assim se conformassem, no futuro (sua análise é focada no nordeste americano). Ainda que não considere a questão da metrópole a partir de sua característica de extensividade, ele transfere tal conceito para a perspectiva de uma ampla região metropolizada. Pode-se considerar, de certa forma, uma polarização com a perspectiva puramente funcional, muito comum aos geógrafos da escola quantitativa-teorética.

Assim, ao propor enormes regiões metropolizadas, Gottman inicia a consideração da possibilidade da extensão do fenômeno urbano como algo importante. Algumas visões mais recentes têm ligação com esta análise que enfatiza o tema das funções exercidas pelas metrópoles, principalmente aquelas ligadas aos estudos da sociedade em rede e das cidades globais.

Estes estudos têm sido conduzidos, principalmente, por Manuel Castells (1999) e Saskia Sassen (1991). Estes enfatizam o terciário e o papel de gestão do capital das principais metrópoles mundiais. Suas análises centram-se no novo perfil de localização das atividades econômicas e no papel que as cidades exercem neste processo. Analisando a questão posta entre a tendência de concentração e dispersão das atividades econômicas no período atual, Castells aponta (assim como Sassen) para a tendência de dispersão das atividades que exigem menor qualificação e a concentração dos centros de poder e de negócios (e das atividades demandantes de maior qualificação) nas principais cidades do planeta. Surge daí uma hierarquia entre estes principais pontos, que se colocam no período atual como nós do espaço de fluxos que vai se formando. Já Sassen acrescenta ainda que nestes principais centros de gestão do capital em rede 
tendem a se localizar as sedes das principais corporações transnacionais e de serviços associados às suas necessidades, como o setor financeiro, representado pelos grandes bancos e bolsas de valores. Este quadro é criado pela economia em sua fase globalizada (em um contexto de ampla desregulamentação, para favorecer a internacionalização do capital e a especulação), com a emergência de novos atores como as corporações multinacionais, os mercados financeiros globais e os blocos internacionais de comércio.

Mais recentemente Sassen (2007) propôs, uma outra perspectiva, as "megarregiões". Estas surgem como uma das novas formações espaciais deste período, que tem como característica a sua diversidade interna, sendo marca disto a mescla das escalas urbanas e regionais aí dentro. Estas agregam a economia de aglomeração de diversas escalas, tornandoas atrativas, por exemplo, a setores que enviaram parte de suas unidades produtivas para pontos de outros territórios. Sassen aponta para algumas tendências destes espaços, como a multipolaridade e a dispersão geográfica dos espaços de moradia.

Os trabalhos destes dois autores dão ênfase, assim, ao formato pelo qual os espaços urbanos se inserem nos nós da economia globalizada, notadamente como espaços de gestão. Os espaços produtivos imediatos (especialmente na região próxima) e a expansão metropolitana deixam de ter maior importância em sua análise, cujo foco recai sobre o espaço em rede, nos quais as principais cidades se põem como seus nós.

Perspectivas que valorizam mais claramente os espaços produtivos próximos às metrópoles e o processo de expansão do tecido metropolitano que eles engendram encontraram grande campo de análise na teoria marxista "clássica" sobre a expansão metropolitana. Uma primeira contribuição é dada mesmo por Harvey (1973) ao analisar que o processo constitutivo dos espaços urbanos, em sua gênese, era a acumulação dos excedentes produzidos no campo que esta cidade dominava. Ampliada em escala quase global, esta dinâmica serviria para explicar, em partes, a expansão mais recente dos enormes espaços metropolitanos. Esta perspectiva subsidiou muito da análise clássica do marxismo em Geografia, tanto da expansão metropolitana como da organização das regiões a partir da dominância da cidade principal.

Nesta seara, outra importante contribuição é dada por Soja (1993). Ele aborda quatro formas urbanas: cidade mercantil, cidade industrial de livre concorrência, do monopólio empresarial e a administrada pelo Estado fordista. Nesta última fase ocorre o que Soja chama de metropolização expansiva. Nela ocorre a ocupação de áreas suburbanas e recintos privados pela classe dos chamados "colarinhos brancos". No centro permanecem alguns setores industriais, setores de livre concorrência, órgãos do Estado e as sedes de empresas. Os imóveis de caráter residencial perdem valor nestas regiões, o que, frequentemente, enseja a realização 
das operações de "revitalização urbana" pelo Estado, que visam "recuperar" as áreas centrais. No entanto, por conta do papel do Estado na administração dos conflitos e na regulação econômica, o modelo entra em declínio a partir da década de 1970. Com a derrocada do modelo da metropolização expansiva, Soja aponta algumas tendências atuais do processo mais recente de reestruturação da forma urbana: aumento da centralização e concentração do capital, na mão de enormes conglomerados empresariais; a integração entre atividades industriais, serviços e pesquisa que tem alargado espacialmente os sistemas produtivos, realocando-os; a aceleração da mobilidade espacial da indústria, aumentando a concorrência territorial; mudanças nas divisões regionais do trabalho, com novos complexos industriais territoriais.

Apesar do modelo de Soja avançar desde o modelo inicial da cidade mercantil até os indícios da metrópole afetada pela globalização, uma limitação de seu modelo é o fato de ele prever uma evolução quase linear das cidades, além de tomar por base a ocorrência de alguma industrialização - isto dificultaria, por exemplo, tomar tal base teórica para compreensão do caso de Brasília. A perspectiva da metropolização expansiva atende claramente ao ocorrido em termos de metropolização nos Estados Unidos, com a migração de parcelas da população de mais alta renda para o subúrbio - no Brasil, esta tendência ainda não é comum em todas metrópoles brasileiras, apesar de seu crescimento. Como anteriormente dito, Soja incorpora em seu trabalho a dimensão extensiva da metropolização e da expansão metropolitana, não a pressupondo a priori a partir da evolução e do acúmulo de funções urbanas.

Outro conceito a abordar tal situação é a perspectiva de cidade-região, proposta por Scott et al (2001). Estes autores partem de uma perspectiva de desenvolvimento regional que aponta maior protagonismo das regiões no processo de desenvolvimento capitalista, já que a questão da proximidade favorece a troca de informações, bens e serviços entre as empresas. Isto relativiza a visão das redes, havendo um resgate da organização regional e da localização dos espaços produtivos, não apenas dos de comando (STORPER; SCOTT, 1992; SCOTT, 1992). A partir disto, na perspectiva da cidade-região, as metrópoles contemporâneas mantem não apenas a primazia da gestão do capital, mas são referência em termos gerais para o planeta, já que tende a ocorrer uma forte associação entre a cidade e seus espaços produtivos imediatos. Espacialmente, vai se formando uma região de ocupação difusa, em que a figura de um centro único - que era próprio de uma análise anterior, ou do modelo "fordista" - perde-se, na medida em que outros centros vão se formando. Entre outros fatores, esse próprio espraiamento das atividades fica responsável pela produção destes novos centros.

Próxima a esta visão está o conceito de "urbanização regional”, proposto por Soja (2013). Na perspectiva original da pós metrópole, Soja a situava como algo além da metrópole 
clássica, que seria um estágio deste processo histórico, surgido, principalmente, após a terceira revolução urbana, tendo como característica fundamental sua notável concentração (de atividades e pessoas). Soja defende a ocorrência de uma "nova fase de urbanização regional multiescalar" (2013, p. 153), que se torna evidente a partir de algumas dinâmicas: refuncionalização e reconfiguração dos espaços de antigas periferias metropolitanas; perda dos limites das antigas metrópoles, a partir de dinâmicas multiescalares - além da participação em dinâmicas de diversas escalas, ocorre na grande metrópole a convergência escalar. Daí se poder falar em uma mistura das escalas urbana, metropolitana e regional subnacional.

A perspectiva da cidade-região e da urbanização regional enfatizam, de forma mais claras, a quase "simbiose" existente entre a cidade e sua região imediata, a partir da extensão em enorme escala do processo metropolitano. Há uma confusão dos enormes espaços urbanizados com a própria região. Soja aí aponta a importância da interescalaridade dos processos (que está na razão desta "simbiose"), bem como da conversão das escalas na cidade; a perspectiva da cidade-região desenvolve o tema frente ao processo de globalização, pontuando a importância da região no processo. Por outro lado, tal perspectiva parece descrever a realidade dos enormes aglomerados urbanos em torno das principais metrópoles do mundo, reportando-se a uma situação singular.

Finalmente, Mark Gottdiener (1997) de ligação com a perspectiva da produção social do espaço, aborda o tema da expansão das metrópoles a partir da ideia da metrópole desconcentrada. Esta é consequência do contexto do capitalismo tardio, cuja uma das consequências é a ocupação mais desconcentrada dos espaços metropolitanos, dado por alguns fatores: a pressão exercida sobre a cidade pelas modificações causadas no campo pelo capitalismo tardio; a atuação do capital imobiliário na busca pela captura de mais-valia em outros pontos do espaço, demandando a expansão das cidades. Este contexto específico do capitalismo tardio tem como uma de suas tendências, no âmbito metropolitano, a mudança centrífuga de pessoas, comércio e indústrias para o subúrbio, e a mudança, para o caso das metrópoles dos EUA. Especificamente sobre a desconcentração, Gottdiener argumenta que a maior parte deste processo de mudança de localização foi puxado pelas habitações, não obrigatoriamente por uma relocalização da indústria ou do comércio. Nisto influenciou a atuação do capital imobiliário, atuando em conjunto com o Estado, abrindo novos espaços e tornando a metrópole mais fragmentada. Já as atividades econômicas, ao se moverem, não tornam o centro principal necessariamente decadente e vazio, já que há uma manutenção dos empregos no centro principal com incremento de novas ocupações nas periferias. 
A proposta de Gottdiener (que analisa mais uma tendência de produção das metrópoles de forma desconcentrada a partir das características espaciais do capitalismo tardio) aponta haver uma "centrifugação" da população, num primeiro momento, impulsionado pela atuação de agentes como o mercado imobiliário, que acaba, num segundo momento "puxando" as atividades econômicas. Gottdiener considera, assim, a importância do processo de expansão metropolitana e o articula ao tema das funções, ao considerar que o centro retém as funções principais ao mesmo tempo em que se expande fisicamente. Na prática, a visão apresentada busca ser um diálogo de duas dimensões que operam em escalas conjuntas, mas as quais a análise tem separado: o papel funcional das metrópoles com a sua extensão física.

A partir da polarização arguida em torno da metropolização (função) e da expansão metropolitana (expansão física), é necessária a busca de um conceito que encaixe as duas dimensões. A partir das perspectivas teóricas analisadas, a perspectiva da urbanização regional de Soja e da metrópole desconcentrada, de Gottdiener, aparentam ser as que melhor lidam com esta necessidade. Isto porque em ambos os conceitos pode-se visualizar que a contradição entre o processo de metropolização e expansão metropolitana é apenas aparente: eles são o subproduto de um processo maior, a saber, a inserção das metrópoles no processo produtivo e de comando do capitalismo global. Desta forma, em uma acepção mais ampla, pode-se mesmo definir a metropolização como este duplo processo: em sentido estrito, remete-se ao processo de densificação funcional e ascendência nas hierarquias urbanas; em sentido mais amplo, abarca um processo obrigatório de expansão de seus espaços em direção ao espaço rural circundante, que tende a ser incorporado a partir de dinâmicas, inicialmente do mercado imobiliário. Esta expansão se manifesta ainda a partir da partilha ou integração de serviços comuns e com a criação de mercados de mão de obra expandidos em torno de um grupo de atividades econômicas que estrutura a cidade/ metrópole.

A análise mostrou a questão da expansão metropolitana e da metropolização, entendendo tais processos como um dos produtores do espaço regional crescentemente globalizado. Observou, também, que o tecido urbanizado tende a fragmentar-se e expandir-se sobre áreas rurais, formando franjas metropolitanas heterogêneas. Articulando-se, por meio do mercado de insumos e da força de trabalho, a áreas urbanas e metropolitanas, outro vetor da organização espacial regional tem sido a expansão da agropecuária moderna, a partir de sua associação com a reestruturação produtiva. 


\subsection{Reestruturação produtiva e expansão da agropecuária moderna}

A segunda parte deste capítulo, dedicado a análise dos processos responsáveis pela produção dos espaços regionais, parte agora para a análise das modificações mais recentes na produção agrícola a partir do impacto causado pelo processo de reestruturação produtiva.

Num primeiro momento, é necessário qualificar melhor a ideia de modernização na agropecuária. Tal discussão foi feita por Graziano da Silva (1996), que define tal processo inicialmente, como sendo a transformação da base técnica que visa aumentar a produtividade. Estas mudanças estão ligadas não apenas a melhoria nas técnicas de produção, mas também no modelo de consumo da produção, ocorrendo incremento no consumo intermediário na agricultura (este seria o "o valor de todos os insumos que entram no processo de produção excetuando a força de trabalho"). Cresce, assim, o consumo de tratores, fertilizantes químicos e, mais recentemente, de sementes geneticamente modificadas.

Graziano da Silva retoma, ainda a ideia da modernização, referindo-se a este processo como "processo genérico de crescente integração da agricultura no sistema capitalista industrial, especialmente por meio de mudanças tecnológicas e de ruptura das relações de produção arcaicas e do domínio do capital comercial" (p. 30). A partir deste conceito, percebese que a modernização está ligada a alguns processos correlatos que demandam análise, podendo ser destacados: integração da agricultura no sistema capitalista industrial e ruptura das relações de produção arcaicas. O conceito proposto por Graziano da Silva amplia a perspectiva de modernização correntemente visto, que associa tal processo especificamente ao uso de máquinas, insumos ou técnicas mais modernas.

É necessário verificar, assim, que não se trata puramente de uma mudança nas formas de produzir; é, primeiramente, um processo histórico que impõe ao capitalismo voltarse para a base técnica da produção no campo e que provoca consequências sociais, econômicas, ambientais e espaciais. No momento mais atual, surgem os impactos causados na agropecuária pelas mudanças no regime regulatório do capitalismo, a partir da reestruturação produtiva.

Neste sentido, há interessante contribuição dada por Denise Elias (2003). Esta autora analisa que, na vigência do meio técnico-científico-informacional, há uma reorganização da relação entre os três fatores clássicos da produção no campo: terra, trabalho e capital. Evidência disto é que, no momento atual, o aumento da produção não ocorre apenas pela incorporação de novos espações à produção, de forma extensiva. É assim que 
produtivas da agropecuária, visto que seus conjuntos técnicos anteriormente hegemônicos não condiziam com a racionalidade vigente no período tecnológico" (p. 60)

A partir de tal necessidade, surgem novos parâmetros de acumulação que, a partir do avanço das bases técnicas, levará a que a terra (e mesmo a natureza) sejam subordinados pela tecnologia e pelo capital, gerando maior dependência dos insumos produzidos pela indústria. Daí que se passa ao controle mais eficaz da produção e menor dependência dos fatores naturais, porém com fortes impactos ambientais. Há uma crescente integração da agropecuária em relação aos outros setores da economia, reduzindo um isolamento antes existente. Elias argumenta que o campo possuía alto potencial de recepção de novas tecnologias e reduzida resistência, haja visto possuir (por conta do isolamento apontado) menor quantidade de técnica empregada, logo, menor quantidade de trabalho morto (mais presente no espaço urbano).

É desta forma que, a partir da análise de Elias, torna-se claro que o campo passa pela reestruturação produtiva capitalista absorvendo tecnologia, mas, ao mesmo tempo, tornando-se um espaço de produção essencial ao capital. Há uma argumentação corrente de que este processo ocorreu por conta dos fatores demográficos específicos do século XX, especialmente no pós-guerra. Porém, assim como a autora, é necessário ver que o campo se torna um espaço de acumulação capitalista e não mero servidor de um interesse demográfico urbano difuso. O capital tem visto no campo um local potencial de aceleração da acumulação e tem aí despejado tecnologias que, se num primeiro momento eram adaptações do que já havia no espaço urbano, tonou-se, com o tempo, tecnologia específica de produção no campo. É assim que a produção rural é revalorizada neste processo e passará, como se verá à frente, pelos processos de flexibilização da produção, terceirização de relações e alienação de espaços de produção em relação aos espaços de comando. Obviamente que o processo não ocorreu de forma unificada, mas deu-se em etapas.

Neste sentido, Graziano da Silva (1996) propõe a análise deste processo de "evolução" da agropecuária a partir de sua modernização. Como anteriormente posto, o primeiro passo refere-se à mudança na base técnica da produção, com o uso de insumos tecnicamente mais complexos (o processo de aumento do chamado consumo intermediário). Em seguida é constituído o complexo agroindustrial (CAI) cuja existência está ligada a integração vertical, sendo resultado do processo de modernização e ainda baliza para os momentos posteriores. A integração da agropecuária com outros setores se aprofunda, surgindo uma produção industrial própria para a produção agrícola. Mais recentemente, é adicionado ao 
processo produtivo o financiamento por meio de linhas de crédito específicas e a organização de sistemas creditícios específicos para a agropecuária. É assim que o processo é guiado, de forma geral, pela integração e inserção da agropecuária na macroestrutura do capital, retirandoa de um isolamento nas fases anteriores do capitalismo. É desta forma que Graziano da Silva enxerga, de forma sintética, três fases no processo: inicialmente a produção de insumos para a agropecuária; o avanço para uma agropecuária moderna, com a crescente incorporação destes insumos; e, finalmente a criação das agroindústrias oligopolísticas, a partir da integração dos capitais e da financeirização da produção.

A análise de Graziano da Silva das etapas do processo de modernização encontra bastante ligação com a perspectiva de Elias, da integração da agricultura como um setor fundamental da produção do meio técnico-científico-informacional do momento atual, não apenas como um sistema produtivo isolado. A integração ao capital, por outro lado, explica a forma como a tecnologia e o capital submetem os outros elementos da produção, notadamente a terra. Um elemento empírico deste processo são as chamadas commodities agrícolas produtos de origem do setor primário da economia cujos preços são estabelecidos nas bolsas de valores do mercado financeiro global. Aliás, a forma atual de negociação evidencia mais claramente esta integração de capitais a que Graziano da Silva se refere.

Traçado este quadro geral, são diversas as consequências das modificações engendradas pelo processo de modernização. Elias (2006) tem analisado que as regiões "tomadas" pelo processo de expansão da agropecuária moderna apresentam um aumento de suas heterogeneidades, dada a atuação seletiva social e espacial do capital (que é aí potencializada), reforçando a criação de espaços "luminosos", incluídos no processo produtivo, e espaços "opacos”, excluídos (SANTOS; SILVEIRA, 2001). Isto ocorre, pois, a integração anteriormente referida é mais verticalizada (com escalas superiores, cidades de maior porte) do que horizontalizada, atendendo a comandos exteriores estranhos às demandas das regiões. Além destes efeitos, outros são mencionados por Elias, como o impacto fundiário causado pela implantação da agropecuária moderna, já que passa a haver interesse de incorporação de novas terras por esta atividade, elevando seu preço, o que acentua os conflitos pela posse. No caso do semiárido nordestino, Elias registra um aumento na grilagem de terras e violência no campo. Além disso novas relações de trabalho são impostas, havendo formalização das relações apenas nos níveis técnicos mais altos. Verificam-se, ainda, o aumento das migrações para cidades/ regiões vizinhas e os impactos ambientais causados pelo processo: desmatamento, estresse hídrico e conflitos em torno da posse da água, alterações no ecossistema. 
Além destas consequências, a estruturação das atividades da agropecuária moderna tem ensejado outras modificações na produção dos espaços de apoio. Muitas destas modificações levaram a que autores como Elias e Pequeno (2007) passassem a se referir a estes espaços urbanos como sendo as "cidades do agronegócio". A existência destas cidades está ligada a novas relações campo-cidade, e um novo relacionamento entre as escalas, nas quais os espaços produtivos tem recebido comando direto de grandes centros urbanos. Para atender as demandas de produção mais imediatas, cidades próximas tornam-se centros de controle operacional desta produção a serviço dos grandes centros, configurando-se como cidades do agronegócio. É assim que se percebe que o "agronegócio globalizado tem o poder de impor especializações territoriais cada vez mais profundas” (p. 29), legando um papel específico aos centros urbanos próximos das grandes lavouras. Pelo exercício desta função, ocorrem consequências negativas no âmbito do espaço destas cidades: fragmentação do espaço urbano e maiores contrastes socioespaciais, convivendo aí áreas favelizadas e condomínios fechados; valorização da terra a excessiva verticalização da habitação; expulsão da população mais pobre para as periferias. Como esteio destes movimentos verifica-se uma valorização do preço da terra urbana e a atuação seletiva do Estado (ELIAS; PEQUENO, 2007).

Assim, o quadro apresentado por Elias e Elias e Pequeno aponta para a reprodução da dinâmica da reestruturação produtiva nestas novas regiões do agronegócio: as cidades do agronegócio e os espaços produzidos ao redor delas são espaços considerados "alienados”, já que são controlados a partir de pontos distantes do território (SANTOS; SILVEIRA, 2001). Atendem os ditames do capital de longas distâncias, dos centros de gestão das grandes metrópoles e das bolsas internacionais de valores, ao custo da brutal destruição das relações de solidariedade local e com o ambiente. Estes e outros impactos sugerem a análise das alterações propostas em âmbito regional causadas pela implantação da agropecuária moderna.

Como se viu, há uma articulação especial da agropecuária moderna com lógicas e pontos de gestão alheios ao território imediato, a partir da estruturação das redes e do fluxo de informação que torna os espaços produtivos controlados pela metrópole de gestão do capital. Nas regiões em que este processo de insere, conforme argumentado por Elias, há o aumento da fragmentação do espaço, à medida que alguns espaços, pelos mais variados motivos, não são integrados ao processo, restando como "espaços opacos". Por outro lado, o papel do Estado, especialmente no caso brasileiro, tem sido o de financiar o processo, ignorando ou tratando de forma insuficiente as consequências deletérias do processo (só no atual projeto de lei da Política 
Nacional de Desenvolvimento Regional ${ }^{7}$ isto é considerado). É assim que, a implantação da moderna agropecuária contribui para aumentar a tendência já verificada no capítulo anterior quando da discussão em torno da ideia de região: estas tornam-se cada vez menos coesas e passam a ter seu espaço produzido por múltiplas lógicas, tornando-se amplamente fragmentadas e desiguais.

Conforme visto, a estruturação física deste processo somente ocorre a partir da criação de infraestrutura específica e da estruturação de eixos de transporte e comunicação, que contribuem para acelerar o circuito do capital e aumentar a lucratividade, o que se verá abaixo.

\subsection{Reestruturação produtiva e estruturação de redes e eixos}

O terceiro processo de interesse para a análise deste capítulo diz respeito ao processo de estabelecimento e estruturação de redes e eixos. Desta forma, verifica-se que tal processo é fundamental na produção dos espaços regionais e, como se verá, seu entendimento está fortemente ligado ao processo de metropolização e ao avanço da agropecuária moderna, anteriormente tratados. A linha adotada na discussão nesta seção parte de um conceito mais geral, a ideia das redes e de sua estruturação no espaço, passando à análise do fenômeno dos fluxos e chegando, finalmente, às formas de materialização destes, abrindo espaço para uma análise final sobre os eixos rodoviários, um dos processos-foco do trabalho.

Neste sentido, a discussão se inicia a partir do tema do estabelecimento das redes no espaço geográfico. Sobre o tema, Milton Santos (1996) parte da ideia de que uma rede possui tanto um aspecto material quanto um aspecto social. Quanto a este segundo aspecto, ele conceitua que "a rede é também social e política, pelas pessoas, mensagens, valores que a frequentam. Sem isso, e a despeito da materialidade com que se impõe aos nossos sentidos, a rede é, na verdade, uma mera abstração" (p. 262). A produção das redes ocorre a partir de três momentos: um período chamado "pré-mecânico", em que estas estavam subordinadas aos ditames naturais; um segundo momento, no qual predomina o desenvolvimento das técnicas necessárias; e um terceiro momento, em que sua estruturação se encontra ancorada nas forças da natureza dominadas pelo homem e pelos objetos técnicos específicos criados para sua existência, sendo materializada, principalmente, por seus pontos.

\footnotetext{
${ }^{7}$ Projeto de Lei do Senado n ${ }^{\circ} 375 / 2015$
} 
Por conta de sua implantação no território, ocorrem impactos na estruturação das regiões. Santos menciona a alteração dos tempos, tornados "rápidos" nos locais atingidos pelas redes - logo mais conectados e integrados que os não atingidos, onde o tempo seria "lento". Além disso as redes têm atuação espacial seletiva, reforçando as heterogeneidades regionais. Elas não são, ainda, uniformes, estando mais densamente concentradas em alguns espaços. São, finalmente responsáveis por uma dialética dos territórios, a partir das diversas formas de relacionamento propostas por processos na escala global e local (aqui pode-se remeter a análise, na seção anterior, dos espaços "alienados", controlados por centros de gestão exteriores e longínquos).

A partir do posto por Santos, é possível visualizar a ligação do pensamento deste autor com a análise anteriormente realizada especialmente da estruturação da agropecuária em nível global e regional, e as tenções que isto provoca. De sua análise é possível ainda extrair algumas das consequências negativas da forma como a reestruturação produtiva vem estruturando os espaços regionais, principalmente no que tange ao aumento das desigualdades regionais internas, o aumento da seletividade espacial e social e algo que se torna claro relembrando tanto o avanço metropolitano quanto a realidade do moderno agronegócio: o rompimento ou relativização da solidariedade local, em favor de lógicas globais de produção.

Em uma ótica próxima da de Santos, Dias (1995) aponta para uma retomada, recente, da noção das redes, a partir dos atributos de instantaneidade e simultaneidade que estas possuem, fundamentais no momento atual de globalização. $\mathrm{Na}$ realidade, as redes são revalorizadas pela questão dos fluxos, já que as redes permitem sua materialização. São valorizadas as propriedades de conexão das redes, e, principalmente, os nós de articulação, que cumprem, no atual momento, o papel de gestão dos fluxos (logo, acumulam poder). Por tal lógica, pode-se pensar numa menor valorização do espaço ao redor das redes, porém Dias refuta tal tendência ao apontar que características próprias do espaço (não apenas a distância) são primordiais na localização das atividades e mesmo dos nós de controle e gestão. Ela reafirma a tendência seletiva, desigual e causadora de heterogeneidades das redes, apontando, sobre a relação global-local uma contradição: as redes são fundamentais, na escala global, à organização da produção; localmente, atuam na desorganização dos espaços produtivos, aí impondo as lógicas globais.

Desta forma, a análise de Dias reafirma o caráter altamente seletivo das redes, especialmente nos locais onde os meios técnicos são instalados para seu funcionamento. Assim, se reproduz o que Dias chama de desorganização local. Há aqui um claro diálogo com a ideia de local-global exposto por Santos. Por outro lado, há uma análise muito similar da questão dos 
efeitos no espaço-tempo: o tempo mais comprimido corresponderia aos tempos rápidos, onde as redes atuam, em oposição aos espaços lentos, onde suas redes técnicas não alcançam. Dias afasta, ainda, ao reafirmar o espaço como algo além da ideia de distância, como este é revalorizado pela questão das redes e fluxos, seja pelo papel estratégico que desempenha na localização da produção e dos nós de gestão, seja pelos efeitos contraditórios da atuação das redes em âmbito local/ regional.

Em uma análise que enfatizava, por outro lado, a importância dos fluxos no espaço, Manuel Castells (1999) propõe uma teoria do espaço a partir da questão dos fluxos, no período da chamada Era da Informação. Ele retoma muito do pensamento, já apresentado, de Sassen acerca das cidades globais. Castells considera, assim, uma nova realidade espacial de organização do capitalismo: a descentralização dos centros produtivos dos principais centros, a retenção das funções de gestão nas principais cidades, a permanência das grandes metrópoles como nós de gestão do capital. Daí advém o que chama de teoria do espaço de fluxos: os fluxos não seriam apenas uma forma de organização social, mas a expressão de processo que dominam a organização da sociedade atual: "o espaço de fluxos é a organização material das práticas sociais de tempo compartilhado que funcionam por meio de fluxos” (p. 436). Os fluxos seriam as sequências de intercâmbio entre posições desarticuladas, a partir dos diversos atores no espaço. Para existirem, os fluxos demandam três camadas de suportes materiais: a primeira é determinada pelo circuito de impulsos eletrônicos; a segunda, pelos nós e centros de comunicação; a terceira, pela organização das elites gerenciais dominantes. Castells aponta, ainda, que o espaço de fluxos não é a única lógica espacial do período atual, mas é a mais importante delas.

A análise de Castells concorda com Santos e Dias, na medida em que considera os fluxos (e as redes, por consequência) como mais de âmbito político que propriamente um dado técnico, ou uma forma técnica de organização da sociedade. Por outro lado, sua leitura do espaço parte da premissa da inserção das cidades globais nos nós de competição da economia globalizada, o que, de certa forma, torna a região um item meramente acessório às principais cidades, que as organizam para tornarem-se mais competitivas. Na realidade a maior parte do que se viu até o momento caminha no sentido oposto: não se verifica uma solidariedade regional ou local, no sentido da inserção de toda a região, mas tão somente de alguns de seus espaços, de forma seletiva, ao passo que todo o resto se torna um imenso espaço "opaco", excluído, nos dizeres de Santos.

Este tema dos fluxos é também tratado por Santos (1988), em sua conhecida formulação sobre os fixos e os fluxos, na qual propõe que o próprio espaço é formado por um 
sistema de fixos e fluxos: "nós temos coisas fixas, fluxos que se originam dessas coisas fixas, fluxos que chegam a essas coisas fixas. Tudo isso, junto, é o espaço" (p. 85). Neste contexto, os fluxos "são o movimento, a circulação e assim eles nos dão também a explicação dos fenômenos da distribuição e do consumo" (p. 86). Os fluxos são fundamentais no entendimento das diferentes fases da realização capitalista, notadamente a circulação, a distribuição e o consumo. Além disto, os fluxos são os responsáveis por atribuir valor aos objetos técnicos postos no espaço, os fixos. Santos aponta, ainda, que no momento atual, dadas as urgências de acumulação, a circulação tem sido muito valorizada, aumentando a importância dos fluxos.

Desta forma, Santos, assim como Castells, aponta para os fluxos como um dos elementos essenciais para o entendimento da produção do espaço atual. Este seriam no seu entender, algo mais amplo do que apenas a circulação de pessoas, bens e informações, mas responsáveis mesmo pela atribuição de valor e sentido aos objetos técnicos, os fixos. Por outro lado, os fixos, para poderem ocorrer, demandam uma base material, sendo útil avançar no sentido de uma teorização acerca dos meios técnicos que possibilitam as redes e seus fluxos existirem, o que inicia o encaminhamento do debate para uma perspectiva possível sobre os eixos.

É assim que a discussão retoma outra contribuição de Santos (1996), sobre os sistemas técnicos. O autor aborda uma evolução no tempo dos diferentes instrumentos utilizados pelo homem, chegando ao momento atual, dos autômatos. Neste sentido, para entender a técnica, é necessário associá-la a ideia de um sistema, já que não se pode entender uma técnica fora do todo ao qual ela pertence. Assim, "as técnicas constitutivas do sistema são integradas funcionalmente" (p. 175). Os sistemas tendem a evoluir com o tempo, buscando coerência com seus elementos internos (materiais e sociais). A partir da evolução na ciência e das técnicas de produção surgem os macrossistemas técnicos, responsáveis pela produção das grandes obras, existindo também os microssistemas técnicos, em escala menor.

Retomando, por outro lado, debate posto por Santos acerca das redes, pode-se resgatar o que ele chama de imperativo da fluidez. Para a estruturação das redes há a necessidade da criação de objetos e lugares próprios para o aumento da fluidez. A fluidez é um atributo relativo, já que deve ser sempre estimulada e se incorpora no valor dos objetos e lugares. Há, desta forma, a necessidade de "suprimir todo obstáculo à livre circulação das mercadorias, da informação e do dinheiro, a pretexto de garantir a livre-concorrência e assegurar a primazia do mercado, tornado um mercado global” (p. 275).

Desta forma, ao descrever o tema dos sistemas técnicos, Santos aponta para sua coesão interna como algo fundamental no entendimento de sua imposição ao território. Tal 
coesão, como se viu, é fundamental na garantia da fluidez, imperativo quase absoluto no momento produtivo atual. Analisando de forma específica o tema da fluidez, é possível ir se aproximando de um dos focos do trabalho, o tema dos eixos rodoviários. Eles são, desta forma, fundamentais ao imperativo de fluidez do momento de produção atual do capitalismo, incorporando as características próprias do sistema técnico ao qual pertencem.

Outro autor que busca compreender as demandas de fluidez sobre o espaço é David Harvey (2013). Em sua análise o espaço é elemento essencial na realização do capital, na medida em que este é obrigado a ajustar o espaço no sentido de acelerar o tempo de acumulação e expandi-lo. A partir de sua "teoria do ajuste espacial", Harvey aponta para a constante necessidade do capital de moldar o espaço de acordo com suas necessidades, tornando-o essencial. Especificamente sobre a circulação, o tema dos transportes (e de suas condições de realização) são tratadas quando o autor aborda a circulação de mercadorias. As mercadorias contêm, em seu preço, os custos socialmente necessários para seu transporte, sendo a velocidade considerada um fator essencial no processo, incorporada no valor das mercadorias. Para que tal coisa ocorra, o capital é obrigado a modernizar e ampliar a rede de infraestrutura existente. A questão é que esta, uma vez posta no espaço, torna-se rígida e vulnerável à desvalorização local. Daí a necessidade quase incessante da produção de novas estruturas.

O proposto por Harvey guarda importantes relações com a perspectiva de Santos, colocada, por outro lado, a partir da necessidade de retirada dos obstáculos do capital ao aumento do acúmulo do capital, a partir da redução do tempo de sua realização. Se Santos fala no imperativo da fluidez, Harvey trata o tema a partir de imperativos maiores do capital, ligados à ideia de compressão do tempo pelo espaço.

É assim, que, a partir das visões propostas nesta seção, pode-se compreender o tema das redes como uma forma de organização da sociedade e do espaço que é específica e não totalizante, já que as redes são social e espacialmente excludentes. Sua estruturação, pode ser vista como a produção da base material linear das redes de circulação, estando ligadas por dois ou mais pontos e produzidas a partir dos imperativos dos fluxos no atual momento do capitalismo. Regionalmente, no atual momento de reestruturação produtiva, tem se mostrado altamente seletivas, re(des)organizando os espaços em que são implantadas, já que atendem a uma solidariedade organizacional distante, indiferente ao que se passa na escala local.

A partir desta discussão, é necessário, por fim, construir uma visão sobre os processos analisados e o modelo de região produzido, algo feito na seção seguinte. 


\subsection{Síntese e ligação}

Considerando os três processos analisados (expansão metropolitana, expansão da agropecuária moderna e estruturação de eixos), estes podem ser considerados como expressão da reestruturação capitalista contemporânea, tendendo a se articular na produção de espaços regionais competitivos. Pode-se ainda visualizar possíveis interrelações entre os três processos considerando, inicialmente, que o processo de expansão metropolitana é visto como aquele em que ocorre a densificação de funções e de expansão da extensão do espaço considerado metropolizado. Em tal processo, como se viu, as relações da cidade com a região próxima são modificadas, na medida em que ao aumento das funções exercidas aumenta a polarização dos espaços metropolitanos e os faz articular tanto espaços regionais mais imediatos como outros distantes. Desta forma, em diversos casos, há o controle de processos que podem ocorrer no espaço rural contíguo à metrópole principal, como o avanço da agropecuária moderna. Fala-se na possibilidade de que isso ocorra pois não há garantia, já que, especialmente no caso brasileiro, tal processo parece ser exercido por metrópoles do topo da cadeia, onde estão os centros de gestão das principais cadeias de produção no campo.

Estes centros distantes, por vezes, tem a obrigação de coordenar a produção a partir de bases em cidades próximas às lavouras, processo que leva à criação das cidades do agronegócio. Assim, estas podem estar "às ordens" não de sua metrópole superior fisicamente mais próxima, mas de outra mais afastada. A grande consequência disto para a região é o aprofundamento de sua fragmentação, pela introdução de novas relações sociais não previamente existentes re(des)organizando a solidariedade local anteriormente existente. Criam-se, assim, dinâmicas territoriais que estão presentes em uma mesma região, se relacionam, mas atendem ao comando de pontos distantes do território nacional. O quadro traçado por Veltz e Allen et al pode ser novamente retomado.

Como estrutura à ocorrência destes processos, redes específicas são produzidas, reproduzindo a tendência de segregação da atuação do capital globalizado, dada sua seletividade. Ligam pontos específicos do território regional, sem a preocupação específica de tornar espaços maiores mais fluídos; a fluidez é um atributo específico dos comandantes das redes e apenas subsidiariamente fornecido aos que se situam às margens dos eixos construídos. É assim que os eixos rodoviários são estruturados, com a finalidade de acelerar a circulação do capital e ampliar sua acumulação.

Considerando os processos acima analisados, é necessário analisar outras das muitas consequências, para as regiões, da reestruturação produtiva, notadamente ligadas às 
funções de comando, gestão e polarização por parte de alguns pontos, materializadas pelos subcentros, e das desigualdades regionais aí produzidas. É este o tema do próximo capítulo. 


\section{CENTROS E SUBCENTROS REGIONAIS E AS DESIGUALDADES REGIONAIS}

Considerando a análise dos efeitos regionais do processo de reestruturação produtiva, este capítulo visa discutir, do ponto de vista teórico, os efeitos deste processo sobre dois elementos da estrutura produtiva e econômica e social das regiões: a questão dos centros e subcentros e as desigualdades socioespaciais internas às regiões. Desta forma, o capítulo visa, num primeiro momento discutir o tema da centralidade (como atributo) e do centro (como forma-conteúdo, objeto espacial) nas escalas urbana, metropolitana e regional, passando, em um segundo momento, à discussão dos métodos de identificação destes espaços. Em seguida, é discutida a questão das desigualdades regionais a partir da análise das teorias de desenvolvimento regional, chegando, também neste caso, a um segundo momento em que as metodologias de aferição destas desigualdades são discutidas.

\subsection{A questão do centro e da centralidade urbana, metropolitana e regional}

O debate aqui proposto acaba por incorporar a dimensão dos subcentros nas escalas urbana e metropolitana não pelo foco da pesquisa, mas, como se verá, pelo conceito e análise estarem mais evoluídos na compreensão da centralidade nestas escalas. Entende-se que a discussão destas escalas ajuda na busca pela definição mais precisa da centralidade em nível regional. Para tanto, esta seção encontra-se dividida em duas fases: inicialmente há a discussão teórica da questão dos centros e subcentros, partindo das análises em escala urbana e metropolitana e passando, finalmente, às visões regionais; em seguida, há a discussão das formas de identificação dos subcentros, que permitirão, à frente, definir o modelo de análise.

\subsubsection{Visões teóricas em torno do centro, centralidade e subcentros nas escalas urbana, metropolitana e regional}

O tema dos centros e subcentros sempre teve apelo junto às escolas de estudo da estrutura urbana. Uma primeira contribuição surge ainda com a Escola Sociológica de Chicago, conhecida como da Ecologia Humana. A cidade para estes estudiosos é vista a partir das relações humanas de competição pelo espaço das cidades, aproximando daquilo que ocorre em âmbito natural. A estrutura urbana proposta por este grupo de estudiosos é o clássico modelo baseado em um centro único, o Central Business District (CBD) e em círculos concêntricos 
formados a partir dele. Tal estrutura, proposta por McKenzie, aponta para a distinção entre um centro comercial principal, ponto de convergência e local de maior acesso e a existência de subcentros comerciais, surgidos nos cruzamentos das principais vias. Além disso, é identificado (entre outros) um processo de distribuição do comércio, dado pelas forças econômicas presentes e um processo de crescimento, tanto axial (ao longo dos meios de transporte, cursos de rios) ou central, para todas as direções (EUFRASIO, 1999). Burgess (1974) retoma uma estrutura baseada em centro único e organizada a partir de círculos concêntricos, com alguma dispersão das atividades de consumo, sem maior aprofundamento no tema dos subcentros.

O modelo proposto, desta forma, é demasiado restrito à perspectiva de um centro único, com reduzidas referências à perspectiva de subcentros. Não era, ainda, preocupação destes estudiosos o tema da região, estando seus esforços centrados em descrever a estrutura urbana existente. Estruturas mais complexas surgem a partir dos trabalhos de Geografia Urbana da corrente da Geografia Teorética-Quantitativa.

Dentro destas visões, há uma importante contribuição dada por Brian Berry (1971). Berry aponta que os principais centros são aqueles que desempenham uma maior quantidade de funções no espaço. É possível, assim, traçar uma hierarquia a partir dos centros de comércio estabelecidos nos centros, sendo alguns equipamentos, como os shoppings centers, de maior alcance espacial - maior área de influência (por desempenharem maior variedade de funções). Apesar desta ampla concentração de funções e de uma variedade maior de bens e serviços oferecidos na área central principal, por conta da questão do deslocamento e da acessibilidade a áreas centrais menores, é comum surgirem, no âmbito das metrópoles, novas centralidades, com o objetivo de atender tais demandas dos espaços periféricos. Estes subcentros atendem demandas locais, reforçando o papel do centro principal também como articulador em escala além da metropolitana, regional. A perspectiva de Berry encontra bastante ressonância na ideia dos centros regionais de Christaller, que será comentada posteriormente.

Estes trabalhos dentro da Geografia de corte pragmático-quantitativo contribuem, principalmente, ao conceberem um modelo dinâmico da estrutura urbana e regional. Há o reconhecimento do centro a partir de sua função elementar, a centralidade e da capacidade deste em articular e gerir os espaços urbano e regional, não sendo reconhecido apenas pela concentração de população e empregos. Entretanto, os modelos ainda concebem o espaço apenas como palco da organização das atividades humanas, além de apresentar uma organização espacial do capitalismo sem contradições inerentes a tal organização, algo mais bem explorado a partir das visões marxistas. Há um claro avanço metodológico, porém a 
análise da estruturação e funcionamento do processo de centralização (e suas contradições) são deixados de lado.

As visões dentro do campo marxista propõem, desta forma, uma análise que incorpora o tema dos conflitos de classe da contradição do desenrolar dos processos sobre o espaço, algo pouco explorado nas visões anteriores. Uma primeira contribuição é dada a partir da corrente do estruturalismo, por meio de Castells (2000). Este autor parte da perspectiva de uma estrutura urbana organizada em diversas instâncias: econômica, política e ideológica. $\mathrm{O}$ centro é visto tanto como um local geográfico e como um conteúdo social. Dentro dele as mediações e trocas entre os moradores são possibilitados e favorecidos. Ele é, assim, um agente integrador da cidade, ponto mais favorável à acessibilidade e à comunicação. É a convergência das diversas instâncias do urbano: no elemento econômico, representa o ponto dos traslados econômicos; no nível político-institucional, representa os nós da administração do Estado e da gestão do espaço, sendo, desta forma também um elemento simbólico; no nível ideológico, o centro é o conversor e o dispersor do simbólico urbano. Castells fala ainda na produção de "minicentros", os quais podem ser reproduções em menor escala dos centros principais ou correspondem à expressão de outras funções que vão cristalizando-se no centro.

A perspectiva de Castells aponta, assim, para o centro como uma convergência, quase um resultado do processo de estruturação dos espaços urbanos. Perde, em partes, o tema de uma produção social do centro, vendo-o mais como resultado da organização de outros processos. O processo de centralização e a centralidade, como função e atributo dos centros, são atribuídos e regidos a outras instâncias da estrutura urbana. Por outro lado, corroborando a ideia dos geógrafos teorético-quantitativos, é valorizada a questão da função do centro, de organização do espaço urbano.

Outros teóricos marxistas têm apresentado análises centradas na questão das economias e deseconomias de aglomeração, caso de Roberto Lobato Correa. Inicialmente, o centro é visto como algo próprio do modo de produção capitalista, elemento que cria uma rede de distribuição e a estrutura necessária à reprodução das classes sociais. Considerando o caso dos países subdesenvolvidos, a rede de centros pode não estar totalmente formada, vindo a ser constituída, em alguns casos, por centralidades temporárias, cujas feiras são o principal exemplo. Durante o dia de ocorrência de tais feiras, a estrutura das centralidades se altera, porém, de forma temporária. A depender da rentabilidade destas feiras, elas podem eventualmente evoluir para centralidades fixas (CORREA, 1997).

Em outro estudo, Correa (1989) apresenta algumas assertivas sobre o centro na perspectiva intraurbana. Este teria como papel essencial a coordenação, integração e ligação 
entre os espaços intraurbanos e interurbanos. Muito por conta disto, nas cidades mais antigas, os centros surgiam ao redor da estação ferroviária ou do porto. Afim de poderem se aproveitar destas funções, as indústrias tinham por hábito localizarem-se próximas a estes centros. Esta área costuma ter uso intensivo do solo, grande verticalização e ser o ponto de convergência dos sistemas de transportes. Próxima desta área central, forma-se uma outra adjacente, com menor verticalização e uso menos intensivo do solo, porém de menor valor e, mais recentemente, alvo das políticas de revitalização urbana. A partir da $2^{\mathrm{a}}$ Guerra Mundial teve início um processo de descentralização das atividades econômicas das áreas centrais tradicionais, em parte por conta das novas funções adquiridas pelo centro, mas também por conta das deseconomias causadas pela excessiva aglomeração. Buscando reencontrar as antigas vantagens existentes no centro, as empresas passam então a se estabelecer em novos pontos, que podem transformar-se em centralidades. É importante considerar o papel dos meios de transporte neste processo, já que pontos de maior acessibilidade tendem a ser os mais escolhidos. A produção destes novos centros é boa para a classe trabalhadora, que pode realizar o consumo em pontos do espaço mais próximos do local de residência e também para o capital, já que isto permite, de certa forma, "drenar" parte da mais-valia dos espaços periféricos da cidade.

A visão de Correa parte da perspectiva do avanço do capitalismo na cidade e sua organização a partir dos centros como forma de organizar e mesmo "drenar" a mais-valia produzida em espaços mais afastados. Tal visão tem ligação muito concreta com as perspectivas da necessidade de expansão do capital no espaço como forma de ampliar a acumulação, conforme já analisado a partir de Harvey e Lipietz, no capítulo de discussão sobre a região (e no caso de Harvey, novamente, quando da análise dos motivos da expansão da circulação de mercadorias por meio dos eixos, apresentada no capítulo anterior). Esta visão se alinha numa perspectiva de comando central do processo, algo que, considerando a visão das regiões fragmentadas e das metrópoles fragmentadas, pode ser questionado, já que múltiplas dinâmicas passam a atuar na produção do espaço. O proposto por Correa tende, ainda, a considerar a cidade de forma unificada e sob o controle do centro principal, o que não parece ser o caso das principais metrópoles do capitalismo global.

Uma perspectiva que pode ser considerada híbrida, por associar elementos da análise mais pragmática junto com elementos próprios de autores críticos é a proposta por Flávio Villaça (1998). As cidades, em sua visão, organizam-se a partir da disputa pelo fator localização, sendo que esta é socialmente produzida a partir da disputa das diversas classes. Desta forma, o valor da terra acaba sendo fortemente determinado pela acessibilidade, fator bastante ligado à questão da localização. A acessibilidade é ligada ao domínio do tempo e pode 
ser influenciada pela técnica, que reduz o tempo dos deslocamentos. Villaça recorre a uma estrutura urbana em círculos concêntricos (própria de Homer Hoyt), cujo principal fator determinante é justamente esta disputa pela localização.

Neste contexto, o centro surge a partir da necessidade de otimizar a localização das atividades e, com isto, reduz o tempo e o custo dos deslocamentos. Villaça fala em uma produção social do centro, já que esta otimização não é naturalmente dada pela mera posição dos atores, mas é resultado das disputas entre os agentes de produção do espaço urbano. Haveria ainda um simbólico ligado ao urbano, com o enaltecimento das principais classes dominantes ou das principais instituições responsáveis pela produção do centro. A questão de novas centralidades é ainda abordada, a partir do enfraquecimento da força aglutinadora do centro principal. Villaça aborda ainda a temática de uma "decadência do centro", algo apontado por ele como sendo, na verdade, o domínio dos centros tradicionais pelas classes populares. Este processo tem ligação com a mudança da burguesia, dos espaços centrais tradicionais para outros, e também pela mobilidade do setor de comércio e serviços, o que enseja a formação dos subcentros. Estes têm ligação, além da decadência do centro principal, com novas demandas de acessibilidade criadas, sendo produzida pelos mesmos mecanismos do centro principal.

A visão proposta por Villaça retoma a perspectiva do centro como resultado das dinâmicas mais gerais de produção do espaço das cidades, notadamente a disputa das diversas classes sociais a partir do tema da acessibilidade. Sua diferença em relação aos estudos dos geógrafos pragmáticos diz respeito à esta luta de classes em torno do fator acessibilidade, que busca incorporar fatores sociais próprios na produção do espaço das cidades. Entretanto, considerando a realidade dos espaços urbanos e metropolitanos atuais, é difícil conceber sua estruturação a partir de apenas um fator, ainda que a ideia de acessibilidade seja abrangente. Há quase uma atualização das bases da Ecologia Humana, na medida em que a competição entre os grupos sociais é transposta para a ideia da luta de classes.

Em uma perspectiva marxista há a análise de Milton Santos (1979) sobre os dois circuitos da economia urbana, e a possibilidade de sua transposição para a compreensão dos centros e subcentros no âmbito urbano e metropolitano. Esta teoria compreende a estrutura econômica da cidade a partir de dois circuitos, um superior, mais ligado aos movimentos de modernização da cidade e sendo o responsável por sua ligação com o território em escalas superiores; um inferior, que se integra de forma periférica ao circuito superior, recebendo de forma desigual o processo de modernização. O circuito superior é dividido em puro (por serem atividades específicas da cidade e do circuito superior, tais como a indústria moderna, o comércio e os serviços), impuro (pois se instalam na cidade para aproveitar suas vantagens 
locacionais, mas seu interesse lhe é exterior, tal como a indústria de exportação) e misto (por terem uma dupla ligação, como os atacadistas e transportadores). Os dois circuitos são definidos, assim, pelo conjunto de atividades que realizam e pelo extrato da população ao qual se ligam. Especificamente sobre tais atividades, no circuito superior encontram-se organização burocrática, emprego reduzido, mão de obra em geral assalariada. No inferior, em contrapartida, encontra-se uma organização primitiva, emprego volumoso e não necessariamente assalariado.

Traduzindo tal situação para a questão específica a respeito dos centros e subcentros, Santos afirma que os centros principais das cidades (os ligados ao CBD) em geral correspondem ao circuito superior, por concentrarem a maior quantidade de tecnologia e de capital oriundo das técnicas, levando a uma apropriação funcional destes espaços (ao menos na maior parte do tempo) pelas classes mais altas. Já o circuito inferior produz espaços de centralidades de menor alcance espacial (menor abrangência no espaço) e mesmo de duração, como no caso das feiras. Ocorre uma ligação com o centro principal, do circuito superior, mas uma apropriação parcial de suas técnicas e uma ligação marginal em relação a ele. Assim, os principais espaços centrais são produtos do domínio e do interesse do capital superior, sendo que ocasionalmente, podem haver centralidades produzidas pelo circuito inferior, mas sempre em relação de dependência com o superior.

Esta teoria retoma a perspectiva de uma coordenação das centralidades existentes no âmbito das cidades e metrópoles, a partir do circuito superior. Por outro lado, dá a entender que este circuito se organiza a partir de uma centralidade única, com papel de coordenação destas outras centralidades menores, ligadas ao circuito inferior. Ao que parece, especialmente nos espaços metropolitanos mais afetados pela reestruturação produtiva, há uma multiplicidade de centros ligados a diversas atividades do mundo globalizado. A teoria de Milton Santos avança no sentido de propor uma ligação entre os pontos de articulação da economia global com aquela própria do "entorno" da realização desta: foge, assim, da perspectiva de exagerada valorização dos nós do capitalismo global. Há aqui, uma interessante possibilidade de expansão desta perspectiva para as regiões, se se puder considerar a existência de mais de um circuito superior em atuação e de múltiplos circuitos inferiores, conjugando a ideia da função dos espaços em nível mais amplo e a sua região imediata.

Antes de passar à análise do tema do centro e centralidade numa perspectiva regional, há ainda o trabalho de Mark Gottdiener (1997). Este, influenciado pelos trabalhos de Lefebvre e a partir de uma perspectiva de produção social do espaço, propõe, inicialmente, uma visão acerca do centro no qual este segue um processo mais geral de produção dos espaços metropolitanos, nos quais há tendência de maior desconcentração. A partir deste quadro, 
ocorrem dois processos concomitantes: o de aglomeração e o de descentralização dispersa pelos espaços regionais. Tal descentralização dispersa tem ligação com a dispersão, no espaço, das funções econômicas urbanas. Há uma produção de espaços centrais afastados das áreas tradicionais, levados, em um primeiro momento, pela mobilidade dos espaços de assentamento, e, posteriormente, pela concentração, nestes novos espaços de assentamento, das atividades econômicas. Este processo é consequência de outro mais geral, o de produção de uma metropolização desconcentrada, diferentemente do padrão anteriormente existente, de metrópoles mais compactas e com espaços gravitando em torno de um único e dominante centro.

A análise de Gottdiener busca dividir o processo de avanço da metropolização a partir de dois processos: primeiro os movimentos próprios dos espaços de habitação e, em seguida, das atividades econômicas. Entretanto, a descrição do processo como ele propõe parece muito baseada no caso das cidades dos EUA, com os subúrbios em processo de dinamização econômica, algo que precisa ser relativizado para o caso brasileiro, dado que muitos espaços periféricos se mantem, aqui, estagnados.

Em certa concordância com Gottdiener, Soja (1993) trabalha com a questão do centro a partir de um processo maior de reestruturação, esta entendida como a tentativa mais recente de modificação dos arranjos espaço-temporais do capitalismo. Muito de seu entendimento quanto ao processo provém da ideia de capitalismo tardio de Ernest Mandel (base também de Gottdiener). Neste sentido, a partir de uma periodização (o que é refutado por Gottdiener), Soja argumenta que a cidade atinge um momento de maior concentração, no período de domínio mais recente da regulação fordista. À medida que esta regulação perde força, e juntamente com ela o poder de atuação do Estado, as metrópoles passam a ter um padrão mais desconcentrado e com a relativização do poder do centro principal. Soja aponta mesmo o papel do Estado na desconcentração demográfica das áreas centrais (para o caso dos EUA) no pós-guerra. A novidade fica por conta justamente da relativização do papel dos centros principais e da emergência de novos centros.

Assim como em Gottdiener, é necessário relativizar esse processo de desconcentração populacional para os casos de outros espaços urbanos que não sejam os dos EUA. A descrição do processo parece ser próxima do que se verifica em algumas das cidades e metrópoles brasileiras, mas sem generalização. Por outro lado, há a dificuldade em transpor tal perspectiva de forma mais ampla, na análise da região.

Na realidade, a partir da revisão acima proposta, será possível ver que o tema da centralidade em âmbito regional tem tido contribuições ainda muito tímidas, especialmente por 
parte dos estudiosos marxistas, o que demanda um esforço de abstração e a tentativa de extensão do entendimento proposto por outros autores em nível urbano e metropolitano.

Neste sentido, a principal contribuição para o entendimento da questão do centro e da centralidade em âmbito regional data dos estudos realizados por Walter Christaller (1966), especialmente a teoria dos lugares centrais. Christaller parte da premissa de que toda forma de assentamento possui algum ordenamento, a partir de relações hierárquicas e funcionais, e que dentro deste sempre algum ponto exercerá a centralidade. A centralidade não está diretamente ligada ao tamanho da população, mas mais ao conceito por ele enunciado de "bens centrais": "Central goods and services are produced and offered at a few necessarily central points in order to be consumed at many scattered points" (1966, p. 19). Tais bens são divididos de acordo com sua ordem, sendo que, quanto mais elevada, maior o alcance regional de sua polarização. É mais determinante, no estabelecimento dos lugares centrais, os locais onde os bens são consumidos, não onde são produzidos. Assim, o desenvolvimento de um lugar central está intimamente ligado à comercialização de um determinado bem central, enquanto seu consumo é realizado em pontos espalhados. Os fatores que afetam o consumo deste bem central, de certa maneira, determinam o alcance da polarização do centro. Um destes fatores é a população da região de influência, se está dispersa ou concentrada. Algumas características dos bens centrais influenciam na polarização, especialmente suas limitações: a restrição quanto a renda dos consumidores; a quantidade mesma de existência dos bens centrais, por conta das restrições na produção; o preço do bem. Dado o lugar central, sua relação com a região complementar depende de características próprias dela: a distribuição da população (como já dito); a rede de transportes; o alcance espacial (definido por Christaller como o limite máximo no qual uma população procura bens centrais de um determinado centro).

A partir do considerado anteriormente, Christaller propõe que, na realidade, há um sistema de lugares centrais. O primeiro pressuposto deste é a existência em maior quantidade dos lugares centrais de menor ordem, projetando um sistema hierárquico em forma piramidal, do ponto de vista funcional (não espacialmente). Considerando o princípio de mercado e um alcance entendido como um anel ao redor dos lugares centrais, forma-se um sistema ao redor de um lugar de mais alto nível, em um círculo grande, no qual se inserem os outros lugares centrais. Depois, por conta do princípio dos mercados centrais, e visando mesmo evitar a sobreposição de um círculo de alcance sobre o outro, Christaller acaba por propor um sistema hexagonal ao redor de um lugar central de alto nível, dentro do qual os outros lugares centrais se inserem. 
O modelo proposto por Christaller (para os lugares centrais é fundamental na busca pela explicação para um padrão regional de centralização, baseado na perspectiva das funções desempenhadas pelas cidades e nos bens que estas ofertam. Há, por outro lado, a perspectiva de uma hierarquia mais rígida existente entre os centros. Talvez tal modelo fosse próximo da realidade em momentos anteriores do capitalismo e de sua organização no espaço. Entretanto, no momento, em que as regiões são percebidas como cada vez mais fragmentadas e descontínuas, não perece ser o caso, de uma estrutura tão rígida. Desta forma, como compreender, em âmbito regional, a estruturação destes processos descontínuos e sua organização a partir de subcentros?

Uma resposta a tal questionamento ainda não possui um correspondente e mesmo a teoria marxista sobre o espaço regional não tem dado respostas suficientes. Em geral, na maior parte das visões há a perspectiva de um controle central, um ponto único de gestão da lógica da produção regional, identificada pela cidade principal. Entretanto, a partir das contribuições de Santos e Elias, tem-se tornado cada vez mais claras as descontinuidades dos processos de articulação das diversas escalas. Neste contexto, como entender a formação dos subcentros e suas funções? As teorias marxistas sobre o centro foram pródigas no âmbito urbano; podem elas apontar (ou subsidiar) uma análise mais profunda em âmbito regional?

A partir deste questionamento, o que se viu até o momento na discussão são visões na teoria marxista que favorecem a perspectiva de uma unidade de controle da produção existente já na região, ou melhor já na cidadel metrópole. Dos autores consultados, quem aponta numa perspectiva diferenciada e que se coaduna com a ideia de descontinuidade/ fragmentação regional advogada neste trabalho diz respeito justamente a Milton Santos. Daí, é possível, num esforço de abstração e considerando a contribuição de Christaller sobre a questão das funções dos centros, é possível pensar na seguinte conceituação para os centros e subcentros numa perspectiva regional:

- O centro principal e os subcentros possuem interrelações entre si, mas não é possível verificar a existência, necessariamente, da subordinação de um centro sobre o outro. Isto seria possível nas cidades, dada a perspectiva de coordenação do circuito superior sobre o inferior - talvez até mesmo nas metrópoles mais espraiadas, as cidades-região, a urbanização regional, seja difícil verificar esta perspectiva de coordenação do centro principal sobre os subcentros;

- Na realidade, nos espaços regionais em que múltiplos processos atuam, surgem, para estruturar seu desenrolar sobre o território, centros especializados e que exercem funções próprias dedicadas àqueles processos. É neste sentido que os 
espaços regionais, especialmente os institucionalizados acabam por abrigar processos múltiplos e subcentros igualmente múltiplos e com funções diferentes.

- A função de cada centro não é puramente determinada apenas pela inclusão destes pontos nas redes globais; tem ligação também com a extensão dos fenômenos a eles ligados nas regiões, que são determinantes na estruturação e no alcance as funções desempenhadas.

Desta perspectiva de imposição da competitividade pela diminuição dos custos de produção, são derivados processos e consequências sobre os espaços regionais, dada a permanência de relações entre os processos e os centros. $\mathrm{O}$ avanço das atividades econômicas estruturadas em redes globais sobre as regiões afeta sua organização, desestruturando relações socioespaciais preexistentes, o que tem levado ao acirramento das desigualdades regionais. Este é o tema discutido na próxima seção. Antes dela, é proposta uma rápida subseção com a intenção de discutir o tema dos métodos de identificação dos subcentros em escala regional, de forma a subsidiar as análises a serem desenvolvidas na parte empírica da pesquisa.

\subsubsection{A identificação de centros e subcentros em escala urbana e regional}

Os métodos de identificação de centros e subcentros tem sido um tema importante e frequente na produção acadêmica em torno da estrutura produtiva específica da cidade e da região. Desta forma, há uma quantidade importante de estudos que visam identificar estes espaços (ou pontos específicos no espaço), apropriando-se do arcabouço teórico específico de diversas disciplinas, com destaque para a chamada economia e geografia regional e urbana. Daí também que os estudos têm se dividido em escalas, sendo alguns direcionados especificamente para a identificação dos subcentros em âmbito estritamente urbano e outros que se dedicam a identificação de novas centralidades em espaços regionais mais amplos.

A revisão aqui representada tem como base outros trabalhos que buscaram aprofundar-se na temática, tendo uma linha-mestra sugerida, principalmente, pelos trabalhos de Kneib (2008) e Duarte et al (2010), além da inclusão de outros trabalhos relacionados ao tema. Desta forma, os trabalhos foram analisados a partir, principalmente, do critério e do método utilizado para a identificação dos subcentros, que, por sua vez, demonstram o próprio conceito de subcentro aí contido. 
Um primeiro grupo de autores trabalha com critérios relacionados a picos de empregos ou a análise de sua densidade a partir de valores de corte. Giuliano e Small (1991) buscaram identificar subcentros para a região de Los Angeles a partir da densidade de empregos. O critério utilizado é duplo: cada zona deveria ter uma densidade mínima de empregos (calculada em relação à sua área) e um valor fixo de empregos. Ainda neste grupo, McDonald (1987) introduziu o tema da contiguidade na perspectiva da densidade de empregos. Assim, uma determinada zona é considerada subcentro se o valor dos dois indicadores acima é maior que o das zonas contíguas. Ele considera que cada zona é, em geral, cercada por pelos menos outras quatro: uma próxima do $\mathrm{CBD}$; duas que estão quase à mesma distância do $\mathrm{CBD}$; e uma que seja mais afastada que ela do CBD. Finalmente, Muniz et al (2003), ainda neste mesmo grupo, propõe a identificação de subcentros na região de Barcelona a partir de múltiplos procedimentos: inicialmente, são utilizadas as medidas adotadas em outros estudos, como os acima citados de McDonald e Giuliano e Small (identifica 23 subcentros); em seguida, foram identificados os municípios que possuem contingente significativo sobre o total da população; por fim, é analisada a distribuição dos empregos pelos subcentros, buscando-se identificar a atração de trabalhadores.

Os trabalhos apresentados indicam a evolução dos estudos dedicados ao tema da densidade de empregos. O uso deste indicador é interessante por avaliar até que ponto há concentração de empregos em um determinado ponto da região, o que possibilita depreender daí relações de polarização. Por outro lado, de forma isolada, este critério desconsidera a função desempenhada pelo subcentro ou a polarização causada por empregos de maior nível técnico.

Um segundo grupo de estudiosos propõe como critério fundamental para a identificação dos subcentros, os fluxos e a funcionalidade dos empregos aí existentes. Bourne (1989), que associa a descentralização à dissociação das residências em relação aos locais de trabalho e à multinucleação das atividades, propõe como metodologia para a identificação dos centros e subcentros o uso de gradientes de densidade e aparência e coeficientes de distribuição da população; medição da distância do trabalho para a casa; destinações dos locais dos fluxos casa/ trabalho (locais dos empregos). Já Gordon e Richardson (1996) propõem a análise dos fluxos diários e de sua densidade de fluxos, já que os subcentros tendem a atrair maior quantidade de fluxos no contexto metropolitano. Em uma metodologia próxima, Nigriello et al (2002) propõe identificar os pontos de articulação, identificados a partir da análise dos fluxos nas cidades e do uso do solo realizado. Aguiléra e Mignot (2004) consideram a análise da polarização a partir dos fluxos para trabalho e estudo, devendo ser identificados, nos municípios (estudam o caso das metrópoles francesas), quais possuem maior quantidade de trabalhadores 
e estudantes de outros municípios. Por fim, Ojima (2008), ao analisar a questão da dispersão dos espaços urbanos, trata também da mobilidade interna, especialmente os movimentos pendulares. Ele propõe dois indicadores para este tema: proporção de movimentos pendulares internos à aglomeração urbana com destino não polarizado na sede; proporção dos movimentos pendulares pelo total da população.

As metodologias propostas por este segundo grupo de autores consideram, assim, que a orientação e a concentração dos fluxos é fundamental na determinação dos subcentros, pois permite avaliar a polarização que eles exercem sobre os outros municípios próximos. A questão da polarização é fundamental e um claro atributo dos subcentros; entretanto, é insuficiente para elucidar melhor as funções exercidas pelos subcentros, precisando ser complementado por outras metodologias.

É neste sentido que tem sido realizadas importantes análises da questão da função como elemento central da identificação de subcentros em trabalhos do IBGE. Estes têm ligação clara com a influência da Geografia pragmática-quantitativa, especialmente nas décadas de 1960 e 1970 e com a teoria de Christaller, dos lugares centrais. Neste sentido, pode ser destacado o trabalho de Duarte (1967) sobre a área central do Rio de Janeiro. O estudo parte da perspectiva de considerar que a área central tem sua importância ligada não à complexidade de suas funções, mas à concentração de uma maior diversidade de funções. Algumas destas funções não são monopolizadas pelo centro, surgindo nos subcentros e sendo indícios da existência destes. Já Duarte (1974) retoma alguns destes trabalhos para identificar, em especial, os subcentros no âmbito do Rio de Janeiro. A centralidade é definida a partir da localização das atividades do terciário. A área central seria a principal concentradora de funções e de empregos, ocorrendo o desenvolvimento dos bens e serviços considerados centrais. A autora busca a identificação do que chama de centros funcionais, nos quais haveria a presença de determinados tipos de atividades terciárias como: atividade comercial (caracterizada por sua multiplicidade e especialização), serviços financeiros, serviços profissionais superiores, serviços cultural e recreativo, oferta de bens e serviços de transporte e comunicação.

Outros trabalhos recentes do IBGE, como a pesquisa da Região de Influência da Cidades - Regic (2008) - e algumas de suas tributárias - como a Pesquisa da Divisão do Arranjo Urbano Regional (2013), mantem, de certa forma, o uso de metodologias próximas a de Duarte. Dentro da primeira pesquisa mencionada, a partir de indicadores ligados, principalmente, às funções de gestão do território, é definida a hierarquia urbana brasileira.

Estes estudos que têm na função o elemento central da identificação de centros e subcentros, tendo como principal vantagem a possibilidade de inserção dos espaços 
identificados em redes mais ampliadas do capital globalizado. Por outro lado, atividades mais intensivas em mão de obra e a forma de organização dos fluxos acabam sendo consideradas de forma apenas complementar.

A partir desta breve apresentação e crítica das metodologias, vê-se que a forma mais adequada de identificação dos subcentros reside, justamente, na análise deles a partir de mais de uma forma de metodologia, porém avaliando indicadores atrelados a estas três funções/ atributos: densidade (especialmente de empregos e de empresas), complexidade funcional e polaridade. De certa forma, é para onde o modelo de análise proposto no foco (no capítulo 9) deste trabalho encaminha sua metodologia.

Antes de passar a análise do tema do desenvolvimento e desigualdade regionais, é importante mencionar a existência de outras metodologias de identificação dos subcentros, não utilizadas neste trabalho. Há um grupo de estudiosos que faz uso de métodos estatísticos econométricos, como McMillen (2001), e outros que fazem uso de metodologias próprias de estatística espacial, como Redfearn (2007), Modarres (2003) e Ramos (2002).

\subsection{Desenvolvimento regional e desigualdades socioespaciais}

$\mathrm{Na}$ presente seção, o interesse se volta à análise de outro dos efeitos da reestruturação produtiva nos espaços regionais: a questão das desigualdades socioespaciais. $\mathrm{O}$ tema das desigualdades é apresentado em face das teorias do desenvolvimento regional produzidas, que visam justamente compreender os fatores responsáveis pela concentração do capital em alguns pontos das regiões, tendendo a ocorrência das desigualdades dado o caráter seletivo do capital no espaço. Numa segunda subseção, são discutidos os procedimentos metodológicos utilizados para aferir o tema das desigualdades regionais, buscando compreender até que ponto eles podem ser utilizados para medir a evolução das desigualdades socioespaciais internas às regiões.

\subsubsection{As teorias do desenvolvimento regional e as desigualdades socioespaciais}

A discussão em torno do tema do desenvolvimento regional possui três matrizes teóricas de interesse deste trabalho para análise, sendo elas: as teorias de cunho keynesianofordistas, as teorias "localistas" (ou endogenistas, na acepção de Brandão, 2007) e as teorias marxistas. 
As teorias de corte keynesiano-fordista partem de um centralismo localizado na figura do Estado como promotor do desenvolvimento regional. Tais teorias terão muita força no período de regulação fordista da produção e do modelo keynesiano de economia, próprio do pós-guerra. No Brasil, serão fortes influenciadoras do pensamento desenvolvimentista, responsável pelas primeiras políticas de desenvolvimento regional mais robustas concebidas. Além disso, há um permanente questionamento da perspectiva de equilíbrio espacial existente na teoria econômica liberal, para a qual o espaço era tratado apenas do ponto de vista da distância a ser percorrida pela produção. Os autores desta perspectiva partem da premissa de que o modelo liberal exacerba as desigualdades regionais por ser regionalmente concentrador, demandando ação do Estado específica para alterar esse quadro.

Dentre os principais autores destaca-se o trabalho de François Perroux (1964), cujo entendimento do desenvolvimento regional é capitaneado a partir da instalação de uma empresa "âncora" (ou motriz) na região e que, pela cadeia que esta estabelece, leva ao desenvolvimento de toda a região atingida. Outra importante contribuição é a de Gunnar Myrdal (1972), que aponta para a ideia de que o sistema capitalista, no espaço, move-se não para o equilíbrio, mas para seu oposto. Myrdal rejeita, ainda, a ideia de que o desenvolvimento ocorre por fatores apenas econômicos, devendo outros serem movidos para que isto ocorra. Para ele, o processo ocorre a partir de diversas mudanças, responsáveis por criar um processo chamado de causação circular e cumulativa. Este processo que abarca uma série de fatores e de processos e pode ser usado para se entender tanto o processo de acumulação capitalista quanto outras questões sociais (vê-se, no pensamento de Myrdal, uma franca abordagem sistêmica). Há ainda as contribuições de Albert Hirschman (1961), que aponta para a necessidade de algum agente coordenador do processo de desenvolvimento (contrário à ideia do livre mercado). Hirschman argumenta que na prática, o que se vê como desenvolvimento equilibrado é, na realidade, a soma de diversos desequilíbrios que tem início em um determinado setor da economia e que se vai propagando, criando um quadro apenas aparentemente equilibrado. Assim, o desenvolvimento é, na prática, uma cadeia de desequilíbrios, pois em se desenvolvendo um determinado setor/ indústria, este, ao tirar vantagem das economias externas, as repassa aos setores próximos (o que o autor chama de capacidade completiva entre os diversos setores).

A partir das teorias acima apresentadas, percebe-se que as desigualdades regionais são fruto do estado "natural" do capitalismo, no qual a organização das atividades com pouca ou nenhuma ação do Estado leva, necessariamente, à concentração do capital em espaços específicos. As três visões convergem na perspectiva de que somente o Estado é capaz de induzir o processo de desenvolvimento e, assim, garantir uma maior equidade entre as regiões. 
No plano da perspectiva regional, estas visões tendem a trabalhar com uma perspectiva mais macrorregional, como foi o caso de sua aplicação nas políticas públicas brasileiras de desenvolvimento. Se, por um lado, há o claro avanço de perceber que o capitalismo por si só é incapaz de equilibrar o desenvolvimento das regiões, não havia a preocupação em torno das desigualdades internamente às regiões: as escalas de análise sempre são as grandes regiões e os Estados-nação.

Críticos à esta tendência e num momento de crise econômica da regulação keynesiano-fordista, o enfoque do desenvolvimento regional abandona a escala do EstadoNação e passa a dar maior ênfase à questão regional em escalas menos abrangentes, além de passar a criticar o papel do Estado como indutor obrigatório dos "desequilíbrios" que levam ao desenvolvimento de uma região. Num contex to de questionamento do papel do Estado em favor das forças de mercado, surge uma perspectiva que passa a observar nos agentes endógenos um componente fundamental para o desenvolvimento regional. Uma vasta quantidade de autores tem, assim, sido classificados como "endogenistas" (BRANDÃO, 2007).

Um dos principais expoentes desta corrente foi Giacomo Becattini, a partir de seus estudos sobre a Terceira Itália. Estes se dão em torno do chamado distrito marshalliano (ou distrito industrial), tido como uma entidade sócio-territorial caracterizada pela presença de uma comunidade ativa e de uma população de empresas em um espaço geográfico historicamente formado por uma identidade comum (BECATTINI, 1992). Uma das características mais marcantes do distrito é o seu sistema de valores e de pensamento relativamente homogêneos, que não se colocam como obstáculos ao processo de desenvolvimento regional.

Também aí considerado está o trabalho da chamada Nova Geografia Econômica, tendo em Paul Krugman um de seus principais expoentes. Krugman (1993) busca demonstrar a importância do espaço para a explicação das trocas internacionais. Ele julga, assim, ser importante fazer uma verdadeira geografia econômica (algo que, segundo o autor, tem sido pouco valorizado pelos economistas e legado a outros estudiosos), por conta da importância própria da localização das atividades econômicas. Para mudar as tendências, Krugman coloca como fator fundamental da explicação do desenvolvimento desigual entre as regiões (e entre as nações) a questão dos retornos crescentes, conceito que dá campo a se pensar numa Nova Geografia Econômica. Segundo ele: "At the grand level, the uneven development of whole regions (which in the United States may well be bigger than European nations) can be driven by cumulative processes that have increasing returns at their root" (p. 10). Além dos retornos crescentes, Krugman baseia seu modelo de concentração espacial também nos custos de transporte e na demanda. A proximidade aos grandes mercados consumidores deve ser 
considerada importante, como no caso da localização industrial dos EUA (ele obviamente considera que as melhoras no sistema de transporte e outros fatores contribuíram também para o aumento nos ganhos de escala). Desta forma, o fato de a tendência da localização da demanda determinar a localização da produção ajuda na criação de um padrão do tipo centro-periferia.

Retomando a questão específica da localização, Krugman retorna os preceitos de Alfred Marshall sobre a localização industrial. Assim, os principais fatores de importância são: a concentração do mercado de trabalho (pode haver ganho de escala por conta da concentração da mão de obra); os inputs intermediários (refere-se ao fato de que indústrias localizadas permitem que surjam indústrias fornecedoras mais especializadas); finalmente, a expansão das tecnologias (fator que ele busca relativizar, dada a importância quase absoluta de alguns estudiosos para o tema da inovação).

São considerados, por Brandão (2007) como sendo endogenistas as teorias de desenvolvimento regional que embasam a visão das cidades globais, de Sassen (1991) e Castells. Isto ocorre porque tal perspectiva aponta para a necessidade de articulação das cidades dentro dos nós do capitalismo global - elas precisam tornar-se continuamente "competitivas" para atrair os fluxos do capital e tornarem-se polos de gestão deste. É ainda considerada uma teoria de desenvolvimento regional endogenista a perspectiva das cidades-região de Scott et al (2001). Para estes autores, o processo de inserção das cidades nas redes do capitalismo global somente ocorre a partir de uma articulação maior, que envolve a região de influência das cidades. Há, assim, a tendência a que as regiões, capitaneadas por suas principais cidades entrem nos circuitos de competição do capitalismo global. Há, entre estas duas visões, uma divergência quanto ao papel das metrópoles na forma como a região se desenvolve: para os dois primeiros autores, a cidade retém o papel do terciário mais moderno, removendo e controlado as plantas fabris de outros espaços; para o segundo grupo de autores, as regiões mais próximas (contíguas) a estas cidades são ainda fundamentais, já que há um papel fundamental da manufatura em seu desenvolvimento e não uma "deslocalização" total como proposto por Castells e Sassen.

As diferentes visões endogenistas partem da perspectiva da necessidade da articulação de fatores locais como primordiais ao desenvolvimento das regiões. Neste sentido, regiões/ metrópoles que não conseguem lograr tal articulação ficam ausentes do processo de desenvolvimento do capitalismo global. As desigualdades regionais, nesta perspectiva explicam-se por fatores próprios dos locais, da escala local. Em algumas visões, é quase impossível desenvolver políticas que retirem as regiões de tal situação - como no caso da perspectiva de Becattini, que valoriza um virtuosismo local, produzido histórica e localmente. 
Em outros, a partir da articulação das metrópoles com suas regiões é possível empreender o desenvolvimento, como na perspectiva das cidades globais ou das cidades-região. Krugman também valoriza elementos locais ao falar dos fatores que estimulam a reprodução dos retornos crescentes como a concentração do mercado de trabalho. De um modo geral, a crítica de Brandão (2007) aos endogenistas se centra justamente na quase "demonização" que estes autores fazem das outras escalas para o desenvolvimento das regiões, especialmente pelo desprezo da atuação do Estado nacional neste processo. Ele argumenta que em escalas mais amplas como a nacional, são regulados fatores fundamentais ao desenvolvimento das regiões, em geral negligenciados pela análise dos endogenistas, como as políticas de crédito ou a política fiscal.

Por fim, um terceiro grupo de autores, identificados com as premissas marxistas apresenta relevantes contribuições à discussão do tema. O entendimento da questão do desenvolvimento regional no âmbito da teoria marxista enfrenta a mesma questão mencionada anteriormente, a da espacialização dos conceitos marxistas. Como já visto, os trabalhos de Harvey (2004; 2013) e Lipietz (1988) sintetizam os importantes esforços neste sentido.

Harvey (2013) busca tal espacialização a partir de uma teoria que considera que o capitalismo é responsável pela produção de espaços/ regiões desigualmente desenvolvidas entre si: "Concentrações de atividade fixas em um lugar contrastam com um desenvolvimento relativamente flexível e disperso em outro. Tudo isso resulta no que chamamos de 'desenvolvimento geográfico desigual' do capitalismo" (p. 478). Desta forma, Harvey questiona que o espaço seja meramente organizado de forma desigual, sendo, por outro lado, produzido desigualmente. A base teórica disto advém da ideia de que o espaço é um "atributo material de todos os valores de uso" (p. 479). Assim, os valores de uso, de troca e o próprio valor se integram na produção do espaço, sendo necessário buscar entender como isto ocorre (este seria o cerne de uma teoria marxista do espaço). Harvey fala, assim, de uma integração espacial: "o vínculo da produção de mercadorias em diferentes localizações por meio da troca" (p. 479). Neste sentido, sua atenção volta-se para a troca, e nas formas como esta se dá no espaço, levando à análise da mobilidade do trabalho e do capital que pode se mover como mercadoria, como dinheiro ou como processo de trabalho.

A partir justamente destas formas de mobilidade do capital, Harvey passa a tratar da localização dos processos de produção. De partida, ele aceita que a localização é socialmente produzida, algo que contradiz as teorias espaciais e econômicas clássicas. Para tanto, Harvey considera a questão da competição, vista como uma competição espacial, alicerçada na mobilidade geográfica da produção capitalista. Neste sentido, a mobilidade de um capitalista 
pode levar a que outros se movam também, no afã de manter o processo concorrencial. Esta tendência de mobilidade encontraria seu limite de acordo com a produção de mais-valia dos capitalistas, sendo que, tão logo esta se encontre maximizada, há uma estabilização momentânea, até que este fino equilíbrio seja novamente alterado. Sobre o tema da localização, Harvey retoma o tema dos ajustes espaciais, como forma de explicar a contradição do capital fixo: o capital necessita dele para se reproduzir, mas ao mesmo tempo demanda destruí-lo e refazê-lo para alavancar a produtividade do trabalho e para aumentar a circulação do capital.

Outro analista do espectro marxista, Lipietz (1988) parte da ideia do desenvolvimento desigual causado pelas diferentes formas e estágios dos modos de produção nas regiões, criando relações assimétricas entre elas a partir de trocas desiguais estabelecidas. Em sua proposta teórica, assume protagonismo a ideia do circuito de ramo, considerando: a divisão de trabalho entre os ramos, suas formas de articulação, a divisão do trabalho interno a ele (isto desloca o centro da análise da firma e do produto). As relações interregionais são dadas pela capacidade do capital em circular pelas regiões, fator influenciado pelas redes de transporte e comunicação. No caso, por exemplo, da industrialização dos países subdesenvolvidos, há um exemplo desta articulação: as indústrias de regiões mais desenvolvidas movem-se para aquelas onde há ainda grande quantidade de capital humano disponível e inexplorado. Lipietz retoma, assim, a ideia do imperialismo (do domínio de uma região sobre outra) e da organização no modelo centro-periferia.

Neste quadro dos autores marxistas, a perspectiva de Harvey retoma a questão da produção dos espaços regionais a partir da ideia dos ajustes espaciais promovidos pelo capitalismo e que levam à produção dos espaços desenvolvidos, em contrariedade a outros que ficam excluídos de tal processo. Neste sentido, a perspectiva do desenvolvimento geográfico desigual proposto revela a tendência seletiva da realização do desenvolvimento regional capitalista, opondo-se a perspectiva da indução do desenvolvimento das grandes regiões, tido nas teorias keynesiano-fordistas, e também ao desenvolvimento numa escala puramente local, como proposto pelos endogenistas. É uma visão que se coaduna com a perspectiva das regiões fragmentadas, tida como a base da compreensão regional neste trabalho. Por outro lado, a teoria proposta por Lipietz, dos diferentes estágios dos modos de produção nas diferentes regiões demandaria maior adequação, já que toma a região a partir de um viés mais fechado, conforme apontado no capítulo 2, além de levar a pensar em regiões homogeneamente em um modo de produção. Uma concepção que considere que estas diferenças ocorrem internamente às regiões parece mais próximo do momento atual de reestruturação produtiva e fragmentação regional. 
É desta forma que se pode entender as desigualdades socioespaciais na estruturação e organização das regiões fragmentadas como uma das consequências da seletividade do avanço do capital, que, ao ajustar o espaço às suas necessidades (com a construção de rodovias, por exemplo), produz desenvolvimentos geográficos desiguais, que ocorrem em múltiplas escalas, inclusive internamente às regiões "estabelecidas". Tal desigualdade ocorre, ainda, como exposto pela teoria marxista, a partir de relações desiguais estabelecidas entre e dentro das regiões, sendo responsável pelas desigualdades socioespaciais próprias do capital. No plano regional, as desigualdades socioespaciais apontam para a concentração em alguns às custas da não concentração em outros. Estes podem estar localizados dentro de uma mesma região, ou a milhares de quilômetros, algo possível pelas redes técnicas atuais. De certa forma, a ideia do imperialismo, muito presente na teoria marxista, ajuda na explicação deste tema, embora seja necessário considerar que as relações de dominação não se dão, obrigatoriamente, entre grandes complexos regionais, podendo ocorrer em escalas mais localizadas. Antes de passar à síntese deste capítulo, são rapidamente apresentadas, na próxima subseção, algumas metodologias de mensuração das desigualdades regionais.

\subsubsection{As formas de mensuração das desigualdades regionais}

O tema das formas de mensuração das desigualdades regionais tem sido alvo de uma densa quantidade de indicadores propostos para esta finalidade. De um modo geral, a maior parte dos indicadores tende a avaliar fatores como a participação das regiões (ou de níveis subregionais) na formulação das contas nacionais ou regionais, notadamente a partir da participação deste no PIB total da região ou do país. Há, ainda, indicadores ligados ao tema da renda e de sua evolução, aparecendo associados a estas análises que analisam o percentual de população abaixo das linhas de pobreza. Além destas medidas, que podem ser consideradas mais clássicas, outros grupos de indicadores vem sendo incorporados, à medida que se percebem outros efeitos das desigualdades regionais: o uso de medidas de evolução da demografia das regiões, a partir, especialmente, da preocupação com o esvaziamento de regiões como consequência do desenvolvimento regional desigual; o uso de medidas próprias para a medição das desigualdades em regiões e microrregiões com domínio econômico das commodities.

Dentro do primeiro grupo de indicadores encontram-se as formulações clássicas em torno do desenvolvimento regional, que avaliam, principalmente, a evolução do PIB e a 
participação do PIB das regiões e sub-regiões nas contas nacionais. Guimarães Neto (1997) usa destas medidas, comparando a participação no PIB nacional das macrorregiões como forma de analisar a evolução das desigualdades regionais no Brasil nas décadas de 1970, 1980 e 1990. A grande questão em torno do uso deste tipo de indicador é que ele pode frequentemente mascarar problemas de divisão interna da renda, sendo mais fundamental no sentido de apontar para o dinamismo econômico de uma região. De forma isolada tem sido ainda utilizado para justificar uma maior desconcentração regional do desenvolvimento brasileiro, porém, pouco consegue considerar, nesta forma de uso, as disparidades internas que, por vezes, ocorrem nas escalas sub-regionais.

Por outro lado, há o uso de diversas medidas referentes à renda como forma de mensurar as desigualdades regionais. São utilizadas desde medidas menos apuradas, como o PIB per capita, até outras que ponderam a divisão de renda a partir de coeficientes e variações próprias da economia regional e urbana. Monasterio (2010) menciona alguma destas medidas: o Coeficiente de variação que é a "razão do desvio padrão dividido pela média" (p. 316) é bastante utilizado e tem como base a renda per capita da região analisada e a renda per capita nacional; o índice de Williamson, usado também para a análise de desigualdades de renda per capita; o índice de Theil, que, a partir de dados sobre a população, permite analisar desigualdade entre regiões maiores e regiões menores, considerando os PIBs de regiões menores e de regiões maiores (ou o PIB nacional). Rocha (1998) usa do índice de Theil para calcular as desigualdades espaciais e a incidência de pobreza nas regiões brasileiras, concluindo pelos impactos diferenciados dos ciclos econômicos nacionais mais recentes - isto somente foi possível pois, como se viu, a medida utilizada permite a análise das desigualdades regionais em níveis subregionais. Ainda neste campo de índices sintéticos de medida das desigualdades, há o frequentemente utilizado Índice de Gini, que, é destinado a medir o grau de concentração de renda. Seu valor varia, numericamente, de 1, que seria a situação de desigualdade suprema (toda a renda na mão de um único indivíduo), a 0 , que seria a situação de igualdade ideal (todos os indivíduos com a mesma renda). O IPEA (2016) aponta que este índice tende ao seguinte: "a prática, o Índice de Gini costuma comparar os $20 \%$ mais pobres com os $20 \%$ mais ricos".

Destes dois grupos de indicadores foram derivados os indicadores da Política Nacional de Desenvolvimento Regional - PNDR (Decreto ${ }^{\circ}$ 6.047, de 22 de fevereiro de 2007 - BRASIL, 2007) atualmente em vigência. Esta traça uma tipologia dos municípios a partir de um indicador de renda, o Rendimento Médio Mensal por Habitante e a Taxa Geométrica de Variação do PIB per capita. Daí é proposta, a partir de uma combinação do resultado destes dois indicadores, uma tipologia que divide as sub-regiões em quatro grupos: sub-regiões de alta 
renda; sub-regiões dinâmicas; sub-regiões de baixa renda; sub-regiões estagnadas. Uma nova proposta de Política tem sido discutida no Congresso e abarca novos indicadores: inicialmente mantém o indicador de renda, que agora passa a ser a Renda Domiciliar per capita e a variação do PIB das microrregiões; incorpora como microrregiões elegíveis à política aquelas em que houve decréscimo demográfico ou em que o crescimento estiver abaixo de $50 \%$ da média nacional, além de eleger também como áreas de atuação as microrregiões em que haja domínio da produção do primário, especialmente de commodities. Há, desta forma, a aceitação pela política de que as desigualdades regionais não se manifestam apenas na componente renda ou dinamização da economia devendo haver uma visão mais ampla da dinâmica de concentração regional.

\subsection{Síntese e ligação}

A análise presente neste capítulo apontou para dois efeitos do processo de reestruturação produtiva do capital nas regiões, a formação de subcentros e o acirramento das desigualdades socioespaciais. Como visto, na medida em que há uma tendência de organização e estruturação dos espaços regionais de forma mais descontínua e a partir de múltiplos processos (alguns deles analisados no capítulo anterior) estes tendem a estruturar suas bases territoriais de forma específica. Um dos elementos desta estrutura é, certamente, a emergência de subcentros que servem tanto de apoio a processos cuja coordenação se dá em escala global ou nacional, como a processos cuja gestão ocorre em escala local. Os subcentros surgem, ainda, no âmbito dos espaços metropolitanos, em geral com funções ligadas ao consumo a partir de novos espaços de habitação, surgidos mais afastados do centro principal.

Por outro lado, à medida em que se tornam mais fragmentadas, as regiões tendem a reproduzir, internamente, suas desigualdades territoriais próprias, dada a seletividade já anteriormente discutida do capital. Isto tende a reproduzir e ampliar a perspectiva de um desenvolvimento desigual, conforme preconizado por Harvey. Esta tendência tende a se atrelar ao processo de produção dos subcentros uma vez que estes exercem um papel de descentralização das atividades de forma não uniforme na região, mas concentrando em seus espaços as funções de gestão do território em escala localizada. Isto tende a gerar, por sua vez uma concentração da renda e da produção econômica nos municípios que abrigam essas centralidades. Considerando a discussão realizada neste capítulo e nos dois anteriores, que 
estabeleceu bases teóricas para a compreensão de processos empíricos em estudo, o trabalho agora passa a analisar especificamente a temática, a partir da escala nacional, a seguir. 


\section{REESTRUTURAÇÃO PRODUtiVA E OS ESPAÇOS METROPOLITANO E REGIONAIS BRASILEIROS: PRODUÇÃO DE SUBCENTROS E DESIGUALDADES SOCIOESPACIAIS}

A partir da análise teórica anteriormente realizada de processos ligados à reestruturação produtiva capitalista, vê-se que diversos deles tem ocorrido no território nacional, nas escalas metropolitana e regional. Ao acompanhar influências da reestruturação produtiva nesses espaços, a discussão adota o pressuposto de que a progressão histórica e a das escalas geográficas condicionam processos contemporâneos localizados. Assim, a análise temporal a partir das macrorregiões e das Regiões Metropolitanas brasileiras, referencia possibilidades para a Ride-DF. Observe-se que, pressupondo uma necessária flexibilidade, o uso da periodização, relativa a uma fase desenvolvimentista e uma neoliberal, visa a apoiar a organização do material em estudo, facilitando a observação de mudanças e continuidades ${ }^{8}$. Esta organização visa delimitar, temporalmente, a evolução de processos mais gerais de produção do espaço brasileiro, em conjugação com a ação, principalmente a do Estado. Como referência para a análise dos períodos propostos, é realizada inicialmente uma breve discussão dos antecedentes.

\subsection{Antecedentes}

Diversos autores apontam para uma constituição inicial do espaço econômicoregional brasileiro a partir de "ilhas produtivas" que se estabeleceram durante a colonização e cuja reversão somente viria a ocorrer com a modernização econômica do país e a integração de seu território ao longo do século XX (BECKER; EGLER, 1993; MOREIRA, 2014). Este processo de integração se tornaria mais claro a partir da década de 1930. A movimentação que dá origem a tal processo dá-se tanto internamente (como a crise da República Liberal, a crise econômica da cafeicultura, o contexto político de forte agitação - e mesmo de conflitos armados - e, por fim, a ascensão de Vargas ao poder) quanto externamente (crise do liberalismo, entre guerras). Moreira (2014) aponta para um momento que perdura até a década de 1950, marcado

\footnotetext{
${ }^{8}$ A periodização considera diferentes orientações de políticas responsáveis pelas principais transformações ocorridas no âmbito da estruturação e organização dos espaços regionais brasileiros. Obviamente que há uma fase de transição de um período para o outro, mas optou-se por serem considerados apenas os dois, já que não se verificaram outras transformações radicais na realidade do objeto que se busca analisar.
} 
pelas tendências já presentes de concentração da indústria no Sudeste, mas ainda com indiferenciação setorial em relação ao produzido. Santos e Silveira (2001) apontam para um período de transição que teria tido início no começo do séc. XX, tendo se estendido até a década de 1940, com a formação de uma rede de cidades, o início da hegemonia de São Paulo sobre esta rede e a formação de um mercado localizado no Centro-Sul.

Ainda na década de 1930, e tendo em vista a necessidade de expansão do mercado interno brasileiro, surgem as primeiras ações efetivas de integração do restante do território brasileiro, havendo alguns esforços de interiorização e ocupação da porção oeste (não litorânea): construção de cidades, como Goiânia, em 1935, instalação de colônias agrícolas, como a Colônia Agrícola Nacional de Goiás, em Ceres (GO), além e de outras frentes pioneiras de ocupação. Tudo isto ocorria já esquadrinhando o modelo econômico do nacionaldesenvolvimentismo, que viria a ficar mais claro na década de 1950.

\subsection{O período desenvolvimentista (1956-1985)}

Tanto neste quanto no período subsequente, a análise ocorre a partir da explanação inicial do contexto socioeconômico (internacional e nacional). Entende-se que este contexto, incluindo forças e pressões contraditórias, condiciona possibilidades para ações de gestão território, segundo momento da análise. Por fim, estas ações levam a desdobramentos ou efeitos sobre o espaço em análise, em um terceiro momento. O contexto abarca fatores políticos, econômicos e demográficos relevantes à compreensão dos processos. As ações compreendem tanto as políticas públicas e a intervenção efetiva do Estado quanto as iniciativas dos agentes privados. Os desdobramentos, para o caso em tela, focam a análise nos espaços macrorregionais brasileiros e nas Regiões Metropolitanas, especialmente nos principais processos de produção destes espaços e nos temas da produção de subcentros e nos efeitos sobre as desigualdades internas.

\subsubsection{Contexto socioeconômico}

Iniciando a análise, em escala internacional caracterizou-se a vigência do modelo de acumulação intensiva identificado com o fordismo, principalmente. Autores como Hobsbawn (1995), Harvey (1992) e Lipietz (1991) apontam como características deste período um acordo entre Estado, trabalhadores e capital privado visando garantir o crescimento da 
produtividade e ganhos de salários aos trabalhadores, além da estabilidade para estes. O regime passou, ainda a ser caracterizado pela produção em massa e de forma padronizada. A partir de 1973 este modelo entra em crise, a partir de fatores como enfraquecimento do papel do Estado, a rigidez do modelo projetado que impedia uma "superacumulação" e a crise das organizações sindicais. Tornou-se difícil conciliar as demandas de crescimento da produtividade e as garantias de estabilidade demandadas pela classe trabalhadora, além da crise fiscal pela qual a maior parte dos Estados passavam.

Em nível nacional, este primeiro período considerado, chamado de desenvolvimentista, foi permeado por ideologia de mesmo nome, que atuou na América Latina e no Brasil, especialmente na política econômica. Como norte principal, buscou respostas próprias ao desenvolvimento do continente entendendo que a pobreza dos países não era uma fase de um processo que seria finalizado com o desenvolvimento, mas uma condição estrutural (MENDES; MATTEO, 2011). Apesar de sua ligação com o fordismo, é necessário apontar, como Cidade (1999a) que o modelo implantado nestes países corresponde à uma versão parcial do fordismo, um "fordismo periférico".

O contexto político deste período aponta para uma sucessão de crises institucionais e políticas, que culminou, principalmente, no golpe de 1964. A questão do desenvolvimento, em termos políticos, foi alvo do embate entre "entreguistas" (favoráveis a abertura do mercado ao exterior e maior integração com economias estrangeiras) e "nacionalistas" (favoráveis a um modelo que desse maior ênfase ao mercado interno). A partir de 1964, com a ditadura militar, a opção pela abertura da economia nacional ao capital estrangeira é feita, em um contexto de progressivo endurecimento e redução das liberdades democráticas (FICO, 2000).

Em termos econômicos, será notória a adoção dos pressupostos desenvolvimentistas. Até o golpe de 1964, o modelo tinha participação clara do Estado no processo. No começo da década de 1960, Celso Furtado (1981) aponta que a economia brasileira, demandava definir a orientação de seu processo de desenvolvimento, bem como reforçar sua capacidade de autotransformação. A partir de 1964, Furtado vê uma mudança nesta tendência, que se estende até 1967, com maior participação do capital privado. Em 1968 iniciase o período do chamado "milagre econômico", em que as taxas de crescimento da economia foram bastante elevadas, até a crise de 1973. Castro e Souza (1985) apontam que diante do quadro de crise econômica então existente, o governo decide pelos mecanismos de financiamento de sua crise, utilizados para superá-la (e não de postergá-la como se convencionou pensar). O modelo desenvolvimentista se esgota no final da década de 1970, com 
o aprofundamento da crise fiscal do Estado. Este processo engendrou modernização na economia brasileira, porém mantendo as bases sociais injustas, segundo Becker e Egler (1993).

Em termos demográficos, o Brasil vivia um período de crescimento populacional, apoiado em altas taxas de natalidade, sendo que Brito (2006) aponta, para a vigência da primeira fase da transição demográfica brasileira: ocorria redução na mortalidade e fecundidade elevada. Os fluxos migratórios estavam orientados para os espaços urbanos, especialmente as metrópoles. Ojima e Marandola Jr. (2012) registram um maior crescimento dos municípios em espaços metropolitanos que em outros de menor porte. Isto se dava muito em função da modernização do campo, que expulsou grandes somas de população do espaço rural. Matos (1995) aponta que o processo de concentração da população, na realidade, era reflexo de uma tendência mais geral de concentração da economia, muito por conta das políticas adotadas pelo Estado no período. Ao término do período, Brito (2007) aponta para o início da passagem a um novo padrão demográfico, iniciando um período de transição marcado pela redução no ritmo de crescimento da população, pela queda da fecundidade.

\subsubsection{Ações de gestão do território}

Conforme já brevemente exposto, as ações de gestão do território analisam, inicialmente, as políticas públicas formuladas para a temática em discussão; em seguida, são analisadas as ações efetivas e a atuação dos agentes privados sobre aquele tema. Considerando os temas de interesse deste trabalho, foram analisadas ações e políticas públicas no âmbito dos seguintes setores: política regional; política metropolitana (e, subsidiariamente, urbana); política agrícola; e política de infraestrutura de transportes 9 .

\section{Política regional}

As ações estarão, de forma geral, orientadas por uma perspectiva de desenvolvimento muito pautada na ideia de industrialização. O Estado, assumiu o protagonismo das ações, o que somente se altera no fim do período, com a crise dos anos 1980. Em termos de política regional, pela a primeira vez, o Estado torna a questão do desenvolvimento regional

\footnotetext{
${ }^{9}$ A escolha destas políticas está atrelada, principalmente, aos três processos focalizados no âmbito da Ride-DF: a expansão metropolitana, a expansão da agropecuária moderna e a estruturação do Eixo Brasília-Anápolis-Goiânia. Ainda que as políticas não sejam essenciais na análise das Regiões Metropolitanas - a seguir - os temas servem como contexto e preparação para a discussão do foco da pesquisa, a partir do próximo capítulo.
} 
como sua pauta de forma mais efetiva (logo, como alvo de políticas públicas). Neste contexto, o pensamento furtadiano foi fundamental, por meio da análise da economia brasileira em um viés estruturalista-regional-histórico, além da busca de um modelo próprio de desenvolvimento (MENDES; MATTEO, 2011).

Dentro das principais políticas públicas para o tema, no período, encontra-se o Plano de Metas, de Juscelino Kubitschek. Ainda que não fosse um plano específico para a questão regional, algumas de suas ações tem claro impacto aí, como a construção de Brasília e de rodovias. É digno de nota, ainda, a criação de instituições voltadas ao desenvolvimento regional, como a Superintendência do Desenvolvimento do Nordeste (Sudene). Depois do Plano de Metas, até a edição dos Planos Nacionais de Desenvolvimento (PNDs), o tema da política regional é mencionado em outros instrumentos de planejamento do governo, sugerindo mesmo a elaboração de uma Política Nacional de Desenvolvimento Regional (caso do Plano Decenal de Desenvolvimento Econômico e Social, de 1967), porém sem haver uma política regional mais clara.

A perspectiva do planejamento regional muda a partir do I Plano Nacional de Desenvolvimento (I PND, 1972-1974). Este tinha como principal objetivo "transformar o Brasil em nação desenvolvida, constitui o modelo brasileiro de desenvolvimento" (BRASIL, 1971, p. 14). Especificamente sobre o tema do desenvolvimento regional, o Plano trabalha a partir de uma estratégia de desenvolvimento regional (ou grande espaço econômico), cuja base era a criação de demanda interna. Assim, a orientação básica dava-se a partir da descentralização econômica, de uma complementação econômica do tripé industrial do país (Belo Horizonte São Paulo - Rio de Janeiro), da integração no sentido Norte-Sul (áreas menos desenvolvidas e mais desenvolvidas) e no sentido Leste-Oeste (áreas menos ocupadas e mais ocupadas).

Seguidamente ao I PND, surge o II Plano Nacional de Desenvolvimento (19751979, Lei $n^{\circ}$ 6.151, de 4 de dezembro de 1974). A perspectiva do plano, ambiciosa, pretendia posicionar o país no grupo das nações consideradas desenvolvidas a partir de uma nação industrial. Dentro deste quadro, a estratégia específica de integração nacional (que demonstra a política regional) tem como preocupações melhorar o equilíbrio político e econômico das regiões e outras de ordem geopolítica, ligadas à ocupação do território. Como estratégia, o foco estava em áreas integradas (como os polos e distritos industriais), a política de colonização e desenvolvimento agropecuário orientado e a demanda de maior investimento em ciência e tecnologia como forma de promover a expansão sem tantos custos ambientais. Para a Amazônia e o Centro-Oeste, as orientações seguem a perspectiva da ocupação produtiva - notadamente para a segunda região (BRASIL, 1974). 
Dando continuidade ao processo de planejamento de escala mais abrangente, é editado em 1980 o III PND. Apesar de manter a preocupação do Estado com a questão da integração e desenvolvimento regional, o Plano pressupunha diretrizes mais amplas que nos planos anteriores. Muito por conta da crise fiscal do país, teve poucos desdobramentos efetivos (BRASIL, 1980).

Analisando as ações efetivas, ou implantadas, sobre o Plano de Metas, Matos (2002) aponta que este se constituiu, provavelmente, como o primeiro esforço de planejamento de mais longo prazo com decomposição das metas, sendo estas por ela consideradas bem definidas. Houve, por outro lado, dependência do capital estrangeiro para os investimentos e uma tendência à concentração de investimentos no Sudeste, reforçando a concentração regional da economia. No período posterior ao Plano De Metas, ainda que não houvesse uma política regional ou de desenvolvimento mais bem delineada (só retomada com o I PND), vale destacar que importantes instituições voltadas à temática regional foram criadas: Banco do Nordeste (BNB), a Superintendência do Desenvolvimento da Amazônia (Sudam), o Banco da Amazônia SA (Basa), a Superintendência para o Desenvolvimento da Zona Franca de Manaus (Suframa), a Superintendência do Desenvolvimento do Centro-Oeste (Sudeco), a Superintendência do Desenvolvimento da Região Sul (Sudesul) e o Ministério que abrigava algumas destas e outras instituições, o Ministério do Interior (Minter).

Quanto ao I PND Senra (2009) destaca o papel do plano no processo de integração dos espaços da Amazônia, Nordeste e Centro-Oeste à economia nacional, baseado em um centro dinâmico (Centro-Sul). Tal perspectiva de integração ocorria também por meio da questão da segurança e da ocupação do território, algo que seria ainda mais reforçado a partir do II PND. Sobre este, Matos (2002) o aponta como a experiência mais válida de planejamento em longo prazo e com articulação após o Plano de Metas. Senra (2009) destaca a atuação do Plano no sentido de permitir a criação de importantes eixos de penetração para a economia nacional, muito puxados pela ideia de ocupação dos “espaços vazios”. Mendes e Matteo (2011) destacam a importância do Plano no processo de desconcentração industrial, mas ainda sem atingir as regiões menos industrializadas, especialmente na escala intrarregional (basta comparar a situação do Nordeste, entre Zona da Mata e Semiárido). Um outro aspecto ainda por ser criticado neste plano parte de Souza (2004) é a prevalência de uma visão setorialista, em detrimento de uma perspectiva mais global, muito por conta da própria forma de organização da administração pública. Por fim, o III PND, como dito, teve pouca aplicação efetiva. 


\section{Política metropolitana}

Antes de falar propriamente da política metropolitana, é necessária alguma consideração sobre a política urbana no período. Especificamente sobre o planejamento urbano, Villaça (2004) aponta para a evolução deste instrumento, na medida em que as ações ultrapassam a perspectiva apenas da realização de obras físicas, passando a uma abordagem multidisciplinar, sendo constituídos "superplanos”, de caráter tecnocrático. É importante ainda o avanço na política em termos federais, com a criação de instituições como o Serviço Federal de Habitação e Urbanismo (Serfhau) em 1964, além do tema da habitação, a partir do Sistema Financeiro da Habitação (SFH), cujo principal braço executor foi o Banco Nacional da Habitação (BNH - também criado em 1964).

Especificamente sobre a política metropolitana, o período considerado demonstra o início da preocupação do governo federal com o tema. Neste ponto, é necessário considerar algumas iniciativas em São Paulo em torno do tema, na segunda metade da década de 1960 . Em âmbito federal, a questão foi tratada na Constituição Federal de 1967, propondo as regiões metropolitanas a partir da ideia de comunidade socioeconômica, dando ainda a prerrogativa de criação destes espaços à União. Tal instrumento seria efetivado em 1973, por meio da Lei Complementar $\mathrm{n}^{\circ} 14$ (BRASIL, 1973).

Esta lei foi responsável pela criação de oito regiões metropolitanas: São Paulo, Belo Horizonte, Porto Alegre, Recife, Salvador, Curitiba, Belém e Fortaleza. Posteriormente, em 1974, por meio da Lei Complementar $n^{0} 20$, de $1^{\text {o }}$ de julho de 1974, é criada a Região Metropolitana do Rio de Janeiro. O modelo de gestão previa a existência de um Conselho Deliberativo, presidido pelo Governador do Estado e composto por cinco membros de reconhecida capacidade técnica, nomeados pelo Governador (ao menos um indicado pelo prefeito da Capital e outro indicado pelos outros municípios membros) e um Conselho Consultivo. Ao Conselho Deliberativo cabia aprovação dos Planos de desenvolvimento e a coordenação da execução dos projetos, enquanto o Conselho Consultivo (composto pelos indicados de cada município) tinha funções não decisórias, como as de acompanhamento das políticas adotadas, tendo caráter consultivo.

O tema da política urbana e metropolitana apareceu ainda nos instrumentos maiores de planejamento, sendo o caso da Política Nacional de Desenvolvimento Urbano (PNDU), elaborada na esteira do II PND. Este instrumento identificava a importância das metrópoles e grandes cidades como irradiadores das melhorias previstas pelo desenvolvimento. Buscava-se, ainda, a redução dos desequilíbrios existentes nas cidades brasileiras e a racionalização do uso 
do solo, além da correção dos desníveis de renda dentro das cidades e a melhoria da estrutura urbana. Como instrumento central da aplicação destas políticas, em termos institucionais, estaria a Comissão Nacional das Regiões Metropolitanas e Política Urbana (CNPU), atuando financeiramente a partir do BNH e de Fundos de Desenvolvimento Urbano de outras fontes. Posteriormente, em 1979, é criado o Conselho Nacional de Desenvolvimento Urbano (CNDU).

De forma efetiva, em relação à política urbana, Villaça (2004) considera que houve evolução na perspectiva de um planejamento urbano integrado (e não apenas visando intervenções pontuais), porém estes eram eivados de forte tecnocracia e buscavam aqui aplicar modelos de planejamento e de cidade estrangeiros, o que resultou em baixa execução geral dos planos. Gouvêa (2005) ressalta a crítica às ações setorializadas do Estado, que elevou a pouca execução do planejado.

Em termos de política metropolitana, a grande inovação do período foi a inserção do tema das metrópoles nas políticas de Estado do país. Analisando sua efetividade, Eghrari (2013) classifica sua forma de governança como top-down, com o governo central impondo seu formato aos governos estaduais e prefeituras. A própria composição das Regiões Metropolitanas era definida por uma legislação federal, também a cargo da regulamentação da gestão desses entes. Isto revela, por outro lado, a necessidade de controle de um território que ia sendo considerado cada vez mais estratégico pelos governos militares. Em relação à efetividade do CNDU, Gouvêa (2005) aponta que a atuação deste órgão não compreendia um planejamento do tipo global ou compreensivo, atuando em um planejamento adaptativo, o que acabou por reduzir a eficácia de sua atuação. Por outro lado, é fundamental apontar a criação de novas instituições voltadas ao planejamento metropolitano e regional no âmbito dos Estados.

\section{Política agrícola}

Relativamente à política agrícola, Graziano da Silva (1996) destaca que o período é marcado pelo início do processo de modernização da agricultura. Em termos de políticas específicas, ele destaca o interesse, já no governo Vargas, da produção de fertilizantes e de máquinas agrícolas internamente, sugerindo o mesmo processo de substituição de importações em curso na indústria. Tal interesse somente veio a se concretizar durante o Plano de Metas, quando a produção interna foi bastante fortalecida. A partir do golpe de 1964, passa a ter fundamental importância o crédito rural, organizado a partir do Sistema Nacional de Crédito Rural (SNCR). De certa forma, a própria política agrícola passa a constar mais claramente no planejamento de longo prazo do governo federal, destacando-se aí o I PND, em oposição ao 
Plano de Metas que não traça claramente uma política para o setor (ao menos não como um todo). O I PND sugeria, assim, o desenvolvimento de uma agricultura de base empresarial, moderna, para o Centro-Sul; uma mudança na agricultura do Nordeste, a partir do avanço da perspectiva empresarial e da modernização do campo; a ocupação e o avanço da fronteira agrícola, no Centro-Oeste e na região Amazônia. É importante ainda considerar o papel do Estado no estímulo à ocupação de novos espaços, seja por meio da formação das colônias agrícolas, seja pelo desenvolvimento de tecnologias necessárias ao plantio em solos antes pouco utilizados, como o dos cerrados. Fora da órbita estatal, há ainda a atuação de agentes financeiros de origens diversas, que passam a ver na produção agropecuária possibilidades de aumento de lucros, alterando bastante o perfil de atuação no setor agrícola.

Em termos efetivos, Graziano da Silva (1996) aponta para dois processos das políticas implantados no período em questão: uma parte como a continuidade da modernização agrícola, no qual a atuação do Estado deu-se especialmente no sentido de modernizar a base técnica por meio da substituição de importações, levando a uma mudança na orientação do principal mercado consumidor (do externo ao interno); e um segundo momento, no qual a atuação passa a se basear em torno do crédito, levando ao aprofundamento do processo de modernização e à associação da agricultura à indústria, formando os Complexos Agroindustriais (CAIs). A atuação efetiva leva, assim, a um abandono das políticas que favoreciam a produção do café sudestino, em um primeiro momento, para uma agricultura modernizada a mais submetida ao urbano, e que, como se verá à frente, foi uma das responsáveis pelas intensas mudanças na organização regional brasileira. Delgado (2005) aponta o prevalecimento de uma visão baseada na economia liberal ortodoxa, de modernização que prescinde da resolução dos problemas sociais do campo, o que levou a perseguições a movimentos rurais de esquerda.

\section{Política de infraestrutura rodoviária e de transportes}

Considerando o período, a política em torno da infraestrutura de transportes conheceu um forte impulsionamento, dado, principalmente pelos imperativos de desenvolvimento e integração regional. Neste sentido, O Plano de Metas, de JK cumpriu importante papel, na medida em que listou em diversas de suas metas o tema do transporte, especialmente o rodoviário. As projeções chegavam a falar na pavimentação de $5.000 \mathrm{~km}$, além do estímulo ao aumento da produção de veículos automotores. A própria construção de Brasília teve importante papel nisto, já que a cidade fora projetada como ponto de irradiação do 
desenvolvimento e da integração nacional, grande preocupação de então. Ainda no governo de Juscelino Kubitschek foram atraídas importantes transnacionais do setor automobilístico, ampliando a produção nacional de automóveis. No restante do período, de forma geral, a política rodoviarista dará o tom do processo de estruturação dos transportes, seguindo-se a tônica da busca pela ocupação e integração dos espaços considerados "vazios". Como principais eixos construídos no período, podem ser destacados aqueles diretamente vinculados à construção da Nova Capital, notadamente a Belém-Brasília (BR 153) e as rodovias de Brasília com outros importantes centros: Brasília-Fortaleza (BR 020), Brasília-Rio de Janeiro (BR 040), Brasília-Santos (BR 050 - passando por São Paulo), Brasília-Campo Grande (BR 060 passando por Goiânia). É ainda notável o esforço de construção de rodovias no espaço da Amazônia, sendo notório o caso da Transamazônica (PEREIRA; LESSA, 2011).

De forma efetiva, houve, de início, o abandono da perspectiva de integração anteriormente posta, na primeira metade do século XX (e desde antes, no séc. XIX), da integração do território a partir das ferrovias e da navegação de cabotagem. Galvão (1996) aponta que a opção pela rodovia foi feita dada a urgência de integração nacional e pela falta de um mercado interno fortalecido, que justificasse economicamente a implantação das ferrovias. A opção pelas rodovias levará à construção e pavimentação de diversas delas, que acabaram por cumprir o papel de integrar um mercado interno que ia se expandido. A partir de Brasília e de alguns novos eixos que surgiam nos "espaços vazios", regiões remotas foram integradas a uma rede nacional, possibilitando falar, claramente, em um mercado nacional. Por outro lado, alguns projetos, especialmente na década de 1970 e sobre a Amazônia restaram inconclusos, o que acabaria por ser reforçado pela crise fiscal do Estado no fim desta década. O modelo foi ancorado em pesados investimentos estatais, sem grande participação da iniciativa privada na construção destes novos eixos.

Em um apanhado geral, as ações deste período apontam para uma progressiva preocupação das políticas públicas em torno dos temas territoriais. Vê-se, de início, a criação de um aparato institucional e de um arcabouço de métodos e técnicas de planejamento em relação ao tema regional, que aos poucos vai incorporando a questão urbana. De forma efetiva, as principais ações serão dirigidas pelo Estado, por manter aí sua política de apoio e direção ao setor privado (com suas exceções, obviamente). Com a crise do Estado de forma mais clara a partir da década de 1980, ações de mais curto prazo ganham mais força, em detrimento do planejamento de horizonte temporal maior. Paralelamente, outros agentes ganham força e ocuparão este espaço de promotor do desenvolvimento econômico nacional e de ordenador do 
território. Estas ações foram fundamentais, para a Ride-DF por conta, inicialmente, da construção de Brasília e da construção de infraestrutura necessária para tal empreitada, bem como, a partir da década de 1970, pela inclusão do Centro-Oeste como espaço produtivo da agropecuária moderna.

\subsubsection{Desdobramentos das ações de gestão do território}

A descrição dos possíveis desdobramentos das ações de gestão do território, para cada período, abarca dois momentos diferentes: inicialmente, uma visão do quadro regional mais amplo do Brasil, com foco nos processos próprios das macrorregiões; num segundo momento a análise em regiões mais específicas e de características similares (ainda que não idênticas, conforme já exposto) à Ride-DF, as Regiões Metropolitanas instituídas. As Regiões Metropolitanas consideradas foram aquelas correspondentes aos espaços classificados como metrópole pela última Pesquisa da Regic (IBGE, 2008), assim sendo: São Paulo, Rio de Janeiro, Belo Horizonte, Curitiba, Porto Alegre, Salvador, Recife, Fortaleza, Belém, Manaus e Goiânia (Brasília está também neste rol, mas não será aqui analisada devido seu processo específico ser estudado como foco do trabalho, nos próximos capítulos).

\section{Desdobramentos no quadro nacional e macrorregional}

A partir das ações acima descritas, os desdobramentos sobre a organização e a produção do espaço nacional foram significativos, podendo ser destacado o esforço em tornar a economia nacional unificada, o que permitiu expandir o mercado interno, algo fundamental na conformação de uma divisão regional do trabalho (MOREIRA, 2014). Este novo período é marcado, assim, por uma concentração claramente existente no Sudeste brasileiro, ocorrendo um processo de polarização das demais regiões. Santos e Silveira (2001) analisam que, pela concentração econômica em torno de Rio de Janeiro e São Paulo, houve a perda de poder de outras metrópoles e centros regionais.

Num segundo momento, a partir de meados da década de 1970, Moreira identifica um processo de reestruturação e relocalização da indústria. Esta fase ocorre, segundo ele, pois a "diferenciação-concentração industrial chega a um grau insustentável, criando efeitos contrários à própria lógica que em sua origem presidira" (p. 260). Por conta das deseconomias de escala e dos problemas ambientais decorrentes da concentração demasiada, além da própria 
atuação do Estado brasileiro (daí o relativo sucesso do II PND), inicia-se um período de desconcentração da produção ao redor de São Paulo (em uma escala maior, do Brasil), o que redefine a divisão regional do trabalho. Em alguns setores específicos, outras macrorregiões serão afetadas, havendo destaque para iniciativas no Nordeste fomentadas pela atuação da Sudene.

Em relação ao espaço produtivo da agropecuária, conforme já brevemente delineado na análise das ações, apresenta como desdobramento o início do processo de modernização da agropecuária nacional. Inicialmente, tal processo ocorreu a partir da incorporação de tecnologias externas, passando, a partir da década de 1970, à produção de maquinário específico para o campo no território brasileiro. Isto se deu muito pela organização da agropecuária a partir das necessidades de exportação, sendo fundamental ao equilíbrio econômico nacional (GRAZIANO DA SILVA, 1996; ELIAS, 2003). Em termos regionais, este processo levará também à ocupação da Região Centro-Oeste como fronteira agrícola, a partir do apoio do Estado ao avanço da produção de commodities. Isto passa a ocorrer a partir do uso e esgotamento das fronteiras do Sul e Sudeste, cuja ocupação e modernização ocorreu mais precocemente. Tal processo reproduziu o apoio do Estado, que se deu tanto pela via tecnológica - na qual a atuação da Empresa Brasileira de Pesquisa Agropecuária (Embrapa) foi fundamental - quanto por meio de apoio financeiro (que acabou por controlar o processo, assim como ocorrido em outras regiões brasileiras). Contribuiu para isto a oferta de terras a preços baixos.

\section{Desdobramentos na organização e estruturação das Regiões Metropolitanas}

Para a compreensão dos desdobramentos específicos sobre as Regiões Metropolitanas, é necessário considerar, inicialmente que o processo de urbanização que resultou das ações de gestão do território ocorreu, no período, de forma rápida, movido pelas correntes migratórias que se moviam para as principais cidades. Isto levou a que as ações de planejamento urbano e metropolitano tenham surtido menor efeito, não conseguindo "acompanhar" o ritmo da urbanização que ocorria. Assim, num primeiro momento, o espaço das metrópoles foi organizado a partir do modelo clássico fordista, com acentuação de uma periferia do capitalismo global: concentração excessiva de funções em um centro único e expansão periférica em espaços economicamente deprimidos e dependentes. Mais o término do período, este modelo apresentou algumas fissuras, por conta da redução da pressão demográfica das migrações, e por desgastes na estrutura de forte concentração e dependência de um centro único (atuou também a desconcentração produtiva que se verificava em nível nacional). As 
metrópoles, a partir de então, perdem a compactação que antes possuíam, expandindo-se a partir dos principais eixos rodoviários e apresentado mesmo a ocupação das periferias por segmentos da classe média (este último processo viria a ser aprofundado posteriormente), o que atraiu atividade antes concentradas no centro principal.

Desta forma, muito pela atuação do Estado (a partir, principalmente do II PND), inicia-se, no âmbito dos espaços das Regiões Metropolitanas, um processo de desconcentração produtiva, reproduzindo a tendência do que já ocorria em escala nacional e regional. Aos municípios núcleo dos espaços metropolizados restou o papel de concentrar os equipamentos de gestão dos fluxos econômicos, ao passo que as plantas industrias passaram a migrar para municípios vizinhos, em geral no âmbito da Região Metropolitana. Em termos regionais, esta tendência foi inicialmente verificada nas metrópoles do sudeste brasileiro, o que, a partir da atuação do governo, passou a ocorrer também em outras regiões (como no caso da atuação da Sudene nas metrópoles nordestinas).

Esse processo mais geral de mudança nos espaços produtivos engendrou, também, modificações no âmbito da questão do centro principal e dos subcentros. Pintaudi (1997) aponta que, entre as décadas de 1950 e 1960 iniciou-se uma modificação no padrão de localização dos grandes equipamentos de consumo, dado que anteriormente havia uma tendência de fusão destes com os usos residenciais, nas áreas centrais principais. A partir, inicialmente, de uma desconcentração dos espaços de moradia, o comércio varejista realiza movimento parecido, acompanhando a expansão dos novos bairros que iam surgindo. Aos centros caberá, desta forma, o exercício de outras funções, como a prestação de serviços de maior complexidade e a localização de grandes equipamentos comerciais, sendo, no caso brasileiro, tal processo mais evidente em São Paulo e no Rio de Janeiro, neste período.

Das duas metrópoles mencionadas, o processo mais complexo é justamente aquele da metrópole que está no topo da hierarquia urbana brasileira, a Região Metropolitana de São Paulo. O processo para seu espaço metropolitano ocorreu como desconcentração não apenas encerrado em si, mas também em uma escala maior, nacional, o que reafirmou seu papel como centro principal de gestão do capital do país. Ali passou a se concentrar a principal praça financeira do país, com a oferta de diversos setores exclusivos e de alcance nacional e internacional (GASPAR et al, 2015; SERRÃO; DIAS, 2015). Lencioni (2011) aponta que tal processo ocorre em formato linear e não aureolar, por conta da influência dos principais eixos de ligação de São Paulo com seu interior. Os municípios mais atingidos por esta nova tendência produtiva serão os do $\mathrm{ABCD}$ paulista (Santo André, São Bernardo, São Caetano do Sul e Diadema), recebendo, principalmente, a indústria automobilística. 
No caso das outras Regiões Metropolitanas, o processo será muito parecido com o ocorrido em São Paulo, porém com extensão reduzida e menor envolvimento do interior de seus estados. O Rio de Janeiro, que talvez tivesse porte para reproduzir processo parecido padeceu de problemas de articulação com seu espaço interiorano, muito por conta dos problemas legais causados pela tardia fusão do Estado da Guanabara com o do Rio de Janeiro, criando barreiras a uma melhor integração e à projeção nacional (SIQUEIRA, 2015). No caso da metrópole carioca e sua região, Siqueira aponta anda para o papel do Estado no processo, induzindo a industrialização nos municípios da Baixada Fluminense.

Já sobre os outros espaços metropolitanos, estes estarão, neste momento cumprindo uma função diversa de acordo com a escala de análise: observando a questão a partir da visão nacional do processo produtivo, conforme já mencionado na subseção anterior, estas metrópoles (especialmente as do Sul) são o lócus do processo de desconcentração originado na metrópole paulista; ao se observar a escala metropolitana, o processo ocorre de forma desconcentrada em relação ao centro principal, que abriga de pronto as funções de gestão. De forma específica, há a desconcentração de algumas atividades na Região Metropolitana de Curitiba, especialmente no município de Araucária, por meio de novas indústrias (MOURA et al, 2015; FIRKOWSKI, 2002). No caso desta, não houve grande envolvimento com outros municípios, restando a eles a atividade agropecuária. Porto Alegre apresenta o surgimento de indústrias nos principais eixos rodoviários de integração, com destaque para o município de Novo Hamburgo (SOARES, 2015).

Um ponto fundamental de análise para os resultados considerados é que o processo de desconcentração, na quase unanimidade da bibliografia consultada, aponta para os efeitos especialmente do II PND no processo de desconcentração. Isto torna-se mais claro ao analisar os casos principalmente das metrópoles nordestinas, cujos processos de industrialização (e de sua posterior desconcentração) foram objeto de importante papel da Sudene. Em maior ou menor escala, o processo favoreceu municípios próximos dos centros principais sendo que alguns já possuíam certa tradição industrial, como no caso da Região Metropolitana de Fortaleza (COSTA; AMORA, 2015; PEREIRA JR., 2015). Nesta o processo irá apontar para uma área entre o município sede e Maracanaú (ainda não emancipado), a partir de impulso da Sudene. No caso da Região Metropolitana de Salvador, são apontados os investimentos em Camaçari (Complexo Petroquímico de Camaçari) e Simões Filho (Centro Industrial de Aratu), visando o estímulo à produção industrial. Ambos atuavam como complemento ao processo industrial do Centro-Sul, produzindo bens intermediários. Para o caso da Região Metropolitana 
do Recife, Rosa e Oliveira (2015) apontam o papel da Sudene na inserção (ou "soldagem") de Recife no contexto industrial nacional, ainda com desconcentração reduzida.

As exceções ao acima posto ficarão por conta de três espaços metropolitanos com pouca tradição industrial: Brasília (a ser analisado à frente), Goiânia e da Região Metropolitana de Belém. Os dois primeiros casos falam de espaços que à época ainda não se constituíam como metrópole (nem estavam formalizadas como Região Metropolitana, no caso de Goiânia, e Região Integrada de Desenvolvimento ${ }^{10}$, no caso de Brasília). Já Belém ocupava uma função de articuladora da rede urbana da Amazônia Oriental, sendo fundamental aos investimentos ocorridos a partir dos grandes projetos de ocupação e aproveitamento mineral amazônicos então em curso (CARDOSO et al, 2015; FERNANDES et al, 2015). Outro caso fora deste padrão foi Manaus, cujo processo de inclusão na produção industrial nacional se fez a partir da atuação específica do governo federal, por meio da Zona Franca de Manaus, restrita ao município (LIMA, 2014).

Desta forma, na maior parte dos espaços metropolitanos nacionais no período, o que se verificou foi uma concentração das atividades notadamente de consumo (e em menor escala, produtivas), seguido de um processo de desconcentração da estrutura produtiva, que originou novos espaços produtivos (industriais) nas margens do tecido metropolitano. Tal processo lega aos espaços centrais (ou polos das Regiões Metropolitanas) novas funções, localizando em si especialmente as atividades de gestão do capital. O perfil do trabalho nestes municípios vai se alterando, ocorrendo um amplo processo de terciarização. Desta forma, neste primeiro momento, o que se percebe é o início de um processo de dispersão do consumo e mais clara dispersão dos espaços produtivos, especialmente nas Regiões Metropolitanas mais industrializadas. Por outro lado, não se verificou uma expansão da agropecuária moderna no espaço das Regiões Metropolitanas, algo que só será mais visível, em algumas delas, no período seguinte. Tal contexto leva a que na Ride-DF, a incidência se dê de forma mais clara na tendência de expansão das áreas ocupadas, mas que, por características próprias, ainda "barrou" a expansão dos espaços de consumo na periferia.

O próximo período demonstrará uma mobilidade maior do capital nacional, que será responsável por produzir subcentros em espaços metropolitanos e regionais ligados a cadeias produtivas externas à Região Metropolitana, com a emergência, por outro lado, de subcentros ligados ao agronegócio modernizado.

\footnotetext{
${ }^{10}$ Feitas as ressalvas de que a Ride-DF não é oficialmente uma Região Metropolitana, conforme já exposto anteriormente.
} 


\subsection{O período do neoliberalismo (1986-2016)}

O traço marcante deste período será a inserção do país na lógica neoliberal global que resultará num novo papel do Estado em relação às ações de planejamento e desenvolvimento socioeconômico. Estas levarão a desdobramentos mais alinhados às tendências da reestruturação produtiva, com novas dinâmicas que refletem uma busca de competitividade atuando em escala macrorregional e sobre as Regiões Metropolitanas.

\subsubsection{Contexto socioeconômico}

O período considerado do neoliberalismo (1986-2002) tem como sua principal característica a hegemonia do modelo neoliberal, que se manifesta pela redução do tamanho do Estado e do seu perfil de intervenção, cada vez menos direto. Hobsbawn (1995) aponta que nos anos finais da década de 1980, o pensamento neoliberal (antes em embate com o keynesiano) alcança seu apogeu, o que levou ao desmonte das políticas econômicas desenvolvimentistas do período anterior. Sem uma interpretação rígida, o período em questão coincidiria com a fase denominada por Harvey (1992) como de acumulação flexível e considerada por Lipietz (1991) como de liberal-produtivismo ${ }^{11}$. O que Harvey (1992) chama de acumulação flexível, como visto, refere-se ao momento em que o capitalismo passa a um regime de produção de menor regulação sobre os fluxos de capitais e em que estes passam a reproduzir-se em bases (inclusive espaciais) mais flexíveis. Lipietz (1991) chama de liberal-produtivismo aponta a experiência de um "novo liberalismo", de bases diferentes do liberalismo clássico, em que há uma busca quase cega pela acumulação, além de um exacerbado individualismo.

No Brasil, em termos políticos, ocorre, de início, a transição para o regime democrático, o que é feito, segundo Vieira (2000) a partir de um processo de conciliação, não ocorrendo a ascensão de um novo grupo ao poder. O principal resultado deste processo será a redação de uma Nova Constituição Federal, promulgada em 1988. A partir do novo texto constitucional, os presidentes da República voltaram a ser eleitos de forma direta, ainda que nem sempre completando seus mandatos, casos de Fernando Collor (1990-1991) e, mais recente

\footnotetext{
${ }^{11}$ Os traços principais e uma discussão sobre a acumulação flexível foram apresentados no capítulo teórico. Considera-se que a periodização adotada ao longo deste trabalho não é estanque, servindo para organizar as análises.
} 
de Dilma Rousseff (2011-2014 e 2015-2016) ${ }^{12}$. Neste período, houve, até 2002, uma orientação política francamente favorável às teses neoliberais. Com a eleição de Luís Inácio Lula da Silva (2003-2006 e 2007-2010), há uma relativização deste modelo, retomando o Estado alguns importantes investimentos e seu papel em coordenar o desenvolvimento socioeconômico nacional. Tal inflexão tem sido chamada por Bresser-Pereira (2006) de "novodesenvolvimentismo".

Analisando o quadro econômico nacional neste período, vê-se um primeiro período, até 1994, no qual ocorre a elaboração de diversos planos econômicos de estabilização. Neste ano, com o Plano Real, houve o controle inflacionário e o início de uma certa estabilização fiscal do Estado. Em 1997 é aberto um novo ciclo de crise, que se acentua em 1999, levando à maxidesvalorização do preço do dólar e forte alta de juros. Este ciclo de crise se manteve até 2003. Entre 2004 e 2009, houve um período de importante crescimento econômico e estabilização, período no qual diversas políticas públicas de distribuição de renda alcançaram seu auge. Entre 2009 e 2013 houve o agravamento da crise econômica internacional, levando a dificuldades econômicas internas, notadamente o descontrole das contas públicas e reduzidas taxas de crescimento (LEVY, 2015; BASTOS, 2015; RIBEIRO, 2015; LAMEIRAS, 2015; CARVALHO, 2015).

Em termos demográficos, a população aprofunda a tendência de redução do seu crescimento, por meio da progressão na redução das taxas de fertilidade, aproximando o padrão demográfico brasileiro do europeu da década de 1970. Rodrigues e Baeninger (2010) apontam, para a década de 2000, a existência de um país urbano, com taxa de fecundidade próxima da reposição (2,1 filhos por mulher) e com padrão de mortandade próximo ao de alguns dos países desenvolvidos, havendo crescimento de incidência de doenças típicas destes países, como a obesidade. É fundamental considerar, de acordo com Brito (2007), que o ritmo da transição varia de acordo com a região, sendo que naquelas de menor renda o ritmo é reduzido (isto se reproduz mesmo na escala metropolitana). Sobre os fluxos migratórios, estes se orientam mais para as áreas de avanço da agropecuária (Centro-Oeste, Norte e alguns vizinhos brasileiros, como o Paraguai) e mais forte e claramente, para as cidades médias. Esta tendência ocorre mesmo internamente nas Regiões Metropolitanas, com a busca de cidades de menor porte próximas aos grandes centros, havendo, aí, forte influência dos eixos de mobilidade (BRITO, 2006; OJIMA; MARANDOLA JR., 2012).

\footnotetext{
12 Sobre o impedimento de Rousseff, há uma extensa lista de pensadores, nos mais variados campos do saber, que consideram o processo como um golpe de Estado, orquestrado pelas velhas oligarquias, com apoio dos monopólios de mídia. $\mathrm{O}$ autor desta tese filia-se a tal pensamento.
} 


\subsubsection{Ações de gestão do território}

Neste período, há uma modificação da arena de poder entre os agentes, especialmente pelo novo papel ocupado pelo Estado, de perfil bem menos executivo que no período anterior. Assim, agentes privados, especialmente os ligados ao grande capital, serão responsáveis, mais diretamente, pelas ações com desdobramentos efetivos no território.

\section{Politica regional}

Considerando um "mutismo" do Governo Federal sobre o tema do desenvolvimento e integração regional (o que só seria rompido, com uma política específica em 2007), é necessário recorrer às peças de planejamento geral dos governos para compreensão da visão deste nível de governo sobre o tema.

A partir da redemocratização, somente a partir do governo Fernando Henrique Cardoso (1995-1998 e 1999-2002) o tema da política regional aparece de forma mais clara. Assim, por meio do Plano Plurianual (PPA) 1996-1999, "Brasil em Ação” (BRASIL, 1996), sobre o tema regional, ao abordar a questão agrícola e industrial, apontava para a necessidade de correção de seus desequilíbrios e à sua concentração espacial. É interessante mencionar que já neste instrumento inicia-se uma explanação sobre os eixos de integração nacional, que mais tarde marcariam a retomada mais efetiva da política regional. Durante o segundo mandato de FHC, é aprovado o PPA 2000-2003, “Avança Brasil” (BRASIL, 2000). Este foi um importante marco para a política regional a partir de um portfólio de investimentos públicos e privados, constituindo os Eixos Nacionais de Integração e Desenvolvimento. Estes são apresentados como uma das agendas do país, sendo possível notar a perspectiva de uma política de desenvolvimento regional baseado nas necessidades de logística dos principais setores produtivos do país, notadamente o agrícola.

Nos governos de Lula e Rousseff, os Planos Plurianuais elaborados sempre abordaram a questão da política regional, sendo, porém, observável a redução da quantidade de programas destinados para a temática (no atual PPA, 2016-2019, há apenas o Programa de Desenvolvimento Regional - $\mathrm{n}^{\mathrm{o}}$ 2029). Nos planos, de 2004-2007, 2008-2011 e 2012-2015 podem ser destacados alguns programas, como: Desenvolvimento da Faixa de Fronteira; Desenvolvimento Integrado e Sustentável do Semiárido (Conviver); Integração de Bacias 
Hidrográficas; Organização Produtiva de Comunidades; Promoção da Sustentabilidade de Espaços Sub-regionais (Promeso); Desenvolvimento Macrorregional Sustentável (BRASIL, 2004; BRASIL, 2008; BRASIL, 2012; BRASIL; MINISTÉRIO DO PLANEJAMENTO, ORÇAMENTO E GESTÃO, 2011; MINISTÉRIO DO PLANEJAMENTO, ORÇAMENTO E GESTÃO, 2015).

Na gestão do Presidente Lula, é aprovada, em 2007, a Política Nacional de Desenvolvimento Regional (PNDR - Decreto $n^{\circ}$ 6.047, de 2007) que tem como principal objetivo a redução das desigualdades regionais do país e a ativação do potencial de desenvolvimento das regiões (MINISTÉRIO DA INTEGRAÇÃO REGIONAL, 2015). Para tanto, tal política adota estratégias específicas nas escalas macrorregional e em escalas subregionais, no caso as mesorregiões, unidades estabelecidas pelo MI como regiões-programa. Além disto, são elencados alguns espaços considerados prioritários para atuação: o Semiárido, a Faixa de Fronteiras, as Regiões Integradas de Desenvolvimento e as treze mesorregiões consideradas diferenciadas. Tal priorização segue como critério uma relação entre o PIB per capita destas mesorregiões e as tendências de crescimento ou decréscimo econômico.

Em relação à efetividade das políticas de planejamento regional contidas nos planos apresentados, pode-se considerar uma baixíssima efetividade dos primeiros PPAs. Até 1994, isto se deu devido, entre outros, ao próprio cenário macroeconômico instável, levado à valorização do "curtoprazismo" nas políticas públicas. Interferiu ainda a "imaturidade" na elaboração e aplicação dos instrumentos (no começo era mais um plano de investimentos, não um plano de longo prazo), a reduzida disponibilidade de recursos para execução das metas, objetivos e investimentos (quadro de ajuste fiscal) e problemas em sua formulação (MATOS, 2002; SENRA, 2009). Os PPAs mais recentes demonstram o interesse em revigorar o papel do Estado como planejador, mas muitas das ações têm dificuldades em ser realizadas por conta de restrições orçamentárias.

Em termos específicos sobre a política regional, o período engendra o declínio sobre o tema e sua retomada. De início, houve e extinção/ transformação de diversos dos órgãos ligados ao tema, tais como as superintendências de desenvolvimento regional (Sudene, Sudam e Sudeco). O tema ficaria muito tempo alocado em Ministérios e órgãos preocupados com outras questões, estando relegado a um segundo plano. Tal quadro começa a se modificar a partir dos Eixos Nacionais de Integração e Desenvolvimento do Programa Avança Brasil, que resgata o tema regional, apesar da ênfase em logística. Em seguida, em 1999, é criado um ministério específico para o tema regional (apesar de ter outas atribuições mais amplas): o 
Ministério da Integração Nacional ${ }^{13}$. Esse processo, posteriormente durante a gestão de Lula se fortalece, com a formulação e aprovação da PNDR, a recriação das Superintendências ${ }^{14}$ e o fortalecimento dos fundos constitucionais dedicados ao desenvolvimento regional: Fundo Constitucional de Financiamento do Centro-Oeste (FCO); Fundo Constitucional de Financiamento do Nordeste (FNE); e Fundo Constitucional do Norte (FNO). Sobre a PNDR, são destacados alguns de seus avanços, especialmente por tratar das desigualdades intrarregionais e buscar a convergência dos indicadores de desenvolvimento adotados (basicamente a Renda per capita média nacional e o crescimento dos PIBs dos municípios). Por outro lado, esta política ainda tem dificuldades em sua total implantação, por alguns fatores: não tem força de lei, o que enfraquece seu poder de obrigação com outros entes da federação; tem ainda diretrizes descoladas daquelas dos instrumentos de financiamento do desenvolvimento regional; mesmo a consideração das mesorregiões não dá conta de fenômenos de desenvolvimento que ocorrem em rede (como as cadeias produtivas); as desigualdades se manifestam internamente às mesorregiões, não sendo suficientemente tratadas na política. Alves et al (2014) apontam ainda dificuldades em torno da tipologia proposta pela PNDR, como o fato de não ter sido discutida e legitimada com outros entes federativos e de não ter sido assumida de forma mais efetiva pelo governo federal como parâmetro para atuação em outras políticas públicas. É importante ainda destacar que o tema do desenvolvimento regional não conseguiu ocupar postos principais nas agendas dos presidentes da República de então, além do perfil do próprio Ministério da Integração Nacional, que possui atribuições diversas e um perfil ainda reconhecido de ministério "obreiro" do Governo Federal.

\section{Política metropolitana}

No período considerado, a política urbana ganhará impulso a partir da obrigatoriedade estabelecida pela Constituição Federal de 1988 da elaboração dos planos diretores por municípios com mais de 20 mil habitantes. Outros instrumentos foram

\footnotetext{
13 Anteriormente à criação do Ministério da Integração Nacional, os temas referentes ao desenvolvimento regional, na década de 1990, estiveram a cargo da Secretaria de Desenvolvimento Regional, ligada à Presidência da República (1990), ao Ministério da Integração Regional (1992) e à Secretaria Especial de Políticas Regionais (SEPRE), do Ministério do Planejamento e Orçamento (1995).

${ }^{14}$ A Superintendência do Desenvolvimento da Amazônia (Sudam) foi recriada por meio da Lei Complementar $n^{\circ}$ 124, de 3 de janeiro de 2007 e a Superintendência do Desenvolvimento do Nordeste (Sudene) pela Lei Complementar $\mathrm{n}^{\circ} 125$, de 3 de janeiro de 2007. Já a Superintendência do Desenvolvimento do Centro-Oeste (Sudeco) somente seria recriada dois anos mais tarde, por meio da Lei Complementar $\mathrm{n}^{\circ} 129$, de 8 de janeiro de 2009, sendo efetivamente instalada apenas em 2011.
} 
posteriormente regulamentados e criados pelo Estatuto da Cidade, Lei $\mathrm{n}^{\mathrm{o}} 10.257$, de 2001 (BRASIL, 2001), que prevê, entre outros, a participação democrática na elaboração dos planos diretores e a cooperação entre os entes federativos sobre os temas do ordenamento do território. Sobre este tema, é fundamental ainda a criação de órgão específico no Poder Executivo Federal, o Ministério das Cidades, em 2003. Relativo ao tema habitacional, a principal política do período ficou por conta do Programa Minha Casa Minha Vida (PMCMV), iniciado em 2009, que tem buscado reduzir o déficit habitacional do país a partir da oferta de crédito imobiliário à população. São selecionados projetos apresentados ao Ministério das Cidades, havendo a financiamento de agentes privados, responsáveis pela construção das moradias. A Caixa Econômica Federal tem sido a principal executora do programa (BOTELHO, 2007). Este banco público tem sido a principal instituição financiadora da habitação e de obras de infraestrutura urbana, com a derrocada do SFH e do BNH.

Em termos de política metropolitana, a Constituição Federal de 1988 operou uma importante alteração no processo de criação de Regiões Metropolitanas. Se, pela carta de 1967, a criação destas ocorria a partir de Lei Complementar federal, a novo dispositivo constitucional prevê, no parágrafo $3^{\circ}$ do artigo 25 , que cabe aos Estados federados, por meio de Leis Complementares estaduais, a criação de regiões metropolitanas, aglomerações urbanas e microrregiões. Refletindo movimentos de descentralização de decisões até então atribuídas à União, o poder conferido aos Estados-membro de estabelecer regiões metropolitanas proporcionou-lhes também a possibilidade de criar diversos arranjos de gestão para estas, o que foi alvo de várias controvérsias.

Buscando normatizar tal situação foi aprovado o Estatuto das Metrópoles (Lei ${ }^{\circ}$ 13.089, de 2015 - BRASIL, 2015a). O objetivo deste diploma legal é justamente tentar normatizar os parâmetros mínimos para a criação e gestão dos espaços metropolitanos, haja vista o silêncio sobre o tema na Constituição Federal de 1988. Além disto, abre possibilidade de criação de Regiões Metropolitanas Interestaduais e cria novos instrumentos de gestão metropolitana. Justamente pelo interesse em normatizar mais claramente o processo de criação e gestão das Regiões Metropolitanas, a referida lei impõe alguns requisitos mínimos à formulação das leis complementares estaduais responsáveis por sua criação, devendo conter: os municípios componentes; os campos funcionais ou funções públicas de interesse comum; a conformação da estrutura de governança inter federativa; os meios de controle social da organização, do planejamento e da execução das funções públicas de interesse comum. Sobre a governança, alguns itens passam a ser obrigatórios, como a existência de uma instância executiva, uma instância deliberativa com representação da sociedade civil, uma organização 
pública com funções técnico-consultivas e um sistema integrado de alocação de recursos. São postos ainda novos instrumentos (Art. $9^{\circ}$ ), havendo claro destaque para o plano de desenvolvimento urbano integrado (estes são considerados obrigatórios, segundo o Art. 10).

Sobre as ações efetivas em torno da política urbana, são importantes os avanços produzidos a partir das políticas e normas elaboradas no período, que obrigaram a elaboração dos instrumentos. Entretanto, apesar da existência de um arcabouço jurídico e institucional novo, diversos planos têm sido elaborados apenas como obrigação, sem maior discussão das reais questões urbanas, além de práticas comuns como o uso do plano para tentar "vender a cidade" - uso do ordenamento do solo como forma de atração de investimentos externos (sobre o tema, há importantes análises de Sánchez, 1997 e Vainer, 2000). Quanto ao Ministério das Cidades, este teve, de início, qualificada equipe técnica, sendo, com o tempo, utilizado como moeda de troca política, o que reduziu sua atuação mais voltada a interesses políticos e partidários (tal "guinada" ocorreu durante o escândalo do "mensalão", no primeiro mandato de Lula). Sobre a política habitacional do período, Botelho (2007) avalia que as políticas habitacionais acabaram por transferir uma maior quantidade de recursos a agentes privados, algo que, de certa forma, foi mantido com o PMCMV. Este programa tinha faixa voltada à baixa renda, o que levou a importante redução do déficit habitacional do país, persistindo problemas ainda nas Regiões Metropolitanas.

Sobre a efetividade das políticas metropolitanas, o período conviveu com uma situação geral de poucas definições, dando muita liberdade aos Estados para definir o tamanho e a forma de gestão das Regiões Metropolitanas. Por conta desta baixa normatividade, e buscando obter recursos federais por meio de programas específicos, foram formalizadas diversas regiões metropolitanas em espaços onde nitidamente não ocorre metropolização (um dos casos extremos diz respeito ao Estado de Santa Catarina, onde todos os municípios do Estado estão abarcados em alguma Região Metropolitana). Quanto a gestão, por conta da não parametrização legal, as experiências de gestão são muito comprometidas por conta da autonomia dos entes participantes e da pouca solidariedade entre eles (COSTA, 2013; GOUVÊA, 2005). Mais recentemente, com o Estatuto das Metrópoles, há expectativa de que aumente o planejamento em escala metropolitana e se reduza a proliferação da criação de novas Regiões Metropolitanas.

\section{Política agrícola}


Relativo à política agrícola, Delgado (2005) aponta que esta variou bastante de acordo com as necessidades do país em relação à sua macroeconomia durante a década de 1980 . Nesta década, por conta da necessidade de geração de saldos de comércio exterior, o setor será bastante estimulado, pela manutenção das políticas de crédito rural. Durante o período de 1994 e 1998, com a conjuntura externa mais favorável e o câmbio muito valorizado, o valor da terra cai, e a atenção ao setor novamente se reduz. Em 1999, com novo cenário de restrições e visando aumentar as exportações do país, o setor volta a ser alvo das políticas de crédito, se beneficiando ainda da maxidesvalorização cambial que então ocorria. Mais recentemente, Lima Jr. (2013) destaca que a política agrícola tem mantido a tendência de fomento ao setor por meio das políticas de crédito rural, muitas delas ampliadas. Ele aponta que o Estado se mantem como organizador da forma de intervenção do capital nos territórios, muito por causa do interesse destes, de diversas origens, no valor crescente da terra, muito impulsionado pela grande valorização das commodities no mercado externo. A agropecuária mantem a tendência de ser utilizada como forma de equilibrar a balança de pagamentos, sendo bastante estimulada.

De forma efetiva, percebe-se a manutenção e o reforço das linhas de crédito em relação ao grande agronegócio, que cada vez mais se afirma como elemento essencial no equilíbrio da balança comercial brasileira. Muitos dos fundos regionais citados anteriormente têm muitas de suas contratações realizadas pelo setor do agronegócio - cujo principal caso é o FCO. Por outro lado, buscou-se atender mais proximamente as demandas da agricultura familiar, com a criação do Ministério do Desenvolvimento Agrário (MDA) ${ }^{15}$, em 2000, e com políticas específicas para estes agricultores, como o Territórios da Cidadania e os Territórios Rurais, porém em menor extensão e com menor quantidade de recursos do que para as políticas voltadas à "grande agricultura".

\section{Política de infraestrutura rodoviária e de transportes}

No período considerado, Pereira e Lessa (2011) apontam para a redução na quantidade de investimentos nos eixos rodoviários, que, na realidade era fração da redução geral dos investimentos em infraestrutura que irão caracterizar o começo do período. Conforme já apontado, isto ocorria por conta da forte crise econômica que o país passava. Ao mesmo tempo, houve maior estímulo para que os estados assumissem a gestão das rodovias, já que o processo

\footnotetext{
${ }^{15}$ Este Ministério foi extinto recentemente, durante o Governo Temer, e parte de suas atribuições foram passadas à Casa Civil da Presidência da República.
} 
de implantação realizado anteriormente esteve sob gestão do governo federal (especialmente os grandes eixos). Esta transferência de competência foi realizada a partir dos ditames dos Planos Plurianuais "Brasil em Ação" e “Avança Brasil”", do governo Fernando Henrique Cardoso. Com a questão da integração nacional ao mercado estrangeiro, no momento de abertura da economia, o tema da logística ganhou força e, com um período de poucos investimentos (década de 1990), havia um gargalo fundamental a ser ultrapassado. É na esteira deste argumento que, a partir de um viés neoliberal, irão se iniciar as concessões das rodovias à iniciativa privada. Nestas, ao mesmo tempo em que poderia cobrar pedágio dos usuários das rodovias, as empresas concessionárias eram obrigadas a realizar obras de manutenção e, em alguns casos, duplicação dos trechos. De início esta lógica foi aplicada em São Paulo, passando com o tempo a se tornar comum em outros estados.

Durante o governo Lula e Rousseff, houve uma certa retomada dos investimentos na estrutura de transportes, destacando-se algumas medidas mesmo no resgate do transporte ferroviário. Por outro lado, houve investimentos diretos na malha rodoviária, com a recuperação de rodovias e a duplicação de alguns importantes trechos, a partir de recursos do Plano de Aceleração do Crescimento (PAC, de 2007). Mais recentemente, a partir do último Plano Nacional de Logística e Transporte o tema das concessões foi ampliado, a partir de novos trechos de rodovias, bem como de aeroportos (alguns concedidos à iniciativa privada por ocasião das demandas de obras para a Copa do Mundo de 2014) e portos.

De forma efetiva, houve a realização efetiva das concessões, notando-se, por outro lado, que uma boa parte dos investimentos privados realizados tem ocorrido em torno dos principais eixos rodoviários, havendo um certo perfil de concentração nestas ações (não sem motivo, o mesmo tem ocorrido com os aeroportos, havendo dificuldade em impulsionar a aviação regional). Pereira e Lessa (2011) apontam para a lógica de "duplo pagamento" quando das concessões: o cidadão paga impostos que deveriam custear a rede de transportes rodoviários e, ao utilizá-la, é obrigado a pagar novo valor. É necessário ressaltar que houve importantes investimentos no setor ferroviário, com a entrega de trechos de ferrovias consideradas de "integração" da malha ferroviária, caso da Norte-Sul. Por outro lado, há ainda uma pesada dependência do modal rodoviário, com poucas perspectivas, especialmente no momento atual de restrições orçamentárias, de um aprofundamento da diversificação da matriz de transporte. O setor privado tem realizado investimentos, mas ainda sem a perspectiva e um papel mais ativo do Estado em atender regiões pouco integradas à economia nacional. 
Desta forma, o quadro de ações acima apresentadas aponta, claramente, para a reorientação no modelo de atuação do Estado, alinhado a perspectivas neoliberais que foram apenas brevemente relativizadas durante os governos de Lula e Rousseff. Houve, num primeiro momento, o abandono de parte das políticas essenciais ao desenvolvimento regional, permitindo uma ação mais livre do mercado, inclusive com a ocorrência da chamada "guerra fiscal”. Já na década de 1990, o Estado busca retomar algum protagonismo em suas ações, especialmente após a estabilização da economia na década de 1990, ocorrendo isto a partir dos eixos de integração. Por outro lado, manteve a tendência de subsídio e apoio às atividades agropecuárias. Na década de 2000, especialmente no período de crescimento econômico da segunda metade desta década foram retomados investimentos em infraestrutura, além das concessões. A crise econômica mais recente tem reduzido tais investimentos e pode reduzir novamente o papel do Estado na atuação sobre o território. Relativo à política metropolitana, houve avanço na elaboração recente de instrumentos específicos, porém as experiências de gestão compartilhada são ainda reduzidas. Os casos de maior sucesso de implementação de ações efetivas parecem restritas aos consórcios públicos entre diferentes entes.

\subsubsection{Desdobramentos das ações de gestão do território}

A partir do quadro de ações acima delineadas, os desdobramentos sobre os espaços regionais e sobre as Regiões Metropolitanas demonstram a emergência de processos que sugerem uma intensificação das articulações da economia à esfera globalizada, induzidos por atores que, em um momento anterior, tinham menor poder de atuação que o Estado. Embora com relativa atenção a aspectos sociais, os investimentos do governo central, ao privilegiar os interesses da acumulação, rebateram-se sobre o território de forma a acentuar as desigualdades. Muito por conta disto, a própria realidade regional torna-se mais fragmentada, a partir de novas relações sociais e econômicas que vão aí se impondo.

\section{Desdobramentos: Quadro nacional e macrorregional no período do neoliberalismo}

Como desdobramento geral das ações de gestão do território, Moreira (2014) propõe, de forma mais geral a divisão do país em quatro regiões principais: a do polígono industrial, que corresponde a uma área de concentração de indústrias de mais alta tecnologia, 
responsável pela produção da maior parte dos bens duráveis do parque industrial brasileiro; a do complexo agroindustrial, cuja formação deu-se a partir do estabelecimento do polígono industrial (já que estes espaços são aí geridos) e pela reorientação da fronteira sulina, passando a ocupar, principalmente, o planalto central; a da difusão da agroindústria e de indústrias não duráveis é identificada pelos espaços no antigo nordeste agrário, que passa por uma refuncionalização em seus espaços; finalmente, a região da fronteira biotecnológica, identificase com a área da Floresta Amazônica (não totalmente), marcada pelas tentativas de integração durante os governos militares.

Desta forma, ocorrem efeitos claros da reestruturação produtiva, com um alargamento do polígono industrial, porém ainda de forma concentrada no Centro-Sul brasileiro, revelando um processo de desconcentração concentrada (DINIZ apud MOREIRA, 2014). Alguns setores industriais antes bastante concentrados no Sudeste aderiram à tendência de desconcentração neste período, sendo exemplo disto o setor automobilístico, que implantará unidades em Regiões Metropolitanas como as de Curitiba, Porto Alegre e Salvador. Além disso, em menor escala dados os ainda escassos investimentos em inovação, surgem alguns tecnopolos, sendo talvez o principal exemplo aquele de aviação em São José dos Campos-SP. De certa forma, há aqui uma retomada do processo de desconcentração, porém, no momento, sem uma clara atuação e orientação do Estado, como quando do II PND.

O processo de definição das funções das regiões brasileiras torna-se ainda mais claro, em que pese o avanço da industrialização em alguns pontos do território e a criação de novos polos industriais. Especificamente o espaço produtivo da indústria é profundamente afetado pelo processo de abertura econômica nacional, que, ao buscar elevar a competitividade nacional, acabou por levar a que alguns setores fossem desnacionalizados. Sobre os novos espaços industriais, destaca-se, por exemplo, o eixo Brasília-Anápolis-Goiânia, com importante parque industrial em Anápolis.

Relativamente à produção agropecuária, Elias (2003) aponta para a incorporação do processo produtivo no campo ao processo geral de reestruturação produtiva. Com a incorporação de técnicas mais avançadas à produção, o processo de expansão das áreas cultivadas também se altera, não sendo mais necessária a incorporação de amplos espaços, podendo isto ocorrer por meio do aumento da produtividade da terra já ocupada. Elias aponta ainda a contradição deste processo, que leva a existência de dois brasis: “de um lado, o Brasil que produz alimentos para o mercado interno, e de outro, o produtor de matéria-prima para as modernas agroindústrias, principalmente as exportadoras" (ELIAS, 2003, p. 69). Essa diferença se traduz diretamente na forma de organização espacial da agropecuária brasileira, com os 
espaços mais tecnificados voltados à exportação e localizados em espaços como o interior de São Paulo, o Paraná e grandes porções do Centro-Oeste brasileiro. Atualmente, é possível perceber o avanço deste modelo agrícola para novas fronteiras do país, dada a ocupação já bem consolidada do Centro-Oeste. Tem ocorrido um avanço em direção ao Norte e à algumas partes do Nordeste brasileiro, em geral no eixo das principais rodovias. Tem se destacado o caso da chamada região do MATOPIBA, espaço de avanço da agropecuária mecanizada entre os Estados do Maranhão, Tocantins, Piauí e Bahia ${ }^{16}$.

De forma resumida, Santos e Silveira (2001) qualificam este período de meio técnico-científico-informacional, que, com a globalização, aprofunda um processo já iniciado nos anos 1970. A partir de um mercado global, a questão da fluidez se renova, reafirmando a importância da informação e das finanças no desenvolvimento, sendo que "o espaço total de um país, isto é, o seu território enquanto suporte da produção em todas as suas instâncias, equivale ao mercado" (p. 53). São identificadas no país, assim, áreas de maior e menor fluência da informação e das finanças. O que diferencia este período do anterior é que a localização dos empreendimentos adquire menor participação das diretrizes do Estado brasileiro, ocorrendo um processo de desconcentração produtivo guiado mais pelos mercados que pela política pública.

\section{Desdobramentos: Regiões Metropolitanas no período do neoliberalismo}

Num quadro geral sobre o tema, especificamente sobre a questão da expansão urbana e metropolitana, esta passa a se mostrar cada vez de forma mais dispersa. Ojima (2008) aponta que o processo tem ligação com a expansão dos eixos de transporte e o uso do transporte individual, bem como a busca da classe média em "fugir" dos problemas das áreas centrais. Limonad (2007) aponta que no Brasil o processo adquire feições próprias: expansão da periferia metropolitana, multiplicação de aglomerações urbanas dispersas, clusters industriais, serviços turísticos e condomínios exclusivos fora do tecido urbano. Mais recentemente, o processo de expansão destes tecidos metropolitanos demonstra ligação com o PMCMV, uma vez que este privilegia a construção de novos espaços urbanizados, muitos deles mais distantes de espaços de assentamento mais consolidados (MARICATO, 2011).

O processo de reestruturação produtiva se manifestará de forma mais evidente a partir do aumento da complexidade das relações dos espaços urbanos e metropolitanos,

\footnotetext{
${ }^{16}$ Este recorte espacial foi recentemente reconhecido por meio do Decreto $\mathrm{n}^{\mathrm{o}} 8.447$, de 6 de maio de 2015 (BRASIL, 2015b),
} 
especialmente com a inserção de novas lógicas de organização da produção e uma ruptura da ideia de submissão absoluta dos espaços metropolitanos e regionais às sedes das metrópoles. Ficarão mais evidentes estudos como o de Lencioni (2011) que buscam identificar nas metrópoles nacionais a perspectiva das cidades-região, dado o modelo mais difuso da expansão urbana e metropolitana e uma estrutura produtiva cada vez menos concentrada.

De um modo geral a reestruturação reforçou a ideia dos espaços centrais das Regiões Metropolitanas como sedes da gestão do capital, não se verificando um esvaziamento de suas funções. A desconcentração produtiva torna-se ainda mais extensiva a novos espaços do território, com o surgimento de novas áreas industriais. Ao mesmo tempo, na medida em que os espaços metropolitanos vão se expandindo de forma difusa, o comércio varejista mantém a tendência de buscar localizar-se de forma mais próxima aos novos espaços de assentamento. Talvez a mudança que ficará mais evidente será o surgimento de equipamentos de consumo de maior porte, como os shoppings centers e os hipermercados, que passam a localizar-se também nestes novos espaços de habitação, passando eles também por uma desconcentração. Muito disto pode ser explicado pelo aumento da renda da população nestes novos espaços, que passam a representar mercados potenciais a tais equipamentos.

Ao mesmo tempo que novos espaços de consumo vão se consolidando nas periferias dos espaços metropolizados, no âmbito de suas regiões mais imediatas este novo quadro vem levando ao surgimento de espaços produtivos industriais e agropecuários ligados não necessariamente à indústria existente, no período anterior, nos municípios principais das Regiões Metropolitanas. Conforme exposto anteriormente, novos parques industriais surgem a partir da desconcentração de plantas industriais dos espaços tradicionais; por outro lado, o avanço da agropecuária moderna transforma alguns municípios da região imediata das metrópoles em pontos de apoio à produção, ou mesmo em amplos espaços produtivos, permitindo pensar, daí novas centralidades.

Especificamente sobre o tema dos centros e subcentros nas Regiões Metropolitanas, considerando o caso da Região Metropolitana de São Paulo, o centro principal, São Paulo, mantém sua função de grande praça financeira nacional, especializando-se ainda mais nisto. Por conta de tal centralização, alguns ramos do setor de serviços passam mais claramente a se desconcentrarem para os municípios vizinhos, mantendo e aprofundando as tendências já verificadas no período anterior. Reforça-se a percepção, na realidade, de uma expansão territorial das funções centrais de São Paulo, que vai, aos poucos, amalgamando e absorvendo municípios próximos à esta lógica (GASPAR et al., 2015; SERRÃO; DIAS, 2015). Num primeiro momento, houve a expansão de algumas atividades do terciário para municípios mais 
próximos da sede, sendo o caso do chamado ABCDOG (Santo André, São Bernardo do Campo, São Caetano do Sul, Diadema, Osasco e Guarulhos), algo que aparenta estar já em ocorrência para outros municípios. A descrição de Serrão e Dias leva a pensar na expansão das funções de gestão do capital e retenção, na sede, dos setores realmente superiores, ligados principalmente pela enorme máquina de gestão financeira, de nível internacional. Lencioni (2011) aponta, na realidade, para a composição de uma cidade-região, marcada pela expansão territorial da metrópole, em uma verdadeira região. De forma mais imediata, a própria região de articulação do centro de São Paulo apresenta-se como sendo a chamada "macrometrópole paulista", composta por outros espaços institucionalizados como Região Metropolitana (caso de Campinas) e outras microrregiões próximas, estendendo sua atuação até a Baixada Santista e o Vale do Paraíba.

Sobre as outras Regiões Metropolitanas do Sudeste (ou da Região Concentrada, segundo Santos e Silveira, 2001), Davidovich (2010) aponta para algum enfraquecimento do papel do Rio de Janeiro como metrópole global a partir da abertura econômica, dado, por exemplo, o fechamento de sua Bolsa de Valores, apontando para uma ainda maior centralização em São Paulo. Por outro lado, Siqueira (2015) observa que mesmo o processo atual de desconcentração não alcançou o mesmo nível de outras metrópoles. É fundamental ainda considerar a tendência do Rio de Janeiro de reafirmar sua posição central, por outro lado, como grande capital cultural e turística nacional, algo bastante reforçado pelos megaeventos realizados no país (Copa do Mundo em 2014 e Jogos Olímpicos em 2016). Tais eventos levaram a fortes investimentos do governo federal na cidade, em setores como mobilidade e infraestrutura urbana. Siqueira aponta para o surgimento de subcentros ligados à economia do petróleo, dada a extração na Bacia de Campos, norte do Estado do Rio de Janeiro (é o caso de São Gonçalo e Niterói, ainda que distantes das áreas de exploração).

Para o caso da Região Metropolitana de Belo Horizonte, Tonucci Filho et al (2015) apontam para um aumento nos investimentos na estrutura produtiva da Região Metropolitana, mas sem uma ampla diversificação, levando a que Belo Horizonte mantenha a primazia no terciário, mas sem crescimento em sua complexidade e absorção de novas funções. Há o crescimento de atividades que já tinham surgido anteriormente, ocorrendo, na porção oeste da região, um avanço do setor metal mecânico impulsionado pela presença da montadora FIAT, especialmente em Betim e Contagem. Ao norte, por conta de investimentos públicos como o Novo Centro Administrativo do Estado e o Aeroporto Internacional de Confins tem ocorrido investimentos no setor de apoio à logística, considerando a posição estratégica da região para o setor. 
No caso das metrópoles da Região Sul, especificamente sobre a Região Metropolitana de Curitiba, Moura et al (2015) apontam para um novo ciclo industrial, inaugurado por conta da instalação das montadoras de automóveis na Região Metropolitana na década de 1990. Tal processo levou ao fortalecimento da centralidade de Curitiba, que acabou por retrair sua participação no secundário e passa a concentrar sua primazia no terciário. Firkowski (2002) fala em uma segunda fase da industrialização da Região Metropolitana, localizando os setores de mais alta tecnologia próximos a Curitiba. Muitos dos investimentos tem ocorrido no eixo logístico, com destaque para São José dos Pinhais. Para o caso da Região Metropolitana de Porto Alegre, Soares (2015) aponta para um processo de desconcentração do setor de serviços, após já ocorrido o processo de desconcentração industrial. Assim, Porto Alegre vai perdendo população e peso econômico no conjunto da Região Metropolitana, mantendo sua primazia a partir da gestão de serviços. Mais recentemente, no caso de Porto Alegre, há algum recuo em sua participação no peso econômico de toda a Região Metropolitana (em que pese seu crescimento no setor de serviços segundo Soares et al, 2015), mantendo-se a tendência de perda de população. Mantém-se sua primazia no terciário, apesar da emergência deste em outros municípios (SOARES, 2015). Nesta região tem se destacado investimentos em Gravataí (fábrica da General Motors), o setor petroquímico em Triunfo e o setor do couro calçadista no Vale dos Sinos.

Sobre as metrópoles nordestinas, para o caso da Região Metropolitana de Salvador, Mello e Silva (2015) apontam para a manutenção da macrocefalia em torno do centro principal, que tem perdido população e peso econômico em velocidade mais reduzida em relação ao caso de outras metrópoles brasileiras. Tal processo de concentração, segundo Carvalho e Borges (2015) leva a uma terciarização baseada na informalidade na capital Salvador, por conta da abertura econômica. No caso desta região, destaca-se o investimento anteriormente realizado no polo petroquímico de Camaçari.

Para o caso da Região Metropolitana de Recife, Rosa e Oliveira (2015) apontam para um período de fortes dificuldades econômicas, em função da ausência de atuação da Sudene e da pouca iniciativa do empresariado local. Apesar disto, o terciário concentra-se principalmente em Recife, mesmo com a perda de sua participação do total do PIB da Região Metropolitana como um todo. Mais recentemente tem ocorrido a retomada de Recife como centralidade regional importante além de seu reforço como centro terciário, pelo peso da administração pública e também pelos investimentos do governo federal e estadual, retomados neste período. Estas autoras identificam possíveis subcentros futuros a partir de investimentos 
realizados em alguns municípios, como os da Copa do Mundo em São Lourenço da Mata, a implantação do Complexo Portuário de Suape em Ipojuca.

Por fim, para a Região Metropolitana de Fortaleza, Costa e Amora (2015) apontam para a atuação aí, de forma específica, das consequências da crise fiscal a das políticas de Estado mínimo, com a perda de apoio da Sudene. Neste quadro, Fortaleza confirma sua concentração no setor terciário. Pereira Jr. (2015), por outro lado, aponta que mesmo em meio ao processo de reestruturação produtiva, Fortaleza mantém sempre alguma concentração industrial. Mais recentemente, o papel de centralidade principal de Fortaleza no setor terciário é mantido, e de certa forma reforçado, pelo papel mais presente do turismo internacional neste (é ponto de recebimento de fluxos oriundos da Europa, principalmente). O mesmo autor aponta para a continuidade do processo de desconcentração, de forma mais contínua e em torno dos principais eixos rodoviários, atingindo, neste caso, Horizonte, Pacajus e São Gonçalo do Amarante.

Para o caso da Região Metropolitana de Belém, Cardoso et al (2015) aponta para a manutenção da função terciária de Belém, com articulação não apenas no âmbito da Região Metropolitana, mas em caráter regional. Tal polarização acaba reduzida pela emergência de cidades médias de importância no interior do Estado do Pará (exemplos de Marabá e Santarém). Os autores rejeitam a perspectiva de desmetropolização, em favor da ideia da metropolização desconcentrada, já que não se verifica uma perda de importância de Belém na hierarquia regional e nacional. A partir disto e da perspectiva de Fernandes et al (2015), o que se pode perceber é que a desconcentração que realmente afeta a função de Belém na rede urbana diz respeito a uma escala regional ampliada, a da Amazônia Oriental, e não apenas de sua Região Metropolitana. Para o caso da Região Metropolitana de Manaus, Lima (2014) aponta para uma crescente concentração produtiva em Manaus, pela atuação da Zona Franca de Manaus, com a extensão do espaço urbano no território de Manaus e dos municípios vizinhos.

Finalmente, para o caso da Região Metropolitana de Goiânia, Arrais (2012) aponta para um processo mais claro, neste período, de expansão do tecido urbano e metropolitano para os municípios próximos, impulsionado pelo capital imobiliário, mas sem a desconcentração produtiva movida pela industrialização, no começo do período. Verificava-se, aí, uma dependência do centro principal, Goiânia, centro já bastante dedicado ao setor terciário. Atualmente, parte deste quadro tem mudado, sendo possível perceber o aumento da complexidade da função de centro principal de Goiânia, tanto pela expansão do espaço urbano conurbado (e sua dependência do terciário da capital goiana) quanto pela maior integração desta com o eixo com Anápolis e Brasília, constituindo um polo prestador de serviços neste contexto. 
Assim, percebe-se uma tendência à manutenção dos centros das Regiões Metropolitanas como polos de prestação de serviços para os espaços metropolitanos imediatos e, no caso de algumas metrópoles, para regiões mais distantes. Esta tendência pode ser considerada relativamente previsível, haja visto o fato de que a reestruturação produtiva, no caso brasileiro, não ter sido responsável pela criação de espaços metropolitanos com áreas centrais (na escala municipal, diga-se de passagem) decadentes; pelo contrário, houve fortalecimento e aumento da influência dos centros principais sobre novos espaços produtivos, metropolitanos e regionais. Por outro lado, no âmbito destas regiões instituídas, tem ocorrido processos de desconcentração que são mais ligados a novas lógicas do setor secundário, sendo exceções as Regiões Metropolitanas de Belém e Goiânia. Verifica-se ainda que, apesar de muitas delas serem espaços que congregam tanto municípios polarizados pelo centro principal como outros menos polarizados, não se verificou um avanço significativo da agropecuária moderna na maior parte das Regiões Metropolitanas, ocorrendo, tal processo e ainda com demanda de maior análise, em Goiânia.

\subsection{Síntese e ligação}

A partir do quadro acima, é possível perceber uma evolução geral no sentido de desconcentração espacial da produção e do consumo, em escala regional e nas Regiões Metropolitanas, favorecendo, por este primeiro movimento, a formação dos primeiros subcentros ligados a comércio e serviços, e também ao apoio à produção industrial já nas décadas de 1970 e 1980. Estes irão se consolidar na década seguinte e passarão, alguns deles, a polarizar novos espaços, muito por se tornarem mais completos mais recentemente, em função do avanço da população sobre eles e dos equipamentos de consumo. Junto a estes, surgem outros puramente ocasionados a partir da expansão dos espaços urbanos das metrópoles, o que tende a levar consigo, após algum tempo e a partir da elevação da renda da população nestes novos espaços, a atração dos grandes equipamentos de consumo. Mesmo não sendo o caso em muitos dos espaços metropolitanos analisados, mas sendo mais próximo do caso dos espaços metropolizados do Centro-Oeste, há ainda uma forte influência da agropecuária modernizada, mais recentemente, levando ao surgimento de subcentros voltados ou a prestação de serviços/ insumos/ máquinas a tais espaços produtivos ou ao processamento do que lá é produzido.

A partir da argumentação acima posta, e considerando os resultados analisados nas Regiões Metropolitanas, vê-se o avanço da produção de espaços mais fragmentados, o que 
ocorre não apenas pela introdução de novos polos de produção de atividades externas à região, mas também de uma expansão e diversificação o terciário, algo muito claro para as metrópoles historicamente mais consolidadas. Naquelas de formação mais recente, há uma precedência das atividades terciárias do centro principal que ainda tem sido relativizadas de forma incipiente.

A discussão sobre a dinâmica socioeconômica da reestruturação produtiva, aliada à busca de compreensão de seus efeitos espaciais em regiões metropolitanas brasileiras, oferece perspectivas para o entendimento de processos semelhantes em outras áreas. A seguir, é iniciada a discussão sobre a Ride-DF, discutindo, em um primeiro momento, o processo histórico da formação de Brasília e de sua região imediata. 


\section{A GÊNESE: O PERÍODO DA IMPLANTAÇÃO DAS BASES TERRITORIAIS DA REGIÃO DE BRASÍLIA (1956-1969)}

Este capítulo apresenta o esforço em construir historicamente a produção das bases territoriais de ocupação da região de Brasília, com uma ênfase que, apesar de ter centralidade na própria evolução da construção de Brasília, que é o centro principal, abrange também o processo nos municípios que constituem o espaço em análise. Ao focar em um espaço chamado de "região de Brasília" está se referindo à porção do espaço que viria, posteriormente, a ser chamada de "Entorno" e posteriormente formalizada a partir da Ride-DF. Como se verá, não havia, especialmente nos primeiros anos, uma delimitação específica do espaço sob influência de Brasília. Tais esforços somente se tornariam mais claros a partir da década de 1970.

\subsection{Antecedentes da implantação de Brasília e das bases territoriais da Ride-DF}

Antes de tratar especificamente da questão da estruturação inicial do espaço da Ride-DF, é fundamental analisar alguns pressupostos que foram essenciais na constituição de tal processo. Desta forma, é importante analisar, inicialmente, a discussão e o processo maior que levou à questão da troca da capital.

A perspectiva de uma Nova Capital, no interior do país era algo proposto desde o período da Inconfidência Mineira. Porém, de forma palpável, passou a ganhar corpo a partir da primeira Constituição da República, de 1891. Esta propunha a construção de uma Nova Capital no Planalto Central brasileiro. Em 1892 foi instituída a Missão Cruls, com a finalidade de estudar e definir sua área exata. A demarcação do chamado "quadrilátero Cruls" observou requisitos como altitude, centralidade e a proximidade com alguns rios brasileiros. Entretanto, até a década de 1930, não haviam condições técnicas para a mudança da capital, especialmente por conta da baixa penetração interior dos transportes terrestres no Brasil, especialmente o modal ferroviário. Além disso, o poder estava territorialmente muito disperso, o que fazia com que o governo central não tivesse orçamento suficiente para tal empreitada (FERREIRA, 2010). A partir do Governo Vargas, tal situação se modifica, com a centralização política e orçamentária. Além disto, por meio da "Marcha para o Oeste", Vargas propôs a ocupação do espaço do Centro-Oeste, o que criou a base da futura transferência da Capital Federal.

A Constituição de 1946 retoma o tema da transferência da capital e novos estudos são realizados, podendo ser destacada a Missão Polli Coelho, que buscou definir mais 
especificamente o local da nova capital, em meio ao debate político em torno da localização que então havia. Buscava-se, segundo Ferreira (2010), uma posição vantajosa do ponto de vista estático (características próprias do espaço da nova cidade) e do ponto de vista dinâmico (ligação e inserção nos fluxos regionais e nacionais). Posteriormente, com o relatório de Donald Belcher, de 1955, é escolhido o sítio castanho, tendo sido escolhido por conta de sua topografia, facilidade de drenagem e potencial suprimento de água e energia. É importante ainda enfatizar que a mudança da Capital ocorreu por influência do processo nacional de integração das regiões brasileiras, no qual a Nova Capital ganhou a função de polo dinamizador e nó da rede de transportes planejada para a integração regional. E, ainda, enfatizar que a transferência não ocorreu para um espaço "vazio": Magalhães (2010) ressalta os impactos nas populações que habitavam a região do Planalto Central de então, as quais nutriam a esperança, rapidamente frustrada, de que a construção de Brasília lhes traria o tão sonhado desenvolvimento e as tiraria do esquecimento em relação ao Poder Público.

\subsection{Contexto socioeconômico}

Conforme visto no capítulo anterior, o contexto nacional demonstra o auge do nacional-desenvolvimentismo, que se traduziu em uma estratégia de desenvolvimento com forte empenho do Estado. Um dos temas relevantes para a estratégia era justamente a necessidade de integração dos mercados e ampliação do mercado interno. Daí, surgem muitas iniciativas, como a ocupação dos "vazios demográficos", o Centro-Oeste incluído. Principal ponto desta estratégia nesta região será justamente a transferência da capital, dada a ideia de impulsionadora do desenvolvimento e ocupação da região.

Desta forma, como acentua Magalhães (2010), neste primeiro período a urgência de mudança da capital acaba por afetar profundamente a política local, especialmente nos municípios próximos e naqueles responsáveis por receber diretamente o canteiro de obras ou ceder território para o novo Distrito Federal. O autor aponta que a retórica mudancista reforça as práticas já autoritárias da política local de então, aumentando o poder das elites aí já estabelecidas. Por outro lado, ao contrário do que em geral se pensa, o processo engendrou algum conflito, já que as desapropriações, em alguns casos, foram consideradas desvantajosas para os proprietários de terra, levando a algum contrassenso com a ideia geral da mudança, do progresso e da modernização que seriam trazidas com a Nova Capital. 
De forma específica, em relação aos municípios que cederam parte de seus territórios e foram ponto importante de apoio à construção da capital, cabe o destaque a três deles: Formosa, Luziânia e Planaltina. O primeiro tornou-se um dos principais pontos de apoio ao processo de construção da cidade, dada sua importância e um papel polarizador em relação aos outros municípios então existentes. Havia grande entusiasmo local com a construção da nova capital, sendo que a política local buscou mover esforços necessários para a construção de Brasília, tendo sido criada uma Comissão Municipal de Cooperação para a Mudança da Capital Federal (CHAUVET, 2005). Luziânia também teve em seu Poder Público municipal importante colaborador da mudança da capital, sendo que a comissão municipal para tanto, segundo Tormin (2004) foi composta por elementos políticos influentes, ligados às tradicionais famílias da política do município de então. Planaltina, finalmente, teve sua sede municipal original absorvida pelo Distrito Federal. Mesmo com a perda substancial de território, o município colaborou de forma especial, com o exercício do Poder Judiciário sobre o canteiro de obras, conforme a CODEPLAN (1973). Mais afastada, mas influente ainda assim no processo, há o caso de Pirenópolis. Almeida (2006) aponta que os principais impactos causados neste município pela construção de Brasília deram-se especialmente pela abertura de novas estradas, responsáveis por melhorar a integração da economia do município com o restante da região. Além destes municípios, há outros de expressão menor no processo, sendo que muitos deles surgiram justamente em decorrência do processo de construção da nova capital, especialmente pela abertura de estradas. Os casos mais notórios de tal processo serão Alexânia e Abadiânia, ao longo da BR 060.

Internamente ao espaço da Nova Capital (em construção), em um primeiro momento havia um contexto próprio de sua construção, tendo um contexto político local, durante a construção, de comando hierárquico rígido do grande canteiro de obras, dada a necessidade de entrega da Nova Capital em prazo reduzido. Após a inauguração, em 1960, esse modelo não se altera durante o restante do período, no âmbito local, sendo a administração definida pela União (os prefeitos eram nomeados por esta esfera).

Outro fato político importante diz respeito ao processo de consolidação da cidade como efetiva capital do país. Ao longo da década de 1960, houve importantes movimentos no sentido de fazer retornar a capital para o Rio de Janeiro, especialmente antes do golpe civilmilitar de 1964, por conta da postura pouco assertiva sobre o tema dos presidentes Jânio Quadros e João Goulart em relação à nova capital (RIBEIRO; HOLANDA, 2015).

Quanto ao contexto econômico, em um quadro regional mais amplo, a economia, no período, apresenta um processo de modernização, induzido por fatores anteriores à 
construção de Brasília (como as iniciativas da "Marcha para o Oeste" - construção de Goiânia, abertura de rodovias, colônias agrícolas) e por este processo em si. Estevam (1997), em uma análise mais ampla que a escala da própria Ride-DF aponta para um predomínio econômico, à época, no contexto do estado de Goiás, do eixo Goiânia-Anápolis. Tal processo acaba por impactar no espaço "primordial" da Ride-DF especialmente dos municípios mais à oeste (Pirenópolis e Corumbá), mas também em um caráter mais geral, pela abertura de estradas e pelo papel importante exercido por estas duas cidades no próprio processo de construção da cidade. Em um contexto geral de desigualdade entre o Norte e o Sul do estado, o Planalto Central de então acabou abarcando atividades ligadas à pecuária, não incorporando ainda as características do sul de Goiás, onde havia pequenas e médias propriedades convivendo com as de maior porte, dedicadas à bovinocultura. Predominava, assim, uma pecuária extensiva em propriedades grandes, com o convívio de posseiros. Algumas cidades, cujo destaque maior se dá a Formosa (por seu tamanho) desempenhavam ainda o papel de centros mercantis, mas com extensão bastante reduzida.

Miragaya (2010) aponta que no período, embora tenha ocorrido uma ampla modernização da economia nacional, com alguns dos lances fundamentais do avanço industrial no país, o Centro-Oeste teve participação geral reduzida. Desta escala e retornando ao foco da análise, percebe-se que as atividades econômicas do espaço da Região de Brasília estiveram muito mais voltadas a uma economia de subsistência local de baixa produtividade, destacandose a pecuária extensiva, cuja inserção em um processo de maior modernização somente ocorreu a partir de meados da década de 1960, com a intenção do governo em inserir a região na economia nacional a partir de uma agropecuária moderna. Obviamente que, em escala menor, algumas outras atividades tiveram sua importância, como no caso da extração mineral em Pirenópolis (xisto quartzífero, segundo ALMEIDA, 2006) e Cristalina e as atividades comerciais em Formosa (já mencionadas).

Sobre o caso específico do Distrito Federal, houve, inicialmente, um predomínio do setor secundário, em função do processo próprio de construção da Nova Capital. A construção civil concentrava a maior parte da massa trabalhadora, ao mesmo tempo em que a mão de obra do serviço público ia migrando para a Nova Capital (com as transferências graduais de seus órgãos). Já na década de 1960 esta tendência vai se invertendo e o quadro de forte concentração no terciário - que perdura até hoje - vai sendo delineado.

Demograficamente, o período demonstra a predominância de uma população em quase sua totalidade imigrante, no caso do Distrito Federal, com grande presença de população jovem. Esperava-se que após a construção de Brasília esta população (ou a maior parte dela) 
retornasse a seus locais de origem, o que não aconteceu - na verdade, ia se dando o oposto, já que Brasília era vista como terra de oportunidades e, aos poucos, atraía população que vinha não apenas para trabalhar na construção civil. Vasconcelos e Gomes (2015) observam que os principais fluxos nestes períodos serão originados do Sudeste e do próprio Centro-Oeste, sendo que os fluxos oriundos no Nordeste somente mais tarde tomarão a dianteira nos números. As autoras observam ainda que a presença de uma grande quantidade de imigrantes altera a posição do Distrito Federal na transição demográfica brasileira que se iniciava, tornando a fecundidade na capital maior que a média brasileira de então. A população dos municípios era, assim, reduzida e concentrada nos espaços rurais. Destacavam-se os contingentes dos municípios mais antigos, no caso Formosa, Luziânia e Unaí.

\subsection{Ações de gestão do território}

A partir do contexto acima posto, as ações de gestão do território tiveram como grande objetivo a implantação da Nova Capital o que moveu, conforme já brevemente mencionado, um grande esforço por parte do governo federal. Estas ações são pautadas, em sua maioria em uma perspectiva autoritária, a partir da escusa da urgência de construção de Brasília. O tema regional ainda entra timidamente na pauta de ações.

Desta forma, neste e nos próximos capítulos, segue-se a análise de quatro eixos de políticas diferentes, essenciais à compreensão do objeto em análise: a política regional, a política urbana e metropolitana, a política agrícola e a política de infraestrutura rodoviária. Obviamente, a maior parte destas políticas é formulada em âmbito extra regional, demandando, para cada caso, a análise específica da atuação dos governos federal e estaduais, a depender do caso.

\subsubsection{Política regional}

No período em questão, não houve uma ação específica de gestão do território em escala regional, ao menos não formulada como tal. Pode-se considerar, de forma indireta, que a grande política regional do período foi a transferência da capital, a partir de seus muitos efeitos regionais. Isto porque não foi apenas a construção de uma cidade de caráter administrativo no Centro-Oeste brasileiro, mas um processo mais amplo de modernização da região e do Estado de Goiás que já vinham acontecendo desde antes. Tal movimento, na perspectiva de Silva 
(2008) teria tido início com a própria Marcha para o Oeste, responsável pelo início de uma maior integração da região com os centros economicamente mais dinâmicos do país. A construção de Brasília ocorre na esteira deste processo de incorporação da região ao capital nacional, demandando uma série de ações que acabaram por alterar profundamente o território goiano, principalmente: a construção de rodovias, melhorias na infraestrutura energética e outros (LIMA, 2015).

Dentro do quadro acima delineado, a atuação em torno da temática regional mais imediata teve uma incidência quase indireta por parte do Estado, sem a existência de um instrumento/ plano específico de atuação em caráter regional, seja por parte do Distrito Federal, do estado de Goiás ou da União.

Neste contexto, a única exceção talvez resida no caso do Fundo de Desenvolvimento do Distrito Federal (Fundefe) cuja criação visou, entre outras coisas, impulsionar a atuação da nova capital como mola propulsora do desenvolvimento regional. Ele surge em 1966, a partir do Decreto-Lei n ${ }^{\circ}$ 82, de 26 de dezembro de 1966, com a finalidade de "viabilizar obras de infraestrutura para suporte das atividades econômicas e sociais do Distrito Federal e região geoeconômica, como forma de contrabalançar os vultosos investimentos aplicados com a interiorização da capital” (SEF-DF, 2016). Sua atuação, posteriormente, foi coordenada com o Programa Especial da Região Geoeconômica de Brasília (Pergeb).

Ainda em âmbito estadual, Arrais (2007a) aborda a importância do Plano de Desenvolvimento Econômico de Goiás, do governo de Mauro Borges, cujas ações foram muito voltadas ao setor agropecuário. Apesar de reconhecer o potencial desequilíbrio causado pela Nova Capital, não há aí um conjunto de medidas específicas para mitigar tal problema. $\mathrm{O}$ mesmo Arrais, em outro trabalho (2007b), aponta para a importância do deslocamento e a ampliação do mercado consumidor do Estado de Goiás (centrados, à época, entre Anápolis e Goiânia - um embrião do futuro eixo Brasília-Anápolis-Goiânia).

De forma efetiva, quanto ao Fundefe, Freitag (2012) aponta para a fragilidade deste instrumento em promover, de forma efetiva, o desenvolvimento regional dos municípios vizinhos à Brasília, já que muitos de seus recursos acabaram empregados no próprio Distrito Federal. Além disto, sua atuação apenas como fundo financiador, sem um programa ou um planejamento regional que lhe dessem maior orientação quanto como e onde investir acabaram por prejudicar sua atuação como mola do desenvolvimento regional.

Já em relação às ações descritas com incidência no Estado de Goiás, Arrais (2007a) aponta para o surgimento de novas cidades e para o estímulo à atividade agropecuária, porém com alcance ainda reduzido, no caso deste, para os municípios em estudo (a concentração mais 
nítida disto ainda era no sul do estado e ao longo da BR 153). A atuação do governo estadual acabou por privilegiar os espaços mais próximos da zona de Goiânia, com atuação reduzida nos municípios vizinhos ao Distrito Federal.

Desta forma, o que se percebe é que em termos de atuação no âmbito regional, o cumprimento da pretendida vocação de Brasília como dínamo do desenvolvimento do antigo Planalto Central era algo ainda pouco cristalizado em políticas públicas específicas para tanto, havendo maior interesse, nesta fase, em construir e ordenar internamente o espaço do Distrito Federal. Não se verifica ainda nenhum planejamento de maior vulto para a região, em que pese a concepção de um instrumento financeiro (Fundefe) e de uma atuação indireta sobre o tema do desenvolvimento regional.

\subsubsection{Política Urbana}

No caso dos municípios da região de Brasília, as ações de ordenamento e planejamento urbano foram, no período, relativamente tímidas em relação à elaboração de instrumentos que então ocorria no Distrito Federal. São relatadas legislações de ordenamento da ocupação do solo em municípios como Formosa (CHAUVET, 2005) e em Luziânia (TORMIN, 2004), muito como uma resposta ao processo de especulação imobiliária já nascente nestes municípios. No caso de Formosa, em 1958 é aprovado um novo plano urbanístico para a sede do município, que promovia alterações pontuais na ocupação de seu pequeno espaço urbano. O tema da política urbana somente ganharia reforço a partir da necessidade de ordenamento dada pelo crescimento metropolitano de Brasília, nas décadas de 1970 e 1980.

No âmbito do Distrito Federal, estas ações foram dirigidas no sentido de implementar a nova cidade, o que se tornou claro a partir do Plano de Metas do governo Juscelino Kubitschek. Assim, o instrumento principal de planejamento urbano do período, circunscrito à Brasília, foi o Plano Piloto de Brasília, de Lúcio Costa, que partia da concepção modernista da arquitetura mundial, concebendo espaços definidos para cada uma das funções urbanas, delimitando claramente os espaços de moradia, trabalho e lazer (GDF et al, 1991). Por outro lado, é importante relembrar que o Plano Piloto de Brasília tratou, de forma apenas difusa, o tema de novas nucleações para o Distrito Federal, que seriam criadas apenas após a passagem de um "teto" demográfico previsto para o Plano Piloto.

Ainda internamente ao Distrito Federal, a Lei n$^{\circ}$ 4. 454, de 10 de dezembro de 1964 (BRASIL, 1964), foi fundamental por balizar a organização interna da administração deste 
território. Ela institucionaliza as Regiões Administrativas (RAs), que fazem parte da administração descentralizada, porém sem personalidade jurídica própria. Outras ações foram de igual importância, especialmente no ordenamento interno do território do Distrito Federal e na definição de algumas posturas para sua ocupação, como os códigos de edificações, e, com maior destaque o Plano Diretor de Água, Esgoto e Controle da Poluição do Distrito Federal (Planidro). Este último documento é importante por conter a orientação de se evitar a ocupação de áreas na bacia do Lago Paranoá, com fins de conter sua eutrofização. Tal orientação, conforme se verá, balizou muitos dos instrumentos de ordenamento da ocupação do espaço do Distrito Federal.

Analisando as ações de forma efetiva, verifica-se uma quantidade reduzida de legislações e planos de atuação no território nos municípios da região de Brasília. Poucos municípios aprovaram instrumentos de ordenamento, sendo este mais frequente à medida que ocorria a especulação pelo valor da terra. Enquanto no Distrito Federal havia uma correlação de forças desigual que pendia para o poder público, nos outros municípios não se verifica ainda, neste primeiro momento, o mesmo contexto de tensão e de disputa, dado que o próprio processo de urbanização em escala maior e de metropolização somente serão visíveis a partir do próximo período.

Sobre as ações efetivas de políticas urbanas no Distrito Federal, Gouvêa (1991) aponta que, inicialmente, durante o período de construção da cidade de Brasília, o Estado agiu no sentido de alocar a mão de obra trabalhadora atraída para as obras em acampamentos provisórios, nos quais as condições de moradia eram ainda precárias. Aliadas a isto, as próprias condições de trabalho com jornadas seguidas contribuíam para o agravamento do quadro de dificuldades enfrentadas. Já neste período inicia-se um processo que seria comum nas primeiras décadas de vida da nova capital: a remoção da população de áreas invadidas. Em muitos casos, a retirada dos moradores foi acompanhada de sua relocação em áreas periféricas carentes de infraestrutura, que se tornaram conhecidas como cidades-satélites. A construção da primeira cidade-satélite, dentro do Distrito Federal, Taguatinga, em 1958, destinada a pessoas provenientes de áreas ocupadas no espaço que seria o Lago Paranoá e de outras ocupações irregulares, evidencia este fato.

Ainda sobre esta fase inicial da construção da cidade, Campos (1991) demonstra que sua produção está associada a um submercado de mais alta produtividade. O processo de produção da habitação, como mercadoria, ocorre a partir de uma forte homogeneização interna. É um período no qual o empreendedor confunde-se com o empregador, característica de um momento de grande construção da habitação. Campos aponta, ainda que, após a construção da 
capital, ela vivencia uma primeira crise (décadas de 1960 e 1970), dada pelo já apontado anteriormente: a dúvida em torno do retorno ou não da capital para o Rio de Janeiro. Isto leva a um refluxo nos investimentos do Estado em relação à construção civil, o que paralisou o setor. Assim como Gouvêa (1991), ele concorda que, no segundo momento, instala-se uma ação efetiva de controle social, oposta à tendência mais clientelista do momento específico da construção. Pelas dificuldades em acessar moradias de qualidade e mais próximas da área central, surge, ainda neste período, um submercado imobiliário, com diversas formas de acesso à terra, normalmente pela sublocação, especialmente nas novas cidades-satélites. Não havia, por outro lado, qualquer aparato formal de legalização de tais práticas.

É importante marcar que, no período em tela, além de Taguatinga, outras cidadessatélites foram construídas no Distrito Federal, entre elas: Gama (1960), Sobradinho (1960), Guará (1969) (este em uma lógica um tanto diversa daquelas outras - foi construída para abrigar parte dos servidores públicos que não encontraram moradia no Plano Piloto).

Sobre o planejamento e a gestão urbanos no âmbito do Distrito Federal, o que se teve foi uma ação autoritária por parte do Estado, que dispunha amplamente da posse das terras no Distrito Federal, podendo distribui-las de acordo com seu interesse, o que levou a uma tentativa constante de manutenção da área do Plano Piloto tal como planejada. A fim de preservá-lo, o governo removia as populações de áreas irregulares e as assentava em espaços afastados do centro da cidade, configurando verdadeiras cidades-dormitórios. Havia um quadro de ações no qual o Estado possuía uma hegemonia praticamente incontestável, organizando o espaço de acordo com seus interesses. Afirmando tecnocraticamente a necessidade de preservação da área central, o Estado agia como principal ator da produção do espaço, tendo, neste período, os agentes do mercado imobiliário e dos setores econômicos um papel coadjuvante.

Dado o contexto desenvolvimentista que circunscreveu a mudança da capital, as políticas regionais e urbanas voltadas para o Distrito Federal e para os municípios próximos enfatizaram, por um lado, a infraestrutura e, por outro a organização do espaço intraurbano. As articulações com o setor agrícola se faziam de acordo com práticas de comercialização tradicionais, sem uma preocupação explícita com uma integração de base regional. 


\subsubsection{Política agrícola}

No período em questão, de forma específica, não se verifica a existência de uma política pública formada voltada para o setor agrícola na região. Silva (2008) destaca que as ações se davam mais pautadas na perspectiva da construção da Nova Capital, sem que houvesse um conjunto formado de políticas voltadas ao setor agrícola. A modernização será uma realidade mais presente a partir da década de 1970, com as ações derivadas do I e II PNDs e outras ações de desenvolvimento.

Como já apresentado quando da análise da temática em escala nacional, a partir de 1965 é estruturado o Sistema Nacional de Crédito Rural (SNCR). Queiroz (2010) destaca que, anteriormente a instituição deste sistema, havia diversos sistemas de crédito rural isolados e pouco articulados, o que demandou ação específica do governo. A unificação foi necessária, como apontado por Graziano da Silva (1996), no sentido de promover a expansão do processo de modernização da agropecuária nacional.

Neste sentido, a questão rural no Centro-Oeste, à época era tratada ainda de forma periférica. Isto se dava, entre outros motivos, pela perspectiva de que a região era uma fronteira a ser incorporada à produção nacional, caracterizada, a partir de discursos (alguns deles repetidos até os dias atuais, mesmo por estudiosos da temática) de que havia um enorme "vazio" na região. Havia, na realidade, população rarefeita e uma integração ainda pouco intensiva com o restante do território, algo que seria posto em evidência e prática mais tarde. É importante ainda mencionar que houve o início da mecanização da produção na região, porém ainda sem a integração com os circuitos mais modernos de produção, alcançados somente na etapa seguinte.

\subsubsection{Política de transportes - eixos rodoviários}

O tema dos transportes, foi, por outro lado, algo de fundamental importância dentro das ações do período, especialmente pela necessidade de construção da Nova Capital. Conforme já brevemente comentado, as rodovias já eram fundamentais ao Estado de Goiás, desde algumas décadas antes, puxadas, de certa forma, pela própria construção de Goiânia. Não havia, por outro lado, ligação com todo o Estado, estando as principais rodovias confinadas nas áreas central (Goiânia e Anápolis) em direção ao Sudeste brasileiro. Regiões como o então Norte 
Goiano (que abarcava o atual território do Estado do Tocantins) e o Nordeste Goiano tinham precária ligação com o centro e o sul do Estado.

Neste sentido, por conta da construção de Brasília, novas rodovias foram construídas e pavimentadas. Algumas se destacam: a Belém-Brasília, BR 153; a BrasíliaCampo Grande, BR 060; a BR 020, que liga Brasília ao Nordeste brasileiro e, por consequência, ao Nordeste Goiano; a BR 040, que liga Brasília à São Paulo e Rio de Janeiro. A partir da estruturação destas rodovias, Queiroz (2010) observa que a própria fluidez interna ao Estado de Goiás torna-se melhor, pela ligação da capital Goiânia com o nordeste do estado.

A abertura destas rodovias, de forma efetiva, buscou principalmente oferecer as condições necessárias à construção da Nova Capital e possibilitar uma maior integração do Sudeste, centro dinâmico do território nacional no momento, com o Norte e Nordeste brasileiro. Não houve, no momento de implantação destas rodovias, preocupação mais focada em seus efeitos imediatos no território, apesar da aura de "otimismo" que as cercava: a população daquelas regiões pouco integradas e fisicamente desconectadas do centro do capitalismo nacional via nas rodovias pavimentadas a esperança de que chegasse, enfim o desenvolvimento. Num segundo momento, percebendo não ser alvo de um conjunto mais estruturado de política, este otimismo acabará desfeito.

É assim que, a partir do quadro de ações acima tratadas, pode-se afirmar que a principal ação de gestão do território esteve centrada na construção da Nova Capital e nos desdobramentos daí tidos. Um pensamento regional específico para o Centro-Oeste e para a região específica de Brasília ainda era algo distante, já que o Centro-Oeste era visto, ainda, como um ponto de integração do Sudeste com as outras macrorregiões brasileiras, não sendo enxergado em sua especificidade. Desta forma, as ações de caráter regional, principalmente, acabaram rareadas, ao passo que as ações de controle do território imediato da capital foram mais intensivas e autoritárias, como se viu. Pode-se mesmo traçar um paralelo: no quadrilátero havia forte presença e controle por parte do Estado planejador; fora dele, na vasta região imediatamente afetada pela construção de Brasília havia a percepção de um enorme "vazio" que se desenvolveria por si mesmo. Dentro deste quadro dual, a seção seguinte analisa os desdobramentos das ações de gestão do território. 


\subsection{Desdobramentos das ações de gestão do território}

As ações acima delineadas, como visto, criaram um quadro desigual de atuação tanto do Estado quanto dos agentes privados sobre uma base territorial anterior de baixa densidade de ocupação e que teve obrigação de desenvolver-se muito rapidamente. O espaço regional foi profundamente alterado a partir disto, vendo maior força de atuação do Estado e de suas próprias seletividades.

Neste sentido, esta seção busca analisar os desdobramentos destas ações de gestão do território sobre a região de Brasília. Inicialmente, os três processos responsáveis pela produção do espaço são analisados, considerados como resultados da atuação dos entes públicos e privados. Em seguida, ainda como desdobramentos, é realizada uma análise da situação do centro e de possíveis subcentros, bem como das desigualdades regionais.

\subsubsection{Desdobramentos e processos espaciais: urbanização, modificações no espaço agrário e implantação das bases do eixo Brasília-Anápolis-Goiânia}

Antes de passar propriamente à análise dos três processos específicos emanados de ações e políticas territoriais anteriores e, ao mesmo tempo, considerados responsáveis pela produção do espaço regional da atual Ride-DF, um esclarecimento é necessário. É evidente que, à época, os três processos tinham ainda uma força reduzida nem se davam com a mesma força que atualmente. Entretanto a análise da história da constituição desta região permite, a partir do olhar escolhido, perceber que desde o processo de implantação da Capital, as bases destes processos estavam já lançadas e examinar sua gênese e evolução dá uma importante contribuição ao discutido sobre a região.

Assim, o primeiro processo em análise é justamente aquele que talvez tenha sido o principal desdobramento das ações em torno da construção a Nova Capital: a urbanização. Esta ocorreu não apenas dentro do quadrilátero, mas, a partir da integração por meio das rodovias, diversos dos outros municípios passaram por processo semelhante.

Considerando a realidade urbana dos municípios da Região de Brasília, vê-se que a maior parte deles manteve, durante o período, uma expansão urbana ainda tímida, frente ao que ocorria no âmbito do Distrito Federal. Passada a febre e a expectativa inicial da construção de Brasília, nas quais esperava-se por um crescimento mais acelerado destas cidades, pode-se afirmar que tal processo caminhou mais na especulação que na realização de fato. Na realidade, 
fazendo leve concessão, alguns casos (como alguns espaços de Luziânia) apresentavam já a potencialidade de um processo futuro, com alguma especulação imobiliária. Porém o quadro geral era de cidades que sofreram um impacto inicial com a construção da nova capital, mas que ainda não pareciam ter sua expansão urbana totalmente "contaminada" pelo processo que então ocorria no Distrito Federal.

No âmbito do Distrito Federal, a produção de um núcleo central - o Plano Piloto, foi acompanhada de um espaço de assentamento disperso, com nucleações longínquas entre si, cuja principal função, como visto anteriormente era promover um mecanismo de segregação socioespacial da população, com vistas a preservar-se a área do Plano Piloto. Para Gouvea, o resultado destas ações foi a formação de um espaço urbano formado por núcleos habitacionais afastados, com enormes espaços entre si, o que foi posteriormente benéfico ao processo de especulação imobiliária (GOUVEA, 1991).

A área planejada restringia-se ao Plano Piloto, destinado, em linhas gerais, a funções político-administrativas e a áreas residenciais para funcionários públicos e grupos sociais em condições de pagar por uma localização privilegiada. Para os trabalhadores da construção civil, inicialmente alojados em acampamentos, não houve previsão de assentamento permanente. Em parte por conta disto, a população passa a agir lutando por moradia, especialmente por uma grande parcela dela não estar contemplada no documento de Lúcio Costa (ou estar apenas parcialmente). A opção será principalmente a invasão de áreas públicas. Nos outros espaços que não o Plano Piloto, outros instrumentos de planejamento serão mais utilizados, em geral voltados principalmente ao controle do uso da terra.

Deste modelo de cidade polinucleada (PAVIANI, 1987), o Plano Piloto colocavase como centralidade única e totalmente dominante em relação à extensão do território, cujas nucleações caracterizavam-se como assentamentos residenciais de populações de baixa renda. Concentrando-se na área central a maior parte dos empregos (no período, concentrados no secundário, por conta da primazia da construção civil) e dos serviços, reforçava-se um quadro de dependência das cidades-satélites em relação ao centro da cidade. A economia das cidadessatélites estava centrada, principalmente, em comércios locais, visando atender às demandas de seus moradores.

O IPEA (2001) aponta, ainda, como resultado, que a formação deste espaço, era uma consequência da ação incrementalista do governo, uma vez que este basicamente reagia aos movimentos da população que, sem acesso à moradia, organizava-se e decidia pela ocupação dos amplos espaços do quadrilátero. Esta forma de ação é uma consequência direta 
da falta de uma política urbana abrangente para todo o território do Distrito Federal (ou para a região próxima) - ainda que o Estado fosse o principal agente produtor do espaço urbano.

Este quadro de atuação, em nível regional, fica claro ao se observar os dados do Censo Demográfico de 1970, na Tabela 6.1:

Tabela 6.1 - População residente nos municípios que formam a atual Ride-DF, 1970.

\begin{tabular}{l|r|r|r|r|r}
\multicolumn{1}{c}{ Municípios } & \multirow{2}{*}{ Total } & \multicolumn{2}{c}{ Urbana } & \multicolumn{3}{c}{ Rural } \\
\cline { 3 - 6 } & & \multicolumn{1}{c}{ Total } & \multicolumn{1}{c}{$\%$} & \multicolumn{1}{c}{ Total } & $\%$ \\
\hline Abadiânia - GO & 7.772 & 1.423 & 18,31 & 6.349 & 81,69 \\
Alexânia - GO & 9.390 & 2.642 & 28,14 & 6.748 & 71,86 \\
Cabeceiras - GO & 4.056 & 784 & 19,33 & 3.272 & 80,67 \\
Corumbá de Goiás - GO & 18.439 & 1.642 & 8,91 & 16.797 & 91,09 \\
Cristalina - GO & 11.600 & 5.612 & 48,38 & 5.988 & 51,62 \\
Formosa - GO & 28.874 & 12.859 & 44,53 & 16.015 & 55,47 \\
Luziânia - GO & 32.807 & 9.604 & 29,27 & 23.203 & 70,73 \\
Padre Bernardo - GO & 8.381 & 1.771 & 21,13 & 6.610 & 78,87 \\
Pirenópolis - GO & 32.065 & 4.982 & 15,54 & 27.083 & 84,46 \\
Planaltina - GO & 8.972 & 582 & 6,49 & 8.390 & 93,51 \\
Buritis - MG & 9.810 & 2.157 & 21,99 & 7.653 & 78,01 \\
Unaín - MG & 52.303 & 14.046 & 26,86 & 38.257 & 73,14 \\
Brasília - DF & 537.492 & 516.007 & 96,00 & 21.485 & 4,00 \\
\hline Fonte: IBGE - Censo Demográfico (dados organizados pelo autor) & & &
\end{tabular}

De uma forma geral, o que se percebe, pelos dados, é uma concentração da maior parte da população no espaço rural, nos municípios vizinhos de Brasília. Como referência, a taxa de urbanização do Brasil em 1970 era de 56\%. A urbanização aparece de forma mais preponderante em Formosa (44,53\% da população residente de então) e em Cristalina (48,38\% da população residente de então). Mesmo em municípios que tiveram importante crescimento demográfico (como foi o caso de Luziânia e de Unaí), não houve um processo ampliado de urbanização, com índices de urbanização, para as duas cidades entre 21 e 27\%. Assim, vê-se que Formosa surgia com alguma urbanização mais significativa, traço mesmo de seu passado, mas ainda em um quadro maior de expansão urbana tímida.

Quanto aos desdobramentos sobre as modificações no espaço agrícola, como posto por Silva (2008), houve um processo inicial de mecanização do campo na região (em consonância com o que ocorria no próprio Centro-Oeste), sem representar, contudo, um processo de modernização da atividade agropecuária. Tanto ele quanto outros autores (QUEIROZ, 2010; LIMA, 2015) convergem na perspectiva de que o ocorrido no período foi mais importante como criação das bases de uma futura modernização, especialmente pela construção dos eixos rodoviários. Desta forma, o quadro final do período, no espaço agrário, 
era, de certa forma, parecido com aquele traçado por Miragaya (2010) ao descrever a situação da economia da região antes da implantação do Brasília: predominava uma economia agropecuária extensiva, com a produção voltada à subsistência.

Finalmente, sobre o processo de implantação das bases do futuro eixo BrasíliaAnápolis-Goiânia, o principal desdobramento foi a criação das bases territoriais para os fluxos futuros, a partir da construção de Brasília. Este esforço levou a constituição das duas rodovias que formam o eixo, as BRs 153 e 060. Estas foram fundamentais, como já mencionado, na própria integração interna ao Estado de Goiás, e possibilitaram, após a construção das duas capitais (Brasília e Goiânia), a criação da base do eixo que viria se formar posteriormente. Um desdobramento da construção destas rodovias é apresentado por Estevam (1997), ao apontar para o crescimento dos núcleos urbanos ao redor dos principais eixos rodoviários abertos no período. Tal movimento, em escala ampla, resultou de um impulso geral à migração, mas que não esvaziou, no caso goiano o papel de Goiânia e Anápolis. O autor vê, a partir deste quadro, um impacto direto do Plano de Metas de Juscelino Kubitschek, principalmente, dado o papel fundamental das rodovias na integração dos novos territórios.

\subsubsection{Desdobramentos e processos espaciais: subcentros e desigualdades regionais na região de Brasília}

A implantação da Nova Capital e as incipientes políticas territoriais na região contribuíram para alterar o quadro de relações interurbanas preexistentes. Com o rápido crescimento da capital e o fortalecimento de suas funções urbanas, observa-se um quadro inicial de um centro urbano, Brasília, em processo de consolidação. Havia, no entanto, dificuldades em polarizar mais claramente sua região imediata, ainda largamente dependente, na escala nacional, de São Paulo, e na escala regional, de Goiânia.

Um panorama esclarecedor pode ser oferecido a partir dos dados levantados por Santana (1974) em pesquisa sobre a economia da região. Sobre a atividade agropecuária, a maior parte da produção concentrava-se em gêneros como o arroz, feijão e mandioca. A produção pecuária era concentrada na criação de bovinos, com destaque para Formosa e Luziânia. Há ainda destaque para a produção bovinocultora e de gêneros como arroz, milho e mandioca no município de Unaí. Isto corrobora o anteriormente afirmado, a respeito do processo de modernização do campo no estado de Goiás, ainda distante dos municípios próximos ao Distrito Federal, já que estes mantinham, de certa forma, uma estrutura de 
produção própria da agropecuária de subsistência. Predominavam ainda uma estrutura fundiária baseada em grandes propriedades, produzindo de forma extensiva e com reduzida produtividade.

Sobre o setor secundário, Santana (1974) aponta para a existência de pequenas indústrias, em geral com tecnificação muito reduzida, demonstrando o predomínio do primário na economia geral deste espaço regional. No Distrito Federal era possível encontrar um setor industrial mais significativo, mas ligado a setores tradicionais, além da própria indústria da construção civil, cujo papel era ainda importante mesmo ao término do período. $\mathrm{O}$ autor identifica ainda que as indústrias existentes eram em sua ampla maioria voltadas ao abastecimento dos mercados internos, com alguma produção para exportação nos casos de Cristalina e Luziânia.

Em relação ao setor terciário, verifica-se a existência de uma realidade dual muito clara. De um lado, o centro de Brasília, identificado principalmente pelo Plano Piloto, que oferecia um leque de serviços de alcance regional muito claro, especialmente no que tange aos serviços públicos de saúde e educação. Era, ainda, um importante centro comercial, cujo centro nervoso concentrava-se ao longo da via W3 sul e, em partes, do comércio em suas superquadras. O Eixo Monumental ia se consolidando como centro da administração pública nacional, exercendo, ainda que por seu próprio caráter institucional, uma influência em nível nacional. De outro lado, dentro do Distrito Federal surgiam nucleações urbanas com comércio de abrangência ainda local e oferta de serviços públicos e privados ainda bastante escassos.

Já no caso do terciário das sedes dos municípios da Região de Brasília, estas mantinham-se como centros urbanos pequenos, com polarização circunscrita ao espaço rural do próprio município. $\mathrm{Na}$ ocasião da demanda de serviços de maior complexidade, surgia a necessidade de buscá-los no Distrito Federal, em geral mais constantemente no Plano Piloto. Não havia, ainda, uma pendularidade marcante da massa trabalhadora destes municípios, cuja economia ainda era muito ruralizada e os centros urbanos ainda em incipiente processo de expansão.

Um caso particular de análise, neste quadro é o de Formosa. Preexistente à Brasília, seu centro urbano tinha relevante papel na coordenação da rede de cidades e vilas existentes no Planalto Central pré-Brasília. Não à toa, foi um dos pontos de apoio fundamental ao processo de construção da nova capital. Contudo, após a construção desta, tal função vai sendo progressivamente reduzida, de forma muito natural até, pela constituição da nova capital federal. De forma a arrematar tal quadro, há a seguinte ponderação de Santana (1974, p. 313): 


\begin{abstract}
"Todos estes aspectos caracterizam a Região sob estudo como uma região em organização ou uma região em potencial, ou seja, um conjunto de cidades em processo de nucleação, com baixo grau de concentração quanto às atividades existentes, o que se reflete em sua interdependência, marcadas por algumas heterogeneidades e complementarmente integradas ao sistema econômico nacional."
\end{abstract}

Aqui surge uma contradição entre o discurso e a prática do Estado brasileiro. Conforme visto anteriormente, um dos argumentos para a construção da nova capital foi justamente a ideia de que ela seria um polo de impulsionamento do desenvolvimento regional. Por outro lado, a discussão das políticas mostrou que o Estado não atuou, neste período, de forma intencional e planejada para tanto, revelando algum descaso com a pretensa dupla função da cidade (além de sede política-administrativa do governo federal).

Sobre o tema das desigualdades regionais, Arrais (2007b) demonstra que a construção de Brasília resultou em um aumento destas em Goiás, muito por conta desta "orfandade" dos municípios vizinhos, ainda muito timidamente atingidos por políticas públicas de integração e de desenvolvimento regional. A construção da Capital Federal não iniciou um processo de resolução da questão, já que, neste primeiro momento, o interesse era em construir a cidade, com pouca ênfase nas ações de cunho regional. Indiretamente, o mesmo autor aponta para uma consolidação de Goiânia como polo principal do estado, especialmente pela abertura de novas rodovias e pela consolidação de seu eixo com Anápolis, reduzindo a histórica influência do triângulo mineiro sobre o território goiano. Apesar de parecer um resultado fora da escala de análise, tal fato constata que, neste princípio de composição do espaço regional ao redor de Brasília a porção oeste, especialmente ao redor da BR 060 será fortemente influenciada pelo processo. De certa forma, algumas das modificações neste período, em Luziânia, apontam já para alguma influência também ao sul.

\title{
6.5 Síntese e ligação
}

Ao término da análise deste período, de implantação das bases territoriais, pode-se afirmar que nesta fase os diversos agentes, sob égide do poder público internamente ao Distrito Federal, e de forma menos coordenada e com maior liberdade de atuação de outras forças no contexto interno aos municípios, levaram à produção de um espaço regional ainda potencializado pela centralidade de Brasília. É observada uma rígida e maior atuação do Estado no quadrilátero, e uma atuação menos rígida em sua região mais imediata, o que levou a uma 
integração ainda reduzida destes espaços, com uma centralidade principal cuja principal força de polarização era restrita aos seus limites políticos. As bases revelam, assim, municípios ligados à Brasília muito pelo apoio prestado à construção da nova capital e pelas rodovias aí abertas, mas não atingidas (e de certa forma frustradas com isto) pela modernização que seria propiciada pela nova capital federal. Há, assim, um centro organizado e dirigido pelo poder público; um espaço regional ainda indiretamente afetado pelas ações, de caráter principalmente da União; e os espaços internos dos municípios com uma atuação reduzida dos governos estaduais e municipais no sentido de promover integração/ desenvolvimento regional.

No próximo capítulo, a partir de uma atuação mais incisiva e planejada do Estado no contexto regional, o processo de urbanização passará a dividir protagonismo com o avanço da agropecuária moderna, ao mesmo tempo em que a própria urbanização alcança outro nível e torna-se um processo de metropolização. 


\section{O PERÍODO DA FORMAÇÃO METROPOLITANA E IMPLANTAÇÃO DA AGROPECUÁRIA MODERNA (1970-1985), NA REGIÃo DE INFLUÊNCIA DE BRASÍLIA}

O segundo período de análise na escala regional abarca o período em que dois dos processos anteriormente ainda em fase preliminar tendem a se desenvolver: a urbanização, que na realidade passa a um processo de metropolização (e consequente expansão metropolitana) e a implantação da agropecuária moderna, principalmente na porção a leste do Distrito Federal, notadamente no oeste mineiro. As ações de gestão do território passarão a ter a dimensão regional de forma mais clara, permitindo novas formas de atuação. A região, antes muito comandada pelo processo de produção do espaço da Capital inicia um processo de fragmentação.

Este período, assim, marca o momento em que as políticas regionais e a agrícola passam a ganhar mais corpo, e é ultrapassada a fase inicial da implantação da Nova Capital. Assim como na escala nacional, as ações serão abaladas a partir da crise fiscal do Estado em fins da década de 1970, iniciando uma transição a outro modelo de atuação do Estado. A periodização adotada, de certa forma, tem ligação com aquela já realizada em outros trabalhos (CARVALHO DE SOUZA, 2010) e alguns trabalhos mais recentes de outros pesquisadores que adotam, entre seus métodos, a reconstrução da história de Brasília, como Resende (2013). Desta forma, este capítulo dá continuidade ao esforço do anterior, de analisar a produção histórica das bases territoriais da ocupação da região de Brasília.

A partir deste período, já há uma lista mais clara dos municípios que fariam parte da chamada "Região do Entorno de Brasília". Isto porque, na década de 1970, a partir de reformulações no Pergeb, tal região foi delimitada. Além dos municípios delimitados pelo Pergeb, foram ainda considerados como municípios do Entorno de Brasília alguns que não foram originalmente classificados desta forma, mas que, a partir de 1998, passaram a integrar a Ride-DF.

\subsection{Contexto socioeconômico}

Sobre o referido período, conforme visto no capítulo sobre a escala nacional, havia um contexto nacional de auge e posterior crise da estratégia desenvolvimentista e da forma de Estado por ela criada. Algumas das repercussões importantes deram-se em torno de uma inicial 
forte atuação estatal, seguida de uma progressiva perda de poder de ação do Estado, por conta do cenário de crise econômica, que afetou toda a administração pública, levando-a a abandonar, sistematicamente, a linha de planejamento da ocupação do território, em suas diversas escalas.

Sobre o contexto político nos municípios da Região do Entorno de Brasília, Tormin (2004) identifica, para o caso de Luziânia, a permanência de tradicionais famílias no poder local, algumas delas diretamente ligadas ao processo de urbanização mais intenso do sul do Distrito Federal, característico deste período. A autora, em conjunto com Oliveira (1983), aponta que a percepção inicial de Brasília, como potencial modificadora da realidade dos municípios goianos da região no rumo da modernização, é alterada para a perspectiva de uma ameaça à tranquilidade anteriormente existente. Isto é muito claro nos municípios-alvo do processo da urbanização mais intensa do período (caso de Luziânia) em que Brasília, de capital da esperança, passa a metrópole ameaçadora, usurpadora da população destes municípios que ainda levemente tocavam o progresso que esperavam.

Dessa forma, vê-se que a transferência da capital, ao invés de fazer emergir novos grupos políticos ao poder acabou por consolidar algumas das velhas famílias que dominavam os municípios, evidenciando que a perspectiva de desenvolvimento e modernidade permaneceu no plano do discurso. Isto se deu pois houve uma associação dos grupos de poder local com os governos estadual e federal, tanto no momento da implantação da Nova Capital quanto posteriormente.

Especificamente em relação ao Distrito Federal, é mantida a nomeação dos governadores pelo Presidente da República, sendo que o de atuação mais destacada, neste período, tenha sido Elmo Serejo, dadas algumas importantes obras viárias aí realizadas. Em termos gerais, apesar da organização de um Poder Executivo local, por conta da ausência de um Poder Legislativo, os governos pautam-se pelo autoritarismo em suas ações, havendo uma inflexão mais ao término (em consonância com o que ocorria em escala nacional). Exemplo disto será, por exemplo, a organização de movimentos dos moradores e inquilinos em algumas das cidades-satélites, cujo caso mais notável é o de Ceilândia, conforme analisado por Resende (1991).

Outro tema fundamental concernente ao período político específico de Brasília diz respeito ao esforço de consolidação da cidade como capital do país, o que ocorreu muito pela transferência de diversas instituições oficiais federais para a Nova Capital, reforçando sua influência como centro político nacional. Isto ficou mais patente a partir da reafirmação do governo militar de Brasília como capital federal, afastando, definitivamente, o temor de um possível retorno ao Rio de Janeiro. Paviani (1985, p. 89) aponta que "nessa fase, 
incrementaram-se as transferências de órgãos públicos, com o propósito de localizar em Brasília os principais organismos de decisão central”.

Em termos econômicos, havia uma concentração das economias dos municípios do Entorno em torno da agropecuária, o que revela que havia uma grande dependência econômica do setor primário. Este setor, deve-se registrar, teria grande impulso no período, a partir da implantação da agropecuária moderna na região. Em alguns dos municípios em que ia ocorrendo um processo de urbanização mais claro, setores de comércio e serviço iam se destacando, sendo este o caso de Luziânia e Formosa. Já em Brasília, os setores ligados ao terciário, comércio e serviços, apareciam como os preponderantes, calcados em uma economia que gravitava (e ainda gravita, atualmente, de certa forma) em torno da Administração Pública (IBGE, 1973).

Havia, mesmo no plano econômico, uma ideologia muito calcada na preservação do Distrito Federal como centro administrativo, aliado, por outro lado, à necessidade de impulsionar-se a ocupação e desenvolvimento do Centro-Oeste. Vale lembrar que este quadro é retomado justamente no momento em que a fronteira agrícola estabelece-se nesta região, com forte apoio estatal, o que impactou na própria política regional do período, sendo retomada a ideia da dupla finalidade de Brasília. É digna de nota, obviamente, a mudança no perfil econômico de alguns municípios, cujo principal caso é Luziânia.

Em termos demográficos, o Distrito Federal continuava a receber grande soma de imigrantes, mantendo-se como polo de atração. Tendo em vista a chegada desta população e o controle exercido pelo Estado sobre a questão do mercado da terra urbana, as tensões em torno da questão habitacional aumentam fortemente, o que, com a redemocratização já em curso (fins da década de 1970 e mais claramente na década de 1980) levará ao surgimento de associações de moradores e de movimentos sociais em prol da moradia (RESENDE, 1991).

Vasconcelos e Gomes (2015) avaliam que o Brasil, neste momento, vai adentrando à fase da transição demográfica marcada pelo início da queda das taxas de fecundidade. No caso de Brasília, por conta da atração de grandes levas de imigrantes jovens, tal tendência se mostrou atenuada, permanecendo uma fecundidade mais elevada que aquela registrada no restante do país. Em termos de distribuição da população, havia uma maior concentração no Distrito Federal, seguida por Luziânia, Unaí e Formosa (IBGE, 1983).

Retomando rapidamente o tema das imigrações, Gouvêa (1991) observa que o grande atrativo da Nova Capital se dava, principalmente, a partir da esperança das pessoas de obter emprego. Muito tem se falado que sua atração teria ocorrido, especialmente mais ao término do período, pela política de distribuição de lotes pelo governo local, sendo que o autor 
enxerga esta demanda como um segundo momento de uma imigração motivada por outros fatores. Isto se explica especialmente pelo fato de o primeiro momento ser marcado por períodos em que a terra foi distribuída de forma controlada, e mesmo períodos de não disponibilização destas (o próprio governo comprara a ideia das migrações serem oriundas da esperança exclusiva de acesso à terra). Não se pode ignorar o próprio processo migratório então em curso no país, no qual o Centro-Oeste, como dito, passa a ser um polo receptor importante. O segundo momento será marcado justamente pelo início da urbanização dos espaços irregulares.

\subsection{Ações de gestão do território}

A partir do contexto acima traçado, as ações governamentais demonstrarão uma mudança na perspectiva de atuação do Estado sobre a região, especialmente no que tange a uma política regional mais clara e sobre uma política urbana que abarca todo o território do Distrito Federal e começa a traçar os primeiros sinais da perspectiva metropolitana.

\subsubsection{Política regional}

Tendo em vista a atuação do Governo Federal sobre a região Centro-Oeste, que pressupunha, conforme visto no capítulo anterior, a inclusão desta no quadro econômico nacional a partir da produção agropecuária, será vista uma ação mais vigorosa do Estado no sentido de incluir a região nos circuitos produtivos nacionais. Para tanto, algumas políticas regionais foram elaboradas no período.

A principal instituição executora destas políticas foi a Sudeco. Silva (2008) aponta

que esta autarquia teve como suas principais funções a identificação dos polos de desenvolvimento e o desenvolvimento de uma agropecuária para exportação. O mesmo autor aponta ainda que a Superintendência, apesar de ter funções parelhas com a Sudam e Sudene, não dispôs dos mesmos instrumentos, especialmente de incentivo fiscal. Sua atuação se pautou por programas especiais de desenvolvimento.

Dentre estes programas, alguns deles foram elaborados ainda durante o I PND. É necessário apontar que este Plano não dava ainda o devido destaque para a Região, conforme aconteceria em sua segunda versão. Entretanto, sob sua égide, alguns programas foram elaborados: o Programa de Desenvolvimento do Centro-Oeste (Prodoeste), de 1971, cujo foco 
esteve concentrado na questão da infraestrutura e na articulação e ampliação dos eixos rodoviários; o Plano de Desenvolvimento Econômico e Social do Centro-Oeste (Pladesco), de 1972, cujo foco das ações esteve na identificação e estabelecimento de áreas (polos) prioritários e na elevação da participação do PIB da Região no PIB nacional e do PIB per capita da população.

A partir do II PND, a região passa a ter diretrizes específicas para si, determinadas e coordenadas, à época, pelo Ministério do Interior (MINTER). Era definido, assim, que a Região vinha tendo seu espaço organizado a partir de dois vetores: "a importância crescente como área produtora de alimentos; sua caracterização, a partir da criação de Brasília como entrada e via principal de ocupação da Amazônia” (MINTER; SUDECO, 1975a, p. 73). Mantinha-se, desta forma, uma visão ainda comum com o I PND: o Centro-Oeste como região “meio" para a ocupação da Amazônia. A região era chamada, neste sentido, a contribuir no equilíbrio da balança comercial brasileira de forma mais clara, a partir de uma agropecuária voltada à exportação.

Dentro desta estratégia geral, dois programas especiais destacam-se: o Programa de Desenvolvimento dos Cerrados (Polocentro) e o Programa Especial da Região Geoeconômica de Brasília (Pergeb).

O Polocentro tinha como finalidade principal a incorporação de novas lavouras à agropecuária, da ordem de 3 milhões de hectares. Sua atuação dava-se a partir de linhas de ação que compreendiam: o incentivo à pesquisa e experimentação agropecuária, atribuição dada a Embrapa e universidades; promoção da extensão agropecuária; estímulo a projetos de florestamento-reflorestamento; a construção de estradas vicinais; eletrificação rural; e a implantação de sistema de beneficiamento e transporte de produtos agrícolas (MINTER; SUDECO, 1975a, p. 98).

Já o Pergeb tinha como objetivo "oferecer à região de influência de Brasília condições de desenvolvimento mais equilibrado e consentâneo com o da Capital da República, visando a integração periférica ao Distrito Federal ao processo de desenvolvimento regional" (MINTER; SUDECO, 1975a, p. 100). Este tinha como ênfase a atuação em núcleos urbanos visando a ampliação da infraestrutura física da área. As ações abrangiam setores específicos como educação, saúde, saneamento ambiental, energia elétrica, desenvolvimento rural e outros.

O Pergeb era organizado em áreas-programa, alvo de sua atuação prioritária. Dentre tais áreas, destacam-se: o Eixo Ceres-Anápolis, cuja orientação centrava-se na implementação de projetos com capacidade de absorver contingentes demográficos; a área de influência das BRs 040 e 050 , cujos projetos deviam priorizar o aproveitamento das potencialidades da 
pecuária leiteira e de corte; o Vale do Paranã, especialmente ao redor da BR 020, que possuía potencial para aproveitamento de sua bacia leiteira; e, por fim, a área de Paracatu, que possuía potencialidade no aproveitamento agrícola (MINTER; SUDECO, 1975a).

Ainda sobre o Pergeb, França (2009) destaca outros objetivos: a promoção de empregos no Entorno o Distrito Federal; a desconcentração de serviços e estruturas; maior integração com outras regiões. No decorrer da execução do Programa, houve uma mudança na estratégia de atuação e foram estabelecidas três escalas de intervenção: uma de contenção, o próprio Distrito Federal; uma de transição e controle (cuja extensão é próxima à do Entorno atual); e uma última, regional, voltada à dinamização por meio dos eixos e áreas acima descritos. Estas três regiões podem ser vistas no mapa da Figura 7.1.

Outras ações de caráter regional são ainda descritas por Arrais (2007a), a partir da administração do executivo goiano de Irapuan Costa Júnior. Em seu plano de atuação para o Estado de Goiás, esta administração colocava os municípios do Entorno como região "leste". A ação deste governo (e, de uma forma geral das outras administrações do Estado de Goiás no período) pouco contemplou tais municípios, já que estava mais centrada nos polos de desenvolvimento e na implantação dos Distritos Industriais em outros municípios do Estado, sendo o de Anápolis o caso de maior destaque.

Uma outra atuação em escala regional a ser mencionada no período diz respeito à subdivisão dos municípios, tendo em vista o ocorrido no período anterior. Verifica-se, no período em questão, uma redução de tal tendência, com a criação de apenas um novo município: Santo Antônio do Descoberto, a partir do fracionamento do território de Luziânia. Pode-se considerar que a redução do processo de criação de novos municípios indica a perda de ênfase da dinâmica primeira da implantação de Brasília, no qual diversos municípios surgiram ao longo dos eixos de ligação da cidade, para um momento de transição. Como se verá à frente, tal tendência será retomada, mas a partir de outras dinâmicas. 
Figura 7.1 - Escalas de abrangência do Pergeb

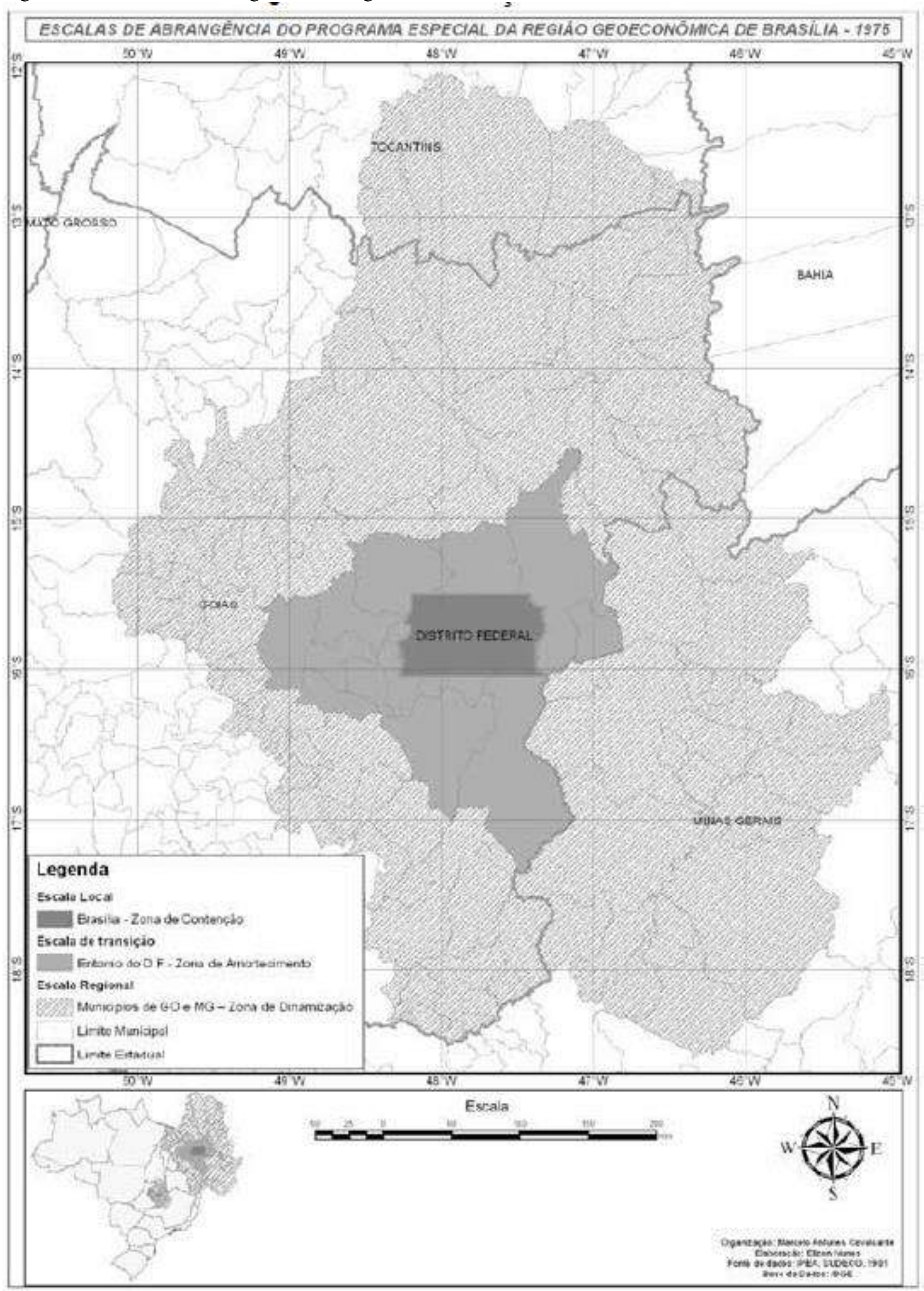

Fonte: CAVALCANTI; BARREIRA, 2011 
Quanto à efetividade de tais ações, especificamente sobre o Polocentro, França (2009) aponta para um favorecimento dos espaços sul e sudeste do Estado de Goiás, com pouca participação ainda dos municípios do Entorno no processo de apropriação dos cerrados pela agropecuária. Estevam (1997) avalia que tal programa foi bastante efetivo no setor de pesquisa e energia, não se cumprindo, por outro lado, na construção de rodovias. Aponta ainda que a atuação do Programa foi muito seletiva, privilegiando os produtores rurais de maior capitalização. Considerando o quadro socioeconômico dos municípios do Entorno, percebe-se o efeito reduzido de tal política neste espaço. Este programa será ainda revisitado, quando for tratada a temática da política agrícola.

Quanto ao Pergeb, França (2009) aponta que sua atuação foi muito voltada para a questão da contenção das migrações, sendo focada, desta forma, no espaço considerado de contenção. Estevam (1997) aponta que a maior parte dos investimentos foram centrados no eixo Ceres-Anápolis e, setorialmente, foram direcionados para os temas do transporte, energia e desenvolvimento rural. Desta forma, vê-se que a atuação do Programa contemplou a perspectiva da região de Brasília em uma escala mais ampla que a atualmente adotada, a partir da Ride-DF, mas, de certa forma, em consonância com o Peot (que foi elaborado durante a vigência do Pergeb) na perspectiva de preservar Brasília (ou o Distrito Federal) das migrações. A atuação em torno dos temas metropolitanos era ainda pouco contemplada, já que o tema viria à tona mais claramente na década de 1980.

Nota-se, a partir das ações destes dois programas, uma contradição inerente a eles e que explicita as perspectivas seletivas do Estado à época. Enquanto o Pergeb buscava a fixação do homem no campo e a criação, como se pode observar no mapa da figura 7.1, de “zonas de contenção" da população imigrante, o Polocentro atuou de forma seletiva, incentivando, de forma oposta, a concentração de terras e as migrações para os grandes centros. Desta forma, ao passo que buscava proteger a Capital das levas de imigrantes, o Estado pouco fez para evitar o êxodo rural de medidas modernizantes do campo, criando uma situação que levou ao crescimento não apenas de Brasília, mas também dos outros grandes centros (CAVALCANTI; BARREIRA, 2011; SILVA, 2008).

É importante ainda mencionar que a atuação em termos regionais, no período, foi fortemente pautada nas políticas de crédito agrícola, não comportando, como se verá abaixo, ações mais específicas de produção de um espaço regional mais coeso. Dadas as demandas consideradas externas ao território, por Silva (2008) - a atuação visou atender o grande capital, e em menor medida, os anseios da população centro-oestina que ia se constituindo. 


\subsubsection{Política urbana}

Considerando a premissa geral de atuação tecnocrática do Estado durante o governo militar, as ações de gestão do território ganham maior importância e passam a ser pautadas, em parte, por instrumentos de planejamento.

Para o caso dos municípios da Região do Entorno de Brasília, não se verificava ainda, à época, o mesmo arcabouço de planejamento existente no Distrito Federal. Por outro lado, as ações de planejamento passam a ser mais frequentes, especialmente nos municípios que iniciavam um processo mais claro de urbanização - afetados pela expansão urbana do Distrito Federal. O caso mais emblemático disto será Luziânia, que então englobava quase toda a porção sul da periferia do Distrito Federal. Contando com território muito grande e passando por um processo de proliferação de núcleos urbanos, o município decide organizar internamente o território e a administração pública a partir de Regiões Administrativas, nos moldes do Distrito Federal. Mais tarde, muitas destas Regiões Administrativas dariam origem a alguns dos municípios do atual sul do Distrito Federal: Cidade Ocidental, Valparaíso e Novo Gama (OLIVEIRA, 1983).

Outros municípios aprovaram legislações referentes à temática urbana e com interface com o planejamento, mas ainda muito afastada da experiência que então ocorria no Distrito Federal. Almeida (2006) destaca, para o caso de Pirenópolis, a aprovação de legislação que definia o seu perímetro urbano e outra referente ao seu código de posturas. A autora menciona ainda a elaboração de um plano de ação urbana, em 1981, com a finalidade de preservar o patrimônio histórico, cujo norte era a organização racional do espaço urbano. No período, são ainda aprovadas legislações sobre o zoneamento urbano e código de edificações. Chauvet (2005), para o caso de Formosa, destaca, no período, a ação do município de doar parte de seu território ao Exército Brasileiro, que ainda hoje ocupa porção significativa do território deste município.

No caso específico do Distrito Federal, a principal diferença em relação ao período anterior será que agora, o planejamento passa a ter extensão para todo o território. Assim, em 1977, é lançado o Plano Estrutural de Organização Territorial do Distrito Federal (Peot), cuja principal premissa era a preservação da área do Plano Piloto, sob a escusa de se preservar a Bacia do Paranoá. O Peot realizava, de início, uma análise sobre o espaço urbano do Distrito Federal, sendo este rígido, por conta dos planos empregados em sua ocupação. Considerando a dispersão da população do Distrito Federal, houve a orientação pelo aumento das densidades dos espaços já habitados, com fins de otimizar e reduzir os custos de implementação da 
infraestrutura. Outro ponto tratado pelo Plano e que dará base às suas orientações diz respeito ao tema do saneamento básico, cujo principal imperativo seria a preservação da Bacia do Lago Paranoá. A partir de tais demandas, considerando o tema dos transportes, o Peot orientava para o crescimento da cidade em sua porção sul/ sudeste, área de maior densidade e na qual orientava-se já um eixo de expansão da cidade em torno dos municípios do entorno sul. Este Plano será pioneiro em sugerir a construção de um metrô em Brasília, indicando justamente o adensamento em torno de sua linha (GDF, 1977).

Ainda neste período, o governo instituiu o Grupo Executivo de Remoção (GER), cuja principal tarefa era remover a população de áreas consideradas irregulares, alocando-a em novas áreas de assentamento, notadamente as cidades-satélites mais jovens (e mais afastadas do Plano Piloto). Ao término do período houve ainda a aprovação do Plano de Ocupação Territorial do Distrito Federal (POT, de 1985), que buscou instituir certo macrozoneamento do território, sem, contudo, ter sido aprovado.

Além da continuidade da política de remoção de invasões e realocação da população em assentamentos afastados do Plano Piloto, Gouvêa (1991) aponta para uma outra política implementada no período: a não-oferta de moradia, entre 1979 e 1983 . O governo local acreditava que não ofertando moradias, e dado seu controle ainda existente sobre o mercado de terras, as migrações cessariam. É importante lembrar que tal atuação tinha consonância com o previsto no Pergeb. Porém tal política não surte os efeitos desejados, já que os fluxos migratórios continuaram a destinar-se para a cidade, que oferecia serviços melhores que na maior parte do país, além de maior oferta de empregos.

Uma outra ação que começa a tomar forma no período em questão será a urbanização de favelas. Na visão de Gouvêa (1991), esta mudança de postura do governo frente a questão das ocupações irregulares tem ligação com interesses eleitoreiros, dado o contexto de redemocratização e abertura política que vinham ocorrendo. As ações de urbanização favoreceram quase exclusivamente a camada mais pobre da população, o que gerou uma pressão dos grupos de renda superior, pouco atendidos então. O governo passou, ainda, a construir casas populares em grandes quantidades, porém de qualidade duvidosa, em uma ação classificada por Gouvêa como de cooptação da população e desmobilização dos movimentos sociais existentes.

De forma efetiva, para o caso dos municípios da Região do Entorno de Brasília, a efetividade das ações de planejamento demonstra, especialmente no caso dos municípios que passaram por forte urbanização, o descolamento do planejamento (quando existente, ou de seus instrumentos próximos) verificado para o caso do Distrito Federal. A lógica dos loteamentos, 
conforme apontado por Tormin (2004) em diversos casos, ocorria a partir de associação de lideranças políticas com agentes do mercado imobiliário, o que ajudava a inviabilizar o cumprimento a contento da política urbana e de algum planejamento urbano existente. Nos outros municípios menores, nos quais o processo de urbanização não seguia o mesmo ritmo do sul do Distrito Federal, o próprio processo de planejamento urbano era ainda bastante incipiente ou mesmo inexistente, muito pelo crescimento urbano moderado, se comparado a outros períodos.

No Distrito Federal, a arena de ações do período revelou o início de uma modificação em relação ao período precedente: o Estado, antes hegemônico como produtor do espaço do Distrito Federal, passa a perder paulatinamente este posto. Face ao contexto de crise, mais claramente delineada a partir da década de 1980, a atuação local passou a reproduzir a atuação nacional no território. Uma das evidências deste processo será a produção de planos e planejamentos em quantidade decrescente durante a referida década, sendo que vários deles sequer foram implementados. Por outro lado, Paviani (1987) aponta que, mesmo com o descolamento e o insucesso de diversas das peças de planejamento, as ações do Estado no Distrito Federal seguiram marcadas pelo paternalismo e pelo assistencialismo. Mesmo com a emergência de novos atores, Paviani reconhece o dirigismo do Estado sobre as ações.

Campos (1991) aponta que neste período começa a ser estruturado um mercado imobiliário em Brasília, tendo em vista o processo de venda das terras sob poder do Estado. É um período em que grandes empresas passam a atuar no espaço do Distrito Federal. Por outro lado, cresce também a produção de residências populares, predominando os conjuntos habitacionais típicos das Sociedade de Habitações de Interesse Social (SHIS) e do SFH. Mais à frente, Campos aponta para o predomínio do capital incorporador, ligado ao processo de urbanização dos municípios do Entorno. É um período no qual a atuação das grandes empreiteiras acaba por concentrar o mercado, reduzindo a atuação de empresas menores. Neste período ocorria uma ação conjunta do Estado com este setor, já que aquele possuía muitas das terras disponíveis e determinava a localização dos empreendimentos.

\subsubsection{Política agrícola}

A partir do quadro apresentado, especialmente das políticas regionais, as ações em torno da produção agropecuária foram balizadas, principalmente, pelo Polocentro. $\mathrm{Na}$ realidade, ainda que seja reconhecida como uma política de caráter regional, sua atuação na 
prática deu-se nas questões agrícolas, especialmente na busca pela implantação de complexos mais modernos de produção no Centro-Oeste, voltados à exportação. As principais linhas de atuação do programa já foram descritas na subseção 7.2.1 deste capítulo; aqui, o foco se volta para a atuação deste programa nos polos identificados com a Região do Entorno de Brasília.

Dos polos/ sub-regiões propostas para atuação deste Programa, três possuem municípios no espaço hoje considerado da Região do Entorno de Brasília: Vão do Paracatu; Paranã; e Pirineus. Para a primeira região mencionada, localizada na porção oeste do Estado de Minas Gerais, foram traçadas quatro metas, sendo elas: "Construção, melhoria e conservação de 300km de estradas vicinais; implantação de sistema de eletrificação rural; instalação de equipamentos de moagem para produção de 90 mil t/ano de pó de calcário; construção de rede de armazéns e silos com capacidade para 200 mil t.” (MINTER; SUDECO, 1975a, p. 99).

Já para as duas sub-regiões localizadas no Estado de Goiás, a do Paranã abarca os seguintes municípios: Alvorada do Norte, Flores de Goiás, Formosa, Guarani de Goiás, Iaciara, Mambaí, Posse e Sítio d'Abadia. Estavam previstas ações específicas sobre armazenamento (com a construção de um armazém específico em Formosa), construção de estradas vicinais e eletrificação. Já a área dos Pirineus abarcava o então território dos municípios de Barro Alto, Padre Bernardo e Pirenópolis. Tinha ações previstas nos subprogramas de Armazéns de Goiás (com a previsão da construção de armazém em Padre Bernardo e Pirenópolis), construção de estradas vicinais, e ações de eletrificação (MINTER; SUDECO, 1975b).

Para o Distrito Federal, o Polocentro reservada a tarefa da produção de conhecimento aplicado, a partir da estruturação de unidades de pesquisa. Era constituído de dois projetos específicos: um, de investimentos, com recursos provenientes do próprio Polocentro; e outro de apoio administrativo aos projetos de pesquisa da Embrapa (MINTER; SUDECO, 1975b).

Além do Polocentro, outro programa específico para a questão agrícola com atuação na região foi o Programa de Cooperação Nipo-Brasileira para o Desenvolvimento dos Cerrados (Prodecer). Este foi fruto de parceria entre o governo brasileiro e o japonês, visando o apoio à expansão da agricultura moderna nos cerrados. Sua atuação dava-se a partir do fornecimento de empréstimos com condições ainda mais vantajosas que as oferecidas pelo Polocentro. Foi renovado em 1985, atuando como linha de apoio às iniciativas do Polocentro (SILVA, 2008).

De forma efetiva, conforme já mencionado, a atuação deu-se a partir destas duas principais linhas: no crédito agrícola e na pesquisa, visando criar as condições para o avanço da produção moderna na Região. Avaliando a efetividade do Programa, Cavalcanti e Barreira 
(2011) apontam o seguinte: o Programa foi exitoso na tarefa de promover o desenvolvimento de uma agricultura moderna no Centro-Oeste, transformando a região numa das principais zonas produtoras do mundo; por outro lado, contribuiu fortemente para o êxodo rural e a perpetuação (e mesmo agravamento) de uma estrutura fundiária injusta; houve enormes danos ambientais (também salientados por Silva, 2008); a distribuição dos investimentos favoreceu o sul do Estado de Goiás, notadamente a área de Rio Verde, que já tinha empresariado rural mais consolidado; as linhas foram demasiado seletivas e beneficiaram poucos produtores, em geral os de médio e grande porte.

Tal seletividade ocorreu também no tema da produção de conhecimento e tecnologia para a produção no campo, já que os dois autores mencionam ainda que as tecnologias produzidas não estavam adaptadas ao pequeno produtor, e a assistência rural atuava a partir da lógica do empresário rural (TEIXEIRA apud BARREIRO; CAVALCANTI, 2011). Quanto ao Prodecer, sua atividade teve impacto limitado, porém com valioso auxílio na expansão da agricultura de caráter empresarial na região (SILVA, 2008).

\subsubsection{Política de transportes - eixos rodoviários}

Quanto à política de transportes, o período apontou para a priorização, por parte do Governo Federal, dos investimentos nos processos de colonização da Amazônia, principalmente, investindo em rodovias de apoio a estes processos. Desta forma, a ação no período anterior, voltada para a abertura de novas rodovias, arrefece no atual período, havendo, por outro lado, avanços em torno da pavimentação de diversos dos trechos abertos. Como visto na própria política regional, havia a previsão de pavimentação de diversos trechos, e muitos dos programas previam tais ações. Dentre estes, encontram-se trechos das BR radiais, como a 070, ligando Brasília à BR 153.

À guisa de comparação, analisando o orçamento previsto para as obras específicas do Programa de Polos Agropecuários e Agrominerais da Amazônia (Poloamazônia), o setor de transportes, que abarca uma grande quantidade de obras de abertura e pavimentação de vias, no âmbito do Centro-Oeste, previa a aplicação de cerca de 38,57\% do orçamento previsto para todo o Programa, entre os anos de 1975-77. No caso do Pergeb, os gastos com infraestrutura de transporte correspondiam um total de $15,81 \%$, para o mesmo período, concentrado principalmente em obras de rodovias vicinais (MINTER, 1975). Analisando a perspectiva de rodovias a serem construídas no Centro-Oeste, as principais obras previam a expansão da malha 
no sentido Amazônia, a partir de Rondônia e de ligações a partir do norte do Mato Grosso com o Pará e o Amazonas.

Das três áreas abrangidas pela Região de Brasília no Polocentro, todas elas previam a construção, melhoria e conservação de estradas vicinais $(300 \mathrm{~km}$ no Vão do Paracatu, $560 \mathrm{~km}$ no Paranã e 300km no Pirineus). Na programação do Pergeb não são mencionados, assim como no Polocentro, grandes projetos de novas rodovias ou eixos.

Ao término do período o investimento geral do país em infraestrutura caiu bastante, por conta do quadro de dificuldades econômicas. Neste quadro, houve, por outro lado, uma ação que ajudará no aprofundamento da integração do futuro eixo Brasília-Anápolis-Goiânia, foi o início da duplicação do trecho da BR 153 entre Goiânia e Anápolis, iniciado em 1981. Por conta da crise econômica, a obra só seria concluída em 1996.

A partir do quadro das ações acima descritas e analisadas, vê-se que a atuação do Estado foi mais incisiva em torno da temática regional, por meio da necessidade de integração do Centro-Oeste às dinâmicas produtivas nacionais. Se no período anterior houve o imperativo da abertura de novas rodovias, no atual as ações voltaram-se para o uso desta base com a finalidade de incluir a região no cenário produtivo nacional. Especificamente para a Região do Entorno de Brasília, a maior parte das ações deu-se no sentido de buscar evitar o crescimento demográfico do Distrito Federal, por meio de círculos de municípios que visavam fixar a população do campo. Por outro lado, a atuação foi contraditória com o previsto no Polocentro, que claramente desalojou população que engrossou os fluxos para os grandes centros. Tal estratégia de contenção foi aliada a uma política urbana que passou a pensar a totalidade do Distrito Federal, por meio de uma lógica de preservação do centro e redução do ingresso de imigrantes. Ao mesmo tempo, por conta da expansão urbana, surgiram as primeiras iniciativas de planejamento urbano nos municípios vizinhos de Brasília. Ao término da década de 1970, com exceção do crédito agrícola (que ainda manteve os níveis de investimento até 1983), a maior parte das ações é descontinuada, e novos agentes assumem a produção do espaço regional, entre eles o capital imobiliário, no âmbito da metrópole que ia se formando, e o grande agronegócio, subsidiado pelo Estado. 


\subsection{Desdobramentos das ações de gestão do território}

A partir do quadro das ações acima discutidas, os desdobramentos sobre a organização espacial na região de Brasília demonstram maior interferência do Estado por meio de seus programas, destacando-se o avanço da agropecuária moderna a leste do Distrito Federal e a expansão urbana da Capital.

\subsubsection{Desdobramentos e processos espaciais: a formação da metrópole brasiliense}

Como um dos desdobramentos das ações de gestão do território, há a expansão urbana de Brasília. A forma de assentamento aí resultante demonstra ainda a existência de uma mancha urbana central, formada pelo Plano Piloto e por outros assentamentos próximos (como o Lago Sul, Lago Norte). A oeste, já aparecem em processo de conurbação os espaços de Taguatinga e Ceilândia, cuja expansão seguiu (o que permanece, ainda hoje) os principais eixos rodoviários de ligação do Distrito Federal, no caso a BR 070. A norte havia os espaços urbanos de Sobradinho e Planaltina e a noroeste o de Brazlândia. A sul, ao longo da BR 040, ia se adensando a cidade-satélite do Gama, ao mesmo tempo em que a urbanização dos municípios goianos tornava-se mais evidente, com o crescimento de Luziânia e o parcelamento e uso urbano de solo de seu território, naquilo que futuramente seriam os municípios de Valparaíso, Novo Gama e Cidade Ocidental (ANJOS, 1991 apud IPEA, 2001).

Conforme já posto acima, em relação ao período anterior a novidade é que o processo passa a atingir de forma mais clara os municípios vizinhos a Brasília, com o aumento da divisão das glebas rurais para uso urbano, ocasionando, em diversos casos, uma rápida urbanização de áreas antes rurais, com pouca ou nenhuma infraestrutura para isto. Em partes, isto aponta para uma dualidade na atuação do Poder Público: muito planejado e firme na atuação dentro do quadrilátero, e pouco planejado e permissivo nos municípios limítrofes. Na realidade, a situação do chamado Entorno em ocupação correspondia às necessidades habitacionais de muitos dos moradores do Distrito Federal ou de imigrantes mais pobres, que não conseguiam encaixar-se em seu mercado imobiliário.

Desta forma, a urbanização dos municípios do chamado Entorno cresce, com destaque para Luziânia, Alexânia, Cristalina, Formosa e Planaltina. Destes, apenas Alexânia não é limítrofe ao Distrito Federal. Nos outros municípios, de forma geral, a urbanização ainda 
não havia se estabelecido totalmente, permanecendo uma maior dependência das atividades no espaço rural (IBGE, 1983).

Junto aos dados que revelam um crescimento no processo de urbanização, há a observação de Margutti (1986), que aponta para um crescimento significativo das cidades de porte médio, especialmente Luziânia-GO e Unaí-MG. O autor identifica aí efeitos do Pergeb, que pressupunha justamente uma área de contenção no Entorno.

Sobre este processo de expansão urbana (e já de caráter metropolitano), Ferreira (1985) aponta para a repetição do mecanismo que havia ocorrido, de forma mais clara, durante as décadas de 1960 e 1970 dentro do Distrito Federal. Assim, os espaços das periferias próximas ofereciam terras de menor valor que atendiam uma população forçada a migrar, tendo perfil de baixa renda. Aqui reside uma mudança em relação ao processo interno ao Distrito Federal: há, uma influência muito mais clara dos mecanismos próprios do mercado (aliado, em alguns momentos, à ausência da oferta de novos lotes, por parte do Estado) do que da vontade do governo local de remover arbitrariamente ocupações indesejadas. Ao mesmo tempo, Oliveira (1983) aponta para um processo de "empurrão" das classes médias para as satélites, alterando o perfil socioeconômico de sua população.

Oliveira (1983), ao analisar o processo de ocupação dos espaços periféricos a partir das dinâmicas imobiliárias internas ao Distrito Federal, observa uma dupla rejeição dos moradores das áreas dos municípios da periferia do Distrito Federal: por um lado, foram "rejeitados" e forçados a migrar para os municípios vizinhos a Brasília, seja pela ação do Estado ou do mercado imobiliário; por outro, há uma rejeição mesmo, no caso específico de Luziânia, dadas as condições precárias da infraestrutura urbana então existente. Oliveira associa o crescimento dos loteamentos à política do Pergeb, de contenção da população nos municípios do Entorno. Mesmo com a atuação da prefeitura de Luziânia buscando conter o processo no município, pouco ela pode frente aos fluxos migratórios e à necessidade de habitação desta população.

Especificamente sobre Luziânia e seu processo de rápida urbanização, Oliveira descreve, com maior precisão, seu processo de urbanização e de integração à lógica metropolitana. O primeiro conjunto habitacional surgido foi Cidade Ocidental, em 1975, surgindo, em seguida, outros: Valparaíso I e II e Novo Gama. Houve, ainda, concentração em outros loteamentos, como Pedregal, Céu Azul e Santo Antônio do Descoberto (este se emancipou em 1983). Estudando especificamente o caso de Cidade Ocidental, identifica que a maior parte da população deste conjunto era de imigrantes oriundos do Distrito Federal, mas que ainda trabalhavam neste espaço, especialmente no Plano Piloto. 
Assim, o processo de metropolização e consequente expansão metropolitana que ia se formando aponta para o início da integração de espaços periféricos fora do Distrito Federal como suas periferias metropolitanas, a partir da extensão do processo de expansão do espaço urbano, tanto internamente ao Distrito Federal quanto de alguns municípios do chamado Entorno. A relação é ainda muito próxima do modelo visto anteriormente, de centro-periferia, porém a influência de Brasília sobre sua região imediata (que, segundo o Pergeb, se estendia para além do espaço da futura Ride-DF) vai se tornando mais sólida do que no período anterior. Muito disto ocorre pela consolidação da cidade como capital, que consolida o setor público federal na cidade, principal motor de sua economia. Os serviços que surgem associados a isto levam também a este quadro, atraindo mão de obra, e ampliando a variedade dos serviços oferecidos, ampliando e consolidando o alcance da influência brasiliense.

Assim, ficava evidente que Brasília já se mostrava um espaço metropolitano, sendo que, mais especificamente no dizer de Paviani (1988), era uma metrópole terciária, considerando, Brasília como uma metrópole incompleta (a partir de Milton Santos), pela dependência de outras metrópoles para exercer plenamente suas funções. Paviani considera que a metrópole era formada pelo Plano Piloto, como centro urbano, pelas cidades-satélites, pelas áreas invadidas e pela periferia goiana, que ia se integrando à dinâmica metropolitana. A estrutura polinucleada da cidade, na visão de Paviani, seria, assim, uma consequência da atuação do governo, promovendo, entre outras ações, um processo de expansão da periferia de forma planejada. Desta forma, ele aponta que a então metrópole estava unificada em torno de uma única função, mas internamente fragmentada devido ao processo de segregação socioespacial. Quanto aos municípios da Região do Entorno de Brasília, sua integração davase como periferia, reproduzindo, como já afirmado, o mesmo processo das cidades-satélites em momentos anteriores.

Outra questão que surge a partir dos resultados analisados diz respeito a uma mudança do foco da relação de Brasília com seu espaço imediato. Se antes a preocupação maior era com um espaço regional ampliado, o processo de urbanização do sul do Distrito Federal (em que pese os indícios de sua ocorrência também ao norte, em Planaltina) e a sua caracterização como metrópole farão com que o foco, especialmente o da academia, se volte ao processo de metropolização, evidente e em expansão mais franca a partir do próximo período. De certa forma, isto tem deixado negligenciadas as pesquisas em torno do papel regional da metrópole terciária, algo que se busca resgatar neste trabalho. 


\subsubsection{Desdobramentos e processos espaciais: a implantação da agropecuária moderna na Região de Brasília}

A partir das ações do Estado, especialmente no que tange à política regional e agrícola, foi possível ver a implantação da agropecuária moderna na região Centro-Oeste como um todo, e mesmo, de forma mais abrangente, nos espaços de cerrados em Minas Gerais. Conforme analisado quanto à efetividade do Polocentro, viu-se que a maior parte dos recursos acabaram capturados setorialmente pelos setores já com características empresariais, e espacialmente concentrando-se ao sul do Estado de Goiás. Entretanto, pelo que se pode verificar pela literatura, duas das áreas que envolviam municípios da Região de Brasília obtiveram importantes recursos que permitiram a implantação inicial da agropecuária moderna: Vão do Paracatu e Paranã. No caso da outra área, Pirineus, as ações não levaram à implantação de uma agropecuária moderna na região neste momento.

A observação de alguns dados referentes ao tema, como a variação do valor investido, por ano, nos municípios da região de Brasília, pode ser feita a partir da Tabela 7.1. A observação dos dados desta Tabela aponta para um forte crescimento geral na comparação do valor de 1970 e 1975. Isto porque o valor total investido era reduzido e qualquer acréscimo significaria um incremento percentual elevado. Neste primeiro período, destaca-se, ainda assim, o investimento no município de Cristalina. Já o segundo período de comparação, entre os anos de 1975 e 1980 aponta para uma situação melhor de comparação, já que foi neste intervalo de tempo que a maior parte das políticas do Polocentro agiu. Nesta fase, nota-se um crescimento importante nos valores dos municípios de Buritis e Luziânia. O último período de comparação, de certa forma, já revela indícios da retirada do investimento no crédito agrícola no período. 
Tabela 7.1 - Investimentos realizados no ano - agropecuária - variação entre os anos pesquisados $(1975,1980$ e 1985)

\begin{tabular}{l|lr|r|r}
\hline UF & Município & $1970-75$ & $1975-80$ & $1980-85$ \\
\hline GO & Abadiânia & 56,23 & 160,89 & 148,37 \\
GO & Alexânia & 342,58 & 159,48 & $-12,35$ \\
GO & Cabeceiras & 249,30 & 75,10 & 86,00 \\
GO & Corumbá de Goiás & 442,61 & 143,14 & 64,27 \\
GO & Cristalina & 749,71 & 86,80 & 38,12 \\
GO & Formosa & 236,86 & 26,72 & 60,54 \\
GO & Luziânia & 188,03 & 236,08 & $-12,63$ \\
GO & Padre Bernardo & 541,11 & $-0,28$ & 110,41 \\
GO & Pirenópolis & 232,66 & 155,07 & $-14,12$ \\
GO & Planaltina & 263,69 & $-26,40$ & 93,09 \\
MG & Buritis & 8,60 & 690,14 & 43,17 \\
MG & Unaí & 158,82 & 147,24 & 26,21 \\
DF & Brasília & 168,56 & 293,04 & 4,80 \\
\hline
\end{tabular}

Fonte: IBGE apud IPEADATA (dados tratados pelo autor)

Além destes dados referentes à evolução do valor investido, os dados apresentados na tabela 7.2 apontam para o avanço da agropecuária no período, ao analisar o crescimento nos intervalos de tempo, da área colhida em lavouras:

Tabela 7.2 - Área colhida - lavoura temporária - variação, em percentual

\begin{tabular}{llrrrr}
\hline UF & Município & $1973-1975$ & $1975-1980$ & $1980-1985$ \\
\hline GO & Abadiânia & 115,41 & $-57,56$ & 12,54 \\
GO & Alexânia & 94,54 & $-50,36$ & 99,22 \\
GO & Cabeceiras & 392,21 & $-27,86$ & 153,42 \\
GO & Corumbá de Goiás & 192,87 & $-53,71$ & 91,01 \\
GO & Cristalina & 152,57 & 85,64 & 272,06 \\
GO & Formosa & 86,10 & 8,77 & 44,61 \\
GO & Luziânia & 138,00 & 45,09 & 42,99 \\
GO & Padre Bernardo & 97,66 & 32,19 & $-3,00$ \\
GO & Pirenópolis & 137,63 & $-30,09$ & 14,38 \\
GO & Planaltina & 321,92 & $-41,43$ & 289,29 \\
MG & Buritis & 4,85 & 112,88 & 78,88 \\
MG & Unaí & 57,03 & $-12,45$ & 24,31 \\
DF & Brasília & 326,75 & 170,13 & 139,22 \\
\hline
\end{tabular}

Fonte: IBGE apud IPEADATA (dados tratados pelo autor)

Os dados apontam haver um crescimento em praticamente todos os municípios no primeiro período considerado, entre 1973 e 1975, anos em que o Polocentro ainda não havia sido implantado. Destaca-se o crescimento da área colhida especialmente em Planaltina e Cabeceiras. Já o segundo período, que corresponde ao período de atuação deste programa 
aponta para grandes crescimentos nos municípios de Buritis e Cristalina (ao lado de Brasília). No último período o crescimento se destaca em Cristalina, Planaltina e Cabeceiras. Neste sentido, percebe-se a concentração da produção em municípios ao sul e leste do Distrito Federal, locais em que as políticas do Polocentro foram mais ativas a partir de áreas programa específicas.

Desta forma, vê-se a estruturação inicial de espaços da agropecuária moderna à leste, nordeste e sul do Distrito Federal, iniciando a conformação posterior do que será chamado de arco da agropecuária moderna.

\subsubsection{Desdobramentos e processos espaciais: a implantação do corredor rodoviário entre Brasília e Goiânia}

No período em questão, este talvez seja o processo cuja evolução se deu de forma mais indireta em relação aos outros dois considerados fundamentais na produção do espaço da Região de Brasília. Isto porque o eixo rodoviário fora criado no período anterior e não recebeu significativos investimentos em sua integração. Ao se falar em evolução do processo, o que pode ser mencionado aqui é a tendência de consolidação de Brasília como Capital Federal e a ampliação da influência de Goiânia. Desta forma, por conta deste duplo movimento, forma-se aí um corredor de transportes entre as duas cidades ainda sem a dinâmica própria que o eixo viria adquirir no momento posterior.

Conforme apontado anteriormente, houve o início da duplicação do trecho da BR 153 entre Goiânia e Anápolis no período. Porém, por conta da crise econômica e da perda de poder de atuação do Estado sobre a infraestrutura, o trecho só seria concluído quinze anos depois.

\subsubsection{Subcentros e desigualdades regionais na Região de Brasília}

Observando os desdobramentos sobre a questão do centro e dos subcentros em formação, o Plano Piloto manteve-se como principal área central, concentrando em si não apenas o maior número de postos de trabalho, mas também os principais e mais bem pagos empregos do Distrito Federal. É consolidado e mantido como centro principal do espaço urbano de Brasília, mas torna-se também o centro principal da metrópole que ia surgindo e se consolida como centro regional da Região do Entorno de Brasília. Tal fator estava claramente associado 
à presença da administração pública e sua consolidação no período, além dos serviços prestados diretamente aos trabalhadores deste setor.

Por outro lado, inicia-se o surgimento de novas centralidades internamente ao Distrito Federal, sendo, para o período, a mais marcante aquela que aparecia entre Taguatinga e Ceilândia. Estes subcentros/ nucleações tem seu surgimento atrelado às demandas de consumo destas satélites, sendo notável o crescimento do comércio, principalmente, nelas. Em trabalhos anteriores (CIDADE, 1999b; CARVALHO DE SOUZA, 2010), a partir do uso de dados sobre o consumo de energia elétrica, é possível perceber uma forte concentração do consumo no Plano Piloto. Carvalho de Souza indica também a preponderância referente ao uso comercial no Plano Piloto, vindo, em segundo lugar, Taguatinga. Paviani (1985), ao analisar dados sobre a distribuição dos postos de trabalho, indica uma concentração secundária em Taguatinga, na década de 1970 e, principalmente, na de 1980.

Em uma conexão com a realidade do que ocorria nos municípios vizinhos do Distrito Federal, Paviani aponta para a ocorrência de um processo interno ao Distrito Federal que se repete para tais espaços: uma contradição entre a concentração de atividades e o padrão disperso da população. Isto leva a que o modelo de polinucleamento já analisado no período anterior se mantenha e se amplie também para os municípios vizinhos.

Um dado que auxilia a compreender como tal dinâmica se desdobrou, ao fim do período, refere-se aos dados sobre o valor adicionado ao PIB pelos setores da economia, contidos na Tabela 7.3. Os dados apontam que importantes municípios com significativos contingentes demográficos aparecem com altos valores no setor agropecuário, como Unaí $(52,88 \%)$. Além deste município, o setor agropecuário demonstra valores acima de $50 \%$ no percentual adicionado ao PIB em outros cinco municípios: Abadiânia, Cabeceiras, Padre Bernardo, Pirenópolis e Buritis. Já os setores industriais aparecem com maiores valores em municípios como Corumbá de Goiás (56,87\%), Formosa $(31,50 \%)$ e Planaltina $(35,15 \%)$. No caso de Corumbá de Goiás, é notória a participação do setor de extrativismo mineral. Quanto ao comércio, este tem grande relevância nos percentuais adicionados de Cristalina $(39,20 \%)$ e Unaí $(13,12 \%)$. Finalmente, o setor de serviços tem um percentual elevado em Brasília (87,89\%), muito puxado pela Administração Pública federal. Os valores neste setor são ainda significativos em Luziânia (52,35\%).

Desta forma, o que se percebe é uma economia dedicada, em muitos dos municípios, à atividade da agropecuária, sendo alguns deles, como no caso de Unaí, alvo de investimentos do Polocentro. Dois outros casos chamam a atenção por estes dados: Formosa, que não apresenta evidente predomínio de nenhum dos setores; e Luziânia, onde os setores 
associados ao terciário se demonstravam com percentuais mais elevados (isto era reflexo do processo de urbanização e integração à dinâmica metropolitana de Brasília que então ocorria).

Tabela 7.3 - Valor adicionado bruto ao PIB municipal, em percentual, dos municípios do Entorno, por setor (agregado), 1985.

\begin{tabular}{|c|c|c|c|c|c|}
\hline Sigla & Município & $\begin{array}{c}\text { Agropecuária } \\
\text { - valor } \\
\text { adicionado }\end{array}$ & $\begin{array}{l}\text { Indústria - } \\
\text { valor } \\
\text { adicionado }\end{array}$ & $\begin{array}{l}\text { Comércio } \\
\text { - valor } \\
\text { adicionado }\end{array}$ & $\begin{array}{l}\text { Serviços - } \\
\text { valor } \\
\text { adicionado }\end{array}$ \\
\hline GO & Abadiânia & 58,35 & 6,54 & 5,87 & 29,24 \\
\hline GO & Alexânia & 49,70 & 7,67 & 9,01 & 33,61 \\
\hline GO & Cabeceiras & 76,37 & 9,21 & 2,78 & 17,21 \\
\hline GO & Corumbá de Goiás & 17,68 & 56,87 & 6,80 & 18,65 \\
\hline GO & Cristalina & 33,84 & 4,60 & 39,20 & 22,35 \\
\hline GO & Formosa & 22,24 & 31,50 & 10,47 & 35,80 \\
\hline GO & Luziânia & 18,01 & 21,20 & 8,44 & 52,35 \\
\hline GO & Padre Bernardo & 60,17 & 7,56 & 10,50 & 21,78 \\
\hline GO & Pirenópolis & 60,38 & 8,19 & 12,99 & 18,44 \\
\hline GO & Planaltina & 23,94 & 35,15 & 12,16 & 28,75 \\
\hline GO & Santo Antônio do Descoberto & 48,83 & 5,11 & 7,52 & 38,55 \\
\hline MG & Buritis & 51,12 & 6,82 & 11,69 & 30,37 \\
\hline MG & Unaí & 52,88 & 8,63 & 13,12 & 25,37 \\
\hline DF & Brasília & 0,34 & 6,03 & 5,75 & 87,89 \\
\hline
\end{tabular}

Fonte: IBGE apud IPEADATA (dados organizados pelo autor)

Em uma análise qualitativa do processo, e com outros dados, Margutti (1986) aponta, no caso dos municípios da Região de Brasília, para um processo mais claro de urbanização em descompasso com as condições de produção. Os dados da PEA para estes municípios demonstram ainda uma forte concentração deste contingente no setor primário. É apresentado ainda um crescimento do setor industrial neste grupo de municípios, porém com absorção relativa da PEA e baixa diversificação, predominando indústria de baixa tecnificação. Tais indústrias concentravam-se, desta forma, nos seguintes gêneros: alimentícios, minerais não metálicos, minerais metálico e de produção de mobiliário. Dada a concentração anteriormente posta no setor primário, e considerando o processo mais geral de modernização da atividade, Margutti aponta para uma absorção ainda tímida do espaço da Região de Brasília neste processo, identificando o município de Unaí-MG como protagonista neste processo. Nos outros municípios, predominava ainda a baixa produtividade e a produção voltada à subsistência.

Ainda por este mesmo estudo, Margutti demonstra uma quase absoluta concentração de serviços superiores em Brasília, com pouca ou nenhuma oferta nos outros municípios. No que tange à saúde o quadro não é muito diferente, com uma alta concentração 
de leitos hospitalares em Brasília. Nestes dois setores, havia alguma participação significativa de Unaí e Formosa (além da prestação de outros serviços).

A análise das informações anteriormente postas permite afirmar que, se por um lado ia ficando mais claro o perfil metropolitano de Brasília (tema a ser retomado posteriormente), em termos de possíveis subcentros em formação, os elementos e dados não permitem claramente afirmar o surgimento de um subcentro regional, embora seja necessário destacar o caso de Luziânia. A preponderância que apresentou nos dados relativos à questão dos serviços e a participação destes nos valores adicionados ao PIB municipal indicam ainda um processo mais claro de urbanização. Por outro lado, considerando o crescimento demográfíco e a incipiente concentração de alguns serviços, é possível afirmar que Luziânia possuía as bases necessárias para constituir-se como subcentro regional, algo que ficará mais claro nos próximos períodos. De forma distinta dos outros municípios, Luziânia demonstrava já potencial para a instalação de equipamentos de consumo e de prestação de serviços em nível maior, não se contentando em ser mera concentração produtiva.

Considerando o perfil produtivo da região, os dados não apontam para a formação de subcentros ligados ao apoio à produção, já que, apesar da visível concentração da economia da maior parte dos municípios no setor primário, as informações dos gêneros produzidos demonstram ainda uma reduzida produtividade, que culmina na dificuldade em alcançar escala com o produzido. Margutti (1986) é taxativo em afirmar que a produção da região de Brasília era ainda insuficiente para suprir as demandas do próprio Distrito Federal. Por outro lado, a produção era voltada à exportação e alguns municípios começaram a estruturar-se como verdadeiras "cidades do agronegócio", colocando-se como pontos de controle técnico da produção. Estes parecem ser os casos de Formosa e Unaí.

Este quadro parece ser corroborado pelas pesquisas do IBGE em torno das Regiões de Influência das Cidades no período. Uma primeira pesquisa, publicada em 1972 (IBGE, 1972), referente à divisão do Brasil em regiões funcionais, estabelece uma hierarquia urbana local estando Brasília sob influência de Goiânia (esta considerada um centro macrorregional). Na referente pesquisa, Brasília é considerada em um centro de nível 2a, que corresponde a centros urbanos com as seguintes características:

“1) De 150 a 300 relacionamentos no total (dentro e fora de sua área de atuação dominante); 2) De 100 a 250 relacionamentos dentro de sua área; 3) Não tem atuação extra-regional, apenas relacionamentos com municípios limítrofes das áreas vizinhas; 4) Recebem bens e serviços para a economia e população de centros $2 a$ ou mesmo $2 b$, 
ou então pela posição geográfica tem forte penetração da metrópole na sua área de atuação; 5) De modo geral, 30 a 40\% dos relacionamentos da área se fazem com centros de igual categoria ou centros de escalão inferior localizados em outras regiões metropolitanas; 6) Centros subordinados de escalões inferiores.” (IBGE, 1972, p. 15).

Neste sentido, nesta pesquisa, Brasília aparece mesmo em nível inferior em relação a Anápolis, revelando seu processo de formação ainda precoce. Dos municípios da região de Brasília que posteriormente viriam a fazer parte da Ride-DF, aparece nesta hierarquia, como centro de nível 3a (imediatamente abaixo do de Brasília), a cidade de Formosa.

Posteriormente, no Estudo das Regiões de Influência das Cidades (IBGE, 1987 cuja coleta dos dados ocorreu em 1983), Brasília é classificada como capital regional, estando, por outro lado, ainda subordinada a Goiânia (aí considerada metrópole regional). Nesta pesquisa, a hierarquia era dada a partir da oferta de bens e serviços e as capitais regionais ofereciam os seguintes (IBGE, 1987, p. 18):

- Comércio varejista: móveis para escritório; material para dentista; oxigênio para hospitais; máquina de calcular; refrigeradores comerciais; material para indústria gráfica; caminhões FNM ou Mercedes Benz; lanchas e motores de popa; pratarias e cristais; livros para engenharia e/ ou medicina; máquinas para filmar e/ ou projetar.

- Comércio atacadista e representações: tecidos, cigarros, jornais diários.

- Serviços: médico oftalmologista, médico cardiologista, médico neurologista, exame de eletrocardiograma, faculdade de economia, faculdade de administração, faculdade de direito, instalações elétricas ou hidráulicas, escritório de arquitetura.

A partir destas características, sob influência de Brasília e na Região do Entorno, aparecem como centros de zona os municípios de Luziânia, Formosa e Unaí. De certa forma, esta informação converge na perspectiva acima proposta: havia elementos de centralidade nestes municípios, porém ainda em estágio incipiente.

Esta segunda hierarquia proposta pode ser visualizada no mapa abaixo (Figura 7.2), proposto pelo IBGE para entender esta fração da hierarquia urbana nacional. A região sob influência de Goiânia possui uma peculiaridade interessante: não se vê um relacionamento direto de Goiânia em relação a Brasília. O mapa demonstra, assim, que Brasília possuía já uma rede sob seu comando em sua região imediata e ampliada, que atingia espaços do oeste baiano e mineiro, além do norte goiano e parte do atual território de Tocantins. O mapa também 
demonstra como a perspectiva do Eixo Brasília-Anápolis-Goiânia ainda era algo distante neste período.

Relativo ao tema das desigualdades regionais, a análise da variação do valor total dos rendimentos recebidos em Brasília e nos municípios do Entorno permite verificar até que ponto o processo de desenvolvimento destas dinâmicas se reverteu na renda, o que pode ser visualizado na Tabela 7.4. É possível perceber um forte crescimento no valor total dos rendimentos nos municípios de Luziânia e Buritis, com variação percentual superior mesmo ao do centro principal, Brasília. Entretanto, à exceção destes dois municípios, todos os outros tiveram um crescimento nesta variável abaixo do centro principal. Nota-se, aqui, a importância, de um lado, das eventuais rendas obtidas a partir da expansão urbana e metropolitana (para o caso de Luziânia) e do processo de modernização agrícola. Entretanto, considerando o ritmo de crescimento abaixo do centro principal na maior parte dos municípios, sugere-se a tendência de concentração de renda e consequente aumento das desigualdades socioespaciais. Já no segundo intervalo, cujo recorte temporal se insere (em parte) no período em análise neste capítulo (1980 a 1991), nota-se uma queda geral no crescimento dos rendimentos, como efeito provável da crise econômica. Talvez por conta desta situação de exceção, o crescimento dos rendimentos médios do centro principal (Brasília) é reduzido, e o crescimento em outros municípios é mais expressivo, com destaque para Planaltina e Luziânia, para o período entre 1980 e 1991. É de se destacar ainda, neste período, a variação negativa nos municípios de Pirenópolis, Buritis e Unaí. 
Figura 7.2 - Região de influência de Goiânia, segundo o estudo da REGIC de 1987.

\section{REGIĀO DE INFLUÊNCIA DE GOIÂNIA}

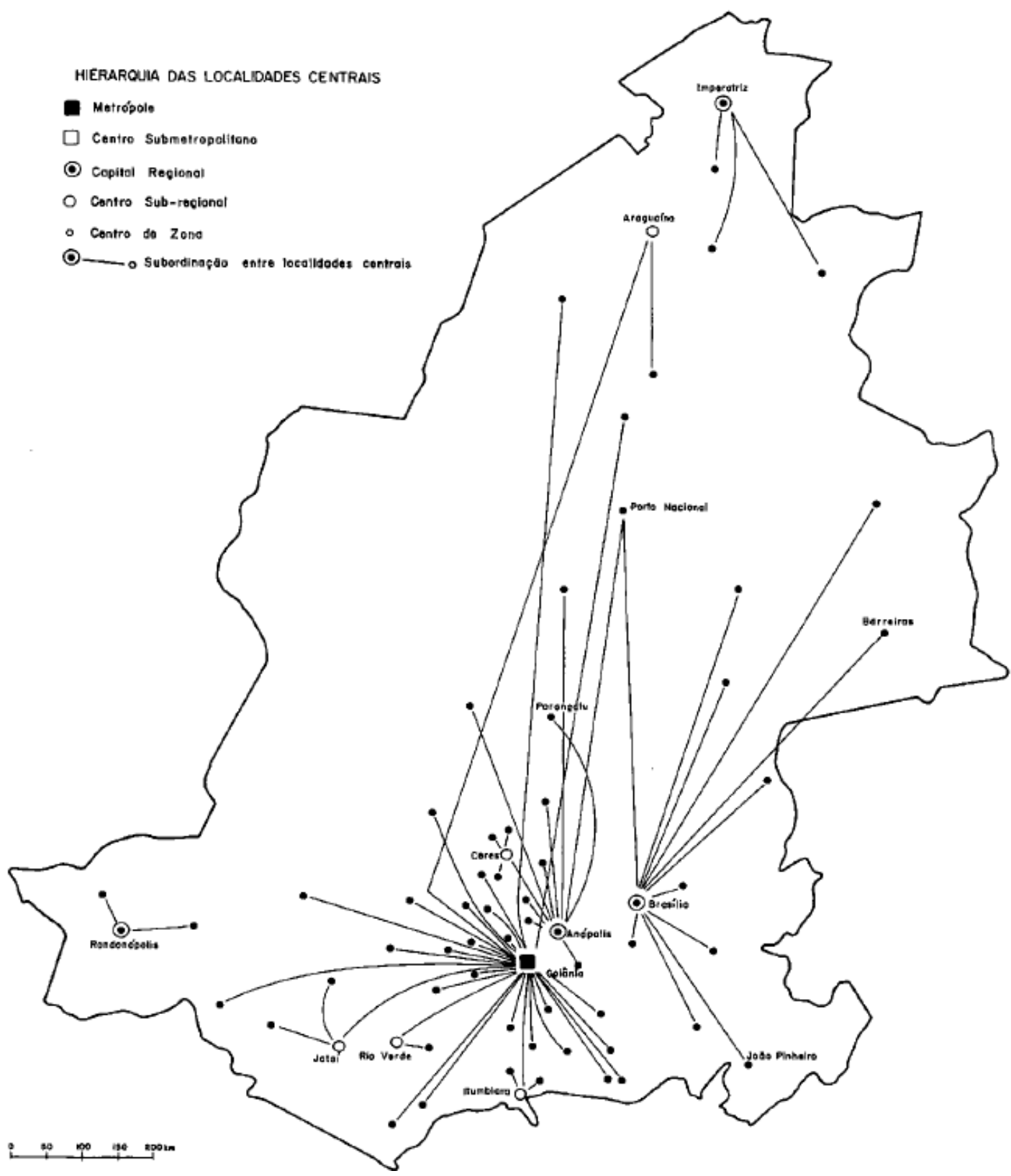

Fonte: IBGE, 1987 
Tabela 7.4 - Valor Total dos Rendimentos recebidos - variação, em percentual, entre os anos registrados

\begin{tabular}{l|lrr}
\hline UF & Município & $1970-80$ & $1980-91$ \\
\hline GO & Abadiânia & 108,68 & 47,00 \\
GO & Alexânia & 191,89 & 26,71 \\
GO & Cabeceiras & 139,08 & 63,18 \\
GO & Corumbá de Goiás & 166,87 & 5,99 \\
GO & Cristalina & 305,68 & 45,96 \\
GO & Formosa & 314,70 & 71,96 \\
GO & Luziânia & 767,88 & 131,54 \\
GO & Padre Bernardo & 192,94 & 19,43 \\
GO & Pirenópolis & 145,86 & $-14,51$ \\
GO & Planaltina & 378,15 & 193,69 \\
MG & Buritis & 553,89 & $-25,80$ \\
MG & Unaí & 260,19 & $-15,65$ \\
DF & Brasília & 428,61 & 34,91 \\
\hline
\end{tabular}

Fonte: IBGE apud IPEADATA (dados tratados pelo autor)

Desta forma, os dados apontam para uma tendência de concentração dos rendimentos justamente no período em que as políticas de desenvolvimento regional estiveram mais em ação. Analisando por município, houve uma participação sempre importante de Luziânia e Unaí, apontando novamente para a ocorrência dos processos de expansão metropolitana e implantação da agropecuária moderna. Com a crise e o desmonte destas políticas, os valores gerais foram sendo reestabelecidos, próximos dos valores de 1970 (apesar de uma concentração importante em Luziânia).

Estes dados servem para dar ideia da desigualdade produzida, em termos subregionais, do processo de desenvolvimento com base no Polocentro e Pergeb. Não sem motivos, este será um período de forte crescimento urbano em Brasília, motivado pela chegada de imigrantes, muitos deles vindos dos municípios vizinhos a Brasília não atendidos pelas políticas de desenvolvimento regional. A análise deste desdobramento revela, ainda, que os objetivos do Polocentro foram claramente mais atendidos que os do Pergeb: este programa pressupunha a fixação do homem no campo; entretanto, com o modelo de desenvolvimento agrícola proposto pelo Polocentro, que ganhou maior atenção do Governo, houve justamente o oposto.

\subsection{Síntese, discussão e ligação}

Considerando o interesse deste capítulo e a continuidade do processo de estruturação e organização da Região de Brasília (Brasília e o chamado Entorno), ainda sem a institucionalização proposta pela Ride-DF, pode-se considerar que a produção deste espaço 
regional teve forte participação do Estado, tanto por suas políticas de cunho regional quanto aquelas de cunho urbano para o Distrito Federal. Na realidade, como se viu, as duas políticas acabaram por se articular na tentativa de "proteger" o espaço do Distrito Federal das imigrações. Porém, tendo em vista o imperativo maior de integração do Centro-Oeste como grande celeiro nacional voltado à exportação, os requisitos concentradores da reestruturação produtiva acabaram se sobrepondo a desígnios de um suposto equilíbrio espacial. Ao mesmo tempo, esta diretriz política levou à produção inicial dos primeiros espaços ligados à agropecuária moderna nos municípios que viriam a fazer parte da Ride-DF. Desta forma, dentre os agentes analisados, a figura do Estado foi primordial por assumir uma perspectiva maior de controle do espaço, em relação ao período passado, no qual este papel esteve restrito ao Distrito Federal. Entretanto, pela tentativa de atender objetivos contraditórios (reduzir a imigração para Brasília; estimular a produção agrícola voltada à exportação), muitos dos objetivos das políticas acabaram não concretizados, e a região tornou-se palco de dois processos principais: um primeiro, estimulado claramente pelo Estado, de avanço do agropecuária moderna; um segundo, de expansão urbana e metropolitana, "não quisto" pelo Estado (ao menos não do ponto de vista do discurso), porém produzido como um dos efeitos colaterais de sua atuação. Os agentes privados mantiveram uma postura reativa aos estímulos do ente estatal. No próximo período, esta tendência muda.

Quanto à expansão metropolitana e a formação de subcentros atrelado a tal papel, guardadas as devidas proporções, é digno de nota apontar que o processo guarda algumas semelhanças com o analisado por Gottdiener (1997): a criação de assentamentos afastados acaba por criar, de certa forma, o gérmen necessário ao surgimento de uma futura nucleação de atividades. Obviamente que este processo não é o único responsável pelo surgimento de subcentros urbanos, metropolitanos ou regionais, mas parece ser fundamental do ponto de vista da criação de novos espaços de consumo. No próximo capítulo esta tendência será aumentada, especialmente no sul do Distrito Federal e a oeste dele.

Quanto ao quadro regional resultante de tal processo, além do movimento da expansão metropolitana vinha se consolidando a introdução da agropecuária moderna na região. Daí o início da fragmentação de seu espaço, quebrando certa "homogeneidade" ou "estabilidade" mais clara do período anterior. Com novas dinâmicas ainda por ser implantadas, o próximo período demonstrará uma região ainda mais fragmentada. É deste processo de fragmentação regional ocorrida em uma região de planejamento legalmente instituída, a RideDF, que trata o próximo capítulo. 


\section{REESTRUTURAÇÃO PRODUTIVA NA RIDE-DF: PERÍODO DA EXPANSÃo METROPOLITANA, EXPANSÃO DA AGROPECUÁRIA MODERNA E INTEGRAÇÃO DO EIXO BRASÍLIA-ANÁPOLIS-GOIÂNIA (1985-2016)}

O presente capítulo visa dar continuidade ao processo de análise, enfocando o período mais recente, no qual os três processos enunciados na Introdução deste trabalho passam a atuar de forma plena, sendo os principais responsáveis pela produção do espaço regional da Ride-DF: a expansão metropolitana, a expansão da agropecuária moderna e a integração do Eixo Brasília-Anápolis-Goiânia. Como se viu nos capítulos anteriores, estes processos já atuavam no território da região de Brasília, cuja primeira formalização deu-se pela Região Geoeconômica de Brasília. Na esteira desta primeira formalização, a partir da década de 1970, iniciou-se a delimitação de uma região mais imediata, chamada de "Entorno". Esta seria formalizada em 1998, por meio de Lei Complementar Federal. O objetivo deste capítulo é analisar a produção recente do espaço desta região "oficial”, a partir da incidência daqueles três processos. Neste sentido, este capítulo explora a terceira questão de pesquisa: "Qual o papel dos processos de expansão metropolitana de Brasília, expansão da agropecuária moderna e integração do Eixo Brasília-Anápolis-Goiânia no sentido de estruturar e organizar o espaço da Ride-DF?".

\subsection{Contexto socioeconômico}

No terceiro período considerado, foi visto que o contexto nacional foi da derrocada do desenvolvimentismo e a sua substituição pelo neoliberalismo como estratégia econômica e política. Tal premissa levou a uma perda crescente do poder de atuação do Estado, que busca um outro papel no desenvolvimento social e econômico do país, legando algumas de suas funções à iniciativa privada e alterando sua relação com o capital em relação às estratégias de ação. Parte disto se dará por meio das privatizações, pelo fim de alguns monopólios de Estado e pela atuação mais centrada na regulação da prestação de alguns serviços públicos pela iniciativa privada, antes de titularidade restrita ao Estado.

Nos municípios da Ride-DF, de uma maneira geral, em termos políticos, as prefeituras sempre tenderam para grupos mais conservadores, sendo, no período, poucos os mandatos de partidos mais progressistas. É possível observar uma grande influência da política do Distrito Federal sobre estas prefeituras, buscando-se, de forma geral, o domínio de um 
mesmo grupo político ou de grupos aliados sobre a região. É importante ainda considerar o processo de formação de novos municípios no período: Mimoso de Goiás e Água Fria de Goiás em 1987, Cocalzinho de Goiás e Cidade Ocidental em 1990, Vila Boa em 1992, Águas Lindas de Goiás, Novo Gama e Valparaíso em 1995. Em Minas Gerais, em 1995, foi emancipado, do território de Unaí, o município de Cabeceira Grande. Muitos deles tiveram origem no grande território de Luziânia, que foi sendo desmembrado a partir dos núcleos de habitação que ali surgiam.

Especificamente para o Distrito Federal, em termos políticos, a principal alteração diz respeito à garantia de sua autonomia política, estabelecida pela Constituição Federal de 1988. Desta forma, o Distrito Federal é reconhecido como um ente próprio da federação, não sendo nem um estado-membro nem um município. A partir da autonomia política, o Distrito Federal passou a poder eleger o chefe de seu Poder Executivo local, bem como pôde instituir a Câmara Legislativa, órgão do Poder Legislativo local (o Poder Judiciário local permaneceu como atribuição da União). Tal situação demonstrou uma alteração no jogo de forças que culmina na formação dos governos, com estes mais abertos a representarem ou a serem influenciados pelos interesses dos grupos políticos locais. Isto tem levado a uma alternância de grupos políticos no poder, ora mais conservadores (como nos casos dos governos de Joaquim Roriz e José Roberto Arruda), ora com governos mais progressistas de esquerda (casos de Cristóvão Buarque e, em menor escala, Agnelo Queiroz e Rodrigo Rollemberg).

Em termos econômicos, a Ride-DF mostra-se ainda demasiado dependente do terciário do Distrito Federal, havendo em alguns municípios, um setor primário mais consolidado, já neste período (como é o caso de Formosa) e outros no qual o processo iniciouse mais tardiamente (caso de Cristalina). As cidades mais populosas, em geral mais próximas do Distrito Federal tem economia baseada no setor terciário, de alcance local. Quanto ao Distrito Federal, sua economia mantém o predomínio da atividade terciária, ainda com forte dependência do setor público e reduzida presença do secundário. Guia (2006) aponta que, internamente ao Distrito Federal houve alguma expansão do secundário e retração do setor primário.

Em relação à economia desta região, dados do $\operatorname{IBGE}^{17}$ demonstram uma tendência de elevada concentração do PIB da Ride-DF no Distrito Federal, em valores sempre acima dos $90 \%$ nos anos de 2000 e 2010. Por outro lado, tem ocorrido uma tendência comum de crescimento do PIB dos municípios da Ride-DF, não se identificando tendências mais evidentes

\footnotetext{
${ }^{17}$ Ver dados da Tabela A 17, no Anexo A.
} 
de desconcentração da economia em torno do Distrito Federal ${ }^{18}$. Caracteriza-se, assim, uma economia concentrada e muito forte em Brasília, centro da Ride-DF e seu principal polarizador, concentrando aí as atividades do terciário ligado à administração pública federal.

Em termos demográficos, a população do quadrilátero segue tendência de crescimento, mas com fluxos migratórios internos direcionados para a Ride-DF caracterizados pela saída do Distrito Federal para municípios vizinhos em busca de acesso à moradia. A capital permanece como recebedora de importantes somas de imigrantes, mas com menor intensidade que nos períodos anteriores. Desta forma, o perfil da população foi sendo progressivamente alterado, havendo um processo de envelhecimento mais claro no interior do Distrito Federal e a existência de uma população mais jovem nos municípios do Entorno. Vasconcelos e Gomes (2015) apontam para uma tendência mais clara de envelhecimento em Brasília, porém em ritmo ainda menor que no restante do país. As mesmas autoras apontam ainda que as regiões mais pobres estão ainda em fases anteriores da transição demográfica, ao passo que a área central, o Plano Piloto, demonstra padrão típico de países já envelhecidos.

A distribuição da população na Ride-DF tem mantido a tendência de concentração no Distrito Federal, ainda que, haja uma tendência de decréscimo nesta concentração, conforme se pode observar na Tabela 8.1. Nos municípios da periferia goiana do Distrito Federal é onde tem ocorrido maior crescimento da população, especialmente em Valparaíso (40,19\%, entre 2000 e 2010) e Cidade Ocidental (38,48\%, entre 2000 e 2010), muito provavelmente motivadas por migrações internas da região: mantem-se a tendência de busca de moradia mais barata, por parte da população do Distrito Federal, nos municípios do Entorno. O mesmo processo explica o rápido crescimento do município de Águas Lindas de Goiás. É notável, ainda, o crescimento acentuado em Vila Boa entre 2000 e 2010, sendo de 44,05\%. Um outro fator a ser analisado refere-se à concentração de população no centro principal, Brasília, possuindo, em 2010, 69,01\% da população da Ride-DF. Em seguida aparecem Luziânia (4,69\%), Águas Lindas de Goiás (4,28\%) e Valparaíso de Goiás (3,57\%), o que evidencia a maior concentração de população no espaço metropolizado da Ride-DF.

\footnotetext{
${ }^{18}$ A subseção 9.2.2, na qual se discutem os resultados da aplicação do modelo de análise para as desigualdades regionais na Ride-DF trará dados sobre este tema.
} 
Tabela 8.1 - População total (2000 e 2010), variação percentual e percentual da população da Ride-DF por município em 2010.

\begin{tabular}{|c|c|c|c|c|}
\hline Município & $\begin{array}{l}\text { População } \\
\text { total (2000) }\end{array}$ & $\begin{array}{l}\text { População } \\
\text { total (2010) }\end{array}$ & $\begin{array}{l}\text { Variação } \\
(\mathrm{em} \%)\end{array}$ & $\begin{array}{l}\text { Percentual } \\
\text { da } \\
\text { População, } \\
\text { da Ride- } \\
\text { DF (2010) }\end{array}$ \\
\hline Abadiânia (GO) & 11.452 & 15.757 & 37,59 & 0,42 \\
\hline Água Fria de Goiás (GO) & 4.469 & 5.090 & 13,90 & 0,14 \\
\hline Águas Lindas de Goiás (GO) & 105.746 & 159.378 & 50,72 & 4,28 \\
\hline Alexânia (GO) & 20.047 & 23.814 & 18,79 & 0,64 \\
\hline Cabeceiras (GO) & 6.758 & 7.354 & 8,82 & 0,20 \\
\hline Cidade Ocidental (GO) & 40.377 & 55.915 & 38,48 & 1,50 \\
\hline Cocalzinho de Goiás (GO) & 14.626 & 17.407 & 19,01 & 0,47 \\
\hline Corumbá de Goiás (GO) & 9.679 & 10.361 & 7,05 & 0,28 \\
\hline Cristalina (GO) & 34.116 & 46.580 & 36,53 & 1,25 \\
\hline Formosa (GO) & 78.651 & 100.085 & 27,25 & 2,69 \\
\hline Luziânia (GO) & 141.082 & 174.531 & 23,71 & 4,69 \\
\hline Mimoso de Goiás (GO) & 2.801 & 2.685 & $-4,14$ & 0,07 \\
\hline Novo Gama (GO) & 74.380 & 95.018 & 27,75 & 2,55 \\
\hline Padre Bernardo (GO) & 21.514 & 27.671 & 28,62 & 0,74 \\
\hline Pirenópolis (GO) & 21.245 & 23.006 & 8,29 & 0,62 \\
\hline Planaltina (GO) & 73.718 & 81.649 & 10,76 & 2,19 \\
\hline St. Antônio do Descoberto (GO) & 51.897 & 63.248 & 21,87 & 1,70 \\
\hline Valparaíso de Goiás (GO) & 94.856 & 132.982 & 40,19 & 3,57 \\
\hline Vila Boa (GO) & 3.287 & 4.735 & 44,05 & 0,13 \\
\hline Buritis (MG) & 20.396 & 22.737 & 11,48 & 0,61 \\
\hline Cabeceira Grande (MG) & 5.920 & 6.453 & 9,00 & 0,17 \\
\hline Unaí (MG) & 70.033 & 77.565 & 10,75 & 2,08 \\
\hline Brasília (DF) & 2.051 .146 & 2.570 .160 & 25,30 & 69,01 \\
\hline Ride-DF & 2.958.196 & 3.724 .181 & 25,89 & 100,00 \\
\hline
\end{tabular}

Fonte: IBGE

Sobre algumas medidas de qualidade de vida associada a tendências demográficas, de acordo com algumas informações do Atlas do Desenvolvimento Humano (Tabela 8.2), tem ocorrido uma expansão do envelhecimento da população também nos municípios do Entorno, seguindo tendência mais caracterizada no Distrito Federal. Pela análise dos dados da tabela, nota-se um padrão mais regular deste dado em 2010 nos municípios da Ride-DF, sendo possível perceber, ao mesmo tempo, um avanço significativo em diversos municípios, tendo variações (entre 2000 e 2010) mais elevadas as registradas em Cabeceiras (10,51\%), Novo Gama $(10,12 \%)$ e Abadiânia $(9,66 \%)$. 
Tabela 8.2 - Esperança de vida da população dos municípios da Ride-DF, em 1991, 2000 e 2010.

\begin{tabular}{l|c|c|r}
\hline Município & 2000 & 2010 & \multicolumn{2}{l}{ Variação, em } \\
$\%$
\end{tabular}

Fonte: Atlas do Desenvolvimento Humano do Brasil

Sobre a taxa de fecundidade (Tabela 8.3), esta revela tendências de decréscimo nos municípios do Entorno em um padrão que vai se tornando mais convergente com aquele de Brasília (sendo que em Abadiânia a fecundidade já e menor, em 2010, sendo de 1,66 filhos por mulher). A análise da variação entre os anos de 2000 e 2010 revelam ter ocorrido maior variação negativa em Abadiânia (-40,07\%), Águas Lindas de Goiás (-34,68\%) e Cristalina (-32,62\%). A variação no centro principal, Brasília, foi de $-10,71 \%$, porém a fecundidade, já em 2000 era reduzida, especialmente na comparação com os outros municípios da Ride-DF. 
Tabela 8.3 - Taxa de fecundidade da população dos municípios da Ride-DF, nos anos de 1991, 2000 e 2010

\begin{tabular}{lrr|r}
\hline Município & 2000 & 2010 & Variação, em \% \\
\hline Abadiânia (GO) & 2,77 & 1,66 & $-40,07$ \\
Água Fria de Goiás (GO) & 3,38 & 2,31 & $-31,66$ \\
Águas Lindas de Goiás (GO) & 3,72 & 2,43 & $-34,68$ \\
Alexânia (GO) & 2,91 & 2,36 & $-18,90$ \\
Cabeceiras (GO) & 3,30 & 2,35 & $-28,79$ \\
Cidade Ocidental (GO) & 2,63 & 1,86 & $-29,28$ \\
Cocalzinho de Goiás (GO) & 2,76 & 2,08 & $-24,64$ \\
Corumbá de Goiás (GO) & 2,77 & 1,98 & $-28,52$ \\
Cristalina (GO) & 2,82 & 1,90 & $-32,62$ \\
Formosa (GO) & 2,70 & 2,04 & $-24,44$ \\
Luziânia (GO) & 2,82 & 1,96 & $-30,50$ \\
Mimoso de Goiás (GO) & 3,38 & 2,80 & $-17,16$ \\
Novo Gama (GO) & 2,84 & 2,14 & $-24,65$ \\
Padre Bernardo (GO) & 3,46 & 2,35 & $-32,08$ \\
Pirenópolis (GO) & 3,15 & 2,29 & $-27,30$ \\
Planaltina (GO) & 3,42 & 2,47 & $-27,78$ \\
Santo Antônio do Descoberto (GO) & 2,90 & 2,21 & $-23,79$ \\
Valparaíso de Goiás (GO) & 2,47 & 1,79 & $-27,53$ \\
Vila Boa (GO) & 3,59 & 2,64 & $-26,46$ \\
Buritis (MG) & 3,21 & 2,54 & $-20,87$ \\
Cabeceira Grande (MG) & 3,29 & 2,72 & $-17,33$ \\
Unaí (MG) & 2,47 & 2,06 & $-16,60$ \\
Brasília (DF) & 1,96 & 1,75 & $-10,71$ \\
\hline Fonte: Atlas &
\end{tabular}

Fonte: Atlas do Desenvolvimento Humano do Brasil

\subsection{Ações de gestão do território}

No período em análise, as ações de gestão do território demonstram alguns momentos diferentes de atuação do Estado: no começo, uma tendência de pouca importância às políticas regionais e maior ênfase à elaboração de instrumentos de gestão do solo urbano. Num segundo momento, quando a política regional inicia sua reabilitação como política pública em âmbito federal, a Ride-DF é formalizada. Por outro lado, a atuação neste espaço tem ocorrido a partir de outras políticas, como a agrícola e a de transportes, com reduzida coordenação entre tais áreas. 


\subsubsection{Política regional}

Conforme visto no Capítulo 5, o período marca uma parte do lapso de ausência de políticas regionais de importância e a retomada destas, a partir dos Eixos Nacionais de Integração e Desenvolvimento. Em 1999 é recriado um ministério específico para o tema do desenvolvimento regional e para as políticas regionais, o Ministério da Integração Nacional. Como se viu, houve uma retomada também do ponto de vista institucional, que culminou na recriação da Sudeco, comentada à frente.

Outro marco deste movimento de retomada será a institucionalização da Política Nacional de Desenvolvimento Regional (PNDR) (BRASIL, 2007). Silva (2008) considera que tal política buscou uma maior convergência dos padrões de desenvolvimento das mesorregiões, sendo um diferencial em relação aos Eixos de Integração, que eram voltados à integração logística voltada à exportação. É importante ainda mencionar que tal instrumento foi importante à gestão da Ride-DF justamente por coloca-la no rol de espaços considerados prioritários, possibilitando condições mais favoráveis ao recebimento, por exemplo, de recursos dos fundos regionais.

Numa retomada da perspectiva de planejamento regional para o Centro-Oeste, e ainda no âmbito da Secretaria de Desenvolvimento do Centro-Oeste (SCO/MI) foi lançado, em 2007, o Plano Estratégico de Desenvolvimento do Centro-Oeste (PEDCO), com vigência entre 2007 e 2020 (MINISTÉRIO DA INTEGRAÇÃO NACIONAL, 2007). O Plano faz a leitura da necessidade de impulsionar uma nova onda de desenvolvimento na região Centro-Oeste, que combine o processo mais recente de desenvolvimento econômico com melhoras na qualidade de vida da população. Parte-se da perspectiva do desenvolvimento econômico criado pela economia da moderna agropecuária, que não foi capaz ainda de se traduzir em melhorias na qualidade de vida da população centro-oestina. A partir daí são traçados macro objetivos e vetores estratégicos de atuação, que buscam solucionar os gargalos da região. Em nenhum destes há a previsão de ações específicas para a Ride-DF, apesar de a PNDR considerar tal espaço como sendo prioritário.

No âmbito da reelaboração das políticas regionais em escala nacional e macrorregional, e como diretriz e objetivos de ambas, foi recriada a Sudeco, criada por meio da Lei Complementar $n^{\circ}$ 129, de 8 de janeiro de 2009 (BRASIL, 2009). Órgão vinculado ao Ministério da Integração Nacional, foi recriado na esteira do preconizado pela PNDR, como instrumento necessário à atuação na região, uma vez que a antiga $\mathrm{SCO} / \mathrm{MI}$ possuía restrições de atuação e competências, frente a uma autarquia especial. $\mathrm{O}$ art. $3^{\circ}$ desta legislação aponta 
que a Sudeco tem por finalidade "promover o desenvolvimento regional, de forma includente e sustentável, e a integração competitiva da base produtiva regional na economia nacional e internacional". Ao abordar a composição da Sudeco, o Conselho Administrativo da Região Integrada de Desenvolvimento do Distrito Federal e Entorno (Coaride) é posto como um de seus órgãos colegiados. Como instrumentos de atuação, são apontados o Plano Regional de Desenvolvimento do Centro-Oeste (PRDCO), o Fundo Constitucional de Financiamento do Centro-Oeste (FCO), o Fundo de Desenvolvimento do Centro-Oeste (FDCO), programas de inventivos e benefícios fiscais e outros instrumentos (art. $6^{\circ}$ ).

O FCO possui embasamento legal de existência na própria Constituição Federal. Foi regulamentado, de forma específica, pela Lei $\mathrm{n}^{\mathrm{o}} 7.827$, de 27 de setembro de 1989 (BRASIL, 1989). Além do FCO, esta lei também criou fundos específicos para as regiões Nordeste e Amazônia. Estes têm como objetivo "contribuir para o desenvolvimento econômico e social" das respectivas regiões em que atuam, a partir da "execução de programas de financiamento ao setor produtivo" (art. $2^{\circ}$ ). A gestão dos recursos do FCO é realizada pela Sudeco em parceria com outras duas instituições: o Ministério da Integração Nacional e o Banco do Brasil S.A (esta instituição trabalha, ainda, com as operações ${ }^{19}$ específicas do fundo). Sua atuação abarca tanto pequenos (atinge mesmo empreendedores individuais, atualmente) quanto grandes tomadores de recursos, e suas linhas estão agrupadas em dois grupos principais: o FCO empresarial e o FCO rural.

Já o FDCO, criado no mesmo diploma legal que a Sudeco, tem como finalidade, segundo o art. 16: "assegurar recursos para a implantação de projetos de desenvolvimento e a realização de investimentos em infraestrutura, ações e serviços públicos considerados prioritários no Plano Regional de Desenvolvimento do Centro-Oeste". A própria descrição do fundo já aponta algumas diferenças em relação ao FCO, sendo o FDCO destinado ao financiamento de obras e projetos de maior vulto e com caráter estruturante na região. Além disso, a operação de seus recursos é feita por outros Bancos oficiais, como a Caixa Econômica Federal. O processo de aprovação dos recursos envolve maior participação da Sudeco na aprovação dos projetos, especialmente no que tange ao potencial de desenvolvimento regional previsto. É importante ressaltar que tanto FCO como FDCO são voltados ao fomento ao setor produtivo, não podendo ter recursos tomados por entes públicos.

\footnotetext{
${ }^{19}$ Outras instituições financeiras podem operar recursos do FCO, desde que conveniadas com o Banco do Brasil. É o caso, na Ride-DF, do Banco de Brasília S.A (BRB), que possui agências em municípios vizinhos ao Distrito Federal.
} 
Com a recriação da Sudeco, a gestão e coordenação das políticas da Ride-DF ficou sob responsabilidade desta Superintendência. Entretanto, antes de abordar as ações mais recentes em torno desta região, é necessário resgatar o processo histórico de sua institucionalização, bem como as outras ações de gestão aí já tidas.

Como já exposto no capítulo anterior, a perspectiva de uma região do "Entorno" de Brasília é algo já tratado desde a década de 1970, por meio do Pergeb. Ao criar, em 1977, uma nova estratégia de gestão, por meio de três escalas, determinou a criação de uma "escala de transição" entre o Distrito Federal ("escala local”) e a escala regional. Esta escala seria transformada, em 1981, no chamado Entorno do Distrito Federal ${ }^{20}$. Este era composto pelos seguintes municípios: Luziânia, Planaltina, Padre Bernardo, Formosa, Unaí, Cristalina, Corumbá de Goiás, Alexânia, Abadiânia e Cabeceiras (CODEPLAN, 1997).

$\mathrm{Na}$ década de 1990, o tema ganhou nova força com a retomada das políticas regionais. Em paralelo, a partir da caracterização de Brasília como uma metrópole ${ }^{21}$, passou-se a pensar na possibilidade da instituição de região específica para esta finalidade. Próxima à institucionalização da Ride-DF, a Codeplan (1997), posicionou-se a favor da instituição de um "espaço metropolitano" menor que o rol de municípios acima listados, que incluiria os seguintes: Luziânia, Cidade Ocidental, Valparaíso de Goiás, Novo Gama, Santo Antônio do Descoberto, Águas Lindas de Goiás e Planaltina (com a possibilidade de inclusão de Formosa, Padre Bernardo e Alexânia). O referido estudo apontava Brasília como tendo uma articulação metropolitana com estes municípios, e regional para com os outros (que, inclusive, ultrapassavam o limite daqueles acima mencionados no Entorno de Brasília). Entretanto, o principal entrave para a formalização de uma Região Metropolitana de Brasília foi a falta de previsão legal, já que a Constituição Federal de 1988, no $\S 3^{\circ}$ de seu art. 25 determina que a criação de regiões metropolitanas deve ser feita por meio de Lei Complementar Estadual, além de não prever a possibilidade de criação de Regiões Metropolitanas Interfederativas (esta lacuna foi recentemente preenchida a partir do Estatuto da Metrópole, cujos efeitos serão comentados à frente).

\footnotetext{
${ }^{20}$ O IBGE iria estabelecer uma microrregião com o nome de Entorno do Distrito Federal em 1990.

${ }^{21}$ Tal caracterização, como já brevemente abordado no capítulo anterior, era bastante aceita na literatura sobre o período, no qual se destacam os trabalhos de Paviani $(1985$; 1988). Por outro lado, a Regic do IBGE de 2000 (cuja coleta de dados deu-se em 1993) reconhecia Brasília como tendo um nível de centralidade "muito forte", o que a caracterizaria como sendo um padrão de cidade "predominantemente submetropolitano". Entretanto, por suas características específicas, foi tratada naquele estudo como sendo uma das "cabeças-de-rede" da rede urbana nacional. Mais recentemente, na Regic de 2007, Brasília é classificada como metrópole de porte nacional, ao lado do Rio de Janeiro.
} 
A partir de tal discussão, houve, em 1998, a institucionalização da Ride-DF², por meio da Lei Complementar nº 94, de 19 de fevereiro de 1998 (BRASIL, 1998a). Este diploma legal, de reduzido tamanho, define, em seu art. $1^{\circ}$, que a Ride-DF deveria ser criada "para efeitos de articulação da ação administrativa da União, dos Estados de Goiás e Minas Gerais e do Distrito Federal”. O $\S 1^{\circ}$ apresenta a relação dos municípios constituintes da Ride-DF sendo eles: "Distrito Federal, pelos Municípios de Abadiânia, Água Fria de Goiás, Águas Lindas, Alexânia, Cabeceiras, Cidade Ocidental, Cocalzinho de Goiás, Corumbá de Goiás, Cristalina, Formosa, Luziânia, Mimoso de Goiás, Novo Gama, Padre Bernardo, Pirenópolis, Planaltina, Santo Antônio do Descoberto, Valparaíso e Vila Boa, no Estado de Goiás, e de Unaí e Buritis, no Estado de Minas Gerais. ${ }^{23}$ Estes podem ser visualizados no mapa da Figura 8.1.

Além da delimitação dos municípios, a legislação autoriza a criação de um Conselho Administrativo para a Ride-DF, a ser delimitado por regulamento próprio. A lei determina ainda os interesses da Ride-DF, que seriam os serviços públicos considerados comuns (estes somente seriam posteriormente definidos em regulamento próprio). É ainda autorizada a elaboração de um Programa Especial para o Desenvolvimento do Entorno do Distrito Federal (Proride) e abordada ainda a questão da unificação das tarifas e de procedimentos nas fronteiras entre as unidades da federação. Por fim, são abordadas as formas de financiamento das ações consideradas prioritárias: recursos de natureza orçamentária (orçamento da União, dos Estados, do Distrito Federal e dos municípios) e operações de crédito externas e internas.

\footnotetext{
${ }^{22}$ A legislação referente à Ride-DF encontra-se, na íntegra, no Anexo B deste trabalho.

${ }^{23}$ Um tema frequentemente controverso diz respeito à inclusão do município de Cabeceira Grande-MG, na RideDF, dado o entendimento de que ele seria contemplado a partir de seu fracionamento de Unaí-MG. Ocorre que tal processo precedeu a instituição da Ride-DF, fazendo com que, juridicamente, Cabeceira Grande não pertença a esta região. Dada a evidente descontinuidade observada nos mapas, considera-se, para efeitos deste trabalho, este município como sendo da Ride-DF. Vale ainda lembrar que há projetos de lei no Congresso Nacional sobre a inclusão de municípios na Ride-DF, sendo que, em sua maioria, há a previsão da correção deste "defeito" legal.
} 
MUNICIPIOS PERTENCENTES A REGIZ̃O INTEGRADA DE DESENVOLVIMENTO DO DISTRITO FEDERAL E ENTORNO - RIDE

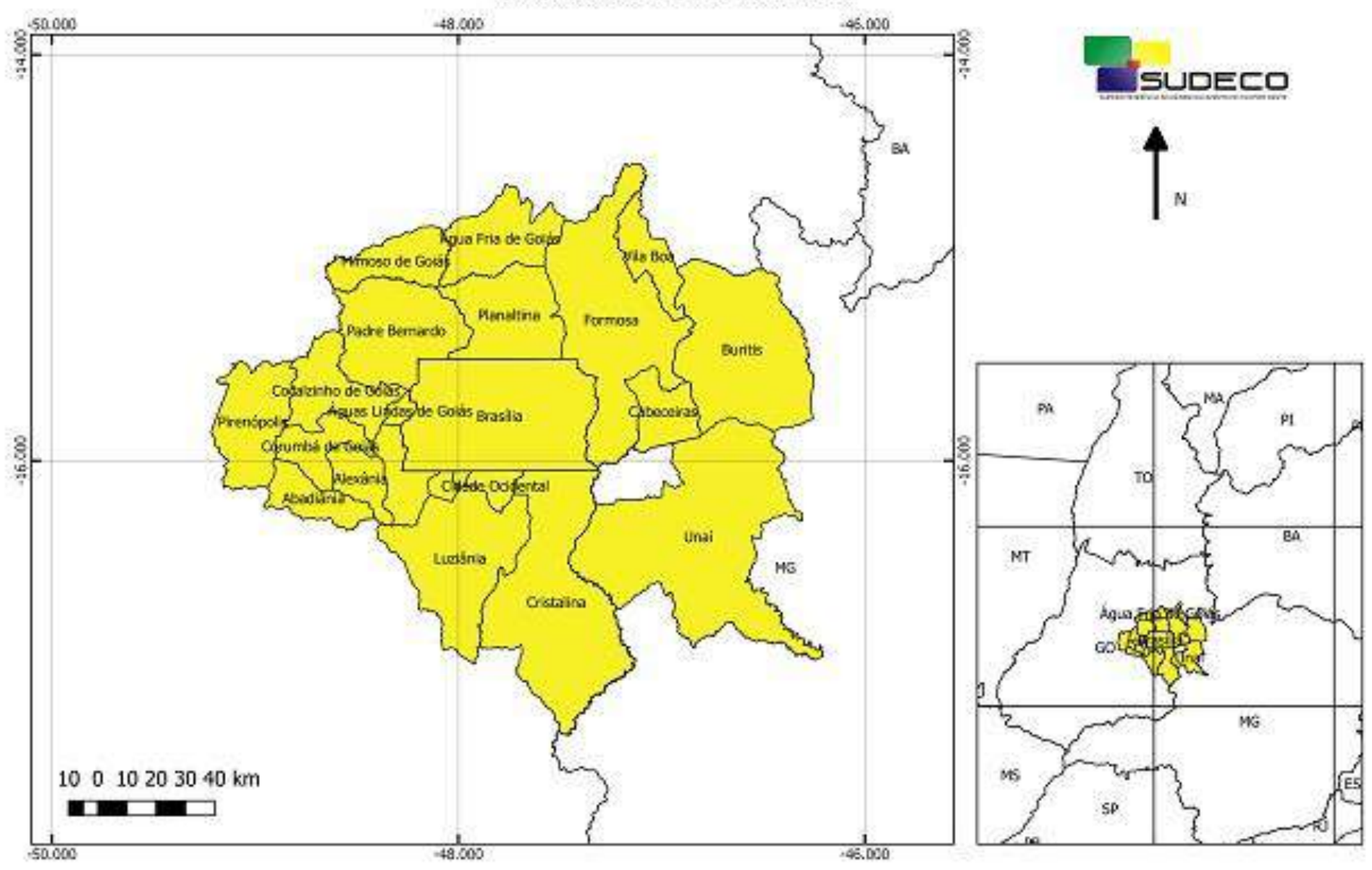


A administração deste ente, em nível federal, deu-se a partir do Coaride, cuja primeira normatização deu-se por meio do Decreto $n^{\circ}$ 2.710, de 4 de agosto de 1998 (BRASIL, 1998b). A regulamentação mais recente foi dada pelo Decreto ${ }^{0} 7.469$, de 4 de maio de 2011 (BRASIL, 2011). As competências do Conselho, definida no art. $3^{\circ}$ deste Decreto, apontam (entre outras) para atividades de coordenação da atuação dos agentes, aprovação de planos e programas e busca de integração dos serviços públicos comuns. Visualiza-se, assim, poucas competências executivas para o Conselho. Quanto à sua composição, esta privilegia, a participação de representantes de pastas do Governo Federal ( 9 membros), com reduzida participação dos Estados, Distrito Federal e Municípios (um membro para cada Unidade da Federação e um para as prefeituras).

Do ponto de vista do planejamento específico para a região, foi elaborado, no ano de 2002 (pela extinta SCO/ MI), o Proride. Tal programa realizava uma leitura do espaço da Ride-DF a partir de anéis concêntricos de integração dos diversos municípios, buscando diferenciá-los a partir do nível de integração com Brasília e com o processo de expansão urbana então em curso. Sugeria, por outro lado, a implementação de diversos projetos, muitos dos quais deveriam ser implementados em conjunto pelos entes federados que participam da Ride-DF. Possuía um foco de atuação voltado para diversos dos temas metropolitanos, especialmente a partilha de serviços públicos comuns.

É ainda importante mencionar que no referido período não houve a aprovação ou renovação de instrumentos mais abrangentes de planejamento para a região, como buscou ser o Proride, elaborado em 2002.

Além destas iniciativas de escala federal, é importante analisar as iniciativas do Estado de Goiás foram verificadas a partir do previsto em seus últimos PPAs. No PPA 20042007 foi previsto o Programa de Desenvolvimento Sustentável do Entorno do Distrito Federal, que teve como objetivo "possibilitar ao Governo do Estado de Goiás conduzir o crescimento harmônico e equilibrado da região com qualidade de vida para todos, articulando parcerias com a União e o Distrito Federal com o objetivo de ampliar investimentos nos municípios do entorno de Brasília". Sua atuação deu-se, principalmente, por meio de obras de pavimentação e de infraestrutura urbana, da reestruturação do transporte público no Entorno, do desenvolvimento institucional e do ordenamento territorial destes municípios (GOIÁS, 2004). No PPA seguinte, entre 2008 e 2011, o mesmo Programa é mantido, com ações muito próximas do da versão anterior. Nesta edição, os objetivos e ações foram praticamente mantidas, havendo incremento mais expressivo em seus valores (GOIÁS, 2008). O PPA 2012-2015 propõe alterações já no nome do programa, passando a chamar-se "Programa de Desenvolvimento Integrado do 
Entorno do Distrito Federal". Teve como objetivo "Corrigir as distorções e os desequilíbrios da região do Entorno do DF, integrando-a às demais regiões do Estado, impulsionando o setor produtivo através do aproveitamento das potencialidades existentes visando a geração de trabalho, renda e a melhoria da qualidade de vida da população" (GOIÁS, 2012, p. 211). No caso deste último programa, é possível perceber uma maior articulação com ações específicas sobre a saúde, educação e segurança pública, em um contexto mais abrangente do desenvolvimento da região.

A partir deste quadro de ações e de instituições em ação, passa-se à análise das ações efetivas. Inicialmente, ainda que não seja o foco do estudo, faz-se necessária uma avaliação do FCO e dos outros instrumentos de promoção do desenvolvimento regional e seus rebatimentos na região. É obviamente necessário reconhecer a retomada do tema em âmbito federal, tendo em vista sua ausência por mais de uma década. Além disso, percebe-se uma clara evolução da política dos Eixos Nacionais de Integração Nacional, focados nos corredores de exportação de commodities, para uma política que busca maior convergência regional. Entretanto, por outro lado, é forçoso reconhecer que os instrumentos financeiros tem sido a principal forma de atuação na região Centro-Oeste, e que, no caso destes, tem ocorrido algo próximo do já visto pelo Polocentro: há uma captura de seus recursos por parte de setores mais organizados do agronegócio. Ainda que possua linhas específicas e condições mais vantajosas de contratação nos espaços considerados prioritários e nas regiões de economia estagnada, isto ainda não tem sido o suficiente para a redução das desigualdades regionais, nem para uma captação mais significativa nestas mesorregiões, já que outros fatores (entre eles a própria ausência de agência bancária em alguns municípios) levam a que não se contrate como esperado. Além disso, a divisão dos recursos do FCO é realizada anualmente pelo Conselho Deliberativo do Desenvolvimento do Centro-Oeste ${ }^{24}$ (Condel/ Sudeco), sendo realizada pelos três Estados e o Distrito Federal. Seria fundamental que o modelo de divisão dos recursos considerasse as microrregiões como unidades básicas para isto. Há, ainda, algumas críticas recorrentes: o FCO tem pouca ligação com a perspectiva de desenvolvimento contida no PEDCO; a aplicação dos recursos do fundo é feita a partir de lógica mais bancária (ou seja, que

\footnotetext{
${ }^{24}$ De acordo com a Lei Complementar $n^{\circ} 129$, de 8 de janeiro de 2009, o Condel/Sudeco é composto: pelos governadores dos Estados de Mato Grosso, Mato Grosso do Sul e Goiás e do Distrito Federal; pelos Ministros da Fazenda, da Integração Nacional e do Planejamento; por representantes dos Municípios de sua área de atuação; por representantes da classe empresarial, da classe dos trabalhadores e de organizações não-governamentais com atuação na Região Centro-Oeste; pelo Superintendente da Sudeco; pelo presidente da instituição financeira federal administradora do FCO (atualmente o Banco do Brasil S.A).
} 
visa maximizar as contratações sem considerar, como se deve, o peso regional da distribuição dos recursos).

Dados estes problemas e mudança de enfoque da política regional, assim como Silva (2008) vê-se que há uma ênfase na atuação do governo federal (e mesmo dos estaduais envolvidos) na atuação sobre tal política a partir da subvenção, via fundos específicos, ao setor privado. Especialmente depois de 2003 o Estado retomou a construção de importantes obras de infraestrutura, porém elas pouco têm se articulado (com algumas exceções, sendo talvez a mais notável, em âmbito geral, o da BR 163) com outras políticas: de desenvolvimento urbano, ambiental e regional. Isto tem desorganizado as economias de alguns municípios, além de favorecer sua captura como economias voltadas à exportação, dado o estímulo exacerbado ao grande agronegócio sem qualquer contrapartida do próprio Estado para, ao menos, mitigar os efeitos deletérios na escala local.

Especificamente sobre as ações de integração na região em estudo, estas ganharam, do ponto de vista da formulação de políticas públicas específicas, com a formalização de uma região "oficial” de Brasília. A formalização da Ride-DF pode possibilitar a integração e planejamento conjunto de políticas visando o ordenamento do território e o desenvolvimento socioeconômico, especialmente para os municípios do Entorno. Há aqui uma redefinição, ao menos do ponto de vista oficial, da escala efetivamente regional de Brasília, com a definição do rol de municípios inseridos na Ride-DF (obviamente que a escala de influência, mesmo regional, é maior ${ }^{25}$ ). Pode-se considerar que o Estado buscou, assim, "oficializar" a região de Brasília, dando prioridade para a antiga escala intermediária do Pergeb. Por conta disto, muitos estudos têm tratado a Ride-DF como sendo o efetivo espaço metropolitano de Brasília, tese em discordância com o que aqui se propõe. Há um processo de metropolização interno à Ride-DF, que não é o único processo aí em curso, já que permanecem relações de integração regional entre Brasília e os outros municípios. Essa "confusão", muito comum em alguns estudos acadêmicos, leva também a que a compreensão e atuação dos órgãos responsáveis seja dificultada: a Ride-DF, em nível federal, é administrada por um órgão com mandato específico para desenvolvimento regional; por outro lado, ela possui uma série de problemas tipicamente metropolitanos; na impossibilidade de aplicar seus instrumentos na resolução destas questões, como a Sudeco pode efetivamente agir?

\footnotetext{
${ }^{25}$ A atual Regic do IBGE aponta como área sob influência direta de Brasília uma porção do território que se estende pelo restante do norte de Goiás, oeste da Bahia e sudeste de Tocantins.
} 
Além desta avaliação inicial, há a contribuição de Azevedo e Alves (2010), especificamente sobre as outras Ride's existentes no Brasil e, mais dedicadamente, à Ride-DF. Sobre esta, as autoras apontam, como problemas: a assimetria econômica entre o município polo e os outros da região; a baixa disponibilidade de recursos para a gestão de ações na região; a forte federalização do Coaride. Sampaio et al (2013) apresentam uma avaliação onde encontram alguns dos mesmos problemas verificados antes da criação deste órgão: baixa capacidade de articulação e de implantação de políticas; ausência de instrumentos de planejamento.

Sobre a atuação federal na Ride-DF, Sampaio et al (2013) observam que tem ocorrido ações não apenas do Ministério da Integração Nacional e de suas vinculadas: o Ministério das Cidades tem atuado no que tange à infraestrutura urbana e o Ministério da Justiça por meio do Programa de Cidadania e Justiça. Há ainda outras ações setoriais e pontuais por parte da cooperação dos governos de Goiás e Distrito Federal. Sobre a governança na região, Bezerra e Scardua (2015) avaliam que o Coaride está, no momento, em frágil posição institucional, mesmo abrigado na Sudeco. A atuação deste Conselho tem se dado por demanda e, esporadicamente, por meio de Grupos de Trabalho. Além disto, a região tem sido alvo de pouca atenção nos últimos PPAs do governo federal, sendo que, quando há alguma menção, é mais abordada a questão da infraestrutura. Os autores identificam ainda a falta de um programa ou projeto de desenvolvimento para a região. A atuação tem se dado a partir de iniciativas setorialistas e pouco integradas pelos diversos agentes. Avaliam eles ainda que há uma densidade de atores com ações e aplicação de recursos na região, porém sem poder de decisão, especialmente sem assento no Coaride. Por outro lado, algumas das instituições com presença neste Conselho não tem ações ou aplicação de seus recursos na região.

De fato, a situação da gestão da Ride-DF no momento, como região de planejamento para promoção de desenvolvimento e de implantação de política públicas encontra-se fragilizada, dada a atual desarticulação do Coaride, mesmo com a existência da Sudeco (não houve reuniões do Conselho no ano de 2015 e nenhuma até o momento em 2016). O que se percebe é uma perda progressiva do interesse na gestão efetiva da região, dado o histórico de baixa efetividade das articulações e o cenário atual de restrição fiscal do Governo Federal. Por outro lado, a ausência de um instrumento de planejamento ou uma agenda de desenvolvimento dificultam a devida articulação da atuação dos muitos entes e agentes na região. 


\subsubsection{Política urbana (e o esboço de uma política metropolitana)}

Inicialmente, sobre o tema da política urbana, vê-se que os municípios da Ride-DF passaram também a produzir os instrumentos de planejamento e ordenamento de seu território, notadamente os Planos Diretores. Estes buscam cumprir, de forma efetiva, o mandamento legal de sua elaboração. É notável, por outro lado, que muitos deles mantem uma estrutura e mesmo texto similar uns dos outros, o que sugere um trabalho de menor reflexão e discussão com a comunidade sobre sua elaboração. Outro tema que poderia ser abordado de forma subsidiária (já que o Plano Diretor não é o instrumento mais indicado para isto) é o tema da integração regional, especialmente a partir da partilha de serviços públicos comuns. Tal tema chega mesmo a ser abordado, de forma em geral genérica. Os setores onde se indicam iniciativas mais contundentes são para a gestão de resíduos sólidos (Planos Diretores de Alexânia, Corumbá de Goiás, Luziânia, Mimoso de Goiás e Valparaíso), recursos hídricos (Luziânia e Cidade Ocidental). Em alguns planos é previsto o consorciamento para atuação em setores como saneamento básico (ALEXÂNIA, 2006; COCALZINHO DE GOIÁS, 2006; CORUMBÁ DE GOIÁS, 2004; PREFEITURA DE CRISTALINA, 2011; PREFEITURA DE CIDADE OCIDENTAL, 2006; PREFEITURA DE SANTO ANTÔNIO DO DESCOBERTO, 2015; FORMOSA, 2004; LUZIÂNIA, 2006; MIMOSO DE GOIÁS, 2006; VALPARAÍSO DE GOIÁS, 2012). Há, por fim, o caso de Unaí, cujo plano pouco aborda possibilidades de integração com outros municípios da Ride-DF (UNAÍ, 2003).

No Distrito Federal, em termos de planejamento urbano, o primeiro documento de importância será o "Brasília Revisitada", de Lúcio Costa (1987). Neste documento, Costa anuncia algumas alterações no desenho do Plano Piloto, permitindo a criação de novos setores habitacionais em espaços próximos à via Estrada Parque Indústria e Abastecimento (EPIA). Já em 1992, visando atender ao mandamento constitucional, é aprovado o primeiro Plano Diretor de Ordenamento Territorial do Distrito Federal (PDOT 1992), por meio da Lei $n^{\circ} 353$. Este documento ratifica a ideia de polinucleamento interno ao DF, reconhecendo haver uma dupla centralidade, formada pelo Plano Piloto e por Taguatinga e Ceilândia. Como diretrizes, podem ser destacadas as seguintes: busca da redução das descontinuidades espaciais da ocupação urbana do solo, no eixo Brasília-Taguatinga-Gama; definição de um aglomerado urbano de características metropolitanas, constituindo-se um novo núcleo central complementar a Brasília; a integração com os municípios da Região Geoeconômica de Brasília. (IPEA, 2001; DISTRITO FEDERAL, 1992). Em 1997 é aprovado o segundo PDOT (Lei Complementar no 17, de 1997 - DISTRITO FEDERAL, 1997), que possuía, entre suas diretrizes básicas, o 
seguinte: a busca por um equilíbrio entre os dois polos, marcados pelas duas centralidades principais, estabelecendo-se um centro regional em Taguatinga, Ceilândia e Samambaia; ocupar e adensar as áreas já urbanizadas dentro do Distrito Federal. O Plano prescreve ainda a importância de uma maior integração com os municípios do Entorno, o que deveria ser feito, no âmbito econômico, a partir da ampliação do terciário modernizado. É importante ainda anotar que o Plano previa o estabelecimento do Programa Estratégico de Desenvolvimento Integrado do Entorno, comportando projetos em recursos hídricos, saneamento básico, transportes e outros.

Mais recentemente foi aprovado um novo PDOT, pela Lei Complementar $n^{\circ} 803$, de 2009 (DISTRITO FEDERAL, 2009). Este retoma o tema das centralidades, a partir da estratégia proposta da estruturação de polos multifuncionais, em diversas das cidades-satélites. Busca-se ainda a dinamização da economia das cidades-satélites, visando reduzir a dependência das centralidades já existentes. Além disso, o Plano prevê novamente a questão da integração com o Entorno, porém no campo das diretrizes, sem prescrever um instrumental efetivo para tanto. Na realidade, o Plano tem muitas de suas ações baseadas em diretrizes que visam orientar outros instrumentos da política urbana. No curto período em que foi implementado, ainda não são perceptíveis suas possíveis alterações, sendo exemplo disto a ideia dos polos multifuncionais e do surgimento de novas centralidades, algo que o planejamento se propõe a fazer, mas que parece ainda incapaz de realizar.

Ainda para este período, é fundamental considerar as ações de agentes privados, especialmente os do mercado imobiliário. Internamente ao Distrito Federal, este, formado por agentes de diferenciados portes, aparenta ter sido um dos agentes (se não o mais) fundamentais para compreender o processo de expansão dispersa da cidade. Isto porque, no período mais recente, as empresas de maior porte deste ramo têm agido fortemente no sentido de obter novos espaços para a expansão da cidade, produzindo um modelo cada vez mais verticalizado de ocupação. Exemplo disto será a produção do espaço de Águas Claras, onde a pressão do capital imobiliário permitiu mudanças no planejamento inicial e sua adaptação a seus interesses. Nos municípios da Ride-DF, notadamente nas cidades mais próximas do DF, o capital imobiliário tem agido no sentido de oferecer moradia a um custo menor justamente para aqueles que residem no Distrito Federal, mas não conseguem acessar tal bem. Nesta lógica, tem havido forte estímulo por parte do PMCMV, levando à incorporação de terrenos nos espaços metropolizados.

Para além destes temas específicos da política urbana, é necessário mencionar o esforço em se pensar (e em esboçar) uma política metropolitana para a Ride-DF. Do ponto de 
vista legal, uma porta foi fechada a partir do veto presidencial a um dos artigos do Estatuto da Metrópole (Lei $\mathrm{n}^{\mathrm{o}}$ 13.089, de 12 de janeiro de $2015^{26}$ - BRASIL, 2015). Entretanto, especialmente por esforços da Codeplan, houve a delimitação de um recorte de análise que vem sendo denominado de Área Metropolitana de Brasília (AMB), assinalada no mapa da Figura 8.2. A análise do mapa aponta que a AMB está contida na Ride-DF e, basicamente, não considera os municípios mais afastados e de integração regional como o espaço de influência de Brasília, buscando reter-se ao espaço efetivamente metropolizado (foram utilizadas, para tanto, dados sobre os fluxos e partilha de serviços com o Distrito Federal - Codeplan, 2014).

De forma específica, não há um conjunto numeroso de ações em caráter metropolitano, dada a não formalização legal desse recorte. Por outro lado, a Codeplan tem realizado importante esforço no sentido de compreender a dinâmica metropolitana, realizando, em parceria com os municípios da AMB, a Pesquisa Metropolitana por Amostra de Domicílios (PMAD).

Um outro fato que permite vislumbrar uma perspectiva de política metropolitana diz respeito à formalização e implementação do Consórcio Público de Manejo dos Resíduos Sólidos e de Águas Pluviais Região Integrada do Distrito Federal e Goiás (Corsap DF/GO), iniciativa inédita de consorciamento do Distrito Federal, do Estado de Goiás e dos municípios da Ride-DF (que aderiram ao Consórcio). Este tem suas ações focadas na gestão comum de elementos descritos na Política Nacional de Resíduos Sólidos. Tem ocorrido um extenso trabalho de articulação com as prefeituras participantes, no sentido de viabilizar a gestão compartilhada destes serviços.

\footnotetext{
${ }^{26}$ A Mensagem Presidencial $n^{\circ}$ 13, de 12 de janeiro de 2015, que contém os motivos dos vetos à referida Lei, aponta o seguinte para o veto mencionado: "Ao tratar de regiões metropolitanas, aglomerações urbanas e microrregiões, a Constituição faz referência, em seu art. 25, § 3o, a agrupamento de Municípios. Neste sentido, as inclusões no escopo do Estatuto da Metrópole de território de um único Município isolado e do Distrito Federal não encontrariam amparo constitucional. Em relação ao Distrito Federal, o instrumento de cooperação federativa adequado é a Região Integrada de Desenvolvimento Econômico - RIDE, prevista no art. 43 da Constituição. Esta já foi, inclusive, criada pelo Decreto no 2.710, de 4 de agosto de 1998 - substituído pelo Decreto no 7.469, de 4 de maio de 2011 - que regulamenta a Lei Complementar no 94, de 19 de fevereiro de 1998 ".
} 
Figura 8.2

Municípios da Ride-DF e da AMB

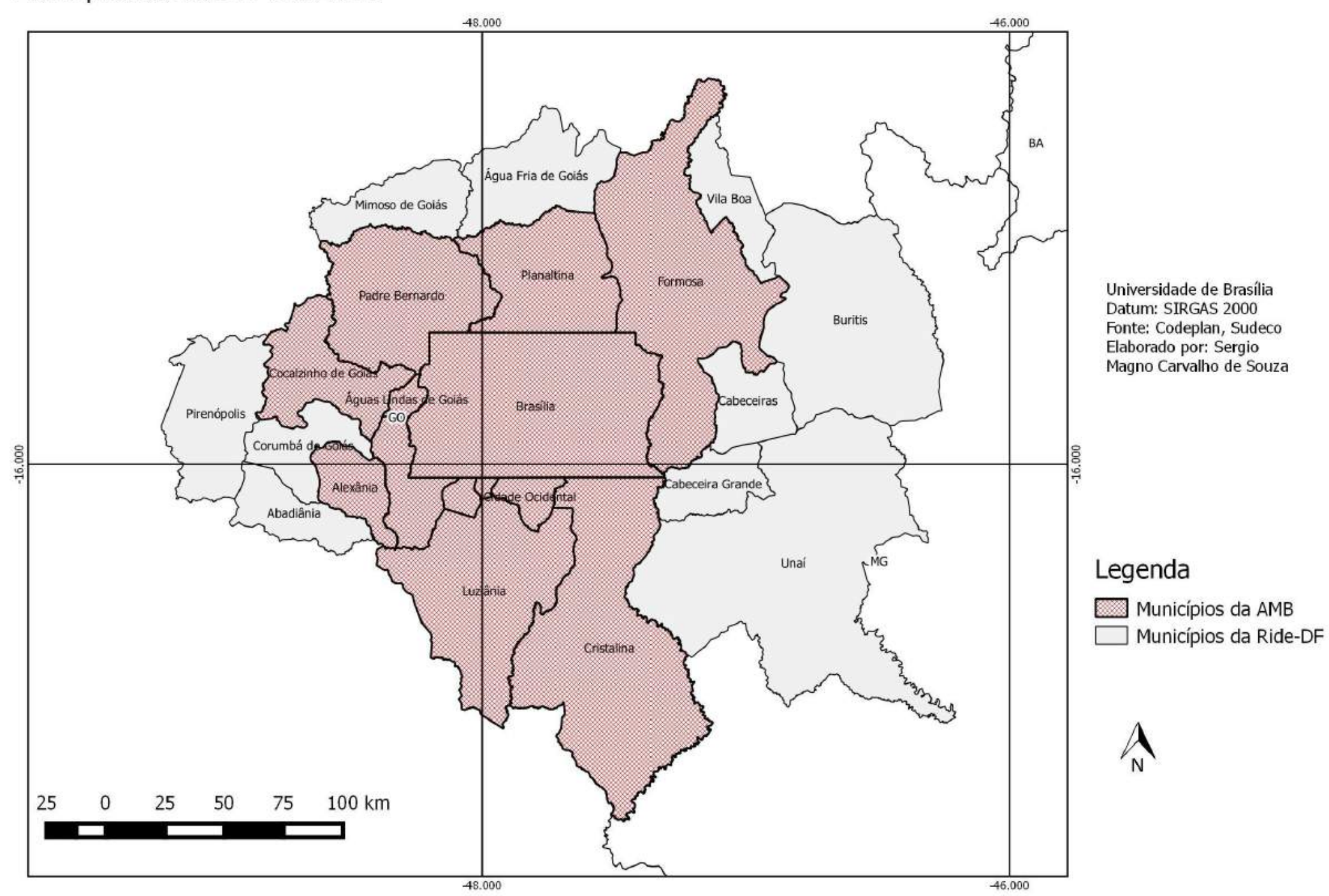


Sobre o planejamento e gestão urbanos nos municípios da Ride-DF, de forma efetiva, o que a análise das legislações permite inferir é uma busca pela aprovação do instrumento a partir de incentivos dos governos estadual e federal (o que levou, por exemplo, à aprovação de plano diretor mesmo em municípios isentos de tal obrigação por seu contingente demográfico). Alguns dos planos demonstram fortes similitudes uns com os outros, apontando para algo recorrente, especialmente após a aprovação do Estatuto das Cidades e da criação do Ministério das Cidades. Em partes isto é fruto do uso de consultorias na elaboração de tais instrumentos, sendo facultado ao município apenas a modificação em pontos de características próprias (há artigos idênticos e mesmas estruturas em diversos dos Planos Diretores). Outro ponto a se salientar diz respeito a uma visão de integração muito restrita aos serviços comuns, na melhor das hipóteses como orientação ao Poder Executivo para que o faça ou planeje. Como dito, não cabe a tais instrumentos planejar políticas de escopo regional; por outro lado, dado o caráter metropolitano/ regional de muitas das questões, seria de se esperar a orientação para uma busca de maior integração das atividades dos municípios. Por outro lado, processos que lhe são eventualmente comuns, como a expansão urbana ou mesmo o desenvolvimento econômico são tratados apenas internamente, sem qualquer perspectiva de atuação conjunta.

É necessário apontar também que muitos dos Planos Diretores destes municípios tem sido utilizado no sentido de atrair grandes empreendimentos, a partir da destinação de áreas especificas para isto (muitos buscam copiar o modelo de Anápolis e de seu Distrito Agroindustrial). Por outro lado, esta perspectiva de planejamento do uso e ocupação do solo e expansão urbana tem sofrido forte pressão do mercado imobiliário fomentado pelo PMCMV, tornando ainda mais complicada a tarefa de ordenar a ocupação do solo por prefeituras, em sua maioria, muito frágeis. Em geral, quando há pressão por parte do capital imobiliário são realizadas modificações nos Planos, visando atrair investimentos. Tal pressão ocorre tanto para a construção de condomínios verticais como horizontais.

Quanto o planejamento e gestão urbana no Distrito Federal, Vicente (2012) avalia, em relação ao primeiro PDOT, que sua elaboração foi fortemente influenciada pelo grupo por ele chamados de "desenvolvimentista" (atua no sentido de usar a terra urbana a partir das leis de mercado, com poucas restrições impostas pelo Estado). Avalia ainda que este PDOT representou a quebra do monopólio de terras por parte do Governo do Distrito Federal, algo que ele identifica a partir da atuação de grupos ligados ao então governador, Joaquim Roriz. Isto levou a um maior desenvolvimento do mercado imobiliário, colocando novas terras à disposição. Sobre o PDOT 1997, este autor o aponta como mais progressivo, pela influência dos grupos ambientalistas (atuam na busca do cumprimento da legislação ambiental, além do 
combate à expansão demasiada dos limites urbanos) e "modernistas" (defendem a manutenção do tombamento do Plano Piloto, com suas consequências para todo o território). Apesar disto, esta legislação voltou a ser "afrouxada", o que ficou claro pela retomada da prática da edição de legislação complementar ou ordinária destinada à modificação das leis de uso e ocupação do solo e mesmo do PDOT (esta prática já fora usada no primeiro PDOT). Sobre o último PDOT, de 2009, Vicente considera sua elaboração ligada a grupos "pró-moradia popular" (atua em torno da abertura de novos espaços para a moradia, vendo na terra urbana meio de inclusão), fazendo ainda concessões ao grupo dos desenvolvimentistas. Na aplicação desta legislação, ele aponta ainda para ganhos pontuais do grupo dos ambientalistas.

Assim, dentro do Distrito Federal, o que se percebe no período é uma aplicação muito relativizada dos instrumentos de planejamento, haja vista a perda de poder que o Estado possuía antes, relativo ao ordenamento do território neste espaço. Por conta de décadas de oferta insuficiente de lotes, incapaz de absorver o grande déficit habitacional de então, ocorreram novas levas de ocupações irregulares de terras públicas. Com extinção do BNH (1987), a passagem de suas atribuições à Caixa Econômica Federal (CEF) e a redução de financiamentos da casa própria, as ocupações passam, neste momento, a ter um caráter mais generalizado, com a participação mais efetiva das classes médias. Desta forma, e sem uma fiscalização efetiva, muitas das zonas e macrozonas dedicadas à preservação ambiental ou à contenção da expansão urbanas serão ocupadas. Por conta deste fato, Medeiros e Campos (2010) observam haver um ceticismo cada vez maior em relação ao planejamento tecnicista clássico, optando o Estado por um modelo de planejamento que visa inserir a cidade nos grandes fluxos financeiros globais, o planejamento estratégico. Em Brasília tal tendência ficará mais evidente a partir de iniciativas como o Projeto Orla.

As ações dos envolvidos na produção do espaço do Distrito Federal revelam uma ascendência do poder dos agentes do mercado imobiliário, especialmente dos grandes empreiteiros, agindo de forma mais efetiva sobre a mudança nas legislações e regramentos existentes sobre o tema, com a finalidade de abrir novos espaços a seus negócios. Se antes houve uma importância de empresas menores e até da autoconstrução, quando do surgimento dos condomínios irregulares, parece que no momento atual as grandes empresas tomam um posto de alta relevância, em certa associação com o Estado, conforme o caso de Águas Claras (que se desdobrou no período e deu origem a um espaço urbano altamente verticalizado) demonstra (LEITE, 2009). 


\subsubsection{Política agrícola}

Ao abordar uma política agrícola, para o período, é necessário apontar a inexistência de um plano sobre o desenvolvimento da região nos termos do Polocentro, que colocou na atividade da agropecuária moderna o papel fundamental de inclusão do Centro-Oeste e de suas sub-regiões no mercado nacional e global. As políticas específicas para o Centro-Oeste, de forma geral, têm preconizado a questão de mitigar alguns dos efeitos regionais negativos da implantação da agropecuária moderna, especialmente a concentração de renda e recursos.

Desta forma, a análise de uma política agrícola para a região passa pela análise do que vem sendo realizado por outros órgãos que não os especificamente de desenvolvimento regional. E, em termos de política agrícola no atual momento, a principal referência são os mecanismos de crédito, que tem orientado muito da atuação governamental. Além destas, especialmente a partir da criação do atualmente extinto Ministério do Desenvolvimento Agrário (MDA), houve a proposição de política públicas específicas para agricultores de menor porte, além de sua organização em programas territoriais específicos (principalmente o Territórios da Cidadania $\left.{ }^{27}\right)$.

Neste sentido, como principais fontes de crédito para o setor agrícola, além do já mencionado FCO, há os recursos próprios dos Estados. No caso, em destaque estão os recursos contratados no Estado de Goiás, através da agência Goiás Fomento. Esta aplica recursos não apenas no setor agrícola, mas visa impulsionar a atividade econômica como um todo. No âmbito da política agrícola, esta agência opera com as seguintes fontes: recursos próprios; fundos $\operatorname{administrados}^{28}$; recursos de repasse ${ }^{29}$.

Considerando estes dados e a abrangência do Sistema Nacional de Crédito Rural, a partir de suas múltiplas fontes, foram calculados os recursos dos financiamentos obtidos a partir de suas fontes. No ano de 2000, em relação aos municípios goianos da Ride-DF, as informações foram as constantes na Tabela 8.4. Os dados demonstram para um valor total financiado via SNCR para a agricultura e pecuária foram elevados, em seu total, no município de Cristalina, totalizando mais de R \$ 36 milhões. Em seguida aparece Luziânia, com mais de R\$ 12 milhões. Quanto aos valores per capita, os maiores valores aparecem em Cristalina (1.083,70 reais per capita) e em Água Fria de Goiás (946,81 reais per capita). Assim, em termos totais os valores

\footnotetext{
${ }^{27}$ Programa instituído pelo Decreto de 25 de fevereiro de 2008 (BRASIL, 2008b).

${ }^{28}$ Os fundos aí inclusos são o Fundo de Fomento a Mineração - FUNMINERAL; o Crédito Produtivo; o Credi PAI Financiamento Popular; e o PRODUZIR.

${ }^{29}$ Estão aqui abrangidos recursos do FCO e os oriundos das linhas de crédito do BNDES.
} 
acabam sendo capturados pelos principais municípios dedicados à agropecuária moderna. A exceção a tal regra aparenta ser, para este caso, Água Fria de Goiás.

Tabela 8.4 - Financiamentos à agricultura e pecuária ${ }^{30}$ - valor total e per capita - 2000 - municípios goianos da Ride-DF

\begin{tabular}{|c|c|c|c|}
\hline Município & $\begin{array}{l}\text { Total financiado - SNCR - } \\
\text { em reais }\end{array}$ & $\begin{array}{l}\text { População } \\
(2000)\end{array}$ & Valor per capita \\
\hline Abadiânia - GO & $619.502,49$ & 11.452 & 54,10 \\
\hline Água Fria de Goiás - GO & 4.231.300,99 & 4.469 & 946,81 \\
\hline Águas Lindas de Goiás - GO & - & 105.746 & - \\
\hline Alexânia - GO & $1.169 .110,74$ & 20.335 & 57,49 \\
\hline Cabeceiras - GO & $3.742 .410,23$ & 6.758 & 553,77 \\
\hline Cidade Ocidental - GO & $246.056,89$ & 40.377 & 6,09 \\
\hline Cocalzinho de Goiás - GO & $1.140 .000,29$ & 14.626 & 77,94 \\
\hline Corumbá de Goiás - GO & $1.088 .643,10$ & 9.679 & 112,47 \\
\hline Cristalina - GO & $36.971 .538,15$ & 34.116 & $1.083,70$ \\
\hline Formosa - GO & $5.514 .137,75$ & 78.651 & 70,11 \\
\hline Luziânia - GO & $12.296 .894,28$ & 141.082 & 87,16 \\
\hline Mimoso de Goiás - GO & $666.166,18$ & 2.801 & 237,83 \\
\hline Novo Gama - GO & - & 74.380 & - \\
\hline Padre Bernardo - GO & $2.167 .600,93$ & 21.514 & 100,75 \\
\hline Pirenópolis - GO & $2.542 .592,51$ & 21.245 & 119,68 \\
\hline Planaltina - GO & $5.141 .426,70$ & 73.718 & 69,74 \\
\hline Santo Antônio do Descoberto - GO & $33.922,80$ & 51.897 & 0,65 \\
\hline Valparaíso de Goiás - GO & - & 94.856 & - \\
\hline Vila Boa - GO & $114.756,01$ & 3.287 & 34,91 \\
\hline
\end{tabular}

Para o ano de 2010, os dados são os da Tabela 8.5. Os valores totais financiados pelo SNCR apontam para o maior volume de contratações em Cristalina (acima de R 169 milhões) e Luziânia (mais de R\$ 62 milhões). Analisando os valores per capita, os mais elevados aparecem em Mimoso de Goiás (R\$ 8.140,64 per capita), Água Fria de Goiás (R\$ 6.653,17 per capita) e Cristalina (R $\$ 3.632,96$ per capita). Desta forma, há uma tendência de concentração dos principais montantes (brutos) nos municípios de agropecuária mais moderna, ao passo que, considerando o valor per capita, há altos valores em municípios de reduzida população. Para além do efeito estatístico, isto pode apontar para um processo de expansão da agropecuária aí, ainda que os serviços superiores estejam em outros municípios mais próximos.

\footnotetext{
${ }^{30}$ Valor dos financiamentos concedidos por instituições financeiras públicas e privadas, pertencentes ao Sistema Nacional de Crédito Rural (SNCR), a produtores e cooperativas de produtores, para fins de custeio, investimento e comercialização nas atividades agrícolas.
} 
Tabela 8.5 - Financiamentos à agricultura e pecuária - valor total e per capita - 2010 - municípios goianos da Ride-DF

\begin{tabular}{|c|c|c|c|}
\hline Município & $\begin{array}{l}\text { Total financiado - SNCR - } \\
\text { em reais }\end{array}$ & $\begin{array}{l}\text { População } \\
\text { (2010) }\end{array}$ & Valor per capita \\
\hline Abadiânia - GO & $9.128 .104,56$ & 15.757 & 579,30 \\
\hline Água Fria de Goiás - GO & $33.864 .660,09$ & 5.090 & $6.653,17$ \\
\hline Águas Lindas de Goiás - GO & $318.642,64$ & 159.378 & 2,00 \\
\hline Alexânia - GO & $4.675 .444,46$ & 23.814 & 196,33 \\
\hline Cabeceiras - GO & $17.055 .469,44$ & 7.354 & $2.319,21$ \\
\hline Cidade Ocidental - GO & $3.557 .747,96$ & 55.915 & 63,63 \\
\hline Cocalzinho de Goiás - GO & $8.141 .278,45$ & 17.407 & 467,70 \\
\hline Corumbá de Goiás - GO & $8.698 .037,31$ & 10.361 & 839,50 \\
\hline Cristalina - GO & $169.223 .456,01$ & 46.580 & $3.632,96$ \\
\hline Formosa - GO & $43.139 .724,53$ & 100.085 & 431,03 \\
\hline Luziânia - GO & $62.664 .901,57$ & 174.531 & 359,05 \\
\hline Mimoso de Goiás - GO & $21.857 .628,20$ & 2.685 & $8.140,64$ \\
\hline Novo Gama - GO & $2.306 .641,44$ & 95.018 & 24,28 \\
\hline Padre Bernardo - GO & $21.079 .541,17$ & 27.671 & 761,79 \\
\hline Pirenópolis - GO & $8.819 .935,93$ & 23.006 & 383,38 \\
\hline Planaltina - GO & $32.769 .092,18$ & 81.649 & 401,34 \\
\hline Santo Antônio do Descoberto - GO & $2.995 .327,86$ & 63.248 & 47,36 \\
\hline Valparaíso de Goiás - GO & $2.425 .954,44$ & 132.982 & 18,24 \\
\hline Vila Boa - GO & $139.994,40$ & 4.735 & 29,57 \\
\hline
\end{tabular}

Fontes: IBGE; IMB (dados tratados pelo autor)

Dentro do rol de políticas aplicadas pelo extinto MDA, uma delas que teve importante destaque foi o Programa Territórios da Cidadania. No âmbito da Ride-DF, havia um destes territórios formalizados, o de Águas Emendadas, que abarca os seguintes municípios: Água Fria de Goiás, Cabeceiras, Formosa, Mimoso de Goiás, Padre Bernardo, Planaltina, Vila Boa, Brasília, Buritis, Cabeceira Grande e Unaí. Em 2013, foram realizadas ações no âmbito do apoio a atividades produtivas, de cidadania e direitos e de infraestrutura. Muitos deles envolveram outros Programas do Governo Federal, como o Programa de Aquisição de Alimentos, o Programa Brasil sem Miséria e outros (PORTAL DA CIDADANIA, 2016).

Assim, de forma efetiva, o que se tem é a aplicação de uma política agrícola que vem concentrando a maior parte dos recursos em torno da agropecuária moderna, o que significa maior incentivo à reprodução de algumas desigualdades socioespaciais internas à Ride-DF. A lógica tida durante a vigência do Polocentro tende, assim, a manter-se: o governo limita sua atuação ao crédito e à securitização da produção. A diferença é que o Polocentro previa uma atuação mais planejada sobre o território, algo que parece ter se perdido no atual momento. A partir desta lógica, e sem a perspectiva de emprego dos recursos (especialmente 
dos fundos regionais) em produtores de menor porte, há tendência de continuidade neste cenário. Parte disto, especialmente a decisão de onde serão alocados os recursos no setor é fortemente influenciado pelas bancadas ligadas ao agronegócio no Congresso Nacional, que sempre se movimentam no sentido de manter recursos permanentes ao crédito agrícola nos Orçamentos da União.

\subsubsection{Política de transportes - eixos rodoviários}

Tendo em vista o quadro geral analisado para a escala Brasil, no capítulo 5, viu-se que o Estado brasileiro buscou uma retomada da questão dos investimentos públicos em infraestrutura a partir da década de 2000. Entretanto, antes deste período, houve a já bastante mencionada política dos Eixos Nacionais de Integração e Desenvolvimento (ENIDs), que seria mais consolidada a partir do PPA 2000-2003 (BRASIL, 2000). Como eles partiam da perspectiva de integração intermodal como forma de promoção do desenvolvimento regional, houve impactos óbvios sobre o tema da política de transportes.

Dentro desta política, o espaço da Ride-DF ficou circunscrito ao eixo AraguaiaTocantins. Mesmo sua disposição espacial demonstra a criação do eixo desaguando na costa do Estado do Maranhão, havendo uma clara orientação no sentido Sul-Norte, como se pode ver na Figura 8.3. É possível observar um privilégio na orientação em torno da BR 153, a Belém Brasília, como principal tronco do eixo a ser formatado. Nasser (2000) aponta para este eixo, em conjunto com o eixo Oeste, o seguinte: eram eixos complementares aos da rede Sudeste e Sul; espaços de colonização recente, podendo cumprir a função como celeiros agrícolas; possibilidade de crescimento (econômico) a partir da agropecuária. Vê-se, assim, a reafirmação da perspectiva do Centro-Oeste como "celeiro" e espaço a ser ocupado produtivamente pela agropecuária moderna.

Na década de 2000, a questão dos transportes específicos em torno da Ride-DF foi retomada pelo PPA 2004-2007 (BRASIL, 2004). Este previa, como ações dentro do Programa “Corredor Araguaia-Tocantins" obras específicas de adequação em trechos da BR 153 (como no entroncamento com a BR 060 e GO 431, em Anápolis; a adequação do trecho rodoviário da BR 060 de Brasília até o entroncamento com a BR 153 e internamente no território do Distrito Federal. No âmbito da Ride-DF, foram previstas ainda obras nas BRs 050, 070, 080 e 450. 
Figura 8.3 - Eixos Nacionais de Integração e Desenvolvimento

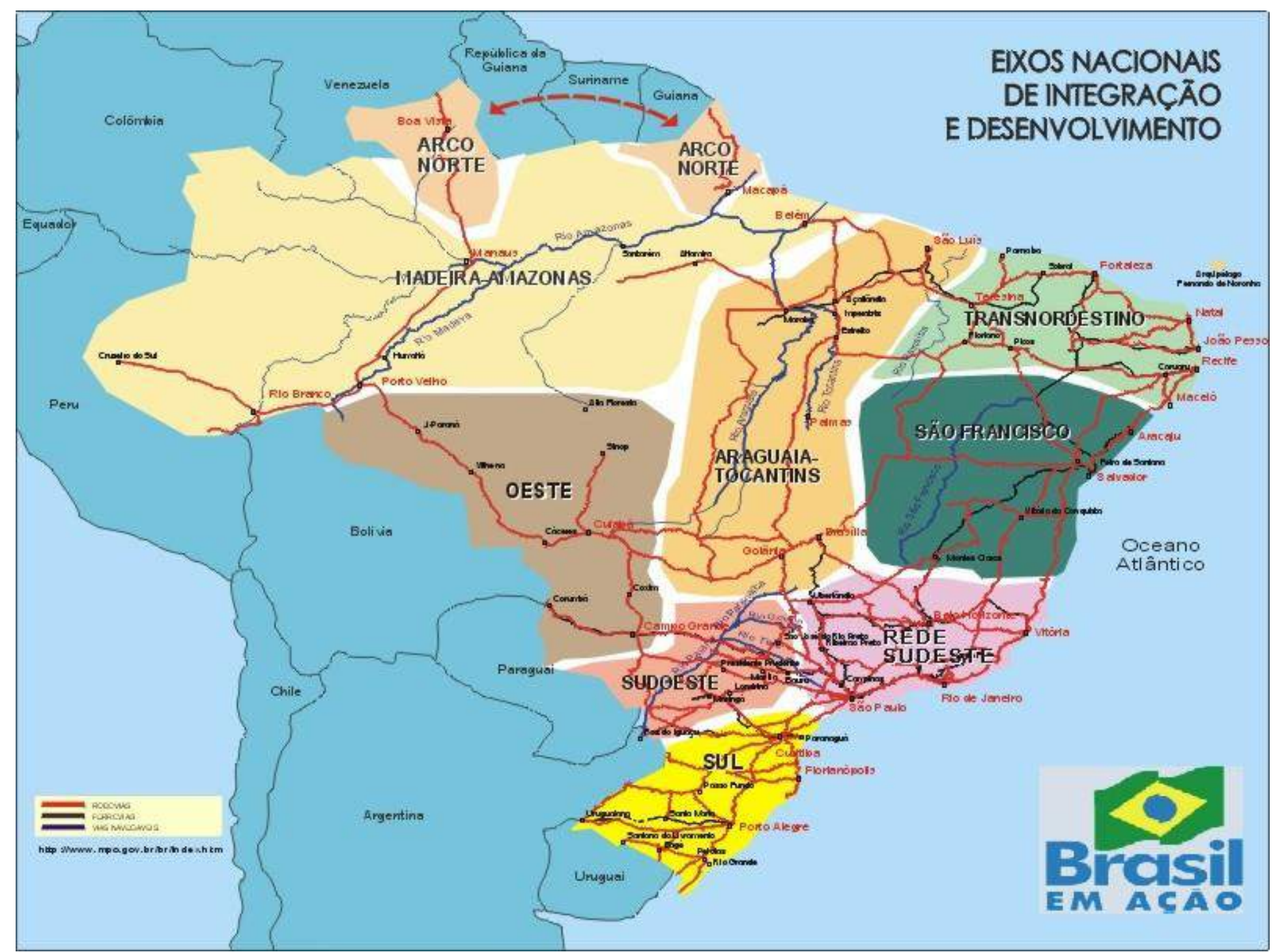

Fonte: BRASIL, 1996. 
A partir destas disposições, e de forma efetiva, foi concluída, em 2007, a duplicação do trecho da BR 060 entre Brasília e Anápolis, conectando-se com o trecho já duplicado da BR 153 entre Anápolis e Goiânia. A conclusão desta obra foi fundamental na ampliação da integração do eixo Brasília-Anápolis-Goiânia, que já havia deixado, há algum tempo, de ser mero corredor de transportes. A conclusão da obra aprofundou a integração econômica entre estas duas metrópoles, e, como se verá na próxima seção, causou profundos impactos na região, criando um eixo economicamente muito dinâmico. É possível visualizar que a política dos ENIDs iniciou o processo, que foi continuado, ainda que com enfoque diferente (basta ver o nome dos eixos previstos no PPA 2004-2007 para se constatar a forte similitude entre estes e os previstos nos ENIDs). Apesar das obras terem enfocado o tema das exportações, será possível ver que não apenas o processo de expansão da agropecuária foi estimulado a partir da consolidação do Eixo Brasília-Anápolis-Goiânia: houve impulso a setores produtivos voltados à economia local. Houve mesmo impulso ao setor de consumo no Eixo, como será melhor descrito à frente.

Por fim, é necessário apontar que a política mais recente tem sido orientada no sentido de conceder as principais rodovias à gestão da iniciativa privada. Considerando o grande valor potencial que representa, o trecho entre Brasília e Anápolis e entre Anápolis e Goiânia foi concedido recentemente ${ }^{31}$, tendo sido iniciada a cobrança de pedágio em 2015 . Numa viagem entre as "pontas" do eixo, existem duas praças de pedágio: em Alexânia e em Goianápolis. Uma crítica recorrente a este modelo (e bastante válida neste caso) é de que o Estado usou de seus recursos para duplicar a via e depois, mais tarde, passou sua administração e conservação ao setor privado - em diversos outros trechos, o modelo de concessão prevê a duplicação, o que aparenta ser mais vantajoso.

Desta forma, em um apanhado geral do quadro de ações descritas nesta seção, é possível visualizar o movimento de retirada do Estado das políticas destinadas, principalmente, ao ordenamento do território, e o surgimento de política regionais descasadas deste propósito, como se viu no período anterior. A retomada de atuação do Estado deu-se após a estabilização da economia na década de 1990, e tem atacados duas frentes com maior repercussão em termos regionais: a subvenção à produção, especialmente da agropecuária moderna; a construção de infraestruturas necessárias à exportação do produzido. Estas tem provocado uma série de estímulos no setor privado, que opta por direcionar seus investimentos aos setores/ áreas mais

\footnotetext{
${ }^{31}$ A concessionária responsável é o Consórcio Triunfa/ Concebra.
} 
rentáveis, impactando a produção dos espaços regionais. Concomitantemente, o processo de expansão metropolitana vem ocorrendo a partir de dinâmicas também de estímulo do Estado e subvenção ao setor privado, notadamente pelos programas habitacionais. No âmbito metropolitano, por outro lado, as ações em torno da infraestrutura ainda estão aquém das necessidades, sem a possibilidade, no caso de Brasília, de uma maior articulação entre os entes federados participantes da Ride-DF. Dentro desta, no âmbito de ações próprias de desenvolvimento regional, tem ocorrido a reprodução da tendência acima comentada: fomento ao setor produtivo, sem maior preocupação com o ordenamento do território e os impactos nas desigualdades socioespaciais internas. A próxima seção busca apresentar e discutir os desdobramentos destas ações no território.

\subsection{Desdobramentos das ações de gestão do território}

A partir das ações acima analisadas, os desdobramentos apontarão para o aprofundamento da fragmentação do espaço da Ride-DF, a partir da atuação de três processos: a expansão metropolitana de Brasília, a expansão da agropecuária moderna e a integração do Eixo Brasília-Anápolis-Goiânia. A discussão aponta que a postura do Estado, à medida em que age na subvenção dos agentes privados, tem reforçado tal tendência.

\subsubsection{Desdobramentos e processos espaciais: expansão metropolitana de Brasília}

Como desdobramentos das ações, sob a forma de reflexos sobre o espaço de assentamento, registra-se, internamente ao Distrito Federal, o aumento da densidade em algumas cidades-satélites mais antigas, com o processo de verticalização de algumas delas. $\mathrm{O}$ adensamento fica ainda mais claro com a abertura de espaços dedicados em sua maioria às moradias verticais, como Águas Claras que iniciou seu processo de ocupação. Este é um caso clássico no qual a pressão do mercado imobiliário age para alterar os usos do espaço, já que a proposta inicial deste bairro foi totalmente alterada. Leite (2009) demonstra claramente como a alteração no que fora antes previsto torna o espaço altamente atrativo ao mercado imobiliário. Ela demonstra uma parceria entre o governo e o capital incorporador: "o capital incorporador e o governo, ao lhe dar condições de atuação, têm sido os principais agentes na produção do espaço em Águas Claras, aos quais o capital construtivo se agrega” (p. 88). 
Considerando os desdobramentos sobre o espaço de assentamento na escala regional e analisando o processo de expansão metropolitana, verifica-se uma verticalização da metrópole, porém com a expansão horizontal permanecendo importante, tanto em áreas internas ao quadrilátero (no qual há o surgimento de condomínios em áreas irregulares, que abrangem todo o espectro de renda), quanto fora dele, com o crescimento dos Municípios polarizados pela economia brasiliense. Surge a figura dos condomínios horizontais exclusivos (mais presentes no interior do Distrito Federal) e de condomínios verticais nos Municípios vizinhos, principalmente ao sul do Distrito Federal, como apontado por Resende e Cidade (2013). A ocupação vai tornando-se uma mancha sem tantos vazios entre si, mais adensadas, tendo agora o espaço metropolitano da Ride-DF uma morfologia interna ainda mais próxima do que se verifica nas outras cidades brasileiras. Este processo de conurbação para fora do Distrito Federal fica mais claro no eixo da BR 040, com os municípios de Valparaíso, Novo Gama, Cidade Ocidental e Luziânia, e a adição de dois eixos: a oeste, pela BR 070, com a rápida expansão urbana de Águas Lindas de Goiás; ao norte, articulada pela BR 020, com os municípios de Planaltina e Formosa. Tal processo comprova os apontamentos de Catalão (2011), que destaca a importância dos eixos de ligação rodoviária no processo, delimitando um processo de dispersão próprio de uma cidade que não possuiu, anteriormente, uma morfologia urbana compacta.

O mapa da Figura 8.4 indica as áreas urbanizadas do chamado Arranjo Populacional de Brasília, identificado pelo produto “Áreas Urbanizadas” do IBGE (2005). A área urbana em destaque corresponde àquela considerada do espaço aglomerado de Brasília, segundo este Instituto. A análise do mapa demonstra a clara ligação do processo de urbanização e as rodovias federais (estão assinaladas apenas as rodovias federais radiais). O processo de evolução da expansão metropolitana segue claramente apoiada na rede de rodovias. Além disso, o processo aponta para a histórica concentração ao sul do Distrito Federal e, posteriormente, atingiu o oeste e o norte.

O processo acima descrito de expansão metropolitana terminou por reforçar a tendência à integração periférica de diversos dos municípios goianos da Ride-DF ao tecido metropolitano de Brasília, algo já presenciado no período anterior e que neste se expande para o sul do território, mas também para o norte e oeste. Com a consolidação da agropecuária como atividade importante para o leste e parte do sul da Ride-DF, novas dinâmicas surgem e as relações de dependência quase total em relação a Brasília iniciam alguma relativização, pela integração destes territórios com outros grandes centros nacionais que comandam sua produção. 
Figura 8.4

Área Urbanizada de Brasília e seu espaço aglomerado

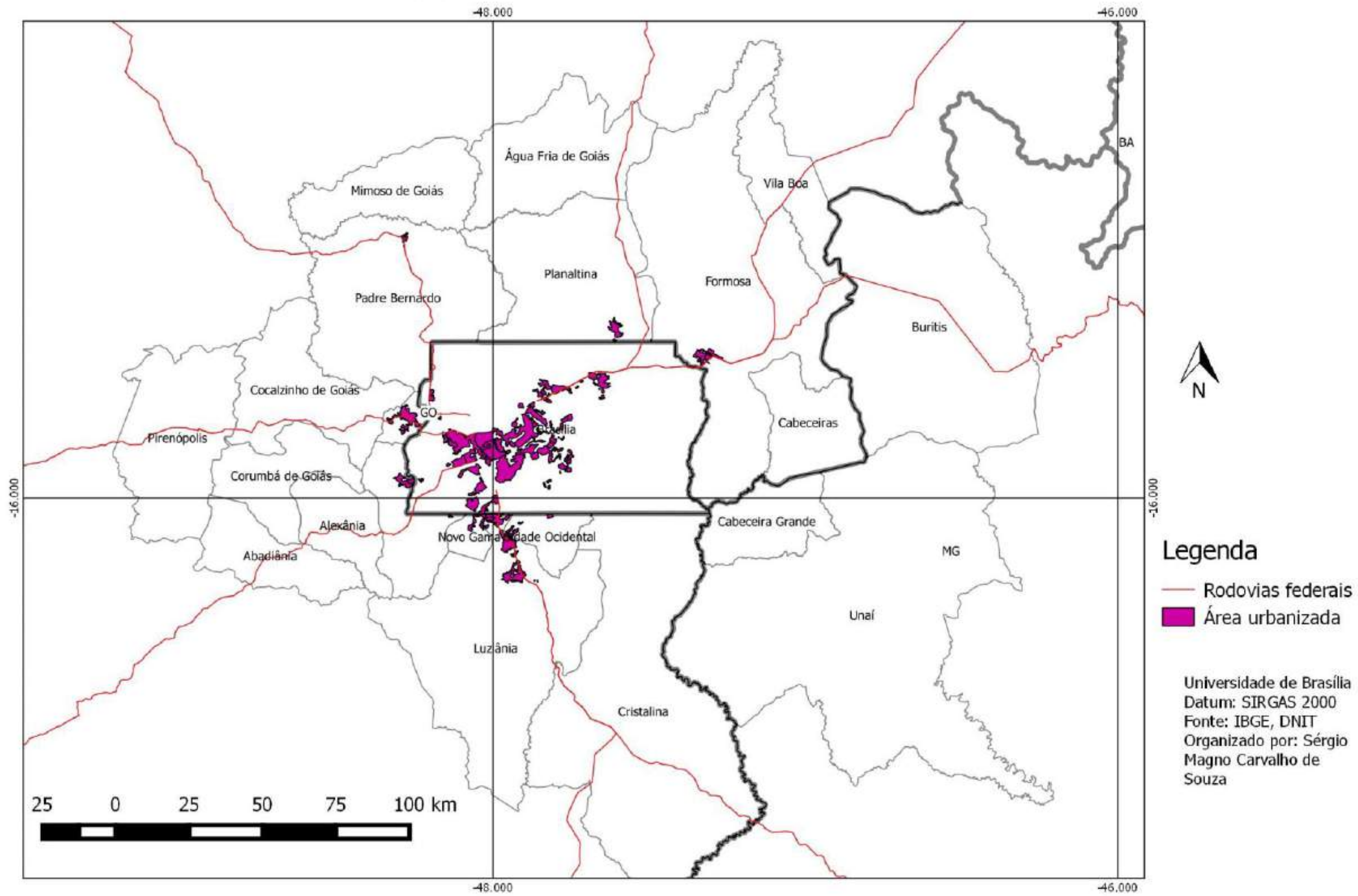




\subsubsection{Desdobramentos e processos espaciais: a expansão da agropecuária moderna na Ride-DF}

A partir, principalmente, da atuação do Estado por meio da subvenção ao setor produtivo, houve a expansão da atividade agropecuária moderna, especialmente em municípios que já tinham sido atingidos pela atuação do Polocentro, notadamente a leste do Distrito Federal. A exceção fica por conta dos espaços a oeste do Distrito Federal. Uma forma de visualizar o processo de expansão é a partir dos dados da Tabela 8.6, sobre a proporção de cada método de irrigação utilizado nos municípios da Ride-DF e no Distrito Federal. Os dados da tabela apontam para um alto percentual de uso de pivô central nas áreas irrigadas dos municípios de Cristalina, Cabeceira Grande, Unaí, Alexânia, Água Fria de Goiás e Luziânia. Considerando a quantidade de recursos necessários para o uso desta técnica, e o fato de que ela representa o uso de meios mais modernos de produção, fica claro um traço de modernização nestes municípios, localizados, principalmente a sudeste e leste do Distrito Federal. É importante considerar ainda elevado uso desta metodologia em Águas Lindas de Goiás e em Brasília; entretanto, por já ter sido exposto que a agropecuária tem participação quase residual no PIB destas duas unidades, o que se constata é a existência de espaços agrícolas modernizados, mas com reduzido impacto em sua economia local. 
Tabela 8.6 - Área dos estabelecimentos por método utilizado para irrigação dos municípios da Ride-DF em 2006 - em percentual ${ }^{32}$

\begin{tabular}{|c|c|c|c|c|c|c|}
\hline Municípios $^{33}$ & Inundação & Sulcos & $\begin{array}{l}\text { Aspersão } \\
\text { (pivô } \\
\text { central) }\end{array}$ & $\begin{array}{l}\text { Aspersão } \\
\text { (outros } \\
\text { métodos) }\end{array}$ & $\begin{array}{l}\text { Localizado } \\
\text { (gotejamento, } \\
\text { microaspersão, } \\
\text { etc.) }\end{array}$ & $\begin{array}{l}\text { Outros } \\
\text { métodos de } \\
\text { irrigação } \\
\text { e/ou } \\
\text { molhação } \\
\end{array}$ \\
\hline Abadiânia - GO & - & 16,67 & - & 49,24 & - & 34,09 \\
\hline Água Fria de Goiás - GO & $\mathrm{X}$ & 0,17 & 76,88 & 8,58 & 0,45 & 13,90 \\
\hline Águas Lindas de Goiás - GO & - & - & - & 55,63 & 10,08 & 34,29 \\
\hline Alexânia - GO & $\mathrm{X}$ & 2,03 & 86,95 & 1,11 & 1,61 & 1,33 \\
\hline Cabeceiras - GO & $\mathrm{X}$ & $\mathrm{X}$ & - & 38,60 & 57,89 & X \\
\hline Cidade Ocidental - GO & - & $\mathrm{X}$ & $\mathrm{X}$ & 18,06 & 0,68 & 2,76 \\
\hline Cocalzinho de Goiás - GO & - & $\mathrm{X}$ & - & $\mathrm{X}$ & $\mathrm{X}$ & 43,86 \\
\hline Corumbá de Goiás - GO & - & 21,42 & $\mathrm{X}$ & 7,29 & $\mathrm{X}$ & 10,61 \\
\hline Cristalina - GO & $\mathrm{X}$ & 0,05 & 99,37 & 0,23 & 0,32 & 0,03 \\
\hline Formosa - GO & 31,41 & 3,81 & 47,98 & 11,07 & 4,37 & 1,36 \\
\hline Luziânia - GO & $\mathrm{X}$ & 0,27 & 69,81 & 16,38 & 0,87 & 9,05 \\
\hline Mimoso de Goiás - GO & $\mathrm{X}$ & - & $\mathrm{X}$ & 11,96 & $\mathrm{X}$ & 11,8 \\
\hline Novo Gama - GO & - & - & - & 86,69 & $\mathrm{X}$ & 6,68 \\
\hline Padre Bernardo - GO & - & - & 59,70 & 35,04 & 3,70 & 1,56 \\
\hline Pirenópolis - GO & 5,28 & 44,87 & - & 34,17 & X & 9,35 \\
\hline Planaltina - GO & - & 6,19 & $\mathrm{X}$ & 18,04 & 18,14 & 6,80 \\
\hline Santo Antônio do Descoberto - GO & $\mathrm{X}$ & X & - & 39,97 & - & 5,36 \\
\hline Valparaíso de Goiás - GO & - & - & - & $\mathrm{X}$ & $\mathrm{X}$ & - \\
\hline Vila Boa - GO & - & - & - & 96,46 & $\mathrm{X}$ & 2,75 \\
\hline Buritis - MG & - & $\mathrm{X}$ & 72,46 & 25,10 & 1,75 & 0,68 \\
\hline Cabeceira Grande - MG & - & - & 99,52 & $\mathrm{X}$ & $\mathrm{X}$ & $\mathrm{X}$ \\
\hline Unaí - MG & - & 0,22 & 92,88 & 5,53 & 1,05 & 0,32 \\
\hline Brasília - DF & 0,18 & 1,41 & 52,44 & 33,1 & 10,26 & 2,61 \\
\hline
\end{tabular}

Fonte: IBGE - Censo agropecuário

A Tabela 8.7 aponta para o ritmo de crescimento da área plantada nos municípios da Ride-DF. A partir destes dados, é possível ver que o período entre os anos de 2003 e 2005 representou variação negativa nos municípios em torno da área plantada. Já no biênio seguinte houve recuperação, havendo um período de forte crescimento entre os anos de 2011 e 2013. Quanto aos municípios, é notável que aqueles mais dedicados à agropecuária modernizada possuem menores variações em torno do ritmo de crescimento ou decréscimo da área plantada, chamando a atenção os casos de Cristalina e Unaí. Isto provavelmente se deve à maior presença de empresas agrícolas de maior porte, que garantem a existência de um certo número de hectares

\footnotetext{
32 Os dados das Unidades Territoriais com menos de 3 (três) informantes estão identificados com o caracter X.

${ }^{33}$ Para efeitos deste trabalho, quando da análise dos dados, Brasília é considerada sinônimo de "Distrito Federal" e aparece equiparada aos municípios.
} 
plantadas todos os anos, diferentemente dos municípios em que predomina a agropecuária de menor porte.

Tabela 8.7 - Variação, em percentual, da área plantada nos municípios da Ride-DF

\begin{tabular}{|c|c|c|c|c|c|c|}
\hline Município & 2003-05 & $2005-07$ & 2007-09 & 2009-11 & 2011-13 & 2013-15 \\
\hline Abadiânia - GO & 10,33 & $-18,32$ & 8,50 & 101,70 & 3,88 & 23,27 \\
\hline Água Fria de Goiás - GO & $-59,60$ & 24,59 & $-8,91$ & 10,24 & 2,82 & 45,71 \\
\hline Águas Lindas de Goiás - GO & - & - & - & 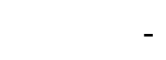 & - & 115,46 \\
\hline Alexânia - GO & $-27,64$ & 16,43 & 0,09 & $-13,54$ & 91,79 & 19,37 \\
\hline Cabeceiras - GO & $-35,49$ & 2,76 & $-8,73$ & 14,89 & 2,83 & 13,37 \\
\hline Cidade Ocidental - GO & $-128,17$ & $-18,95$ & $-14,33$ & 8,16 & 10,28 & 21,04 \\
\hline Cocalzinho de Goiás - GO & 28,95 & 33,75 & $-4,22$ & 3,29 & 50,38 & 7,19 \\
\hline Corumbá de Goiás - GO & 8,50 & 16,38 & 18,91 & 23,00 & 49,67 & 96,55 \\
\hline Cristalina - GO & $-14,82$ & 6,70 & 37,32 & 11,15 & 14,77 & 3,50 \\
\hline Formosa - GO & $-35,79$ & $-11,20$ & 4,70 & 58,04 & 12,67 & 1,30 \\
\hline Luziânia - GO & $-7,91$ & 6,92 & $-11,28$ & 18,38 & 3,10 & 6,00 \\
\hline Mimoso de Goiás - GO & $-50,37$ & 11,45 & 47,48 & 19,73 & 111,81 & $-68,32$ \\
\hline Novo Gama - GO & $-62,50$ & $-43,32$ & 325,71 & 9,90 & $-63,36$ & $-100,00$ \\
\hline Padre Bernardo - GO & $-195,93$ & $-23,86$ & 44,61 & 68,08 & 73,00 & 23,86 \\
\hline Pirenópolis - GO & $-0,57$ & 37,95 & 4,93 & 10,70 & 13,59 & $-13,53$ \\
\hline Planaltina - GO & $-41,06$ & 6,17 & - & 24,79 & 11,62 & $-2,88$ \\
\hline Santo Antônio do Descoberto - GO & $-745,45$ & 277,11 & 13,24 & 26,98 & $-78,75$ & 32,00 \\
\hline Valparaíso de Goiás - GO & - & - & - & - & - & - \\
\hline Vila Boa - GO & $-12,15$ & 47,16 & 239,86 & 40,81 & $-5,34$ & 27,08 \\
\hline Buritis - MG & $-18,95$ & $-6,47$ & 27,74 & 16,53 & $-6,42$ & 14,17 \\
\hline Cabeceira Grande - MG & $-40,74$ & $-14,74$ & 12,59 & 10,82 & 1,35 & $-1,31$ \\
\hline Unaí - MG & $-6,35$ & 5,97 & 3,62 & 11,22 & 10,22 & 1,68 \\
\hline Brasília - DF & $-24,13$ & 2,75 & $-4,99$ & 4,95 & 7,11 & 17,77 \\
\hline
\end{tabular}

Fonte: IBGE - Pesquisa Agrícola Municipal (dados tratados pelo autor)

Por fim, um último dado que demonstra claramente para o crescimento da agropecuária na região diz respeito à curva de crescimento do total de hectares plantados nos municípios da Ride-DF, demonstrado no Gráfico 8.1. Este aponta para um crescimento no total da área plantada em todos os anos, havendo uma acentuação do crescimento entre 2012 e 2014, quando o ápice é atingido. Apenas para o intervalo entre 2014 e 2015 é registrada queda na quantidade total de área plantada, o que pode ser um primeiro efeito da crise econômica do país e consequente menor disponibilidade crédito agrícola. 
Gráfico 8.1

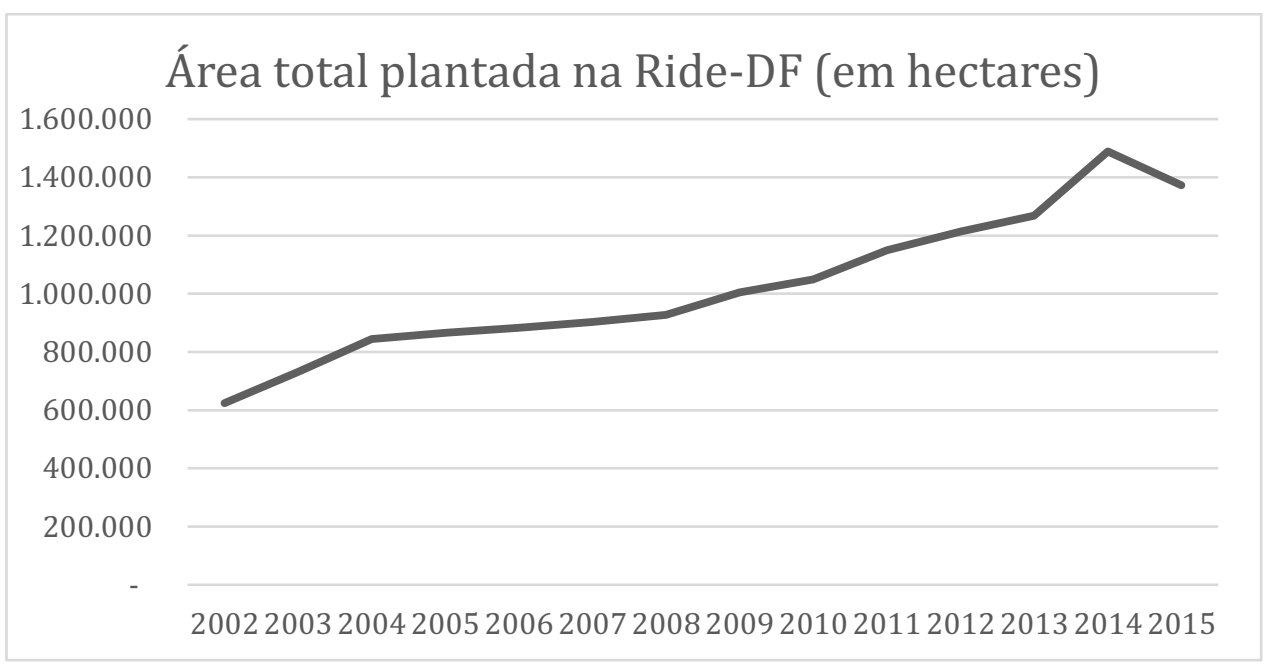

Fonte: IBGE - Pesquisa Agrícola Municipal (gráfico elaborado pelo autor)

Desta forma, os dados acima apresentados e a discussão proposta anteriormente, especialmente a análise das ações sobre a política agrícola apontam que a atuação do Estado tem de fato favorecido o crescimento da área plantada e, a partir dos dados sobre irrigação, da modernização da produção em alguns dos municípios da Ride-DF. Dentro da região, os dados sobre uso de pivotagem central demonstram os municípios em que tem ocorrido o avanço com modernização, localizados ao sul e a leste do Distrito Federal. Quando for realizada a análise sobre os subcentros, outros dados sobre bens e serviços voltados à agropecuária na região serão discutidos.

\subsubsection{Desdobramentos e processos espaciais: a integração do Eixo Brasília- Anápolis-Goiânia}

O terceiro processo responsável pela organização do espaço da Ride-DF no período atual é a integração do eixo econômico entre Brasília, Anápolis e Goiânia. A constituição deste eixo, conforme já mencionado em outros momentos deste trabalho teve como origem a construção das duas capitais. Ela se deu, dessa forma, a partir de intenção explícita do Estado no sentido de ocupar o espaço do Centro-Oeste brasileiro. A análise mostrou que Goiânia foi construída na década de 1930 não apenas para abrigar a nova sede do Estado de Goiás, mas como esforço de ocupação e povoamento da região na esteira da "Marca para o Oeste" de Getúlio Vargas. Já Brasília foi construída a partir dos imperativos de integração do território nacional no auge do processo de industrialização nacional. Posteriormente, na década de 1970, 
houve a integração produtiva do Centro-Oeste, processo que iria mudar tanto a organização interna do espaço destas cidades quanto de seu papel na rede urbana regional e nacional.

É assim que, segundo Miragaya (2003) a estruturação deste eixo tem como motor principal o processo de desenvolvimento das duas capitais Goiânia e Brasília. Analisando o processo de desenvolvimento destas duas cidades, o autor aponta para a manutenção de Brasília como polo de serviços, não tendo jamais incorporado atividades de importância dos setores primário e secundário. Por outro lado, Goiânia foi beneficiada pelo processo de avanço da agropecuária moderna no Estado, como consequência da atuação dos programas regionais do governo federal. A cidade acabou incorporando o papel de, como centro distribuidor, contribuir para expandir o consumo de bens intermediários à produção no campo, como fertilizantes, tratores, sementes e outros. Entre eles está localizada Anápolis, cidade que vem assumindo importante papel como centro logístico nacional e polo industrial moderno.

No contexto da integração destas três cidades, está um eixo de transportes que recebeu (como visto na subseção 8.2.4 e representado na Figura 8.5) importantes investimentos nos últimos anos. Além da duplicação das BRs 060 e 153, houve importantes investimentos na integração de modais, sendo notáveis: a entrega do trecho da ferrovia Norte-Sul de Anápolis até Palmas; a ampliação dos aeroportos internacionais de Brasília e Goiânia. Além da integração já existente, pode-se esperar, no futuro, mantidos os investimentos, a formação de um eixo econômico ainda mais forte. Está em estudo a construção de uma linha de passageiros e uma linha de cargas para transporte ferroviário entre as três cidades, conduzido, no momento pela Agência Nacional de Transportes Terrestres (ANTT). Analisando a conformação deste modelo de transporte, Araújo Sobrinho (2008) aponta que o modelo não seria propriamente um eixo, mas um $h u b$ se se considerar o papel dos aeroportos internacionais e a conectividade que eles proporcionam.

Além do processo antes mencionado de projeção das economias das duas capitais, Araújo Sobrinho (2008) destaca, mais recentemente, o papel da atração de investimentos realizados, principalmente, pelo Estado de Goiás. Tem sido oferecida, em parceria com as prefeituras, uma série de vantagens no sentido de atrair grandes empreendimentos e plantas fabris. 
Figura 8.5

Ride-DF, Anápolis, Região Metropolitana de Goiânia e a BR 060

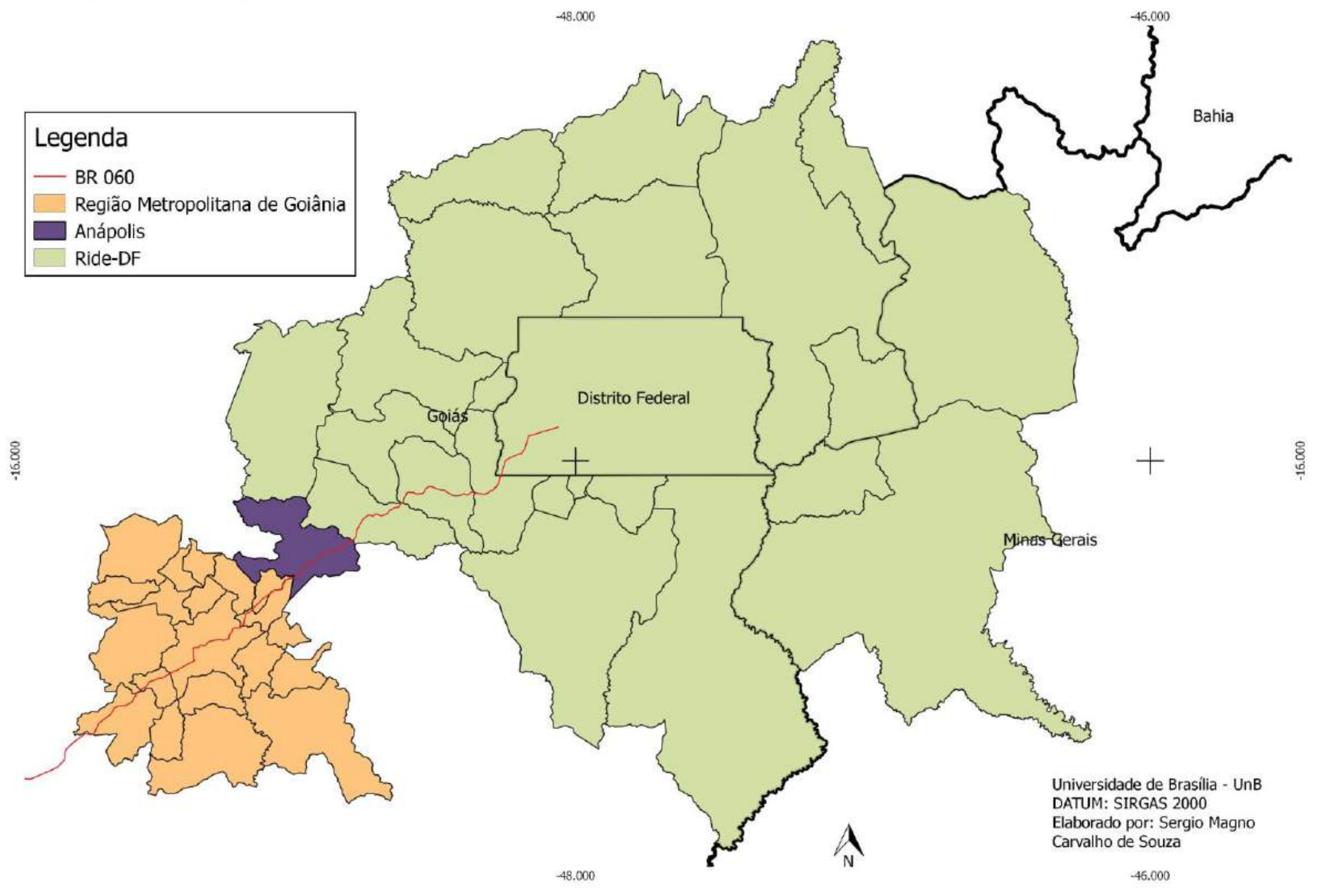


Estes processos, tanto os atuais como os mais antigos, têm gerado, por outro lado, consequências para a produção do espaço urbano e metropolitano dos três pontos nodais do eixo. Haddad e Moura (2016) apontam para a acentuação do processo de verticalização já muito perceptível em Goiânia e Brasília, motivado, entre outros fatores, por processo de caráter local, como a própria integração do Eixo e o avanço da agropecuária moderna. Tal verticalização tem ligação com a valorização da terra nestas cidades, reforçando, ainda, o processo de expansão de seus espaços metropolitanos.

\subsection{Síntese, fecho e ligação}

A análise do período mais recente da produção do espaço da Ride-DF aponta para a ocorrência, "em plenitude", dos três processos considerados estruturantes para tanto: a expansão metropolitana de Brasília, a expansão da agropecuária moderna e a integração do Eixo Brasília-Anápolis-Goiânia. Estes podem ser visualizados a partir da Figura 8.6. A divisão de municípios pela ocorrência dos processos estruturantes é, de certa forma, uma primeira aproximação para uma tipologia de municípios da Ride-DF, esforço que será apresentado de forma completa na seção 9.3.

Assim, a expansão metropolitana manteve seu curso, atingindo novas áreas, como os municípios vizinhos à oeste e norte do Distrito Federal. Este processo tem sido responsável pela inserção, como periferia dependente, de municípios vizinhos ao quadrilátero. Ocorre pela manutenção da incorporação de novas terras pelo mercado imobiliário, visando atender a busca de terras mais baratas de moradores do Distrito Federal. Além do centro regional e metropolitano, Brasília, atinge, no atual momento, aos municípios de Águas Lindas de Goiás, Cidade Ocidental, Novo Gama, Planaltina, Santo Antônio do Descoberto e Valparaíso de Goiás.

Já o caso da agropecuária moderna, esta tende a se expandir do espaço em que esteve circunscrita no período anterior, ao redor dos municípios de Unaí e Formosa. Ela passa a tomar a porção territorial leste da Ride-DF, ligando-se a cadeias produtivas que estão fora desta região. Ainda mais recentemente, tem ocorrido uma vigorosa expansão ao sul do Distrito Federal, abarcado Cristalina e parte do território de Luziânia. Abarca, assim, os seguintes municípios: Cabeceiras, Cristalina, Formosa, Vila Boa, Buritis, Cabeceira Grande e Unaí. 


\section{Processos estruturantes do espaço da Ride-DF}

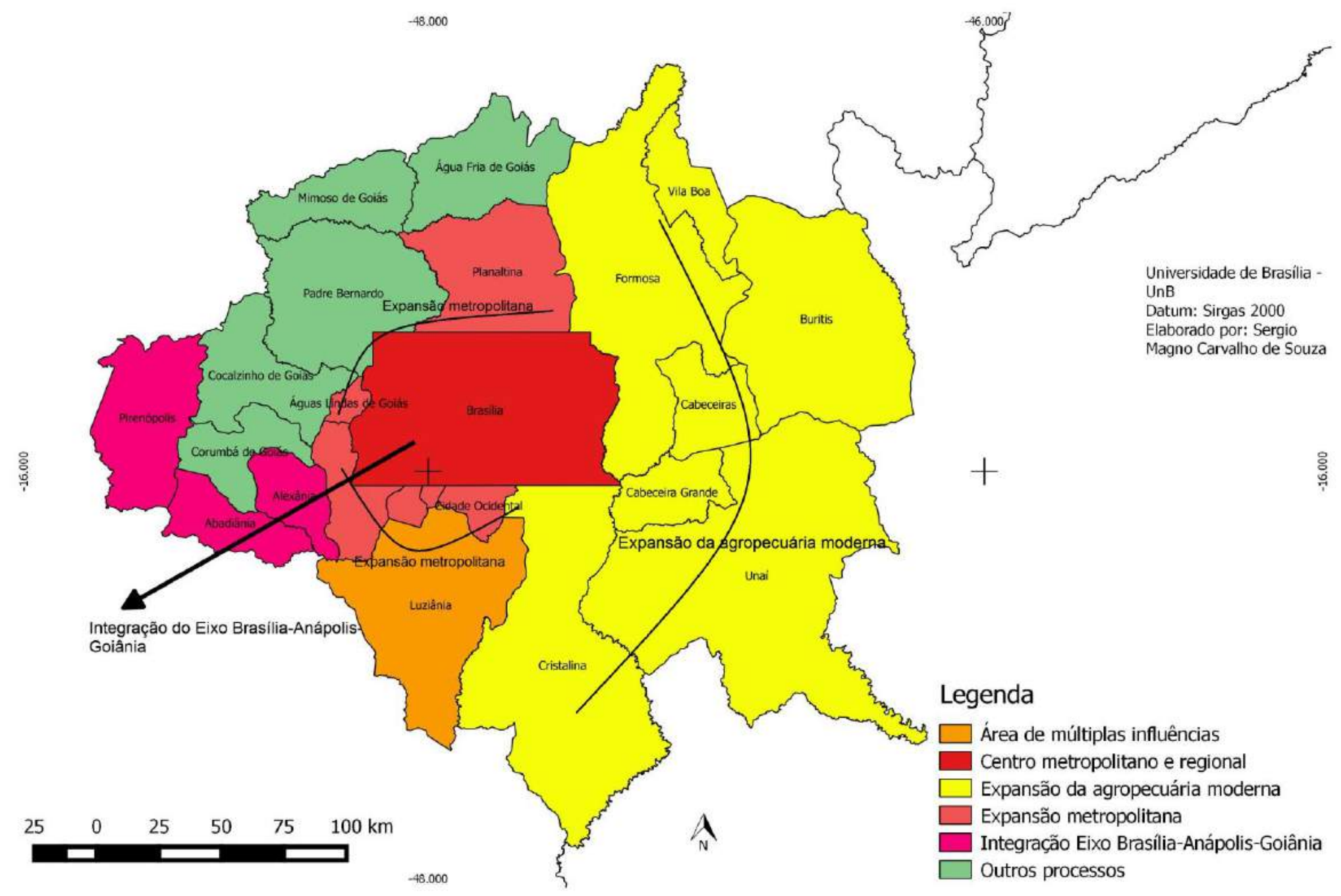


O terceiro processo que passa a atuar como estruturante da Ride-DF, como se viu, tem origem mais recente que os outros dois e ganhou relevância a partir da integração econômica entre Brasília e Goiânia. No âmbito da Ride-DF, ele atinge alguns dos municípios cortados pela BR 060, cuja exceção é Santo Antônio do Descoberto, que tem sua sede afastada da rodovia e dinâmica mais próxima de município dormitório. Por outro lado, foi incorporado a este processo, neste momento, o município de Pirenópolis, que possui economia ligada ao turismo.

Luziânia apresenta um caso singular nesta divisão, já que em seu território tem se desenrolado processos próximos à expansão metropolitana e à expansão da agropecuária moderna. Uma parte significativa de seu território cumpre função típica de dormitório, especialmente o bairro Jardim Ingá. Já o centro da cidade e sua porção sul aparentam maior ligação com as dinâmicas do agronegócio moderno. Por este motivo, o município foi classificado como sendo área de múltiplas influências.

Os outros municípios, especialmente a norte e noroeste do Distrito Federal tem a produção de seus espaços associados a outros processos. Nestes, há uma ligação histórica com a agropecuária tradicional, algo que parece se manter no momento.

A atuação destes três processos, especialmente da expansão da agropecuária moderna e a integração do Eixo Brasília-Anápolis-Goiânia são expressões mais claras do processo de reestruturação produtiva. Isto porque a atividade agropecuária moderna tende a reproduzir as características vistas em outros espaços nacionais, como a seletividade e o estabelecimento de relações de "comando" com centros de controle estrangeiros à região. No caso do Eixo, diversos novos investimentos, como plantas fabris, e mesmo alguma expansão da atividade agropecuária moderna expressam a associação à reestruturação produtiva. Mesmo a manutenção de Brasília como centro de gestão e controle do território corresponde a tal característica, vista, no capítulo 5, para os outros centros metropolitanos. Obviamente, no caso da metrópole brasiliense, esta tendência é fortemente reforçada pelo caráter administrativo perene que a cidade possui (e que parece se reforçar com a reestruturação).

Os efeitos que estes três processos causam sobre a estrutura regional, especificamente a produção de subcentros e as desigualdades socioespaciais é o objeto de análise do próximo capítulo. 


\section{A PRODUÇÃO DE SUBCENTROS E AS DESIGUALDADES SOCIOESPACIAIS NA RIDE-DF}

Considerando os três processos analisados como estruturadores da Ride-DF (expansão metropolitana, expansão da agropecuária moderna e integração do Eixo BrasíliaAnápolis-Goiânia), e à medida que estes três processos aí atuam, ocorrem mudanças significativas na estrutura econômica. É significativo, assim, analisar modificações em tal estrutura, especialmente no que tange à produção de subcentros regionais e modificações no quadro das desigualdades socioespaciais. A análise destas modificações é o objetivo deste capítulo, que visa explorar a quarta questão de pesquisa: "Como se relacionam os processos de consolidação de Brasília como centro principal e de produção de subcentros regionais, associados à dinâmica de desigualdades socioespaciais na Ride-DF?”.

\subsection{A produção de subcentros na Ride-DF}

Embora a formação de nucleações urbanas possa ser visível e sua percepção intuitiva, do ponto de vista de uma compreensão do papel que elas exercem nos processos socioeconômicos urbanos e regionais, a observação simples ou mesmo a consulta a dados estatísticos oferece apenas uma aproximação. A análise da produção de subcentros na Ride-DF comporta, obrigatoriamente, um processo de identificação destes espaços. Para tanto, a partir das características e dimensões enunciadas no Capítulo 4, foi criado um modelo específico de análise, descrito abaixo. Após a descrição deste, são descritos e analisados os resultados de sua aplicação.

\subsubsection{O modelo de análise utilizado}

O modelo proposto visa, especificamente, tornar operacional o conceito de "centro" e "subcentro", focando, principalmente, na perspectiva de sua identificação. É importante ressaltar que não se objetiva identificar centros e subcentros intraurbanos em cada um dos municípios e no Distrito Federal que compõem a Ride-DF e, mesmo por isto, o município é considerado a unidade elementar da análise. Por toda a discussão apresentada, o Distrito Federal é, de antemão, identificado como centro principal, sendo a tarefa principal o reconhecimento dos subcentros. 
Para tanto, a perspectiva do centro, enquanto elemento da estrutura regional, foi dividia em três dimensões (que consideram, principalmente, o posto na subseção 4.1.2 deste trabalho): a densidade de empregos, a complexidade funcional e a polarização.

A primeira dimensão (ou aspecto) foi identificada a partir de um método em um dos procedimentos propostos por Duarte et al (2010) ${ }^{34}$. A densidade de empregos é avaliada tendo como fonte principal os dados sobre o número de empregos da Relação Anual de Informações Sociais (Rais) do Ministério do Trabalho e Emprego (MTE) e a população residente nos municípios (de acordo com o Censo de 2010). Assim, é considerado de "alta densidade" o município que possuir, ao mesmo tempo, as seguintes condições: mais de 1\% do total de empregos e um valor de empregos per capita acima do mesmo valor registrado para a região. Caso o município atenda a apenas uma das condições, foi considerado de "média densidade"; caso não tenha atendido nenhuma delas, foi considerado de "baixa densidade" de empregos. A escolha dos critérios visa, primeiramente, aferir uma densidade mínima em relação ao emprego nos municípios e, em seguida, avaliar a significância deste em relação ao restante da região (razão pela qual utiliza-se o valor de empregos per capita como segunda medida). $\mathrm{O}$ valor de 1\% foi extraído de Duarte et al (2010), e o método de aferição da densidade é próximo do de Giuliano e Small (1991), sendo estes dois trabalhos que exploram a densidade de empregos como indicador de centralidade. Considerando o peso do Distrito Federal no total de empregos, a análise comparou apenas os municípios do Entorno entre si, comparando, apenas de forma secundária, os dados com o Distrito Federal.

A segunda dimensão, a complexidade funcional, buscou avaliar a caracterização ou não de certas funções, ligadas à centralidade regional. Tal centralidade é aqui posta de forma próxima àquela em geral posta nos trabalhos do IBGE: está mais próxima de uma centralidade o município que exerce maior número de funções. Os critérios utilizados variaram, sendo que, em alguns casos (especialmente os que avaliam densidade de empresas, por setor - como no caso do apoio à agropecuária), foram utilizados os critérios de aferição de densidade mencionados no parágrafo anterior. Em outros (como para a presença de equipamentos de saúde), a simples presença/ ausência dos equipamentos ou de uma quantidade deles foi utilizada como critério. As funções analisadas e os indicadores utilizados foram os seguintes:

\footnotetext{
${ }^{34}$ A adaptação diz respeito ao uso da população para comparação entre os municípios, sendo que, no estudo de Duarte et al (2010) o critério utilizado é a área dos municípios. Considerando o tamanho, muito variável, dos municípios da Ride-DF, optou-se pelo uso da população com a finalidade de evitar que municípios territorialmente muito pequenos tivessem valores da densidade de empregos considerados relevantes o tempo todo.
} 
- Função comercial: densidade de empresas do setor comercial; presença de equipamentos de consumo de grande porte;

- Função de prestação de serviços financeiros: densidade de agências bancárias;

- Função de prestação de serviços educacionais superiores: densidade de matrículas no ensino superior;

- Função de prestação de serviços de saúde: densidade de leitos; presença e especialidade de hospitais; densidade de procedimentos cirúrgicos.

- Função de prestação de serviços públicos do Executivo Federal: presença de agências de prestação de serviço do governo federal;

- Função de prestação de serviços públicos do Judiciário: presença de sedes de varas ou tribunais estaduais ou federais;

- Função de apoio à atividade agropecuária: densidade de empresas (unidades) de agricultura, pecuária e serviços relacionados; densidade de empregos nas empresas (unidades) de agricultura, pecuária e serviços relacionados.

A partir de critérios específicos para cada função, cada uma foi classificada como sendo "caracterizada", "parcialmente caracterizada" ou "não caracterizada". Finalmente, ao término da operação com todas as funções, estas foram comparadas com as funções existentes no centro principal (Distrito Federal). Este é tomado apenas como referência, não estando propriamente na comparação proposta. Para os resultados finais, foi atribuída pontuação ao resultado da caracterização das funções, correspondendo dois pontos para cada função considerada "caracterizada", um ponto para cada função "parcialmente caracterizada" e zero pontos para cada função "não caracterizada". Considerando o Distrito Federal como o parâmetro para a definição dos subcentros, ao término do somatório dos pontos, adotou-se o seguinte critério: "complexidade elevada" caso a pontuação final tenha correspondido a dois terços ou mais do valor da pontuação do centro principal; "complexidade intermediária", caso a pontuação final tenha sido menor que dois terços e maior ou igual a um terço da pontuação do centro principal; "complexidade baixa" caso a pontuação tenha sido menor que um terço da pontuação do centro principal. Por se buscar considerar ao menos três intervalos possíveis para a caracterização das funções, adotou-se um critério matemático objetivo, daí a divisão a partir de "terços" do valor do centro principal. Esta dimensão teve como fonte diversos dados, mas a maior parte proveio da pesquisa do Cadastro Central de Empresas e da Pesquisa sobre Gestão do Território, ambas elaboradas pelo IBGE. 
Finalmente, a terceira dimensão analisada diz respeito à polarização. Esta foi mensurada a partir da mobilidade, tendo como base dados sobre trabalho (local de trabalho) e uso de equipamentos de educação (uso de equipamentos de saúde e educação em outros municípios). Foi calculada a polarização por outro município a partir dos dados sobre o local de moradia e de trabalho. Inicialmente, foi considerado o percentual máximo de pessoas que trabalhavam em outro município. O município de maior valor foi considerado parâmetro (pois não se encontrou, na literatura, um valor paramétrico para tanto e se buscou um valor de referência para a realidade regional em estudo) e a polarização foi definida a partir do percentual dos outros municípios, sendo assim considerado: número de pessoas que trabalhavam fora do município de residência igual ou acima de $66,6 \%$ do percentual máximo (percentual máximo corresponde ao valor do município de maior percentual): "polarização por outro município" caracterizada; abaixo de $66,6 \%$ e maior ou igual a 33,3\% do percentual máximo: polarização "parcialmente caracterizada"; igual ou abaixo de 33,3\% do percentual máximo: polarização "não caracterizada". O mesmo procedimento foi realizado em relação à educação. Depois, os dois valores foram comparados, e, a partir das seguintes combinações, os municípios foram considerados na seguinte tipologia: "elevada polarização por outro município"; "média polarização por outro município"; "baixa polarização por outro município”. Os dados de origem para este procedimento provêm dos dados da amostra do Censo Demográfico 2010 do IBGE.

Ao término, foi montado um quadro geral com os resultados das três dimensões, que permitiu averiguar a existência dos subcentros na Ride-DF. Considerando as três dimensões analisadas e seus resultados, foi atribuída a seguinte pontuação, de acordo com os seguintes resultados:

- Dimensão 1 - densidade de empregos: alta - 2 pontos; média - 1 ponto; baixa - 0 pontos.

- Dimensão 2 - complexidade funcional: elevada - 2 pontos; intermediária - 1 ponto; reduzida -0 pontos.

- Dimensão 3 - polarização (pelo centro principal ou por outro município): baixa - 2 pontos; média - 1 ponto; alta -0 pontos.

A partir do somatório dos pontos, e considerando que os subcentros são formas menos comuns na estrutura econômica regional (daí a necessidade de mais elementos para sua 
caracterização ${ }^{35}$ ), os municípios foram classificados ou não como subcentros a partir do seguinte critério:

- "subcentro": 6 pontos;

- "subcentro emergente": 4 ou 5 pontos;

- "não caracterizado": 3 pontos ou menos.

O item abaixo inicia a apresentação dos resultados, por dimensões.

\subsubsection{Dimensão 1 -densidade de empregos}

A partir do método descrito para a análise desta dimensão, o resultado, utilizando dados da Rais de 2014 e do Censo de 2010, foram os seguintes, descritos na Tabela 9.1. Nas colunas "número total de empregos no município" e " $\mathrm{n}^{\mathrm{o}}$ de empregos per capita" aparecem destacados os valores que atendem aos critérios postos para a densidade de empregos (lembrando que é considerada alta densidade nos municípios que atendem os dois critérios).

Assim, o resultado do cálculo da densidade de empregos aponta para uma alta densidade nos municípios de Abadiânia, Alexânia, Cristalina, Formosa, Luziânia, Pirenópolis, Valparaíso, Buritis e Unaí. Todos os outros municípios (a exceção de Corumbá de Goiás) foram considerados de média densidade. A título de comparação, e evidenciado o maior peso da economia de Brasília na região, nenhum município possui número de empregos per capita sequer igual ao da Ride-DF como um todo, considerando Brasília.

\footnotetext{
${ }^{35}$ Considerando que a maior parte das dimensões foi explorada a partir de comparações dos municípios da RideDF entre si sem o Distrito Federal, é necessário estabelecer um critério mais rigoroso para a caracterização dos subcentros, uma vez que as assimetrias entre os municípios são menores e haveria o risco de considerar municípios que manifestadamente não possuem características de subcentros como o sendo.
} 
Tabela 9.1 - Número total de empregos no município, população e densidade de empregos nos municípios da Ride-DF

\begin{tabular}{|c|c|c|c|c|}
\hline Município & $\begin{array}{l}\text { Número total } \\
\text { de empregos } \\
\text { no município } \\
(2013)\end{array}$ & $\begin{array}{l}\text { População } \\
(2010)\end{array}$ & $\begin{array}{l}\mathrm{N}^{o} \text { de } \\
\text { empregos } \\
\text { per capita }\end{array}$ & $\begin{array}{l}\text { Densidade de } \\
\text { empregos }\end{array}$ \\
\hline Abadiânia - GO & 2.171 & 15.757 & 0,1378 & Alta \\
\hline Água Fria de Goiás - GO & 790 & 5.090 & 0,1552 & Média \\
\hline Águas Lindas de Goiás - GO & 10.845 & 159.378 & 0,0680 & Média \\
\hline Alexânia - GO & 4.329 & 23.814 & 0,1818 & Alta \\
\hline Cabeceiras - GO & 901 & 7.354 & 0,1225 & Média \\
\hline Cidade Ocidental - GO & 3.928 & 55.915 & 0,0702 & Média \\
\hline Cocalzinho de Goiás - GO & 1.484 & 17.407 & 0,0853 & Média \\
\hline Corumbá de Goiás - GO & 1.038 & 10.361 & 0,1002 & Baixa \\
\hline Cristalina - GO & 11.516 & 46.580 & 0,2472 & Alta \\
\hline Formosa - GO & 14.799 & 100.085 & 0,1479 & Alta \\
\hline Luziânia - GO & 22.299 & 174.531 & 0,1278 & Alta \\
\hline Mimoso de Goiás - GO & 400 & 2.685 & 0,1490 & Média \\
\hline Novo Gama - GO & 4.711 & 95.018 & 0,0496 & Média \\
\hline Padre Bernardo - GO & 2.670 & 27.671 & 0,0965 & Média \\
\hline Pirenópolis - GO & 3.814 & 23.006 & 0,1658 & Alta \\
\hline Planaltina - GO & 6.542 & 81.649 & 0,0801 & Média \\
\hline Santo Antônio do Descoberto - GO & 4.723 & 63.248 & 0,0747 & Média \\
\hline Valparaíso de Goiás - GO & 16.270 & 132.982 & 0,1223 & Alta \\
\hline Vila Boa - GO & 928 & 4.735 & 0,1960 & Média \\
\hline Buritis - MG & 3.515 & 22.737 & 0,1546 & Alta \\
\hline Cabeceira Grande - MG & 791 & 6.453 & 0,1226 & Média \\
\hline Unaí - MG & 17.031 & 77.565 & 0,2196 & Alta \\
\hline Municípios do Entorno & 135.495 & 1.154.024 & 0,1174 & \\
\hline Brasília - DF & 1.321 .758 & 2.570 .160 & 0,5143 & Centro principal \\
\hline Ride-DF & 1.457 .253 & 3.724 .184 & 0,3913 & \\
\hline
\end{tabular}

Fonte: RAIS/MTE, IBGE (dados tratados pelo autor)

Os resultados apontam para uma maior concentração de empregos em alguns dos municípios associados ao processo de expansão metropolitana de Brasília: Luziânia e Valparaíso. Isto demonstra como este processo de expansão da metrópole brasiliense tem ainda um forte componente de concentração de empregos. Associado ao processo de expansão da agropecuária moderna surgem os municípios de Cristalina, Formosa, Buritis e Unaí. Já associados ao processo de integração do Eixo Brasília-Anápolis-Goiânia estão Abadiânia, Alexânia e Pirenópolis (este último com maior concentração se devendo, provavelmente, ao turismo).

Desta forma, percebe-se que os municípios que concentram as maiores somas de população e onde tem ocorrido o processo de metropolização ainda tendem a cumprir papel de 
dormitório dos trabalhadores, que provavelmente trabalham em Brasília. Já o agronegócio moderno tende a concentrar empregos nos municípios que prestam a maior parte do apoio à sua produção.

\subsubsection{Dimensão 2 - Complexidade funcional}

Considerando o interesse em analisar o tema da complexidade funcional, a primeira função a ser analisada é a comercial, que buscou ser caracterizada a partir de dois indicadores diferentes: densidade de empresas dos setores comerciais; presença de grandes equipamentos de consumo. Abaixo, na Tabela 9.2, estão os resultados referentes ao cálculo da densidade ${ }^{36}$ de empresas (unidades) do setor comercial - aparecem marcados, nas colunas "total de unidade do setor" e "unidades do setor per capita" os valores que atendem aos critérios para determinação da densidade.

O resultado para o primeiro indicador da função comercial aponta valores significantes para os municípios de Alexânia, Cocalzinho de Goiás, Cristalina, Formosa, Luziânia, Padre Bernardo, Pirenópolis, Buritis e Unaí. São considerados como parcialmente significantes os resultados para Abadiânia, Águas Lindas de Goiás, Cidade Ocidental, Novo Gama, Planaltina, Santo Antônio do Descoberto e Valparaíso de Goiás. Do resultado, a densidade somente foi considerada significante em um único município mais claramente atingido pela expansão metropolitana: Luziânia. Muitos dos municípios do espaço metropolizado aparecem na categoria "parcialmente significante". Nos outros, diversos estão associados à agropecuária moderna (Cristalina, Formosa, Buritis e Unaí), com valores mais significantes.

\footnotetext{
${ }^{36}$ Para todos os indicadores que consideram "densidade", o método de cálculo foi o mesmo do cálculo da densidade de empregos, da subseção 9.1.2, sendo utilizados aí os mesmos critérios.
} 
Tabela 9.2 - Total de unidades do setor comercial, unidade do setor comercial per capita e densidade de empresas do setor comercial, para os municípios da Ride-DF - 2014

\begin{tabular}{|c|c|c|c|c|}
\hline Município & $\begin{array}{l}\text { Total de } \\
\text { unidades } \\
\text { do } \\
\text { setor }^{37} \text { - } \\
2014 \\
\end{array}$ & $\begin{array}{l}\text { População } \\
\text { - Censo } \\
2010\end{array}$ & $\begin{array}{l}\text { Unidades } \\
\text { do setor } \\
\text { per } \\
\text { capita }^{38}\end{array}$ & Resultado \\
\hline Abadiânia - GO & 108 & 15.757 & 0,69 & Parcialmente significante \\
\hline Água Fria de Goiás - GO & 24 & 5.090 & 0,47 & Não Significante \\
\hline Águas Lindas de Goiás - GO & 1.093 & 159.378 & 0,69 & Parcialmente significante \\
\hline Alexânia - GO & 294 & 23.814 & 1,23 & Significante \\
\hline Cabeceiras - GO & 61 & 7.354 & 0,83 & Não Significante \\
\hline Cidade Ocidental - GO & 350 & 55.915 & 0,63 & Parcialmente significante \\
\hline Cocalzinho de Goiás - GO & 160 & 17.407 & 0,92 & Significante \\
\hline Corumbá de Goiás - GO & 51 & 10.361 & 0,49 & Não Significante \\
\hline Cristalina - GO & 539 & 46.580 & 1,16 & Significante \\
\hline Formosa - GO & 1.381 & 100.085 & 1,38 & Significante \\
\hline Luziânia - GO & 1.520 & 174.531 & 0,87 & Significante \\
\hline Mimoso de Goiás - GO & 7 & 2.685 & 0,26 & Não Significante \\
\hline Novo Gama - GO & 426 & 95.018 & 0,45 & Parcialmente significante \\
\hline Padre Bernardo - GO & 320 & 27.671 & 1,16 & Significante \\
\hline Pirenópolis - GO & 217 & 23.006 & 0,94 & Significante \\
\hline Planaltina - GO & 613 & 81.649 & 0,75 & Parcialmente significante \\
\hline Sto. Ant. Descoberto - GO & 287 & 63.248 & 0,45 & Parcialmente significante \\
\hline Valparaíso de Goiás - GO & 1.036 & 132.982 & 0,78 & Parcialmente significante \\
\hline Vila Boa - GO & 32 & 4.735 & 0,68 & Não Significante \\
\hline Buritis - MG & 212 & 22.737 & 0,93 & Significante \\
\hline Cabeceira Grande - MG & 36 & 6.453 & 0,56 & Não Significante \\
\hline Unaí - MG & 1.082 & 77.565 & 1,39 & Significante \\
\hline Municípios do Entorno & 9.849 & 1.154.021 & $\mathbf{0 , 8 5}$ & \\
\hline Brasília - DF & 32.073 & 2.570 .160 & 1,25 & Centro Principal \\
\hline Ride-DF & 41.922 & 3.724 .181 & 1,13 & \\
\hline
\end{tabular}

Fonte: IBGE - Cadastro Central de Empresas

O segundo indicador da função comercial diz respeito aos grandes equipamentos de consumo presentes nos municípios da Ride-DF. Foram considerados, principalmente, a presença de shoppings centers e de algumas grandes lojas de departamento, que caracterizam grandes centros comerciais. A partir da coleta destas informações, o resultado foi considerado significante para a caracterização da função caso o município possuísse uma loja das cadeias selecionadas ou um shopping center, sendo considerado como não significante os municípios

\footnotetext{
${ }^{37}$ O Setor aqui considerado refere-se ao setor "G - Comércio; reparação de veículos automotores e motocicletas" da Classificação Nacional de Atividades Econômicas (CNAE).

${ }^{38}$ Resultados multiplicados por cem.
} 
que não possuíam qualquer uma das lojas selecionadas ou shopping center ${ }^{39}$. $\mathrm{O}$ resultado aparece abaixo, na tabela 9.3:

Tabela 9.3 - Grandes equipamentos de consumo na Ride-DF - 2016

\begin{tabular}{|c|c|c|c|c|c|c|}
\hline \multirow[b]{2}{*}{ Município } & \multirow{2}{*}{$\begin{array}{l}\text { Shopping } \\
\text { Centers }\end{array}$} & \multicolumn{4}{|c|}{ Lojas de Departamento } & \multirow[b]{2}{*}{ Resultado } \\
\hline & & C\&A & Riachuelo & \begin{tabular}{|l|} 
Lojas \\
Americanas
\end{tabular} & & \\
\hline Abadiânia - GO & - & & - & & - & Não significante \\
\hline Água Fria de Goiás - GO & - & & - & & - & Não significante \\
\hline Águas Lindas de Goiás - GO & 1 & & - & & 2 & Significante \\
\hline Alexânia - GO & 1 & & - & & - & Significante \\
\hline Cabeceiras - GO & - & & - & & - & Não significante \\
\hline Cidade Ocidental - GO & - & & - & & - & Não significante \\
\hline Cocalzinho de Goiás - GO & - & & - & & - & Não significante \\
\hline Corumbá de Goiás - GO & - & & - & & - & Não significante \\
\hline Cristalina - GO & - & & - & & - & Não significante \\
\hline Formosa - GO & - & & - & & 1 & Significante \\
\hline Luziânia - GO & 1 & & - & & 1 & Significante \\
\hline Mimoso de Goiás - GO & - & & - & & - & Não significante \\
\hline Novo Gama - GO & - & & - & & 1 & Significante \\
\hline Padre Bernardo - GO & - & & - & & - & Não significante \\
\hline Pirenópolis - GO & - & & - & & - & Não significante \\
\hline Planaltina - GO & - & & - & & - & Não significante \\
\hline Santo Antônio do Descoberto - GO & - & & - & & - & Não significante \\
\hline Valparaíso de Goiás - GO & 1 & & 1 & & 1 & Significante \\
\hline Vila Boa - GO & - & & - & & - & Não significante \\
\hline Buritis - MG & - & & - & & - & Não significante \\
\hline Cabeceira Grande -MG & - & & - & & - & Não significante \\
\hline Unaí - MG & - & & - & & - & Não significante \\
\hline Brasília - DF & 21 & & 8 & & 7 & Centro principal \\
\hline
\end{tabular}

Fontes: ABRASCE, C\&A, Riachuelo, Lojas Americanas (dados tratados pelo autor)

Os resultados apontam que os grandes equipamentos de consumo se encontram concentrados em poucos municípios além do centro principal, sendo eles: Águas Lindas de Goiás, Alexânia, Formosa, Luziânia, Novo Gama e Valparaíso de Goiás. Em comum estes municípios possuem a participação no processo de metropolização de Brasília. Fica claro o efeito causado pela elevação da renda nestes municípios, cujo crescimento foi impulsionado, principalmente, pela emigração de população do Distrito Federal: tendo um maior poder de consumo, passam a demandar bens e serviços mais próximos de si. Por outro lado, é notável o

\footnotetext{
${ }^{39}$ Considerando a pouca ocorrência destes equipamentos pelos municípios, decidiu-se pela eliminação de uma categoria intermediária de resultado "parcialmente significante", considerando a simples existência de uma das lojas ou shopping center como suficiente para que o indicador fosse significante.
} 
caso de Valparaíso de Goiás, que possui pelo menos um shopping e uma de cada uma das lojas selecionadas, o que indica sua tendência de consolidação como polo de consumo ao sul do Distrito Federal.

Ao término da análise do resultado dos dois indicadores, houve a sua compilação em um quadro (Quadro 9.1) e extraída daí a caracterização da função comercial. Desta forma, a função foi considerada como "caracterizada" caso o município possuísse os dois indicadores considerados "significantes"; foi considerada "parcialmente caracterizada" caso apenas um indicador fosse considerado "significante" (ou se os dois fossem considerados "parcialmente significantes"); foi considerada "não caracterizada" caso nenhum indicador fosse considerado significante (ou apenas um considerado "parcialmente significante").

A partir da análise do Quadro 9.1, vê-se que a função foi considerada "caracterizada" nos municípios de Alexânia, Formosa e Luziânia. Determinante para tanto foi o fato de nestes três municípios haver grandes equipamentos de consumo, associados a uma densidade mais significativa de empresas do setor comercial. Chama a atenção o resultado para o caso de Valparaíso de Goiás, que possui grandes equipamentos, mas não uma densidade que caracterizasse a função comercial no município. Além de Valparaíso de Goiás, foram classificados ainda como tendo a função comercial parcialmente caracterizada: Águas Lindas de Goiás, Cocalzinho de Goiás, Cristalina, Novo Gama, Padre Bernardo, Pirenópolis, Buritis e Unaí. 
Quadro 9.1 - Comparativo dos resultados para a função comercial para os municípios da Ride-DF

\begin{tabular}{|c|c|c|c|}
\hline Município & $\begin{array}{l}\text { Densidade de empresas } \\
\text { do setor comercial }\end{array}$ & $\begin{array}{l}\text { Presença de } \\
\text { equipamentos de } \\
\text { consumo de } \\
\text { grande porte }\end{array}$ & Caracterização da função \\
\hline Abadiânia - GO & Parcialmente significante & Não significante & Não caracterizada \\
\hline Água Fria de Goiás - GO & Não significante & Não significante & Não caracterizada \\
\hline Ág. Lindas de Goiás - GO & Parcialmente significante & Significante & Parcialmente caracterizada \\
\hline Alexânia - GO & Significante & Significante & Caracterizada \\
\hline Cabeceiras - GO & Não significante & Não significante & Não caracterizada \\
\hline Cidade Ocidental - GO & Parcialmente significante & Não significante & Não caracterizada \\
\hline Cocalzinho de Goiás - GO & Significante & Não significante & Parcialmente caracterizada \\
\hline Corumbá de Goiás - GO & Não significante & Não significante & Não caracterizada \\
\hline Cristalina - GO & Significante & Não significante & Parcialmente caracterizada \\
\hline Formosa - GO & Significante & Significante & Caracterizada \\
\hline Luziânia - GO & Significante & Significante & Caracterizada \\
\hline Mimoso de Goiás - GO & Não significante & Não significante & Não caracterizada \\
\hline Novo Gama - GO & Parcialmente significante & Significante & Parcialmente caracterizada \\
\hline Padre Bernardo - GO & Significante & Não significante & Parcialmente caracterizada \\
\hline Pirenópolis - GO & Significante & Não significante & Parcialmente caracterizada \\
\hline Planaltina - GO & Parcialmente significante & Não significante & Não caracterizada \\
\hline St. Ant. Descoberto - GO & Parcialmente significante & Não significante & Não caracterizada \\
\hline Valparaíso de Goiás - GO & Parcialmente significante & Significante & Parcialmente caracterizada \\
\hline Vila Boa - GO & Não significante & Não significante & Não caracterizada \\
\hline Buritis - MG & Significante & Não significante & Parcialmente caracterizada \\
\hline Cabeceira Grande -MG & Não significante & Não significante & Não caracterizada \\
\hline Unaí - MG & Significante & Não significante & Parcialmente caracterizada \\
\hline Brasília - DF & Significante & Significante & Centro Principal \\
\hline
\end{tabular}

Fonte: elaboração própria

Após a função comercial, inicia-se a análise da função de prestação de serviços, sendo o primeiro serviço analisado o bancário. A caracterização da função serviços bancários foi feita a partir de um indicador único, a densidade de agências, cujos resultados estão na Tabela 9.4. 
Tabela 9.4 - Número de agências bancárias, população, agências bancárias per capita e resultado do cálculo de densidade das agências bancárias para a Ride-DF

\begin{tabular}{|c|c|c|c|c|}
\hline Municípios & $\begin{array}{l}\text { Número } \\
\text { de } \\
\text { Agências } \\
\text { Bancárias }\end{array}$ & $\begin{array}{l}\text { População } \\
\text { (Censo } \\
\text { 2010) }\end{array}$ & $\begin{array}{l}\text { Agências } \\
\text { bancárias per } \\
\text { capita }^{40}\end{array}$ & $\begin{array}{l}\text { Função de prestação de } \\
\text { serviços bancários }\end{array}$ \\
\hline Abadiânia - GO & 2 & 15.757 & 0,13 & Caracterizada \\
\hline Água Fria de Goiás - GO & - & 5.090 & - & Não caracterizada \\
\hline Águas Lindas de Goiás - GO & 6 & 159.378 & 0,04 & Parcialmente caracterizada \\
\hline Alexânia - GO & 4 & 23.814 & 0,17 & Caracterizada \\
\hline Cabeceiras - GO & 1 & 7.354 & 0,14 & Caracterizada \\
\hline Cidade Ocidental - GO & 3 & 55.915 & 0,05 & Parcialmente caracterizada \\
\hline Cocalzinho de Goiás - GO & 2 & 17.407 & 0,11 & Caracterizada \\
\hline Corumbá de Goiás - GO & 3 & 10.361 & 0,29 & Caracterizada \\
\hline Cristalina - GO & 4 & 46.580 & 0,09 & Caracterizada \\
\hline Formosa - GO & 9 & 100.085 & 0,09 & Caracterizada \\
\hline Luziânia - GO & 11 & 174.531 & 0,06 & Parcialmente caracterizada \\
\hline Mimoso de Goiás - GO & - & 2.685 & - & Não caracterizada \\
\hline Novo Gama - GO & 5 & 95.018 & 0,05 & Parcialmente caracterizada \\
\hline Padre Bernardo - GO & 3 & 27.671 & 0,11 & Caracterizada \\
\hline Pirenópolis - GO & 4 & 23.006 & 0,17 & Caracterizada \\
\hline Planaltina - GO & 5 & 81.649 & 0,06 & Parcialmente caracterizada \\
\hline Sto. Ant. do Descoberto - GO & 5 & 63.248 & 0,08 & Caracterizada \\
\hline Valparaíso de Goiás - GO & 7 & 132.982 & 0,05 & Parcialmente caracterizada \\
\hline Vila Boa - GO & - & 4.735 & - & Parcialmente caracterizada \\
\hline Buritis - MG & 3 & 22.737 & 0,13 & Caracterizada \\
\hline Cabeceira Grande - MG & - & 6.453 & - & Não caracterizada \\
\hline Unaí - MG & 7 & 77.565 & 0,09 & Caracterizada \\
\hline Municípios do Entorno & 84 & 1.154.021 & $\mathbf{0 , 0 7}$ & \\
\hline Brasília - DF & 453 & 2.570 .160 & 0,18 & Centro Principal \\
\hline Ride-DF & 537 & 3.724.181 & $\mathbf{0 , 1 4}$ & \\
\hline
\end{tabular}

Fonte: Banco Central do Brasil (dados tratados pelo autor)

A análise dos dados da Tabela 9.4 aponta que a função de prestação de serviços bancários encontra-se caracterizada nos municípios de Abadiânia, Alexânia, Cabeceiras, Cocalzinho de Goiás, Corumbá de Goiás, Cristalina, Formosa, Padre Bernardo, Pirenópolis, Santo Antônio do Descoberto, Buritis e Unaí. Desta forma, diversos municípios tem a função caracterizada, o que indica que a função se tornou comum em diversos municípios. Novamente, diversos dos municípios do espaço metropolizado aparecem com a função parcialmente caracterizada (Águas Lindas de Goiás, Cidade Ocidental, Novo Gama, Luziânia, Planaltina, Valparaíso de Goiás), o que indica, novamente, a concentração da função em torno do centro

\footnotetext{
${ }^{40}$ Resultados multiplicados por mil.
} 
principal, Brasília. Há uma tendência de não existência de agências em maior quantidade nos municípios mais populosos e nos ligados à dinâmica metropolitana de Brasília na Ride-DF, provavelmente pelo uso de agências no Distrito Federal, dada a pendularidade dos trabalhadores destes municípios. A questão da presença e ausência de agências deve considerar ainda outros dois aspectos: por um lado, o uso mais frequente de serviços bancários que prescindem a presença física do usuário do serviço (uso do internet banking); por outro, o fato de que a presença física de agências nos municípios pode estar ligada à realização de operações bancárias de mais alto vulto, como aquelas do crédito agrícola.

Ainda no campo da prestação de serviços, a próxima função analisada diz respeito à prestação de serviços de educação superior, que possuem alto potencial de polarização. Sua análise se deu pela densidade de matrículas no ensino superior, que englobam tanto a modalidade presencial quanto à distância. A Tabela 9.5 apresenta os dados e o resultado quanto à caracterização da função.

Os dados apontam que a função se encontra caracterizada nos municípios de Cristalina, Formosa, Luziânia, Valparaíso de Goiás e Unaí. A função foi considerada parcialmente caracterizada nos municípios de Águas Lindas de Goiás, Alexânia, Cidade Ocidental, Cocalzinho de Goiás, Padre Bernardo, Pirenópolis, Planaltina e Santo Antônio do Descoberto. Verifica-se, no caso deste indicador, uma densidade mais acentuada em municípios ligados, alguns deles, à dinâmica metropolitana, casos de Valparaíso de Goiás e Luziânia, e outros ligados ao processo de expansão da agropecuária moderna, casos de Cristalina, Formosa e Unaí. Estas últimas atividades exigem uma maior quantidade de pessoal formado em nível superior (ou tecnológico superior) com a finalidade de operação dos modernos equipamentos da agricultura. Já no caso dos municípios ligados à dinâmica metropolitana, especialmente no caso de Valparaíso de Goiás, tal qualificação tende a atender as demandas existentes de um mercado mais voltado ao setor de serviços de Brasília. É notável, por outro lado, a concentração de matrículas em Brasília, mas a existência, na maior parte dos municípios da Ride-DF, de matriculados em ensino superior, o que está ligado à oferta de ensino à distância, muito presente nestes municípios. Como se verá nos dados sobre a mobilidade (dimensão 3), isto leva a fluxos pendulares entre os municípios (especialmente os do sul do Distrito Federal) e Brasília. 
Tabela 9.5 - Densidade de matrículas, número de matrículas de nível superior, população e matrículas per capita, nos municípios da Ride-DF.

\begin{tabular}{|c|c|c|c|c|}
\hline Municípios & $\begin{array}{l}\mathrm{N}^{\mathrm{o}} \text { de } \\
\text { matrículas } \\
-2012\end{array}$ & $\begin{array}{l}\text { População } \\
\text { (Censo } \\
\text { 2010) }\end{array}$ & $\begin{array}{l}\text { Matrículas } \\
\text { per } \\
\text { capita }^{4 l}\end{array}$ & Função \\
\hline Abadiânia - GO & - & 15.757 & - & Não caracterizada \\
\hline Água Fria de Goiás - GO & - & 5.090 & - & Não caracterizada \\
\hline Águas Lindas de Goiás - GO & 819 & 159.378 & 5,14 & Parcialmente caracterizada \\
\hline Alexânia - GO & 335 & 23.814 & 14,07 & Parcialmente caracterizada \\
\hline Cabeceiras - GO & - & 7.354 & - & Não caracterizada \\
\hline Cidade Ocidental - GO & 308 & 55.915 & 5,51 & Parcialmente caracterizada \\
\hline Cocalzinho de Goiás - GO & - & 17.407 & - & Não caracterizada \\
\hline Corumbá de Goiás - GO & - & 10.361 & - & Não caracterizada \\
\hline Cristalina - GO & 1.217 & 46.580 & 26,13 & Caracterizada \\
\hline Formosa - GO & 4.719 & 100.085 & 47,15 & Caracterizada \\
\hline Luziânia - GO & 4.445 & 174.531 & 25,47 & Caracterizada \\
\hline Mimoso de Goiás - GO & - & 2.685 & - & Não caracterizada \\
\hline Novo Gama - GO & 198 & 95.018 & 2,08 & Não caracterizada \\
\hline Padre Bernardo - GO & 246 & 27.671 & 8,89 & Parcialmente caracterizada \\
\hline Pirenópolis - GO & 301 & 23.006 & 13,08 & Parcialmente caracterizada \\
\hline Planaltina - GO & 937 & 81.649 & 11,48 & Parcialmente caracterizada \\
\hline Santo Antônio do Descoberto - GO & 309 & 63.248 & 4,89 & Parcialmente caracterizada \\
\hline Valparaíso de Goiás - GO & 3.654 & 132.982 & 27,48 & Caracterizada \\
\hline Vila Boa - GO & - & 4.735 & - & Não caracterizada \\
\hline Buritis - MG & 23 & 22.737 & 1,01 & Não caracterizada \\
\hline Cabeceira Grande - MG & - & 6.453 & - & Não caracterizada \\
\hline Unaí - MG & 2.630 & 77.565 & 33,91 & Caracterizada \\
\hline Municípios do Entorno & 20.141 & 1.154.021 & 17,45 & \\
\hline Brasília - DF & 191.077 & 2.570 .160 & 74,34 & Centro Principal \\
\hline Ride-DF & 211.218 & 3.724 .181 & 56,72 & \\
\hline
\end{tabular}

Fonte: Inep - InepData

Outra função analisada diz respeito à prestação de serviços públicos por parte do Governo Federal, a partir de agências de órgãos federais presentes nos municípios. Foi levantada a quantidade de agências da Previdência Social, da Receita Federal e Agências Regionais do trabalho. Em geral, estas pertencem a órgãos federais que prestam serviço direto à população, tendo maior capilaridade. A função de prestação de serviços públicos do Executivo Federal foi “caracterizada" caso o município possuísse agências de três ou duas das instituições; foi "parcialmente caracterizada" caso possuísse apenas uma; e "não caracterizada" caso não possuísse qualquer das agências listadas. A Tabela 9.6 apresenta a quantidade de agências e os resultados.

\footnotetext{
${ }^{41}$ Valores multiplicados por mil.
} 
Os resultados apontam a função caracterizada para os municípios de Formosa, Luziânia e Unaí. A função foi parcialmente caracterizada nos municípios de Alexânia, Cidade Ocidental, Cristalina, Padre Bernardo, Pirenópolis, Planaltina, Santo Antônio do Descoberto, Valparaíso de Goiás, Vila Boa e Buritis. Os dados demonstram a tendência de que municípios mais antigos possuam maior quantidade de agências federais, dado pelo peso histórico e pela implantação antiga de muitas das agências. Ainda que a simples presença não diga respeito à abrangência do serviço prestado, nem mesmo sua relação com as atividades econômicas que aí estão, fica indicado que o município desempenha esta função de prestação de serviços (a associação desta prestação com o quadro geral será feita quando todas as funções tiverem sido analisadas). Isto fica patente ao se observar o caso de Valparaíso, município de grande importância comercial e pela densidade de empregos, mas com uma rede de serviços desta função ainda resumida a uma agência da Previdência Social. Aliás, é de se notar a presença na maioria dos municípios de agências desta instituição, o que explica mesmo municípios pequenos terem sido considerados como parcialmente caracterizados na função. 
Tabela 9.6 - Agências da Previdência Social, Receita Federal e Regionais do Trabalho, e resultado quanto à função de prestação de serviços públicos do Executivo Federal - 2016

\begin{tabular}{|c|c|c|c|c|}
\hline Municípios & $\begin{array}{l}\text { Agências da } \\
\text { Previdência } \\
\text { Social }\end{array}$ & $\begin{array}{l}\text { Agências da } \\
\text { Receita } \\
\text { Federal } \\
\text { (Unidades de } \\
\text { Atendimento } \\
\text { ao } \\
\text { Contribuinte) }\end{array}$ & $\begin{array}{l}\text { Agências } \\
\text { Regionais do } \\
\text { trabalho - } \\
\text { MTPS }\end{array}$ & Função \\
\hline Abadiânia - GO & & - & . & Não caracterizada \\
\hline Água Fria de Goiás - GO & & - & - & Não caracterizada \\
\hline Águas Lindas de Goiás - GO & & - & . & Não caracterizada \\
\hline Alexânia - GO & & - & . & Parcialmente caracterizada \\
\hline Cabeceiras - GO & & - & . & Não caracterizada \\
\hline Cidade Ocidental - GO & & - & . & Parcialmente caracterizada \\
\hline Cocalzinho de Goiás - GO & & - & . & Não caracterizada \\
\hline Corumbá de Goiás - GO & & - & . & Não caracterizada \\
\hline Cristalina - GO & & - & . & Parcialmente caracterizada \\
\hline Formosa - GO & & 1 & 1 & Caracterizada \\
\hline Luziânia - GO & & 1 & 1 & Caracterizada \\
\hline Mimoso de Goiás - GO & & - & & Não caracterizada \\
\hline Novo Gama - GO & & - & . & Não caracterizada \\
\hline Padre Bernardo - GO & & - & . & Parcialmente caracterizada \\
\hline Pirenópolis - GO & & - & rata & Parcialmente caracterizada \\
\hline Planaltina - GO & & - & 1 & Parcialmente caracterizada \\
\hline Santo Antônio do Descoberto - GO & & - & r & Parcialmente caracterizada \\
\hline Valparaíso de Goiás - GO & & - & . & Parcialmente caracterizada \\
\hline Vila Boa - GO & & - & . & Não caracterizada \\
\hline Buritis - MG & & - & & Parcialmente caracterizada \\
\hline Cabeceira Grande - MG & & - & & Não caracterizada \\
\hline Unaí - MG & & - & 1 & Caracterizada \\
\hline Brasília - DF & & 2 & 7 & Centro Principal \\
\hline
\end{tabular}

Fontes: Ministério do Trabalho e Previdência Social, Receita Federal do Brasil.

Em seguida, a análise da função de prestação de serviços públicos do Poder Judiciário, considerando tanto a esfera estadual quanto a federal. Para tanto, foram copilados os dados sobre a presença de varas federais do Tribunal Federal da $1^{\text {a }}$ Região - que abrange a região da Ride-DF - varas da Justiça do Trabalho e Varas e Juizados Estaduais ou do Tribunal de Justiça do Distrito Federal e Territórios. No caso deste último, federal, sua atuação é restrita ao Distrito Federal, mas seus dados foram considerados, até para efeito de comparação. A função foi "caracterizada" nos municípios que possuíam ao menos uma das varas dos Poder Judiciário Federal e ao menos uma do Poder Judiciário Estadual. Caso possuísse apenas do Poder Judiciário Estadual, a função foi considerada "parcialmente caracterizada". Caso não 
possuísse qualquer vara, a função foi considerada "não caracterizada". A tabela 9.7 apresenta os resultados.

Tabela 9.7 - Varas da Justiça Federal, da Justiça do Trabalho e do Poder Judiciário Estadual na Ride-DF - 2016

\begin{tabular}{|c|c|c|c|c|}
\hline \multirow[b]{2}{*}{ Municípios } & \multicolumn{2}{|c|}{ Poder Judiciário Federal } & \multirow{2}{*}{\begin{tabular}{l}
\multicolumn{1}{c}{$\begin{array}{c}\text { Poder } \\
\text { Judiciário } \\
\text { Estadual }\end{array}$} \\
Varas e \\
Juizados \\
estaduais \\
e do \\
TJDFT*
\end{tabular}} & \multirow[b]{2}{*}{ Função } \\
\hline & $\begin{array}{l}\text { Justiça } \\
\text { Federal - } \\
\text { TRF 1a } \\
\text { Região - } \\
\text { Varas } \\
\text { Federais }\end{array}$ & $\begin{array}{l}\text { Justiça do } \\
\text { Trabalho } \\
\text { - Varas } \\
\text { do } \\
\text { trabalho }\end{array}$ & & \\
\hline Abadiânia - GO & \multicolumn{2}{|c|}{-} & - & Não caracterizada \\
\hline Água Fria de Goiás - GO & \multicolumn{2}{|c|}{-} & - & Não caracterizada \\
\hline Águas Lindas de Goiás - GO & \multicolumn{2}{|c|}{-} & 5 & Parcialmente caracterizada \\
\hline Alexânia - GO & \multicolumn{2}{|c|}{-} & - & Não caracterizada \\
\hline Cabeceiras - GO & \multicolumn{2}{|c|}{-} & - & Não caracterizada \\
\hline Cidade Ocidental - GO & \multicolumn{2}{|c|}{-} & 4 & Parcialmente caracterizada \\
\hline Cocalzinho de Goiás - GO & \multicolumn{2}{|c|}{-} & - & Não caracterizada \\
\hline Corumbá de Goiás - GO & \multicolumn{2}{|c|}{-} & - & Não caracterizada \\
\hline Cristalina - GO & \multicolumn{2}{|c|}{-} & 4 & Parcialmente caracterizada \\
\hline Formosa - GO & \multicolumn{2}{|c|}{1} & 6 & Caracterizada \\
\hline Luziânia - GO & \multicolumn{2}{|c|}{1} & 7 & Caracterizada \\
\hline Mimoso de Goiás - GO & \multicolumn{2}{|c|}{-} & - & Não caracterizada \\
\hline Novo Gama - GO & \multicolumn{2}{|c|}{-} & 4 & Parcialmente caracterizada \\
\hline Padre Bernardo - GO & \multicolumn{2}{|c|}{-} & 2 & Parcialmente caracterizada \\
\hline Pirenópolis - GO & \multicolumn{2}{|c|}{-} & 2 & Parcialmente caracterizada \\
\hline Planaltina - GO & \multicolumn{2}{|c|}{-} & 4 & Parcialmente caracterizada \\
\hline Santo Antônio do Descoberto - GO & \multicolumn{2}{|c|}{-} & 4 & Parcialmente caracterizada \\
\hline Valparaíso de Goiás - GO & \multicolumn{2}{|c|}{-} & 4 & Caracterizada \\
\hline Vila Boa - GO & \multicolumn{2}{|c|}{-} & - & Não caracterizada \\
\hline Buritis - MG & \multicolumn{2}{|c|}{-} & 1 & Parcialmente caracterizada \\
\hline Cabeceira Grande - MG & \multicolumn{2}{|c|}{-} & - & Não caracterizada \\
\hline Unaí - MG & \multicolumn{2}{|c|}{-} & 4 & Caracterizada \\
\hline Brasília - DF & \multicolumn{2}{|c|}{27} & 226 & Centro principal \\
\hline
\end{tabular}

Fontes: Tribunal Regional Federal da $1^{a}$ Região, Tribunal Regional do Trabalho da $10^{a}$ Região, Tribunal Regional do Trabalho da $18^{\mathrm{a}}$ Região, Tribunal Superior do Trabalho, Tribunal de Justiça de Goiás, Tribunal de Justiça de Minas Gerais, Tribunal de Justiça do Distrito Federal e Territórios

*O Tribunal de Justiça do Distrito Federal e Territórios compõe a Justiça Federal, fazendo com que seus juízes e varas sejam federais, ainda que atue em âmbito distrital.

Os resultados apontam que a função de prestação de serviços do Poder Judiciário encontra-se caracterizada nos municípios de Formosa, Luziânia, Valparaíso e Unaí. Com exceção de Valparaíso, os outros municípios possuem, em comum, o fato de serem de formação 
mais antiga, possuindo varas instaladas há mais tempo, o que reforça sua polarização. O caso de Valparaíso reforça a importância deste município no contexto local, possuindo uma vara da Justiça do Trabalho. A função foi parcialmente caracterizada nos municípios de Águas Lindas de Goiás, Cidade Ocidental, Novo Gama, Padre Bernardo, Pirenópolis, Santo Antônio do Descoberto e Buritis. Estes municípios possuem varas das respectivas Justiças estaduais, tendo serviços de menor potencial de polarização como no caso dos que possuem varas federais. Vêse que o serviço não é oferecido nos menores municípios, o que reflete uma hierarquização e racionalização do trabalho, centrado nos municípios maiores.

Referente à prestação dos serviços de saúde, foram considerados três indicadores para sua caracterização, nos municípios: a densidade de leitos; especialização e existência de hospitais; e variedade de especialidades médicas. Estes foram escolhidos por serem utilizados comumente em análises sobre a estrutura de saúde. Além disso, o segundo indicador aponta tendências de especialização, o que reforça o papel de centralidade. $\mathrm{O}$ cálculo do primeiro encontra-se abaixo, na Tabela 9.8, cujos critérios para o resultado são os mesmos já utilizados nos cálculos de densidade.

Os resultados que a densidade de leitos foi considerada significantes nos municípios de Alexânia, Cabeceiras, Cocalzinho de Goiás, Corumbá de Goiás, Cristalina, Formosa, Padre Bernardo, Pirenópolis, Santo Antônio do Descoberto, Vila Boa, Buritis e Unaí. O resultado foi parcialmente significante nos municípios de Águas Lindas de Goiás, Cidade Ocidental, Luziânia, Planaltina e Valparaíso de Goiás. Este último grupo de municípios teve este resultado por conta do fator demográfico, o que aponta uma insuficiência da estrutura de saúde aí existente. Se se considerar a mobilidade da população de outras regiões, tal quadro fica ainda mais grave. 
Tabela 9.8 - Total de leitos, população, leitos per capita e resultado do cálculo de densidade dos leitos para a RideDF - 2016

\begin{tabular}{|c|c|c|c|c|}
\hline Municípios & $\begin{array}{l}\text { Recursos físicos } \\
\text { - Total de leitos } \\
\text { (hospitalares, } \\
\text { urgência e } \\
\text { repouso) }\end{array}$ & $\begin{array}{l}\text { População } \\
\text { (Censo } \\
\text { 2010) }\end{array}$ & $\begin{array}{l}\text { Leitos per } \\
\text { capita }^{42}\end{array}$ & Resultado \\
\hline Abadiânia - GO & 8 & 15.757 & 0,51 & Não significante \\
\hline Água Fria de Goiás - GO & 2 & 5.090 & 0,39 & Não significante \\
\hline Águas Lindas de Goiás - GO & 63 & 159.378 & 0,40 & Parcialmente significante \\
\hline Alexânia - GO & 34 & 23.814 & 1,43 & Significante \\
\hline Cabeceiras - GO & 20 & 7.354 & 2,72 & Significante \\
\hline Cidade Ocidental - GO & 59 & 55.915 & 1,06 & Parcialmente significante \\
\hline Cocalzinho de Goiás - GO & 27 & 17.407 & 1,55 & Significante \\
\hline Corumbá de Goiás - GO & 29 & 10.361 & 2,80 & Significante \\
\hline Cristalina - GO & 63 & 46.580 & 1,35 & Significante \\
\hline Formosa - GO & 161 & 100.085 & 1,61 & Significante \\
\hline Luziânia - GO & 135 & 174.531 & 0,77 & Parcialmente significante \\
\hline Mimoso de Goiás - GO & - & 2.685 & - & Não significante \\
\hline Novo Gama - GO & 4 & 95.018 & 0,04 & Não significante \\
\hline Padre Bernardo - GO & 38 & 27.671 & 1,37 & Significante \\
\hline Pirenópolis - GO & 60 & 23.006 & 2,61 & Significante \\
\hline Planaltina - GO & 83 & 81.649 & 1,02 & Parcialmente significante \\
\hline Sto. Ant. do Descoberto - GO & 184 & 63.248 & 2,91 & Significante \\
\hline Valparaíso de Goiás - GO & 102 & 132.982 & 0,77 & Parcialmente significante \\
\hline Vila Boa - GO & 14 & 4.735 & 2,96 & Significante \\
\hline Buritis - MG & 39 & 22.737 & 1,72 & Significante \\
\hline Cabeceira Grande - MG & - & 6.453 & - & Não significante \\
\hline Unaí - MG & 195 & 77.565 & 2,51 & Significante \\
\hline Municípios do Entorno & 1.320 & 1.154 .021 & 1,14 & \\
\hline Brasília - DF & 8.406 & 2.570 .160 & 3,27 & Centro Principal \\
\hline Ride-DF & 9.726 & 3.724 .181 & 2,61 & \\
\hline
\end{tabular}

Fonte: DATASUS (dados tratados pelo autor)

O segundo indicador da função prestação de serviços de saúde, especialização e existência de hospitais, é apresentado abaixo, na Tabela 9.9. O resultado foi considerado "significante" caso o município possuísse tanto hospitais gerais quanto hospital especializado; "parcialmente significante" caso possuísse apenas hospitais gerais; "não significante" caso não possuísse qualquer hospital.

${ }^{42}$ Resultados multiplicados por mil. 
Tabela 9.9 - Especialização e existência de hospitais nos municípios da Ride-DF - 2016

\begin{tabular}{|c|c|c|c|c|}
\hline Municípios & $\begin{array}{l}\text { Hospital } \\
\text { especializado }\end{array}$ & $\begin{array}{l}\text { Hospital } \\
\text { geral }\end{array}$ & & Resultado \\
\hline Abadiânia - GO & & & - & Não significante \\
\hline Água Fria de Goiás - GO & & & - & Não significante \\
\hline Águas Lindas de Goiás - GO & & & 1 & Parcialmente significante \\
\hline Alexânia - GO & & & 1 & Parcialmente significante \\
\hline Cabeceiras - GO & & & 1 & Parcialmente significante \\
\hline Cidade Ocidental - GO & & & 2 & Parcialmente significante \\
\hline Cocalzinho de Goiás - GO & & & - & Não significante \\
\hline Corumbá de Goiás - GO & & & 1 & Parcialmente significante \\
\hline Cristalina - GO & & & 3 & Parcialmente significante \\
\hline Formosa - GO & & & 3 & Significante \\
\hline Luziânia - GO & & & 4 & Significante \\
\hline Mimoso de Goiás - GO & & & - & Não significante \\
\hline Novo Gama - GO & & & - & Não significante \\
\hline Padre Bernardo - GO & & & 1 & Parcialmente significante \\
\hline Pirenópolis - GO & & & 2 & Parcialmente significante \\
\hline Planaltina - GO & & & 3 & Parcialmente significante \\
\hline Santo Antônio do Descoberto - GO & & & 2 & Significante \\
\hline Valparaíso de Goiás - GO & & & 1 & Significante \\
\hline Vila Boa - GO & & & 1 & Parcialmente significante \\
\hline Buritis - MG & & & 1 & Parcialmente significante \\
\hline Cabeceira Grande - MG & & & - & Não significante \\
\hline Unaí - MG & & & 4 & Parcialmente significante \\
\hline Brasília - DF & & & 31 & Centro principal \\
\hline
\end{tabular}

Fonte: DATASUS/ MS (dados tratados pelo autor)

Os resultados apontam como sendo significante a existência e especialização dos hospitais em Formosa, Luziânia, Santo Antônio do Descoberto e Valparaíso de Goiás. Isto demonstra que, apesar da densidade de leitos não apontar ser significante em muitos destes municípios, estes possuem uma melhor e mais especializada estrutura de atendimento. Foram ainda caracterizados como parcialmente significantes os resultados em Águas Lindas de Goiás, Alexânia, Cabeceiras, Cidade Ocidental, Corumbá de Goiás, Cristalina, Padre Bernardo, Pirenópolis, Planaltina, Vila Boa, Buritis e Unaí.

O terceiro indicador, referente densidade de cirurgias realizadas, foi aferido a partir de dados referentes à produção hospitalar retirados do DataSUS. Foram considerados os procedimentos cirúrgicos realizados por local de internação. Tal medida possibilita verificar onde procedimentos de maior complexidade são realizados, sendo indicador de possível centralidade. Os resultados estão na Tabela 9.10. 
Tabela 9.10 - Densidade de procedimentos cirúrgicos, procedimentos cirúrgicos, por local de internação ${ }^{43}$, população, procedimentos cirúrgicos per capita nos municípios da Ride-DF.

\begin{tabular}{|c|c|c|c|c|}
\hline Municípios & $\begin{array}{l}\text { Procedimentos } \\
\text { cirúrgico }(2015)\end{array}$ & $\begin{array}{l}\text { População } \\
(2010)\end{array}$ & $\begin{array}{l}\text { Procedimentos } \\
\text { cirúrgicos per } \\
\text { capita }^{44}\end{array}$ & Resultado \\
\hline Abadiânia - GO & - & 15.757 & - & Não significante \\
\hline Água Fria de Goiás - GO & - & 5.090 & - & Não significante \\
\hline Águas Lindas de Goiás - GO & 5.086 & 159.378 & 31,91 & Significante \\
\hline Alexânia - GO & 896 & 23.814 & 37,62 & Significante \\
\hline Cabeceiras - GO & - & 7.354 & - & Não significante \\
\hline Cidade Ocidental - GO & 33 & 55.915 & 0,59 & Não significante \\
\hline Cocalzinho de Goiás - GO & - & 17.407 & - & Não significante \\
\hline Corumbá de Goiás - GO & - & 10.361 & - & Não significante \\
\hline Cristalina - GO & 684 & 46.580 & 14,68 & Significante \\
\hline Formosa - GO & 1.206 & 100.085 & 12,05 & Parcialmente significante \\
\hline Luziânia - GO & 722 & 174.531 & 4,14 & Parcialmente significante \\
\hline Mimoso de Goiás - GO & - & 2.685 & - & Não significante \\
\hline Novo Gama - GO & - & 95.018 & - & Não significante \\
\hline Padre Bernardo - GO & 111 & 27.671 & 4,01 & Não significante \\
\hline Pirenópolis - GO & 6 & 23.006 & 0,26 & Não significante \\
\hline Planaltina - GO & 1.169 & 81.649 & 14,32 & Significante \\
\hline Santo Antônio do Descoberto - GO & - & 63.248 & - & Não significante \\
\hline Valparaíso de Goiás - GO & - & 132.982 & - & Não significante \\
\hline Vila Boa - GO & - & 4.735 & - & Não significante \\
\hline Buritis - MG & 1.029 & 22.737 & 45,26 & Significante \\
\hline Cabeceira Grande - MG & - & 6.453 & - & Não significante \\
\hline Unaí - MG & 3.519 & 77.565 & 45,37 & Significante \\
\hline Municípios do Entorno & 14.461 & 1.154 .021 & 12,53 & \\
\hline Brasília - DF & 59.447 & 2.570 .160 & 23,13 & Centro principal \\
\hline Ride-DF & 73.908 & 3.724.181 & 19,85 & \\
\hline
\end{tabular}

Fonte: DataSUS (dados tratados pelo autor)

A partir dos dados tratados, o resultado foi considerado significante nos municípios de Águas Lindas de Goiás, Alexânia, Cristalina, Planaltina e Unaí. Chama a atenção, especialmente pela estrutura existente, a consideração como "parcialmente significante" dos dados de Formosa e Luziânia, o que aponta que a quantidade de procedimentos realizados é ainda insuficiente para o atendimento da população destes municípios (que concentram grandes somas de população, se considerados os municípios da Ride-DF). Neste indicador, aparecem

\footnotetext{
${ }^{43}$ Os dados são referentes à Produção Hospitalar, considerando o número de Autorizações de Internação Hospitalar (AIH). Não foram considerados os procedimentos cirúrgicos oriundos dos dados da Produção Ambulatorial pois a maior parte deles refere-se a procedimentos de mais baixa complexidade, ao passo que os dados da Produção Hospitalar, nos municípios em estudo, referem-se, em sua maioria, a procedimentos de média complexidade. ${ }^{44}$ Valores multiplicados por mil.
} 
dois municípios considerados do espaço metropolizado por Brasília, Águas Lindas de Goiás e Planaltina, com valores considerados significantes, o que aponta melhoria em sua estrutura de saúde e possível menor dependência da Capital Federal. No caso dos municípios do espaço metropolizado ao sul do Distrito Federal, apenas Luziânia apareceu tendo resultado considerando parcialmente significante, o que explica parte do fluxo pendular existente entre estes municípios e o centro principal. Já associados à expansão da agropecuária moderna, há os resultados de Cristalina, Buritis e Unaí. Há, ainda, o caso de Alexânia, ligado à integração do Eixo Brasília-Anápolis-Goiânia.

A partir dos resultados dos três indicadores, o Quadro 9.2 apresenta os resultados finais para a caracterização da função prestação de serviços de saúde. A função foi considerada "caracterizada" caso os municípios apresentassem dois ou mais resultados considerados significantes para os indicadores analisados; "parcialmente caracterizada" caso os municípios apresentassem apenas um indicador considerado significante os três indicadores considerados como parcialmente significante; "não caracterizada" caso nenhum indicador tenha sido considerado significante ou até dois indicadores considerados parcialmente significantes. 
Quadro 9.2 - Comparativo dos resultados para a função prestação de serviços de saúde para os municípios da Ride-DF

\begin{tabular}{|c|c|c|c|c|}
\hline Município & $\begin{array}{l}\text { Densidade de } \\
\text { leitos }\end{array}$ & $\begin{array}{l}\text { Existência e } \\
\text { especialização de } \\
\text { hospitais }\end{array}$ & $\begin{array}{l}\text { Densidade de } \\
\text { procedimentos cirúrgicos }\end{array}$ & Caracterização da função \\
\hline Abadiânia - GO & Não significante & Não significante & Não significante & Não caracterizada \\
\hline Água Fria de Goiás - GO & Não significante & Não significante & Não significante & Não caracterizada \\
\hline $\begin{array}{l}\text { Ág. Lindas de Goiás - } \\
\text { GO }\end{array}$ & $\begin{array}{l}\text { Parcialmente } \\
\text { significante }\end{array}$ & $\begin{array}{l}\text { Parcialmente } \\
\text { significante }\end{array}$ & Significante & Parcialmente caracterizada \\
\hline Alexânia - GO & Significante & $\begin{array}{l}\text { Parcialmente } \\
\text { significante }\end{array}$ & Significante & Caracterizada \\
\hline Cabeceiras - GO & Significante & $\begin{array}{l}\text { Parcialmente } \\
\text { significante }\end{array}$ & Não significante & Parcialmente caracterizada \\
\hline Cidade Ocidental - GO & $\begin{array}{l}\text { Parcialmente } \\
\text { significante }\end{array}$ & $\begin{array}{l}\text { Parcialmente } \\
\text { significante }\end{array}$ & Não significante & Não caracterizada \\
\hline $\begin{array}{l}\text { Cocalzinho de Goiás - } \\
\text { GO }\end{array}$ & Significante & Não significante & Não significante & Parcialmente caracterizada \\
\hline Corumbá de Goiás - GO & Significante & $\begin{array}{l}\text { Parcialmente } \\
\text { significante }\end{array}$ & Não significante & Parcialmente caracterizada \\
\hline Cristalina - GO & Significante & $\begin{array}{l}\text { Parcialmente } \\
\text { significante }\end{array}$ & Significante & Caracterizada \\
\hline Formosa - GO & Significante & Significante & Parcialmente significante & Caracterizada \\
\hline Luziânia - GO & $\begin{array}{l}\text { Parcialmente } \\
\text { significante }\end{array}$ & Significante & Parcialmente significante & Parcialmente caracterizada \\
\hline Mimoso de Goiás - GO & Não significante & Não significante & Não significante & Não caracterizada \\
\hline Novo Gama - GO & Não significante & Não significante & Não significante & Não caracterizada \\
\hline Padre Bernardo - GO & Significante & $\begin{array}{l}\text { Parcialmente } \\
\text { significante }\end{array}$ & Não significante & Caracterizada \\
\hline Pirenópolis - GO & Significante & $\begin{array}{l}\text { Parcialmente } \\
\text { significante }\end{array}$ & Não significante & Parcialmente caracterizada \\
\hline Planaltina - GO & $\begin{array}{l}\text { Parcialmente } \\
\text { significante }\end{array}$ & $\begin{array}{l}\text { Parcialmente } \\
\text { significante }\end{array}$ & Significante & Parcialmente caracterizada \\
\hline St. Ant. Descoberto - GO & Significante & Significante & Não significante & Caracterizada \\
\hline $\begin{array}{l}\text { Valparaíso de Goiás - } \\
\text { GO }\end{array}$ & $\begin{array}{l}\text { Parcialmente } \\
\text { significante }\end{array}$ & Significante & Não significante & Parcialmente caracterizada \\
\hline Vila Boa - GO & Significante & $\begin{array}{l}\text { Parcialmente } \\
\text { significante }\end{array}$ & Não significante & Parcialmente caracterizada \\
\hline Buritis - MG & Significante & $\begin{array}{l}\text { Parcialmente } \\
\text { significante }\end{array}$ & Significante & Caracterizada \\
\hline Cabeceira Grande -MG & Não significante & Não significante & Não significante & Não caracterizada \\
\hline Unaí - MG & Significante & $\begin{array}{l}\text { Parcialmente } \\
\text { significante }\end{array}$ & Significante & Caracterizada \\
\hline Brasília - DF & Centro principal & Centro principal & Não significante & Centro Principal \\
\hline
\end{tabular}

Fonte: elaboração própria

A partir dos critérios propostos, a função de prestação de serviços de saúde foi caracterizada nos municípios de Alexânia, Cristalina, Formosa, Padre Bernardo, Santo Antônio do Descoberto, Buritis e Unaí. Muitos destes municípios destacaram-se, principalmente, na existência de leitos aí presentes. A função foi ainda considerada "parcialmente caracterizada" nos municípios de Águas Lindas de Goiás, Cabeceiras, Cocalzinho de Goiás, Corumbá de 
Goiás, Luziânia, Pirenópolis, Planaltina, Valparaíso de Goiás e Vila Boa. Considerando tanto os municípios em que a função foi considerada caracterizada como parcialmente caracterizada, destacam-se diversos dos municípios do espaço metropolizado por Brasília, indicando que há, até certo ponto, uma expansão dos serviços de saúde, mas aquém do necessário, o que obriga muitos dos pacientes a irem buscar tratamento em Brasília. Por outro lado, municípios mais afastados e ligados às atividades da agropecuária moderna também se encaixam neste perfil, o que revela, dado não serem grandes recebedores de imigrantes para tratamento de saúde, uma melhoria efetiva em sua estrutura de serviços.

Por fim, considerando as especificidades da região, é importante (especialmente por já se ter caracterizado um processo de estruturação dado pela expansão da agropecuária moderna) analisar a função de prestação de serviços e comércio direcionado para a agropecuária. Como indicadores foram utilizadas a densidade de empresas do setor "agricultura, pecuária e serviços relacionados", de acordo com a Classificação Nacional de Atividades Econômicas (CNAE), e os empregos nestas empresas, neste mesmo setor. Os resultados do primeiro indicador aparecem na tabela 9.11.

Os resultados apontam para resultado significante nos municípios de Água Fria de Goiás, Cabeceiras, Corumbá de Goiás, Cristalina, Formosa, Luziânia, Padre Bernardo, Vila Boa, Buritis e Unaí. Parcialmente significante foi o resultado nos municípios de Alexânia, Cidade Ocidental, Mimoso de Goiás, Pirenópolis, Planaltina e Santo Antônio do Descoberto. O grupo de municípios nos quais o indicador é mais significante corresponde àqueles em que há tradicional maior participação na atividade agropecuária, sendo alguns deles alvos dos investimentos que levaram à modernização da atividade na Ride-DF. 
Tabela 9.11 - No de empresas, população e empresas per capita do setor "agricultura, pecuária e serviços relacionados" - 2006

\begin{tabular}{|c|c|c|c|c|}
\hline Município & $\begin{array}{l}\mathrm{N}^{\mathrm{o}} \text { de } \\
\text { empresas }\end{array}$ & $\begin{array}{l}\text { População } \\
(2010)\end{array}$ & $\begin{array}{l}\text { Empresas per } \\
\text { capita }\end{array}$ & Resultado \\
\hline Abadiânia - GO & 2 & 15.757 & 0,127 & Não significante \\
\hline Água Fria de Goiás - GO & 4 & 5.090 & 0,786 & Significante \\
\hline Águas Lindas de Goiás - GO & 1 & 159.378 & 0,006 & Não significante \\
\hline Alexânia - GO & 4 & 23.814 & 0,168 & Parcialmente significante \\
\hline Cabeceiras - GO & 15 & 7.354 & 2,040 & Significante \\
\hline Cidade Ocidental - GO & 5 & 55.915 & 0,089 & Parcialmente significante \\
\hline Cocalzinho de Goiás - GO & 3 & 17.407 & 0,172 & Não significante \\
\hline Corumbá de Goiás - GO & 4 & 10.361 & 0,386 & Significante \\
\hline Cristalina - GO & 48 & 46.580 & 1,030 & Significante \\
\hline Formosa - GO & 42 & 100.085 & 0,420 & Significante \\
\hline Luziânia - GO & 54 & 174.531 & 0,309 & Significante \\
\hline Mimoso de Goiás - GO & 2 & 2.685 & 0,745 & Parcialmente significante \\
\hline Novo Gama - GO & 2 & 95.018 & 0,021 & Não significante \\
\hline Padre Bernardo - GO & 9 & 27.671 & 0,325 & Significante \\
\hline Pirenópolis - GO & 5 & 23.006 & 0,217 & Parcialmente significante \\
\hline Planaltina - GO & 13 & 81.649 & 0,159 & Parcialmente significante \\
\hline Santo Antônio do Descoberto - GO & 6 & 63.248 & 0,095 & Parcialmente significante \\
\hline Valparaíso de Goiás - GO & 1 & 132.982 & 0,008 & Não significante \\
\hline Vila Boa - GO & 12 & 4.735 & 2,534 & Significante \\
\hline Buritis - MG & 10 & 22.737 & 0,440 & Significante \\
\hline Cabeceira Grande - MG & 1 & 6.453 & 0,155 & Não significante \\
\hline Unaí - MG & 58 & 77.565 & 0,748 & Significante \\
\hline Municípios do Entorno & 301 & 1.154.021 & 0,261 & \\
\hline Brasília - DF & 319 & 2.570 .160 & 0,124 & Centro principal \\
\hline Ride-DF & 620 & 3.724 .181 & 0,166 & \\
\hline
\end{tabular}

Fonte: IBGE - Cadastro Central de Empresas (dados tratados pelo autor)

$\mathrm{O}$ segundo indicador para a função de apoio à agropecuária moderna foi o da densidade do pessoal ocupado nas empresas do setor analisado no primeiro indicador, na Tabela 9.12. O resultado deste segundo indicador demonstra que ele é significante apenas no município de Vila Boa. O resultado é parcialmente significante nos municípios de Alexânia, Cabeceiras, Cidade Ocidental, Cristalina, Formosa, Luziânia, Padre Bernardo, Pirenópolis, Planaltina, Santo Antônio do Descoberto, Buritis e Unaí. Assim, o resultado aponta que as empresas do setor que apoia o agronegócio ainda concentram uma quantidade limitada do pessoal ocupado, sendo o dado significativo apenas em um pequeno município. 
Tabela 9.12 - Pessoal ocupado, população, pessoal ocupado per capita e densidade do pessoal ocupado nas empresas do setor "agricultura, pecuária e serviços relacionados" - 2006

\begin{tabular}{|c|c|c|c|c|}
\hline Município & $\begin{array}{l}\text { Pessoal ocupado } \\
\text { total }\end{array}$ & $\begin{array}{l}\text { População } \\
(2010)\end{array}$ & $\begin{array}{l}\text { Pessoal } \\
\text { ocupado } \\
\text { per capita }^{45}\end{array}$ & Resultado \\
\hline Abadiânia - GO & - & 15.757 & - & Não significante \\
\hline Água Fria de Goiás - GO & 11 & 5.090 & 0,22 & Não significante \\
\hline Águas Lindas de Goiás - GO & - & 159.378 & - & Não significante \\
\hline Alexânia - GO & 119 & 23.814 & 0,50 & Parcialmente significante \\
\hline Cabeceiras - GO & 83 & 7.354 & 1,13 & Parcialmente significante \\
\hline Cidade Ocidental - GO & 34 & 55.915 & 0,06 & Parcialmente significante \\
\hline Cocalzinho de Goiás - GO & 4 & 17.407 & 0,02 & Não significante \\
\hline Corumbá de Goiás - GO & 16 & 10.361 & 0,15 & Não significante \\
\hline Cristalina - GO & 270 & 46.580 & 0,58 & Parcialmente significante \\
\hline Formosa - GO & 280 & 100.085 & 0,28 & Parcialmente significante \\
\hline Luziânia - GO & 589 & 174.531 & 0,34 & Parcialmente significante \\
\hline Mimoso de Goiás - GO & - & 2.685 & - & Não significante \\
\hline Novo Gama - GO & - & 95.018 & - & Não significante \\
\hline Padre Bernardo - GO & 65 & 27.671 & 0,23 & Parcialmente significante \\
\hline Pirenópolis - GO & 23 & 23.006 & 0,10 & Parcialmente significante \\
\hline Planaltina - GO & 40 & 81.649 & 0,05 & Parcialmente significante \\
\hline Santo Antônio do Descoberto - GO & 32 & 63.248 & 0,05 & Parcialmente significante \\
\hline Valparaíso de Goiás - GO & - & 132.982 & - & Não significante \\
\hline Vila Boa - GO & 116 & 4.735 & 2,45 & Significante \\
\hline Buritis - MG & 87 & 22.737 & 0,38 & Parcialmente significante \\
\hline Cabeceira Grande - MG & - & 6.453 & - & Não significante \\
\hline Unaí - MG & 378 & 77.565 & 0,49 & Parcialmente significante \\
\hline Municípios do Entorno & 2.147 & 1.154.021 & 0,19 & \\
\hline Brasília - DF & 2.802 & 2.570 .160 & 0,11 & Centro principal \\
\hline Ride-DF & 4.949 & 3.724 .181 & 0,13 & \\
\hline
\end{tabular}

Fonte: IBGE - Cadastro Central de Empresas (dados tratados pelo autor)

A partir destes dois indicadores, o Quadro 9.3 apresenta o resultado final para a caracterização da função prestação de serviços e comércio direcionado para a agropecuária:

${ }^{45}$ Valores multiplicados por cem. 
Quadro 9.3 - Comparativo dos resultados para a função prestação de serviços e comércio direcionado para a agropecuária para os municípios da Ride-DF

\begin{tabular}{|c|c|c|c|}
\hline Município & $\begin{array}{l}\text { Densidade de empresas } \\
\text { do setor "agricultura, } \\
\text { pecuária e serviços } \\
\text { relacionados" }\end{array}$ & $\begin{array}{l}\text { Densidade do pessoal } \\
\text { ocupado nas empresas } \\
\text { do setor "agricultura, } \\
\text { pecuária e serviços } \\
\text { relacionados" } \\
\end{array}$ & Caracterização da função \\
\hline Abadiânia - GO & Não significante & Não significante & Não caracterizada \\
\hline Água Fria de Goiás - GO & Significante & Não significante & Parcialmente caracterizada \\
\hline Ág. Lindas de Goiás - GO & Não significante & Não significante & Não caracterizada \\
\hline Alexânia - GO & Parcialmente significante & Parcialmente significante & Parcialmente caracterizada \\
\hline Cabeceiras - GO & Significante & Parcialmente significante & Parcialmente caracterizada \\
\hline Cidade Ocidental - GO & Parcialmente significante & Parcialmente significante & Parcialmente caracterizada \\
\hline Cocalzinho de Goiás - GO & Não significante & Não significante & Não caracterizada \\
\hline Corumbá de Goiás - GO & Significante & Não significante & Parcialmente caracterizada \\
\hline Cristalina - GO & Significante & Parcialmente significante & Parcialmente caracterizada \\
\hline Formosa - GO & Significante & Parcialmente significante & Parcialmente caracterizada \\
\hline Luziânia - GO & Significante & Parcialmente significante & Parcialmente caracterizada \\
\hline Mimoso de Goiás - GO & Parcialmente significante & Não significante & Parcialmente caracterizada \\
\hline Novo Gama - GO & Não significante & Não significante & Não caracterizada \\
\hline Padre Bernardo - GO & Significante & Parcialmente significante & Parcialmente caracterizada \\
\hline Pirenópolis - GO & Parcialmente significante & Parcialmente significante & Parcialmente caracterizada \\
\hline Planaltina - GO & Parcialmente significante & Parcialmente significante & Parcialmente caracterizada \\
\hline St. Ant. Descoberto - GO & Parcialmente significante & Parcialmente significante & Parcialmente caracterizada \\
\hline Valparaíso de Goiás - GO & Não significante & Não significante & Não caracterizada \\
\hline Vila Boa - GO & Significante & Significante & Caracterizada \\
\hline Buritis - MG & Significante & Parcialmente significante & Parcialmente caracterizada \\
\hline Cabeceira Grande -MG & Não significante & Não significante & Não caracterizada \\
\hline Unaí - MG & Significante & Parcialmente significante & Parcialmente caracterizada \\
\hline Brasília - DF & Centro principal & Centro principal & Centro principal \\
\hline
\end{tabular}

Fonte: elaboração própria

O resultado aponta, como tendo a função prestação de serviços e comércio direcionado para a agropecuária caracterizada apenas o município de Vila Boa. Muitos outros municípios, nos quais a atividade tende a ser mais bem caracterizada aparecem tendo a função "parcialmente caracterizada": Água Fria de Goiás, Alexânia, Cabeceiras, Cidade Ocidental, Corumbá de Goiás, Cristalina, Formosa, Luziânia, Mimoso de Goiás, Padre Bernardo, Pirenópolis, Planaltina, Santo Antônio do Descoberto, Buritis e Unaí. Este resultado se deve à reduzida quantidade de mão de obra empregada nas empresas consideradas agrícolas. 
Concluída a análise das funções, o Quadro 9.4 apresenta o resultado do somatório de pontos, de acordo com o proposto na descrição do modelo de análise.

A partir dos critérios propostos, atingiram a pontuação necessária para serem considerados de "elevada complexidade funcional" (resultado maior ou igual a dois terços do valor do centro principal) os municípios de Alexânia, Cristalina, Formosa, Luziânia, Padre Bernardo e Unaí. Foram considerados de "complexidade intermediária" (valor abaixo de dois terços e maior ou igual a um terço do valor do centro principal) os municípios de Águas Lindas de Goiás, Cidade Ocidental, Pirenópolis, Planaltina, Santo Antônio do Descoberto, Valparaíso de Goiás e Buritis. Todos os demais foram considerados de reduzida complexidade (valor menor que um terço do valor do centro principal).

Estes resultados apontam para a consolidação do processo de acúmulo de funções dos municípios que historicamente deram suporte à organização da região de Brasília, sendo alvo de investimentos desde os períodos anteriores. Formosa e Unaí claramente tem ligação com a questão da agropecuária moderna. Já o caso de Luziânia aponta para uma situação híbrida, já que a análise das funções deixa transparecer a perspectiva de um importante subcentros de comércio e serviços, ao mesmo tempo em que há importantes investimentos na agropecuária moderna. Vai se configurando, para este último município, a perspectiva de uma dinâmica híbrida, influenciada tanto pelos processos de expansão metropolitana quanto de expansão da agropecuária moderna. Cristalina tem impulsionamento ligado às funções que assume como centro de apoio ao agronegócio moderno. Alexânia aponta ter suas funções tornadas mais complexas por conta da integração do Eixo Brasília-Anápolis-Goiânia. Já Padre Bernardo aparenta despontar como município de apoio a possível expansão do agronegócio em novo vetor.

Já os municípios apontados como de complexidade funcional intermediária tem, nos casos de Águas Lindas de Goiás, Cidade Ocidental, Planaltina e Valparaíso de Goiás o perfil de áreas atingidas pela metropolização de Brasília. Isso revela a emergência da concentração de algumas funções nestes municípios, ligadas aos serviços mínimos necessários e à evolução da renda em alguns deles. Os outros municípios de densidade funcional considerada intermediária aparecem ligados a outros processos de estruturação da Ride-DF: Pirenópolis ao Eixo Brasília-Anápolis-Goiânia; Buritis, ligado ao espaço já tradicional da agropecuária moderna, a leste do Distrito Federal. 
Quadro 9.4 - Resultado final da análise da complexidade funcional (primeira parte)

\begin{tabular}{|c|c|c|c|c|}
\hline Municípios & Função comercial & $\begin{array}{l}\text { Função de prestação de } \\
\text { serviços financeiros }\end{array}$ & $\begin{array}{l}\text { Função de prestação } \\
\text { de serviços } \\
\text { educacionais de nível } \\
\text { superior }\end{array}$ & $\begin{array}{l}\text { Função de prestação de } \\
\text { serviços públicos - } \\
\text { Executivo Federal }\end{array}$ \\
\hline Abadiânia - GO & Não caracterizada & Caracterizada & Não caracterizada & Não caracterizada \\
\hline Água Fria de Goiás - GO & Não caracterizada & Não caracterizada & Não caracterizada & Não caracterizada \\
\hline Ág. Lindas de Goiás - GO & $\begin{array}{l}\text { Parcialmente } \\
\text { caracterizada }\end{array}$ & \begin{tabular}{|l|} 
Parcialmente \\
caracterizada
\end{tabular} & \begin{tabular}{|l|} 
Parcialmente \\
caracterizada
\end{tabular} & Não caracterizada \\
\hline Alexânia - GO & Caracterizada & Caracterizada & \begin{tabular}{|l|} 
Parcialmente \\
caracterizada
\end{tabular} & \begin{tabular}{|l|} 
Parcialmente \\
caracterizada
\end{tabular} \\
\hline Cabeceiras - GO & Não caracterizada & Caracterizada & Não caracterizada & Não caracterizada \\
\hline Cidade Ocidental - GO & Não caracterizada & $\begin{array}{l}\text { Parcialmente } \\
\text { caracterizada }\end{array}$ & \begin{tabular}{|l|} 
Parcialmente \\
caracterizada
\end{tabular} & $\begin{array}{l}\text { Parcialmente } \\
\text { caracterizada }\end{array}$ \\
\hline Cocalzinho de Goiás - GO & $\begin{array}{l}\text { Parcialmente } \\
\text { caracterizada }\end{array}$ & Caracterizada & Não caracterizada & Não caracterizada \\
\hline Corumbá de Goiás - GO & Não caracterizada & Caracterizada & Não caracterizada & Não caracterizada \\
\hline Cristalina - GO & $\begin{array}{l}\text { Parcialmente } \\
\text { caracterizada }\end{array}$ & Caracterizada & Caracterizada & \begin{tabular}{|l|} 
Parcialmente \\
caracterizada
\end{tabular} \\
\hline Formosa - GO & Caracterizada & Caracterizada & Caracterizada & Caracterizada \\
\hline Luziânia - GO & Caracterizada & $\begin{array}{l}\text { Parcialmente } \\
\text { caracterizada }\end{array}$ & Caracterizada & Caracterizada \\
\hline Mimoso de Goiás - GO & Não caracterizada & Não caracterizada & Não caracterizada & Não caracterizada \\
\hline Novo Gama - GO & $\begin{array}{l}\text { Parcialmente } \\
\text { caracterizada }\end{array}$ & $\begin{array}{l}\text { Parcialmente } \\
\text { caracterizada }\end{array}$ & Não caracterizada & Não caracterizada \\
\hline Padre Bernardo - GO & $\begin{array}{l}\text { Parcialmente } \\
\text { caracterizada }\end{array}$ & Caracterizada & $\begin{array}{l}\text { Parcialmente } \\
\text { caracterizada }\end{array}$ & $\begin{array}{l}\text { Parcialmente } \\
\text { caracterizada }\end{array}$ \\
\hline Pirenópolis - GO & $\begin{array}{l}\text { Parcialmente } \\
\text { caracterizada }\end{array}$ & Caracterizada & $\begin{array}{l}\text { Parcialmente } \\
\text { caracterizada }\end{array}$ & $\begin{array}{l}\text { Parcialmente } \\
\text { caracterizada }\end{array}$ \\
\hline Planaltina - GO & Não caracterizada & \begin{tabular}{|l|} 
Parcialmente \\
caracterizada
\end{tabular} & $\begin{array}{l}\text { Parcialmente } \\
\text { caracterizada }\end{array}$ & $\begin{array}{l}\text { Parcialmente } \\
\text { caracterizada }\end{array}$ \\
\hline $\begin{array}{l}\text { Sto. Ant. do Descoberto - } \\
\text { GO }\end{array}$ & Não caracterizada & Caracterizada & $\begin{array}{l}\text { Parcialmente } \\
\text { caracterizada }\end{array}$ & $\begin{array}{l}\text { Parcialmente } \\
\text { caracterizada }\end{array}$ \\
\hline Valparaíso de Goiás - GO & $\begin{array}{l}\text { Parcialmente } \\
\text { caracterizada }\end{array}$ & \begin{tabular}{|l|} 
Parcialmente \\
caracterizada
\end{tabular} & Caracterizada & $\begin{array}{l}\text { Parcialmente } \\
\text { caracterizada }\end{array}$ \\
\hline Vila Boa - GO & Não caracterizada & $\begin{array}{l}\text { Parcialmente } \\
\text { caracterizada }\end{array}$ & Não caracterizada & Não caracterizada \\
\hline Buritis - MG & \begin{tabular}{|l|} 
Parcialmente \\
caracterizada
\end{tabular} & Caracterizada & Não caracterizada & \begin{tabular}{|l|} 
Parcialmente \\
caracterizada
\end{tabular} \\
\hline Cabeceira Grande - MG & Não caracterizada & Não caracterizada & Não caracterizada & Não caracterizada \\
\hline Unaí - MG & \begin{tabular}{|l|} 
Parcialmente \\
caracterizada
\end{tabular} & Caracterizada & Caracterizada & Caracterizada \\
\hline Brasília - DF & Centro Principal & Centro Principal & Centro Principal & Centro Principal \\
\hline
\end{tabular}

Fonte: elaboração própria 
Quadro 9.4 - Resultado final da análise da complexidade funcional (segunda parte)

\begin{tabular}{|c|c|c|c|c|c|}
\hline Municípios & $\begin{array}{l}\text { Função de } \\
\text { prestação de } \\
\text { serviços } \\
\text { públicos - } \\
\text { Poder } \\
\text { Judiciário }\end{array}$ & $\begin{array}{l}\text { Função de prestação de } \\
\text { outros serviços de saúde }\end{array}$ & $\begin{array}{l}\text { Função de apoio à } \\
\text { produção agropecuária }\end{array}$ & $\begin{array}{l}\text { Pontua } \\
\text { ção } \\
\text { final }\end{array}$ & $\begin{array}{l}\text { Complexidade } \\
\text { funcional }\end{array}$ \\
\hline Abadiânia - GO & $\begin{array}{l}\text { Não } \\
\text { caracterizada }\end{array}$ & Não caracterizada & Não caracterizada & 2 & Reduzida \\
\hline Água Fria de Goiás - GO & $\begin{array}{l}\text { Não } \\
\text { caracterizada }\end{array}$ & Não caracterizada & Parcialmente caracterizada & 1 & Reduzida \\
\hline Ág Lindas de Goiás - GO & $\begin{array}{l}\text { Parcialmente } \\
\text { caracterizada }\end{array}$ & Parcialmente caracterizada & Não caracterizada & 5 & Intermediária \\
\hline Alexânia - GO & $\begin{array}{l}\text { Não } \\
\text { caracterizada }\end{array}$ & Caracterizada & Parcialmente caracterizada & 9 & Elevada \\
\hline Cabeceiras - GO & $\begin{array}{l}\text { Não } \\
\text { caracterizada }\end{array}$ & Parcialmente caracterizada & Parcialmente caracterizada & 4 & Reduzida \\
\hline Cidade Ocidental - GO & $\begin{array}{l}\text { Parcialmente } \\
\text { caracterizada }\end{array}$ & Não caracterizada & Parcialmente caracterizada & 5 & Intermediária \\
\hline Cocalzinho de Goiás - GO & $\begin{array}{l}\text { Não } \\
\text { caracterizada }\end{array}$ & Parcialmente caracterizada & Não caracterizada & 4 & Reduzida \\
\hline Corumbá de Goiás - GO & $\begin{array}{l}\text { Não } \\
\text { caracterizada }\end{array}$ & Parcialmente caracterizada & Parcialmente caracterizada & 4 & Reduzida \\
\hline Cristalina - GO & $\begin{array}{l}\text { Parcialmente } \\
\text { caracterizada }\end{array}$ & Caracterizada & Parcialmente caracterizada & 10 & Elevada \\
\hline Formosa - GO & Caracterizada & Caracterizada & Parcialmente caracterizada & 13 & Elevada \\
\hline Luziânia - GO & Caracterizada & Parcialmente caracterizada & Parcialmente caracterizada & 11 & Elevada \\
\hline Mimoso de Goiás - GO & $\begin{array}{l}\text { Não } \\
\text { caracterizada }\end{array}$ & Não caracterizada & Parcialmente caracterizada & 1 & Reduzida \\
\hline Novo Gama - GO & $\begin{array}{l}\text { Parcialmente } \\
\text { caracterizada }\end{array}$ & Não caracterizada & Não caracterizada & 3 & Reduzida \\
\hline Padre Bernardo - GO & $\begin{array}{l}\text { Parcialmente } \\
\text { caracterizada }\end{array}$ & Caracterizada & Parcialmente caracterizada & 9 & Elevada \\
\hline Pirenópolis - GO & $\begin{array}{l}\text { Parcialmente } \\
\text { caracterizada }\end{array}$ & Parcialmente caracterizada & Parcialmente caracterizada & 8 & Intermediária \\
\hline Planaltina - GO & $\begin{array}{l}\text { Parcialmente } \\
\text { caracterizada }\end{array}$ & Parcialmente caracterizada & Parcialmente caracterizada & 6 & Intermediária \\
\hline Sto. Ant. do Descoberto - GO & $\begin{array}{l}\text { Parcialmente } \\
\text { caracterizada }\end{array}$ & Caracterizada & Parcialmente caracterizada & 8 & Intermediária \\
\hline Valparaíso de Goiás - GO & Caracterizada & Parcialmente caracterizada & Não caracterizada & 8 & Intermediária \\
\hline Vila Boa - GO & $\begin{array}{l}\text { Não } \\
\text { caracterizada }\end{array}$ & Parcialmente caracterizada & Caracterizada & 4 & Reduzida \\
\hline Buritis - MG & $\begin{array}{l}\text { Parcialmente } \\
\text { caracterizada }\end{array}$ & Caracterizada & Parcialmente caracterizada & 8 & Intermediária \\
\hline Cabeceira Grande - MG & $\begin{array}{l}\text { Não } \\
\text { caracterizada }\end{array}$ & Não caracterizada & Não caracterizada & 0 & Reduzida \\
\hline Unaí - MG & Caracterizada & Caracterizada & Parcialmente caracterizada & 12 & Elevada \\
\hline Brasília - DF & $\begin{array}{l}\text { Centro } \\
\text { principal }\end{array}$ & Centro Principal & Centro Principal & 14 & $\begin{array}{l}\text { Centro } \\
\text { principal }\end{array}$ \\
\hline
\end{tabular}

Fonte: elaboração própria

\subsubsection{Dimensão 3 - polarização}

A terceira dimensão de análise do tema dos subcentros na Ride-DF diz respeito aos indicadores de mobilidade da população para trabalho, estudos e uso de equipamentos de saúde. Estes são importantes pois demonstram a capacidade de polarização dos municípios 
internamente à região, permitindo compor um quadro mais dinâmico que o estabelecido pela identificação das densidades de emprego (dimensão 1) e pelas funções exercidas pelos municípios no contexto regional (dimensão 2). A ideia de polarização aqui trabalhada diz respeito, principalmente, à atração da população de outros municípios por parte daqueles que possuem estruturas de consumo e mercado de trabalho mais amplo. Tal conceito aproxima-se do trabalho de Aguiléra e Mignot (2004), analisando este aspecto para os espaços metropolitanos franceses.

Para tanto, foram considerados dados da amostra do Censo Demográfico de 2010 do IBGE, especificamente em relação ao local de trabalho e estudo, para os municípios da RideDF. A partir destes dois indicadores, definiu-se a polarização dos municípios em relação ao centro principal e outros municípios.

Em relação aos indicadores referentes à polarização por parte de um município sobre outro na Ride-DF, o primeiro indicador utilizado está ligado ao uso (frequência, por parte da população) de instituição de ensino em outro município. A partir dos dados obtidos, foi considerado o percentual das populações que estudam no próprio município e em outros municípios. O maior percentual de população que frequentava escola ou creche fora do município foi tomado como referência. Daí, foram estabelecidas as seguintes faixas: os municípios que possuíssem um percentual de população frequentando escola ou creche fora do município com valor igual ou superior a dois terços do máximo valor teve a polarização considerada como "caracterizada" (maior ou igual que 14,62\%); caso este valor tenha ficado abaixo de dois terço e maior ou igual a um terço, a polarização foi considerada "parcialmente caracterizada" (entre 14,61 e 7,31\%); caso o referido valor fosse menor que um terço, a polarização foi considerada "não caracterizada" (abaixo de 7,10\%). A Tabela 9.13 apresenta os resultados deste indicador.

A análise dos resultados apontou como sendo polarizados por outros municípios, neste quesito, Água Fria de Goiás, Cidade Ocidental, Corumbá de Goiás, Novo Gama, Padre Bernardo, Santo Antônio do Descoberto e Valparaíso. Alguns destes municípios claramente possuem uma boa parte de sua população polarizada pelo centro principal, algo que pode ser deduzido pela distância, como nos casos de Novo Gama, Cidade Ocidental, Santo Antônio do Descoberto e Valparaíso. Os outros casos tratam de municípios muito pequenos que provavelmente buscam em outros municípios atendimento às suas necessidades, porém dificilmente no centro principal, dada a distância. A polarização foi "parcialmente identificada" em Abadiânia, Águas Lindas de Goiás, Cocalzinho de Goiás, Cristalina, Luziânia, Mimoso de Goiás, Pirenópolis e Buritis. Destes casos, percebe-se que, à medida em que há algum 
afastamento do centro principal a polarização se reduz, como no caso de Luziânia e Cristalina, se comparado aos municípios ao sul do Distrito Federal e que estavam na tipologia anterior.

Tabela 9.13 - Pessoas que frequentavam escola ou creche e resultado da caracterização da polarização - 2010

\begin{tabular}{|c|c|c|c|c|c|}
\hline \multirow[t]{2}{*}{ Municípios } & \multicolumn{2}{|l|}{$\begin{array}{l}\text { Município de } \\
\text { residência }\end{array}$} & \multicolumn{2}{|c|}{ Outro município } & \multirow{2}{*}{$\begin{array}{l}\text { Polarização por } \\
\text { outro município }\end{array}$} \\
\hline & Total & $\%$ & Total & $\%$ & \\
\hline Abadiânia - GO & 3.808 & 86,05 & 617 & 13,95 & Parcialmente caracterizada \\
\hline Água Fria de Goiás - GO & 1.232 & 85,19 & 214 & 14,81 & Caracterizada \\
\hline Águas Lindas de Goiás - GO & 48.296 & 89,60 & 5.586 & 10,36 & Parcialmente caracterizada \\
\hline Alexânia - GO & 6.316 & 92,98 & 477 & 7,02 & Não caracterizada \\
\hline Cabeceiras - GO & 2.008 & 93,04 & 150 & 6,96 & Não caracterizada \\
\hline Cidade Ocidental - GO & 16.029 & 80,85 & 3.796 & 19,15 & Caracterizada \\
\hline Cocalzinho de Goiás - GO & 4.648 & 91,66 & 423 & 8,34 & Parcialmente caracterizada \\
\hline Corumbá de Goiás - GO & 2.341 & 81,85 & 519 & 18,15 & Caracterizada \\
\hline Cristalina - GO & 13.659 & 91,27 & 1.307 & 8,73 & Parcialmente caracterizada \\
\hline Formosa - GO & 31.175 & 96,27 & 1.195 & 3,69 & Não caracterizada \\
\hline Luziânia - GO & 51.417 & 91,76 & 4.617 & 8,24 & Parcialmente caracterizada \\
\hline Mimoso de Goiás - GO & 685 & 90,38 & 73 & 9,62 & Parcialmente caracterizada \\
\hline Novo Gama - GO & 24.599 & 77,85 & 7.000 & 22,15 & Caracterizada \\
\hline Padre Bernardo - GO & 7.775 & 88,53 & 1.007 & 11,47 & Caracterizada \\
\hline Pirenópolis - GO & 5.744 & 91,48 & 523 & 8,33 & Parcialmente caracterizada \\
\hline Planaltina - GO & 25.069 & 93,48 & 1.749 & 6,52 & Não caracterizada \\
\hline Sto Ant do Descoberto - GO & 20.126 & 88,69 & 2.566 & 11,31 & Caracterizada \\
\hline Valparaíso de Goiás - GO & 37.709 & 83,10 & 7.667 & 16,90 & Caracterizada \\
\hline Vila Boa - GO & 1.184 & 92,90 & 91 & 7,10 & Não caracterizada \\
\hline Buritis - MG & 6.973 & 92,62 & 556 & 7,38 & Parcialmente caracterizada \\
\hline Cabeceira Grande - MG & 1.937 & 94,20 & 119 & 5,80 & Não caracterizada \\
\hline Unaí - MG & 22.618 & 96,09 & 921 & 3,91 & Não caracterizada \\
\hline Brasília - DF & 826.011 & 94,11 & 51.117 & 5,82 & Não caracterizada \\
\hline
\end{tabular}

Fonte: Amostra do Censo Demográfico IBGE 2010 (dados tratados pelo autor)

O segundo indicador de polarização realizou a mesma operação, com os mesmos critérios, porém a partir dos dados de ocupação. Os resultados aparecem na Tabela 9.14. Estes apontam para a caracterização da polarização por outros nos municípios de Águas Lindas de Goiás, Cidade Ocidental, Novo Gama, Planaltina, Santo Antônio do Descoberto e Valparaíso de Goiás. Todos estes municípios participam, atualmente, do processo de expansão da metropolização de Brasília, podendo ser caracterizados como franja de tal processo, sendo, muitos deles, ainda, cidades-dormitório de população que trabalha no centro principal. Como tendo polarização por outros parcialmente caracterizada estão os municípios de Cocalzinho de Goiás, Luziânia e Padre Bernardo. Há, aqui, uma mescla de municípios mais próximos de 
Brasília e outros a uma distância maior, caso de Padre Bernardo. Porém, todos eles possuem distritos que acabam por fornecer mão de obra a Brasília.

Tabela 9.14 - Pessoas de 10 anos ou mais de idade, ocupadas, por local de ocupação, e resultado quanto à polarização

\begin{tabular}{|c|c|c|c|c|c|}
\hline \multirow[t]{2}{*}{ Município } & \multicolumn{2}{|l|}{$\begin{array}{l}\text { Município de } \\
\text { residência }\end{array}$} & \multicolumn{2}{|c|}{$\begin{array}{l}\text { Outro município ou } \\
\text { mais de um } \\
\text { município }\end{array}$} & \multirow[t]{2}{*}{$\begin{array}{l}\text { Polarização por outro } \\
\text { município }\end{array}$} \\
\hline & Total & $\%$ & Total & $\%$ & \\
\hline Abadiânia - GO & 7.015 & 95,01 & 368 & 4,99 & Não caracterizada \\
\hline Água Fria de Goiás - GO & 2.194 & 94,68 & 124 & 5,32 & Não caracterizada \\
\hline Ág. Lindas de Goiás - GO & 29.442 & 41,83 & 40.938 & 58,17 & Caracterizada \\
\hline Alexânia - GO & 9.200 & 89,76 & 1.050 & 10,24 & Não caracterizada \\
\hline Cabeceiras - GO & 2.616 & 86,12 & 421 & 13,88 & Não caracterizada \\
\hline Cidade Ocidental - GO & 10.421 & 40,11 & 15.558 & 59,89 & Caracterizada \\
\hline Cocalzinho de Goiás - GO & 5.364 & 76,75 & 1.620 & 23,18 & Parcialmente caracterizada \\
\hline Corumbá de Goiás - GO & 4.464 & 93,36 & 313 & 6,54 & Não caracterizada \\
\hline Cristalina - GO & 20.646 & 95,43 & 989 & 4,57 & Não caracterizada \\
\hline Formosa - GO & 41.710 & 85,95 & 6.797 & 14,00 & Não caracterizada \\
\hline Luziânia - GO & 50.803 & 65,77 & 26.437 & 34,22 & Parcialmente caracterizada \\
\hline Mimoso de Goiás - GO & 879 & 86,01 & 143 & 13,99 & Não caracterizada \\
\hline Novo Gama - GO & 14.970 & 37,95 & 24.474 & 62,04 & Caracterizada \\
\hline Padre Bernardo - GO & 8.982 & 78,31 & 2.488 & 21,68 & Parcialmente caracterizada \\
\hline Pirenópolis - GO & 11.199 & 97,28 & 313 & 2,72 & Não caracterizada \\
\hline Planaltina - GO & 18.173 & 51,12 & 17.376 & 48,88 & Caracterizada \\
\hline Sto Ant do Descoberto - GO & 13.169 & 49,69 & 13.331 & 50,31 & Caracterizada \\
\hline Valparaíso de Goiás - GO & 28.449 & 45,56 & 33.963 & 54,39 & Caracterizada \\
\hline Vila Boa - GO & 1.781 & 97,38 & 48 & 2,62 & Não caracterizada \\
\hline Buritis - MG & 9.790 & 95,47 & 464 & 4,53 & Não caracterizada \\
\hline Cabeceira Grande - MG & 2.414 & 85,86 & 398 & 14,13 & Não caracterizada \\
\hline Unaí - MG & 37.981 & 95,06 & 1.973 & 4,93 & Não caracterizada \\
\hline Brasília - DF & 1.169 .572 & 90,84 & 117.831 & 9,15 & Não caracterizada \\
\hline
\end{tabular}

Fonte: Amostra do Censo Demográfico IBGE 2010 (dados tratados pelo autor)

A partir da análise destes dois indicadores, foi produzido um quadro em que os resultados são comparados e a partir do qual é definida a polarização em relação ao centro principal ou a um outro subcentro. Desta forma, a polarização foi considerada "alta" quando os dois indicadores apontaram haver polarização caracterizada; "média" quando apenas um dos indicadores apontou haver polarização; "baixa" quando nenhum dos indicadores apontou haver polarização. O Quadro 9.5 contém estas informações. 
Quadro 9.5 - Resultados da polarização dos municípios da Ride-DF, em relação ao centro principal ou outros subcentros

\begin{tabular}{|c|c|c|c|}
\hline Municípios & Polarização - educação & Polarização - ocupação & $\begin{array}{l}\text { Resultado - polarização } \\
\text { pelo centro principal ou por } \\
\text { outro subcentro }\end{array}$ \\
\hline Abadiânia - GO & Parcialmente caracterizada & Não caracterizada & Baixa \\
\hline Água Fria de Goiás - GO & Caracterizada & Não caracterizada & Média \\
\hline Ág. Lindas de Goiás - GO & Parcialmente caracterizada & Caracterizada & Média \\
\hline Alexânia - GO & Não caracterizada & Não caracterizada & Baixa \\
\hline Cabeceiras - GO & Não caracterizada & Não caracterizada & Baixa \\
\hline Cidade Ocidental - GO & Caracterizada & Caracterizada & Alta \\
\hline Cocalzinho de Goiás - GO & Parcialmente caracterizada & Parcialmente caracterizada & Média \\
\hline Corumbá de Goiás - GO & Caracterizada & Não caracterizada & Média \\
\hline Cristalina - GO & Parcialmente caracterizada & Não caracterizada & Baixa \\
\hline Formosa - GO & Não caracterizada & Não caracterizada & Baixa \\
\hline Luziânia - GO & Parcialmente caracterizada & Parcialmente caracterizada & Média \\
\hline Mimoso de Goiás - GO & Parcialmente caracterizada & Não caracterizada & Baixa \\
\hline Novo Gama - GO & Caracterizada & Caracterizada & Alta \\
\hline Padre Bernardo - GO & Caracterizada & Parcialmente caracterizada & Média \\
\hline Pirenópolis - GO & Parcialmente caracterizada & Não caracterizada & Baixa \\
\hline Planaltina - GO & Não caracterizada & Caracterizada & Média \\
\hline Sto. Ant. Descoberto - GO & Caracterizada & Caracterizada & Alta \\
\hline Valparaíso de Goiás - GO & Caracterizada & Caracterizada & Alta \\
\hline Vila Boa - GO & Não caracterizada & Não caracterizada & Baixa \\
\hline Buritis - MG & Parcialmente caracterizada & Não caracterizada & Baixa \\
\hline Cabeceira Grande - MG & Não caracterizada & Não caracterizada & Baixa \\
\hline Unaí - MG & Não caracterizada & Não caracterizada & Baixa \\
\hline Brasília - DF & Parcialmente caracterizada & Não caracterizada & CENTRO PRINCIPAL \\
\hline
\end{tabular}

Fonte: elaboração própria

Os resultados apresentados apontam para uma alta polarização por parte de outro município nos casos de Cidade Ocidental, Novo Gama, Santo Antônio do Descoberto e Valparaíso de Goiás. Estes municípios, todos no espaço metropolizado por Brasília, apresentam, desta forma, uma relação, em algum grau, de município-dormitório em relação ao centro principal, dependendo dele para obtenção de trabalho e dos serviços educacionais.

A polarização foi considerada média para os municípios de Água Fria de Goiás, Águas Lindas de Goiás, Cocalzinho de Goiás, Corumbá de Goiás, Luziânia, Padre Bernardo e Planaltina. Destes casos, mais próximos ao centro principal estão Águas Lindas de Goiás, Luziânia e Planaltina, em um caso de dependência daquele, porém em menor grau do que dos municípios limítrofes ao Distrito Federal em sua porção sul. Já os outros casos são municípios mais afastados do centro principal, podendo, inclusive, haver polarização por outros municípios próximos. 
O grupo dos municípios de baixa polarização pelo centro principal ou outro subcentro abarca Abadiânia, Alexânia, Cabeceiras, Cristalina, Formosa, Mimoso de Goiás, Pirenópolis, Vila Boa, Buritis, Cabeceira Grande e Unaí. Este grupo, mais heterogêneo, contém desde municípios nos quais a baixa polarização é indicativo de centralidade, como nos casos de Formosa, Cristalina e Unaí (Formosa principalmente, tendo em vista a relativa proximidade de seu centro com o centro principal) e outros de menor porte, nos quais a baixa polarização indica afastamento de seus centros em relação a outros centros urbanos maiores, ou mesmo efeito de sua população predominantemente agrária.

Tendo realizado a análise das três dimensões propostas para a identificação dos subcentros, o próximo item se dedica a analisar estes resultados e a identificar os subcentros.

\subsubsection{O centro principal e os subcentros identificados}

Este último item da análise do tema dos subcentros visa sintetizar a análise realizada pelas três dimensões propostas no modelo e análise, identificando, finalmente, os subcentros presentes na Ride-DF e principal consequência das ações, públicas e privadas. O quadro 9.6 apresenta a síntese. 
Quadro 9.6 - Resultado final das dimensões de análise dos subcentros

\begin{tabular}{|c|c|c|c|c|c|}
\hline Municípios & $\begin{array}{l}\text { Resultado } \\
\text { dimensão } 1 \text { - } \\
\text { densidade de } \\
\text { empregos }\end{array}$ & $\begin{array}{l}\text { Resultado } \\
\text { dimensão } 2 \text { - } \\
\text { complexidade } \\
\text { funcional }\end{array}$ & $\begin{array}{l}\text { Resultado } \\
\text { dimensão } 3 \text { - } \\
\text { polarização pelo } \\
\text { centro principal } \\
\text { ou outro } \\
\text { subcentro }\end{array}$ & Pontuação & $\begin{array}{l}\text { Identificação } \\
\text { como subcentro }\end{array}$ \\
\hline Abadiânia - GO & Alta & Reduzida & Baixa & 4 & $\begin{array}{l}\begin{array}{l}\text { Subcentro } \\
\text { emergente }\end{array} \\
\end{array}$ \\
\hline $\begin{array}{l}\text { Água Fria de } \\
\text { Goiás - GO }\end{array}$ & Média & Reduzida & Média & 2 & $\begin{array}{l}\text { Não } \\
\text { caracterizada }\end{array}$ \\
\hline $\begin{array}{l}\text { Águas Lindas de } \\
\text { Goiás - GO }\end{array}$ & Média & Intermediária & Média & 3 & \begin{tabular}{|l|} 
Não \\
caracterizada
\end{tabular} \\
\hline Alexânia - GO & Alta & Elevada & Baixa & 6 & Subcentro \\
\hline Cabeceiras - GO & Média & Reduzida & Baixa & 3 & \begin{tabular}{|l|} 
Não \\
caracterizada
\end{tabular} \\
\hline $\begin{array}{l}\text { Cidade Ocidental } \\
\text { - GO }\end{array}$ & Média & Intermediária & Alta & 2 & $\begin{array}{l}\text { Não } \\
\text { caracterizada }\end{array}$ \\
\hline $\begin{array}{l}\text { Cocalzinho de } \\
\text { Goiás - GO }\end{array}$ & Média & Reduzida & Média & 2 & \begin{tabular}{|l|} 
Não \\
caracterizada
\end{tabular} \\
\hline $\begin{array}{l}\text { Corumbá de } \\
\text { Goiás - GO }\end{array}$ & Baixa & Reduzida & Média & 1 & \begin{tabular}{|l|} 
Não \\
caracterizada
\end{tabular} \\
\hline Cristalina - GO & Alta & Elevada & Baixa & 6 & Subcentro \\
\hline Formosa - GO & Alta & Elevada & Baixa & 6 & Subcentro \\
\hline Luziânia - GO & Alta & Elevada & Média & 5 & $\begin{array}{l}\text { Subcentro } \\
\text { emergente }\end{array}$ \\
\hline $\begin{array}{l}\text { Mimoso de Goiás } \\
\text { - GO }\end{array}$ & Média & Reduzida & Baixa & 3 & \begin{tabular}{|l|} 
Não \\
caracterizada
\end{tabular} \\
\hline Novo Gama - GO & Média & Reduzida & Alta & 1 & $\begin{array}{l}\text { Não } \\
\text { caracterizada }\end{array}$ \\
\hline $\begin{array}{l}\text { Padre Bernardo - } \\
\text { GO }\end{array}$ & Média & Elevada & Média & 4 & \begin{tabular}{|l|}
$\begin{array}{l}\text { Subcentro } \\
\text { emergente }\end{array}$ \\
\end{tabular} \\
\hline Pirenópolis - GO & Alta & Intermediária & Baixa & 5 & \begin{tabular}{|l|}
$\begin{array}{l}\text { Subcentro } \\
\text { emergente }\end{array}$ \\
\end{tabular} \\
\hline Planaltina - GO & Média & Intermediária & Média & 3 & \begin{tabular}{|l|} 
Não \\
caracterizada
\end{tabular} \\
\hline $\begin{array}{l}\text { Sto Ant do } \\
\text { Descoberto - GO }\end{array}$ & Média & Intermediária & Alta & 2 & \begin{tabular}{|l|} 
Não \\
caracterizada
\end{tabular} \\
\hline $\begin{array}{l}\text { Valparaíso de } \\
\text { Goiás - GO }\end{array}$ & Alta & Intermediária & Alta & 3 & $\begin{array}{l}\text { Não } \\
\text { caracterizada }\end{array}$ \\
\hline Vila Boa - GO & Média & Reduzida & Baixa & 3 & \begin{tabular}{|l|} 
Não \\
caracterizada
\end{tabular} \\
\hline Buritis - MG & Alta & Intermediária & Baixa & 5 & \begin{tabular}{|l|}
$\begin{array}{l}\text { Subcentro } \\
\text { emergente }\end{array}$ \\
\end{tabular} \\
\hline $\begin{array}{l}\text { Cabeceira } \\
\text { Grande - MG }\end{array}$ & Média & Reduzida & Baixa & 3 & \begin{tabular}{|l} 
Não \\
caracterizada
\end{tabular} \\
\hline Unaí - MG & Alta & Elevada & Baixa & 6 & Subcentro \\
\hline Brasília - DF & Centro principal & Centro principal & Centro Principal & - & \begin{tabular}{|l} 
Centro \\
Principal
\end{tabular} \\
\hline
\end{tabular}

Fonte: elaboração própria

A partir destes dados, foi produzido o mapa da Figura 9.1. A análise do resultado e da figura, a partir dos critérios postos quando da descrição do modelo de análise, demonstram 
que foram caracterizados como subcentros os municípios de Alexânia, Cristalina, Formosa e Unaí. Como subcentros emergentes foram identificados os municípios de Abadiânia, Luziânia, Padre Bernardo, Pirenópolis, Valparaíso de Goiás e Buritis. 
Figura 9.1

\section{Subcentros identificados na Ride-DF}

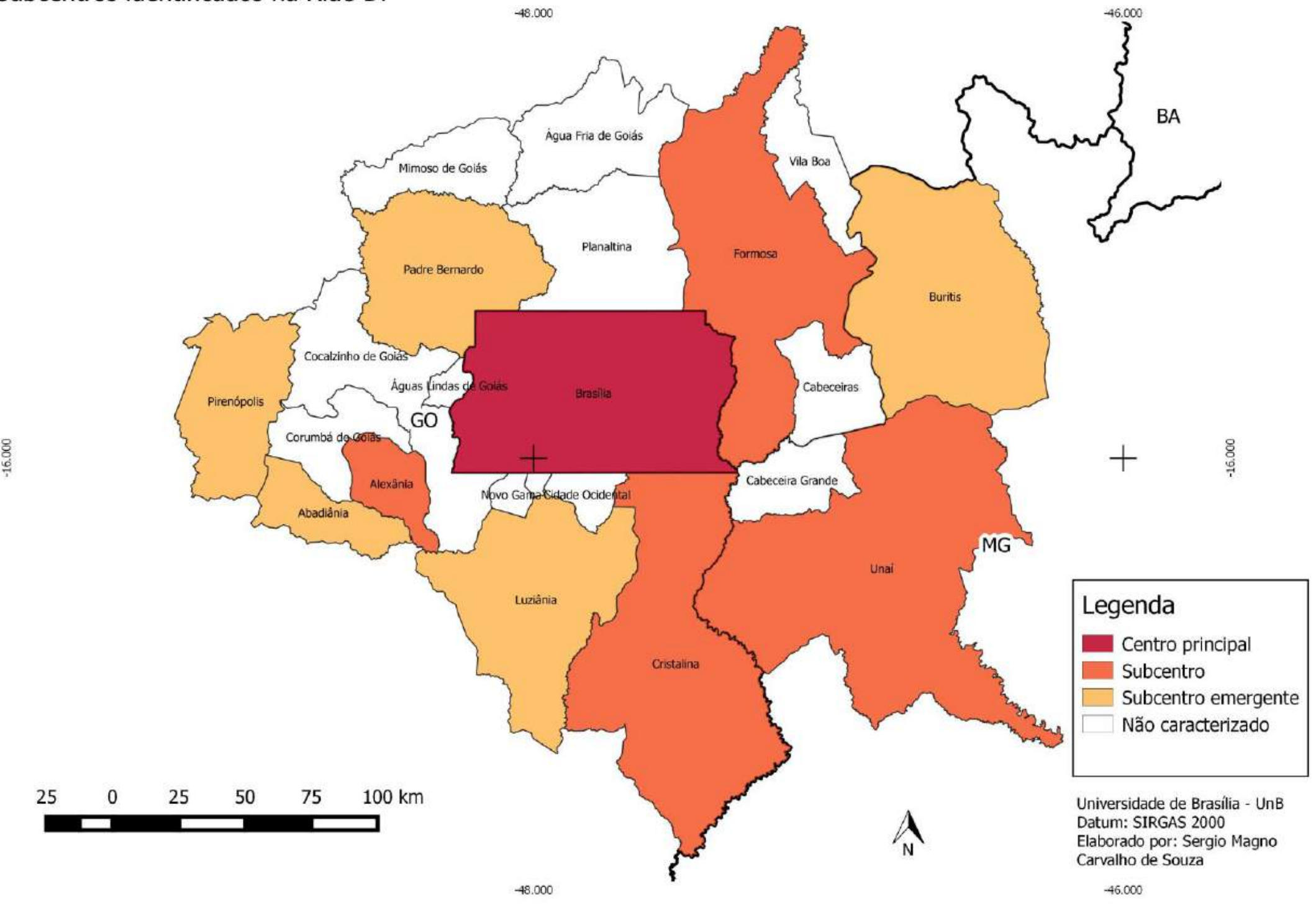


Figura 9.2

Subcentros identificados, área urbanizada a processos estruturantes na Ride-DF

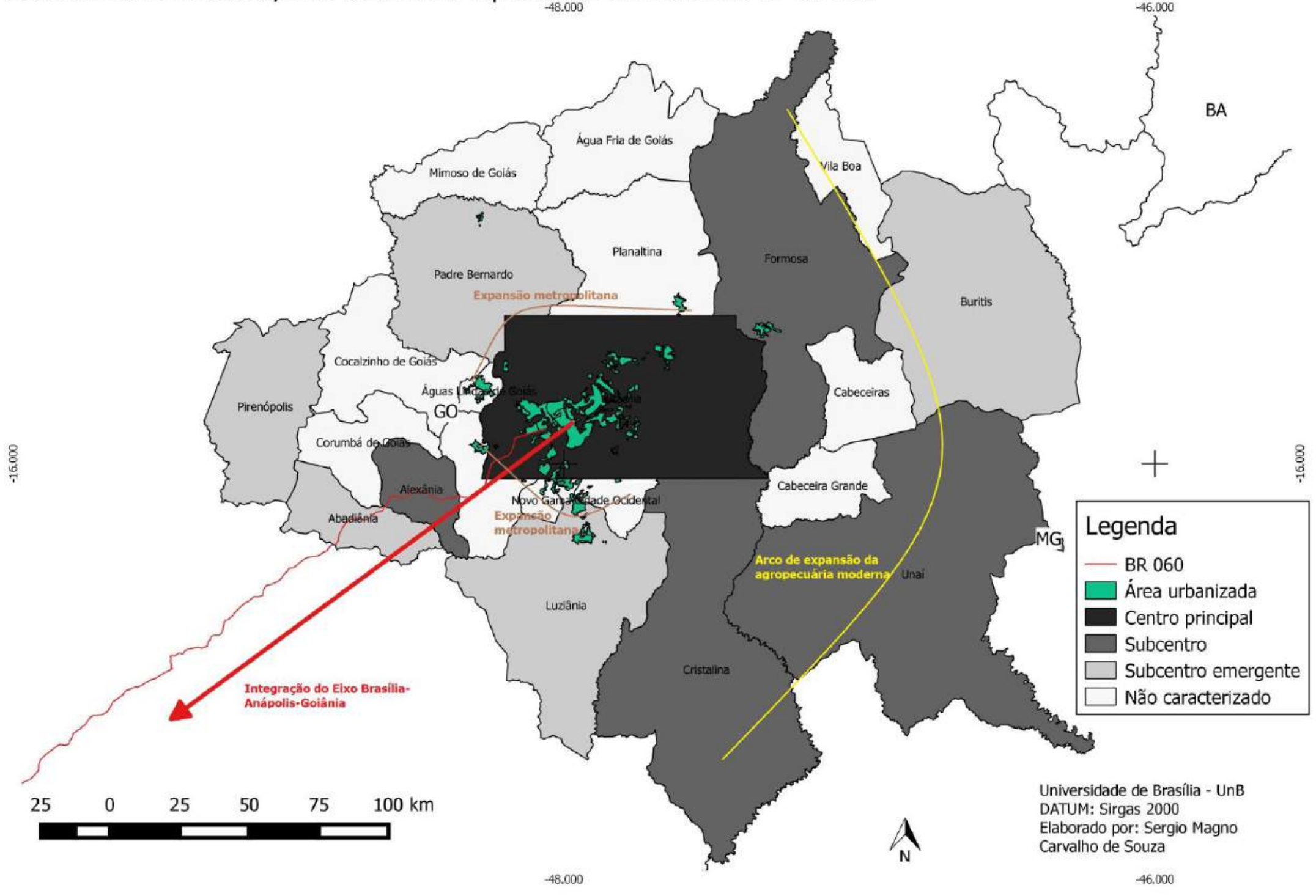


Analisando o resultado à luz dos processos anteriormente estudados como estruturantes da Ride-DF (expansão metropolitana, expansão da agropecuária moderna e integração do Eixo Brasília-Anápolis-Goiânia, postos na Figura 9.2), pode-se afirmar, inicialmente, que o processo de expansão metropolitana é responsável pela produção de apenas um único subcentro emergente, Luziânia (como se verá, Formosa e Alexânia, apesar de estarem inseridas no recorte da AMB, foram incluídas nos outros dois processos estruturantes da RideDF). Luziânia não foi caracterizada como subcentro "plenamente" por conta da polarização sobre ela exercida por Brasília, especialmente sobre frações importantes de seu espaço urbano. Por outro lado, por ter extenso território, o município tem ligação com atividades da agropecuária moderna, que serão analisadas posteriormente. Assim, vê-se que a expansão metropolitana é um processo, no caso de Brasília, ainda bastante concentrador das funções e na estrutura urbana, impondo dependência dos municípios nele envolvidos do centro principal.

Já para o caso do processo de expansão da agropecuária moderna, principalmente naquela que ocorre a leste do Distrito Federal, foram identificados como subcentros os municípios de Cristalina, Formosa e Unaí, além do subcentro emergente em Buritis. Desta forma, em comparação com a expansão metropolitana, verifica-se uma tendência mais clara de formação de subcentros, muito provavelmente pelas necessidades que estes municípios possuem de desempenhar funções de apoio técnico ao agronegócio moderno instalado na região.

Por fim, para o processo de integração do Eixo Brasília-Anápolis-Goiânia, foi identificado como subcentro Alexânia. Este município, muito por conta da atração de novos empreendimentos, aparenta ser aquele que mais beneficiado tem sido pela integração proposta pela economia das capitais federal e goiana e pelo fato de estar situado às margens da BR 060 . Foram caracterizados ainda como subcentros emergentes os municípios de Abadiânia, beneficiada, possivelmente, pelos mesmos efeitos de integração do Eixo, mas em menor escala que Alexânia e Pirenópolis, onde a atividade do turismo parece impulsionar a economia local.

Há ainda o caso de Padre Bernardo, caracterizado como subcentro emergente, e que não está inserido claramente em nenhum dos processos estruturantes. Isto aponta para o surgimento de uma nucleação de atividades ligada a tendências de modernização de uma subregião que, em sua maior parte, está ainda ligada à agropecuária tradicional.

Observando em uma lógica histórica, analisando a tipologia da Regic de 1987 (comentada na subseção 7.3.4 deste trabalho), vê-se que os municípios de Luziânia, Formosa e Unaí, que lá apareciam como "centros de zona", mantiveram destaque e tendem a se manter como subcentros importantes na Ride-DF (e mesmo fora dela, para o caso, principalmente, de 
Unaí). Desta forma, a atividade da agropecuária moderna, já importante naquela época, manteve sua tendência de produzir subcentros voltados ao apoio às atividades produtivas.

Tendo em vista a identificação dos subcentros e de sua caracterização potencial como pontos de concentração de recursos e riqueza, surge a indagação: como o processo se revela na socioeconomia das populações locais? Assim, a próxima seção dedica-se a analisar os efeitos do processo de reestruturação produtiva sobre as desigualdades socioespaciais na Ride-DF no período recente.

\subsection{Os efeitos sobre as desigualdades socioespaciais na Ride-DF}

Considerando a realidade recente do desenvolvimento econômico da região, durante o trabalho foi exposta a ideia de que efeitos da reestruturação produtiva capitalista podem atingir o quadro das desigualdades socioespaciais internas à Ride-DF. Esta seção dedicase a analisar tais rebatimentos.

\subsubsection{O modelo de análise proposto}

Diante do tema das desigualdades socioespaciais no âmbito intrarregional, foi realizada a discussão do tema no âmbito da subseção 4.2.2 deste trabalho. Parte do modelo utilizado tem ligação com a discussão ali realizada.

Neste sentido, considerando as muitas possibilidades de métodos possíveis de serem aplicados no sentido de analisar as desigualdades socioespaciais - tema amplo e subjetivo - optou-se por adotar a perspectiva do desenvolvimento regional, discutida no Capítulo 4.

Tais procedimentos tem se refletido, principalmente, nos critérios de elegibilidade das microrregiões na Política Nacional de Desenvolvimento Regional (PNDR). Atualmente, está no Senado Federal, sob o nome de Projeto de Lei do Senado n ${ }^{\circ} 375$, de 2015, o projeto de uma nova PNDR, que contém uma tipologia para elegibilidade das microrregiões, fruto de discussões internas no Ministério da Integração Nacional e no processo conferencial que desembocou no Projeto de Lei. A sistemática ora proposta é uma adaptação desta metodologia, que se refere, primordialmente, às microrregiões; aqui, busca-se adaptar os critérios para a análise de uma região singular, a Ride-DF. 
O Projeto de Lei da PNDR prevê, no texto legal, quatro objetivos para a política, que se traduzem em critérios específicos de elegibilidade das microrregiões. Destes objetivos, dois preveem, no corpo da lei, os critérios sugeridos. Os objetivos são os seguintes:

"I - promover a convergência do nível de desenvolvimento e da qualidade de vida entre e intra as regiões brasileiras e a equidade no acesso a oportunidades de desenvolvimento em regiões que apresentam baixos indicadores socioeconômicos;

II - garantir a competitividade regional e a geração de emprego e renda em regiões que apresentam declínio populacional e elevadas taxas de emigração; ”

De tais objetivos, são propostos os seguintes critérios:

“Art. $8^{\circ}$ Em relação ao objetivo constante do inciso I do art. $2^{\circ}$, são elegíveis as microrregiões cujo Rendimento Domiciliar per Capita - RDPc médio se encontre abaixo de $75 \%$ do RDPc médio do País.

Parágrafo único. As prioridades de atuação nessa classificação são definidas pelo indicador de dinamismo econômico, medido pela variação do Produto Interno Bruto - PIB na microrregião considerado em relação à mediana da variação do PIB nacional, sendo:

I - prioridade I: espaços com RDPc abaixo de 50\% da média nacional e entre $50 \%$ e $75 \%$ da média, de baixo dinamismo, sendo a variação do PIB menor que mediana da variação do PIB nacional;

II - prioridade II: espaços com RDPc entre 50\% e 75\% da média nacional e com alto dinamismo, sendo a variação do PIB maior que a mediana da variação do PIB nacional.

Art. $9^{\circ}$ Em relação ao objetivo constante do inciso II do art. $2^{\circ}$, são elegíveis as microrregiões que apresentaram crescimento populacional negativo e aquelas que cresceram a taxas inferiores a $50 \%$ da média nacional, medidos pela taxa de crescimento populacional da microrregião em relação à média nacional do último censo demográfico do IBGE." 
A partir destes, vê-se que a Política busca trabalhar com indicadores de três áreas específicas: renda, crescimento econômico e crescimento demográfico. A partir destes, é proposta uma adaptação para o estudo em curso para a Ride-DF e suas unidades componentes. Assim, os valores de referência nacional tornam-se valores de referência em escala regional; no lugar das microrregiões, unidades básicas da política, são considerados como elementares os municípios.

Assim, além desta adaptação, considerando a disponibilidade dos dados, algumas das fontes foram também alteradas. Desta forma, foi trabalhada, para renda, a renda per capita dos municípios; para o crescimento econômico: a variação percentual do PIB dos municípios. No caso da população, manteve-se o cálculo do crescimento demográfico com base no Censo Demográfico, para os anos de 2000 e 2010 (aqui tratado como variação percentual).

No caso da renda per capita, apropriando-se dos critérios postos pelo Projeto de Lei da PNDR, os municípios foram divididos em três faixas, a partir da porcentagem do valor que possuíam em relação ao valor da Ride-DF: acima de 75\% - alta renda; 75\% a 50\% - renda intermediária; abaixo de 50\% - baixa renda. Foram utilizados dados da amostra do Censo Demográfico de 2010.

Para o crescimento da economia, foi comparada a variação percentual do PIB dos municípios entre os anos de 2000 e 2010 e comparada à mesma variação da Ride-DF. Caso o valor fosse maior que o da Ride-DF, o município foi considerado de economia dinâmica; se abaixo, o município foi considerado de economia estagnada.

Ao término dos cálculos para renda e crescimento da economia, os resultados foram cruzados, gerando uma tipologia que analisa a evolução e associação dos dois fatores para a Ride-DF. De certa forma, é uma aproximação ao que a própria PNDR faz para eleger suas microrregiões, tanto na atual versão quanto na anterior, em que combina justamente a renda das microrregiões com a tendência de crescimento ou decréscimo da economia.

Depois, buscando explorar a questão do crescimento demográfico, foi analisada a variação percentual (usando os dados dos Censos Demográficos 2000 e 2010) da população dos municípios da Ride-DF, comparando-se o valor desta variação dos municípios em relação ao da região. Caso o valor tenha sido maior que $50 \%$, o município foi considerado de crescimento demográfico elevado; caso o valor tenha sido menor ou negativo, o município foi considerado de crescimento demográfico reduzido.

Por fim o resultado referente à tipologia produzida pelo cruzamento dos dados da renda e do crescimento da economia foram comparados com a variação percentual do Índice de Gini dos municípios (também para os anos de 2000 e 2010, a partir de dados do Atlas do 
Desenvolvimento Humano). Este índice tem a propriedade de analisar as desigualdades de renda internas aos municípios. A variação percentual do Índice de Gini foi ainda comparada aos processos estruturantes em curso na Ride-DF.

Ao término da análise dos indicadores referentes às desigualdades socioespaciais, os resultados foram comparados aos processos analisados anteriormente (tanto os três processos estruturantes quando a produção de centros e subcentros.

\subsubsection{Resultados da análise}

Considerando o modelo de análise proposto, o primeiro indicador a ser analisado é o de renda, composto pela renda per capita dos municípios. Os dados encontram-se na Tabela 9.15. Os resultados apontam que o único a obter a classificação como alta renda foi Brasília, possuindo uma renda per capita acima daquela registrada na Ride-DF. Foram considerados de renda intermediária os municípios de Cristalina, Formosa, Valparaíso de Goiás e Unaí. Desta forma, vê-se que os estratos mais elevados de renda são verificados, de forma geral, nos municípios identificados na seção anterior como "subcentros". Vai se delineando, desta forma, uma associação entre o processo de constituição dos subcentros e a existência de rendas relativamente altas nestes municípios. Todos os outros municípios foram considerados de baixa renda, inclusive a grande maioria dos municípios atingidos pela expansão metropolitana de Brasília. 
Tabela 9.15 - Renda per capita, faixa de percentual da renda per capita da região e tipologia de renda, por município da Ride-DF, 2010.

\begin{tabular}{|c|c|c|c|}
\hline Município & $\begin{array}{l}\text { Renda per } \\
\text { capita } \\
(2010)\end{array}$ & $\begin{array}{l}\text { Percentual da Renda } \\
\text { per capita da região }\end{array}$ & Renda \\
\hline Abadiânia (GO) & 519,87 & Abaixo de $50 \%$ & Baixa \\
\hline Água Fria de Goiás (GO) & 525,20 & Abaixo de $50 \%$ & Baixa \\
\hline Águas Lindas de Goiás (GO) & 449,38 & Abaixo de $50 \%$ & Baixa \\
\hline Alexânia (GO) & 498,09 & Abaixo de $50 \%$ & Baixa \\
\hline Cabeceiras (GO) & 420,47 & Abaixo de $50 \%$ & Baixa \\
\hline Cidade Ocidental (GO) & 647,64 & Abaixo de $50 \%$ & Baixa \\
\hline Cocalzinho de Goiás (GO) & 450,47 & Abaixo de $50 \%$ & Baixa \\
\hline Corumbá de Goiás (GO) & 503,01 & Abaixo de $50 \%$ & Baixa \\
\hline Cristalina (GO) & 686,90 & Entre 50 e $75 \%$ & Intermediária \\
\hline Formosa (GO) & 732,24 & Entre 50 e $75 \%$ & Intermediária \\
\hline Luziânia (GO) & 580,88 & Abaixo de $50 \%$ & Baixa \\
\hline Mimoso de Goiás (GO) & 474,44 & Abaixo de $50 \%$ & Baixa \\
\hline Novo Gama (GO) & 498,44 & Abaixo de $50 \%$ & Baixa \\
\hline Padre Bernardo (GO) & 518,12 & Abaixo de $50 \%$ & Baixa \\
\hline Pirenópolis (GO) & 544,78 & Abaixo de $50 \%$ & Baixa \\
\hline Planaltina (GO) & 466,69 & Abaixo de $50 \%$ & Baixa \\
\hline Santo Antônio do Descoberto (GO) & 449,39 & Abaixo de $50 \%$ & Baixa \\
\hline Valparaíso de Goiás (GO) & 764,73 & Entre 50 e $75 \%$ & Intermediária \\
\hline Vila Boa $(\mathrm{GO})$ & 376,72 & Abaixo de $50 \%$ & Baixa \\
\hline Buritis (MG) & 505,59 & Abaixo de $50 \%$ & Baixa \\
\hline Cabeceira Grande (MG) & 424,47 & Abaixo de $50 \%$ & Baixa \\
\hline Unaí (MG) & 720,51 & Entre 50 e $75 \%$ & Intermediária \\
\hline Brasília (DF) & $1.715,11$ & Acima de $75 \%$ & Alta \\
\hline Ride-DF & $1.362,52$ & & \\
\hline
\end{tabular}

Fonte: Atlas do Desenvolvimento Humano (dados tratados pelo autor)

O segundo indicador analisado, referente ao crescimento econômico, realizou sua análise, como prescrito, a partir da variação percentual do PIB dos municípios da Ride-DF. Os resultados estão na Tabela 9.16, a seguir. De um modo geral, o crescimento da economia da maior parte dos municípios da Ride-DF foi acima daquele registrado para a região como um todo, o que aponta para um processo de dinamização geral das economias. As exceções à tendência são justamente o que mais chama a atenção. O caso mais emblemático é o de Brasília. Com uma economia atrelada ao setor público, pode ser que a cidade não tenha conseguido aproveitar-se de outros processos que tem impulsionado a economia dos municípios da RideDF, como a expansão da agropecuária moderna. Muito disso deriva também da dificuldade que o Distrito Federal tem em atrair investimentos, que em geral preferem (muitos deles ligados ao setor secundário) localizar-se em Goiás, que possui uma política de atração de investimentos 
claramente mais agressiva. Ainda nesta lista de municípios estão Cidade Ocidental e Santo Antônio do Descoberto, cujo resultado se associa à tendência de manutenção destas como periferia dependente do centro metropolitano e regional, o que parece se refletir na dificuldade em ter um crescimento econômico mais vigoroso. Finalmente, há o caso de Corumbá de Goiás, pequeno município de economia centrada na agropecuária menos modernizada, que apesar da proximidade ao Eixo Brasília-Anápolis-Goiânia, ainda não consegue, ao que parece, se inserir nos processos de desenvolvimento que aí ocorrem.

Tabela 9.16 - PIB nos anos de 2000 e 2010 (em mil reais), variação percentual do PIB e classificação das economias, por municípios da Ride-DF.

\begin{tabular}{|c|c|c|c|c|}
\hline Município & $\begin{array}{l}\text { PIB - em mil reais } \\
(2000)\end{array}$ & $\begin{array}{l}\text { PIB - em mil reais } \\
(2010)\end{array}$ & $\begin{array}{l}\text { Variação } \\
(\mathrm{em} \%)\end{array}$ & Economia \\
\hline Abadiânia (GO) & 26.008 & 109.773 & 322,07 & Dinâmica \\
\hline Água Fria de Goiás (GO) & 17.579 & 131.009 & 645,26 & Dinâmica \\
\hline Águas Lindas de Goiás (GO) & 164.372 & 676.645 & 311,65 & Dinâmica \\
\hline Alexânia (GO) & 50.183 & 327.857 & 553,32 & Dinâmica \\
\hline Cabeceiras (GO) & 28.381 & 131.844 & 364,55 & Dinâmica \\
\hline Cidade Ocidental (GO) & 86.232 & 264.069 & 206,23 & Estagnada \\
\hline Cocalzinho de Goiás (GO) & 35.484 & 127.155 & 258,34 & Dinâmica \\
\hline Corumbá de Goiás (GO) & 22.657 & 73.871 & 226,04 & Estagnada \\
\hline Cristalina $(\mathrm{GO})$ & 217.495 & 1.122 .296 & 416,01 & Dinâmica \\
\hline Formosa (GO) & 217.755 & 911.489 & 318,58 & Dinâmica \\
\hline Luziânia (GO) & 573.127 & 2.071 .930 & 261,51 & Dinâmica \\
\hline Mimoso de Goiás (GO) & 8.522 & 28.987 & 240,14 & Dinâmica \\
\hline Novo Gama (GO) & 127.153 & 432.307 & 239,99 & Dinâmica \\
\hline Padre Bernardo (GO) & 43.011 & 187.005 & 334,78 & Dinâmica \\
\hline Pirenópolis (GO) & 48.415 & 172.333 & 255,95 & Dinâmica \\
\hline Planaltina $(\mathrm{GO})$ & 123.679 & 440.380 & 256,07 & Dinâmica \\
\hline Santo Antônio do Descoberto (GO) & 87.294 & 280.866 & 221,75 & Estagnada \\
\hline Valparaíso de Goiás (GO) & 204.198 & 844.615 & 313,63 & Dinâmica \\
\hline Vila Boa (GO) & 8.993 & 73.057 & 712,38 & Dinâmica \\
\hline Buritis (MG) & 97.169 & 378.229 & 289,25 & Dinâmica \\
\hline Cabeceira Grande (MG) & 27.394 & 113.758 & 315,27 & Dinâmica \\
\hline Unaí (MG) & 388.462 & 1.402 .293 & 260,99 & Dinâmica \\
\hline Brasília (DF) & 46.474 .890 & 149.906 .319 & 222,55 & Estagnada \\
\hline Ride-DF & 49.078.453 & 160.208.087 & 226,43 & \\
\hline
\end{tabular}

Fonte: IBGE (dados tratados pelo autor)

Em seguida, buscando um paralelo com o realizado pela PNDR, os dados dos dois primeiros indicadores foram comparados, o que gerou uma tipologia preliminar. Tais informações encontram-se no Quadro 9.7, abaixo: 
Quadro 9.7 - Tipologias de renda e dinamismo da economia, por municípios da Ride-DF

\begin{tabular}{|c|c|c|c|}
\hline Município & Renda & $\begin{array}{l}\text { Dinamismo } \\
\text { da } \\
\text { economia }\end{array}$ & Tipologia renda e dinamismo da economia \\
\hline Abadiânia (GO) & Baixa renda & Dinâmica & Baixa renda e economia dinâmica \\
\hline Água Fria de Goiás (GO) & Baixa renda & Dinâmica & Baixa renda e economia dinâmica \\
\hline Águas Lindas de Goiás (GO) & Baixa renda & Dinâmica & Baixa renda e economia dinâmica \\
\hline Alexânia (GO) & Baixa renda & Dinâmica & Baixa renda e economia dinâmica \\
\hline Cabeceiras (GO) & Baixa renda & Dinâmica & Baixa renda e economia dinâmica \\
\hline Cidade Ocidental (GO) & Baixa renda & Estagnada & Baixa renda e economia estagnada \\
\hline Cocalzinho de Goiás (GO) & Baixa renda & Dinâmica & Baixa renda e economia dinâmica \\
\hline Corumbá de Goiás (GO) & Baixa renda & Estagnada & Baixa renda e economia estagnada \\
\hline Cristalina (GO) & Renda intermediária & Dinâmica & Renda intermediária e economia dinâmica \\
\hline Formosa (GO) & Renda intermediária & Dinâmica & Renda intermediária e economia dinâmica \\
\hline Luziânia (GO) & Baixa renda & Dinâmica & Baixa renda e economia dinâmica \\
\hline Mimoso de Goiás (GO) & Baixa renda & Dinâmica & Baixa renda e economia dinâmica \\
\hline Novo Gama (GO) & Baixa renda & Dinâmica & Baixa renda e economia dinâmica \\
\hline Padre Bernardo (GO) & Baixa renda & Dinâmica & Baixa renda e economia dinâmica \\
\hline Pirenópolis (GO) & Baixa renda & Dinâmica & Baixa renda e economia dinâmica \\
\hline Planaltina (GO) & Baixa renda & Dinâmica & Baixa renda e economia dinâmica \\
\hline Santo Antônio do Descoberto (GO) & Baixa renda & Estagnada & Baixa renda e economia estagnada \\
\hline Valparaíso de Goiás (GO) & Renda intermediária & Dinâmica & Renda intermediária e economia dinâmica \\
\hline Vila Boa (GO) & Baixa renda & Dinâmica & Baixa renda e economia dinâmica \\
\hline Buritis (MG) & Baixa renda & Dinâmica & Baixa renda e economia dinâmica \\
\hline Cabeceira Grande (MG) & Baixa renda & Dinâmica & Baixa renda e economia dinâmica \\
\hline Unaí (MG) & Renda intermediária & Dinâmica & Renda intermediária e economia dinâmica \\
\hline Brasília (DF) & Alta renda & Estagnada & Alta renda e economia estagnada \\
\hline
\end{tabular}

Fonte: Elaboração própria

A partir dos dados do Quadro 9.7, foi elaborado o mapa da Figura 9.3, abaixo: 
Figura 9.3

Classificação dos municípios da Ride-DF a partir da tipologia proposta para renda e crescimento da economia

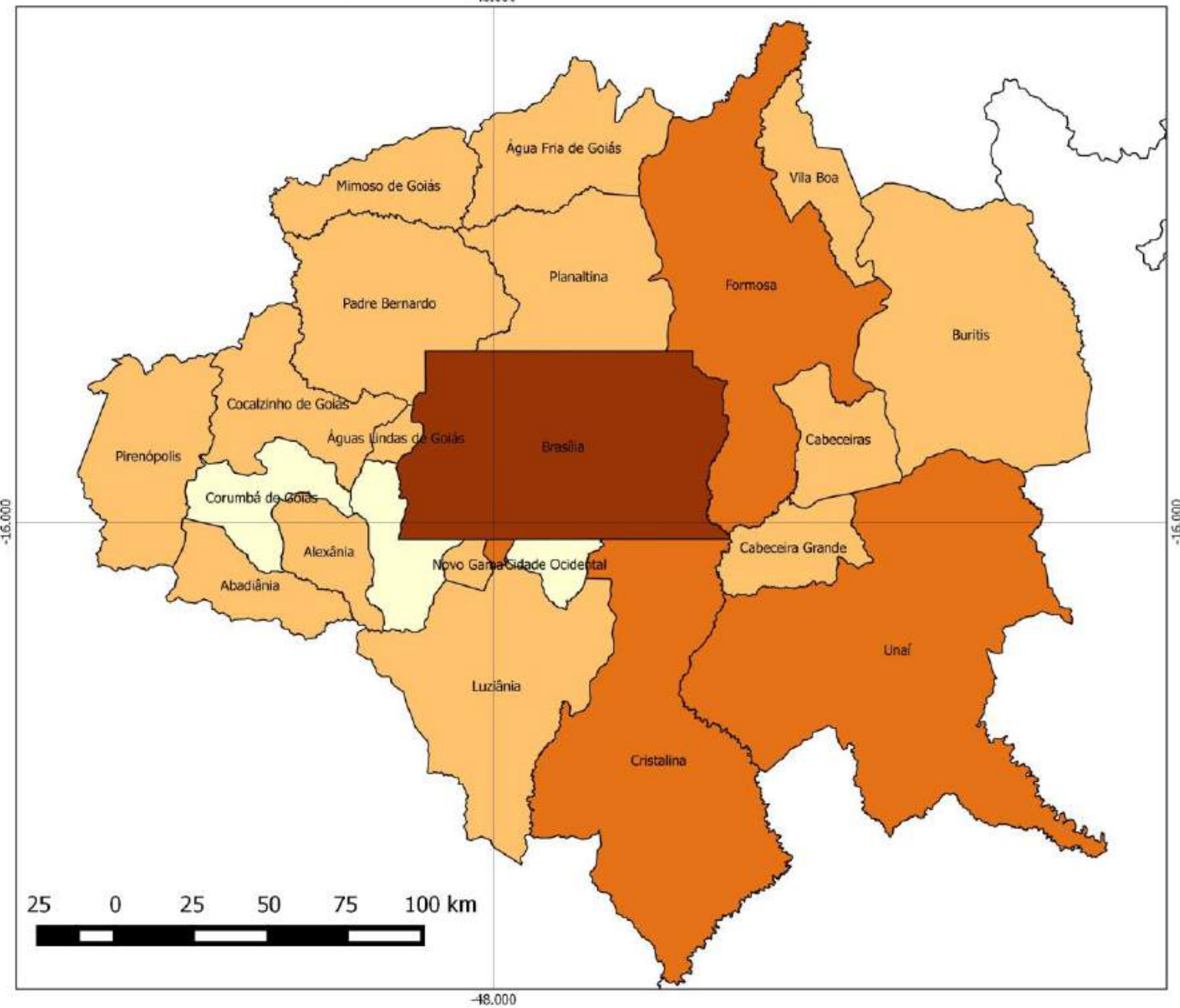

Universidade de Brasilia - Un DATUM: Sirgas 2000

Elaborado por: Sergio Magno

Carvalho de Souza

\section{Legenda}

Alta renda

economia estagnada

Renda intermediária

economia dinâmica

Baixa renda

economia dinâmica

Baixa renda

economia estagnada

A 
A partir dos dados do Quadro 9.7 e da Figura 9.3 acima, os resultados sugerem, inicialmente, 15 municípios na tipologia "baixa renda e economia dinâmica". Conforme visto na subseção 8.4, tal tipologia abarca municípios envolvidos nos três processos estruturantes da Ride-DF (expansão metropolitana, expansão da agropecuária moderna e integração do Eixo Brasília-Anápolis-Goiânia). Por outro lado, deste grupo de municípios, apenas um foi identificado como subcentro "pleno", Alexânia. Há ainda os casos de Buritis, Luziânia, Alexânia, Abadiânia e Pirenópolis, considerados subcentros emergentes. Além disto, o fato de muitos dos municípios da Ride-DF estarem associados a tal tipologia sugere que possivelmente os processos estruturantes citados são responsáveis pelo crescimento econômico, manifestado no PIB. No entanto, parecem ser ainda pouco capazes de distribuir renda. Essa característica estaria muito patente na produção do moderno agronegócio: a PNDR, que serve de referência para esta parte do estudo, possui um objetivo específico de atuação nas microrregiões onde há grande produção de commodities. O pressuposto é de que há baixa diversificação produtiva e tendência a concentração de renda.

Já os resultados referentes à renda intermediária e economia dinâmica surgem associados a três dos subcentros "plenos" identificados, quais sejam Formosa, Unaí e Cristalina e ainda a um município afetado pela expansão metropolitana de Brasília (Valparaíso). Tal dado aponta para a seguinte inferência: estes quatro municípios, junto com Brasília, tornam-se pontos de controle dos processos estruturantes em curso e, ao apoiarem sua ocorrência, tem sido os principais beneficiados por tanto, já que aí se alia o crescimento econômico e valor de renda ao menos intermediários. No caso de Brasília, esta mantém sua renda elevada, apesar de não conseguir engendrar um maior crescimento de sua economia e, relação ao total da Ride-DF.

Há ainda o caso dos três municípios registrados como de baixa renda e economia estagnada: Corumbá de Goiás, Cidade Ocidental, e Santo Antônio do Descoberto. O primeiro, apesar da proximidade à Anápolis, e por ter uma economia baseada na agropecuária tradicional, parece não se inserir nas dinâmicas de desenvolvimento econômico mais recentes da Ride-DF, não sendo incluída no processo estruturante de integração do Eixo Brasília-Anápolis-Goiânia. Já os casos de Cidade Ocidental, e Santo Antônio do Descoberto, aparentam manter a tendência como dormitórios, apontando para a tendência de sua manutenção como periferias dependentes e de economia deprimida em relação a Brasília.

Em seguida, é feita a análise do indicador referente ao crescimento demográfico, cujos resultados estão na Tabela 9.17. A partir dos dados desta tabela, vê-se que a maior parte dos municípios (15) da Ride-DF possui variação percentual em sua população total acima de $50 \%$ do valor correspondente para a Ride-DF. Os municípios que estão abaixo deste patamar 
(e foram considerados de crescimento demográfico reduzido) são: Cabeceiras, Corumbá de Goiás, Mimoso de Goiás, Pirenópolis, Planaltina, Buritis, Cabeceira Grande e Unaí. Este grupo possui diversos municípios associados à atividade da agropecuária moderna, que tende a oferecer relativamente poucos empregos, especialmente nos casos de Cabeceiras, Buritis, Cabeceira Grande e Unaí. Outros são pequenos municípios no quais predomina a atividade agropecuária de menor modernização, casos de Corumbá de Goiás e Mimoso de Goiás. Há ainda o caso de Pirenópolis e Planaltina - este último município associado ao processo de expansão metropolitana de Brasília, o que sugere que a tendência de ter menor renda, além de não se constituir como subcentro pode estar levando a menor atração de população.

Tabela 9.17 - População total nos anos de 2000 e 2010, variação percentual e classificação do crescimento demográfico, por municípios da Ride-DF

\begin{tabular}{|c|c|c|c|c|}
\hline Município & $\begin{array}{l}\text { População } \\
\text { total (2000) }\end{array}$ & $\begin{array}{l}\text { População } \\
\text { total (2010) }\end{array}$ & $\begin{array}{l}\text { Variação } \\
(\text { em \%) }\end{array}$ & $\begin{array}{l}\text { Crescimento } \\
\text { demográfico }\end{array}$ \\
\hline Abadiânia (GO) & 11.452 & 15.757 & 37,59 & Elevado \\
\hline Água Fria de Goiás (GO) & 4.469 & 5.090 & 13,90 & Elevado \\
\hline Águas Lindas de Goiás (GO) & 105.746 & 159.378 & 50,72 & Elevado \\
\hline Alexânia (GO) & 20.047 & 23.814 & 18,79 & Elevado \\
\hline Cabeceiras (GO) & 6.758 & 7.354 & 8,82 & Reduzido \\
\hline Cidade Ocidental (GO) & 40.377 & 55.915 & 38,48 & Elevado \\
\hline Cocalzinho de Goiás (GO) & 14.626 & 17.407 & 19,01 & Elevado \\
\hline Corumbá de Goiás (GO) & 9.679 & 10.361 & 7,05 & Reduzido \\
\hline Cristalina (GO) & 34.116 & 46.580 & 36,53 & Elevado \\
\hline Formosa (GO) & 78.651 & 100.085 & 27,25 & Elevado \\
\hline Luziânia (GO) & 141.082 & 174.531 & 23,71 & Elevado \\
\hline Mimoso de Goiás (GO) & 2.801 & 2.685 & 4,14 & Reduzido \\
\hline Novo Gama (GO) & 74.380 & 95.018 & 27,75 & Elevado \\
\hline Padre Bernardo (GO) & 21.514 & 27.671 & 28,62 & Elevado \\
\hline Pirenópolis (GO) & 21.245 & 23.006 & 8,29 & Reduzido \\
\hline Planaltina (GO) & 73.718 & 81.649 & 10,76 & Reduzido \\
\hline Santo Antônio do Descoberto (GO) & 51.897 & 63.248 & 21,87 & Elevado \\
\hline Valparaíso de Goiás (GO) & 94.856 & 132.982 & 40,19 & Elevado \\
\hline Vila Boa (GO) & 3.287 & 4.735 & 44,05 & Elevado \\
\hline Buritis (MG) & 20.396 & 22.737 & 11,48 & Reduzido \\
\hline Cabeceira Grande (MG) & 5.920 & 6.453 & 9,00 & Reduzido \\
\hline Unaí (MG) & 70.033 & 77.565 & 10,75 & Reduzido \\
\hline Brasília (DF) & 2.051 .146 & 2.570 .160 & 25,30 & Elevado \\
\hline Ride-DF & 2.958.196 & 3.724.181 & 25,89 & \\
\hline
\end{tabular}

Fonte: IBGE (dados tratados pelo autor)

A partir dos resultados, a análise mostrou, inicialmente, que os indicadores de renda tendem a ser mais próximos de valores elevados nos municípios identificados como subcentros, 
sendo o caso de Cristalina, Formosa e Unaí. A combinação deste indicador junto ao de crescimento econômico demonstra uma tendência de crescimento econômico na maior parte dos municípios da Ride-DF, o que sugere estar ocorrendo um processo de expansão da economia que não corresponde, obrigatoriamente, à melhora de renda da população. $\mathrm{O}$ caso do centro principal chama a atenção por este concentrar os melhores indicadores de renda, porém com economia que cresce em ritmo mais lento.

Por fim, os resultados da tipologia proposta foram comparados com a variação percentual do Índice de Gini dos municípios da Ride-DF. Os resultados de tal comparação constam na Tabela 9.18. Inicialmente, os dados apontam para uma melhoria geral no Índice de Gini de praticamente todos os municípios, o que pode ser creditado, de uma forma geral, à tendência nacional de melhoria na distribuição de renda nos últimos anos. Por outro lado, vêse que o resultado geral para a Ride-DF foi baixo, tendo uma variação de $-1,54 \%$ entre 2000 e 2010. Tal resultado pode ser creditado à Brasília, onde o Índice manteve-se inalterado no período. Isto significa que no centro principal, local de maior concentração da população a desigualdade de renda interna manteve-se inalterada, possuindo, além disso, o maior valor registrado para o ano de 2010. Assim, as políticas de distribuição de renda e a própria dinâmica de desenvolvimento econômico da região não foram capazes de tornar a renda melhor distribuída no centro principal. Há ainda o caso de Cidade Ocidental, onde o índice, ao invés de variar negativamente, variou positivamente em 2,04\%. Considerando que este município apareceu, na tipologia renda e dinamismo econômico como sendo de baixa renda e economia estagnada, vê-se que este é talvez o município com os piores indicadores analisados. 
Tabela 9.18 - Índice de Gini (2000 e 2010), variação percentual, tipologia renda e crescimento econômico e divisão por processo estruturante, na Ride-DF

\begin{tabular}{|c|c|c|c|c|c|}
\hline Município & $\begin{array}{l}\text { Índice de } \\
\text { Gini } \\
(2000)\end{array}$ & $\begin{array}{l}\text { Índice de } \\
\text { Gini } \\
(2010)\end{array}$ & $\begin{array}{l}\text { Variação } \\
(\mathrm{em} \%)\end{array}$ & Tipologia renda e dinamismo econômico & Processo estruturante \\
\hline Abadiânia (GO) & 0,54 & 0,43 & $-20,37$ & Baixa renda e economia dinâmica & Integração Eixo BAG \\
\hline Água Fria de Goiás (GO) & 0,67 & 0,60 & $-10,45$ & Baixa renda e economia dinâmica & Outros processos \\
\hline Águas Lindas de Goiás (GO) & 0,45 & 0,43 & $-4,44$ & Baixa renda e economia dinâmica & Expansão metropolitana \\
\hline Alexânia (GO) & 0,54 & 0,46 & $-14,81$ & Baixa renda e economia dinâmica & Integração Eixo BAG \\
\hline Cabeceiras (GO) & 0,56 & 0,48 & $-14,29$ & Baixa renda e economia dinâmica & Expansão da agropecuária moderna \\
\hline Cidade Ocidental (GO) & 0,49 & 0,50 & 2,04 & Baixa renda e economia estagnada & Expansão metropolitana \\
\hline Cocalzinho de Goiás (GO) & 0,51 & 0,47 & $-7,84$ & Baixa renda e economia dinâmica & Outros processos \\
\hline Corumbá de Goiás (GO) & 0,60 & 0,51 & $-15,00$ & Baixa renda e economia estagnada & Outros processos \\
\hline Cristalina (GO) & 0,58 & 0,57 & $-1,72$ & Renda intermediária e economia dinâmica & Expansão da agropecuária moderna \\
\hline Formosa (GO) & 0,61 & 0,56 & $-8,20$ & Renda intermediária e economia dinâmica & Expansão da agropecuária moderna \\
\hline Luziânia (GO) & 0,56 & 0,50 & $-10,71$ & Baixa renda e economia dinâmica & Área de múltiplas influências \\
\hline Mimoso de Goiás (GO) & 0,59 & 0,58 & $-1,69$ & Baixa renda e economia dinâmica & Outros processos \\
\hline Novo Gama (GO) & 0,50 & 0,46 & $-8,00$ & Baixa renda e economia dinâmica & Expansão metropolitana \\
\hline Padre Bernardo (GO) & 0,61 & 0,56 & $-8,20$ & Baixa renda e economia dinâmica & Outros processos \\
\hline Pirenópolis (GO) & 0,55 & 0,49 & $-10,91$ & Baixa renda e economia dinâmica & Integração Eixo BAG \\
\hline Planaltina (GO) & 0,55 & 0,43 & $-21,82$ & Baixa renda e economia dinâmica & Expansão metropolitana \\
\hline St. Antônio do Descoberto (GO) & 0,48 & 0,45 & $-6,25$ & Baixa renda e economia estagnada & Expansão metropolitana \\
\hline Valparaíso de Goiás (GO) & 0,53 & 0,50 & $-5,66$ & Renda intermediária e economia dinâmica & Expansão metropolitana \\
\hline Vila Boa (GO) & 0,52 & 0,48 & $-7,69$ & Baixa renda e economia dinâmica & Expansão da agropecuária moderna \\
\hline Buritis (MG) & 0,70 & 0,57 & $-18,57$ & Baixa renda e economia dinâmica & Expansão da agropecuária moderna \\
\hline Cabeceira Grande (MG) & 0,52 & 0,47 & $-9,62$ & Baixa renda e economia dinâmica & Expansão da agropecuária moderna \\
\hline Unaí (MG) & 0,70 & 0,54 & $-22,86$ & Renda intermediária e economia dinâmica & Expansão da agropecuária moderna \\
\hline Brasília (DF) & 0,63 & 0,63 & 0,00 & Alta renda e economia estagnada & Centro regional e metropolitano \\
\hline Ride-DF & 0,65 & 0,64 & $-1,54$ & & \\
\hline
\end{tabular}

Fonte: Atlas do Desenvolvimento Humano 
Por outro lado, considerando que a variação foi negativa na maior parte dos municípios, uma análise possível é compreender o quanto tal variação negativa se deu, a partir daqueles que mais variaram. A partir disto, pode-se proceder à associação deste "ranking" à tipologia renda e dinamismo econômico e ao processo estruturante. Desta forma, considerando os municípios em que a variação negativamente mais elevada, destacam-se Unaí (-22,86\%), Planaltina, (-21,82\%), Abadiânia (-18,57\%), Corumbá de Goiás (-15,00\%), Alexânia (-14,81\%) e Cabeceiras (-14,29\%). O perfil destes municípios, a partir da tipologia renda e dinamismo econômico e processo estruturante não aponta para um padrão comum (ou para a dominância de uma tipologia/ processo estruturante). Em um intervalo que pode ser considerado “intermediário", estão os resultados de Luziânia (-10,71\%), Água Fria de Goiás (-10,45\%), Cabeceira Grande (-9,62\%), Formosa (-8,20\%), Padre Bernardo (-8,20\%), Novo Gama (8,00\%), Cocalzinho de Goiás (-7,84\%) e Vila Boa (-7,69\%). Novamente, estes municípios não aparentam ter um padrão ou dominância específica quanto à tipologia e ao processo estruturante que aí atua.

Tal quadro se altera ao se analisar os seis últimos colocados, considerando a variação percentual negativa. São eles: Santo Antônio do Descoberto (-6,25\%), Valparaíso de Goiás (-5,66\%), Águas Lindas de Goiás (-4,44\%), Cristalina (-1,72\%), Mimoso de Goiás (1,69\%), Brasília (0,00\%) e Cidade Ocidental (2,04\%). Aí se identificam, especialmente no que tange ao processo estruturante, espaços associados ao centro regional e metropolitano e à sua expansão metropolitana (Santo Antônio do Descoberto, Valparaíso de Goiás, Águas Lindas de Goiás, Cidade Ocidental, Brasília). Desta forma, vê-se que a redução das desigualdades socioespaciais é menor justamente na porção do território que concentra a maior parte da população da região (segundo dados do $\mathrm{IBGE}^{46}$, cerca de $80,06 \%$ da população em 2010). Em parte, tal processo de redução das desigualdades socioespaciais internas é menor por conta dos dados analisados em torno do crescimento demográfico, que, como visto, aponta para o crescimento mais acentuado destes municípios. Há efeito, assim, da elevada imigração sobre os valores da redução das desigualdades socioespaciais nestes municípios. Isto reforça a ideia de que houveram melhorias na distribuição de renda se se considera os casos dos municípios; porém, de modo geral, (inclusive como revela a variação percentual para a Ride-DF, na Tabela $9.18,-1,54 \%$ ), o avanço foi reduzido, pois nas áreas mais populosas a renda se desconcentrou menos.

\footnotetext{
${ }^{46}$ Estes dados encontram-se expostos na Tabela 8.1, pag. 153.
} 
Assim, considerando o resultado da combinação dos indicadores de renda e dinamismo econômico, não ficaram demonstradas tendências de associação direta a nenhum dos três processos estruturantes da Ride-DF (expansão metropolitana, expansão da agropecuária moderna e integração do Eixo Brasília-Anápolis-Goiânia). Por outro lado, houve clara associação ao processo de constituição de subcentros. Desta forma, pode-se inferir que a reestruturação produtiva impacta na questão das desigualdades socioespaciais na região por meio da imposição de ritmos diferenciados de desenvolvimento dos municípios, acelerando tal processo e elevando a renda naqueles que são postos no papel de apoio e controle a atividades produtivas (especialmente a agropecuária). Há aí uma concentração, em subcentros, diante de um "mar" de municípios em que predomina baixa renda e economia dinâmica. Assim, pode-se evocar, em âmbito regional, o que Correa (1989) via em âmbito urbano: haveria uma relação de "drenagem" da mais-valia produzida não apenas nos próprios municípios, mas também nos municípios vizinhos. Isto provavelmente ocorre porque naqueles em que há a combinação de baixa renda e economia dinâmica localizam-se os espaços das lavouras, o local da produção em si. Por outro lado, as funções de controle da produção tendem a ocorrer nos subcentros identificados. Estes acabam por obter melhorias em sua renda e se estruturam como subcentros. Desta forma, os dois processos (produção de subcentros e evolução recente das desigualdades socioespaciais) que parecem consequências não associadas da reestruturação produtiva na região sugerem uma articulação entre si, além de revelar as tendências desiguais da reestruturação produtiva capitalista.

O indicador referente ao crescimento demográfico revelou, por outro lado, que alguns dos municípios atingidos pela expansão da agropecuária moderna tem apresentado crescimento demográfico reduzido. Isto pode apontar para tendências de emigração para o espaço metropolizado de Brasília, além de sugerir a possibilidade de a concentração de terras (processo associado à modernização) gerar efeitos de expulsão da população nestes espaços. Outros municípios em que o crescimento foi identificado como reduzido são pequenos e, pela falta de estrutura de oferta de bens e serviços, tendem a crescer mais lentamente, o que para municípios de pequeno porte e sem atividade econômica de maior vulto pode ser determinante em um quadro alongado de pobreza (este parece ser bem a característica de Mimoso de Goiás, onde há decréscimo da população).

Já a análise do Índice de Gini apontou para uma melhoria na maior parte dos municípios, porém com melhora reduzida ao se considerar onde está localizada a maior parte da população (e onde está localizado o centro metropolitano e regional, Brasília). Desta forma, e considerando a possibilidade acima apontada de "expulsão" da população dos espaços em que 
tem ocorrido o processo de expansão da agropecuária moderna, a melhoria no Índice de Gini dos municípios em que este processo tem ocorrido pode ser efeito estatístico, a partir de uma "transferência" da população mais pobre para o centro metropolitano e regional e alguns dos municípios afetados pela expansão metropolitana. Nestes, especialmente naqueles ao sul do Distrito Federal (Santo Antônio do Descoberto, Valparaíso de Goiás, Águas Lindas de Goiás, Cidade Ocidental), o Índice demonstrou variação negativa abaixo do valor registrado nos outros municípios (havendo variação positiva, no caso de Cidade Ocidental e variação nula em Brasília). Assim, pode-se afirmar que há melhoria na distribuição da renda na maior parte dos municípios da Ride-DF, porém, considerando a população, a variação é ainda reduzida e temse mantido a tendência de redução lenta na concentração de renda.

A próxima seção dedica-se, a partir destes resultados e do discutido no capítulo, "reconstituir" a região e posicionar as dinâmicas territoriais em curso, sintetizando as análises.

\subsection{Síntese: um esforço de leitura da Ride-DF}

Considerando os esforços de análise das subseções anteriores, viu-se que há três processos responsáveis pela estruturação e organização do espaço da Ride-DF: a expansão metropolitana de Brasília, a expansão da agropecuária moderna e a integração do Eixo BrasíliaAnápolis-Goiânia. Viu-se ainda que a articulação destes três processos levou à formação de subcentros e à alteração no quadro das desigualdades socioespaciais na Ride-DF. Revelou-se uma concentração de renda superior nos municípios considerados subcentros, sugerindo que sua dinâmica econômica está articulada à reestruturação produtiva, que atua de forma seletiva e no sentido de impor fragmentação à região. Tal fragmentação torna-se sensível a partir da análise dos processos estruturantes, que podem também ser lidos como as relações sociais, econômicas e produtivas impostas à região neste novo momento do capitalismo.

Assim, a partir do discutido, é possível agora pensar em uma leitura de síntese para a Ride-DF identificando os rebatimentos territoriais dos processos analisados. Buscando representar as relações em curso, sugere-se uma tipologia para os municípios que compõem esta região. Este esforço é iniciado a partir da Figura 9.4, abaixo: 


\section{Regionalização sugerida para os municípios da Ride-DF}

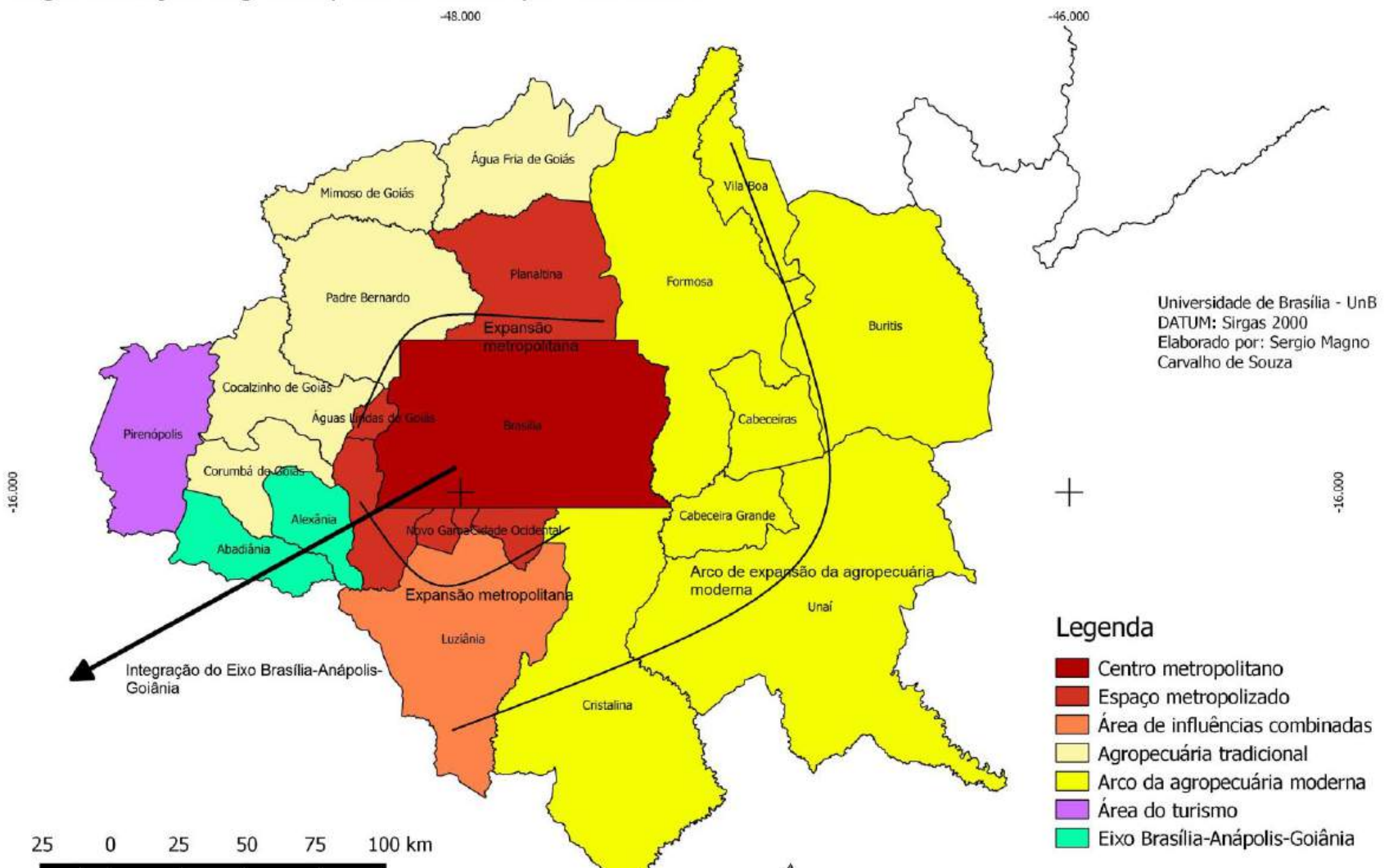


Nesse sentido, a regionalização/ tipologia proposta para os municípios é composta das seguintes sub-regiões:

- Centro metropolitano e espaço metropolizado: corresponde ao espaço atingido pelo processo de metropolização iniciado em Brasília, área core da região e comandante deste processo. É a sub-região responsável pela oferta de bens e serviços de maior valor para a região. Por ter forte caráter concentrador, viu-se que ainda não foi caracterizado nenhum subcentro para esta sub-região. Quanto às desigualdades socioespaciais, é o espaço que tem os maiores valores de variação percentual na população não conseguindo, por outro lado, melhorar a distribuição de renda para a população imigrante que aí chega. Tem, desta forma, os serviços públicos mais pressionados. As Fotos 9.1 e 9.2 apresentam os contrastes existentes nos espaços metropolizados: primeiramente o centro de Novo Gama, município que, conforme se viu na análise dos dados, altamente dependente de Brasília e com traços claros de município dormitório, com uma economia deprimida; no segundo caso, Valparaíso dá mostras de se tornar um importante subcentro comercial (apesar de não caracterizado pelo modelo analisado) ao sul do Distrito Federal e que atende os municípios vizinhos mais dependentes de Brasília, porém ainda muito dependente do centro principal. No caso de Valparaíso de Goiás, o fato de ser cortada e de ter seu espaço urbano estruturado em torno da BR 060 revela-se uma vantagem em relação a municípios vizinhos, como Novo Gama e Cidade Ocidental.

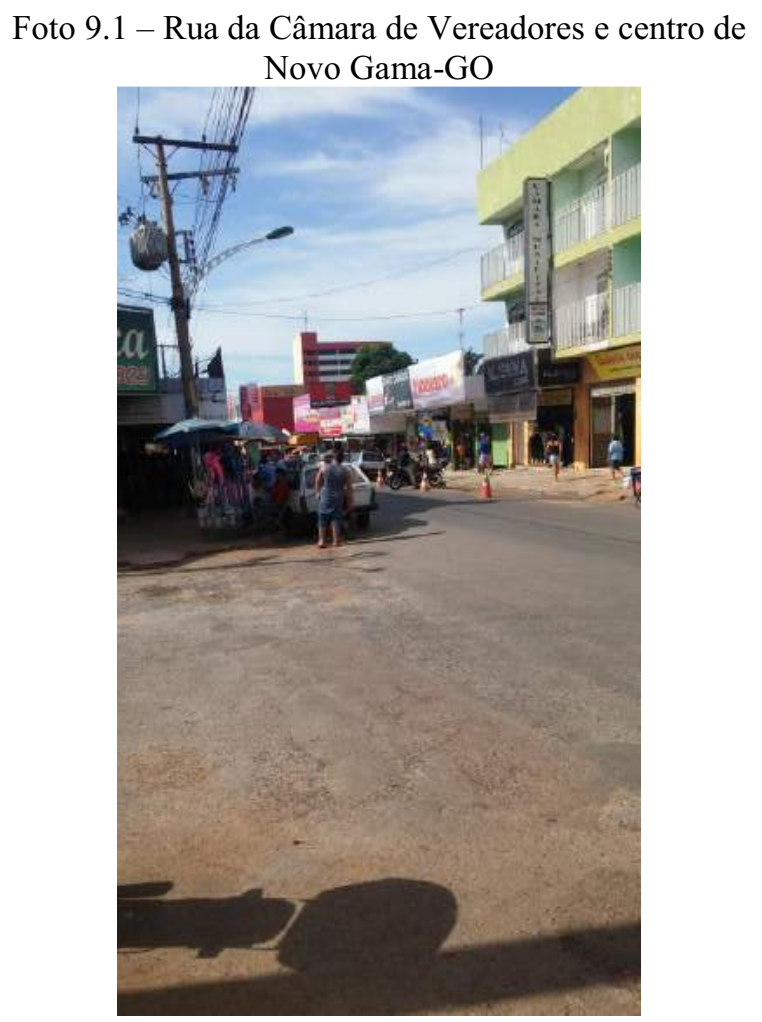

Fonte: acervo do autor 


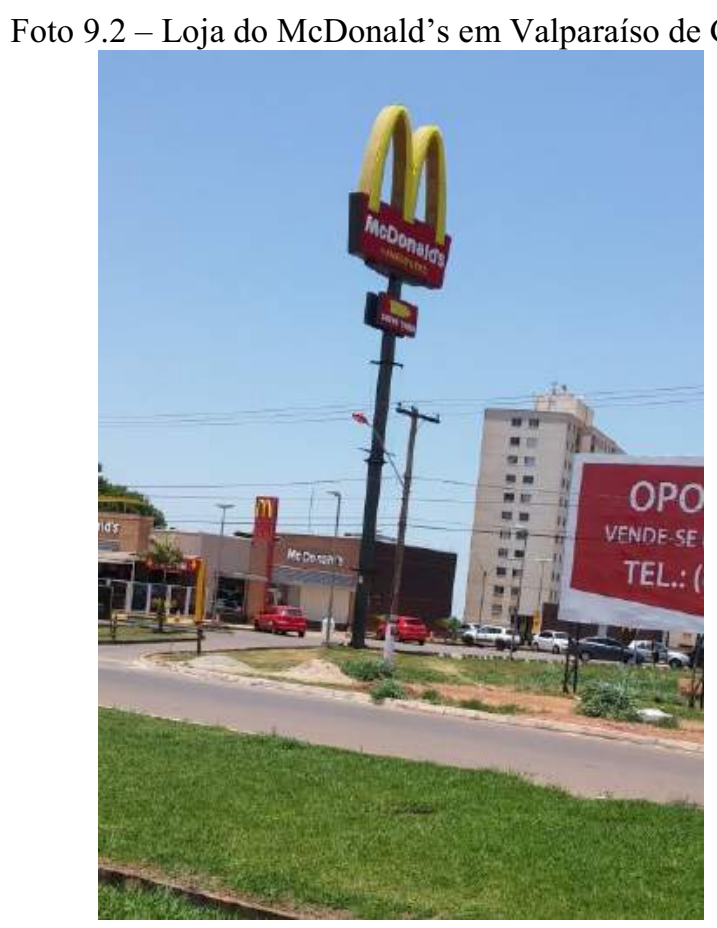

Fonte: acervo do autor

- Área de influências combinadas - Luziânia: Luziânia recebe uma classificação única, tendo em vista seu papel tanto no processo de expansão metropolitana quanto na expansão e estruturação do arco da agropecuária moderna. Em seu grande território, abarca as duas dinâmicas, não estando totalmente inserido em apenas uma. As Fotos 9.3 e 9.4 apontam a existência de uma área (município) de contrastes: na primeira, o shopping center no centro da cidade, que aponta a reprodução de um centro comercial ao sul do Distrito Federal, porém mais independente do centro principal; a segunda, o espaço da agropecuária modernizada. 
Foto 9.3 - Luziânia Shopping, no centro da cidade de Luziânia-GO

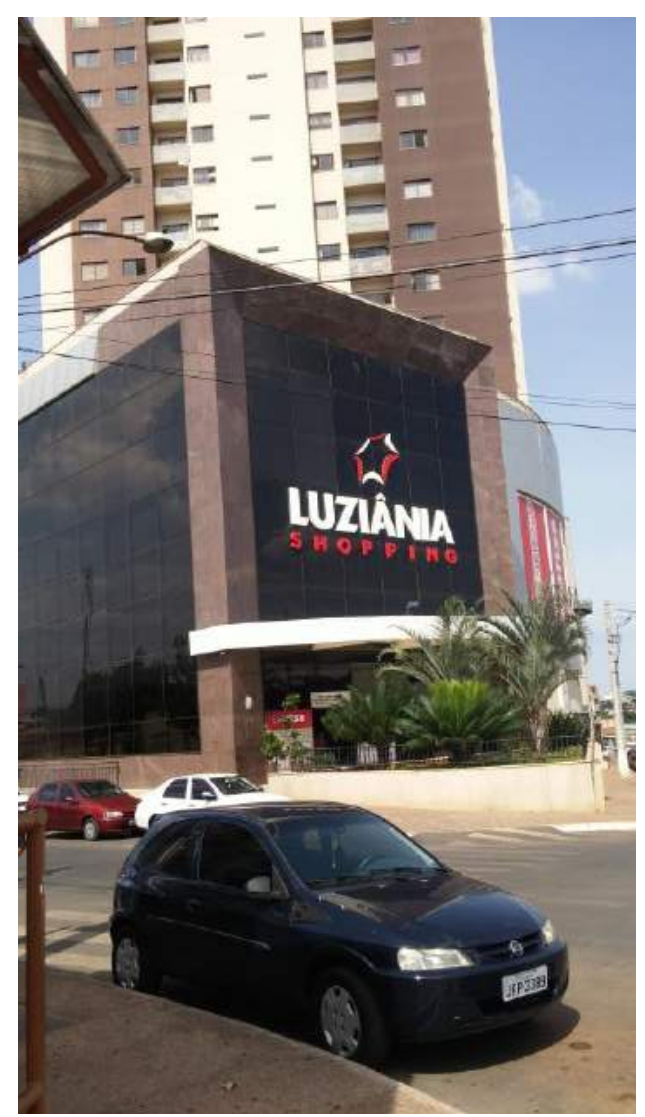

Fonte: acervo do autor

Foto 9.4 - Lavoura nos arredores da cidade de Luziânia-GO (margens da GO 010)

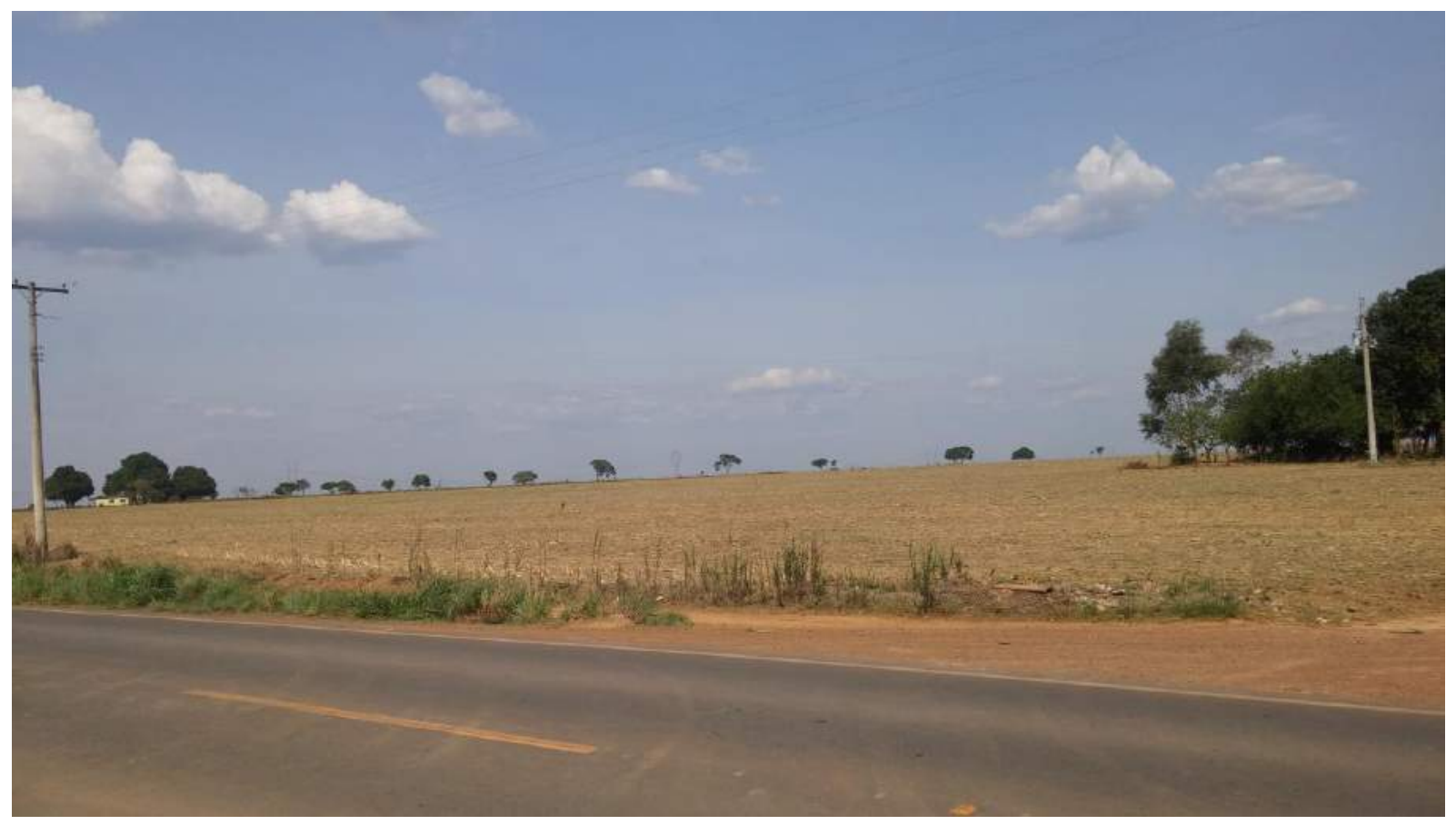

Fonte: acervo do autor 
- Arco da agropecuária modernizada: Corresponde a um amplo grupo de municípios a leste do Distrito Federal (Cabeceiras, Cristalina, Formosa, Vila Boa, Buritis, Cabeceira Grande e Unaí) e que tem sido, desde o Polocentro, palco da expansão do agronegócio mais modernizado. Este processo fora iniciado anteriormente em Unaí, porém se expandiu tanto para os municípios mineiros da Ride-DF, quanto foi alcançado ao sul por Cristalina e ao norte a partir de Formosa. Considerando o avanço da agropecuária no sul e sudeste de Goiás, há indícios de que estes espaços estão "se encontrando", de modo que o que ocorre na Ride-DF tende a representar a expansão de um processo já em curso de modernização da agropecuária do Centro-Oeste. Neste sentido, a Foto 9.4 representa um desses espaços de agropecuária modernizada, em Unaí, com as já típicas paisagens monótonas das lavouras da agropecuária moderna. A Figura 9.5 representa os efeitos urbanos deste processo, com a verticalização que começa a se verificar em Buritis. Por fim, na Figura 9.6, um elemento quase onipresente nos municípios ligados à agropecuária moderna: concessionárias de máquinas agrícolas, das quais a John Deere claramente se destaca, revelando que os espaços urbanos destes espaços cumprem papel de apoio à agropecuária moderna.

Foto 9.5 - Lavoura em Unaí-MG

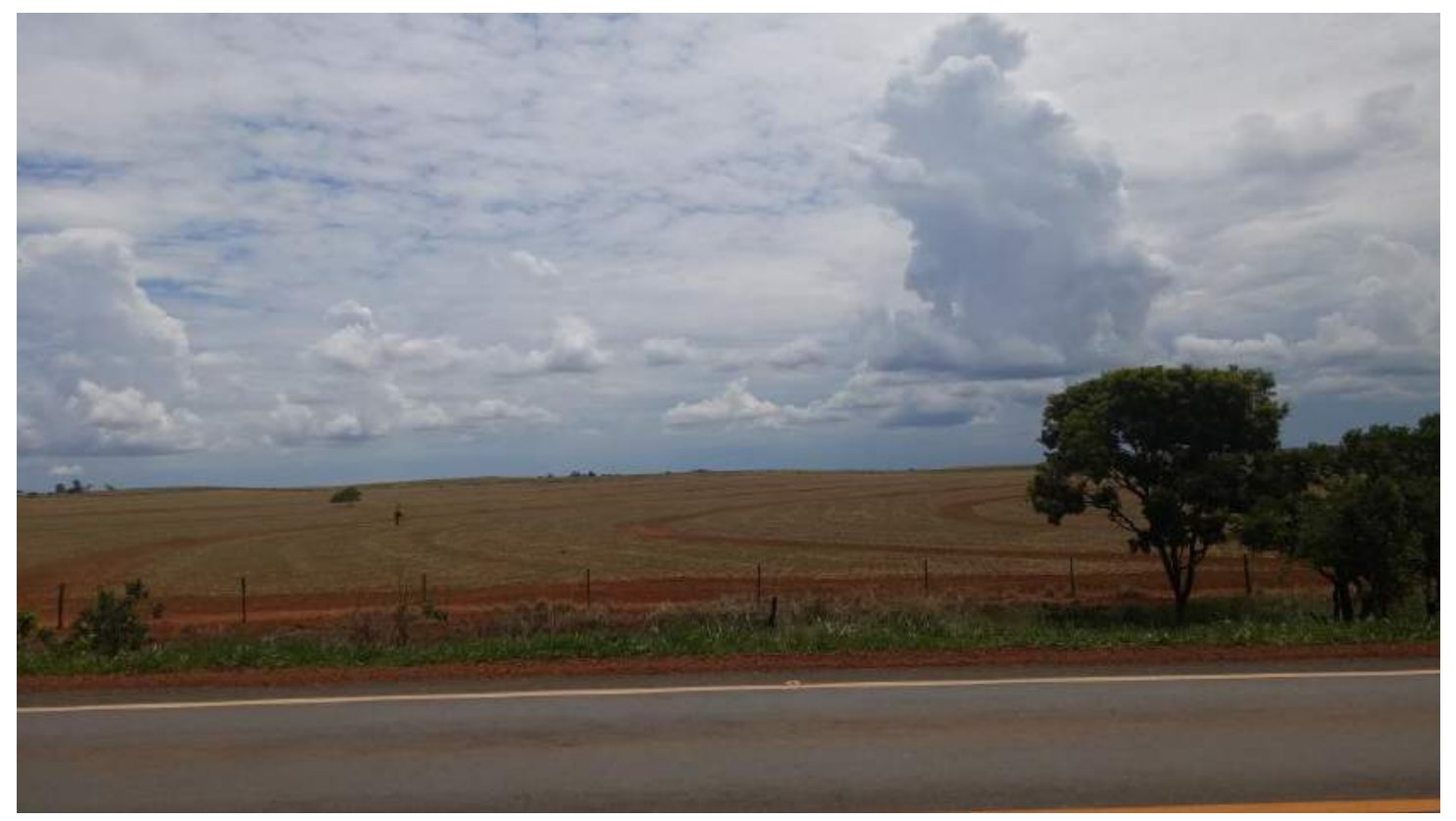

Fonte: acervo próprio do autor 
Foto 9.6 - Edifício residencial em Buritis-MG

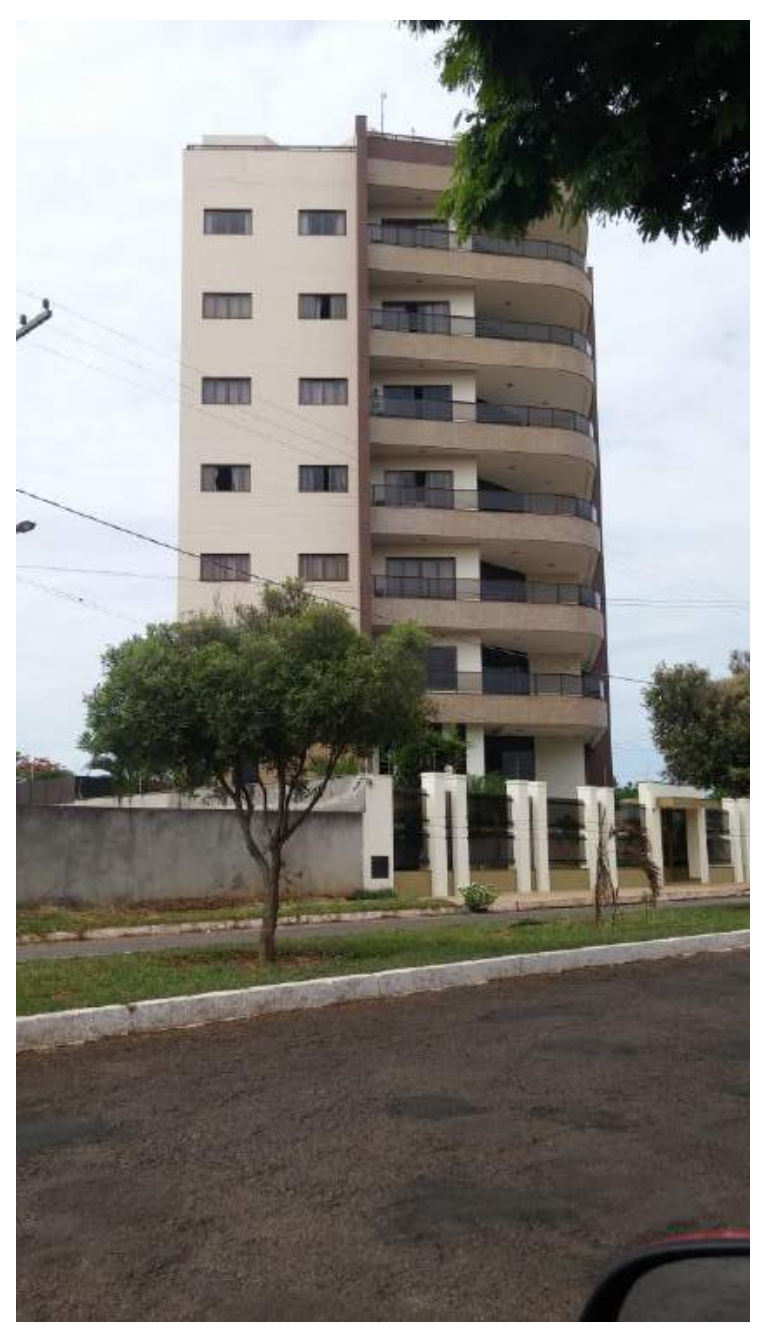

Fonte: acervo próprio do autor

Foto 9.7 - Concessionária da John Deere em Cristalina-GO

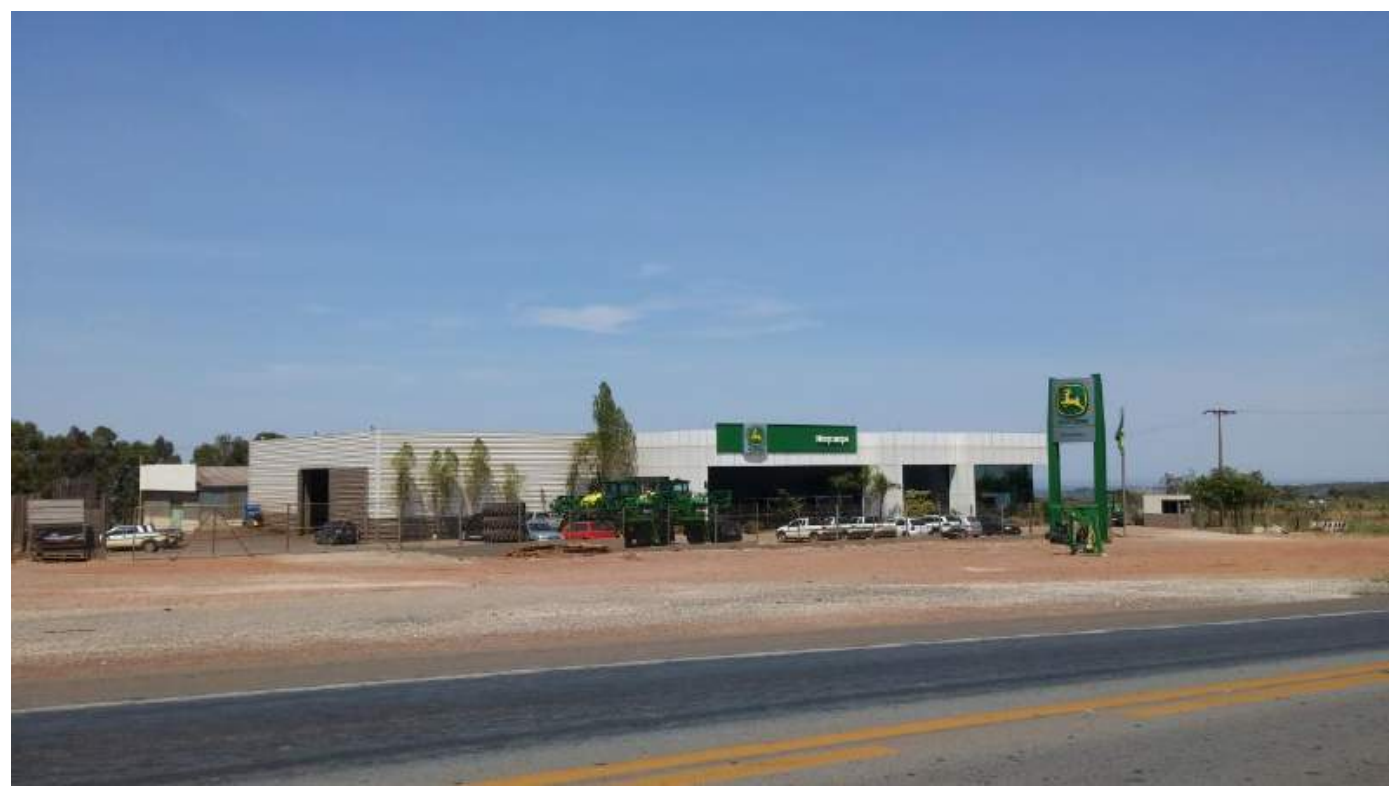

Fonte: acervo próprio do autor 
- Municípios de agropecuária tradicional: estes municípios não estão diretamente sob a influência dos três processos responsáveis pela organização do espaço da Ride-DF (expansão metropolitana de Brasília, expansão da agropecuária moderna e integração do eixo Brasília-Anápolis-Goiânia), tendo economias voltadas a uma agropecuária de menor porte e menos modernizada (de subsistência). Alguns municípios encontram-se sob influência de Anápolis e outros tem dinâmicas muito próximas daquelas dos municípios do norte e nordeste goiano, com desenvolvimento econômico e redes de infraestrutura limitadas. Há o caso de Padre Bernardo, caracterizado como subcentro emergente, em que já há indícios de modernização agrícola (Foto 9.8), porém, há predomínio, em geral, da agropecuária tradicional (Foto 9.9).

Foto 9.8 - Silos de armazenagem em Padre Bernardo - GO

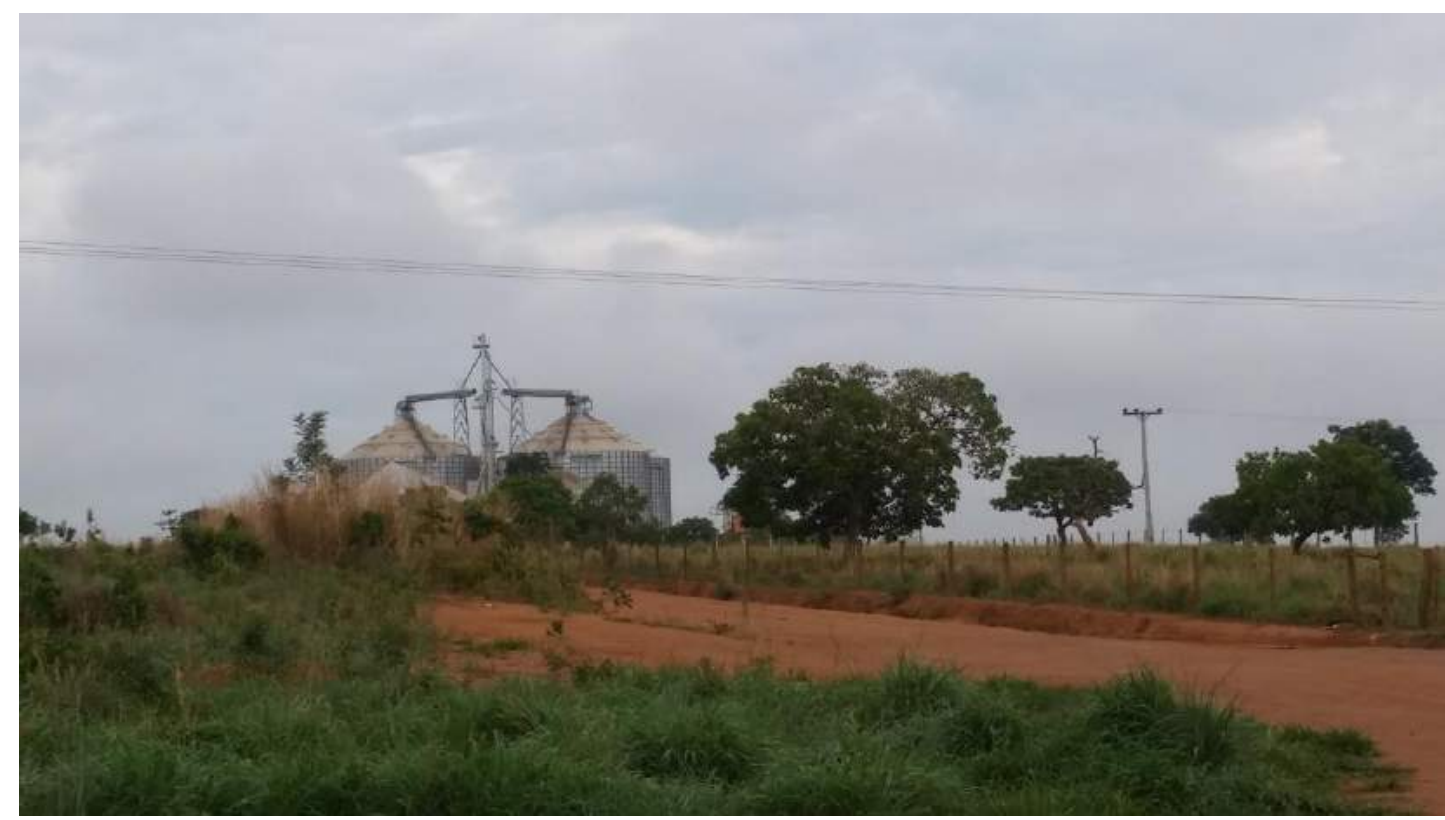

Fonte: acervo pessoal do autor 
Foto 9.9 - Pastagem em Mimoso de Goiás-GO

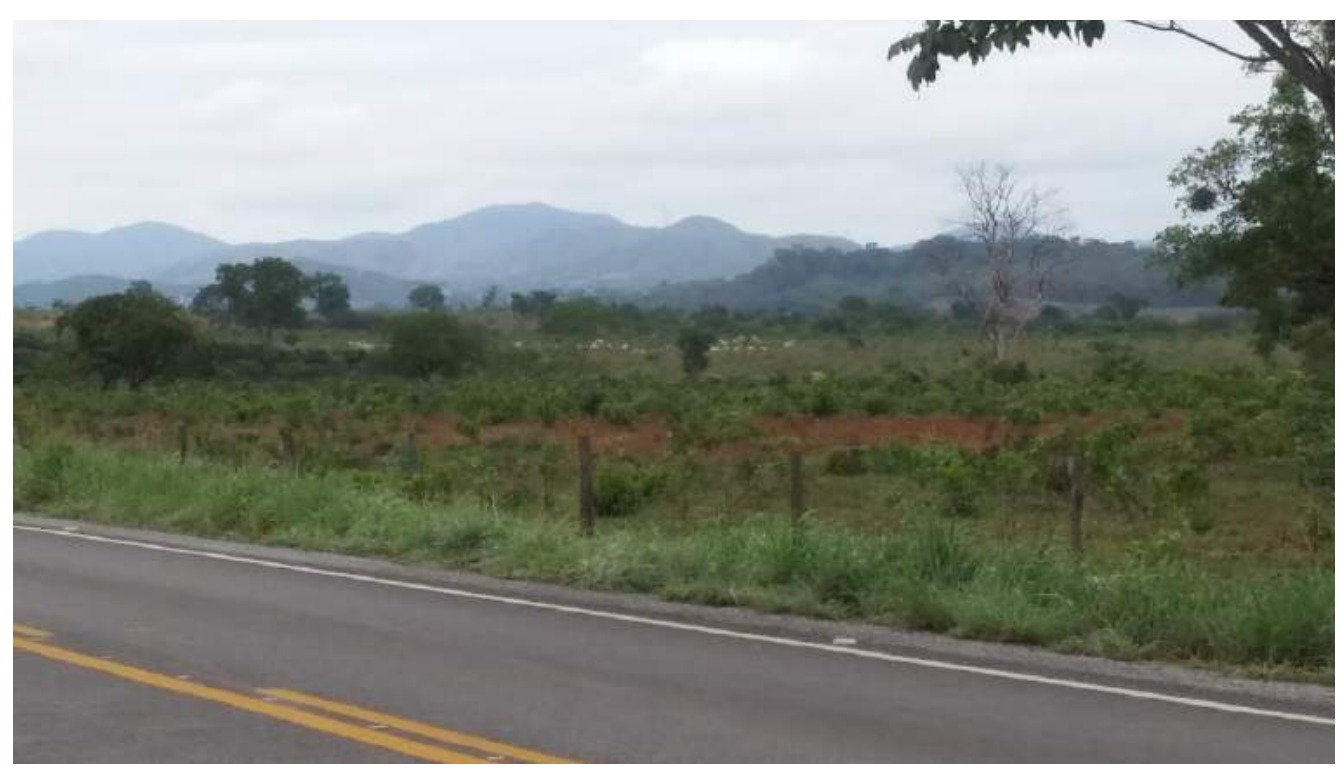

Fonte: acervo pessoal do autor

- Eixo Brasília-Anápolis-Goiânia: esta sub-região é constituída, no âmbito da RideDF, além do próprio Distrito Federal e de parte de Santo Antônio do Descoberto (cuja notação de cor na Figura 9.4 privilegia sua participação no Centro metropolitano e Espaço metropolizado), pelos municípios de Alexânia e Abadiânia. Ambos têm recebido, mais diretamente a influência da estruturação deste eixo, que parece se manifestar mais claramente em Alexânia, que tem atraído investimentos industriais e comerciais. A economia de Abadiânia permanece ligada à agropecuária, à prestação de serviços às margens da BR 060 e ao turismo religioso. Estas atividades, contudo, ainda não foram suficientes para alçar qualquer destes municípios ao posto de subcentros "plenos". Considerando investimentos recentes e o aumento da importância do PIB desta região, identifica-se uma tendência de impulsionamento das economias destes municípios. A Foto 9.10 aponta para um dos principais investimentos aí realizados e que visa justamente atender o mercado consumidor de todo o Eixo, o Outlet Premium; já a Foto 9.11 aponta para a existência de espaços da agropecuária modernizada também no Eixo. 
Foto 9.10 - Outlet Premium em Alexânia-GO

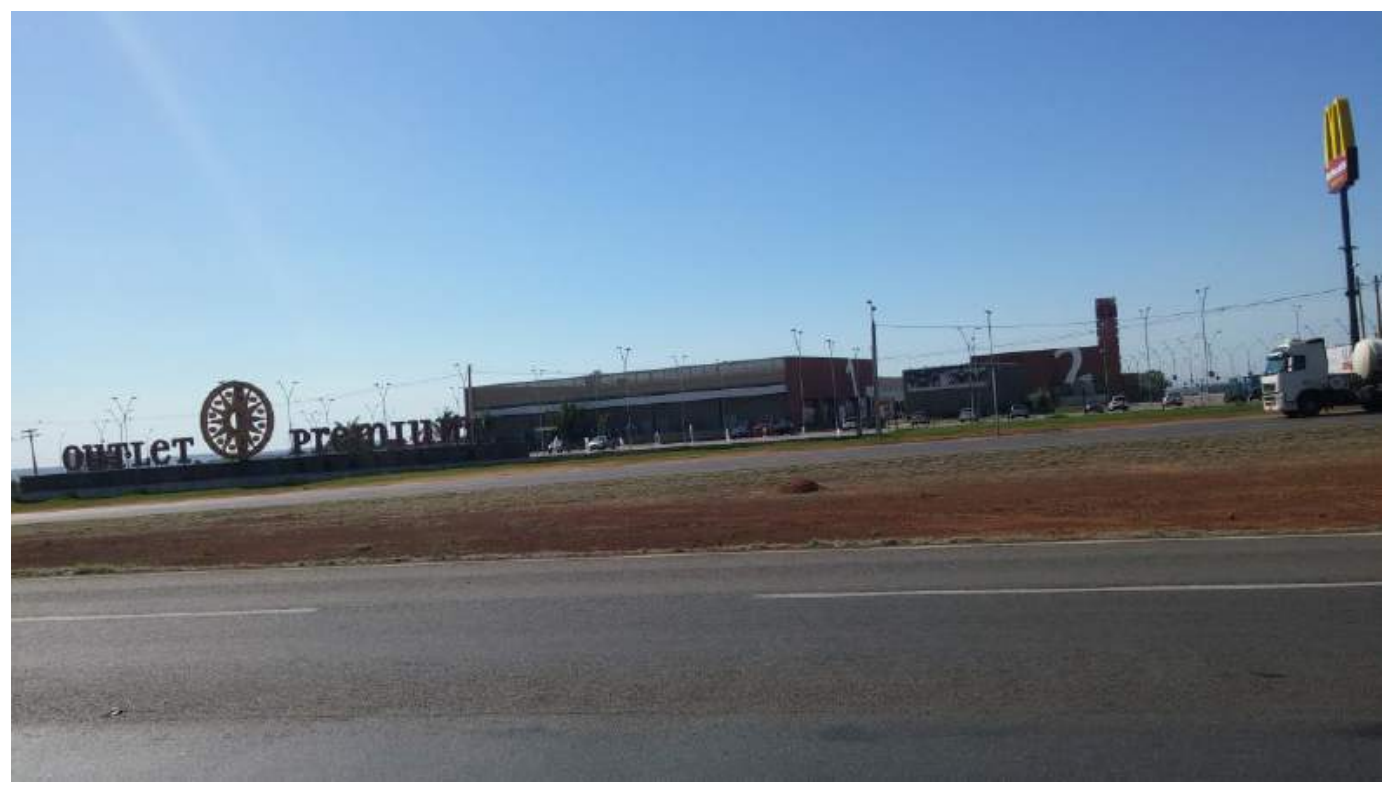

Fonte: acervo pessoal do autor

Foto 9.11 - Silo de armazenagem, na franja urbana de Alexânia-GO

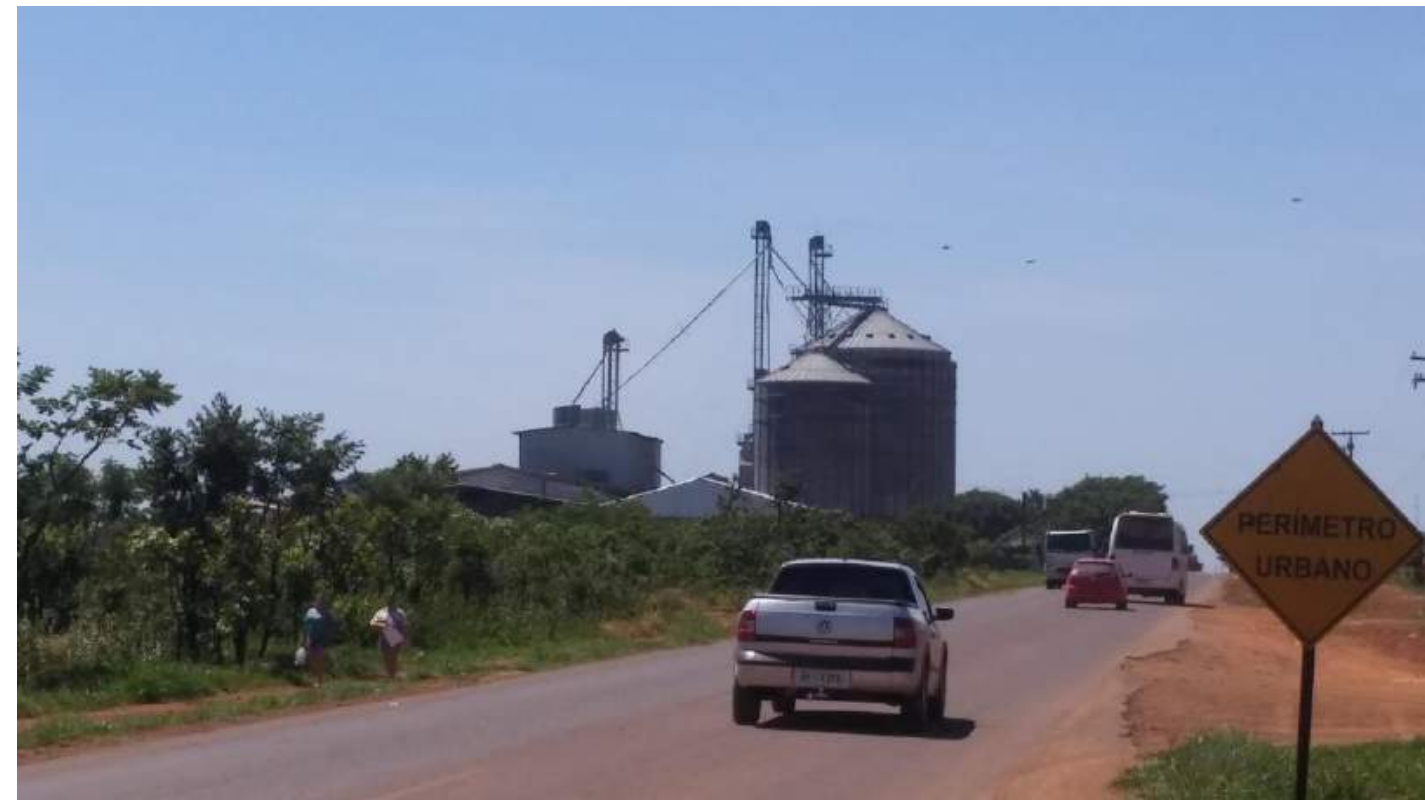

Fonte: acervo pessoal do autor

- Área do turismo: abarca apenas o município de Pirenópolis, que possui, por sua formação ainda no período da mineração, patrimônio histórico de características coloniais, único na Ride-DF. Contudo, a atividade encontra-se restrita ao município e com pouco poder de polarização das atividades econômicas e populações de outros municípios (há algumas iniciativas neste sentido em Corumbá de Goiás, como algumas pousadas, mas muito incipientes). Por suas características singulares, optou-se por considerar o município 
isoladamente, apesar de parte de sua dinâmica estar ligada aos municípios de agropecuária pouco modernizada. A Foto 9.12 retrata o centro de Pirenópolis e sua Igreja Matriz, um dos principais pontos turísticos da cidade, que costuma ficar movimentada nos fins de semana (junto com a praça na qual se situa e nas ruas próximas onde há bares, restaurantes e o comércio de artesanato), justamente por turistas vindos das cidades próximas e das capitais Brasília e Goiânia, igualmente próximas.

Foto 9.12 - Igreja Matriz de Pirenópolis-GO

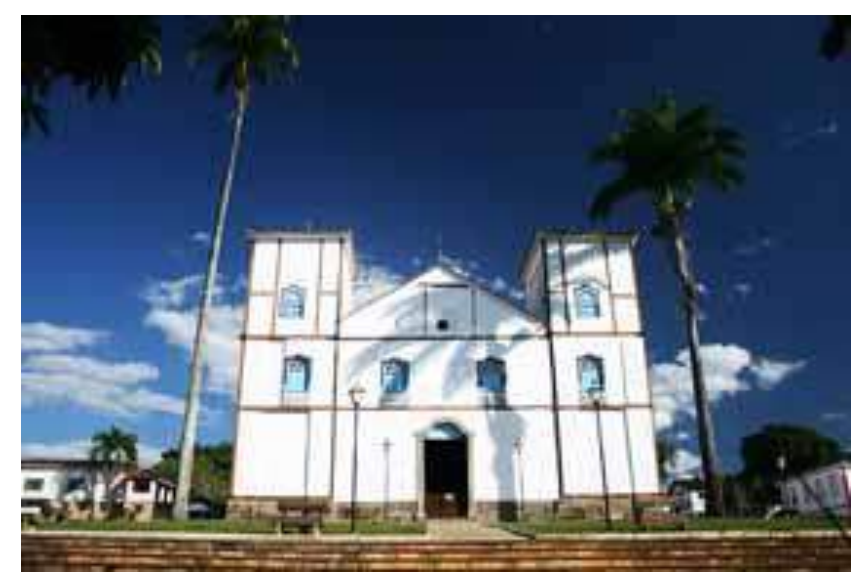

Fonte: Prefeitura de Pirenópolis, 2016

Desta forma, a análise desenvolvida deixa clara a perspectiva de uma fragmentação na Ride-DF, na medida em que os três processos estruturantes estudados - expansão metropolitana de Brasília, expansão da agropecuária moderna e integração do Eixo BrasíliaAnápolis-Goiânia - apresentam expressões distintas e, às vezes potencialmente conflitantes na organização do espaço desta região (como no caso da área de transição, em Luziânia). Por outro lado, a dinâmica evidenciada sugere que os processos em curso partem de uma lógica comum, a da reestruturação produtiva, enquanto se articulam ou se superpõem para trazer modificações profundas ao espaço em estudo. Pode-se considerar que este quadro tem grande ligação com a atuação do Estado, que tem estimulado, de forma coordenada ou pontual, a ocorrência destes processos, principalmente, como se viu, a partir de subsídios e incentivos do Estado ao setor privado.

Por outro lado, a regionalização proposta não demonstra, obrigatoriamente, uma relação de hierarquia entre os processos, já que as escalas de comando deles podem estar, como no caso da agropecuária modernizada, a milhares de quilômetros. É o caso, especialmente de Cristalina que vem se destacando na produção agropecuária não apenas local, mas nacionalmente. Não parece, num primeiro olhar, que Brasília seja um dos pontos de controle 
deste processo de produção moderno. O que parece ocorrer, juntamente com uma articulação em curso, é uma tendência à fragmentação do território. Reunindo um papel de centro político da nação, funções decisórias, serviços especializados, capital financeiro-imobiliário e um espaço construído em expansão, o centro metropolitano (e regional) de Brasília tem clara ascendência no processo de expansão metropolitana. Em sentido oposto, em parte avançando sobre possíveis reservas para a expansão da crescente malha urbanizada, e apoiando-se sobre núcleos urbanos que, aos poucos, se especializam, estende-se de forma acelerada o arco da agropecuária moderna. Por outro lado, a economia metropolitana se dilata para integrar a organização produtiva e a estruturação do Eixo Brasília-Anápolis-Goiânia. Nesse quadro de desenvolvimento e modernização - refreados durante a crise econômica dos últimos anos -, emergem funcionalidades que atendem aos três processos e se organizam em subcentros. A dinâmica econômica apresenta, como contrapartida, tendências a uma concentração e à desigualdade.

Findas estas análises, o capítulo seguinte traz as conclusões deste trabalho. 


\section{CONCLUSÃO}

O objetivo deste trabalho foi compreender as modificações recentes na organização espacial da Ride-DF, sob o pano de fundo da reestruturação produtiva. Partiu-se da hipótese de trabalho de que o processo de reestruturação produtiva manifesta-se na Ride-DF a partir de três processos, principais responsáveis pela estruturação deste espaço regional: a expansão metropolitana de Brasília, a expansão da agropecuária moderna e, mais recentemente a integração do Eixo Brasília-Anápolis-Goiânia.

Partiu-se de um contexto geral considerando o processo de reestruturação produtiva como responsável pela indução de diversas modificações nas regiões, dadas, inicialmente pela reorganização espacial da produção, tanto agrícola quanto industrial. Viu-se que a Ride-DF apresentava potencial para ser analisada como região afetada por tal lógica e, a partir daí, foi elaborada uma revisão em torno da região, de seus processos de organização e delimitação no período moderno (especificamente aqueles necessários à compreensão do objeto de estudo) e, por fim, do tema dos centros e subcentros e das desigualdades socioespaciais regionais.

Desta forma, a argumentação do trabalho foi balizada pela perspectiva de considerar a região não como um todo homogêneo, mas como objeto de distintas influências, especialmente a partir da reestruturação produtiva. Esta, ao tornar os espaços locais articulados a lógicas, fluxos e relações de ordem global, tem contribuído para reorganizar (ou mesmo desorganizar) os espaços regionais, associando-se a processos já existentes e impondo outros. A partir destes processos, ocorrem alterações na estrutura regional, especialmente das funções ligadas ao controle do capital e gestão do território, que, aliadas a movimentos de dinamização econômica e especialização funcional, tendem a gerar os subcentros. A partir destas discussões, passou-se a uma análise histórica e geográfica contextual e para a análise do objeto, propriamente dita, de forma empírica. A descrição e análise dos resultados é sumarizada na seção abaixo, sob a forma de breve registro das respostas às questões que orientaram a pesquisa.

\subsection{Análise e discussão dos resultados obtidos}

Com a finalidade de balizar o trabalho empírico e as discussões, foram enunciadas quatro questões de pesquisa. A primeira delas, "Sob que aspectos é possível discernir a influência da reestruturação produtiva capitalista em espaços de articulação metropolitana e regional brasileiros?", foi respondida a partir de uma análise dos efeitos da reestruturação 
produtiva nas regiões brasileiras e nas Regiões Metropolitanas. Sobre as regiões brasileiras os principais efeitos se deram sobre uma base regional anteriormente montada com forte auxílio do Estado central, que agiu no sentido de integrar os espaços regionais nacionais, expandir o mercado interno e desconcentrar a atividade econômica. Tal movimento gerou a expansão de atividades como a agropecuária moderna no Centro-Oeste e alguma desconcentração industrial em relação ao Sudeste. A partir da reestruturação produtiva, no período mais recente, tem havido uma nova rodada de desconcentração, pela mudança das bases produtivas para cidades médias ou Regiões Metropolitanas anteriormente não atingidas pelo processo, no caso das plantas industriais; para a agropecuária moderna, tem ocorrido o avanço da fronteira em novos espaços, em direção à Amazônia e às porções de cerrado do Nordeste brasileiro.

No caso das Regiões Metropolitanas, o processo tem se reproduzido em menor escala. No caso das metrópoles do Sul e Sudeste brasileiro não se percebe a presença tão imediata de espaços agrícolas modernos (ao menos não dentro do espaço oficialmente delimitado pelas Regiões Metropolitanas) e a desconcentração e formação de subcentros tem sido mais típica de novos espaços industriais. Nos outros espaços metropolitanos, especialmente nos do Centro-Oeste, há a presença mais clara da agropecuária moderna como indutora do surgimento de novos espaços produtivos. Tanto no caso das Regiões Metropolitanas quanto no das macrorregiões, a marca desta nova rodada tem sido o apoio do Estado por meio da subvenção ao capital privado, abandonando a perspectiva de ordenamento do território antes tida. Assim, esta nova postura na atuação do Estado tem sido, possivelmente, a principal responsável pela emergência destes processos, nos quais o capital privado ganha maior protagonismo na produção dos espaços regionais brasileiros.

A segunda questão de pesquisa, "Como se constituiu historicamente a produção das bases territoriais de ocupação da região de Brasília? ", foi explorada a partir de uma análise do histórico de organização do espaço regional de Brasília, desde sua implantação até sua formação metropolitana. Neste sentido, foram aí definidos dois períodos: o primeiro abarcou o intervalo entre 1956 e 1969 e foi chamado de "implantação das bases territoriais da Região de Brasília". Este período teve como sua principal marca a implantação da Nova Capital no Planalto Central brasileiro, processo que contou com forte mão do Estado em suas diversas frentes. A implantação da Nova Capital gerou alguns efeitos imediatos, como a organização de novos núcleos urbanos em sua região imediata e alterações naqueles já existentes. A ação do Estado teve como foco principal a construção da Nova Capital, e não uma ação planejada em torno de sua região. Daí que, ao término do período, Brasília era ainda um canteiro de obras cujos efeitos 
de organização sobre sua região eram mediatos, dados a partir, principalmente, da rede de infraestrutura viária construída para sua viabilização.

Num segundo período, chamado de "formação metropolitana e implantação da agropecuária moderna", cuja extensão deu-se entre 1970 e 1985, a postura do Estado em torno da questão regional muda, e passa a haver maior interesse no ordenamento da região e no seu desenvolvimento. A partir da atuação de dois programas principalmente (Polocentro e Pergeb), houve, como resultado, a implantação da agropecuária moderna na Região do Entorno de Brasília. Por outro lado, concomitantemente a isto, Brasília ia se tornando uma metrópole, a partir de sua consolidação como Capital Federal. Internamente a política de ordenamento do território e uso do solo foi bastante restritiva, obrigando parte da população a buscar moradia nos municípios vizinhos. Iniciou-se um processo de expansão urbana que viria a se tornar metropolitana. Desta forma, o período se encerra com a ocorrência destes dois processos, expansão metropolitana e expansão da agropecuária moderna, possuindo um centro principal, Brasília, e embriões de centros secundários, Unaí e Formosa, associados à agropecuária moderna. As desigualdades socioeconômicas tendem a se acirrar à medida que o investimento, em termos regionais, favoreceu aos espaços do Polocentro que estavam no âmbito do Entorno de Brasília; nos espaços em metropolização isto ocorria pela repetição da prática de expulsão de populações mais pobres para as franjas urbanas.

A terceira questão de pesquisa, "Qual o papel dos processos de expansão metropolitana de Brasília, expansão da agropecuária moderna e integração do Eixo BrasíliaAnápolis-Goiânia no sentido de estruturar e organizar o espaço da Ride-DF?", foi explorada a partir da análise do período mais recente (1986-2016) da organização da Ride-DF, a partir de seus processos principais e das consequências deles sobre a região. Inicialmente, viu-se que a atuação do Estado na região foi alinhada ao já visto na escala nacional: passou à subvenção do capital privado, por meio do crédito e da construção da infraestrutura necessária à produção econômica. Isto se deu tanto na escala regional, por meio do crédito rural, tanto na escala metropolitana, por meio do crédito imobiliário. Tendo em vista este quadro, passam a atuar três processos fundamentais na organização da região escolhida como espaço de estudo: a expansão metropolitana, a expansão da agropecuária moderna e a integração do Eixo Brasília-AnápolisGoiânia. O primeiro já vinha ocorrendo, conforme dito, desde o período anterior. Este tende a se apresentar, no presente momento, a partir de uma forte expansão sobre os municípios ao sul do Distrito Federal (eixo clássico, em torno da BR 040), e, mais recentemente, sobre espaços a oeste e norte. Possui uma tendência de ocorrer de forma cada vez mais dispersa, demandando maior atuação do Estado na construção de infraestruturas. O segundo também teve sua 
implantação no período passado, mas encontrou forte impulso no atual, a partir de mudanças nos fundos regionais na década de 2000. Isto tem levado a que mais municípios venham a se dedicar a atividades da agropecuária moderna, formando, no espaço, um arco de municípios a leste do Distrito Federal. Por fim, o terceiro processo tem ocorrência mais recente e foi estimulado a partir de obras do Estado (especialmente a duplicação de trechos da BR 060 e 153) bem como da expansão e projeção da economia de Brasília e Goiânia. Tem se revelado um processo potencial de modificação do espaço regional de Brasília, dada a atração de investimentos externos.

Por fim, a quarta questão de pesquisa, "Como se relacionam os processos de consolidação de Brasília como centro principal e de produção de subcentros regionais, associados à dinâmica de desigualdades socioespaciais na Ride-DF?”, teve sua exploração realizada a partir, inicialmente, do estudo dos centros e subcentros na Ride-DF. Foi criado um modelo próprio de identificação dos subcentros regionais, com base em outras metodologias, que considerou três aspectos: densidade de empregos, complexidade funcional e polarização. Ao término das análises, foram identificados, como subcentros "consolidados" os municípios de Alexânia, Formosa, Unaí e Cristalina. Formosa e Unaí, conforme exposto acima, já possuíam características de centralidade desde o período anterior, dado o apoio à expansão da agropecuária moderna que exerciam. Houve tendência de manutenção destes como centros secundários na região. O caso de Cristalina revela a força da expansão do agronegócio moderno na região, elevando o município ao posto de subcentro em um tempo reduzido. Alexânia vem atraindo importantes investimentos por conta da integração econômica entre Brasília-AnápolisGoiânia, o que tem contribuído para a expansão de sua oferta de bens e serviços que, em alguns casos, atinge justamente as pontas do Eixo formado por estas três cidades. Junto a eles foram caracterizados como "subcentros emergentes" os municípios de Abadiânia, Luziânia, Padre Bernardo, Pirenópolis e Buritis. Destes, um aparece ligado ao processo de integração do Eixo Brasília-Anápolis-Goiânia, Abadiânia, no qual tem ocorrido a atração de novos investimentos (em menor grau que em Alexânia) e certo incentivo à agropecuária moderna, além de atividades ligadas ao turismo religioso. Pirenópolis tem se destacado como área do turismo, em atividade que explora seu potencial como cidade histórica. Buritis surge como um centro menor do processo da agropecuária moderna a leste da Ride-DF. Luziânia revela-se como espaço de transição e de contradição: é tanto um subcentro emergente da atividade do agronegócio, que ocupa parte de seu município, como do processo de expansão metropolitana, dada sua função muito importante no setor de serviços. Ainda sobre Luziânia, há a permanência de um bairro que reproduz as características de município-dormitório clássicas, o Jardim Ingá, apontando 
para a fragmentação e contradição da produção do espaço deste município. Há, finalmente, o caso de Padre Bernardo, que dá mostras de envolvimento com a expansão de uma agropecuária em modernização num espaço cuja lógica de produção está majoritariamente associada à agropecuária tradicional. Com a constatação de que a expansão metropolitana não foi capaz de gerar um subcentro considerado "consolidado" (apenas um, Luziânia - considerada subcentro emergente - e, de certa forma, "dividido" com o processo de expansão da agropecuária moderna), constata-se o caráter concentrador economicamente e de funções deste processo (é bem verdade que há potencial de surgimento de futuros subcentros em Valparaíso de Goiás e Águas Lindas de Goiás, principalmente).

O último desdobramento analisado foi a questão das desigualdades socioespaciais internas à Ride-DF geradas como efeito da reestruturação produtiva. A partir de um modelo de análise composto por indicadores adaptados daqueles utilizados para a medição do desenvolvimento regional, os resultados demonstraram haver uma quantidade considerável de municípios que apresentam uma economia dinâmica, com ritmo de crescimento acima do registrado para a região, mas que convivem com baixa renda. Isto indica a tendência de que as atividades econômicas (ligadas aos três processos estruturantes da Ride-DF) não tem levado ao desenvolvimento destes municípios, potencializando, por outro lado, as desigualdades socioespaciais. Tal quadro se completa ao se considerar que os municípios que possuem economias mais dinâmicas e faixas de renda intermediária e superior são justamente os municípios identificados como subcentros (e centro, no caso de Brasília), sendo exceção a tal tendência Alexânia. O quadro sugere, desta forma, que as desigualdades socioespaciais estão associadas à produção dos subcentros, que tendem a concentrar melhor renda que os outros municípios. Por fim, ao analisar a evolução do crescimento demográfico, verificou-se que em municípios pequenos tem se registrado um crescimento reduzido, além daqueles municípios a leste da Ride-DF associados à agropecuária moderna. Isto sugere que os municípios pequenos, por não conseguirem se inserir nos circuitos produtivos e de consumo principais da região crescem em ritmo reduzido se comparado com os espaços metropolizados, os que registram os maiores crescimentos (principalmente os municípios periféricos). No caso dos municípios associados ao agronegócio moderno, este crescimento em ritmo menor possivelmente está ligado aos aspectos negativos desta atividade, como a concentração fundiária.

Diante de tais resultados, fica evidente o entendimento da Ride-DF como uma região fragmentada. Esta fragmentação fica óbvia ao se analisar a forma como a região tem sido organizada mais atualmente e pelas profundas modificações que os processos tem criado. Estes processos, especialmente o da agropecuária moderna, são evidentes marcas do alinhamento da 
região a lógicas externas e coordenadas, não apenas na escala nacional, mas também em escala global. A integração do Eixo Brasília-Anápolis-Goiânia tem potencial para dar continuidade a isto - e provavelmente já o faz, porém em escala e espaços não abarcados pela Ride-DF. A constatação da fragmentação da região sugere, por um lado, a possibilidade mesmo de que a Ride-DF seja uma "não região", dado que os três processos estruturantes não possuem um claro papel de coordenação oriundo do centro principal. Por outro lado, porém, permanecem relações entre os espaços fragmentados, e nem todo o papel de centro principal de Brasília se resume apenas à coordenação da dinâmica econômica da região: a cidade exerce papel, por exemplo, na oferta de bens e serviços mais raros à toda Ride-DF, sendo notório o caso da saúde.

Outra constatação é a de que os processos de expansão da agropecuária moderna e integração do Eixo Brasília-Anápolis-Goiânia tem extensão territorial para além da Ride-DF, estando conectados a outras dinâmicas regionais. Na realidade, a Ride-DF é uma das regiões de Brasília, uma possível e institucionalizada. Ainda que careça de melhor gestão, serve como referencial para a análise destes processos que estão associados àquele esforço inicial do Estado em "desenvolver" o Centro-Oeste brasileiro. Não se dão, obviamente, de forma contínua e coordenada por um único ponto no território, mas têm em comum as redes e possibilidades abertas pela transferência da Capital Federal na década de 1950-1960. Ao mencionar a continuidade dos processos, é importante registrar que a integração econômica entre Brasília, Anápolis e Goiânia, cuja base territorial é a BR 060, tem mostras também de ser mais longa, acompanhando não apenas este eixo rodoviário. Há clara associação do que ocorre no Eixo Brasília-Anápolis-Goiânia com o processo de inserção do Estado de Goiás (e mesmo da Região Centro-Oeste) na dinâmica da reestruturação produtiva, marcada, principalmente, por novos espaços industriais e pelo avanço da agropecuária moderna.

A identificação dos subcentros foi bastante útil no entendimento do funcionamento destes processos. Permitiu vislumbrar que a agropecuária moderna demanda, para se estruturar na região, de pontos de controle técnico e de apoio, conforme posto por Elias (2003). Isto provavelmente explica a estruturação dos subcentros identificados, muitos associados a esta atividade, e torna evidente outro traço da reestruturação produtiva na região estudada. Ao mesmo tempo, em associação com as lógicas comentadas no parágrafo anterior (da reestruturação produtiva nas escalas Goiás e Região Centro-Oeste), há o caso de Alexânia, claramente marcada pela atração de novos investimentos das recentes políticas de desenvolvimento do Estado de Goiás. A identificação dos subcentros revelou, ainda, que o processo de expansão metropolitana não é capaz de produzir maior quantidade de subcentros claramente identificáveis nos municípios atingidos pelo processo, reafirmando a concentração 
econômica muito forte presente em Brasília. Aparentemente, e em continuidade com o estudado em outro momento (CARVALHO DE SOUZA, 2010), a formação de subcentros parece algo ainda restrito ao próprio Distrito Federal.

Finalmente, o estudo da evolução recente das desigualdades socioespaciais na região permitiu visualizar os efeitos perversos do processo, alguns já evidentes quando da identificação dos subcentros. Tem ocorrido um processo de concentração da pobreza no espaço metropolizado, ao mesmo tempo em que os espaços dominados pela agropecuária moderna têm reduzido seu ritmo de crescimento demográfico. Isto tende a transformar a metropolização num processo ainda mais duro, dada a concentração de oportunidades em Brasília, o alto valor da terra e a tendência de expansão dispersa. Obviamente, o processo analisado apresenta benesses, como ficou claro nas análises da melhoria de indicadores como expectativa de vida e oferta de serviços (como educação em nível superior). Entretanto, não se pode deixar de enxergar as contradições que tal modelo de desenvolvimento apresenta, nem mesmo o processo de concentração que vem ocorrendo. Além do centro da metrópole, os municípios mostram-se como concentradores do processo de desenvolvimento, e possivelmente já sofrem com as consequências desta concentração pontual. A "rica" (para alguns, obviamente) terra do agronegócio moderno atua expulsando população e concentrando renda, retroalimentando o problema. Para além disso tudo, é necessário considerar que o Estado é forte subventor desta lógica e tem feito pouco para amenizá-la. Este ponto precisa suscitar, especialmente nos órgãos de desenvolvimento regional, a necessidade de uma atuação mais coordenada sobre o tema, bem como a revisão do modelo de atuação dos fundos regionais.

\subsection{Limitações e perspectivas de pesquisa}

A partir do material tratado e discutido no âmbito desta tese, diversos pontos não foram suficientemente esclarecidos e demandam aprofundamento posterior. O primeiro deles parece ser, claramente, a compreensão sobre as efetivas relações existentes entres os processos que tem organizado o espaço da Ride-DF e, de forma mais ampla, a Região de Brasília. Parece claro que o presente trabalho teve êxito em identificar quais são esses processos e em mapeálos, mas ainda carece de suficiente explicitação em torno do entendimento se há coordenação ou competição entre eles. Uma perspectiva interessante que se abre é o estudo das relações dos agentes responsáveis pela mobilização destes processos, notadamente o capital imobiliário e o capital do agronegócio. 
Um segundo ponto diz respeito ao tema da gestão específica da Ride-DF. Durante a discussão ficaram claras as suas deficiências, especialmente pela relativa ausência da Sudeco no papel de coordenação das ações de desenvolvimento e dos interesses envolvidos. Parece haver clara dificuldade em mobilizar "capital político", especialmente dos agentes privados, para o tema da gestão regional, provavelmente porque seus interesses são diversos, e tem ligação com os processos de organização do espaço desta região. O trabalho não avançou suficientemente neste ponto, mesmo porque não era sua preocupação fundamental o tema da gestão, que pode ser melhor investigado posteriormente.

Um terceiro ponto, que advém de uma das limitações do trabalho, vem da análise daqueles municípios considerados, na tipologia proposta na seção 9.3, como de "agropecuária pouco modernizada". Deveria haver maior interesse em compreender a dinâmica socioespacial destes, já que alguns interessantes indícios surgiram durante a pesquisa, como, por exemplo, o fato de Mimoso de Goiás tem recebido importantes somas de recursos do SNCR. Seria aquele espaço mais um novo eixo de expansão da agropecuária moderna? Se sim, quais municípios tem servido como base de apoio para isto? Eles estão na Ride-DF ou fora dela? Além destes pontos, nunca é demais relembrar a escassez de estudos sobre as pequenas cidades no âmbito da Geografia nacional.

Finalmente, um último ponto diz respeito à evolução da integração do Eixo BrasíliaAnápolis-Goiânia. Como se viu, tal processo tem um potencial de evolução capaz de produzir modificações na organização não apenas do espaço da Ride-DF, mas da macrorregião CentroOeste. A questão é que o processo é relativamente recente e pode sofrer modificações com algumas obras previstas, sendo a principal delas a construção de uma linha férrea de passageiros entre os três vértices do Eixo. Caso se concretize tal obra, estaria aberta a possibilidade de formação de um amplo mercado de trabalho sub-regional, que reuniria a possibilidade de atração de diversos novos investimentos, resultando, provavelmente, no reforço à tendência de fragmentação regional. Seria, evidentemente, um amplo campo para futuras novas pesquisas. 


\section{REFERÊNCIAS BIBLIOGRÁFICAS}

AGUILÉRA, A; MIGNOT, D. Urban Sprawl, polycentrism and commuting. A comparison of seven French urban areas. Urban Public Economics Review, nº 001, p. 93-113, 2004.

ALBUQUERQUE JR, D. M. A invenção do Nordeste e outras artes. São Paulo: Cortez, 1999.

ALEXÂNIA. Lei Complementar $n^{\circ}$ 892, de 11 de outubro de 2006. Dispõe sobre a Política Urbana do Município, instituindo o Plano Diretor de Alexânia. Disponível em < http://portal.alexania.go.gov.br/transp/assets/filesupload/leis/KWNvEdakt5Plano_Diretor_Co mpleto.pdf $>$. Visto em abril de 2016.

ALLEN, J; MASSEY, D; COCHRANE, A. Rethinking the region. Londres: Routledge, 1998.

ALMEIDA, M. L. A cidade de Pirenópolis e o impacto do tombamento. 137f. Dissertação (Mestrado em Arquitetura e Urbanismo). Faculdade de Arquitetura e Urbanismo, Universidade de Brasília, Brasília, 2006.

ALVES, A. M; ROCHA NETO, J. M; AMPARO, P. P. Política regional brasileira: retrospectiva e novos rumos. Revista Brasileira de Desenvolvimento Regional, $n^{0}$ 2(2), p. 107-132, 2014.

ARAÚJO SOBRINHO, F. L. Turismo e dinâmica territorial no eixo Brasília - Goiânia. 447 f. Tese (Doutorado em Geografia). Universidade Federal de Uberlândia, Uberlândia, 2008.

ARRAIS, T. P. A. Planejamento e desenvolvimento regional: a intervenção governamental e a problemática regional em Goiás. Mercator - Revista de Geografia da UFC, vol. 6, $\mathrm{n}^{\mathrm{o}} 12$, 2007a, p. 25-36.

. O território goiano: uma abordagem quase contemporânea do desenvolvimento regional. In: XII Encontro da Anpur, 2007, Belém. Anais. Belém: Anpur, 2007b, p. 1-21.

A escala de análise metropolitana em questão: considerações sobre o processo de metropolização. Revista do Departamento de Geografia da USP, vol. 24, 2012, p. 4-23.

ARTIGUES, A; RULLAN, O. Nuevo modelo de producción residencial y territorio urbano disperso (Mallorca, 1998-2006). Scripta Nova, vol. XI, num. 245 (10), 2007. Disponível em:

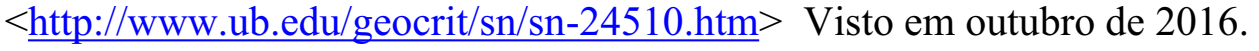


AZEVEDO, H. P. L; ALVES, A. M. Rides - por que criá-las? Geografias, nº 06, vol. 2, 2010, p. $87-101$.

BANCO CENTRAL DO BRASIL. Relação de Agências, Postos e Filiais de Administradoras de Consórcio (transferência de arquivos). Disponível em < http://www.bcb.gov.br/fis/info/agencias.asp $>$ Visto em outubro de 2016.

BASTOS, E. K. X. Plano Real, consolidação da estabilidade, crise internacional e desequilíbrios (1994-1998). In: RIBEIRO, F. J. S. P (org.). Economia brasileira no período 1987-2013: relatos e interpretações da análise de conjuntura no Ipea. Brasília: Ipea, 2015.

BECATTINI, G. Le district marshallien: une notion sócio-économique. In: BENKO, G; LIPIETZ, A (org.s). Les régions qui gagnent. Paris: PUF, 1992.

BECKER, B; EGLER, C. Brasil: uma nova potência regional na economia-mundo. Rio de Janeiro: Bertrand Brasil, 1993.

BERRY, B. J. L. A synthesis of formal and functional regions using a general field theory of spatial behavior. In: BERRY, B. J. L (ed). Spatial analysis: a reader in statistical geography. Englewood Cliffs, N.J. : Prentice Hall, 1968.

Geografia de los centros de mercado y distribucion al por menor. Barcelona: VicensVives, 1971.

BERRY, B. J. L; HORTON, F. E. Geographic perspectives on urban systems. Nova Jersey: Prentice-Hall, Englewood Cliffs, 1970.

BEZERRA, M. C. L; SCARDUA, F. P. Política públicas e governança na Região Integrada de Desenvolvimento do Entorno do Distrito Federal. In: RIBEIRO, R. J. C; TENORIO, G. S; HOLANDA, F. (orgs.) Brasília: transformações na ordem urbana. Rio de Janeiro: Letra Capital, 2015, p. 305-345.

BORSDORF, A. Hacia la Ciudad Fragmentada. Tempranas Estructuras Segregadas en la Ciudad Latinoamericana. Scripta Nova, Barcelona, vol. 7, n. 146, 2003. Disponível em

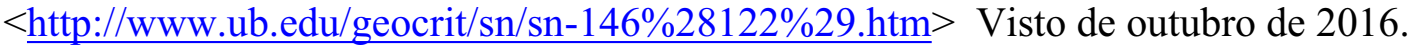

BOTELHO, A. O urbano em fragmentos: a produção do espaço e da moradia pelas práticas do setor imobiliário. São Paulo: Annablume; FAPESP, 2007.

BRANDÃO, C. Território \& desenvolvimento: as múltiplas escalas entre o local e o global. Campinas: Editora da Unicamp, 2007. 
BOURNE, L. S. Are new urban forms emerging? Empirical tests for canadian urban areas. The canadian geography, vol. 33, $\mathrm{n}^{\circ} 4$, p. 312-328, 1989.

BRASIL. Lei $\mathrm{n}^{0}$ 4.454, de 10 de dezembro de 1964. Dispõe sôbre a reestruturação administrativa do Distrito Federal, e dá outras providências. Diário Oficial da União, Brasília, 14 dez. 1964.

I Plano Nacional de Desenvolvimento (PND) - 1972-1974 (Suplemento da Lei $\mathrm{n}^{\circ}$ $\overline{5.727}$, de 4 de novembro de 1971). Brasília, 1971.

. Lei Complementar $\mathrm{n}^{\mathrm{o}}$ 14, de 8 de junho de 1973. Estabelece as regiões metropolitanas de São Paulo, Belo Horizonte, Porto Alegre, Recife, Salvador, Curitiba, Belém e Fortaleza. Diário Oficial da União, Brasília, seção 1, 11 jun. 1973.

. Lei $\mathrm{n}^{\circ}$ 6.151, de 4 de dezembro de 1974. Dispõe sobre o Segundo Plano Nacional de Desenvolvimento (PND), para o período de 1975 a 1979. Diário Oficial da União, Brasília, 6 dez. 1974.

III Plano Nacional de Desenvolvimento - 1980-85. Brasília: SEPLAN-PR, 1980.

Constituição da República Federativa do Brasil de 1988. Brasília: PR, 1988. Disponível em $<$ http://www.planalto.gov.br/ccivil 03/Constituicao/Constituicao.htm $>$ Visto em dezembro de 2015.

. Lei $\mathrm{n}^{\mathrm{o}} 7.827$, de 27 de setembro de 1989. Regulamenta o art. 159, inciso I, alínea c, da Constituição Federal, institui o Fundo Constitucional de Financiamento do Norte - FNO, o Fundo Constitucional de Financiamento do Nordeste - FNE e o Fundo Constitucional de Financiamento do Centro-Oeste - FCO, e dá outras providências. Diário Oficial da União, Brasília, seção 1, 28 de set. 1989.

Lei $\mathrm{n}^{0}$ 9.276, de 9 de maio de 1996. Dispõe sobre o Plano Plurianual para o período de 1996/1999 e dá outras providências. Diário Oficial da União, Brasília, 10 mai. 1996.

. Lei Complementar no 94, de 19 de fevereiro de 1998. Autoriza o Poder Executivo a criar a Região Integrada de Desenvolvimento do Distrito Federal e Entorno - RIDE e instituir o Programa Especial de Desenvolvimento do Entorno do Distrito Federal, e dá outras providências. Diário Oficial da União, Brasília, 20 fev. 1998a.

Decreto $\mathrm{n}^{\circ}$ 2.710, de 4 de agosto de 1998. Regulamenta a Lei Complementar ${ }^{\circ}$ 94, de 19 de fevereiro de 1998, que autoriza o Poder Executivo a criar a Região Integrada de 
Desenvolvimento do Distrito Federal e Entorno - RIDE e instituir o Programa Especial de Desenvolvimento do Entorno do Distrito Federal, e dá outras providências. Diário Oficial da União, Brasília, 5 ago. 1998b.

. Lei $\mathrm{n}^{\circ}$ 9.989, de 21 de julho de 2000. Dispõe sobre o Plano Plurianual para o período de $\overline{2000 / 2003 . ~ D i a ́ r i o ~ O f i c i a l ~ d a ~ U n i a ̃ o, ~ B r a s i ́ l i a, ~} 24$ jul. 2000.

. Lei $\mathrm{n}^{\mathrm{o}} 10.257$, de 10 de julho de 2001. Regulamenta os arts. 182 e 183 da Constituição Federal, estabelece diretrizes gerais da política urbana e dá outras providências. Diário Oficial da União, Brasília, 11 jul. 2001.

Lei $\mathrm{n}^{\mathrm{o}} 10.933$, de 11 de agosto de 2004. Dispõe sobre o Plano Plurianual para o período 2004/2007. Diário Oficial da União, Brasília, 12 ago. 2004.

. Decreto $\mathrm{n}^{\mathrm{o}}$ 6.047, de 22 de fevereiro de 2007. Institui a Política Nacional de Desenvolvimento Regional - PNDR e dá outras providências. Diário Oficial da União, Brasília, 23 de fevereiro de 2007.

. Lei $\mathrm{n}^{\mathrm{o}} 11.653$, de 7 de abril de 2008. Dispõe sobre o Plano Plurianual para o período 2008/2011. Diário Oficial da União, Brasília, 8 abr. 2008a.

Decreto de 25 de fevereiro de 2008. Institui o Programa Territórios da Cidadania e dá outras providências. Diário Oficial da União, Brasília, 26 fev. 2008 b.

Lei Complementar $n^{0} 129$, de 8 de janeiro de 2009. Institui, na forma do art. 43 da Constituição Federal, a Superintendência do Desenvolvimento do Centro-Oeste - SUDECO, estabelece sua missão institucional, natureza jurídica, objetivos, área de atuação, instrumentos de ação, altera a Lei no 7.827, de 27 de setembro de 1989, e dá outras providências. Diário Oficial da União, Brasília, 9 de janeiro de 2009.

. Decreto $\mathrm{n}^{\circ}$ 7.469, de 4 de maio de 2011. Regulamenta a Lei Complementar no 94, de 19 de fevereiro de 1998, que autoriza o Poder Executivo a criar a Região Integrada de Desenvolvimento do Distrito Federal e Entorno - RIDE e instituir o Programa Especial de Desenvolvimento do Entorno do Distrito Federal. Diário Oficial da União, Brasília, 5 de maio de 2011.

. Lei $\mathrm{n}^{\mathrm{o}} 12.593$, de 18 de janeiro de 2012. Institui o Plano Plurianual da União para o período de 2012 a 2015. Diário Oficial da União, Brasília, 19 jan. 2012.

. Lei $\mathrm{n}^{\mathrm{o}} 13.089$, de 12 de janeiro de 2015. Institui o Estatuto da Metrópole, altera a Lei ${ }^{\mathrm{o}}$ 10.257, de 10 de julho de 2001, e dá outras providências. Diário Oficial da União, Brasília, 13 jan. 2015a. 
. Decreto $\mathrm{n}^{\mathrm{o}}$ 8.447, de 6 de maio de 2015. Dispõe sobre o Plano de Desenvolvimento Agropecuário do Matopiba e a criação de seu Comitê Gestor. Diário Oficial da União, Brasília, 7 mai. 2015 b.

BRASIL; MINISTÉRIO DO PLANEJAMENTO, ORÇAMENTO E GESTÃO. Plano Plurianual 2012-2015: projeto de lei. Brasília: MP, 2011. Disponível em: < http://www.planejamento.gov.br/secretarias/upload/arquivo/spi-1/ppa-

1/2012/mensagem_presidencial_ppa-2.pdf $>$ Visto em dezembro de 2015.

BRESSER-PEREIRA, L. C. O novo desenvolvimentismo e a ortodoxia convencional. São Paulo em perspectiva, vol. 20, n. 3, p. 5-25, 2006.

BRITO, F. O deslocamento da população brasileira para as metrópoles. Estudos Avançados, nº 20 (57), 2006.

. A transição demográfica no Brasil: as possibilidades e os desafios para a economia e a sociedade. Texto para discussão no 318. Belo Horizonte: Cedeplar, 2007.

BURGESS, E. W. The growth of the city: an introduction to a research project. In: PARK, R. E; BURGESS, E. W. The city. Chicago: University of Chicago Press, 1974.

CAMPOS, N. A segregação planejada. In: PAVIANI, A. (org.). A Conquista da Cidade: movimentos populares em Brasília. Brasília: EdUnB, 1991.

CARDOSO, A. C. D; FERnANDES, D. A; BASTOS, A. P. V. A inserção da RMB na Amazônia e na rede urbana brasileira. In: CARDOSO, A. C. D; LIMA, J. J. F. (org.s). Belém: transformações na ordem urbana. Rio de Janeiro: Letra Capital, 2015.

CARVALHO, I. M. M; BORGES, A. M. C. A Região Metropolitana de Salvador na transição econômica: estrutura produtiva e mercado de trabalho. In: CARVALHO, I. M. M; PEREIRA, G. C. Salvador: transformações na ordem urbana. Rio de Janeiro: Letra Capital, 2015.

CARVALHO, L. M. O papel das políticas anticíclicas e o agravamento dos desequilíbrios macroeconômicos (2009-2013). In: RIBEIRO, F. J. S. P (org.). Economia brasileira no período 1987-2013: relatos e interpretações da análise de conjuntura no Ipea. Brasília: Ipea, 2015.

CARVALHO DE SOUZA, S. M. Expansão urbana, centralidade e constituição de subcentros no Distrito Federal. 130 f. Dissertação (Mestrado em Geografia). Departamento de Geografia, Universidade de Brasília, Brasília, 2010. 
CASTELLS, M. A era da informação: economia, sociedade e cultura. São Paulo: Paz e Terra, 1999.

A questão urbana. Rio de Janeiro: Paz e Terra, 2000.

CASTRO, A. B; SOUZA, F. E. P. A economia brasileira em marcha forçada. Rio de Janeiro: Paz e Terra, 1985.

CATALÃO, I. 2011. Transição pós-metropolitana e dispersão urbana em Brasília: formas, processos e escalas. Anais do XII Simpósio Nacional de Geografia Urbana (Simpurb), Belo Horizonte. Disponível em $<$ http://xiisimpurb2011.com.br/app/web/arq/trabalhos/83e3ea5ea23f65295fceff35638e5b36.p

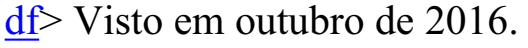

CAVAlCANTI, M. A; BARREIRA, C. C. M. A. Ações da Sudeco no desenvolvimento do Centro-Oeste no Estado de Goiás. Boletim Goiano de Geografia, v. 31, nº 2, p. 179-191, 2011.

CHAUVET, G. Brasília e Formosa: 4.500 anos de história. Goiânia: Kelps, 2005.

CHRISTALLER, W. Central places in southern germany. New Jersey: Prentice-Hall, Englewood Cliffs, 1966.

CIDADE, L. C. F. Acumulação flexível e gestão do território. In: PAVIANI, A. (org.). Brasília - gestão urbana: conflitos e cidadania. Brasília: EdUnB, 1999a.

. Planejamento, desconcentração e produção social do espaço no Distrito Federal. Espaço e Geografia, Brasília, v. 2, n. 1, p. 57-65, 1999 b.

CIDADE, L. C. F.; VARGAS, G. M; JATOBÁ, S. U. Regime de acumulação e configuração do território no Brasil. Cadernos Metrópole, São Paulo, n. 20, p. 13-35, 2008. Disponível em: $<$ http://web.observatoriodasmetropoles.net/download/cm artigos/cm20 144.pdf $>$ Visto em abril de 2016.

COCALZINHO DE GOIÁS. Lei Complementar n ${ }^{\circ}$ 06, de 10 de outubro de 2006. Dispõe sobre a Política Urbana do Município, instituindo o Plano Diretor de Alexânia. Disponível em: $<$ http://www.acheipublicacoes.com.br/media/arquivos/leis/lei complementar 006.pdf $>$ Visto em abril de 2016. 
COMPANHIA DE DESENVOLVIMENTO DO PLANALTO CENTRAL. Planaltina: 18591973. Brasília: CODEPLAN, 1973.

. Delimitação do espaço metropolitano de Brasília: estudo preliminar para subsidiar a proposta de criação da Região Metropolitana de Brasília. Brasília: CODEPLAN, 1997.

. Nota Técnica $n^{0}$ 1/2014. Delimitação do espaço metropolitano de Brasília (Área Metropolitana de Brasília). Brasília: Codeplan, 2014. Disponível em: < http://www.codeplan.df.gov.br/images/CODEPLAN/PDF/pesquisa_socioeconomica/desenvol vimento_regional/2014/AMB\%20-\%20Nota\%20Tecnica\%20dez2014.pdf $>$ Visto em abril de 2016.

CORUMBÁ DE GOIÁS. Lei ñ 1.101 , de 13 de dezembro de 2004. Dispõe sobre a instituição do Plano Diretor de Corumbá de Goiás e dá outras providências. Disponível em: < http://www.corumbadegoias.go.gov.br/legislacao/>. Visto em abril de 2016.

COSTA, M. A. Quarenta anos de regiões metropolitanas no Brasil: um breve balanço exploratório. In: COSTA, M. A; TSUKUMO, I. T. L (org.s). 40 anos de regiões metropolitanas no Brasil. Brasília: IPEA, 2013.

COSTA, M. C. L; AMORA, Z. B. Fortaleza na rede urbana brasileira: de cidade à metrópole. In: COSTA, M. C. L; PEQUENO, R. (eds.). Fortaleza: transformações na ordem urbana. Rio de Janeiro: Letra Capital, 2015.

CORREA, R. L. O espaço urbano. São Paulo: Atica, 1989.

. Trajetórias geográficas. Rio de Janeiro: Bertrand Brasil, 1997.

DAVIDOVICH, F. O estado do Rio de Janeiro: o urbano metropolitano. Hipóteses e questões. Geo UERJ, ano 12, n. 21, vol. 2, 2010. Disponível em $<$ http://www.geouerj.uerj.br/>. Visto em 01 de março de 2015.

DELGADO, G. C. A questão agrária no Brasil, 1950-2003. In: JACOUD, L. (org.). A questão social e políticas sociais no Brasil contemporâneo. Brasília: IPEA, 2005, p. 51-90.

DIAS, L. C. Redes: emergência e organização. In: CASTRO, I. E; GOMES, P. C. C; CORRÊA, R. L. (orgs.) Geografia: conceitos e temas. Rio de Janeiro: Bertrand Brasil, 1995.

DISTRITO FEDERAL. Lei no 353, de 18 de dezembro de 1992. Aprova o Plano Diretor de Ordenamento Territorial do Distrito Federal, institui o Sistema de Planejamento Territorial e 
Urbano do Distrito Federal, e dá outras providências. Diário Oficial do Distrito Federal, Brasília, 19 de dezembro de 1992.

Lei Complementar $\mathrm{n}^{\mathrm{o}} 17$, de 28 de janeiro de 1997. Aprova o Plano Diretor de Ordenamento Territorial do Distrito Federal - PDOT e dá outras providências. Diário Oficial do Distrito Federal, Brasília, 29 de janeiro de 1997.

. Lei Complementar $n^{\circ} 803$, de 25 de abril de 2009. Aprova a revisão do Plano Diretor de Ordenamento Territorial do Distrito Federal - PDOT e dá outras providências. Diário Oficial do Distrito Federal, Brasília, 27 de abril de 2009.

DUARTE, A. C. A área central da cidade do Rio de Janeiro. Rio de Janeiro: IBGE, 1967.

DUARTE, C. M; NUÑEZ, C. A; LINEROS, M. R. ¿Hacia un sistema de metrópoles españolas policéntricas?: caracterización de su estrutura metropolitana. In: $6^{\circ}$ INTERNATIONAL CONFERENCE VIRTUAL CITY AND TERRITORY, 2010, Cidade do México, Anais. Disponível em: $<$ http://upcommons.upc.edu/bitstream/handle/2099/12731/01_Marmolejo_Aguirre_Ruiz.pdf $>$ Visto em julho de 2016.

DUARTE, H. S. B. A cidade do Rio de Janeiro: descentralização das atividades terciárias. Os centros funcionais. Revista Brasileira de Geografia, ano 36, nº 1, p. 53-98, 1974.

DUPAS, G. Economia global e exclusão social: Pobreza, emprego, Estado e o futuro do capitalismo. São Paulo: Paz e Terra, 2001.

EGHRARI, S. Arranjo institucional, articulação governamental, gestão de recursos financeiros e planejamento na governança metropolitana: a referência de Montreal e a experiência brasileira. 254 f. Tese (Doutorado em Planejamento Urbano). Faculdade de Arquitetura e Urbanismo, Universidade de Brasília, Brasília, 2013.

ELIAS, D. Globalização e agricultura: a região de Ribeirão Preto. São Paulo: EdUSP, 2003. Ensaios sobre os espaços agrícolas de exclusão. Revista Nera, no 8, 2006, p. 29-51.

ELIAS, D; PEQUENO, R. Desigualdades socioespaciais nas cidades do Agronegócio. Revista Brasileira de Estudos Urbanos e Regionais, vol. 9, nº 1, p. 25-39, 2007.

ESTEVAM, L. A. O tempo da transformação: estrutura e dinâmica na formação econômica de Goiás. 203f. Tese (Doutorado em Economia). Instituto de Economia, Universidade Estadual de Campinas, Campinas, 1997. 
EUFRÁSIO, C. M. C. Estrutura urbana e ecologia humana: a escola sociológica de Chicago (1915-1940). São Paulo: Editora 34, 1999.

FERNANDES, D. A; SOUSA, C. N; RODRIGUES, D. L. A metrópole Belém na transição econômica: estrutura produtiva e mercado de trabalho. In: CARDOSO, A. C. D; LIMA, J. J. F. (orgs.) Belém: transformações na ordem urbana. Rio de Janeiro: Letra Capital, 2015.

FERREIRA, I. C. B. O processo de urbanização e a produção do espaço metropolitano de Brasília. In: PAVIANI, A. (org.) Brasília, ideologia e realidade: espaço urbano em questão. Brasília: Projeto, 1985.

. Brasília: mitos e contradições na história de Brasília. In: PAVIANI, A; BARRETO, F. F. P; FERREIRA, I. C. B; CIDADE, L. C. F; JATOBÁ, S. U. Brasília 50 anos: da capital a metrópole. Brasília: EdUnB, 2010.

FICO, C. O Brasil no contexto da Guerra Fria: democracia, subdesenvolvimento e ideologia do planejamento (1946-1964). In: MOTA, C. G. Viagem incompleta: a experiência brasileira (1500-2000): a grande transação. São Paulo: Senac, 2000.

FIRKOWSKI, O. L. C. F. A nova lógica de localização industrial no Aglomerado Metropolitano de Curitiba. Revista Paranaense de Desenvolvimento, nº 103, 2002, p. 79-100.

FORMOSA. Lei n ${ }^{\circ} 251$, de 20 de dezembro de 2004. Dispõe sobre a instituição do Plano Diretor de Formosa e dá outras providências. Disponível em: < http://www.formosa.go.leg.br/leis/mais-acessadas/plano-diretor-1> . Visto em abril de 2016.

FRANÇA, K. C. B. Complexidade da região urbana GAB: o fragmento Alexânia-GO. 189f. Dissertação (Mestrado em Geografia). Departamento de Geografia, Universidade de Brasília, Brasília, 2009.

FRAZÃO, D. C. Expansão Urbana, Nucleações e a Formação de Centralidades no Distrito Federal: o Caso do Gama. 158f. Dissertação (Mestrado em Geografia). Departamento de Geografia, Universidade de Brasília, Brasília, 2009.

FREITAG, P. B. A institucionalização do planejamento regional de Brasília: o Fundefe e o Pergeb sob a lógica da metropolização. 156f. Dissertação (Mestrado em Arquitetura e Urbanismo). Faculdade de Arquitetura e Urbanismo, Universidade de Brasília, Brasília, 2012.

FURTADO, C. O Brasil pós milagre. Rio de Janeiro: Paz e Terra, 1981. 
GALVÃO, O. J. A. Desenvolvimento dos transportes e integração regional no Brasil - uma perspectiva histórica. Planejamento e políticas públicas, nº 13, pp. 183-214, 1996.

GASPAR, R. C; APARÍCIO, C. A. P; BESSA, V. C. A metrópole de São Paulo: desenvolvimento econômico recente e configuração interna. In: BÓGUS, L. M. M; PASTERNAK, S. (org.s). São Paulo: transformações na ordem urbana. Rio de Janeiro: Letra Capital, 2015.

GEORGE, P; VERGER, F. Dictionnaire de la géographie. Paris : PUF, 1970 (2013).

GIDDENS, A. A constituição da sociedade. São Paulo: Martins Fontes, 1989 (2003).

GIULIANO, G. SMALL, K. . Subcenters in the Los Angeles Region. Regional Science and Urban Economics, vol. 119, 1990.

GOIÁS. Lei $\mathrm{n}^{\circ} 14.680$, de 16 de janeiro de 2004. Dispõe sobre o Plano Plurianual para o quadriênio 2004/2007. Diário Oficial do Estado de Goiás, suplemento, Goiânia, 19 de janeiro de 2004. Disponível em: < http://www2.seplan.go.gov.br/seplan/ppa/> . Visto em abril de 2016.

Lei $\mathrm{n}^{\mathrm{o}}$ 20.030, de 30 de janeiro de 2008. Dispõe sobre o Plano Plurianual para o quadriênio 2008/2011. Diário Oficial do Estado de Goiás, suplemento, Goiânia, 30 de janeiro de 2008. Disponível em: <http://www2.seplan.go.gov.br/seplan/down/ppa/ppa2008-2011.pdf > . Visto em abril de 2016.

Lei $n^{\circ}$ 21.264, de 13 de janeiro de 2012. Dispõe sobre o Plano Plurianual para o quadriênio 2012-2015. Diário Oficial do Estado de Goiás, suplemento, Goiânia, 13 de janeiro de 2012. Disponível em: < http://www.seplan.go.gov.br/ppa 2012-2015.pdf $>$. Visto em abril de 2016.

GORDON, P; RICHARDSON, H. W. Beyond polycentricity. The dispersed metropolis, Los Angeles, 1970-1990. Journal of the American Planning Association, vol. 62, $\mathrm{n}^{\circ}$ 3, p. 289 295, 1996.

GOTTDIENER, M.A produção social do espaço urbano. São Paulo: EdUSP, 1997.

GOTTMAN, J. Megalopolis, or the urbanization of the northeastern seabord. In: MAYER, H. M; KOHN, C. F. (ed.s) Readings in Urban Geography. Chicago: The University of Chicago Press, 1959.

GOVERNO DO DISTRITO FEDERAL. Plano Estrutural de Ocupação Territorial do Distrito Federal - Peot (vol. I e II). Brasília: Convênio Seplan/ PR-GD, 1977. 
GOVERNO DO DISTRITO FEDERAL; COMPANHIA DE PLANEJAMENTO DO DISTRITO FEDERAL; ARQUIVO PÚBLICO DO DISTRITO FEDERAL. Relatório do Plano Piloto de Brasília. Brasília: GDF, 1991.

GOUVÊA, L. A. A Capital do controle e da segregação social. In: PAVIANI, A. (org.). A Conquista da Cidade: movimentos populares em Brasília. Brasília: EdUnB, 1991.

GOUVÊA, R. G. A questão metropolitana no Brasil. Rio de Janeiro: Editora FGV, 2005.

GRAZIANO DA SILVA, J. A nova dinâmica da agricultura brasileira. Campinas: UNICAMP-IE, 1996.

GRIGG, D. Regiões, modelos e classes. In: CHORLEY, R. J; HAGGETT, P. Modelos integrados em Geografia. São Paulo: Ed. Da Universidade de São Paulo, 1974.

GUIA, G. A.. Políticas territoriais, segregação e reprodução das desigualdades sócioespaciais no Aglomerado Urbano de Brasília. 198f. Dissertação (Mestrado em Arquitetura e Urbanismo - Área de Concentração: Planejamento Urbano e Regional). Faculdade de Arquitetura e Urbanismo, Universidade de Brasília, Brasília, 2006.

GUIMARÃES NETO, L. Desigualdades e políticas regionais no Brasil: caminhos e descaminhos. Planejamento e Políticas Públicas, nº 15, p. 41-99, 1997.

HADDAD, M. B; MOURA, R. Dinâmicas de expansão do arranjo urbano-regional BrasíliaAnápolis-Goiânia. Cadernos Metrópole, vol. 18, nº 36, p. 583-603, 2016.

HAESBAERT, R. Regional-global: dilemas da região e da regionalização na geografia contemporânea. Rio de Janeiro: Bertrand Brasil, 2014.

HALL, P. The world cities. Nova Iorque: McGraw-Hill Book Company, 1966.

HARVEY, D. Justiça social e a cidade. São Paulo: Hucitec, 1973.

. A condição pós-moderna: uma pesquisa sobre as origens da mudança cultural. São Paulo: Loyola, 1992.

Espaços de esperança. São Paulo: Loyola, 2004. 
. Os limites do capital. São Paulo: Boitempo, 2013.

HEINRICHS, D; NUISSL, H; SEEGER, C. R. Dispersión urbana y nuevos desafios para la gobernanza (metropolitana) en América Latina: el caso de Santiago de Chile. Eure, vol. 35, $\mathrm{n}^{\mathrm{o}}$ 104, pp. 29-46, 2009.

HIRSCHMAN, A. Estratégia do desenvolvimento econômico. Rio de Janeiro: Fundo de Cultura, 1961.

HOBSBAWN, E. A era dos extremos: o breve século XX (1914-1991). São Paulo: Companhia das Letras, 1995.

INSTITUTO DE PESQUISA ECONÔMICA APLICADA. Gestão do uso do solo e disfunções do crescimento urbano: instrumentos de planejamento e gestão urbana: Brasília e Rio de Janeiro. Brasília: IPEA, 2001

IPEADATA. Disponível em <http://www.ipeadata.gov.br $>$. Visto em setembro de 2016.

INSTITUTO BRASILEIRO DE GEOGRAFIA E ESTATÍSTICA (IBGE). Brasil: censo demográfico 1950. Rio de Janeiro: IBGE, 1956.

Censo demográfico de 1960: Minas Gerais. Rio de Janeiro: IBGE, 1962.

Censo demográfico de 1960: Goiás. Rio de Janeiro: IBGE, 1962.

Censo demográfico de 1970. Rio de Janeiro: IBGE, 1973. Disponível em: < http://biblioteca.ibge.gov.br/biblioteca-catalogo.html? view=detalhes\&id=769>. Visto em outubro de 2016.

Divisão do Brasil em regiões funcionais urbanas. Rio de Janeiro: IBGE, 1972.

. Censo demográfico de 1980. Rio de Janeiro, IBGE, 1983. Disponível em $<\underline{\mathrm{http}}$ ://biblioteca.ibge.gov.br/biblioteca-catalogo? view $=$ detalhes\&id=775 $>$. $\quad$ Visto em setembro de 2016.

Regiões de influência das cidades. Rio de Janeiro: IBGE, 1987. 


\section{Censo Demográfico 1991. Disponível em <}

$\overline{\mathrm{http}} / /$ www.ibge.gov.br/home/estatistica/populacao/censodem/default_censo1991.shtm $>$ Visto em outubro de 2016.

Censo Demográfico 2000. Disponível em

$\overline{<\mathrm{http}}$ ://www.ibge.gov.br/home/estatistica/populacao/censo2000/> Visto em outubro de 2016.

Áreas urbanizadas do Brasil - 2005. Disponível em: < http://www.ibge.gov.br/home/geociencias/geografia/geografia urbana/areas urbanizadas/defa

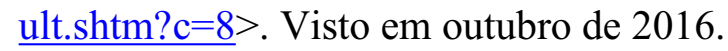

Censo Agropecuário 2006. Disponível em: < http://www.ibge.gov.br/home/estatistica/economia/agropecuaria/censoagro/>..$\quad$ Visto em outubro de 2016.

Censo Demográfico 2010. Disponível em

$\overline{<\mathrm{http}}$ ://www.ibge.gov.br/home/estatistica/populacao/censo2010/>. Visto em outubro de 2016.

Cadastro Central de Empresas. Disponível em < http://www.sidra.ibge.gov.br/bda/pesquisas/cempre/> Visto em outubro de 2016

Produto Interno Bruto dos Municípios. Disponível em $\overline{<\mathrm{http}}$ ://www.ibge.gov.br/home/estatistica/pesquisas/pesquisa resultados.php?id pesquisa $=46$ >. Visto em outubro de 2016.

Regiões de influência das cidades. Rio de Janeiro: IBGE, 2008. Disponível em $\overline{<\mathrm{http}}$ ://www.ibge.gov.br/home/geociencias/geografia/regic.shtm $>$. Visto em junho de 2015.

Divisão Urbano Regional. Rio de Janeiro: IBGE, 2013. Disponível em: < http://www.ibge.gov.br/home/geociencias/geografia/default_divisao urbano regional.shtm>. Visto em outubro de 2016.

Produção Agrícola Municipal 2015. Disponível em < http://www.sidra.ibge.gov.br/bda/pesquisas/pam/>. Visto em outubro de 2016.

INSTITUO MAURO BORGES (IMB). Estatísticas Municipais (séries históricas). Disponível em: < http://www.imb.go.gov.br/perfilweb/estatistica_bde.asp $>$. Visto em outubro de 2016. 
INSTITUTO NACIONAL DE ESTUDOS E PESQUISAS EDUCACIONAIS ANÍSIO TEIXEIRA (INEP). InepData. Disponível em $<$ http://portal.inep.gov.br/inepdata $>$. Visto em outubro de 2016.

JANOSCHKA, M. El Nuevo modelo de la ciudad latinoamericana: fragmentación y privatización. EURE, Santiago, vol. 28, n. 85, 2002 Disponível em $<\underline{\text { http://www.scielo.cl/scielo.php?script }=\text { sci_arttext\&pid }=\mathrm{S} 025071612002008500002 \& \text { lang }=\mathrm{e}}$ s $>$. Visto em março de 2015 .

KRUGMAN, P. Geography and trade. Leuven: Leuven Univ. Press, 1993.

KNEIB, E. C. Subcentros urbanos: contribuição conceitual e metodológica à sua definição e identificação para planejamento de transportes. 207f. Tese (Doutorado em Transportes). Departamento de Engenharia Civil e Ambiental, Universidade de Brasília, Brasília. 2008.

LAMEIRAS, M. A. P. Da retomada do crescimento à crise financeira internacional (20042008). In: RIBEIRO, F. J. S. P (org.). Economia brasileira no período 1987-2013: relatos e interpretações da análise de conjuntura no Ipea. Brasília: Ipea, 2015.

LEITE, S. S. C. Produção do Espaço em Águas Claras/ Brasília: uma leitura a partir da relação contraditória entre capital e trabalho na construção civil. 186f. Dissertação (Mestrado em Geografia). Departamento de Geografia, Universidade de Brasília, Brasília, 2009.

LENCIONI, S. A metamorfose de São Paulo: o anúncio de um novo mundo de aglomerações difusas. Revista Paranaense de Desenvolvimento, n. 120, p. 133-148, 2011. Disponível em $<$ http://www.ipardes.pr.gov.br/ojs/index.php/revistaparanaense/article/view/176>. Visto em junho de 2015.

LEVY, P. M. Inflação crônica, estagnação e instabilidade: o difícil caminho até a estabilização (1987-1994). In: RIBEIRO, F. J. S. P (org.). Economia brasileira no período 1987-2013: relatos e interpretações da análise de conjuntura no Ipea. Brasília: Ipea, 2015.

LIMA, M. C. Quando o amanhã vem ontem: a institucionalização da Região Metropolitana de Manaus e a indução ao processo de metropolização do espaço na Amazônia Ocidental. 298f. Tese (Doutorado em Geografia). Departamento de Geografia, Universidade de São Paulo, São Paulo, 2014.

LIMA, R. C. O uso corporativo do território pelo agronegócio e a questão da logística de transportes em Mato Grosso. 278 f. Tese (Doutorado em Geografia). Departamento de Geografia, Universidade de Brasília, Brasília, 2015. 
LIMA JR. A. T. A questão agrária e as disputas territoriais no atual ciclo de desenvolvimento econômico. In: BOUERI, R; COSTA, M. A (eds.). Brasil em desenvolvimento 2013: Estado, planejamento e políticas públicas. Brasília: Ipea, 2013.

LIMONAD, E. Urbanização dispersa: mais uma forma de urbanização? Revista Formação, vol. 1, n. 14, p. 31-45, 2007.

LIPIETZ, A. O capital e seu espaço. São Paulo: Nobel, 1988.

Audácia: uma alternativa para o século 21. São Paulo: Nobel, 1991.

LUZIÂNIA. Lei no 2.987, de 03 de outubro de 2006. Institui o Plano Diretor do Município de Luziânia GO., e dá outras providências. Disponível em: < http://www.cassianatormin.com.br/log/conteudo/download.php?arquivo=upload/PLANO DE

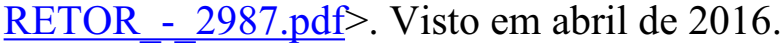

MAGALHÃES, L. R. Sertão planaltino: cultura, religiosidade e política no cadinho da modernização (1950-1964). 299f. Tese (Doutorado em História). Faculdade de História, Universidade Federal de Goiás, Goiânia, 2010.

MARGUTTI, M. Brasília e sua região geoeconômica: guia do investidor. Rio de Janeiro: Europa, 1986.

MARICATO, E. O impasse da política urbana no Brasil. Petrópolis: Vozes, 2011.

MATOS, P. O. Análise dos planos de desenvolvimento elaborados no Brasil após o II PND. 203f. Dissertação (Mestrado em Ciências). Escola Superior de Agricultura Luiz de Queiroz, Universidade de São Paulo, Piracicaba, 2002.

MATOS, R. Questões teóricas acerca dos processos de concentração e desconcentração da população no espaço. Revista Brasileira de Estudos da População, no 12 (1/2), p. 35-58, 1995.

McDONALD, J F. The identification of urban employment subcenters. Journal of Urban Economics, no 32, p. 242-258, 1987.

McMILLEN, D.P. Non-Parametric Employment Subcenter Identification. Journal of Urban Economics, $n^{\circ}$ 50, pp. 448-473, 2001. 
MEDEIROS, A. E; CAMPOS, N. Cidade projetada, construída, tombada e vivenciada: pensando o planejamento urbano de Brasília. In: PAVIANI, A; BARRETO, F. F. P; FERREIRA, I. C. B; CIDADE, L. C. F; JATOBÁ, S. U. Brasília 50 anos: da capital a metrópole. Brasília: EdUnB, 2010.

MELLO E SILVA, S. B; SILVA, B. C. N; SILVA, M. P. A Região Metropolitana de Salvador na rede urbana brasileira e sua configuração interna. In: CARVALHO, I. M. M; PEREIRA, G. C. Salvador: transformações na ordem urbana. Rio de Janeiro: Letra Capital, 2015.

MENDES, C. C; MATTEO, M. Formação e evolução do pensamento regional no Brasil. In: CRUZ, B. O; FURTADO, B. A; MONASTERIO, L; RODRIGUES JÚNIOR, W (org.s). Economia regional e urbana: teorias e métodos com ênfase no Brasil. Brasília: IPEA, 2011.

MIMOSO DE GOIÁS. Lei no 236, de 10 de outubro de 2006. Dispõe sobre a Política urbana do Município, instituindo o Plano Diretor de Mimoso de Goiás. Disponível em: < http://www.nucleogov.com.br/mimosodegoias/anexos/leis/lei_20151104164916.pdf>. Visto em abril de 2016.

MINISTÉRIO DA INTEGRAÇÃO NACIONAL (MI). Política Nacional de Desenvolvimento Regional - PNDR. Disponível em $<\underline{\text { http://www.integracao.gov.br/politica- }}$ nacional-de-desenvolvimento-regional-pndr>. Visto em junho de 2015. $\overline{2007 .}$

Plano Estratégico de Desenvolvimento do Centro-Oeste 2007-2020. Brasília: MI,

MINISTÉRIO DA SAÚDE. Datasus. Disponível em < http://www2.datasus.gov.br/DATASUS/index.php?area=0201>. Visto em outubro de 2016.

MINISTÉRIO DO INTERIOR (MINTER). II Plano Nacional de Desenvolvimento: programa de ação do governo na área de desenvolvimento urbano. Brasília: MINTER, 1975.

MINISTÉRIO DO INTERIOR; SUPERINTENDÊNCIA DO DESENVOLVIMENTO DO CENTRO-OESTE (SUDECO). II Plano Nacional de Desenvolvimento: Programa de ação do Governo para a Região Centro-Oeste. Brasília: SUDECO, 1975a.

Polocentro no Estado de Goiás e DF: elenco de programas e projetos. Brasília: SUDECO, 1975b.

MINISTÉRIO DO PLANEJAMENTO, ORÇAMENTO E GESTÃO (MPOG). PPA Mais Brasil. Disponível em $<\underline{\mathrm{http}}$ //ppamaisbrasil.planejamento.gov.br/sitioPPA/paginas/todoppa/objetivos.xhtml?programa=2029>. Visto em dezembro de 2015. 
. Programa de Investimentos em Logística. Disponível em

$\overline{<\mathrm{http}}$ ://www.logisticabrasil.gov.br/>. Visto em dezembro de 2015.

MINISTÉRIO DO TRABALHO E EMPREGO. Relação Anual de Informações Sociais (Rais). Disponível em $<$ http://acesso.mte.gov.br/portal-mte/rais/>. Visto em outubro de 2016.

MIRAGAYA, J. F. G. Dinâmica econômica, migrações e integração do território no Centro-Oeste: o impacto do eixo Brasília-Goiânia. Dissertação (Mestrado em Geografia). Departamento de Geografia, Universidade de Brasília, Brasília, 2003.

. Dos bandeirantes a JK: a ocupação do Planalto Central brasileiro anterior à fundação de Brasília. In: PAVIANI, A; BARRETO, F. F. P; FERREIRA, I. C. B; CIDADE, L. C. F; JATOBÁ, S. U (orgs.). Brasília 50 anos: a capital e a metrópole. Brasília: EdUnB, 2010.

MODARRES, A. Policentricity and transit service. Transportation Research, Part A $\mathrm{n}^{\mathbf{0}} 37$, 2003.

MONASTERIO, L. Indicadores de análise regional e espacial. In: CRUZ, B. O; FURTADO, B. A; MONASTERIO, L; RODRIGUES JÚNIOR, W (org.s). Economia regional e urbana: teorias e métodos com ênfase no Brasil. Brasília: IPEA, 2011.

MOREIRA, R. A formação espacial brasileira: contribuição crítica aos fundamentos especiais da geografia do Brasil. Rio de Janeiro: Consequência, 2014.

MOURA, R; DELGADO, P. R; CINTRA, A. P. U. A metrópole de Curitiba na rede urbana brasileira e sua configuração interna. In: FIRKOWSKI, O. L. C. F; MOURA, R. Curitiba: transformações na ordem urbana. Rio de Janeiro: Letra Capital, 2015.

MUNIZ, I; GALINDO, A; GARCÍA, M. A. ¿Es Barcelona uma ciudad policéntrica? Document de Treball, Department d'Economia Aplicada, Universitat Autònoma de Barcelona, 2003. Disponível em: $<$ http://www.ecap.uab.es/RePEc/doc/wpdea0309.pdf $>$. Visto em julho de 2016.

MYRDAL, G. Teoria econômica e regiões subdesenvolvidas. Rio de Janeiro: Saga, 1972.

NASSER, B. Economia regional, desigualdade regional no Brasil e os estudos dos Eixos Nacionais de Integração e Desenvolvimento. Revista do BNDES, Rio de Janeiro, vol. 7, n. 4, p. $145-178,2000$. 
NIGRIELlO, A; PEREIRA, A. L. S.; METRAN, J. Pontos de articulação. Revista dos transportes públicos, ano 25 ( $4^{\circ}$ trimestre), p. 91-108, 2002.

OLIVEIRA, F. Elegia para uma re(li)gião: Sudene, Nordeste, planejamento e conflito de classes. Rio de Janeiro: Paz e Terra, 1981.

OLIVEIRA, M. L. P. O mercado imobiliário urbano na periferia do Distrito Federal: um estudo de caso - a Cidade Ocidental. 211 f. Dissertação (Mestrado em Planejamento Urbano). Instituto de Arquitetura e Urbanismo, Universidade de Brasília, Brasília, 1983.

OJIMA, R. Novos contornos do crescimento urbano brasileiro? O conceito de urban sprawl e os desafios para o planejamento regional e ambiental. Geographia, vol. 10, n 19, 2008

OJIMA, R; MARANDOLA JR., E. Mobilidade populacional e um novo significado para as cidades: dispersão urbana e reflexiva na dinâmica regional não metropolitana. Revista Brasileira de Estudos Urbanos e Regionais, vol. 14, nº 2, p. 103-116, 2012.

PAVIANI, A. A metrópole terciária. In: PAVIANI, A. (org.) Brasília, ideologia e realidade: espaço urbano em questão. Brasília: Projeto, 1985.

Periferização Urbana. In: PAVIANI, A. (org.). Urbanização e Metropolização: a gestão dos conflitos em Brasília. Brasília: EdUnB, Codeplan, 1987

. Brasília a metrópole em crise: ensaios sobre urbanização.Brasília: EdUnB, 1988.

PEREIRA, L. A. G; LESSA, S. N. O processo de planejamento e desenvolvimento do transporte rodoviário no Brasil. Caminhos da Geografia, v. 12, nº 40, 2011, p. 26-45.

PEREIRA JR., E. Dinâmica territoriais no Ceará e na Região Metropolitana de Fortaleza - um olhar orientado pelo processo de industrialização. In: COSTA, M. C. L; PEQUENO, R. (eds.). Fortaleza: transformações na ordem urbana. Rio de Janeiro: Letra Capital, 2015.

PERROUX, F. A economia do século XX. Lisboa: Herder, 1964.

PINTAUDI, S. M. Las metrópolis y los grandes equipamientos comerciales. Anais do VI EGAL, Buenos Aires, $1997 . \quad$ Disponivel em < http://www.observatoriogeograficoamericalatina.org.mx/egal6/Geografiasocioeconomica/Geo grafiaeconomica/71.pdf $>$. Visto em dezembro de 2015. 
PORTAL DA CIDADANIA. Território de Águas Emendadas. Disponível em: < http://www.territoriosdacidadania.gov.br/dotlrn/clubs/territriosrurais/dasaguasemendadasdfgo

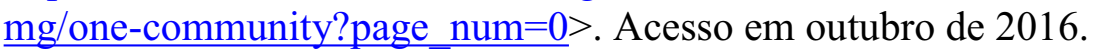

PREFEITURA DE CIDADE OCIDENTAL. Plano Diretor de Cidade Ocidental. Cidade Ocidental: Prefeitura Municipal de Cidade Ocidental, 2006. Disponível em $<$ http://www2.seplan.go.gov.br/seplan/down/planodiretor/PD_CidadeOcidental.pdf $>$. Visto em abril de 2016.

PREFEITURA DE CRISTALINA. Plano Diretor participativo do Município de Cristalina. Cristalina: Prefeitura Municipal de Cristalina, 2011. Disponível em: < http://cristalina.go.gov.br/planodiretor/planodiretor2011.pdf>. Visto em abril de 2016.

PREFEITURA DE PIRENÓPOLIS. Patrimônio Histórico. Disponível em: < http://www.pirenopolis.go.gov.br/patrimonio-historico/>. Visto em dezembro de 2016.

PREFEITURA DE SANTO ANTÔNIO DO DESCOBERTO. Diagnóstico situacional como subsídio à revisão do Plano Diretor de Santo Antônio do Descoberto. Santo Antônio do Descoberto: Prefeitura Municipal de Santo Antônio do Descoberto, 2014. Disponível em: $<$ http://santoantoniododescoberto.go.gov.br/wp-

content/uploads/2014/11/DIAGN\%C3\%93STICO-SITUACIONAL.pdf $>$. Visto em abril de 2016.

PROGRAMA DAS NAÇÕES UNIDAS PARA O DESENVOLVIMENTO (PNUD); FUNDAÇÃO JOÃO PINHEIRO; INSTITUTO DE PESQUISA ECONÔMICA APLICADA (IPEA). Atlas do Desenvolvimento Humano. Disponível em < http://www.atlasbrasil.org.br/2013/>. Visto em outubro de 2016.

QUEIROZ, E. P. A formação histórica da região do Distrito Federal e Entorno: dos municípios-gênese à presente configuração territorial. 135 f. Dissertação (Mestrado em Geografia). Departamento de Geografia, Universidade de Brasília, Brasília, 2007.

QUEIROZ, G. J. F. Modernização agrícola e transformações socioespaciais em Goiás: desigualdades e concentração no desenvolvimento regional no período 1930 a 2007.278 f. Tese (Doutorado em Geografia). Instituto de Geografia, Universidade Federal de Uberlândia, Uberlândia, 2010.

RAMOS, F. R. Análise espacial de estruturas intra-urbanas: o caso de São Paulo. 142f. Dissertação (Mestrado em Sensoriamento Remoto). Instituto Nacional de Pesquisas Espaciais, São José dos Campos, 2002. 
RANDOLPH, R. Avanços da metropolização e formação de novas fronteiras: investigações sobre trajetórias da urbanização em torno das metrópoles. Scripta Nova, vol. XVI, nº 418 (43), 2002. Disponível em < http://www.ub.edu/geocrit/sn/sn-418/sn-418-43.htm>. Visto em março de 2015.

REDFEARN, C. L. The Topography of Metropolitan Employment: Identifying Centers of Employment in a Polycentric Urban Area. Journal of Urban Economics, no 61, p. 519-561, 2007.

RESENDE, M. Movimentos de moradores: a experiência dos inquilinos em Ceilândia. In: PAVIANI, A. (org.). A conquista da cidade: movimentos populares em Brasília. Brasília: EdUnB, 1991.

RESENDE, L. G. Expansão metropolitana, promotores imobiliários e discurso da sustentabilidade ambiental, no Aglomerado Urbano de Brasília: o caso do condomínio Alphaville. 165 f. Dissertação (Mestrado em Geografia). Departamento em Geografia, Universidade de Brasília, Brasília, 2013.

RESENDE, L. G; CIDADE, L. C. F. Adensamento, dispersão e pressões na Brasília metropolitana. Brasília em Debate, Brasília, n. 4, p. 13-18, 2013. Disponível em : $<$ http://www.codeplan.df.gov.br/images/CODEPLAN/PDF/BRASILIA\%20EM\%20DEBATE $/$ Revista\%20Bras\%C3\%ADlia\%20em\%20Debate\%204.pdf $>$. Visto em setembro de 2016

RIBEIRO, F. J. Ajuste interno e externo e consolidação de um novo regime de política econômica (1999-2003). In: RIBEIRO, F. J. S. P (org.). Economia brasileira no período 19872013: relatos e interpretações da análise de conjuntura no Ipea. Brasília: Ipea, 2015.

RIBEIRO, R. J. C; HOLANDA, F. A metrópole de Brasília na rede urbana brasileira e configuração interna. In: RIBEIRO, R. J. C; TENORIO, G. S; HOLANDA, F. (org.s). Brasília: transformações na ordem urbana. Rio de Janeiro: Letra Capital, 2015.

ROCHA, S. Desigualdade regional e pobreza no Brasil: a evolução - 1981/95. Texto para discussão Ipea, nº 567, 1998.

RODRIGUES, F; BAENINGER, R. Dinâmica da população e políticas sociais. In: BAENINGER, R. (org.). População e cidades: subsídios para o planejamento e para as políticas sociais. Campinas: Nepo/ Unicamp, 2010.

ROSA, J. R. A. M; OLIVEIRA, F. L. P. Tendências de reestruturação territorial na Região Metropolitana do Recife: economia e mercado de trabalho. In: SOUZA, M. A. A; BITOUN, J. Recife: transformações na ordem urbana. Rio de Janeiro: Letra Capital, 2015. 
SALGUEIRO, T. B. Novos produtos imobiliários e reestruturação urbana. Finisterra, vol. XXIX, no 57, p. 79-101, 1994.

SAMPAIO, C. S; PAZ, F; CORREAA, G; CASTRO, S. M. Arranjos institucionais de gestão metropolitana: o caso da Ride-DF. In: COSTA, M. A; TSUKUMO, I. T. L. (orgs.) 40 anos de regiões metropolitanas no Brasil. Brasília: IPEA, 2013.

SÁNCHEZ, F. Cidade Espetáculo: política, planejamento e city marketing. Curitiba: Palavra, 1997.

SANTANA, R. N. M. Área de influência direta de Brasília. Brasília: Convênio GDF/ FUB, 1974. Volume III.

SANTOS, M. O espaço dividido: os dois circuitos da economia urbana dos países subdesenvolvidos. São Paulo: EdUSP, 2008 (1979).

Espaço e Método. São Paulo: EdUSP, 2012 (1985).

Metamorfoses do espaço habitado. São Paulo: EdUSP, 2012 (1988).

A natureza do espaço: técnica e tempo, razão e emoção. São Paulo: EdUSP, 2008 $\overline{(1996) .}$

SANTOS, M; SILVEIRA, M. L. O Brasil: território e sociedade no início do século XXI. São Paulo: Record, 2001.

SASSEN, S. Cidades na economia mundial. São Paulo: Estudio Nobel, 1991.

El reposicionamiento de las ciudades y regiones urbanas en una economía global: ampliando las opciones de políticas y gobernanza. Eure, vol. XXXIII, nº 100, p. 9-34, 2007.

SCOTT, A. L'économie métropolitaine: organisation industrielle et croissance urbaine. In: BENKO, G; LIPIETZ, A (org.s). Les régions qui gagnent. Paris: PUF, 1992.

SCOTT, A. J; AGNEW, J; SOJA, E; STORPER, M. 2001.Global city-regions. In: SCOTT, A. J. (org.) Global city-regions: trends, theory, policy. Oxford: Oxford University Press, 2001. 
SECRETARIA DE ESTADO DE FAZENDA DO DISTRITO FEDERAL (SEF-DF). Fundo de Desenvolvimento do Distrito Federal - Fundefe. Disponível em < http://www.fazenda.df.gov.br/area.cfm?id area=169>. Visto em fevereiro de 2016.

SENRA, K. V. Políticas federais de desenvolvimento regional no Brasil: uma análise comparada dos períodos pós-guerra (1945-1964), pós-golpe militar (1964-1988) e pósConstituição Federal de 1988 (1988-2009). 128f. Dissertação (Mestrado em Geografia). Departamento de Geografia, Universidade de Brasília, Brasília, 2009.

SERRÃO, R. S; DIAS, J. M. P. A metrópole de São Paulo na transição econômica: estrutura produtiva e mercado de trabalho. In: BÓGUS, L. M. M; PASTERNAK, S. (org.s). São Paulo: transformações na ordem urbana. Rio de Janeiro: Letra Capital, 2015.

SILVA, H. L. Desenvolvimento agrícola, gestão do território e efeitos sobre a sustentabilidade na região Centro-Oeste, Brasil. 368f. Tese (Doutorado em Desenvolvimento Sustentável). Centro de Desenvolvimento Sustentável, Universidade de Brasília, Brasília, 2008.

SIQUEIRA, H. Estrutura produtiva e divisão espacial do trabalho no Estado e na metrópole. In: RIBEIRO, L. C. Q. (ed.). Rio de Janeiro: transformações na ordem urbana. Rio de Janeiro: Letra Capital, 2015.

SOARES, P. R. R. A Região Metropolitana de Porto Alegre nos (des)caminhos da metropolização brasileira. In: FEDOZZI, L; SOARES, P. R. R. (eds.) Porto Alegre: transformações na ordem urbana. Rio de Janeiro: Letra Capital, 2015.

SOARES, P. R. R; STERNBERG, S. S. W; FERNANDES, A. C; FLORES, A. M. Região Metropolitana de Porto Alegre: reestruturação produtiva, mercado de trabalho e espaços industriais. In: FEDOZZI, L; SOARES, P. R. R. (eds.) Porto Alegre: transformações na ordem urbana. Rio de Janeiro: Letra Capital, 2015.

SOJA, E. Geografias pós-modernas: a reafirmação do espaço na teoria social crítica. Rio de Janeiro: Jorge Zahar, 1993.

Para além de Postmetropolis. Revista da UFMG, vol. 20, nº 1, p. 136-167, 2013.

SOUZA, M. A. A. O II PND e a política urbana brasileira: uma contradição evidente. In: DÉAK, C; SCHIFFER, S. R. (orgs.) O processo de urbanização no Brasil. São Paulo: EdUSP, 2004, p. 111-143.

STORPER, M. The regional world: territorial development in a global economy. Nova York: Guilford, 1997. 
STORPER, M; SCOTT, A. Pathways to industrialization and regional development. Nova Iorque: Routledge, 1992.

TONUCCI FILHO, J. B. M; MAGALHÃES, F. N. C; OLIVEIRA, A. M; SILVA, H. Estrutura produtiva e mercado de trabalho na Região Metropolitana de Belo Horizonte: formação histórica e perspectivas contemporâneas. In: ANDRADE, L. T; MENDONÇA. J. G; DINIZ, A. M. A. Belo Horizonte: transformações na ordem urbana. Rio de Janeiro: Letra Capital, 2015.

TORMIN, C. V. Um lugar e suas raízes: o pensamento político em Luziânia/GO. 125f. Dissertação (Mestrado em Geografia). Departamento de Geografia, Universidade de Brasília, Brasília, 2004.

UNAÍ. Lei Complementar $n^{\circ}$ 44, de 25 de março de 2003. Dispõe sobre o Plano Diretor de Desenvolvimento urbano e dá outras providências. Disponível em: < https://leismunicipais.com.br/a1/mg/u/unai/lei-complementar/2003/5/44/lei-complementar-n44-2003-dispoe-sobre-o-plano-diretor-de-desenvolvimento-urbano-e-da-outrasprovidencias? $\mathrm{q}=44>$. Visto em abril de 2016.

VALPARAÍSO DE GOIÁS. Lei Complementar nº 063, de 19 de julho de 2012. Dispõe sobre o Plano Diretor do Município de Valparaíso de Goiás, e dá outras providências. Disponível em: $<\underline{\text { http://www.nucleogov.com.br/camaravalparaisodegoias/anexos/leis/lei_20150811120450.pd }}$ f>. Visto em abril de 2016.

VAINER, C. Pátria, empresa e mercadoria: notas sobre a estratégia discursiva do planejamento estratégico urbano. In: ARANTES, O. VAINER, C. MARICATO, E. A cidade do pensamento único. Petrópolis: Vozes, 2000.

VASCONCELOS, A. M. N; GOMES, M. M. F. A metrópole de Brasília na transição demográfica brasileira. In: RIBEIRO, R. J. C; TENORIO, G. S; HOLANDA, F. (org.s). Brasília: transformações na ordem urbana. Rio de Janeiro: Letra Capital, 2015.

VELTZ, P. Mondialisation, villes et territoires : l'économie d'archipel. Paris : PUF, 1996.

VICENTE, V. M. B. Análise de mudanças institucionais na política de ordenamento territorial urbano no Distrito Federal (1991-2009). 246f. Tese (Doutorado em Administração). Faculdade de Economia, Administração e Contabilidade, Universidade de Brasília, Brasília, 2012.

VIEIRA, E. Brasil: do golpe de 1964 à redemocratização. In: MOTA, C. G. Viagem incompleta: a experiência brasileira (1500-2000): a grande transação. São Paulo: Senac, 2000. 
VILLAÇA, F. Espaço intra-urbano no Brasil. São Paulo: Estudio Nobel, 1998.

. Uma contribuição para a história do planejamento urbano no Brasil. In: DÉAK, C; SCHIFFER, S. R. (orgs.) O processo de urbanização no Brasil. São Paulo: EdUSP, 2004, p. $169-244$. 


\section{ANEXOS}

\section{ANEXO A - TABELAS DE APOIO}

Tabela A 1 - População nos municípios do espaço da Ride-DF, 1950

\begin{tabular}{lrrr}
\hline Município & População Total & População nas cidades \\
\hline Cristalina & 5.333 & 1.719 \\
Formosa & 23.273 & 3.631 \\
Planaltina & 7.335 & 1.385 \\
Corumbá de Goiás & 21.952 & 1.071 \\
Luziânia & 19.657 & 1.811 \\
Pirenópolis & 22.430 & 2.170 \\
Unaí & 28.860 & 868 \\
\hline
\end{tabular}

Fonte: IBGE, 1956 (dados organizados pelo autor)

Tabela A 2 - População nos municípios do espaço da Ride-DF, 1960

\begin{tabular}{lr}
\hline Município & Total \\
\hline Abadiânia & 8.186 \\
Cabeceiras & 3.120 \\
Corumbá de Goiás & 13.173 \\
Cristalina & 9.165 \\
Formosa & 21.708 \\
Luziânia & 27.444 \\
Olho d'Água (Alexânia) & 8.022 \\
Pirenópolis & 26.494 \\
Planaltina & 6.123 \\
Unaí & 45.975 \\
\hline
\end{tabular}

Fonte: IBGE 1962a; IBGE 1962b (dados organizados pelo autor)

Tabela A 3 - População residente nos municípios que formam a atual Ride-DF, 1970.

\begin{tabular}{|c|c|c|c|c|c|}
\hline \multirow{2}{*}{ Municípios } & \multirow{2}{*}{ Total } & \multicolumn{2}{|l|}{ Urbana } & \multicolumn{2}{|l|}{ Rural } \\
\hline & & Total & $\%$ & Total & $\%$ \\
\hline Abadiânia - GO & 7.772 & 1.423 & 18,31 & 6.349 & 81,69 \\
\hline Alexânia - GO & 9.390 & 2.642 & 28,14 & 6.748 & 71,86 \\
\hline Cabeceiras - GO & 4.056 & 784 & 19,33 & 3.272 & 80,67 \\
\hline Corumbá de Goiás - GO & 18.439 & 1.642 & 8,91 & 16.797 & 91,09 \\
\hline Cristalina - GO & 11.600 & 5.612 & 48,38 & 5.988 & 51,62 \\
\hline Formosa - GO & 28.874 & 12.859 & 44,53 & 16.015 & 55,47 \\
\hline Luziânia - GO & 32.807 & 9.604 & 29,27 & 23.203 & 70,73 \\
\hline Padre Bernardo - GO & 8.381 & 1.771 & 21,13 & 6.610 & 78,87 \\
\hline Pirenópolis - GO & 32.065 & 4.982 & 15,54 & 27.083 & 84,46 \\
\hline Planaltina - GO & 8.972 & 582 & 6,49 & 8.390 & 93,51 \\
\hline Buritis - MG & 9.810 & 2.157 & 21,99 & 7.653 & 78,01 \\
\hline Unaí - MG & 52.303 & 14.046 & 26,86 & 38.257 & 73,14 \\
\hline Brasília - DF & 537.492 & 516.007 & 96,00 & 21.485 & 4,00 \\
\hline
\end{tabular}


Fonte: IBGE - Censo Demográfico (dados organizados pelo autor)

Tabela A 4 - PIB municipal a preços constantes e valor adicionado bruto, por setor, dos municípios da Ride-DF, 1975.

\begin{tabular}{|c|c|c|c|c|c|c|c|c|}
\hline \multirow[t]{2}{*}{ UF } & \multirow[t]{2}{*}{ Município } & \multirow{2}{*}{$\begin{array}{l}\text { PIB municipal } \\
\text { a preços } \\
\text { constantes - } \\
\text { exceto } \\
\text { impostos (em } \\
\text { mil reais) }\end{array}$} & \multicolumn{2}{|c|}{$\begin{array}{c}\text { PIB Municipal - } \\
\text { indústria - valor } \\
\text { adicionado - preços } \\
\text { básicos }\end{array}$} & \multicolumn{2}{|c|}{$\begin{array}{l}\text { PIB Municipal - } \\
\text { comércio e serviços - } \\
\text { valor adicionado - } \\
\text { preços básicos }\end{array}$} & \multicolumn{2}{|c|}{$\begin{array}{l}\text { PIB Municipal - } \\
\text { agropecuária - } \\
\text { valor adicionado - } \\
\text { preços básicos }\end{array}$} \\
\hline & & & Total & $\%$ & Total & $\%$ & Total & $\%$ \\
\hline GO & Abadiânia & $12.093,93$ & 119,68 & 0,99 & $4.763,84$ & 39,39 & $7.210,41$ & 59,62 \\
\hline GO & Alexânia & $14.631,48$ & $1.345,08$ & 9,19 & $6.801,68$ & 46,49 & $6.484,71$ & 44,32 \\
\hline $\mathrm{GO}$ & Cabeceiras & $8.524,06$ & 97,55 & 1,14 & $1.575,45$ & 18,48 & $6.851,05$ & 80,37 \\
\hline GO & Corumbá de Goiás & $36.825,98$ & $13.921,79$ & 37,80 & $8.197,40$ & 22,26 & $14.706,79$ & 39,94 \\
\hline $\mathrm{GO}$ & Cristalina & $47.268,74$ & 449,18 & 0,95 & $27.863,98$ & 58,95 & $18.955,58$ & 40,10 \\
\hline $\mathrm{GO}$ & Formosa & $68.287,88$ & $2.046,47$ & 3,00 & $43.205,96$ & 63,27 & $23.035,46$ & 33,73 \\
\hline GO & Luziânia & $82.275,04$ & $5.612,59$ & 6,82 & $49.297,83$ & 59,92 & $27.364,62$ & 33,26 \\
\hline GO & Padre Bernardo & $12.975,52$ & 207,05 & 1,60 & $4.758,39$ & 36,67 & $8.010,08$ & 61,73 \\
\hline $\mathrm{GO}$ & Pirenópolis & $50.141,84$ & $2.133,10$ & 4,25 & $13.574,66$ & 27,07 & $34.434,08$ & 68,67 \\
\hline GO & Planaltina & $12.628,60$ & 403,81 & 3,20 & $3.364,95$ & 26,65 & $8.859,84$ & 70,16 \\
\hline MG & Buritis & $11.190,60$ & 725,69 & 6,48 & $5.272,50$ & 47,12 & $5.192,42$ & 46,40 \\
\hline MG & Unaí & $137.111,84$ & $12.556,80$ & 9,16 & $59.056,35$ & 43,07 & $65.498,69$ & 47,77 \\
\hline DF & Brasília & $7.281 .184,10$ & $1.882 .085,19$ & 25,85 & $5.371 .029,88$ & 73,77 & $28.069,04$ & 0,39 \\
\hline
\end{tabular}

Fonte: IBGE apud IPEADATA (dados organizados pelo autor)

Tabela A 5 - População total e população por situação de domicílio, municípios da Ride-DF, 1980

\begin{tabular}{|c|c|c|c|c|c|}
\hline \multirow{3}{*}{ Município } & \multirow{3}{*}{ Total } & \multicolumn{4}{|c|}{ Situação do domicílio } \\
\hline & & \multicolumn{2}{|c|}{ Urbana } & \multicolumn{2}{|l|}{ Rural } \\
\hline & & Total & $\%$ & Total & $\%$ \\
\hline Abadiânia - GO & 9.030 & 3.469 & 38,42 & 5.561 & 61,58 \\
\hline Alexânia - GO & 12.116 & 6.218 & 51,32 & 5.898 & 48,68 \\
\hline Cabeceiras - GO & 4.993 & 1.407 & 28,18 & 3.586 & 71,82 \\
\hline Corumbá de Goiás - GO & 20.212 & 2.447 & 12,11 & 17.765 & 87,89 \\
\hline Cristalina - GO & 15.977 & 10.459 & 65,46 & 5.518 & 34,54 \\
\hline Formosa - GO & 43.297 & 29.618 & 68,41 & 13.679 & 31,59 \\
\hline Luziânia - GO & 92.817 & 75.977 & 81,86 & 16.840 & 18,14 \\
\hline Padre Bernardo - GO & 15.855 & 7.233 & 45,62 & 8.622 & 54,38 \\
\hline Pirenópolis - GO & 29.329 & 6.652 & 22,68 & 22.677 & 77,32 \\
\hline Planaltina - GO & 16.178 & 9.275 & 57,33 & 6.903 & 42,67 \\
\hline Buritis - MG & 15.429 & 5.772 & 37,41 & 9.657 & 62,59 \\
\hline Unaí - MG & 67.885 & 29.841 & 43,96 & 38.044 & 56,04 \\
\hline Brasília - DF & 1.176 .908 & 1.138 .994 & 96,78 & 37.914 & 3,22 \\
\hline
\end{tabular}

Fonte: IBGE, 1983 (dados organizados pelo autor)

${ }^{47}$ Em valores atualizados para o ano 2000. 
Tabela A 7 - Número total de Estabelecimentos ou Unidades Locais, por setor, 1975-1985

\begin{tabular}{l|l|r|r|r|r|r|r|rrr}
\hline \multirow{2}{*}{ UF } & \multicolumn{3}{c|}{ Município } & \multicolumn{3}{c|}{ Comércio } & \multicolumn{3}{c}{ Indústria } & \multicolumn{3}{c}{ Serviços } \\
\cline { 3 - 10 } & & 1975 & 1980 & 1985 & 1975 & 1980 & 1985 & 1975 & 1980 & 1985 \\
\hline GO & Abadiânia & 34 & 27 & 29 & 13 & 7 & 3 & 16 & 6 & 19 \\
GO & Alexânia & 57 & 58 & 68 & 20 & 30 & 9 & 37 & 24 & 27 \\
GO & Cabeceiras & 13 & 15 & 30 & 3 & 7 & 15 & 11 & 11 & 18 \\
GO & Corumbá de Goiás & 87 & 64 & 140 & 24 & 33 & 84 & 36 & 41 & 85 \\
GO & Cristalina & 91 & 89 & 123 & 9 & 22 & 4 & 47 & 28 & 32 \\
GO & Formosa & 234 & 221 & 276 & 59 & 75 & 74 & 213 & 176 & 178 \\
GO & Luziânia & 141 & 294 & 354 & 67 & 182 & 95 & 123 & 167 & 175 \\
GO & Padre Bernardo & 50 & 60 & 119 & 12 & 27 & 37 & 25 & 27 & 74 \\
GO & Pirenópolis & 142 & 83 & 146 & 75 & 97 & 129 & 69 & 49 & 61 \\
GO & Planaltina & 8 & 71 & 91 & 2 & 11 & 19 & 2 & 35 & 37 \\
GO & Santo Antônio do Descoberto & & & 36 & & & 5 & & & 8 \\
MG & Buritis & 34 & 62 & 100 & 7 & 15 & 21 & 24 & 25 & 51 \\
MG & Unaín & 237 & 405 & 473 & 78 & 81 & 68 & 251 & 238 & 189 \\
DF & Brasília & 4233 & 5563 & 6.267 & 625 & 1199 & 1.066 & 2980 & 4611 & 5.408 \\
\hline
\end{tabular}

Fonte: IBGE apud IPEADATA (dados organizados pelo autor) 
Tabela A 8 - Pessoal ocupado, por setor, 1975-1985.

\begin{tabular}{|c|c|c|c|c|c|c|c|c|c|c|c|c|c|}
\hline \multirow{2}{*}{ UF } & \multirow{2}{*}{ Município } & \multicolumn{3}{|c|}{ Pessoal ocupado - agropecuária } & \multicolumn{3}{|c|}{ Pessoal ocupado - Comércio } & \multicolumn{3}{|c|}{ Pessoal ocupado - Industria } & \multicolumn{3}{|c|}{ Pessoal ocupado - Serviços } \\
\hline & & 1975 & 1980 & 1985 & 1975 & 1980 & 1985 & 1975 & 1980 & 1985 & 1975 & 1980 & 1985 \\
\hline GO & Abadiânia & 1.967 & 2.897 & 4.023 & 49 & 59 & 64 & 23 & 26 & 7 & 107 & 11 & 46 \\
\hline GO & Alexânia & 2.478 & 4.043 & 3.022 & 106 & 134 & 177 & 107 & 127 & 62 & 91 & 101 & 96 \\
\hline GO & Cabeceiras & 2.311 & 1.781 & 2.224 & 26 & 28 & 61 & 22 & 31 & 71 & 28 & 30 & 46 \\
\hline GO & $\begin{array}{l}\text { Corumbá de } \\
\text { Goiás }\end{array}$ & 1.203 & 1.495 & 2.643 & 131 & 189 & 307 & 341 & 373 & 626 & 61 & 146 & 179 \\
\hline GO & Cristalina & 2.414 & 4.380 & 3.986 & 202 & 189 & 359 & 36 & 74 & 19 & 229 & 82 & 83 \\
\hline GO & Formosa & 6.727 & 5.933 & 7.913 & 636 & 785 & 929 & 272 & 603 & 439 & 600 & 541 & 502 \\
\hline GO & Luziânia & 7.307 & 12.593 & 9.145 & 389 & 828 & 1.096 & 495 & 956 & 695 & 288 & 677 & 691 \\
\hline GO & Padre Bernardo & 3.536 & 5.070 & 6.172 & 82 & 140 & 183 & 18 & 118 & 124 & 35 & 92 & 168 \\
\hline GO & Pirenópolis & 11.136 & 12.751 & 12.723 & 290 & 239 & 271 & 335 & 500 & 331 & 149 & 151 & 129 \\
\hline GO & Planaltina & 4.643 & 3.584 & 4.737 & 12 & 217 & 174 & 0 & 81 & 132 & & 82 & 61 \\
\hline GO & $\begin{array}{l}\text { Santo Antônio } \\
\text { do Descoberto }\end{array}$ & & & 3.045 & & & 81 & & & 24 & & & 16 \\
\hline MG & Buritis & 3.778 & 5.222 & 6.801 & 54 & 122 & 234 & 25 & 37 & 56 & 43 & 48 & 127 \\
\hline MG & Unaí & 14.368 & 19.757 & 21.486 & 571 & 1.057 & 1.437 & 299 & 426 & 321 & 458 & 590 & 444 \\
\hline DF & Brasília & 8.582 & 14.628 & 17.178 & 24.793 & 35.128 & 45.551 & 11.144 & 15.574 & 16.548 & 31.052 & 59.257 & 56.942 \\
\hline
\end{tabular}

Fonte: IBGE apud IPEA (dados organizados pelo autor) 
Tabela A 9 - Valor adicionado bruto ao PIB municipal, em percentual, dos municípios do Entorno, por setor, 1975.

\begin{tabular}{|c|c|c|c|c|c|c|c|c|c|c|c|}
\hline Sigla & Município & $\begin{array}{l}\text { Indústria - } \\
\text { transformação } \\
\text { e extrativa } \\
\text { mineral }\end{array}$ & $\begin{array}{l}\text { Indústria - } \\
\text { construção }\end{array}$ & $\begin{array}{c}\text { Indústria } \\
\text { - serviços } \\
\text { de } \\
\text { utilidade } \\
\text { pública } \\
\end{array}$ & $\begin{array}{l}\text { Serviços - } \\
\text { transporte, } \\
\text { armazenagem e } \\
\text { correio }\end{array}$ & $\begin{array}{c}\text { Serviços - } \\
\text { intermediação } \\
\text { financeira }\end{array}$ & $\begin{array}{c}\text { Serviços - } \\
\text { administração } \\
\text { pública }\end{array}$ & $\begin{array}{c}\text { Serviços - } \\
\text { atividades } \\
\text { imobiliárias } \\
\text { e aluguel }\end{array}$ & $\begin{array}{l}\text { Serviços } \\
\text { - outros }\end{array}$ & $\begin{array}{c}\text { Agropecuária } \\
\text { - valor } \\
\text { adicionado }\end{array}$ & $\begin{array}{c}\text { Serviços } \\
- \\
\text { comércio }\end{array}$ \\
\hline $\mathrm{GO}$ & Abadiânia & 0,36 & 0,49 & 0,13 & 2,44 & 6,37 & 6,60 & 9,35 & 11,63 & 59,62 & 3,00 \\
\hline $\mathrm{GO}$ & Alexânia & 7,74 & 0,90 & 0,56 & 11,26 & 6,37 & 6,02 & 8,28 & 8,77 & 44,32 & 5,79 \\
\hline GO & Cabeceiras & 0,65 & 0,41 & 0,09 & 1,58 & 6,37 & 3,06 & 4,99 & 1,92 & 80,37 & 0,57 \\
\hline GO & Corumbá de Goiás & 34,85 & 0,82 & 2,13 & 3,65 & 6,37 & 3,33 & 5,76 & 1,32 & 39,94 & 1,82 \\
\hline $\mathrm{GO}$ & Cristalina & 0,30 & 0,59 & 0,06 & 2,99 & 6,37 & 7,05 & 20,03 & 17,78 & 40,10 & 4,72 \\
\hline GO & Formosa & 1,57 & 1,14 & 0,29 & 5,33 & 6,37 & 8,51 & 10,78 & 21,46 & 33,73 & 10,81 \\
\hline GO & Luziânia & 4,15 & 2,43 & 0,25 & 11,05 & 6,37 & 10,61 & 18,07 & 7,56 & 33,26 & 6,25 \\
\hline GO & Padre Bernardo & 0,33 & 1,24 & 0,02 & 2,33 & 6,37 & 4,07 & 12,84 & 3,81 & 61,73 & 7,25 \\
\hline GO & Pirenópolis & 3,71 & 0,42 & 0,12 & 2,99 & 6,37 & 2,05 & 8,22 & 3,25 & 68,67 & 4,19 \\
\hline GO & Planaltina & 1,20 & 1,96 & 0,04 & 2,73 & 6,37 & 6,45 & 9,84 & 0,54 & 70,16 & 0,70 \\
\hline MG & Buritis & 1,16 & 4,83 & 0,50 & 4,94 & 4,25 & 4,70 & 23,22 & 3,77 & 46,40 & 6,25 \\
\hline MG & Unaí & 4,75 & 3,64 & 0,77 & 4,14 & 4,25 & 2,85 & 8,99 & 8,78 & 47,77 & 14,07 \\
\hline $\mathrm{DF}$ & Brasília & 20,59 & 3,98 & 1,27 & 4,01 & 11,72 & 35,78 & 5,54 & 8,91 & 0,39 & 7,80 \\
\hline
\end{tabular}


Tabela A 10 - Valor adicionado bruto ao PIB municipal, em percentual, dos municípios do Entorno, por setor, 1980.

\begin{tabular}{|c|c|c|c|c|c|c|c|c|c|c|c|}
\hline Sigla & Município & $\begin{array}{c}\text { Indústria - } \\
\text { transformação } \\
\text { e extrativa } \\
\text { mineral }\end{array}$ & $\begin{array}{l}\text { Indústria - } \\
\text { construção }\end{array}$ & $\begin{array}{c}\text { Indústria } \\
\text { - serviços } \\
\text { de } \\
\text { utilidade } \\
\text { pública } \\
\end{array}$ & $\begin{array}{l}\text { Serviços - } \\
\text { transporte, } \\
\text { armazenagem e } \\
\text { correio }\end{array}$ & $\begin{array}{l}\text { Serviços - } \\
\text { intermediação } \\
\text { financeira }\end{array}$ & $\begin{array}{c}\text { Serviços - } \\
\text { administração } \\
\text { pública }\end{array}$ & $\begin{array}{c}\text { Serviços - } \\
\text { atividades } \\
\text { imobiliárias } \\
\text { e aluguel }\end{array}$ & $\begin{array}{l}\text { Serviços } \\
\text { - outros }\end{array}$ & $\begin{array}{c}\text { Agropecuária } \\
\text { - valor } \\
\text { adicionado }\end{array}$ & $\begin{array}{c}\text { Serviços } \\
- \\
\text { comércio }\end{array}$ \\
\hline GO & Abadiânia & 1,35 & 4,45 & 0,61 & 3,47 & 5,95 & 2,59 & 9,17 & 1,50 & 65,73 & 5,19 \\
\hline $\mathrm{GO}$ & Alexânia & 9,76 & 3,38 & 5,18 & 11,80 & 5,95 & 3,59 & 7,40 & 8,14 & 42,54 & 2,25 \\
\hline GO & Cabeceiras & 2,36 & 2,43 & 0,36 & 3,33 & 5,95 & 1,76 & 9,12 & 5,95 & 67,62 & 1,12 \\
\hline GO & Corumbá de Goiás & 63,06 & 1,36 & 3,01 & 2,23 & 5,96 & 1,86 & 3,78 & 2,52 & 15,05 & 1,17 \\
\hline GO & Cristalina & 13,29 & 6,21 & 0,72 & 9,48 & 5,96 & 14,94 & 14,48 & 8,75 & 21,33 & 4,85 \\
\hline GO & Formosa & 2,83 & 3,43 & 0,40 & 3,96 & 5,95 & 5,09 & 7,44 & 5,67 & 58,43 & 6,81 \\
\hline GO & Luziânia & 13,44 & 10,35 & 0,77 & 11,67 & 5,96 & 11,16 & 13,15 & 12,16 & 15,74 & 5,60 \\
\hline $\mathrm{GO}$ & Padre Bernardo & 9,52 & 3,53 & 0,61 & 2,74 & 5,95 & 1,86 & 9,51 & 5,15 & 57,93 & 3,21 \\
\hline GO & Pirenópolis & 10,35 & 2,32 & 0,34 & 3,80 & 5,95 & 1,50 & 7,97 & 2,43 & 63,50 & 1,84 \\
\hline GO & Planaltina & 17,39 & 12,84 & 1,96 & 3,63 & 5,96 & 4,70 & 8,75 & 5,93 & 31,59 & 7,25 \\
\hline MG & Buritis & 1,14 & 4,08 & 0,88 & 3,50 & 4,92 & 1,30 & 10,57 & 3,61 & 67,31 & 2,68 \\
\hline MG & Unaí & 3,62 & 3,66 & 0,82 & 4,83 & 5,00 & 2,32 & 6,51 & 5,71 & 61,74 & 5,79 \\
\hline $\mathrm{DF}$ & Brasília & 7,35 & 1,55 & 0,41 & 3,84 & 35,44 & 24,15 & 5,93 & 16,21 & 0,38 & 4,74 \\
\hline
\end{tabular}


Tabela A 11 - Valor adicionado bruto ao PIB municipal, em percentual, dos municípios do Entorno, por setor, 1985.

\begin{tabular}{|c|c|c|c|c|c|c|c|c|c|c|c|}
\hline Sigla & Município & $\begin{array}{c}\text { Indústria - } \\
\text { transformação } \\
\text { e extrativa } \\
\text { mineral }\end{array}$ & $\begin{array}{l}\text { Indústria - } \\
\text { construção }\end{array}$ & $\begin{array}{c}\text { Indústria } \\
- \\
\text { serviços } \\
\text { de } \\
\text { utilidade } \\
\text { pública }\end{array}$ & $\begin{array}{l}\text { Serviços - } \\
\text { transporte, } \\
\text { armazenagem e } \\
\text { correio }\end{array}$ & $\begin{array}{c}\text { Serviços - } \\
\text { intermediação } \\
\text { financeira }\end{array}$ & $\begin{array}{c}\text { Serviços - } \\
\text { administração } \\
\text { pública }\end{array}$ & $\begin{array}{c}\text { Serviços - } \\
\text { atividades } \\
\text { imobiliárias } \\
\text { e aluguel }\end{array}$ & $\begin{array}{l}\text { Serviços } \\
\text { - outros }\end{array}$ & $\begin{array}{c}\text { Agropecuária } \\
\text { - valor } \\
\text { adicionado }\end{array}$ & $\begin{array}{c}\text { Serviços } \\
- \\
\text { comércio }\end{array}$ \\
\hline GO & Abadiânia & 0,42 & 5,33 & 0,79 & 7,75 & 7,16 & 2,81 & 5,89 & 5,63 & 58,35 & 5,87 \\
\hline GO & Alexânia & 1,70 & 3,67 & 2,30 & 16,11 & 7,16 & 1,48 & 4,28 & 4,58 & 49,70 & 9,01 \\
\hline GO & Cabeceiras & 7,22 & 1,85 & 0,14 & 3,24 & 7,16 & 1,08 & 2,04 & 3,69 & 76,37 & $-2,78$ \\
\hline GO & Corumbá de Goiás & 51,57 & 1,78 & 3,52 & 2,67 & 7,16 & 1,08 & 2,58 & 5,16 & 17,68 & 6,80 \\
\hline GO & Cristalina & 0,29 & 3,91 & 0,40 & 6,18 & 7,16 & 3,38 & 3,79 & 1,84 & 33,84 & 39,20 \\
\hline GO & Formosa & 25,58 & 4,93 & 0,99 & 8,07 & 7,16 & 2,58 & 5,24 & 12,75 & 22,24 & 10,47 \\
\hline GO & Luziânia & 5,72 & 14,48 & 1,00 & 21,59 & 7,16 & 8,75 & 5,90 & 8,95 & 18,01 & 8,44 \\
\hline GO & Padre Bernardo & 3,35 & 3,78 & 0,43 & 3,49 & 7,16 & 1,18 & 3,90 & 6,05 & 60,17 & 10,50 \\
\hline GO & Pirenópolis & 5,98 & 1,94 & 0,27 & 4,69 & 7,16 & 0,73 & 2,75 & 3,11 & 60,38 & 12,99 \\
\hline GO & Planaltina & 14,71 & 18,79 & 1,65 & 8,43 & 7,16 & 3,45 & 4,27 & 5,44 & 23,94 & 12,16 \\
\hline GO & Santo Antônio do Descoberto & 3,52 & 1,47 & 0,12 & 2,18 & 7,16 & 0,89 & 25,40 & 2,92 & 48,83 & 7,52 \\
\hline MG & Buritis & 1,27 & 4,38 & 1,17 & 3,51 & 9,21 & 3,38 & 6,27 & 8,00 & 51,12 & 11,69 \\
\hline MG & Unaí & 3,37 & 4,14 & 1,12 & 4,38 & 9,21 & 3,27 & 3,33 & 5,18 & 52,88 & 13,12 \\
\hline DF & Brasília & 4,94 & 0,78 & 0,31 & 13,51 & 32,03 & 17,48 & 5,75 & 19,12 & 0,34 & 5,75 \\
\hline
\end{tabular}

Fonte: IBGE apud IPEADATA (dados organizados pelo autor) 
Tabela A 12 - Estrutura Social dos municípios do Entorno, 1982.

\begin{tabular}{|c|c|c|c|c|c|c|c|c|c|c|c|c|c|c|}
\hline \multirow{3}{*}{ Município } & \multicolumn{3}{|c|}{ Bancos } & \multicolumn{6}{|c|}{ Ensino } & \multicolumn{5}{|c|}{ Saúde } \\
\hline & \multirow[b]{2}{*}{ Total } & \multirow[b]{2}{*}{ Oficial } & \multirow[b]{2}{*}{ Privado } & \multicolumn{2}{|c|}{$1^{\circ} \mathrm{Grau}$} & \multicolumn{2}{|c|}{$2^{\circ} \mathrm{Grau}$} & \multicolumn{2}{|c|}{ Superior } & \multicolumn{3}{|c|}{ Estabelecimentos } & \multirow[t]{2}{*}{$\mathrm{N}^{\mathrm{o}}$ de leitos } & \multirow[t]{2}{*}{$\mathrm{N}^{\mathrm{o}}$ Medio } \\
\hline & & & & Estab. & Alunos & Estab. & Alunos & Estab. & Alunos & Total & Com internação & Sem internação & & \\
\hline Abadiânia & 1 & - & 1 & 2 & 2.019 & 1 & 60 & & & 1 & - & 1 & - & 1 \\
\hline Alexânia & 1 & - & 1 & 22 & 2.061 & 1 & 68 & & & 2 & 1 & 1 & 36 & 5 \\
\hline Cabeceiras & 1 & - & 1 & 8 & 1.190 & - & - & & & 1 & - & 1 & - & 1 \\
\hline Corumbá de Goiás & 2 & 1 & 1 & 54 & 4.092 & 1 & 43 & & & 3 & 1 & 2 & 13 & 3 \\
\hline Cristalina & 2 & 2 & 1 & 33 & 4.235 & 2 & 293 & & & 3 & 1 & 2 & 27 & 7 \\
\hline Formosa & 5 & 4 & 1 & 55 & 10.794 & 5 & 1.322 & & & 5 & 2 & 3 & 64 & 15 \\
\hline Luziânia & 9 & 4 & 5 & 100 & 21.962 & 3 & 1.044 & & & 11 & 3 & 8 & 293 & 32 \\
\hline Padre Bernardo & 1 & - & 1 & 34 & 3.388 & 1 & 120 & & & 2 & 1 & 1 & 21 & 2 \\
\hline Pirenópolis & 3 & 2 & 1 & 76 & 3.305 & 1 & 238 & & & 3 & 1 & 2 & 51 & 2 \\
\hline Planaltina & 1 & - & 1 & 25 & 4.186 & - & - & & & 11 & 10 & 1 & - & 1 \\
\hline Unaí & 6 & 5 & 1 & 167 & 15.883 & 3 & 881 & & & 4 & 2 & 2 & 149 & 18 \\
\hline Brasília & 149 & 74 & 75 & 408 & 254.319 & 68 & 48.529 & 12 & 28.845 & 67 & 33 & 34 & 3.944 & 2.916 \\
\hline
\end{tabular}


Tabela A 13 - Valor Total dos Rendimentos recebidos - percentual de crescimento entre os anos registrados

\begin{tabular}{l|lrr}
\hline UF & Município & $1970-80$ & $1980-91$ \\
\hline GO & Abadiânia & 108,68 & 47,00 \\
GO & Alexânia & 191,89 & 26,71 \\
GO & Cabeceiras & 139,08 & 63,18 \\
GO & Corumbá de Goiás & 166,87 & 5,99 \\
GO & Cristalina & 305,68 & 45,96 \\
GO & Formosa & 314,70 & 71,96 \\
GO & Luziânia & 767,88 & 131,54 \\
GO & Padre Bernardo & 192,94 & 19,43 \\
GO & Pirenópolis & 145,86 & - \\
GO & Planaltina & 378,15 & 193,51 \\
MG & Buritis & $553,89-$ & $-25,80$ \\
MG & Unaí & $260,19-$ & 15,65 \\
DF & Brasília & 428,61 & 34,91 \\
\hline Fonte:
\end{tabular}

Fonte: IBGE apud IPEADATA (dados tratados pelo autor)

Tabela A 14 - Valor Total dos Rendimentos recebidos - percentual dos rendimentos recebidos pelos municípios da Região de Brasília em relação ao centro principal (Brasília)

\begin{tabular}{llr|r|r}
\hline UF & Município & 1970 & 1980 & 1991 \\
\hline GO & Abadiânia & 0,39 & 0,16 & 0,17 \\
GO & Água Fria de Goiás & - & - & 0,05 \\
GO & Alexânia & 0,47 & 0,26 & 0,25 \\
GO & Cabeceiras & 0,17 & 0,08 & 0,10 \\
GO & Corumbá de Goiás & 0,82 & 0,41 & 0,33 \\
GO & Cristalina & 0,66 & 0,50 & 0,55 \\
GO & Formosa & 1,84 & 1,44 & 1,84 \\
GO & Luziânia & 2,00 & 3,28 & 5,64 \\
GO & Mimoso de Goiás & - & - & 0,04 \\
GO & Padre Bernardo & 0,47 & 0,26 & 0,23 \\
GO & Pirenópolis & 1,26 & 0,58 & 0,37 \\
GO & Planaltina & 0,35 & 0,32 & 0,70 \\
GO & Santo Antônio do Descoberto & - & - & 0,64 \\
MG & Buritis & 0,33 & 0,41 & 0,23 \\
MG & Unaí & 3,17 & 2,16 & 1,35 \\
& Total & $\mathbf{1 1 , 9 4}$ & $\mathbf{9 , 8 7}$ & $\mathbf{1 2 , 4 6}$ \\
\hline
\end{tabular}

Fonte: IBGE apud IPEADATA (dados tratados pelo autor) 
Tabela A 15 - Investimentos realizados no ano - agropecuária - total - R\$, a preços do ano 2000 (mil

\begin{tabular}{|c|c|c|c|c|c|c|}
\hline UF & Município & 1970 & 1975 & 1980 & 1985 & 1996 \\
\hline GO & Abadiânia & $1.015,23$ & $1.586,09$ & $4.137,91$ & $10.277,44$ & $2.492,10$ \\
\hline GO & Água Fria de Goiás & - & - & - & - & $2.679,61$ \\
\hline GO & Alexânia & 436,33 & $1.931,10$ & $5.010,82$ & $4.391,77$ & $4.309,54$ \\
\hline $\mathrm{GO}$ & Cabeceiras & 925,33 & $3.232,16$ & $5.659,43$ & $10.526,51$ & $1.661,71$ \\
\hline GO & Cidade Ocidental & - & - & - & - & 628,34 \\
\hline $\mathrm{GO}$ & Cocalzinho de Goiás & - & - & - & - & $2.861,60$ \\
\hline GO & Corumbá de Goiás & 843,06 & $4.574,48$ & $11.122,22$ & $18.270,10$ & $2.406,63$ \\
\hline $\mathrm{GO}$ & Cristalina & $1.081,64$ & $9.190,80$ & $17.168,80$ & $23.713,09$ & $7.707,95$ \\
\hline GO & Formosa & $3.938,34$ & $13.266,59$ & $16.811,43$ & $26.989,32$ & $7.234,52$ \\
\hline $\mathrm{GO}$ & Luziânia & $3.278,09$ & $9.441,87$ & $31.731,92$ & $27.722,94$ & $6.665,78$ \\
\hline GO & Mimoso de Goiás & - & - & - & - & $2.123,10$ \\
\hline $\mathrm{GO}$ & Padre Bernardo & $1.606,44$ & $10.299,12$ & $10.270,03$ & $21.609,26$ & $7.714,52$ \\
\hline $\mathrm{GO}$ & Pirenópolis & $2.846,61$ & $9.469,54$ & $24.154,18$ & $20.742,45$ & $9.695,20$ \\
\hline $\mathrm{GO}$ & Planaltina & $3.165,77$ & $11.513,74$ & $8.474,21$ & $16.363,03$ & 742,16 \\
\hline $\mathrm{GO}$ & Santo Antônio do Descoberto & - & - & - & $5.056,70$ & $1.253,94$ \\
\hline GO & Vila Boa & - & - & - & - & $1.182,20$ \\
\hline MG & Buritis & $1.610,27$ & $1.748,83$ & $13.818,17$ & $19.783,10$ & $5.787,11$ \\
\hline MG & Unaí & $7.989,75$ & $20.678,80$ & $51.126,90$ & $64.529,75$ & $24.130,42$ \\
\hline DF & Brasília & $7.557,54$ & $20.296,40$ & $79.773,48$ & $83.601,42$ & $26.713,20$ \\
\hline
\end{tabular}

Fonte: IBGE apud IPEADATA (dados organizados pelo autor) 
Tabela A 16 - Área colhida - lavoura temporária - Hectare

\begin{tabular}{|c|c|c|c|c|c|c|c|c|c|c|c|c|c|c|}
\hline UF & Município & 1973 & 1974 & 1975 & 1976 & 1977 & 1978 & 1979 & 1980 & 1981 & 1982 & 1983 & 1984 & 1985 \\
\hline $\mathrm{GO}$ & Abadiânia & 4.789 & 8.277 & 10.316 & 6.125 & 5.280 & 4.315 & 5.010 & 4.378 & 3.780 & 3.421 & 2.840 & 4.093 & 4.927 \\
\hline GO & Alexânia & 3.314 & 4.916 & 6.447 & 4.578 & 2.422 & 2.315 & 3.532 & 3.200 & 7.066 & 5.511 & 4.716 & 4.462 & 6.375 \\
\hline GO & Cabeceiras & 1.707 & 2.601 & 8.402 & 2.701 & 4.367 & 2.743 & 8.746 & 6.061 & 5.181 & 6.202 & 6.910 & 8.050 & 15.360 \\
\hline GO & Corumbá de Goiás & 4.841 & 10.568 & 14.178 & 11.085 & 7.175 & 6.555 & 6.573 & 6.563 & 11.612 & 12.616 & 12.995 & 11.634 & 12.536 \\
\hline $\mathrm{GO}$ & Cristalina & 2.492 & 3.520 & 6.294 & 2.437 & 5.513 & 7.929 & 7.362 & 11.684 & 28.532 & 25.097 & 21.730 & 40.785 & 43.472 \\
\hline $\mathrm{GO}$ & Formosa & 7.007 & 11.331 & 13.040 & 11.167 & 9.685 & 10.862 & 13.858 & 14.184 & 11.750 & 15.882 & 17.294 & 16.876 & 20.512 \\
\hline $\mathrm{GO}$ & Luziânia & 5.369 & 9.200 & 12.778 & 4.895 & 6.158 & 6.158 & 11.506 & 18.540 & 27.208 & 30.107 & 16.013 & 25.026 & 26.511 \\
\hline GO & Padre Bernardo & 6.996 & 12.044 & 13.828 & 15.345 & 10.548 & 8.045 & 11.210 & 18.279 & 21.661 & 32.958 & 30.772 & 19.147 & 17.730 \\
\hline GO & Pirenópolis & 14.826 & 30.106 & 35.231 & 35.500 & 18.115 & 25.927 & 25.604 & 24.630 & 30.132 & 30.092 & 27.989 & 29.621 & 28.171 \\
\hline GO & Planaltina & 2.181 & 3.579 & 9.202 & 4.098 & 1.783 & 1.743 & 4.865 & 5.390 & 5.296 & 9.318 & 10.244 & 15.535 & 20.983 \\
\hline $\mathrm{GO}$ & $\begin{array}{l}\text { Santo Antônio do } \\
\text { Descoberto }\end{array}$ & - & - & - & 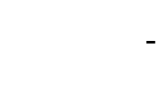 & - & 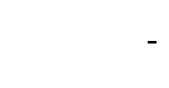 & - & - & - & 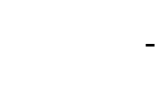 & 1.403 & 1.465 & 1.505 \\
\hline MG & Buritis & 8.410 & 10.397 & 8.818 & 8.763 & 13.308 & 6.753 & 8.913 & 18.772 & 19.680 & 29.740 & 26.640 & 25.650 & 33.580 \\
\hline MG & Unaí & 60.970 & 121.022 & 95.741 & 78.650 & 63.570 & 71.733 & 56.443 & 83.817 & 84.210 & 101.148 & 85.752 & 93.495 & 104.195 \\
\hline DF & Brasília & 2.161 & 6.844 & 9.222 & 9.677 & 5.524 & 7.567 & 11.083 & 24.911 & 39.440 & 43.205 & 42.720 & 48.865 & 59.591 \\
\hline
\end{tabular}

Fonte: IBGE apud IPEADATA (dados organizados pelo autor) 
Tabela A 17 - PIB em mil reais e percentual em relação ao PIB da Ride-DF, 2000 e 2010.

\begin{tabular}{|c|c|c|c|c|}
\hline Município & $\begin{array}{l}\text { PIB - em mil } \\
\text { reais }(2000)\end{array}$ & $\%$ & $\begin{array}{l}\text { PIB - em mil reais } \\
(2010)\end{array}$ & $\%$ \\
\hline Abadiânia (GO) & 26.008 & 0,05 & 109.773 & 0,07 \\
\hline Água Fria de Goiás (GO) & 17.579 & 0,04 & 131.009 & 0,08 \\
\hline Águas Lindas de Goiás (GO) & 164.372 & 0,33 & 676.645 & 0,42 \\
\hline Alexânia (GO) & 50.183 & 0,10 & 327.857 & 0,20 \\
\hline Cabeceiras (GO) & 28.381 & 0,06 & 131.844 & 0,08 \\
\hline Cidade Ocidental (GO) & 86.232 & 0,18 & 264.069 & 0,16 \\
\hline Cocalzinho de Goiás (GO) & 35.484 & 0,07 & 127.155 & 0,08 \\
\hline Corumbá de Goiás (GO) & 22.657 & 0,05 & 73.871 & 0,05 \\
\hline Cristalina $(\mathrm{GO})$ & 217.495 & 0,44 & 1.122 .296 & 0,70 \\
\hline Formosa (GO) & 217.755 & 0,44 & 911.489 & 0,57 \\
\hline Luziânia (GO) & 573.127 & 1,17 & 2.071 .930 & 1,29 \\
\hline Mimoso de Goiás (GO) & 8.522 & 0,02 & 28.987 & 0,02 \\
\hline Novo Gama (GO) & 127.153 & 0,26 & 432.307 & 0,27 \\
\hline Padre Bernardo (GO) & 43.011 & 0,09 & 187.005 & 0,12 \\
\hline Pirenópolis (GO) & 48.415 & 0,10 & 172.333 & 0,11 \\
\hline Planaltina $(\mathrm{GO})$ & 123.679 & 0,25 & 440.380 & 0,27 \\
\hline Santo Antônio do Descoberto (GO) & 87.294 & 0,18 & 280.866 & 0,18 \\
\hline Valparaíso de Goiás (GO) & 204.198 & 0,42 & 844.615 & 0,53 \\
\hline Vila Boa (GO) & 8.993 & 0,02 & 73.057 & 0,05 \\
\hline Buritis (MG) & 97.169 & 0,20 & 378.229 & 0,24 \\
\hline Cabeceira Grande (MG) & 27.394 & 0,06 & 113.758 & 0,07 \\
\hline Unaí (MG) & 388.462 & 0,79 & 1.402 .293 & 0,88 \\
\hline Brasília (DF) & 46.474 .890 & 94,70 & 149.906 .319 & 93,57 \\
\hline Ride-DF & 49.078.453 & 100,00 & 160.208 .087 & 100,00 \\
\hline
\end{tabular}

Fonte: IBGE 


\section{ANEXO B - LEGISLAÇÃO REFERENTE À RIDE-DF}

\section{LEI COMPLEMENTAR Nº 94, DE 19 DE FEVEREIRO DE 1998.}

Autoriza o Poder Executivo a criar a Região Integrada de Desenvolvimento do Distrito Federal e Entorno - RIDE e instituir o Programa Especial de Desenvolvimento do Entorno do Distrito Federal, e dá outras providências.

O PRESIDENTE DA REPÚBLICA Faço saber que o Congresso Nacional decreta e eu sanciono a seguinte Lei Complementar:

Art. $1^{\circ}$ É o Poder Executivo autorizado a criar, para efeitos de articulação da ação administrativa da União, dos Estados de Goiás e Minas Gerais e do Distrito Federal, conforme previsto nos arts. 21, inciso IX, 43 e 48, inciso IV, da Constituição Federal, a Região Integrada de Desenvolvimento do Distrito Federal e Entorno - RIDE.

$\S 1^{\circ}$ A Região Administrativa de que trata este artigo é constituída pelo Distrito Federal, pelos Municípios de Abadiânia, Água Fria de Goiás, Águas Lindas, Alexânia, Cabeceiras, Cidade Ocidental, Cocalzinho de Goiás, Corumbá de Goiás, Cristalina, Formosa, Luziânia, Mimoso de Goiás, Novo Gama, Padre Bernardo, Pirenópolis, Planaltina, Santo Antônio do Descoberto, Valparaíso e Vila Boa, no Estado de Goiás, e de Unaí e Buritis, no Estado de Minas Gerais.

$\S 2^{\circ}$ Os Municípios que vierem a ser constituídos a partir de desmembramento de território de Município citado no $\S 1^{\circ}$ deste artigo passarão a compor, automaticamente, a Região Integrada de Desenvolvimento do Distrito Federal e Entorno.

Art. $2^{\circ}$ É o Poder Executivo autorizado a criar um Conselho Administrativo para coordenar as atividades a serem desenvolvidas na Região Integrada de Desenvolvimento do Distrito Federal e Entorno.

Parágrafo único. As atribuições e a composição do Conselho de que trata este artigo serão definidas em regulamento, dele participando representantes dos Estados e Municípios abrangidos pela RIDE.

Art. $3^{\circ}$ Consideram-se de interesse da RIDE os serviços públicos comuns ao Distrito Federal e aos Municípios que a integram, especialmente aqueles relacionados às áreas de infra-estrutura e de geração de empregos.

Art. $4^{\circ}$ É o Poder Executivo autorizado a instituir o Programa Especial de Desenvolvimento do Entorno do Distrito Federal.

Parágrafo único. O Programa Especial de Desenvolvimento do Entorno do Distrito Federal, ouvidos os órgãos competentes, estabelecerá, mediante convênio, normas e critérios para unificação de procedimentos relativos aos serviços públicos, abrangidos tanto os federais e aqueles de responsabilidade de entes federais, como aqueles de responsabilidade dos entes federados referidos no art. $1^{\circ}$, especialmente em relação a:

I - tarifas, fretes e seguros, ouvido o Ministério da Fazenda;

II - linhas de crédito especiais para atividades prioritárias;

III - isenções e incentivos fiscais, em caráter temporário, de fomento a atividades produtivas em programas de geração de empregos e fixação de mão-de-obra. 
Art. $5^{\circ}$ Os programas e projetos prioritários para a região, com especial ênfase para os relativos à infra-estrutura básica e geração de empregos, serão financiados com recursos:

I - de natureza orçamentária, que lhe forem destinados pela União, na forma da lei;

II - de natureza orçamentária que lhe forem destinados pelo Distrito Federal, pelos Estados de Goiás e de Minas Gerais, e pelos Municípios abrangidos pela Região Integrada de que trata esta Lei Complementar;

III - de operações de crédito externas e internas.

Art. $6^{\circ}$ A União poderá firmar convênios com o Distrito Federal, os Estados de Goiás e de Minas Gerais, e os Municípios referidos no $\S 1^{\circ}$ do art. $1^{\circ}$, com a finalidade de atender o disposto nesta Lei Complementar.

Art. $7^{\circ}$ Esta Lei Complementar entra em vigor na data de sua publicação.

Art. $8^{\circ}$ Revogam-se as disposições em contrário.

\title{
DECRETO N 7.469, DE 4 DE MAIO DE 2011
}

\author{
Regulamenta a Lei Complementar no 94, de 19 de fevereiro de 1998, que autoriza o Poder Executivo a criar a \\ Região Integrada de Desenvolvimento do Distrito Federal e Entorno - RIDE e instituir o Programa Especial de \\ Desenvolvimento do Entorno do Distrito Federal.
}

A PRESIDENTA DA REPÚBLICA, no uso das atribuições que lhe confere o art. 84, incisos IV e VI, alínea "a", da Constituição, e tendo em vista o disposto na Lei Complementar no 94, de 19 de fevereiro de 1998, e na Lei Complementar no 129, de 8 de janeiro de 2009, DECRETA:

Art. 1o A Região Integrada de Desenvolvimento do Distrito Federal e Entorno - RIDE destinase à articulação da ação administrativa da União, dos Estados de Goiás e de Minas Gerais e do Distrito Federal.

$\S 1$ o A RIDE é constituída pelo Distrito Federal, pelos Municípios de Abadiânia, Água Fria de Goiás, Águas Lindas, Alexânia, Cabeceiras, Cidade Ocidental, Cocalzinho de Goiás, Corumbá de Goiás, Cristalina, Formosa, Luziânia, Mimoso de Goiás, Novo Gama, Padre Bernardo, Pirenópolis, Planaltina, Santo Antônio do Descoberto, Valparaíso e Vila Boa, no Estado de Goiás, e de Unaí e Buritis, no Estado de Minas Gerais.

$\S 20$ Integram-se automaticamente à RIDE os Municípios que vierem a ser constituídos em virtude de desmembramento de Município mencionado no $\S 10$.

Art. 2o O Conselho Administrativo da Região Integrada de Desenvolvimento do Distrito Federal e Entorno - COARIDE, vinculado à Superintendência do Desenvolvimento do CentroOeste - SUDECO, tem a finalidade de coordenar as atividades a serem desenvolvidas na RIDE.

Art. 3o Compete ao COARIDE: 
I - coordenar as ações dos entes federados que compõem a RIDE, visando ao desenvolvimento e à redução das desigualdades regionais;

II - aprovar e supervisionar planos, programas e projetos para o desenvolvimento integrado da RIDE;

III - programar a integração e a unificação dos serviços públicos que lhes são comuns;

IV - indicar providências para compatibilizar as ações desenvolvidas na RIDE com as demais ações e instituições de desenvolvimento regional;

$\mathrm{V}$ - harmonizar os programas e projetos de interesse da RIDE com os planos regionais de desenvolvimento;

VI - coordenar a execução de programas e projetos de interesse da RIDE; e

VII - aprovar seu regimento interno.

Parágrafo único. Consideram-se de interesse da RIDE os serviços públicos comuns ao Distrito Federal, aos Estados de Goiás e de Minas Gerais e aos Municípios que a integram, relacionados com as seguintes áreas:

I - infraestrutura;

II - geração de empregos e capacitação profissional;

III - saneamento básico, em especial o abastecimento de água, a coleta e o tratamento de esgoto e o serviço de limpeza pública;

IV - uso, parcelamento e ocupação do solo;

$\mathrm{V}$ - transportes e sistema viário;

VI - proteção ao meio ambiente e controle da poluição ambiental;

VII - aproveitamento de recursos hídricos e minerais;

VIII - saúde e assistência social;

IX - educação e cultura;

$\mathrm{X}$ - produção agropecuária e abastecimento alimentar;

XI - habitação popular;

XII - serviços de telecomunicação;

XIII - turismo; e

XIV - segurança pública.

Art. 4o O COARIDE tem a seguinte composição:

I - o Ministro de Estado da Integração Nacional, que o presidirá;

II - o Diretor-Superintendente da SUDECO;

III - um representante, de cada um dos seguintes Ministérios, indicados por seus titulares:

a) do Planejamento, Orçamento e Gestão;

b) da Fazenda; e

c) das Cidades;

IV - um representante da Casa Civil da Presidência da República, indicado por seu titular;

V - dois representantes do Ministério da Integração Nacional, indicados por seu titular;

VI - um representante da SUDECO, indicado por seu titular;

VII - um representante do Distrito Federal, um do Estado de Goiás e um do Estado de Minas Gerais, indicados pelos respectivos Governadores; e

VIII - um representante dos Municípios que integram a RIDE, indicado pelos respectivos Prefeitos.

$\S 1$ o Os membros a que se referem os incisos VII e VIII terão mandato de dois anos, permitida a recondução. 
$\S 20$ Os membros do COARIDE e respectivos suplentes serão designados pelo Ministro de Estado da Integração Nacional.

Art. 5o As atividades de Secretaria-Executiva do COARIDE serão exercidas pela Diretoria de Implementação de Programas e de Gestão de Fundos da SUDECO.

Art. 6o As decisões do COARIDE serão tomadas por maioria simples de seus membros, cabendo ao seu Presidente o voto de qualidade.

Art. 7o A participação no COARIDE não será remunerada, sendo considerada serviço público relevante.

Art. 8o O Programa Especial de Desenvolvimento do Entorno do Distrito Federal, ouvidos os órgãos competentes, estabelecerá, mediante convênio, normas e critérios para a unificação de procedimentos relativos aos serviços públicos de responsabilidade Distrital, Estadual e Municipal de entes que integram a RIDE, especialmente em relação a:

I - tarifas, fretes e seguro, ouvido o Ministério da Fazenda;

II - linhas de crédito especiais para atividades prioritárias;

III - isenções e incentivos fiscais, em caráter temporário, de fomento a atividades produtivas em programas de geração de empregos e de fixação de mão de obra.

Art. 9o Os programas e projetos prioritários para a RIDE, principalmente no que se refere e à infraestrutura básica e geração de empregos, serão financiados com recursos:

I - do orçamento da União;

II - dos orçamentos do Distrito Federal, dos Estados de Goiás e de Minas Gerais e dos Municípios abrangidos pela RIDE; e

III - de operações de crédito externas e internas.

Art. 10. A União estabelecerá convênios com o Distrito Federal, com os Estados de Goiás e de Minas Gerais e com os Municípios referidos no $§ 10$ do art. 1o, com a finalidade de atender ao disposto neste Decreto.

Art. 11. Este Decreto entra em vigor no dia 16 de maio de 2011.

Art. 12. Ficam revogados:

I - o Decreto no 2.710, de 4 de agosto de 1998;

II - o Decreto no 3.445, de 4 de maio de 2000; e

III - o Decreto no 4.700, de 20 de maio de 2003. 